THIAGO JABUR CARNEIRO

\title{
CONTRIBUIÇÃO AO ESTUDO DO CONTRATO DE LICENÇA DE USO DE MARCA
}

\author{
TESE DE DOUTORADO
}

ORIENTADOR: PROF. DR. NEWTON SILVEIRA

FACULDADE DE DIREITO DA UNIVERSIDADE DE SÃO PAULO SÃO PAULO 2011 


\section{FOLHA DE APROVAÇÃo}

Thiago Jabur Carneiro

Contribuição ao Estudo do Contrato de Licença de Uso de Marca.

Tese apresentada à Faculdade de Direito da Universidade de São Paulo para obtenção do título de Doutor em Direito.

Área de Concentração: Direito Comercial

Aprovado em:

Banca Examinadora

Prof. Dr.

Instituição:

Assinatura:

Prof. Dr.

Instituição:

Assinatura

Prof. Dr.

Instituição:

Assinatura

Prof. Dr.

Instituição:

Assinatura:

Prof. Dr. (Orientador)

Instituição:

Assinatura: 


\section{DEDICATÓRIA}

Dedico este trabalho primeiramente a Deus, pois, sem Ele, nada seria possível e não estaríamos aqui reunidos, deleitando, juntos, destes momentos que nos são tão únicos e preciosos.

Aos meus pais, Sandra Jabur e José Roberto Carneiro, avós e duplamente pais, Kamal Jabur e Sayd Jabur, e tias Márcia Jabur e Eliana Jabur, pela exemplar e brilhante criação, educação e cultura transmitidas ao longo de minha vida. Aos meus irmãos Rafael Jabur e Marcela Jabur. À Juliana e Tereza Mangini, pelo apoio e constante estímulo. Ao meu brilhante orientador, Dr. Newton Silveira. Por fim, aos meus primos, amigos e colegas de trabalho, pelo companheirismo constante nesta curta, porém valiosa caminhada.

Em especial (in memorian), ao meu eterno e inolvidável amigo Vanderlei Arcanjo da Silva, pelos momentos de companheirismo, solidariedade e alegria proporcionados ao longo de todo o curso de graduação na Faculdade de Direito da Universidade de São Paulo. 


\section{Agradecimentos}

Em especial, ao meu Orientador, Professor Dr. Newton Silveira, pela tranqüilidade, confiança depositada, estímulo, aplicação, sabedoria transmitida e constante suporte acadêmico nas atividades e discussões concernentes à escolha, preparação, desenvolvimento e conclusão desta Tese de Doutorado.

Ao Dr. José Carlos Madia Souza e ao Dr. Vadim da Costa Arsky, pelo grande estímulo e constante apoio empenhados ao longo dos cursos de mestrado e doutorado realizados na memorável Academia do Largo de São Francisco.

A todos os professores dos cursos de graduação, mestrado e doutorado, verdadeiros mananciais de sabedoria: Ada Pellegrini Grinover, Álvaro Villaça Azevedo, Antônio Rodrigues de Freitas Jr., Carlos Alberto Dabus Maluf, Carlos Alberto de Salles, Edmir Netto de Araújo, José Fernando Simão, José Rogério Cruz e Tucci, José Rubens de Moraes, Kazuo Watanabe, Paulo Fernando Campos Salles de Toledo, Teresa Ancona Lopez, pelo espírito inovador na tarefa de disseminar seus conhecimentos, pela motivação e paciência ao ministrar assuntos jurídicos de expressiva importância, pelos seminários, debates travados e trabalhos sugeridos, esforços estes sem os quais esta obra restaria, por certo, ainda mais limitada.

Aos professores: Dr. Haroldo Malheiros Duclerc Verçosa e Dr. Balmes Vega Garcia, pelas observações críticas e valiosas sugestões feitas no exame qualificatório, as quais foram de enorme valia para a finalização desta obra.

A todos os idealizadores, coordenadores e funcionários, da Faculdade de Direito da Universidade de São Paulo, sobretudo pela gentileza, hospitalidade, paciência, esforço e suporte para a composição desta obra. A todos os demais professores e convidados das Arcadas, faculdade esta que, orgulhosamente, fui afortunado de ter-me tornardo bacharel e, ainda, de ter concluído os cursos de mestrado e doutorado, pela dedicação, entusiasmo e esforços envidados ao longo do curso de graduação e pós-graduação. Por fim, aos colegas de classe, pela espontaneidade e empenho na troca de informações e materiais, em uma grande demonstração de dedicação e solidariedade. 


\section{RESUMO}

CARNEIRO, Thiago Jabur. Contribuição ao Estudo de Contrato de Licença de Uso de Marca. 2011. 388 p. Tese de Doutorado - Faculdade de Direito, Universidade de São Paulo, São Paulo, 2011.

O escopo da presente tese reside na análise do contrato de licença de uso de marca à luz da Lei 9.279/96 e do Código Civil de 2002, bem como os efeitos jurídicos daí decorrentes, sobretudo na ambiência do direito pátrio. Sinaliza, por igual, que o tema em questão carece de análise mais depurada em torno dos princípios e cláusulas gerais de direito contratual arraigados ao diploma civil em vigor, dada a sua complexidade e a ampla gama de institutos de Direito Civil e Comercial que encerra, além dos elementos econômicos indissociáveis da realidade jurídica que o permeia. São objetos do presente estudo as matérias que circunscrevem a órbita dos contatos de licença de uso de marca e que, portanto, são indispensáveis à compreensão e à análise crítica do instituto, para o qual se recorre ao Direito Estrangeiro e ao amplo exame da jurisprudência pátria. Na esteira dos objetivos da presente tese, fá-se, ainda, análise das evoluções legislativa, doutrinária e jurisprudencial dispensadas ao instrumento contratual em exame. São externalizados, por igual, debates acerca das novas tendências de tratamento do tema no Direito alienígena e no Brasil, sobretudo em relação à aplicação dos dispositivos consignados na Lei 9.279/96 e outros dispositivos normativos consignados no Código Civil vigente, em cujo diploma houve a unificação do direito obrigacional. A delimitação dos preceitos jurídicos aplicáveis aos contratos de licença de marca ainda remanesce pendente de assentamento no Brasil, em função da atipicidade desta figura contratual de direito industrial. Por fim, com respaldo no princípio da função social do contrato, apresenta-se recomendação no sentido de se reformatar redação de dispositivo normativo consignado na legislação marcária vigente, de tal sorte a harmonizá-lo ao princípio contratual em referência.

Palavras-Chave: Contrato, Licença, Uso, Marca, Lei 9.279/96. 


\section{AbSTRACT}

CARNEIRO, Thiago Jabur. Contribution to the Study of the Trademark License Agreement. 2011. 388 p. Thesis (Doctor’s Degree) - Faculdade de Direito, Universidade de São Paulo, São Paulo, 2011.

The scope of this thesis is the analysis of the Trademark License Agreement in the light of Law 9.279/96 (Brazilian Industrial Property Law) and the Civil Code of 2002, as well as the legal consequences arising therefrom, especially under the national legal system. This work equally indicates that the agreement under review requires further investigation on the principles and provisions of general contract law rooted in civil code in force, given its complexity and wide range of institutes of Civil and Commercial Law, as well as indissoluble economic elements of the legal reality which permeates it. The topics that limit the orbit of the Trademark License Agreement are objects of this study and are, therefore, essential for the understanding and critical analysis of the institute, for which we will also run over the international law and comparative jurisprudence. In the wake of the goals of the current thesis, it is intended to proceed with the examination of legislative, doctrinal and jurisprudential developments with regard to the juridical instrument under consideration. Debates concerning the new trends in treatment of the subject under the International and Brazilian Law are also mentioned, especially in relation to the application of the general principles of Contract Law and other regulations established by the current Civil Code, in which there was the amalgamation of the Obligation Law. The demarcation of the civil principles applicable to the Trademark License Agreements still remains pending consolidation in Brazil, due to the newly and still embryonic civil legislation, as may be largely understood from this study. Finally, in accordance with the social function principle, there is recommendation in order to rewrite an article set forth by the current trademark law, with the aim to harmonize the modified article with the afore said principle.

Keywords: Agreement, License, Use, Trademark, Law 9.279/96. 


\section{RIASSUNTO}

CARNEIRO, Thiago Jabur. Contributo allo Studio del Contratto di Licenza di Uso di Marchio. 2011. 388 p. Tesi di Dottorato - Facoltà di Diritto, Università di São Paulo, São Paulo, 2011.

L'obiettivo di questa tesi è l'analisi del contratto di licenza d'uso del marchio alla luce della Legge 9.279/96 e del Codice Civile del 2002, nonché le conseguenze giuridiche che ne derivano, soprattutto in ambiente del diritto brasiliano. Segnali, ugualmente, che il soggetto in esame richiede analisi più dettagliate sui principi e le disposizioni generali di diritto contrattuale radicata nel diritto civile vigente, data la sua complessità e la vasta gamma di istituti di diritto civile e commerciale che contiene, oltre a inseparabile dalla elementi economici della realtà giuridica che pervade. Sono oggetti del presente studio dei materiali che comprendono l'orbita di contratti di licenza d'uso del marchio e che, pertanto, sono indispensabili per la comprensione e l'analisi critica dell'istituto, a cui si ricorre al diritto straniero e l'esame completo della patria giurisprudenza . Sulla scia degli obiettivi di questa tesi, lo fa, ancora, l'analisi degli sviluppi legislativi, dottrinali e giurisprudenziali rinunciato allo strumento contrattuale in questione. Vengono esternalizzate, ugualmente, dibattiti sulle nuove tendenze nel trattamento del soggetto e diritto straniero in Brasile, in particolare in relazione alla attuazione delle disposizioni contenute nella legge 9.279/96 e le altre disposizioni regolamentari contenute nel codice civile, in cui il diploma è stato l'unificazione del diritto obligational. La linea di demarcazione dei principi legali applicabili ai contratti di licenza d'uso del marchio resta ancora in attesa di insediamento in Brasile, secondo l'atipicità di questa figura contrattuale di diritto industriale. Infine, sostenendo il principio del contratto sociale, si presenta raccomandazione per riformattare dispositivo legislativo di legislazione di marchio in vigore, in modo da allinearlo con tale principio del diritto dei contratti

Parole chiave: Contratto, Licenza, Uso, Marchio, Legge 9.279/96. 


\section{SUMÁRIO}

PREFÁCIO. $\mathbf{X}$

II. CONTRIBUIÇÃO AO ESTUDO DA MARCA: OBJETO NUCLEAR DO CONTRATO DE LICENÇA EM EXAME

II.1Marca: valioso elemento intangivel do estabelecimento empresarial.

II.2 Histórico e Evolução..

II.3 Definição.

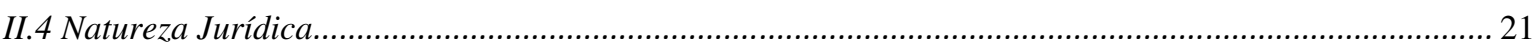

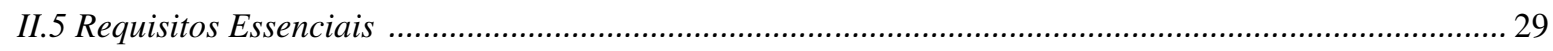

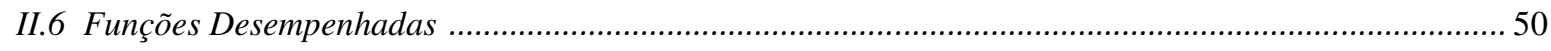

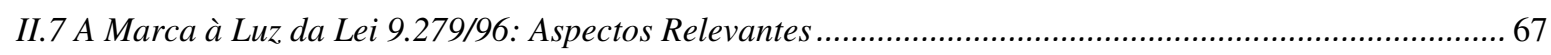

II.8 Diferenças entre "Marca" e "Nome Empresarial"............................................................................... 81

III. CONSIDERAÇÕES INICIAIS ACERCA DO CONTRATO DE LIÇENCA DE USO DE MARCA: ACEPÇÃO JURÍDICA E IMPORTÂNCIA ECONÔMICA.......................................................................88

III.1 Acepção Jurídica do Contrato de Licença de Uso de Marca..................................................................8

III.2 Importância Ecônomica do Licenciamento do Uso de Marca............................................................... 93

III.2.1 Licenciamento do Uso de Marca no Mundo .................................................................................. 97

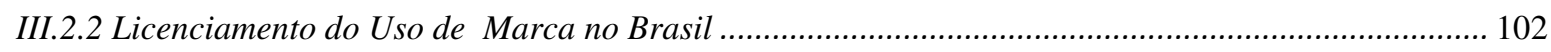

IV. A NOVA ORDEM DO DIREITO PRIVADO E A UNIFICAÇÃO DOS CONTRATOS CIVIS E EMPRESARIAIS: EVOLUÇÃO DO DIREITO COMUM INCIDENTE SOBRE O CONTRATO DE LIÇENCA DE USO DE MARCA ....................................................................................................................... 111

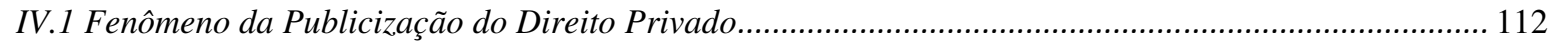

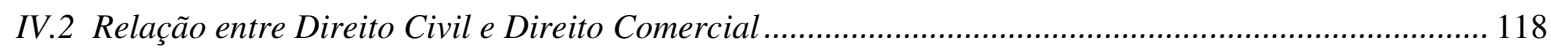

IV.3 Unificação do Direito das Obrigações no Brasil............................................................................... 120 


\section{REGIME JURÍDICO INCIDENTE SOBRE O CONTRATO DE LICENÇA DE USO DE MARCA..127}

V.1 A Atipicidade do Contrato de Licença de Uso de Marca.

V.2 Disciplinamento Jurídico aplicável ao Contrato de Licença de Uso de Marca (Contrato Atípico Misto)

V.3 Princípios Gerais de Direito Contratual incidentes sobre o Contrato de Licença de Uso de Marca...... 150

V.4 Análise dos Contratos de Licença de Uso de Marca à Luz da Teoria da Aplicação Analógica.

V.4.1 Contrato de Licença de Uso de Marca não Remunerado consoante a aplicação dos dispositivos normativos incidentes sobre o Contrato de Comodato.

V.4.2 Contrato de Licença de Uso de Marca Remunerado consoante a aplicação dos dispositivos normativos incidentes sobre o Contrato de Locação de Coisas.....

V.5 Os Contratos de Licença de Uso de Marca à luz do princípio da fiel autonomia da vontade 198

V.5.1 Modalidades de Contrato de Licença de Uso de Marca. 200

V.5.2 Estudo dos dispositivos juridicos integrantes dos Contratos de Licença de Uso de Marca. 208

V.6 Registro do Contrato de Licença de Uso de Marca no Instituto Nacional de Propriedade Industrial (INPI).

V.7 Legitimidade do Licenciado para Agir em Defesa da Marca 252

V.8 Extinção do Contrato de Licença de Uso de Marca 260

VI. O LICENCIANTE E O DEVER DE EXERCER O CONTROLE DE QUALIDADE SOBRE O USO DA MARCA LICENCIADA: ANÁLISE CRÍTICA DO ARTIGO 139 DA LEI 9.279/96.

VI.1 Formas de o Licenciante Exercer o Controle de Qualidade sobre o Uso da Marca Licenciada 81

VII. DEBATES EM TORNO DO LICENCIAMENTO DO USO DE MARCA E DA IMPORTAÇÃO PARALELA NO DIREITO PÁTRIO..

XI. ANEXO: CONTRATO DE LICENÇA DE USO DE MARCA REMUNERADO - Minuta contratual elaborada à luz da tese "Contribuição ao Estudo do Contato de Licença de Uso de Marca"...... 


\section{PREFÁcio}

Fui afortunado de estar presente no VI Simpósio Nacional de Direito Civil, jornada realizada em homenagem ao saudoso professor titular da Faculdade de Direito da USP, Antônio Junqueira de Azevedo. Neste evento, o professor Renan Lotufo, em uma de suas brilhantes intervenções, assinalou, em tom fortemente persuasivo, que, no Direito, não há teses mirabolantes; que surgem do nada; bombásticas. Estas pseudo-teorias não passam de verdadeiros disparates jurídicos. O que há, ou pelo menos o que se espera que sempre haja, são teses, as quais, se utilizando de teorias, proposições, subsídios e elementos préexistentes no ordenamento jurídico histórico e vigente, contribuam, em pequenas doses, porém de formas original, valiosa, gradual e consistente, para a formação de um Direito mais coeso, pujante e, por corolário, evoluído. É imbuído deste espírito que, modestamente, encaminho a presente Tese de Doutorado à Douta Banca Examinadora da área de Direito Comercial da Faculdade de Direito do Largo de São Francisco.

Corresponde à concretização de uma aspiração de ter a oportunidade de elaborar e expor a presente tese, razão pela qual espero, com todo o esforço envidado para concluí-lo, honrar o elevado nível de excelência a que faz jus esta inigualável Academia.

Em que pese as limitações temporais inerentes à vida moderna, sobretudo aquelas de ordem profissional, busquei, com imperfeito, porém intenso trabalho de investigação, observar a dedicação e o rigor necessários para a preparação de um trabalho sólido e coeso, porquanto elaborado em consonância com parcela significativa da doutrina e da jurisprudência mais autorizadas a respeito da matéria sob comento, e não menos criativo, na medida em que galguei, dentro dos limites da razoabilidade científica e do escopo de uma tese de doutorado, refletir sobre os ensinamentos que vivenciei, mais do que meramente organizá-los e reproduzi-los de maneira fortuita e acrítica.

Seduziu-me o fato desta expressiva matéria ter notável aplicabilidade prática, sobretudo com o crescimento econômico fruto da intensa globalização na qual nos 
encontramos imersos, além de ser permeada de diversos dados e princípios interdisciplinares, corporificados por elementos que povoam os Direitos Constitucional, Civil e Comercial, simultaneamente, o que a torna tão atraente, desafiadora e merecedora de análise pormenorizada.

Intenciono que esta obra seja proveitosa no mundo jurídico, sob os vieses pragmático e acadêmico, sobretudo ao operador do direito que a ela venha a ter acesso, e que atinja os fins a que se propõe cumprir, em sua tentativa de ponderar, de forma coerente, sistematizada e, de algum modo, inovadora, alguns dos mais significativos elementos e princípios relacionados ao Contrato de Licença de Uso de Marca, tema este de notável importância jurídica, especialmente por ser fruto de uma verdadeira revolução econômica ocorrida em um momento de efervecência da globalização mundial.

Thiago Jabur Carneiro 


\section{- I -}

\section{INTRODUÇÃO}

A presente tese busca, com ineditismo no que tange à configuração argumentativa abordada, prestar contribuição original ao estudo jurídico do Contrato de Licença de Uso de Marca. A apreciação desta matéria justifica-se por duas razões: uma de cunho econômico e a outra de cunho notadamente jurídico. A primeira razão para o estudo desta espécie contratual é de natureza econômica e consiste na expressiva importância que assume a operação empresarial do licenciamento de uso de marca no mercado globalizado hodierno, que, conforme restará adiante demonstrado, anualmente movimenta cifras milionárias. A segunda razão, de cunho jurídico, repousa no fato de inexistir, no ordenamento jurídico vigente, regulamentação legal mais aprofundada sobre este contrato empresarial de direito industrial, o qual, de acordo com a matéria que será examinada em capítulo oportuno desta tese, é considerado contrato atípico misto.

Nos capítulos subseqüentes, este autor procederá ao estudo aprofundado de matéria de grande relevância mercadológica, a qual, contudo, não tem obtido acolhida jurídica à altura de sua repercurssão no mundo econômico, especialmente em decorrência da ausência de sua regulamentação pelo sistema legal brasileiro.

Aliado ao estudo do contrato em destaque, carente de regulamentação pelo ordenamento jurídico pátrio, este autor se inclinará à análise crítica do artigo 139 da Lei 9.279, de 14 de maio de 1996, também conhecida como Lei da Propriedade Industrial. Este dispositivo consubstancia-se no único artigo de lei que, laconicamente, faz referência ao Contrato de Licença de Uso de Marca. Com efeito, se buscará a apreciação crítica do mencionado artigo, tal como se encontra positivado, de modo a sugerir, conclusivamente, a alteração de sua redação, como forma de resguardar os interesses das partes envolvidas no contrato em estudo, bem como salvaguardar os interesses de terceiros que da contratação não tenham participado, tudo com respaldo no princípio da função social do contrato, 
celebrado pela Constituição Federal do Brasil e, agora, festejado pelo Código Civil Brasileiro.

$\mathrm{O}$ ato de licenciar marcas tem se apresentado como eficiente estratégia de mercado, da qual se utilizam, desde pessoas físicas reconhecidas pelo público como "celebridades", até uma vasta gama de sociedades empresárias nacionais e estrangeiras que almejam galgar espaço na mente dos consumidores, de forma mais célere e pujante. Esta operação de disponibilização de bem intangível, autorizada pelo Direito, acaba sendo, na grande maioria das vezes, mais hábil e frutífera, especialmente se cotejada com o ato de se constituir marca novel, cuja dissiminação no mercado é mais vagarosa e incerta, sem se ter a certeza, ainda, do alcance do sucesso como resultado do trabalho da aludida propagação.

Associar-se a marcas ilustres pré-concebidas corresponde, em geral, a maiores chances de êxito no competitivo mercado contemporâneo. No ano de 2007, em consonância com os números apresentados pela Associação Brasileira de Licenciamento (ABRAL) ${ }^{1}$, conforme será abalizado em capítulo opoturno da presente tese, o faturamento foi de 3 bilhões de reais ao mercado revendedor. Foram disponibilizadas, no Brasil, aproximadamente, 450 licenças, com royalties variando entre 4 a 12\%, com média aproximada de $6 \%$. O mercado cresceu $6 \%$.

Para o ano de 2008 houve um faturamento estimado de, aproximadamente, 3 bilhões e 200 milhões de reais, com royalties variando de 6 a 14\%. Para o ano de 2009, a ABRAL aferiu estimativamente faturamento em torno de 3 bilhões e 400 milhões de reais, com royalties variando de 6 a 14\%. De tal sorte, os efeitos decorrentes do licenciamento de marca podem ser verificados a curto ou longo prazo, dependendo de como o licenciado aproveitar o signo adquirido em caráter temporário.

A grande serventia, pois, de um produto ou serviço se conectar a uma marca préconcebida é que este produto ou serviço ficará em proeminência nos meios de comunicação social e na mente de determinado mercado consumidor. Utilizar-se, por exemplo, da marca "Pelê" para a produção de camisetas esportivas torna-se um negócio

\footnotetext{
1 Disponível em: < http://www.abral.org.br/default.asp?tp=3\&pag=menu/setor.htm>. Acesso em 09 jun. 2009.
} 
extremamente benéfico e lucrativo, a curto prazo, haja vista se tratar de um dos maiores e mais reconhecidos ícones mundiais.

Após o exame analítico-econômico do licenciamento da marca, burcar-se-á investigar as implicações e efeitos irradiados por tais operações empresariais no mundo jurídico. Com efeito, a presente tese terá por escopo o estudo das diversas matizes decorrentes de tal negócio jurídico, buscando se ater aos principais institutos e dispositivos jurídicos pátrios e alienígenas aplicáveis ao instrumento contratual que corporifica a relação jurídica em apreço.

Os elementos e efeitos irradiados pelos contratos de licença de uso de marca são apreciados, com recorrência, tanto pelos ordenamentos jurídicos dos países cujo sistema jurídico delineia-se sob o manto do Direito Consuetudinário (Common Law), como pelos ordenamentos arraigados ao Direito Continental (Civil Law), grupo no qual se encontra o sistema pátrio.

Após larga investigação de cunho legal, doutrinário e jurisprudencial ${ }^{2}$, o presente estudo terá o condão de expor os principais pontos e contribuições atinentes ao instrumento contratual cujo objeto consiste na licença do uso da marca, à luz da Lei 9.279/96 e do Código Civil vigente, pautando-se na premissa maior de que os contratos, figurando como o negócio jurídico da mais alta valia no Direito Contemporâneo ${ }^{3}$, têm o objetivo maior de garantir a livre circulação de bens e serviços e a produção de riquezas, dentro dos limites da lei, de sorte a evitar a infração a normas de ordem pública, lesão a direitos de terceiros e abuso de poder econômico ${ }^{4}$.

\footnotetext{
${ }^{2}$ No que tange ao papel exercido pela jurisprudência no Direito Positivo Contemporâneo, registre-se o legado deixado pelo mestre Norberto Bobbio. Elucida o saudoso jurista: "A concepção juspositivista da ciência jurídica sofreu um forte declínio no nosso século. Hoje, o movimento de pensamento que diz respeito ao realismo jurídico tende a conceber como tarefa da jurisprudência extrair do estudo de uma dada realidade (o direito, considerado como dado de fato sociológico) proposições empiricamente verificáveis, que permitam formular previsões sobre futuros comportamento humanos (particularmente, prever as decisões que os juizes tomarão para os casos que deverão julgar." (BOBBIO, Norberto. O Positivismo Jurídico: Lições de Filosofia do Direito. tradução e notas Márcio Pugliesi, Edson Bini, Carlos E. Rodrigues. São Paulo: Ed. Ícone. 1995. pp. 211-222)

${ }^{3}$ KELSEN, Hans. Teoria Pura do Direito. tradução João Baptista Machado. $6^{\text {a }}$ ed. São Paulo: Ed. Martins fontes. 1998. p. 286.

${ }^{4}$ Enzo Roppo refere-se ao contrato como um "instrumento indispensável ao desenvolvimento profícuo e eficaz de toda a actividade económica organizada". (ROPPO, Enzo. O Contrato. Tradução de Ana Coimbra e M. Januário C. Gomes. Coimbra: Almedina. 1998. p.67)
} 
Trata-se de matéria, por certo, de grande interesse a ser examinada, sobretudo com o advento do Código Civil de 2002, em que se consagrou a unificação do direito obrigacional e, por via de consequiência, o direito contratual. Ademais, o tema em apreço se apresenta como de extrema importância no ordenamento jurídico em que se encontra insculpido, em função de sua complexidade e da vasta gama de institutos de Direito Civil e Comercial que o encerram, além de elementos econômicos indissociáveis da realidade jurídica que o permeia.

$A b$ initio, buscar-se-á tracejar as características marcantes do signo objeto do contrato sob análise: a marca, um dos elementos incorpóreos formadores do estabelecimento comercial de maior expressividade econômica. Este bem intangível, amplamente albergado pelo direito da propriedade industrial assume, gradativamente, as mais diversas cátedras carecedoras da tutela do sistema legal pátrio hodierno. Dentre as principais funções assumidas pelo sinal em comento, merecem destaque as funções: identificadora, diferenciadora, indicativa de qualidade, de credibilidade, econômica e social, esta última expressamente celebrada pela Lei Magna de $1988^{5}$.

Serão sopesados, outrossim, os aspectos relevantes do sinal em debate, em conformidade com os ditames arraigados à Lei 9.279/96, tais quais, porém não se limitando a: o registro, classificação das marcas em consonância com a legislação marcária vigente, suas formas de apresentação, a vigência do registro em suas peculiaridades, bem como os crimes tipificados em decorrência da infração cometida contra as marcas e registros correspondentes, sob a égide do direito concorrencial.

Abordar-se-á, por igual, o impacto econômico dos contratos de licença de uso de marca, demonstrando a importância cada vez mais crescente do instrumento contratual em referência. O intercâmbio do uso das marcas resulta na movimentação de bilhões de dólares anualmente. Os dados estatísticos a serem oportunamente apresentados

\footnotetext{
${ }^{5}$ A Constituição Federal Brasileira consagra a propriedade privada, bem como a função social a ela inerente. Neste sentido, assinala Manoel Gonçalves Ferreira Filho que a Constituição não veda o direito exclusivo do dono sobre sua propriedade. No entanto, o diploma legal supremo exige do proprietário o uso condicionado ao bem estar social, condenando, veementemente, a concepção de propriedade absoluta utilizada de modo "puramente egoístico", sem considerar o interesse da sociedade. (FERREIRA FILHO. Manoel Gonçalves. Curso de Direito Constitucional. $25^{\text {a }}$ ed. rev. São Paulo: Saraiva. 1999. p. 353)
} 
demonstrarão, cabalmente, o enorme peso deste segmento de negócio na economia mundial.

As sociedades nacionais sediadas em território brasileiro, que antes apenas licenciavam marcas de empresas sediadas no exterior, passam, doravante, e com frequiência cada vez maior, a figurar como licenciantes, promovendo a licença de suas marcas tanto em ambiência interna quanto internacional.

Validamente, para se acompanhar a evolução econômica das relações em destaque e,

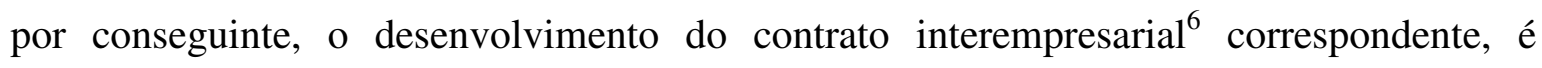
imperioso que se busquem mecanismos jurídicos amplos e hábeis o suficiente, com o desígnio de se promover maior segurança aos contratos de licença, sempre se partindo da proposição maior de que a segurança jurídica das obrigações assumidas e contratos entabulados entre as partes é condição basilar para o progresso econômico ${ }^{7}$.

Com a publicação da nova legislação civil, licenciante e licenciado se quedaram mais resguardados contra vícios contratuais, defeitos, eventos não vislumbrados contratualmente, atitudes tomadas em contrariedade ao contrato e ao espírito da lei etc., circunstâncias estas advindas da relação jurídica projetada e não suficientemente arrazoadas pela lei marcária, em decorrência do profundo laconismo e brandura com que referida legislação regulamenta a matéria.

Portanto, a lei civil vigente vem para alargar e robustecer a proteção legal a este negócio jurídico de significante valor econômico, externando princípios e dispositivos com o fim de evitar lesões a qualquer das partes contratantes e, concomitantemente, estimular o empresariado a ingressar neste próspero segmento, com a segurança de que, na omissão do contrato, estará devidamente salvaguardado contra desaranjos ou lesões encetadas pela

\footnotetext{
${ }^{6}$ Conforme melhor doutrina de Waldírio Bulgarelli, figuram como contratos interempresariais aqueles firmados pelos empresários ou sociedades empresárias entre si. Por seu turno, consideram-se contratos empresariais aqueles entabulados entre os empresários ou sociedades empresárias e os consumidores. (BULGARELLI. Waldírio. Diretrizes Gerais dos Contratos Empresariais. Novos Contratos Empresariais. Carlos Alberto Bittar (coord.). São Paulo: Ed. Revista dos Tribunais. 1990. pp. 17-19)

${ }^{7}$ BRAMBILA, Silvio. A Antijuridicidade das Cláusulas Contratuais Abusivas e as Sanções do Ordenamento Jurídico. in Revista de Direito Empresarial. Curitiba. N. ${ }^{\text {3 }}$. jan./jun. 2005. pp. 211-229.
} 
parte que opera em desconformidade com: a lei, as cláusulas contratuais e os princípios que regem esta espécie contratual.

Temos, assim, que a consagração da unificação do direito obrigacional pelo código civil deu ensejo a uma maior proteção jurídica dos contratos de licença de uso de marca, diretamente beneficiados pela fusão contratual consolidada pela nova legislação civil. As cláusulas gerais contratuais doravante codificadas, sobretudo no que diz respeito aos contratos atípicos, conferiram aos contratantes maior mobilidade no momento da contratação, de sorte a conciliar a segurança jurídica com a livre manifestação de vontade das partes, sem que terceiros sejam de alguma forma lesados em decorrência da celebração de mencionado negócio jurídico.

O Código Civil atual, conforme lição da civilista Judith Martins $\operatorname{Costa}^{8}$, passa a ser aplicado aos contratos empresariais e é calcado, essencialmente, em um "sistema em construção" onde são disseminadas cláusulas gerais amplas, cujo preenchimento é verificado casuisticamente pelo magistrado. De tal modo, pelo fato destas cláusulas gerais não serem exaustivas, passam a atuar como verdadeiras "metanormas", tendo por corolário remeter o juiz a uma vasta gama de casos a serem decididos de forma nem sempre uniforme. Tem-se, pois, que os contornos e especificidades dos casos decididos sob o alicerce das ditas cláusulas, ao contrário do que ocorria com outros diplomas em que a rigidez fazia-se prevalecer, serão corroborados pela via jurisprudencial em substituição à unicidade da via legal ordinária.

Dentre as principais diretrizes contratuais ou cláusulas gerais, cujos efeitos impactam diretamente na espécie contratual em estudo, serão ponderadas, pormenorizadamente, os princípios: (a) da autonomia da vontade, albergado sob o manto do artigo 170 da constituição federal, cujo comando prescreve que a todos é assegurado o livre exercício de qualquer atividade econômica, independentemente de autorização governamental, à exceção do disposto em lei especial; (b) supremacia da ordem pública, em que há o abalizamento do princípio da livre iniciativa; (c) obrigatoriedade do contrato, arraigado ao preceito de maior autoridade no direito contratual: o pacta sunt servanda; (d)

\footnotetext{
8 MARTINS-COSTA. Judith Hofmeister. O Direito Privado como um "sistema em construção": as cláusulas gerais no Projeto do Código Civil brasileiro. Jus Navegandi, Teresina, ano 4, n. 41, maio 2000. Disponível em: <http://jus2.uol.com.br/doutrina/texto.asp?id=513>. Acesso em 04/11/2008.
} 
intangibilidade dos contratos, (e) probidade e boa-fé objetiva, à guisa do que preceitua o novo diploma civil; (f) relatividade; (g) vedação da onerosidade excessiva, (h) atipicidade; e (i) função social do contrato.

No entanto, conforme restará demonstrado, a aplicação das aludidas diretrizes ao contrato empresarial em estudo deve se operar de forma moderada e extremamente criteriosa. Isto para que se evitem possíveis abalos à estrutura desta modalidade de negócio, bem como para que se impeça a disseminação da insegurança jurídica que possa emergir do emprego descriterioso e desenfreado das ditas cláusulas gerais. A linha mestra que se adotará nesta tese, quando do estudo dos princípios gerais, é a de que os contratos empresariais, gênero do qual são espécies os contratos de licença, são contratos de risco, em sua essência. Por tal razão, tão-somente se submetem aos ditos princípios sociais, nos eventos em que o desequilíbrio contratual infligido ao negócio originalmente estabelecido não for proveninente da "álea normal do negócio".

No que atine à função social, impõe-se destacar o exercício hermenêutico desenvolvido pela doutrina, a qual estende aos contratos o conceito enquadrado pela Constituição Federal de função social da propriedade privada. Com efeito, o conceito de propriedade é amplo, sendo, destarte, perfeitamente aplicável às obrigações e contratos.

Adicionalmente, o comando do parágrafo único do artigo 2.035, do Código Civil, reza que nenhuma convenção prevalecerá se contrariar normas de ordem pública, tais como aquelas consignadas no diploma civil, naturalmente com o fito de se assegurar a função social da propriedade e dos contratos.

$\mathrm{Na}$ outra vertente, conforme será examinada ao longo desta argumentação, a nova ordem dos contratos, em que há de ser considerada a sua função social, não deve repelir sua função individual, devendo, pois, ser harmonizados os interesses privados com os interesses da sociedade 9 , com fulcro no "princípio de geometria variável"

\footnotetext{
${ }^{9}$ PEREIRA, Cáio Mário da Silva. Instituições de Direito Civil. $8^{\mathrm{a}}$ ed. Rio de Janeiro: Forense, 1990. p. 13.

${ }^{10}$ Cite-se, neste sentido, o esclarecedor magistério de Arnoldo Wald, ao assinalar que “(...) é preciso encontrar o justo equilíbrio entre as duas aspirações, sob pena de criar um mundo justo, mas inviável, em vez de uma sociedade eficiente mas injusta, quando é preciso conciliar a justiça e a eficiência (...) Entre princípios antagônicos, num mundo dominado pela teoria da relatividade, cabe adotar, também no campo do direito, o que alguns juristas passaram a chamar dos princípios de geometria variável, ou seja, o
} 
Serão ponderados, outrossim, os contratos de licença de marca em sua essência, trazendo-se ao exame do presente estudo, à luz dos direitos pátrio e alienígena: as modalidades do instrumento sob análise, o regime jurídico ao qual esta espécie contratual encontra-se submetida, os elementos e cláusulas que o permeiam, os dispositivos (antigos e novéis) do código civil aplicáveis aos contratos sob examine e os efeitos irradiados por esta modalidade de negócio jurídico em razão do registro do instrumento contratual pelo Instituto Nacional de Propriedade Industrial.

Buscar-se-á, por igual, a investigação do licenciamento de marca e a importação paralela no Brasil, sopesando-se, especialmente, os limites da legalidade da aludida modalidade de importação, em detida análise doutrinária de estudos tracejados por autoridades nacionais que revelaram preciosos estudos atinentes ao referido tema, bem como em largo exame concernente ao posicionamento e tendência externados pelas cortes pátrias ao se depararem com matéria de tamanha complexidade.

Por fim, o contrato de licença de uso de marca será cotejado com o contrato de franquia, de modo a estabelecer as semelhanças e diferenças entre estes dois negócios jurídicos, cujos objetos nucleares consistem na licença do uso da marca. Das comparações que serão delineadas, buscar-se-á, conclusivamente: apresentar os impactos e conseqüências emergentes de um contrato ou de outro; bem como apontar as vantagens de se adotar uma modalidade de negócio jurídico com exclusão da outra.

equilíbrio entre justiça e segurança, com a prevalência da ética, mas sem desconhecer a economia" (WALD, Arnoldo. Obrigações e Contratos. $14^{\mathrm{a}}$ ed. rev. atual. colaboração do prof. Semy Glanz. São Paulo: Ed. Revista dos Tribunais. 2000. pp. 198-199) 


\section{- II -}

\section{Contribuição ao Estudo da Marca: ObJETo NuClear do CONTRATO DE LICENÇA EM EXAME}

O presente capítulo tem o escopo precípuo de analisar o objeto central do contrato a ser examinado na presente tese. Destarte, procurar-se-á investigar, em linhas gerais, o instituto da marca, como valioso elemento intangível do estabelecimento empresarial, e suas implicações no ordenamento jurídico pátrio.

O instituto da marca será analisado, sobretudo em consonância com os elementos essenciais que a permeiam à luz dos preceitos consignados nos diplomas legais vigentes atinentes ao tema, bem como pelas interpretações emprestadas pelas doutrinas e jurisprudências nacional e estrangeira.

Sem que se tenha plena cognição a respeito do sinal em comento, o operador do direito poderá enfrentar situações, decerto, espinhosas, ao se deparar com o instrumento central do presente estudo. Ante o exposto, forçoso faz-se compreender o instituto ora referenciado, antes de adentrarmos ao instrumento contratual, matéria basilar desta tese.

\section{II.1 MARCA: VALIOSO ELEMENTO INTANGÍVEL DO ESTABELECIMENTO EMPRESARIAL}

A marca é, indubitavelmente, um dos principais elementos que compõem o estabelecimento empresarial. Conforme restará adiante demonstrado, pelo Código da Propriedade Industrial de 1945, a marca não era passível de alienação, sem que com ela também fosse alienado o estabalecimento. Com o advento das legislações subseqüentes, a partir de 1967, esta regra foi revogada, podendo o sinal distintivo em comento ser disposto, nas modalidades de cessão ou licenciamento, independentemente da alienação do estabelecimento correspondente. Isto não significa, contudo, que o estabelecimento empresarial perdeu a sua importância, no âmbito do estudo marcário. Muito pelo contrário, 
porque, pelo fato da marca constituir imperioso elemento intangível do estabelecimento empresarial, em inúmeros casos, a maximização da avaliação econômica do estabelecimento se dará em razão da boa avaliação econômica advinda da marca que o integra. Por certo, ambos os institutos estão intimamente ligados, a despeito de, repise-se, a marca poder ser cedida ou licenciada separadamente do estabelecimento correspondente. Passemos, pois, à análise concisa do estabelecimento comercial, hodiernamente denominado estabelecimento empresarial.

Oscar Barreto Filho define o estabelecimento comercial como "o complexo de bens, materiais ou imateriais, que constitui o instrumento utilizado pelo comerciante para a exploração da atividade mercantil" ${ }^{11}$.

Na lição de Rubens Requião ${ }^{12}$, o estabelecimento comercial é fruto da conjugação dos bens corpóreos e incorpóreos. $\mathrm{Na}$ esteira dos ensinamentos disseminados pelo mencionado comercialista, o sujeito de direito e, por via de consequiência, proprietário do estabelecimento, é o empresário ou a sociedade empresarial ${ }^{13}$.

Requião $^{14}$ assinala que, muito embora o estabelecimento seja corroborado pela agremiação de bens corpóreos e incorpóreos, formando uma singularidade, cada bem que o integra não perde a sua individualidade. Desta forma, pode-se depreender que a marca, como sendo um dos elementos formadores do estabelecimento ou fundo de empresa ${ }^{15}$, não

\footnotetext{
${ }^{11}$ BARRETO FILHO, Oscar. Teoria do Estabelecimento Comercial.2a ed. São Paulo: Saraiva, 1988, p.75

${ }^{12}$ REQUIÃO, Rubens. Curso de Direito Comercial. 23a ed. rev. e atual. São Paulo: Ed. Saraiva, 1998. vol. I, p. 244.

${ }^{13}$ O art. 966 do Código Civil considera empresário "quem exerce profissionalmente atividade economia organizada para a produção ou circulação de bens ou serviços”. Neste diapasão, pode-se depreender, a partir da sistemática da teoria da empresa insculpida na sistemática do Código Civil de 2002, que podem figurar como empresário tanto pessoa jurídica, como pessoa física, contanto que preencham os elementos insculpidos no artigo 966 do Diploma Civil.
}

\footnotetext{
${ }^{14}$ Neste sentido, assinala Requião: "Somos da opinião que o estabelecimento comercial pertence à categoria de bens móveis, transcendendo às unidades de coisas que o compõem e são mantidas unidas pela destinação que lhes dá o empresário, formando em decorrência dessa unidade um patrimônio comercial, que deve ser classificado como incorpóreo. O estabelecimento comercial constitui, em nosso sentir, um bem incorpóreo, constituído de um complexo de bens que não se fundem, mas mantém unitariamente sua individualidade própria”. (cf. REQUIÃO, Rubens. Curso de Direito Comercial. 23a ed. rev. e atual São Paulo: Ed. Saraiva, 1998. vol. I, p. 244.)
}

${ }^{15} \mathrm{O}$ termo fundo de comércio cedeu lugar ao conceito de estabelecimento. Conforme magistério do saudoso prof. Miguel Reale, "o tormentoso e jamais claramente determinado conceito de ato de comércio é 
perde a sua individualidade como tal, podendo, portanto, ser destacada se o empresário ou a sociedade dela titular assim desejar proceder ${ }^{16}$.

No tocante ao valor econômico, De Plácido e Silva ${ }^{17}$ aponta que o estabelecimento comercial, como sendo um produto final da congregação de bens corpóreos e incorpóreos, assume valor econômico objetivo, valor este que não podemos confundir com o valor singular dos elementos que integram o fundo de empresa. Ademais, ainda segundo os ensinamentos do insigne jurista, o estabelecimento comercial é representado pela universalidade dos seguintes elementos: bens corpóreos (mercadorias, instalações, maquinas e utensílios etc.) e bens incorpóreos (contratos, créditos, dívidas, patentes, modelos de utilidade, patente, marcas, desenho industrial, ponto comercial, clientela etc. $)^{18}$.

Consigne-se que a desarticulação de bens supérfluos do estabelecimento, tais quais cadeiras, mesas, máquinas comuns, computadores, armários etc. não lhe diminuirá o valor de mercado. No entanto, quando do estabelecimento são destacados expressivos bens imateriais (como aqueles tutelados pelo direito da propriedade industrial), como, por exemplo, patentes, modelos de utilidade, marcas, segredos industriais, conhecimentos técnicos etc., bens imateriais estes classificados, em certas ocasiões, como essenciais ao exercício da empresa, elevada é a probabilidade de que a segregação destes bens imateriais de seu estabelecimento correspondente resulte em significante desvalorização econômica do estabelecimento empresarial.

substituído pelos atos de empresa e atividade empresarial, assim como a categoria de fundo de comércio cede lugar à de estabelecimento”. (REALE, Miguel. Exposição de Motivos do Projeto de Código Civil. Subsecretaria de Edições Técnicas do Senado Federal, v. 5, t. 2, Brasília, 1989, p. 17).

16 “A idéia, mesmo não tendo forma física, já tem uma configuração que lhe permite ser utilizada, até na ausência do criador, e é passível de transferência como qualquer elemento patrimonial” (LOPES DE SÁ, Antônio. Os valores intangíveis da riqueza patrimonial e a contabilidade do intelectual. Disponível em: $<$ http://www.lopesdesa.com.br/intangiveis.html>. Acesso em: 10/10/2008.)

${ }^{17}$ SILVA, De Plácido e. Vocabulário Jurídico. 15. ed. Atual. Nagib Slaibi Filho e Geraldo Magela Alves. Rio de Janeiro: Forense, 1999. p. 374

\footnotetext{
${ }^{18}$ Imperioso salientar a precisa definição apresentada por Rubens Requião no que tange aos bens corpóreos e incorpóreos. Assim, bens corpóreos são aqueles que ocupam lugar no espaço no mundo exterior, ao passo que os bens incorpóreos não são materializados, porquanto não ocupam lugar no mundo exterior. "São ideais, frutos da elaboração abstrata da inteligência ou do conhecimento humano. Existem na consciência coletiva. Nessa categoria estão os direitos que seu titular integra no estabelecimento comercial e que, em nosso país, são objeto, muitos deles, da Lei da Propriedade Industrial (Lei 9.279/96)". (cf. REQUIÃO, Rubens. Curso de Direito Comercial. 23a rev. atual. São Paulo. Ed. Saraiva, 1998. vol. I, p. 254/255.)
} 
De outra parte, a segregação de um determinado bem material ou imaterial, tido como essencial, de um estabelecimento, ao passo em que acarreta a diminuição de seu valor econômico, pode impactar diretamente no valor econômico do estabelecimento empresarial receptor do bem destacado. Ilustrativamente, se uma marca de alto valor de mercado é licenciada, com exclusividade, de uma sociedade empresária "A" para uma sociedade empresária "B", é natural que o estabelecimento empresarial "A" seja depreciado, ao passo que o estabelecimento empresarial " $B$ " tenha seu valor de mercado maximizado.

Após importantes evoluções legislativas, pautadas, sobretudo, no direito estrangeiro, decidiu o legislador nacional ${ }^{19}$, por intermédio do Código Civil de 2002, conceituar o estabelecimento empresarial nos artigos 1.142 e 1.143 , os quais, devido a suas importâncias para o presente estudo, seguem abaixo colacionados:

Art. 1.142. Considera-se estabelecimento todo complexo de bens organizado, para exercício da empresa, por empresário, ou por sociedade empresária.

Art. 1.143. Pode o estabelecimento ser objeto unitário de direitos e de negócios jurídicos, translativos ou constitutivos, que sejam compativeis com a sua natureza.

Ante as breves considerações atinentes ao conceito e elementos integrantes do estabelecimento empresarial, passemos ao exame dos atributos de um de seus mais preciosos elementos incorpóreos: a marca.

${ }^{19}$ Registre-se que no direito nacional, até a publicação da Lei 10.406/2002 (Código Civil), não havia definição ou regramento para o estabelecimento comercial, que fora construída pela doutrina e jurisprudência e, após, incorporada ao Direito Positivo Brasileiro. Nesta linha de inserção de normas ao direito positivado, preciosas se fazem as palavras do prof. Miguel Reale, alicerçando-se em pensamento corroborado por Tullio Ascarelli, ao afirmar, in verbis, "se os precedentes jurisprudenciais não exercem, nos países de tradição romanística, o papel por eles desempenhado na experiência do common law, nem por isso é secundária a sua importância. Pode mesmo dizer-se que o seu alcance aumenta dia a dia, como decorrência da pletora legislativa e pela necessidade de ajustar as normas legais cada vez mais genérica ou tipológicas, como modelos normativos abertos (standards), às peculiaridades das relações sociais". (REALE, Miguel. Lições Preliminares de Direito. 24a ed. São Paulo: Ed. Saraiva. 1998. p. 169) 


\section{II.2 HISTÓRICO E EVOLUÇÃO}

No que tange à procedência das marcas, há doutrinadores, comumente representados pelos Europeus, que indicam a sua origem na antiguidade, ao passo que há corrente doutrinária que considera a Idade Média como o marco do surgimento da marca ${ }^{20}$.

Alguns autores europeus e nacionais indicam o surgimento das marcas na Idade Antiga, já em Roma. Compartilham desta doutrina autores franceses, como Marie-Angéle Perot-Morel, que preleciona que "o uso de uma marca de fábrica ou de comércio é uma manifestação espontânea da luta contra a concorrência, cujos traços são encontrados na mais remota antiguidade" ${ }^{21}$, como, da mesma forma, Maillard de Marafy e Alexandre Braun $^{22}$. Doutrinadores brasileiros, tais quais Waldemar Ferreira ${ }^{23}$ e Paulo Roberto Tavares $\mathrm{Paes}^{24}$, a esta tese igualmente se inclinam, ao indicar que a marca teve sua origem na Roma antiga.

Para outros autores, a origem da marca dá-se no período medieval. Carvalho de Mendonça $^{25}$ vislumbra o aparecimento mais concreto das marcas na Idade Média. Para o este tratadista, o uso deste sinal operou-se com muita constância naquele período, lembrando que o uso das marcas era, de certa forma, imposto pelos estatutos da época a todo os comerciantes, de tal sorte que as marcas deveriam ser devidamente registradas na

\footnotetext{
${ }^{20}$ MORO, Maitê Cecília Fabbri. Direito de Marcas: abordagem das marcas notórias d Lei 9.279/1996 e nos acordos internacionais. São Paulo: Ed. Revista dos Tribunais, 2003. p. 23.

21 “l'utilisation d'une marque de fabrique ou de commerce est uma manifestation spontanée de la lutte contre la concurrence dont on trouve des traces dans l'antiquité la plus reculée" (Marie-Angèle Pérot-Morel. L" extension de la protecion des marques notories. Revue Trimestrel Du Droit Comercial. Paris, vol. 19, p. 10, 1966, Apud MORO, Maitê Cecília Fabbri, ob. Cit. p. 23.)

${ }^{22}$ MARAFY, Maillard de. Grand Dicitionnaire International de la Popriété Industrielle, vol. 1o, v. Antiquité de marques; BRAUN, Alexandre. Nouveau Traité des Marques de Fabrique et de Commerce. N. 1, p. 19. apud CERQUEIRA, João da Gama, Tratado da Propriedade Industrial. Rio de Janeiro: Ed. Forense, 1946, vol. I, p. 340 e ss.

${ }^{23}$ FERREIRA, Waldemar. Tratado de Direito Comercial. São Paulo: Ed. Saraiva, 1962. vol. VI, p. 254.

${ }^{24}$ PAES, Paulo Roberto Tavares. Propriedade Industrial. $2^{\text {a }}$ ed., revista e ampliada. São Paulo: Ed. Saraiva. 1987. p. 13.

${ }^{25}$ MENDONÇA, José Xavier Carvalho de, Tratado de Direito Comercial Brasileiro. Rio de Janeiro: Freitas

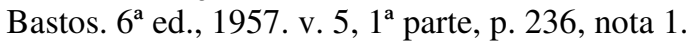


corporação dos mercadores e, por via de conseqüência, registradas no livro da corporação. Adicionalmente, ainda na esteira dos ensinamentos do renomado tratadista, os sinais que guardavam certas semelhanças com outros previamente registrados nas corporações não poderiam ser inscritos, devendo o mercador, portanto, alterar aqueles sinais por outros que não colidissem com aqueles anteriormente registrados.

João da Gama Cerqueira ${ }^{26}$, por igual, aponta, incisivamente, que o surgimento do uso da marca, com os caracteres assemelhados àqueles hodiernamente apresentados, ocorreu na Idade Média. Para um dos principais expoentes do direito da propriedade intelectual, no medievo, as marcas apresentavam contornos e elementos concebidos pelas legislações marcárias contemporâneas, tendo, pois, caráter de propriedade mais próximo com a conceituação corroborada pela legislação e doutrina contemporâneas pertinentes ao tema. Nos dizeres do mencionado tratadista, foi naquele período que se obteve a primeira legislação de marcas que se teve conhecimento na História, sendo que, na Idade Média, as marcas não eram somente admitidas, mas também disciplinadas e resguardadas pela legislação da época.

Em que pese a afirmação de corrente doutrinária de que o surgimento da marca operou-se na antiguidade, convergimos para o entendimento de que o período medieval é o marco do surgimento do sinal em comento, como instituto jurídico, especialmente com os traços e feições externados pela legislação contemporânea, ou seja, com o escopo maior de identificar e diferenciar produtos ou serviços congêneres produzidos em um mesmo nicho de mercado daqueles gerados por outros empresários, sob um viés notadamente concorrencial.

Com efeito, a marca passa a assumir enorme importância jurídica na Idade Média, passando, a partir deste período, a ter proteção contra sua má utilização, salvaguardando, assim, os direitos de seus titulares. Merece apreciação, neste sentido, precioso ensaio confeccionado pelo professor Newton Silveira ${ }^{27}$, com amparo no estudo

\footnotetext{
${ }^{26}$ CERQUEIRA, João da Gama, Tratado da Propriedade Industrial. Rio de Janeiro: Ed. Forense, 1946 , vol. I, p. 340 e ss.

27 SILVEIRA, Newton. Sinais Distintivos da Empresa. In Revista da ABPI- Associação Brasileira da Propriedade Intelectual n. ${ }^{\circ}$ 98. São Paulo: ABPI, jan/fev 2009, pp. 4-8.
} 
realizado pelo jurista peruano Carlos Alejandro Guerrero, em texto sobre a Historia del derecho de marcas $^{28}$.

Para Carlos Guerrero, não há que se confundir o advento das marcas, como símbolos passíveis de identificação de propriedade, com o surgimento do instituto jurídico das marcas, ou melhor, o "direito das marcas". São fatos, cujas origens se distanciam por milhares de anos. As marcas, na primeira acepção (desvencilhada da concepção de instituto jurídico), tem seu uso comprovado na China, há aproximadamente 5.000 anos, em que sua utilização era verificada em cerâmica, ou mesmo, no Egito, em que há provas da utilização das marcas de fogo de gado e marcas para identificar as pedreiras que deram origem às pedras que integravam as edificações e pirâmides, há 2.000 anos antes da Era Cristã. No entanto, para o jurista peruano, a marca, vista como instituto jurídico, apresenta-se, em seu estado embrionário, a partir da Idade Média, com o aparecimento do direito mercantil. Com o surgimento deste segmento do direito, as marcas corporativas (derivadas de cada corporação de ofício) constituíam elementos de controle da concorrência, dentro de um sistema de concorrência delimitada, em que havia pré-fixação e uniformização dos preços dos produtos comercializados à época.

Mais importante do que a origem da marca, é a evolução de sua função nos diversos contextos em que este sinal encontra-se imerso. Com efeito, a função primordial da marca, no contexto medieval, era a identificação da origem do produto e não do produto em si. De tal modo, a função original da marca era primordialmente identificadora, porquanto tinha o escopo precípuo de apontar o estabelecimento no qual havia sido manufaturado ou mesmo comercializado determinado produto, indicando a corporação de ofício que havia dado ensejo ao produto ${ }^{29}$.

Este predicado da marca, à época, revestia-se de "função de garantia de qualidade", pois que consistia em verdadeira "marca coletiva" (proveniente de determinada entidade reconhecida pelo público consumidor principalmente). Isto porque a marca corporativa era aliada à marca do mestre. Esta conjugação de "marcas” possuía claro intuito de proteger o

\footnotetext{
${ }^{28}$ GUERRERO, Carlos Alejandro Cornejo. in CARVALHO, Patrícia Luciane de (coord.). Propriedade Intelectual - Estudos em homenagem à professora Maristela Basso. Vol. 2. $1^{\mathrm{a}}$ ed. Curitiba: Juruá Editora, 2008, p. 103-123.

${ }^{29}$ FERREIRA, Waldemar. ob. cit. p. 256.
} 
consumidor em caso de produto defeituoso, considerando que o consumidor lesado, exercendo o controle de qualidade, teria a quem reclamar para pleitear reparação pelos danos sofridos (função identificadora da marca ou "indicação de origem ou procedência da mercadoria" ${ }^{30}$ ).

Neste tocante, impõe-se mencionar lição ministrada por Cesare Vivante ${ }^{31}$, para quem a marca, em sua função de identificação da origem do produto, tinha por fim demonstrar ao público quem colocou no comércio determinados produtos, bem como demarcar quais foram os empresários que haviam logrado êxito na consquista de crédito e de uma extensa clientela fidelizada. Esta identificação ocasionada pela marca, para Vivante, tinha como escopo final proteger o público das contrafações dos produtos originais, porque a simples inspeção da marca era suficiente para assegurar a origem e qualidade de tais produtos.

Citando Remo Franceschelli ${ }^{32}$, P.R. Tavares Paes sinaliza que a marca tinha por desígnio determinar a procedência e, igualmente, a qualidade refinada do produto, marcando sua superioridade qualitativa em relação à concorrência, como, por exemplo, “o vinho do lácio", "cerâmica de Arezzo" etc.

Robustecendo a importância das marcas na Idade Média, impende-se registrar que foi nesta época que se deu o surgimento do delito da contrafação, obviamente guardandose as devidas proporções instas àquele tempo. Leciona Franceschelli ${ }^{33}$ que, na utilização de uma marca que já estava sendo utilizada por outrem, sujeitava-se o contrafator a perder a mercadoria, tê-la destruída e ainda ficar proibido de proceder ao exercício da profissão por determinado período, além daquelas sanções de caráter mais radical que proibiam definitivamente, e em caráter irrevogável, o mercador de exercer seu ofício.

\footnotetext{
${ }^{30}$ SILVEIRA, Newton. Sinais distintivos da empresa....op. cit. p. 2.

${ }^{31}$ VIVANTE. Cesare. Instituições de Direito Comercial. $2^{\mathrm{a}}$ ed. São Paulo: Ed. Minelli. 2007. pp. 150/151

${ }^{32}$ FRANCESCHELLI, Remo, Tratadi di Diritto Industriale, v. 1, p. 77. Giuffré. Milão Apud PAES, P.R., TAVARES, Nova Lei da Propriedade Industrial. Lei 9.279, de 14.05.1996., São Paulo. Ed. Revista dos Tribunais, 1996. p. 81.

${ }^{33}$ Remo Franceschelli. Trattato di diritto industriale. Milão. Giufreè, 1973, vol. I, p. 156, Apud Douglas Gabriel Domingues. Marcas e Expressões de Propaganda. São Paulo: Ed. Forense, 1984, p. 7.
} 
$\mathrm{Na}$ Era Moderna, com a promoção da liberdade de concorrência e estímulo às atividades industrial e comercial, fruto dos valores disseminados pela Revolução Francesa, surge um novo direito marcário, em que a "marca passa a ser considerada como objeto de propriedade com o fim de identificar o produto em si" ${ }^{34}$, e não mais o seu produtor (empresário), como ocorria na Idade Média. Segundo Marie-Angèle Pérot-Morel, na época moderna, a marca passa a representar o sinal distintivo mais importante de um produto, lhe conferindo, desta sorte, importância econômica de primeiro plano ${ }^{35}$.

A partir de 1803, a França volta a editar normas de cunho marcário. Em que pese a ausência de efetividade, a mencionada legislação, prevendo o registro facultativo da marca, previa sanção aos contrafatores por crimes de falsificação de documentos privados ${ }^{36}$. Registre-se, outrossim, que foi a lei francesa de 1857 que se tornou fonte de inspiração para a edição inaugural da legislação marcária brasileira ${ }^{37}$, em 1875.

No Brasil, no plano constitucional, o instituto jurídico da marca não chegara a ser expressamente recepcionado pela Constituição Imperial de 1824, diploma este que apenas conferia aos inventores "a propriedade de suas descobertas ou de suas produções". A Constituição Republicana de 1891 foi o primeiro texto constitucional que aderiu expressamente a proteção em matéria de marcas comerciais. O $\S 27$, do artigo 72, da aludida Carta, previa, textualmente, que "a lei assegurará também a propriedade das marcas de fábrica". O Carta Suprema de 1967, em seu artigo 150, § 24, assegurava que "a lei garantirá aos autores de inventos Industriais privilégio temporário para sua utilização e assegurará a propriedade das marcas de indústria e comércio, bem como a exclusividade do

\footnotetext{
${ }^{34}$ SILVEIRA. Newton. Sinais distintivos da empresa. op. cit. p. 5.

35 "Al' époque moderne la marque est avant tout Le symbole d'um produit et la force de son pouvoir d's évocation lui confere une importance économique de premier plan”. (Marie-Angéle Pérot-Morel. L'extension....ob. cit. p. 11 Apud MORO, Maitê Cecília Fabri, Direito de Marcas. Ob. cit. p.26).

36 Cf. MARTINS, Fran. Curso de Direito Comercial: empresa comercial, empresários individuais, microempresas, sociedades empresárias, fundo de comércio. $33^{\mathrm{a}}$ ed. rev. e atual. por Carlos Henriue Abrão. Rio de Janeiro: Forense. 2010. p. 447; e MORO, Maitê Cecília Fabri, op. cit. p. 27.

${ }^{37}$ CERQUEIRA, Joao da Gama. Tratado da Propriedade Industrial. $3^{\mathrm{a}}$ ed. Atualizada por: Newton Silveira e Denis Borges Barbosa. Rio de Janeiro: Ed. Lumen Júris. 2010. Vol.I. Parte I. p. 271. (Nota: Esta terceira edição do Tratado da Propriedade Industrial, atualizada por Newton Silveira e Denis Borges Barbosa, reproduz, fidedignamente, o texto original de 1946, tendo, apenas, sido inseridas notas destacadas de atualização, sinalizando as alterações legislativas, jurisprudenciais e doutrinárias que modificaram o Direito da Propriedade Industrial nos mais de 60 anos trasncorridos desde a publicação da obra inaugural de João da Gama Cerqueira)
} 
nome comercial”. Finalmente, a Constituicao da República Federativa do Brasil, de 1988, em vigor, estabeleceu em seu artigo 5, inciso XXIX, que “ a lei assegurará aos autores de inventos industriais privilégio temporário para sua utilização, bem como proteção às criações industriais, à propriedade das marcas, aos nomes de empresas e a outros signos distintivos, tendo em vista o interesse social e o desenvolvimento tecnológico e econômico do País”.

$\mathrm{Na}$ esfera legal, a primeira lei de marcas foi criada em 1875, fruto do Decreto 2.682 de 1875. Este foi o primeiro diploma legal em matéria de proteção de marcas. Originou-se do esforço do então advogado Rui Barbosa perante o Parlamento Nacional para que esta proteção fosse expressamente mencionada em lei. A aludida representação perante o parlamento sucedeu o evento em que Rui Barbosa advogou em favor da empresa "Meuron \& Cia.”, sediada na Bahia, na defesa da marca de rapé Areia Preta, que houvera sido usurpada por terceiros. O resultado desta demanda foi totalmente desfavorável à empresa titular da marca, cujos interesses eram patrocinados por Rui Barbosa. Tal afirmação decorre do fato de que o Tribunal de Relação da Bahia entendeu que "nem o Código Criminal, nem nenhuma outra lei qualifica delito o fato em que se assentou o processo". A despeito do fato da usurpação ter sido cabalmente demonstrado, era patente o laconismo legal no âmbito desta matéria de direito industrial, não tendo os magistrados, à época, elementos jurídicos suficientes para proceder à pleiteada condenação e reposanbilização civil dos fraudadores. Após a edição da Lei de 1875, e com o objetivo de adequar a legislação interna às convenções e acordos internacionais, procedeu-se à edição da Lei n. ${ }^{\circ}$ 1.887. Na seqüência, vieram outros diplomas versando sobre a proteção das marcas, com destaque para os Códigos de Propriedade Industrial de 1945, 1969 e 1971. Presentemente, o disciplinamento jurídico das marcas se dá pela Lei n. ${ }^{0} 9.279$, de 14 de maio de $1996 .{ }^{38}$

\footnotetext{
${ }^{38}$ Cf. PAES, P.R. Tavares. Nova Lei de Propriedade Industrial. Lei 9.279 de 14/05/1996. São Paulo. Ed. Revista dos Tribunais. p. 82; e REQUIÃO, Rubens. Curso de Direito Comercial. São Paulo: Saraiva, 2003. pp. $240 / 241$.
} 


\section{II.3 DEFINIÇÃO}

A contribuição doutrinária para a formação de um conceito singular de marca é, por certo, farta. Inúmeras são as definições encontradas na doutrina para o sinal sob estudo. Complexa, todavia, se faz a busca de uma definição doutrinária única, perfeita, porquanto muitas delas são claras e bem definem o conceito que se busca alcançar.

Carvalho de Mendonça ${ }^{39}$, remetendo-se à Lei n. ${ }^{\circ} 1.236$, de 24 de setembro de $1904^{40}$, conceitua a marca como "sinais gráficos ou figurativos, destinados a individualizar os produtos de uma empresa industrial ou as mercadorias postas à venda em uma casa de negócio, dando a conhecer a origem ou proveniência a atestando a atividade e o trabalho de que são o resultado" ${ }^{41}$.

João da Gama Cerqueira" ${ }^{42}$ define a marca como "todo sinal distintivo aposto facultativamente aos produtos e artigos das indústrias em geral para identificá-los e diferenciá-los de outros idênticos ou semelhantes de origem diversa”. Saliente-se que o ilustre tratadista confere à definição por ele delineada um caráter notadamente híbrido, no sentido de que a marca detém uma função identificadora do produto e, concomitantemente, distintiva em comparação com outros produtos iguais ou semelhantes, que tenham se originado de produtores distintos.

\footnotetext{
${ }^{39}$ MENDONÇA, J.X. Carvalho. Tratado de Direito Comercial Brasileiro. $2^{\text {a }}$ ed. vol. V. Livro III. Rio de Janeiro: Ed. Freitas Bastos. 1934. p. 215.

40 "A lei [1236/1904] não define a marca; contentou-se com a disposição do art. $1^{\text {o }}$, que vale mais que definição". (Idem, Ibidem, p. 215)

${ }^{41}$ Neste sentido, esta definição ganha ainda mais credibilidade, após afiançada por Gama Cerqueira, posto que esta definição ministrada por Carvalho de Mendonça à Gama Cerqueira parece "a mais exata". (Cf. CERQUEIRA, João da Gama. Tratado da Propriedade Industrial. $3^{\mathrm{a}}$ ed. atual. por Newton Silveira e Denis Borges Barbosa......op. cit. Vol. I. Parte I. p. 254).

42 CERQUEIRA, João da Gama. Tratado da Propriedade Industrial. $3^{\mathrm{a}}$ ed. atual. por Newton Silveira e Denis Borges Barbosa......op. cit. Vol. I. Parte I. p. 253.
} 
Conforme melhor magistério de Waldemar Ferreira", as marcas são "palavras, sinais ou figuras, isoladas ou em conjunto, de forma original, adotados e de uso exclusivo do fabricante ou comerciante, assegurado pelo registro, a fim de assinalarem-se seus produtos ou mercadorias as exporem à venda".

Para Tavares Paes, a marca consiste no sinal ou expressão que tem a finalidade de individualizar os produtos produzidos ou serviços prestados por uma empresa, de tal sorte que os mesmos sejam visivelmente identificados ${ }^{44}$.

No escólio do espanhol Carlos Fernández-Novoa ${ }^{45}$, a marca consiste na conjugação do sinal exteriorizado e antes idealizado pelo empresário com o produto que se almeja lançar no mercado. Com efeito, o binômio sinal/produto corrobora a formação da marca. Podemos depreender, a partir dos ensinamentos do jurista sob análise, que os elementos segregados não são aptos a formar a marca. Apenas a agremiação de dois bens materiais (sinal e produto) dará ensejo à formação de um bem incorpóreo: a marca.

No que concerne às acepções adotadas pelas legislações nacional e internacional, merecem destaque as definições a seguir esposadas.

A OMPI ${ }^{46}$ (Organização Mundial da Propriedade Intelectual) define a marca como "sinais distintivos usados para diferenciação entre produtos idênticos ou parecidos ofertados por diferentes produtores ou prestadores de serviços" $" 47$.

\footnotetext{
${ }^{43}$ FERREIRA, Waldemar.... op. cit. p. 31.

${ }^{44}$ PAES, P.R. Tavares. Nova Lei de Propriedade Industrial. ob. cit. p. 83.

45 FERNÁNDEZ-NOVOA, Carlos. Fundamento del derecho de marcas. Madrid. Editorial Montecorvo, 1984. p. 24 e seguintes.
}

46 A WIPO (OMPI, sigla em português) é uma agência da Organização das Nações Unidas (ONU). Ela é dedicada a desenvolver um equilibrado e acessível sistema de propriedade intelectual, o qual recompensa a criatividade, estimula a inovação e contribui para o desenvolvimento econômico ao mesmo tempo em que salvaguarda o interesse público. A OMPI foi fundada em 1967 com o objetivo de promover a proteção da propriedade intelectual pelo mundo através da cooperação entre os estados e em colaboração com outras organizações internacionais. < http://www.wipo.int/about-wipo/en/what/>. Acessado em 28/10/2008.

${ }^{47}$ Segue a definição original, extraída do website oficial da OMPI. "Trademarks are distinctive signs, used to differentiate between identical or similar goods and services offered by different producers or services providers. Trademarks are a type of industrial property, protected by intellectual property rights". (Tradução Livre). (http://www.wipo.int/trademarks/en/). Acesso em 28/10/2008. 
Por fim, cabe mencionar o conceito legal conferido pela Lei 9.279/96, em vigor no Brasil, que prescreve, em seu artigo 122: São suscetíveis de registro como marca os sinais distintivos visualmente
perceptiveis, não compreendidos nas proibições legais. (grifou-se)

Desta forma, decidiu o legislador adotar conceito modesto e genérico, pautando-se, sobretudo, na máxima de que aquilo que não está proibido é permitido ${ }^{48}$.

\section{II.4 NATUREZA JURÍDICA}

Preliminarmente, cumpre assinalar que o estudo da natureza jurídica da marca se faz de expressiva importância, porquanto, dependendo da natureza que lhe for atribuída, aplicar-se-á um regime jurídico ou outro. Portanto, concomitantemente ao caráter acadêmico, o estudo da natureza jurídica da marca assume especial importância de cunho pragmático, mormente para se alcançar o regime jurídico próprio que lhe será aplicado.

Dentre as doutrinas que buscam alcançar e definir a natureza jurídica do sinal em apreço se apresentam, com recorrência, a doutrina do direito pessoal, a doutrina dos direitos intelectuais, a teoria dos direitos sobre bens imateriais e, finalmente, a teoria do direito de propriedade. ${ }^{49}$

\footnotetext{
${ }^{48}$ Utilizando-se desta máxima principiológica de que aquilo que não é proibido, é permitido, arraigada ao ordenamento jurídico brasileiro, o Superior Tribunal de Justiça assim tem se pronunciado em caso de extrema complexidade, a seguir colacionado: "Processo Civil. Ação Declaratória de União Homoafetiva. Princípio da Identidade Física do Juiz. Ofensa não caracterizada ao artigo 132 do CPC. Possibilidade Jurídica do Pedido. Alegação de lacuna legislativa. Possibilidade de emprego da analogia como método integrativo. (....). 3. A despeito da controvérsia em relação à matéria de fundo, o fato é que, para a hipótese em apreço, onde se pretende a declaração de união homoafetiva, não existe vedação legal para o proseguimento do feito." (grifou-se). (Superior Tribunal de Justiça. Recurso Especial n. ${ }^{\circ} 820.475$ - RJ (2006/0034525). Min. Rel. Antônio de Pádua Ribeiro. Doc. no 4299769).

${ }^{49}$ CERQUEIRA, Joao da Gama. Tratado da Propriedade Industrial. $3^{\mathrm{a}}$ ed. Atualizada por: Newton Silveira e Denis Borges Barbosa. pp. Cit..... Vol.I. Parte I. pp. 243-252.
} 
A doutrina do direito pessoal ministra a tese do direito à marca como direito de personalidade. Os defensores desta corrente, capitaneada pelo jurista italiano Luigi Di Franco, assinalam que a marca é uma extensão da personalidade humana, da criação do homem. Com efeito, a lesão ao direito de propriedade não fere o direito de propriedade em si mesmo, mas sim o próprio indivíduo, em seu direito pessoal. Isto porque, ao contrário do que ocorre com as produções literárias, artísticas e invenções industriais, que "possuem consistência bem definida e distinta da pessoa do autor", a marca, "além de não ser, em si, o resultado de nenhum trabalho, mesmo intelectual, que lhe empreste individualidade distinta e autônoma, nunca de destaca da pessoa do industrial",50.

Gama Cerqueira, contudo, rechaça veementemente a teoria do direito pessoal, precipuamente ao asseverar que os direitos de personalidade recaem sobre a pessoa, enquanto que a marca incide sobre o produto, objeto exterior segregado do indivíduo criador $^{51}$. Ademais, os direitos de personalidade são inalienáveis, imprescritíveis e destituídos de valoração econômica. A marca, por seu turno, é perfeitamente passível de segregação de seu titular, seja por meio de cessão, seja por meio de licença, conforme restará adiante demonstrado.

Newton Silveira, alicerçando-se nas lições disseminadas pelo ilustre Túlio Ascarelli, por igual, converge para o entendimento de que a marca representa um bem imaterial tutelado que é extrínseco ao titular do direito não se confundindo, por conseguinte, com a personalidade deste. Ilustra, ainda, que o nome empresarial e a marca, a despeito de estarem inseridos no rol dos direitos de propriedade intelectual, são disciplinados sob o manto de regimes jurídicos distintos. A marca é tutelada sob o regime de direito real (propriedade), podendo o seu titular usar, dispor e fruir do sinal quando lhe aprouver. Por seu turno, o nome empresarial é regulado pelos direitos da personalidade, insculpidos, à exaustão, no novo diploma civil, não podendo, portanto, sê-lo alienado, tal qual ocorre com o nome da pessoa física, em sendo este atributo intrinsecamente conectado à intimidade da pessoa ${ }^{52}$.

\footnotetext{
${ }^{50}$ FRANCO, Luigi Di. Trattato della proprietà indusrtiale. Milano. Società Editrice Libraria, 1933. p. 19 apud CERQUEIRA, Joao da Gama. Tratado da Propriedade Industrial. $3^{\mathrm{a}}$ ed. op. cit..p. 247.

${ }^{51}$ Para o jurista, "a marca é um bem exterior à pessoa e não inerente a ela". (Cf. CERQUEIRA, Joao da Gama. Tratado da Propriedade Industrial. $3^{\mathrm{a}}$ ed. op. cit..pp. 247-248).

52 SILVEIRA, Newton. A Propriedade Intelectual no Novo Código Civil Brasileiro. in "Revista de Direito
} 
A segunda doutrina que investiga a natureza jurídica das marcas consiste na doutrina dos direitos intelectuais. Em consonância com esta corrente, os direitos sobre as marcas não se enquadrariam nos direitos pessoais, reais e de obrigações, porquanto estão albergados em uma nova categoria de direitos, corporificados pelos direitos intelectuais ${ }^{53}$.

A terceira doutrina apresentada sobre o tema consiste naquela que defende o direito marcário como direito sobre bens imateriais. Tal corrente doutrinária confirma o entendimento de que o uso das marcas confunde-se com a natureza de direito individual, limitando-se, até certo ponto, à teoria do direito pessoal ${ }^{54}$.

Por fim, impende-se destacar a teoria da qual nos apresentamos partidários, corporificada na defesa do direito de marcas como direito de propriedade, devendo tais sinais ser albergados por este regime jurídico. Nesta esteira, registrem-se, in verbis, os preciosos ensinamentos de Gama Cerqueira ${ }^{55}$ ao afirmar, categoricamente, a natureza de direito de propriedade às marcas:

Tratando, agora, de marcas industriais em particular, não nos apartamos dessas conclusões, considerando o direito sobre as marcas como um direito privado patrimonial, de natureza real, que tem por objeto bens ou coisas incorpóreas, tal como os outros direito que compõem o quadro da propriedade imaterial. (....) O fato de ser incorpóreo o objeto desse direito não lhe tira o caráter de propriedade, a cujo conceito não é essencial a natureza imaterial, tangível, do objeto. $O$ mesmo acontece com o direito sobre a marca, que também constitui uma propriedade imaterial, recaindo sobre uma propriedade incorpórea, que é a marca, considerada, não nos seus exemplares materiais, mas de modo ideal e abstrato. (grifou-se)

Empresarial”. Curitiba. N.2. jul/dez. 2004. p. 195-117.

${ }^{53}$ Esta doutrina é, por igual, repelida por Gama Cerqueira. Conforme preleciona o ilustre tratadista, "esta teoria, que gozou de bastante voga, mas que não se impôs definitivamente, é inteiramente falha em relação às marcas e outros sinais distintivos, que não podem ser considerados como concepções ou criações intelectuais”. Ademais, explicita referido autor: “(...) é certo que, em relação, às marcas, a ocupação é, realmente, a apropriação de um sinal de uso comum; em segundo lugar, porque, tratando-se de marcas que se distingam pelo seu cunho artístico, como verdadeira criação ou concepção intelectual, o direito resultantes dessa criação constituiria propriedade artística de seu autor e, como tal deveria colocar-se na primeira categoria das produções intelectuais [direito de autor]".(Cf. CERQUEIRA, Joao da Gama. Tratado da Propriedade Industrial. $3^{\mathrm{a}}$ ed. op. cit..p.p. 250-251).

${ }^{54}$ CERQUEIRA, Joao da Gama. Tratado da Propriedade Industrial. $3^{\mathrm{a}}$ ed. op. cit....pp. 251-252.

${ }^{55}$ Idem, Ibidem, p. 244. 
Do entendimento acima exposto compartilha Rubens Requião ${ }^{56}$, ao assinalar à "marca" um caráter de direito notadamente patrimonial, cujo fito é a proteção de bens incorpóreos. Neste sentido, e até certo ponto se remetendo à doutrina dos direitos pessoais, Requião indica que a "criação ideal", portanto bem incorpóreo, é que é protegida. A matéria que exterioriza aquela criação intelectual não seria passível de proteção. $O$ "exemplar" da marca é apenas um padrão que veicula a criação intelectual com o mundo exterior.

Portanto, é majoritária a doutrina que converge para o entendimento de que o direito de propriedade ${ }^{57}$ é perfeitamente aplicável às marcas. Ademais, com o advento da Carta Magna de 1988, fora expressamente recepcionado o direito de propriedade às marcas, no capítulo que elenca os direitos e garantias fundamentais, conforme se pode depreender do dispositivo constitucional infra transcrito, ipsis literis:

Art. $5^{\circ}$ - Todos são iguais perante a lei, sem distinção de qualquer natureza, garantindo-se aos brasileiros $e$ aos estrangeiros residentes no País a inviolabilidade do direito à vida, à liberdade, à igualdade, à segurança e à propriedade, nos termos seguintes:

XXIX - a lei assegurará aos autores de inventos industriais privilégio temporário para sua utilização, bem como proteção às criações industriais, à propriedade das marcas, aos nomes de empresas e a outros signos distintivos, tendo em vista o interesse social e o desenvolvimento tecnológico e econômico do País; (grifou-se)

Sucede, todavia, que o direito de propriedade aplicável às marcas deve ser "especial", e se fazer em consonância com os elementos e dispositivos normativos próprios da legislação específica ${ }^{58}$. Neste aspecto, o direito de propriedade aplicável aos sinais em

\footnotetext{
${ }^{56}$ REQUIÃO, Rubens. Curso de Direito Comercial. São Paulo. Saraiva. 2003. vol 1. $25^{\text {a }}$ ed. p. 241.

${ }^{57}$ Nesse sentido, ver também: BERTOLDI, Marcelo M. e RIBEIRO, Márcia Carla Pereira. Curso Avançado de Direito Comercial. $4^{\mathrm{a}}$ ed. atualizada. São Paulo: Revista dos Tribunais. 2008. p. 114.

${ }^{58}$ Neste sentido, convém transcrever a conclusão dos ensinamentos de Maitê Cecília Fabbri, ao estudar a obra de José Roberto Gusmão (“'L' acquisition Du droit sur la marque au Brésil. Paris: Litec, 1990. p. 9-47): "O direito de propriedade sui generis não nega o direito de propriedade, mas alerta para a especificidade do regime jurídico que deve ser empregado para os bens imateriais. É um regime particular adaptado aos bens imateriais. É um regime particular adaptado aos bens incorpóreos, podendo, por isso, ser considerado o regime mais adequado para tutelá-los" (MORO, Maitê Cecília Fabbri. Direito de Marcas: abordagem das marcas notórias da Lei 9.279/1996 e nos acordos internacionais. São Paulo. Ed. Revista dos Tribunais, 2003. p. 52)
} 
apreço merece destaque, mormente quando o titular da marca registrada, como detentor de um direito real sobre um bem imaterial, tem a prerrogativa legal de reivindicar como seu aquilo que foi legitimamente adquirido, de usar, gozar e dispor dessa marca, com exclusão de outrem, nos limites da lei ${ }^{59}$.

Conforme nos elucida o saudoso professor Silvio Rodrigues ${ }^{60}$, o proprietário de determinado bem dispõe das seguintes:

(i) Faculdade de Uso (jus utendi): Pela qual se reconhece ao proprietário a possibilidade de usar o bem para a satisfação de suas próprias necessidades, com a exclusão de terceiros no que concerne ao mesmo uso;

(ii) Faculdade de Gozo (jus fruendi): Pela qual o proprietário pode auferir os frutos que o bem produzir. Saliente-se, neste tocante, o comando insculpido no artigo 1.232 do Código Civil que prescreve que os frutos do bem, ainda que deste segregados, pertencem ao proprietário, salvo se, por previsão normativa diversa, couberem a outrem; e

(iii) Faculdade de Disposição (jus abutendi): pela qual the cabe o poder de dispor do bem através de atos de várias naturezas, como venda, doação ou alienação outra $^{61}$.

Forçoso concluir, portanto, ao assumir a teoria da aplicação do direito de propriedade às marcas, que o titular tem o direito de dispor do sinal que ele tenha registrado e venha utilizando em seus produtos e/ou serviços, o que se opera, nesta seara,

\footnotetext{
59 “Ius utendi, fruendi et abutendi re sua, exclusis aliis, quatenus iuris ratio patitur” - Digestae, 7, 8, 2, par.

${ }^{60}$ RODRIGUES, Sílvio. Direito civil - Direito das Coisas. São Paulo. Ed. Saraiva, São Paulo. 2003. vol. 5. pp. $77 / 78$.

${ }^{61}$ Silvio Rodrigues chama atenção para esta faculdade ao qual faz jus o proprietário, apontando para a nova ordem jurídica em que a função social da propriedade deve imperar. Forçoso, pois, trazer à baila os ensinamentos do exímio civilista que preceitua, in literis: "[o direito de dispor] não significa prerrogativa de abusar da coisa, destruindo-a gratuitamente. Aliás, se nem no direito romano se admitia a idéia de um uso anti-social do domínio, hoje tal noção é inconcebível, principalmente em um país como o nosso, cujas várias Constituições de há muito proclamam que o uso da proprieadade será condicionado ao bem-estar social”. (RODRIGUES, Silvio. ob cit. p. 78)
} 
por meio dos contratos de cessão ou licença de marca, negócio jurídico este que será estudado mais pormenorizadamente em capítulo oportuno desta obra.

Consigne-se, contudo, conforme preleciona Luiz Guilherme Loureiro" ${ }^{62}$, que "o titular da marca não tem sobre esse sinal, em si mesmo considerado, uma propriedade absoluta". Ilustração clássica sobre a limitação ao direito de propriedade ${ }^{63}$ no que tange à proteção marcária consiste na possibilidade de terceiro registrar marca previamente registrada, porém em outro ramo de atividade. Estamos diante, na hipótese em apreço, do princípio da especificidade, que se apresenta como marco delimitador do direito de propriedade à marca, conforme restará demonstrado no capítulo subseqüente apresentado.

No tocante ao uso efetivo da marca de "forma limitada", porquanto restrito à determinada classe de produto ou serviço, é oportuno trazer à colação a teoria do monopólio sobre a marca.

Douglas Gabriel Domingues, ao se debruçar sobre o tema, advoga a tese de que a exclusividade externada por lei para a utilização dos sinais, em cujo rol podemos incluir a marca, representa um verdadeiro "monopólio legal". Para o jurista, "por um ato de império impõe-se à coletividade e outorga-se a alguém um direito de uso exclusivo que terceiros ficam obrigados a respeitar". E continua com o discurso seguinte: "historicamente, inclusive, trata-se do único direito que torna possível a alguém erguer uma proibição ou restrição erga omnes que impede o exercício de atividades que de outra forma poderiam

\footnotetext{
${ }^{62}$ LOUREIRO, Luiz Guilherme de A.V.. A Lei de Propriedade Industrial Comentada (Lei n. 9.279 de 14 de mai de 1996). São Paulo. Ed. Lejus. 1999. p. 229.

${ }^{63} \mathrm{O}$ tema da limitação ao direito de propriedade, em conformidade com os ditames arraigados à Carta Magnos pátria, tem sido amplamente enfrentado pela doutrina. Conforme lição de Denis Barbosa, quando houver conflito entre a livre concorrência e o direito de propriedade do titular, duas análises daí deverão advir. A primeira no sentido de que o titular, como tendo direito real sobre sua criação, poderá se opor erga omines, restringindo, desta sorte, a livre concorrência prevista pela Constituição Federal no artigo 170, principalmente com o corolário de se proteger e estimular os investimentos em novas pesquisas e desenvolvimento. A segunda análise reside na tese de que, para atendimento do interesse público e em cumprimento à função social da propriedade, o titular de uma propriedade intelectual terá seu direito restringido em beneficio da livre concorrência ou saúde pública, de forma a permitir que mais pessoas venham a ter acesso àquele produto. (BARBOSA, Denis Borges. Como conciliar os ditames constitucionais da livre concorrência com o sistema de patentes? Disponível em <www.nbb.com.br>. Acesso em 10 out. 2008) Acrescenta Newton Silveira que "os direitos fundamentais do autor e do inventor permanecem constitucionalmente invioláveis enquanto na esfera pessoal de seus titulares, mas sujeitam-se ao princípio da proporcionalidade com relação ao art. 170 da Constituição quando são postos no mercado" (SILVEIRA, Newton. A Propriedade Intelectual no Novo Código Civil Brasileiro. in "Revista de Direito Empresarial". Curitiba. N.2. jul/dez. 2004. p. 117)
} 
ser livremente exercitadas por todos". Por fim, adverte: "Entretanto, ressalte-se que o monopólio concedido pelo Estado, longe de ser um arma de ataque contra a liberdade econômica, na realidade constitui um instrumento de defesa, vez que é o monopólio legal que impede os atos de concorrência desleal". ${ }^{64}$

O professor Newton Silveira ${ }^{65}$, respaldando-se na melhor doutrina de Remo Fraceschelli, converge, igualmente, para a teoria do monopólio em oposição à teoria da propriedade sobre a marca.

Leciona o professor em comento que, a despeito da lei ter fincado a marca no âmbito do direito de propriedade, tornando-a suscetível de propriedade e circulação como objeto de negócios jurídicos, não é tecnicamente preciso o entendimento que insere a marca no regime jurídico da propriedade, assim como ocorre com outros bens imateriais e obras intelectuais. O que haveria, em verdade, é apenas a propriedade sobre a "aplicação do sinal a determinado produto, mercadoria ou serviço", correspodendo ao uso privativo do sinal em relação à determinada classe de bens materiais ou imateriais (serviços), corroborando, desta sorte, um verdadeiro monopólio privado instituído por lei, e outorgado pelo Estado, cujo desuso implicaria a perda desta autorização de uso ${ }^{66}$.

Pela teoria do monopólio privado sobre a marca, portanto, o Estado confere ao titular do registro marcário, o poder/dever de se utilizar do sinal registrado, em determinada classe de produto ou serviço. "Poder", pelo fato de o titular ter a prerrogativa de usar e dispor daquele bem (seja por meio da cessão ou licença de marca), como melhor lhe aprouver e nos limites da lei . "Dever", pelo fato de o titular ter a obrigação de se utilizar da marca, sob pena de, não o fazendo, perder o registro conferido pelo Estado,

\footnotetext{
${ }^{64}$ DOMINGUES, Douglas Gabriel. Marcas e Expressões de Propaganda. São Paulo: Ed. Forense, 1984. pp. $316 / 317$.

${ }^{65}$ SILVEIRA, Newton. Licença de uso de marca e outros sinais distintivos. $1^{\mathrm{a}}$ edição. São Paulo: Ed. Saraiva, 1984, pp. 25-28.

66 “(...) Ao menos quanto aos sinais distintivos registrados pode-se concordar com Franceschelli que se tratam de monopólios privados instituídos por lei. (...) Mas, tanto a lei leva em conta o uso, como substrato do direito que extingue o monopólio (propriedade) se, em certo tempo, o titular do registro não consolida o direito pelo uso. Mais uma vez, lembrando Ascarelli, há uma aquisição gradual do direito que só se completa, no caso da marca registrada, pelo registro mais o uso ( no caso da marca não registrada, o uso garante outro tipo de direito que decorre unicamente do uso - assimilado à posse do direito civil (...)" (Cf. SILVEIRA, Newton. Licença de uso de marca e outros sinais distintivos......op. cit p. 26).
} 
através do órgão registrário competente. Preceitua o artigo 143, da Lei 9279 que "caducará o registro se, decorridos 5 (cinco) anos da sua concessão, na data do requerimento, o uso da marca não tiver sido iniciado no Brasil; ou o uso da marca tiver sido interrompido por mais de 5 (cinco) anos consecutivos, ou se, no mesmo prazo, a marca tiver sido usada com modificação que implique alteração de seu caráter distintivo original, tal como constante do certificado de registro".

Convergimos para este entendimento, principalmente no que concerne ao poder/dever de uso da marca registrada (predicado capital do monopólio de uso sobre a marca), sem, contudo, abdicar da teoria da propriedade sobre a marca, especialmente porque o titular da marca detém para si todas as prerrogativas inatas ao "direito de propriedade lato sensu", quais sejam, os direitos de usar, gozar e dispor do sinal, ainda que o faça de "forma limitada", e em relação à determinada classe de bens ou serviços.

Aliás, neste aspecto, convém apontar que o direito de propriedade lato sensu, há muito, não mais é absoluto e intangível. Nosso ordenamento jurídico recepciona uma vasta gama de limitações para que o direito de propriedade seja exercido por seu titular, dentro de certo enquadramento jurídico, sempre se visando o bem comum e da coletividade, e não mais se focando exlcusivamente no interesse privado do proprietário ${ }^{67}$. Dentre todas estas limitações, de forma similar com a que se sucede no direito marcário, o ordenamento jurídico nacional prevê $\hat{e}^{68}$, inclusive, a perda do imóvel pela sua não utilização. Esta limitação reside na "desapropriação-sanção", representada pelo instituto do usucapião. Reconheça-se, assim, que mencionado instituto ressalta ainda mais o caráter social da propriedade lato sensu na Carta Magna. As limitações ao exercício da propriedade (incluindo-se a propriedade da marca) decorrem, pois, do equilíbrio que deve prevalecer entre o interesse social e privado, com lastro nos princípios de justiça e do bem comum ${ }^{69}$.

\footnotetext{
${ }^{67}$ MALUF, Carlos Alberto Dabus, Limitações ao Direito de Propriedade: de acordo com o novo código civil e com o estatuto da cidade; prefácio do prof. Miguel Reale - $2^{\mathrm{a}}$ ed. rev. atual. e ampl. São Paulo: Ed. Revista dos Tribunais, 2005. p. 15.

${ }^{68}$ Cf. Art. 1.238 do Código Civil Brasileiro: “Aquele que, por quinze anos, sem interrupção, nem oposição, possuir como seu um imóvel, adquire-lhe a propriedade, independentemente de título e boa-fé; podendo requerer ao juiz que assim o declare por sentença, a qual servirá de título para o registro no Cartório de Registro de Imóveis".

${ }^{69}$ Convém apontar a delimitação ocorrida no campo do direito da propriedade lato sensu, demonstrando a tendência a ser obsernada em todos os segmentos do direito albergados por este regime jurídico. É irretorquível a revolução verificada no direito de propriedade ao longo dos últimos tempos. Neste aspecto,
} 


\section{II.5 REQUISITOS ESSENCIAIS}

A Lei 9.279/96, através da combinação dos dispositivos 122 e 124, exige que a marca preencha requisitos judiciosos para que lhe seja concedido o registro competente. Estes requisitos são considerados pela doutrina dominante como vitais para que o criador de determinado signo logre êxito quando do encaminhamento do pedido de registro ao órgão público competente.

Preliminarmente, cumpre mencionar o princípio da territorialidade o qual é compreendido como o limite precursor do direito de marcas ${ }^{70}$. Assim, reza o artigo 129 da Lei 9.279/96:

A propriedade da marca adquire-se pelo registro validamente expedido, conforme as disposições desta Lei, sendo assegurado ao titular seu uso exclusivo em todo o território nacional, observado quanto às marcas coletivas e de certificação o disposto nos arts. 147 e 148. (grifou-se)

Portanto, os efeitos jurídicos irradiados e a proteção jurídica conferida pelo registro da marca, via de regra, têm abrangência estritamente nacional.

Tem-se debatido sobre as vantangens e desvantagens de o Brasil aderir ao Protocolo de Madri ${ }^{71}$. Até o ano de 2010, aproximadamente, 80 países aderiram este

houve uma intensa flexibilização do direito de propriedade que pode ser verificada sob três diferentes prismas, conforme mencionado por Eros Roberto Grau, se referindo à J. P. Gilli. ${ }^{69}$ Assim, temos que uma parte da propriedade foi (i) amputada, conforme se pode facilmente depreender na legislação sobre minas, energia hidráulica, sobre a distribuição de energia elétrica e de circulação de aeronaves (espaço aéreo); outra parte foi (ii) condicionada, pela legislação urbanística; e o terceiro prisma, e aqui consumando a tese de total flexibilização da propriedade, repousa na (iii) violabilidade da propriedade privada pelo Estado, principalmente no que se refere às desapropriações em prol do interesse público. (Cf. GRAU, Eros Roberto, Função Social da Propriedade. Enciclopédia do Direito. Vol. 39. São Paulo: Saraiva, 1979. p. 17).

70 Gérard Dasssa. L'élargissement de la protection des marques - em droit français, allemand et international. Paris: Litec, 1976. p.1 Apud MORO, Maitê. Direito das Marcas. ob. cit. p. 63.

${ }^{71}$ Cf. REQUIÃO, Rubens. Curso de Direito Comercial. 25 a ed. atual. São Paulo: Saraiva, 2003. vol. 1. p. 238. 
acordo internacional. Os principais foram: Estados Unidos, Itália, Alemanha, França, países do Reino Unido, Espanha, Portugal, dentre outros países da Europa, China e Japão. Este acordo corresponde a um tratado internacional para registro de marcas. Foi criado em 1989, mas sua entrada em vigor deu-se em 1996. Por esta sistemática de centralização registrária, o titular de uma marca não é mais obrigado a registrar seu sinal em cada um dos países para os quais exporta seus produtos ou serviços. $\mathrm{O}$ registro em apenas um dos países signatários basta para que a marca registrada no país de origem, como decorrência automática, seja protegida em todos os demais países signatários, sem que, para isto, o titular tenha de proceder ao registro em cada país separadamente.

A despeito das pressões externas, o Brasil não figura como signatário deste ajuste internacional, mantendo-se fiel ao tradicional princípio da territorialidade, cujo registro confere ao titular a proteção exclusiva de sua marca tão-somente em todo o território nacional.

Para aqueles que defendem o ingresso do Brasil neste tratado, este procedimento traria os seguintes benefícios: (i) diminuição da burocracia; (ii) redução de $\operatorname{custos}^{72}$; (iii) aumento de exportações de pequenas e médias empresas (que não costumam registrar suas marcas no exterior) ${ }^{73}$; (iv) aumento do alcance do registro marcário; (v) desnecessidade de pagar honorários de agentes e advogados, taxas de tradução, consularização, envio de documentos, registros locais etc.

\footnotetext{
${ }^{72}$ Para José Graça Aranha, diretor da Divisão de Informação e Promoção do Setor de Marcas, Desenhos Industriais e Indicações Geográficas da Ompi, o sistema de Madri possibilita uma economia de mais de $90 \%$ nos custos de registro de marcas. Para o dirigente, o valor pago para o registro de uma marca em cerca de 50 países varia entre US\$ 80 mil e US\$ 100 mil, ao passo que, por intermédio do Protocolo de Madri, esse valor não alcançaria o montante de US\$ 7,5 mil. Ainda segundo Aranha, as marcas brasileiras deixam de ser registradas no exterior por causa dos elevados custos do procedimento de registro. Na mesma medida, o quadrinista Maurício de Sousa, criador da Turma da Mônica, também defende o ingresso do Brasil ao Protocolo. Para o artista e empresário titular de uma das marcas mais famosas do Brasil, gasta-se " $3 \%$ do faturamento só para garantir nossas marcas e nossos direitos em outros países". Produtos com a chancela da Turma da Mônica - como revistas, jornais e desenhos, entre outros - já são exportados para cerca de 30 países. Segundo Maurício de Sousa, muitas vezes "evitamos investir mais no exterior por causa dos altos custos gerados com a proteção legal. Via Protocolo de Madri, exportaríamos três vezes mais que hoje utilizando a mesma fatia do faturamento". (Cf. HAIDAR, Rodrigo. Estrutura do INPI é obstáculo para adesão ao Protocolo de Madri. Artigo Jurídico publicado na revista Update, da Câmara Americana de Comércio. Disponível em <http://www.conjur.com.br/2005-jun-05/estrutura_inpi_obstaculo_adesao_brasil >. Acesso em 11 jun. 2010.)

${ }^{73}$ Empresas do porte de $O$ Boticário, Natura e Suzano são algumas das que fazem parte do movimento para que o Brasil se insira no Protocolo de Madri. (Cf. HAIDAR, Rodrigo. Estrutura do INPI é obstáculo para adesão ao Protocolo de Madri...op. cit)
} 
Assim defente o presidente do Instituto Nacional de Propriedade Industrial (INPI) de 2010, Jorge Ávila, que assegura que "se o Brasil aderisse hoje ao Protocolo de Madri, os empresários brasileiros poderiam aproveitar imediatamente as vantagens do tratado que permite o depósito internacional das marcas de forma simples, ágil e mais barata”. Ainda de acordo com Ávila, “o Instituto já está preparado para atuar com o protocolo, tanto em termos técnicos quanto depessoal" 74 .

Segundo melhor doutrina de Paulo Borba Casella ${ }^{75}$, não há que se falar em inconstitucionalidade do eventual ingresso do Brasil no referido Protocolo internacional. Para o professor titular de Direito Internacional Público da Universidade de São Paulo, tudo é uma "questão de adaptação do contexto do nosso ordenamento e da organização do sistema de registro aplicado no Brasil, para linha consentânea com a prática internacional”. Portanto, para o internacionalista apenas deve haver "ajustes de forma de de fundo em relação ao regime vigente para a lei e prática brasileiras”. Assim, o Brasil não pode permanecer destacado do mundo. O país não pode se posicionar na contramão do sistema internacional vigente, sempre se preservando, contudo, "as garantias da ordem pública e os fundamentos do sistema político e jurídico nacional". Até porque é uma via de duas mãos, onde os benefícios que são dados aos estrangeiros no Brasil, na mesma medida são dados aos nacionais em território estrangeiro, porquanto "a reciprocidade é princípio básico do direito internacional". Por fim, arremata Casella:

\begin{abstract}
Não vejo incostitucionalidade, vejo alguns ajustes de forma a serem implementados. E estes têm antes natureza operacional que relativos ao conteúdo e princípios do ordenamento e terão de ser vistos não somente em função da comodiade e da praxe do INPI, mas em relação ao interesse público brasileiro, como um todo, no seu sentido mais amplo e mais relevante. Podem não ser tais mudanças operacionais e ajustes imediata e incondicionalmente passíveis de aceitação e implementação, no ordenamento jurídico brasileiro vigente, mas isso não lhes pode acarretar a pecha da inconstitucionalidade. ${ }^{76}$
\end{abstract}

\footnotetext{
74 Disponível em <http://www.inpi.gov.br/noticias/inpi-esta-pronto-para-atuar-com-o-protocolo-de-madrianuncia-avila> Acesso em 10 jun. 2010.

75 CASELlA, Paulo Borba. Registro Internacional de Marcas, o Brasil e o Protocolo de Madri. in CARVALHO, Patrícia Luciane (coord.). Propriedade Intelectual. $2^{a}$ ed. Curitiba: Juruá, 2008. v. 2. pp. 83119.

${ }^{76}$ CASELLA, Paulo Borba. Registro Internacional de Marcas.... op. cit. p. 119.
} 
De outra parte, conforme entendimento dominante da doutrina majoritária, rechaçase o ingresso do Brasil neste sistema internacional de registro de marca, com arrimo nos seguintes argumentos: (i) princípio da isonomia. Este protocolo ofende o princípio da isonomia (mesmo tratamento conferido a nacionais e estrangeiros). Isto porque, pelo Protocolo de Madrid, o escritório de registro (no caso INPI) tem 18 meses para conceder o registro da marca. O INPI tem concedido o registro, para os nacionais, em aproximadamente 30 meses. Ademais, os estrangeiros, via Protocolo de Madri, dispenderiam custo menor do que os nacionais, para registrar suas marcas no Brasil ${ }^{77}$. Portanto, haveria uma diferença de tratamentos entre os nacionais e os estrangeiros, onde os estrangeiros seriam beneficiados; (ii) idioma. Pelo citado registro internacional, o registro deverá ser feito em um único idioma (inglês, francês etc), não podendo ser feito em português, o idioma oficial praticado no Brasil; (iii) proibição de marcas de defesa pela Lei Marcária Brasileira. O registro internacional daria azo ao surgimento das chamadas marcas de defesa. Vale lembrar que, no Brasil, pela sistemática da Lei de Propriedade Industrial (art. 128), só são registradas aquelas marcas para atividades lícitas e que estejam sendo efetivamente utilizadas. É defeso, portanto, o registro de marca apenas para impedir que terceiro dela se utilize. Este mecanismo, extraído do aludido sistema internacional, é, pois, ilegal, porquanto fere o art. 128 da LPI; e inconstitucional, porque fere o princípio da livre concorrência previsto no artigo 170, inciso IV, da Constituição Federal vigente. (iv) procurador. Pelo Protocolo de Madrid, não se faz necessária a constituição de procurador em outro país. A partir do momento em que se registra a marca em um pais signatário, automaticamente este registro será estendido para os demais países signatários. Esta disposição colide com a lei nacional, pois que, pela lei Brasileira, é imprescindível a constituição de procurador no Brasil para receber citações e responder ações judiciais. Vale lembrar que, pelo Protocolo de Madrid, as ações judiciais deverão ser propostas em cada país signatário de forma autônoma e independente.

Registre-se, nesta senda, melhor doutrina do exímio constitucionalista, ex-ministro do Supremo Tribunal Federal e ex-Ministro da Justiça, Célio Borja:

\footnotetext{
77 Conforme pondera Gustavo Leonardos, ex-presidente da ABPI (Associação Brasileira de Propriedade Intelectual), há algumas notas inseridas no Protocolo que violam frontalmente a Carta Política Brasileira. Exemplificativamente, ele faz alusão à lesão ao princípio magno da isonomia, posto que os registros concedidos pelo Sistema de Madri custariam aproximadamente cinco vezes mais que o valor dos registros concedidos internamente aos nacionais. Para o especialista em propriedade intelectual, "trata-se de outra situação em que se dariam vantagens às marcas internacionais em detrimento das empresas brasileiras". (Cf. HAIDAR, Rodrigo. Estrutura do INPI é obstáculo para adesão ao Protocolo de Madri....op. cit)
} 
(...) Convém sublinhar as razões de oportunidade e conveniência que desaconselham, presentemente, a adesão ao Protocolo de Madrid: a) a posição de desvantagem do registro nacional e das marcas nele depositadas ou registradas, em face do registro internacional, devido a custos, procedimentos $e$ prazos; b) a vulnerabilidade dos titulares das marcas do registro nacional, em face da concessão do registro internacional sem o exame de prioridades $\boldsymbol{e}$ anterioridades e da preclusão pro judicato do direito de recusa; c) a menor eficácia, no Brasil, dos meios judiciais de defesa e de composição do dano; d) o reduzido interesse dos titulares brasileiros pelo registro internacional de suas marcas" 78 (grifou-se)

Wilson Silveira $^{79}$, por igual, sinaliza para a absoluta inconveniência e afronta às leis brasileiras, no evento de o Brasil tornar-se parte signatária do citado Protocolo. De acordo com o especialista em direito marcário, o Protocolo de Madri, confere aos estrangeiros mais direitos, em território nacional, do que aqueles concedidos aos nacionais. Adicionalmente, afirma que, no evento de o INPI não proferir decisão em determinado prazo, o pedido de registro estrangeiro será automaticamente convertido em registro marcário, a despeito da necessária ausência de análise, como ocorre nos registros nacionais. Por fim, em tom notadamente crítico, o jurista assinala que o INPI não possui estrutura suficiente para dar funcionamento às diretrizes impostas pelo protocolo, principalmente em decorrência da absoluta ausência de funcionários, os quais, há longo tempo, não têm sequer condições de dar prosseguimento aos processos nacionais então recebidos pelo escritório brasileiro de registro marcário. Desta feita, os processos estrangeiros seriam deferidos antes mesmo que os processos nacionais, não pela celeridade da análise, mas pelo decurso automático do prazo assinalado pelo tratado internacional em comento.

A Comissão de Propriedade Industrial e Pirataria da Ordem do Advogados do Brasil - Seccional Rio de Janeiro, na mesma esteira, se manifestou contra a adesão do Brasil ao Protocolo de Madrid, externando o seguinte parecer a seguir reproduzido:

\footnotetext{
${ }^{78}$ BORJA. Célio de Oliveira. Parecer - Protocolo de Madri. São Paulo: Revista da ABPI. Edição n. 59. jul/ago de $2002 . \quad$ Disponível em <http://www.abpi.org.br/materiais/textospublicos/ParecerProtocolodeMadri.pdf>Acesso em 10 jun. 2010.

${ }^{79}$ Cf. SILVEIRA, Wilson. Parecer. São Paulo: Revista ABPI, Edição n. 75. Março/Abril 2005. Disponível em <http://www.abpi.org.br/resolucoes/resolucao23.htm> Acesso em 10 jun. 2010.
} 
Marcas de defesa, depositadas/registradas com o único propósito de evitar o seu registro em favor de terceiros (no caso, as empresas brasileiras), em detrimento do princípio constitucional da livre concorrência, sem que o seu titular tenha efetivo interesse na respectiva utilização no Brasil. Com isso, o empresariado brasileiro estará impedido de obter determinadas marcas que, de outro modo, poderiam ser registradas no Brasil em nome de empresas nacionais. Em outras palavras, o Protocolo ampliará exponencialmente a chance de colisão entre pedidos de registros nacionais e marcas internacionais que não se pretende utilizar no Brasil, além de comprometer a eficiência do exame dos pedidos de registros pelo INPI, que se verá às voltas com este expressivo volume adicional DEVIDO PROCESSO LEGAL - Quando de pedidos de proteção das marcas de reserva, uma marca for publicada e ninguém oferecer oposição a ela pelo prazo máximo de sete meses, será concedida automaticamente. Tal preceito fere frontalmente o direito de contraditório, pois o prazo previsto no art. $5^{\circ}$ do Protocolo não é suficiente para a manifestação daqueles que se julgarem prejudicados, dada a amplitude do acordo, que atualmente conta 78 signatários. $^{80}$

Apresentada a espinhosa discussão em torno do Protocolo de Madrid, do qual, repise-se, o Brasil não é signatário, cumpre assinalar que a única exceção que se faz ao princípio da territorialidade, nos moldes propostos pelo ordenamento pátrio, ocorre quando do registro de marca notoriamente reconhecida. Com efeito, com fulcro no artigo $6^{\circ}$ bis (I), da Convenção da União de Paris para Proteção da Propriedade Intelectual ${ }^{81}$, evocado pelo artigo 126 da Lei do INPI ${ }^{82}$, a "marca notoriamente conhecida em seu ramo de atividade goza de proteção especial, independentemente de estar previamente depositada ou registrada no Brasil”.

${ }^{80}$ MONTANÉS, Maria Isabel. Protocolo de Madrid - Vantagens e Desvantagens para o Brasil. Revista Jurídica Consulex $\mathrm{n}^{\circ}$ 297. Disponível em <http://profbadaro.blogspot.com/2010/05/protocolo-de-madrivantagens-e.html> Acesso em 09 jun. 2010.

${ }^{81}$ A Convenção de Paris é o primeiro acordo internacional relativo à Propriedade Intelectual, assinado em 1883 em Paris, para a Proteção da Propriedade Industrial (CUP), continua em vigor em sua versão de Estocolmo, inclusive por força do Acordo TRIPs. O Brasil ratificou e internalizou ao ordenamento jurídico pátrio a Convenção retro mencioanda através da edição do Decreto n. ${ }^{\circ} 19.056$, de 31/12/1929, publicado em 10/05/1930.Assim, reza o art. 6 bis da CUP: “(1) Os países da União comprometem-se a recusar ou invalidar o registro, quer administrativamente, se a lei do país o permitir, quer a pedido do interessado e a proibir o uso de marca de fábrica ou de comércio que constitua reprodução, imitação ou tradução, suscetíveis de estabelecer confusão, de uma marca que a autoridade competente do país do registro ou do uso considere que nele é notoriamente conhecida como sendo já marca de uma pessoa amparada pela presente Convenção, e utilizada para produtos idênticos ou similares. O mesmo sucederá quando a parte essencial da marca notoriamente conhecida ou imitação suscetível de estabelecer confusão com esta...."

${ }^{82}$ Cf. Art. 126 - "A marca notoriamente conhecida em seu ramo de atividade nos termos do art. $6^{\circ}$ bis (I), da Convenção da União de Paris para Proteção da Propriedade Industrial, goza de proteção especial, independentemente de estar previamente depositada ou registrada no Brasil.§ $1^{\circ} \mathrm{A}$ proteção de que trata este artigo aplica-se também às marcas de serviço. $\S 2^{\circ} \mathrm{O}$ INPI poderá indeferir de ofício pedido de registro de marca que reproduza ou imite, no todo ou em parte, marca notoriamente conhecida". 
O escopo precípuo do reconhecimento, pelos países unionistas, da marca notoriamente reconhecida, repousa na blindagem contra a pirataria sob a qual devem se guarnecer os países tratadistas. Como consequiência deste revestimento, aumenta-se o estímulo à expansão comercial e à exportação de produtos que são marcantemente reconhecidos pelo consumidor no país em que se operou o registro inaugural. Portanto, no evento de o empresário, que envidou grandes esforços para criar e estabelecer marca de reconhecimento considerável em território estrangeiro, decidir pela introdução e disseminação de seus negócios no mercado nacional, poderá fazê-lo, ainda que, em princípio, a sua marca tenha sido registrada no INPI por terceiro. Comprovada a notoriedade da marca, a lei faculta ao empresário a prerrogativa de pleitear a nulidade do registro marcário obtido por terceiro, reivindicando para si o registro da marca (inauguralmente registrada em território estrangeiro) no Brasil.

A jurisprudência nacional tem se rendido à força da marca notória. Com efeito, há julgados se pronunciando favoravelmente à proteção da marca notória, muito embora este sinal especial ainda não esteja registrado no órgão administrativo competente (INPI).

Em caso apreciado pelo Tribunal de Justiça do Estado de São Paulo, a corte estadual, por unanimidade, avalizou medida liminar deferida pelo juízo de primeira instância ${ }^{83}$. No citado caso, a "Mattel do Brasil S/A" ingressou com medida cautelar de busca e apreensão em face de terceiro, com o escopo de obstar a continudade da comercialização dos bonecos e de todos os produtos da famosa marca internacional "MAX STEEL" e, por via de conseqüência, estancar a produção de todo e qualquer material que reproduzisse sinais indentificadores do herói infantil internacionalmente conhecido no segmento de aventura. Isto porque a empresa ré procedia à contínua comercialização de artigos produzidos em exploração do personagem, sem pagar qualquer contraprestação (royalties) por esta utilização indevida, o que, para o Tribunal, representava enriquecimento ilícito e ameaça ao público consumidor, provável vítima do risco oriundo dos produtos contrafeitos.

A referida liminar foi obtida em primeira instância. Contudo, o contrafator

\footnotetext{
${ }^{83}$ Recurso de Agravo de Instrumento n. ${ }^{\circ}$ 287.363-4/5. Terceira Câmara de Direito Privado. TJSP. Rel. Des. Ênio Santarelli Zuliani. Julg. em 01 jun. 2003.
} 
insurgiu-se contra a decisão, argüindo que a "Mattel do Brasil" era parte ilegítima, porque lhe faltava o requisito da titularidade da marca ou o rgistro no INPI, com amparo no artigo 127 da Lei 9279/96. A despeito da repulsa do contrafator, a liminar concedida em primeira instância foi ratificada pelo Tribunal.

Neste particular, segundo acórdão proferido pelo Rel. Des . Ênio Santarelli Zuliani, ainda que não tenha havido pronunciamento do órgão administrativo competente (INPI), concedendo-se a titularidade da marca mundialmente consagrada ao autor da ação, esta situação "não retira da sociedade constituída para expandir o lucro imposto pela fama e sucesso do produto inédito, a legitimidade, o intersse e o poder de reinvidicar defesa contra a pirataria que prejudica o titular da marca e o consumidor". Ainda segundo o eminente Desembargador, "basta consultar o artigo 126 da Lei 9279, de 1996, para se ter certeza de que a defesa do que é notório não poderia ficar à mercê do efeito deletério da demora na conclusão dos registros". E conclui com pragmatismo ${ }^{84}$ :

Portanto, independente de estar aprovado o registro no Brasil, da marca notória e de paternidade da sócia controladora da autora, poderá o Estado-Juiz. expedir comandos moralizadores da prática comercial, apreendendo objetos contrafeitos e alardeando comandos de abstinência de atividades predatórias, para que o comércio não sofra agressões da competitividade desleal inexplicável, como essa de produzir objetos, sem pagamento de comissóes pela licença que corretamente deveria ser contratada de forma onerosa. Não é somente a titular da marca que sofre com essa prática que poderá ser qualificada de ilícita na sentença final; o consumidor, não esclarecido da origem espúria do produto, poderá sofrer danos com a provável falta de qualidade, uma conclusão que se toma por faltar inspeção ou controle de autoridades de vigilância sanitária e de segurança pública.

Impõe-se mencionar entendimento desta mesma Câmara de Direito Privado, em outro julgado, em que se antecipou a tutela de direito pleiteada, em face da morosidade da tramitação do processo de registro de marca (notória). Segundo as razões apresentadas: “(...) é permitido ao Estado-juiz emitir tutela antecipada de cunho inibitório, afastando preventivamente o risco de dano decorrente de ilícito mercadológico. (...) O tempo que se gasta para legalizar os atos formais que sustentam a setença justa servia à concorrência

${ }^{84}$ Recurso de Agravo de Instrumento n. ${ }^{\text {2 } 287.363-4 / 5 . ~ T e r c e i r a ~ C a ̂ m a r a ~ d e ~ D i r e i t o ~ P r i v a d o . ~ T J S P . ~ R e l . ~ D e s . ~}$

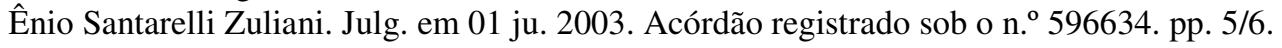


desleal predatória e nociva, como a exploração de uma marca comercial ou a contrafação de um produto patenteado, por exemplo. Até que se pontofinalizasse o julgamento inibidor da prática comercial abusiva, o estrago estava feito pela prática ou realidade da vida cotidiana, que segue implacável, enquanto o processo se arrasta a passos de tartatuga e, na maioria das vezes, perpetuava o dano injusto. Hoje, o ordenamento jurídico municia os operadores do direito com estratégias rápidas e totalmente eficientes (...)". ${ }^{85}$

José Carlos Tinoco Soares ${ }^{86}$, ao comentar o artigo 126, da Lei 9279/96, explicita, com clareza, as condições de excepcionalidade ao princípio da territorialidade, com fundamento no art. 6 bis, da Convenção da União de Paris. Para Tinoco Soares, calcandose na Resolução do Comitê Executivo da $\operatorname{AIPPI}^{87}$, é imprescindível que a marca seja classificada como "notoriamente reconhecida" no país para qual é dirigido o pedido de proteção.

Ademais, a marca deve ser utilizada no país para o qual a proteção é requerida, bem como a proteção deve se restringir apenas aos produtos ou serviços idênticos ou semelhantes e não a todas as atividades ou classes de produtos, conforme ocorre com a marca de alto renome, que será oportunamente examinanda, quando do estudo do princípio da especificidade.

No que concerne aos elementos essenciais, o primeiro que merece destaque é a distintividade que deve estar adstrita à marca. Neste sentido, a marca deve ter o desígnio de diferenciar produtos que sejam idênticos ou mesmo que guardem semelhanças entre si. Em síntese, as marcas devem ser diferentes de outras marcas pré-existentes, sobretudo daquelas que identifiquem produtos ou atividades semelhantes àqueles representados pela marca inaugural ${ }^{88}$.

\footnotetext{
${ }^{85}$ Recurso de Agravo de Instrumento n. ${ }^{\circ}$ 181.711-4/1. Terceira Câmara de Direito Privado. TJSP. Rel. Des.

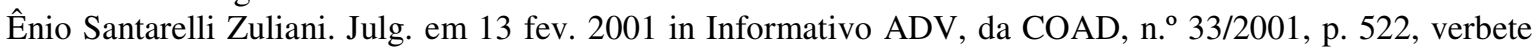
n. ${ }^{\circ} 98241$.

${ }^{86}$ SOARES, José Carlos Tinoco. Lei de Patentes, Marcas e Direitos Conexos. Lei 9.279 de 1996. São Paulo. Ed. Revista dos Tribunais. 1997. p.206.

${ }^{87}$ Cf. AIPPI - Annuaire, 1990/VII, p. 83.

${ }^{88}$ Pautando-se neste requisito, preleciona Gama Cerqueira que “(...) a marca deve ser diferente de outras marcas em uso, porque, do contrário, confundindo-se com elas, não corresponderia ao seu fim primordial de distinguir os produtos a que se aplicam" (Cf. CERQUEIRA, João da Gama. Tratado da Propriedade Industrial. $3^{\text {a }}$ ed. atual. por Newton Silveira e Denis Borges Barbosa......op. cit. Vol. I. Parte I. p. 256)
} 
Outro requisito imperioso à concessão do registro da marca consiste na novidade. Por este elemento ou princípio, conforme classificado por alguns doutrinadores ${ }^{89}$, para que um sinal seja passível de registro, ele deve ser novo e estar disponível, ou seja, terceiros não podem ter registrado aquele sinal previamente ao sujeito que deseja fazê-lo. No entanto, convém destacar que esta novidade não é absoluta e somente se opera em relação a um mesmo ramo de atividade.

Oportuno assinalar que a novidade da marca deve ser igualmente considerada com relação às marcas estrangeiras. Eugene Pouillet ${ }^{90}$, não levando em consideração que tenha havido fraude e má-fé por parte do titular posterior de uma mesma marca utilizada em país diverso do titular originário, aclara que a marca que é disseminada em outros territórios não obsta que tal sinal seja registrado na França. Destarte, e obviamente com exceção da marca notória, se a marca estrangeira é utilizada em outros países, não significa que ela encontrará arrimo legal no Brasil, se aqui não estiver registrada. Naturalmente, esta regra aplica-se ao Brasil, pois que, conforme mencionado, este país não aderiu ao Protocolo de Madri, não estando, portanto, sujeito ao sistema internacional de marcas.

Conclui-se, ante o acima exposto, que, seja a marca nacional ou internacional, prevalece, via de regra, o princípio da anterioridade da marca arraigado ao princípio da territorialidade. Insta repisar que tais princípios, consoante oportunamente esposado no presente estudo, não se aplicam às marcas notariamente conhecidas, que possuem proteção internacional, com fulcro no artigo 6 bis da Convenção da União de Paris e proteção pela legislação nacional em conformidade com os preceitos insertos no artigo 126 da Lei $9.279 / 96$.

A veracidade da marca encontra-se arraigada à novidade. Conforme magistério de Carvalho de Mendonça ${ }^{91}$ :

\footnotetext{
${ }^{89}$ Cf. LOUREIRO, Luiz Guilherme, ob. cit. p. 230 e ss; MORO, Maitê Cecília Fabbri. Direito de Marcas. ob. cit. p. 63 e ss.

${ }^{90}$ POUILLET, Eugene. Traite des marques de fabrique et de la concurrence deloyale en tous 6 ed. Paris : Marchal \& Billard, 1912. p. 36.

${ }^{91}$ MENDONÇA, José Xavier Carvalho de, Tratado de Direito Comercial Brasileiro. ob. cit. vol V, parte O, p. 265.
} 
A marca de indústria ou de comércio, para corresponder ao seu fundamento e escopo, deve ser distintiva, evitando confusão dos produtos ou mercadorias similares. Os escritores exprimem essa idéia dizendo que a marca deve ter o caráter de novidade. Outrossim, converter-se-ia a marca em instrumento de fraude, se seu titular a usasse visando enganar o público sobre a origem ou a qualidade do produto, que assinalasse. Para evitar tão má-aplicação, exige-se a sua veracidade. A garantia legal não lhe é concedida sem esses dois requisitos específicos; faltando qualquer deles, sobretudo o primeiro, não existe marca merecedora daquela garantia.

Sobre o predicato da veracidade, o qual deve ser ínsito às marcas, o professor Haroldo Malheiros Duclerc Verçosa afirma que as marcas devem ser verdadeiras, no sentido de não-deceptivas. Para o comercialista, a "marca pode apresentar um caráter de pura fantasia, não fazendo qualquer referência às caracteristícas do produto ou serviço que vem a designar, e ainda assim ser verdadeira". E, conclui, de forma concisa: "a marca é verdadeira (ou não-deceptiva) sempre que não for enganosa, tendo em conta, para tal efeito, a pessoa do consumidor". 92

Portanto, a marca necessita, imprescindivelmente, de idoneidade e transparência para que seu registro seja legitimado ${ }^{93}$. Sem tais elementos, a marca, que, dentre as várias funções desempenhadas, tem o escopo de informar o consumidor sobre o produto vendido, poderá ser desclassificada como tal.

Adicionalmente, conforme outrora mencionado, a marca deve ser lícita ${ }^{94}$. Tal essencialidade repousa no fato de que não se pode utilizar de marcas cujo conteúdo seja ilícito $^{95}$ (se apresente em contrariedade ao sistema jurídico vigente). No que tange às

${ }^{92}$ Cf. VERÇOSA. Haroldo Malheiros Duclerc. Curso de Direito Comercial. $2^{\mathrm{a}}$ ed. rev e atual. São Paulo: Malheiros, 2008. vol. 1. p. 357.

${ }^{93}$ Neste sentido, propugna Rubens Requião que a marca "deve ser honesta, não contendo palavra, figura ou sinais com indicações que não sejam verdadeiras sobre a origem ou sobre a qualidade das mercadorias e dos produtos, ou ainda que induzam a engano na escolha da coisa assinalada”. (REQUIÃO, Rubens. Curso de Direito Comercial. São Paulo. Saraiva. 2003. vol 1. 25ª ed. p. 249).

94 Neste sentido, entende o Colendo Superior Tribunal de Justiça, ao assinalar licitude, veracidade, disntinguibiildade e novidade relativa como requisitos essenciais para a consecução do registro da marca. “(...) O registro de marca deve obedecer os requisitos de distinguibilidade, novidade relativa, veracidade e licitude.” (STJ. MS 328/DF, Rel. Min. Luiz Vicente Cernicchiaro, Primeira Seção, julgado em 24/04/1990, DJ 21/05/1990, p. 4421).

95 Esta previsão encontra-se expressa no art. $7^{\circ}$ da Convenção da União Internacional para a Proteção da Propriedade Industrial, o qual prescreve: “Artigo 7 bis. 1) Os países da União se comprometem a admitir o 
proibições legais, em conformidade com o artigo 124 da Lei 9.279/96, não podem ser registrados como marca os sinais adiante externados, conforme classificação de Newton Silveira ${ }^{96}$ :

(A) Signos de entidades públicas. Correspondem aos signos que pertençam a entidades ou organizações de direito público ou similares, a saber:

"I - brasão, armas, medalha, bandeira, emblema, distintivo e monumento oficiais, públicos, nacionais, estrangeiros ou internacionais, bem como a respectiva designação, figura ou imitação;

IV - designação ou sigla de entidade ou órgão público, quando não requerido o registro pela própria entidade ou órgão público;

$X I$ - reprodução ou imitação de cunho oficial, regularmente adotada para garantia de padrão de qualquer gênero ou natureza;

XIII - nome, prêmio ou símbolo de evento esportivo, artístico, cultural, social, político, econômico ou técnico, oficial ou oficialmente reconhecido, bem como a imitação suscetível de criar confusão, salvo quando autorizados pela autoridade competente ou entidade promotora do evento;

XIV - reprodução ou imitação de título, apólice, moeda e cédula da União, dos Estados, do Distrito Federal, dos Territórios, dos Municípios, ou de país."

(B) Sinais pertencentes à "linguagem comum". Correspondem aos signos que compõem a linguagem comum (trivial) e que, por tal razão, não são suscetíveis de apropriação a título privativo, retirando-os do domínio público, a saber:

registro e a proteger as marcas coletivas pertencentes a coletividades cuja existência não seja contrária à lei do país de origem, ainda que essas coletividades não possuam estabelecimento industrial ou comercial. 2) Cada país será juiz das condições particulares em que a marca coletiva será protegida e poderá recusar a proteção se essa marca for contrária ao interesse público. 3) Entretanto, a proteção dessas marcas não poderá ser recusada a qualquer coletividade cuja existência não contraria a lei do país de origem, em virtude de não se achar estabelecida no país onde a proteção é requerida ou de não se ter constituído nos termos da legislação desse país.

${ }^{96}$ Cf. SILVEIRA, Newton. Marcas: signo do empresário a título originário e a título derivado. Disponível em <http://www.silveiraadvogados.com.br/show_artigo.php?id=66>. Acesso em 20 maio de 2010. 
"II - letra, algarismo e data isoladamente, salvo quando revestidos de suficiente forma distintiva;

VI - sinal de caráter genérico, necessário, comum, vulgar ou simplesmente descritivo, quando tiver relação com o produto ou serviço a distinguir, ou aquele empregado comumente para designar uma característica do produto ou serviço, quanto à natureza, nacionalidade, peso, valor, qualidade e época de produção ou de prestação do serviço, salvo quando revestidos de suficiente forma distintiva;

VIII - cores e suas denominações, salvo se dispostas ou combinadas de modo peculiar e distintivo;

XVIII - termo técnico usado na indústria, na ciência e na arte, que tenha relação com o produto ou serviço a distinguir;"

(C) Direitos de personalidade. Correspodem aos signos que possam lesar os direitos de personalidade de outrem, tais como:

"II - expressão, figura, desenho ou qualquer outro sinal contrário à moral e aos bons costumes ou que ofenda a honra ou a imagem de pessoas ou atente contra liberdade de consciência, crença, culto religioso ou idéia e sentimento dignos de respeito e veneração;

$X V$ - nome civil ou sua assinatura, nome de família ou patronímico e imagem de terceiros, salvo com consentimento do titular, herdeiros ou sucessores;

XVI - pseudônimo ou apelido notoriamente conhecidos, nome artístico singular ou coletivo, salvo com consentimento do titular, herdeiros ou sucessores;"

(D) Direitos Autorais. Correspondem aos sinais que, de algum modo, possam ferir direitos autorais de terceiros, como: 
"XVII - obra literária, artística ou científica, assim como os títulos que estejam protegidos pelo direito autoral e sejam suscetíveis de causar confusão ou associação, salvo com consentimento do autor ou titular;"

(E) Direitos de Propriedade Industrial. Representam os sinais que confrontem com, ou possam vir a lesar, direitos de propriedade industrial de terceiros (compreendendo aqueles com tutela específica, bem como aqueles tutelados pelas leis de repressão à concorrência desleal, como, por exemplo, título de estabelecimento e outros sinais distintivos sem tutela específica):

" $V$ - reprodução ou imitação de elemento característico ou diferenciador de título de estabelecimento ou nome de empresa de terceiros, suscetível de causar confusão ou associação com estes sinais distintivos;

IX - indicação geográfica, sua imitação suscetível de causar confusão ou sinal que possa falsamente induzir indicação geográfica;

XII - reprodução ou imitação de sinal que tenha sido registrado como marca coletiva ou de certificação por terceiro, observado o disposto no art. 154;

XIX - reprodução ou imitação, no todo ou em parte, ainda que com acréscimo, de marca alheia registrada, para distinguir ou certificar produto ou serviço idêntico, semelhante ou afim, suscetível de causar confusão ou associação com marca alheia;

XXII - objeto que estiver protegido por registro de desenho industrial de terceiros; $e$

XXIII - sinal que imite ou reproduza, no todo ou em parte, marca que o requerente evidentemente não poderia desconhecer em razão de sua atividade, cujo titular seja sediado ou domiciliado em território nacional ou em país com o qual o Brasil mantenha acordo ou que assegure reciprocidade de tratamento, se a marca se destinar a distinguir produto ou serviço idêntico, semelhante ou afim, suscetível de causar confusão ou associação com aquela marca alheia;" 
(F) Desenvolvimento técnico. Correspondem aos sinais que, de certa forma, se confudem com o desenvolvimento técnico, a saber:

"XXI - a forma necessária, comum ou vulgar do produto ou de acondicionamento, ou ainda aquela que não possa ser dissociada de efeito técnico;"

\section{(G) Outras proibições:}

"VII - sinal ou expressão empregada apenas como meio de propaganda;

$X X$ - dualidade de marcas de um só titular para o mesmo produto ou serviço, salvo quando, no caso de marcas de mesma natureza, se revestirem de suficiente forma distintiva;"

(H) Falsa indicação. Por fim, aqueles sinais que, pela sua particularidade, possam, potencialmente, induzir terceiros (principalmente o consumidor) a erro (intitulada por Newton Silveira como marcas deceptivas):

"X - sinal que induza a falsa indicação quanto à origem, procedência, natureza, qualidade ou utilidade do produto ou serviço a que a marca destina."

As proibições acima elencadas assumem especial importância, quando da celebração do contrato de licença, cuja marca, objeto central do licenciamento convencionado, não poderá coincidir com os sinais retro descritos, sob pena de o contrato ser considerado nulo, em conformidade com o comando exteriorizado pelo artigo 166, inciso II, do Código Civil vigente, segundo o qual é nulo o negócio jurídico quando seu objeto for ilícito.

Convém esclarecer, com alicerce nos esclarecedores ensinamentos de Gama Cerqueira $^{97}$, que devem ser distinguidas as marcas que são formadas em contrariedade à lei

${ }^{97}$ CERQUEIRA, João da Gama. Tratado da Propriedade Industrial. $3^{\mathrm{a}}$ ed. atual. por Newton Silveira e Denis Borges Barbosa......op. cit. Vol. I. Parte I. p. 263. 
daquelas que preenchem todos os elementos autorizadores insculpidos no direito marcário, porém são apostas em produtos ilícitos. No primeiro caso, a marca deverá ser desconstituída como tal. No segundo caso, a marca permanece válida, porquanto em consonância com os requisitos marcários essenciais para sua formação. O que ocorrerá, na hipótese em tela, é a manutenção da marca legitimamente adquirida, não obstante a promoção de ação penal contra o sujeito, cujo argumento principal residirá não na marca utilizada em si mesma, porém, essencialmente, na comercialização de produtos classificados como ilícitos.

Para fins ilustrativos do que fora acima exposto, remetemo-nos a dois exemplos demonstrativos da comparação acima traçada. O primeiro consiste na utilização de um brasão, arma ou bandeira nacional para a formação de uma marca, em flagrante contrariedade ao artigo 124, inciso I, da Lei 9.279/96. Neste caso, a marca deverá ser declarada nula e o seu titular, por via de conseqüência, punido em acordância com a legislação marcária vigente. O segundo exemplo consiste na utilização de marca legítima, inclusive com registro legalmente conferido pelo Instituto Nacional de Propriedade Intelectual (INPI), porém para a aposição em armas comercializadas sob o manto do tráfico bélico efetivado às margens da lei. Neste caso hipotético, a marca poderá ser mantida, porém o titular correspondente será processado criminalmente pela prática daquele ato ilícito, devendo cessar, de imediato, a atividade praticada.

Passemos a tratar o princípio da especificidade, certamente considerado um dos princípios (condição) fundamental e de maior autoridade no direito marcário recente. Por este princípio, tem-se que uma marca somente pode ser registrada em uma determinada classe de atividade ou produto ${ }^{98}$.

Para a classificação, de forma uniforme e integrativa entre os países partidários da defesa da propriedade industrial, concernente às atividades e produtos nos quais deverão

\footnotetext{
${ }^{98}$ Neste sentido, cite-se Luiz Guilherme Loureiro, que leciona, in verbis: "para constituir uma anterioridade de maneira a impedir que um sinal seja registrado como marca, é necessário que a anterioridade exista no mesmo setor comercial daquele produto ou serviço para o qual se pretende registrar a marca. Portanto, se o sinal é utilizado em outro produto ou serviço de um ramo comercial diferente, não constitui anterioridade para o fim de impedir o registro da nova marca. A exceção a essa regra é constituída pela marca notória." (LOUREIRO, Luiz Guilherme de A.V. Loureiro. A lei de propriedade industrial comentada. ob. cit. p. 231).
} 
ser registradas as marcas, fora confeccionada uma classificação internacional de produtos e serviços para registro de marcas, igualmente conhecido como "NICE" 99 .

Mencionada classificação internacional fora instituída por um Acordo concluído por ocasião da Conferência Diplomática de Nice, em 15 de junho de 1957, e revista em Estocolmo, em 1967, e em Genebra, em 1977, e corrigida em 1979.

Os países que fazem parte do Acordo de Nice constituem uma União particular dentro da estrutura da União de Paris para a Proteção da Propriedade Industrial ${ }^{100}$. Estes países adotaram e aplicam a Classificação de Nice para o registro de marcas.

Cada um dos países signatários do Acordo de Nice é obrigado a aplicar a Classificação de Nice para o registro de marcas, quer como classificação principal, quer como classificação auxiliar, assim como incluir, nas publicações e nos documentos oficiais relativos a seus registros, os números das classes da Classificação a que pertençam os produtos e os serviços para os quais as marcas são registradas.

O emprego da Classificação de Nice é obrigatório não apenas para o registro nacional de marcas nos países signatários do Acordo de Nice, mas também para o registro internacional de marcas efetuado pelo Bureau Internacional da OMPI, em virtude do Acordo de Madri Relativo ao Registro Internacional de Marcas e do Protocolo Relativo ao Acordo de Madri Referente ao Registro Internacional de Marcas e para o registro de marcas feito pela Organização Africana de Propriedade Intelectual (OAPI), pelo Escritório de Marcas do Benelux e pelo Instituto de Harmonização do Mercado Interno (Marcas e Desenhos) (OAMI).

\footnotetext{
${ }^{99}$ Cf. website do Instituto Nacional de Propriedade Industrial (INPI), o qual explana claramente acerca do sistema que tal autarquia vem utilizando para a classificação das marcas e produtos. < http://www.inpi.gov.br/menu-esquerdo/marca/dirma_classificacao/oculto/NICE/menuesquerdo/marca/dirma_classificacao/oculto/NICE/a-classificacao-internacional-de-produtos-e-servicos-parao-registro-de-marcas/> Acessado em 05 nov. 2008.

${ }^{100}$ Constituem países integrantes do acordo NICE: Albânia, Alemanha, Algéria, Antiga Iugoslávia, Armênia , Austrália, Áustria, Azerbaijão, Bahrain, Barbados, Bélgica, Benin, Bielorússia, Bósnia, Bulgária, Cazaquistão, China, Cingapura, Croácia, Cuba, Dinamarca, Dinamarca, Egito, Eslováquia, Eslovênia, Espanha, Estados Unidos da América, Estônia, Federação Russa, Finlândia, França, Geórgia, Grécia, Guiné, Hungria, Irlanda, Islândia, Israel, Itália, Jamaica, Japão, Letônia, Líbano, Liechtenstein, Lituânia, Luxemburgo, Malaui, Marrocos, México, Moçambique, Mônaco, Mongólia, Noruega, Países Baixos, Polônia, Portugal, Quirguistão, Reino Unido, República Árabe da Síria, República Checa, República da Coréia, Romênia, Suécia, Suíça, Turquia, Ucrânia, Uruguai, dentre outros.
} 
A Classificação de Nice também é aplicada por vários países que não firmaram o Acordo de Nice. O Brasil encontra-se inserido no grupo destes países que não subscreveram o acordo, porém que o utilizam como base para o registro das marcas no território nacional.

Ademais, a classificação nacional atual, instituída pelo Ato Normativo INPI n. ${ }^{\circ}$ 51, de 1981, é composta de 41 classes, sendo 35 referentes a produtos e 6 a serviços, onde cada uma das classes é dividida em itens. Determinadas classes, normalmente as mais demandadas, possuem grande número de itens. Esse é o caso, por exemplo, da Classe 05 (Medicamentos), com 17 itens. Outras, como plantas e flores (Classe 10), têm apenas um item $^{101}$.

Gama Cerqueira ${ }^{102}$ propugna que a crescente evolução do capitalismo e a presença cada vez mais acentuada da globalização trouxeram à baila as primeiras situações de grau mais complexo para a apreciação das marcas sob o prisma do princípio da especialidade. Tal indagação do ilustre tratadista reside no fato de que, outrora, a coexistência de marcas idênticas para a indicação de produtos distintos era facilmente perceptível. Isto de dava em decorrência da fácil diferenciação entre os produtos.

Exemplificativamente, conforme anota Gama Cerqueira, não se podia confundir uma garrafa de vinho com uma balança ou um automóvel. Por certo, são produtos evidentemente distintos. Hodiernamente, entretanto, complexo se faz distinguir produtos ou serviços semelhantes, mormente com a constante e gradual dinamização verificada no mundo dos negócios, ensejada, sobretudo, pela globalização crescente e necessidade de agilidade nas relações interempresariais.

Aurélio Wander Bastos $^{103}$, com notada clareza, elucida o princípio da especificidade como aquele que garante a proteção para os produtos, mercadorias ou serviços que, de fato, condizem com a atividade exercida pelo titular. Ainda na esteira do

\footnotetext{
101 Informações extraídas do website do INPI: < http://www.inpi.gov.br/menuesquerdo/marca/dirma_classificacao/oculto/nacional> Acessado em 05 nov. 2008.

102 CERQUEIRA, João da Gama. Tratado da Propriedade Industrial. $3^{\mathrm{a}}$ ed. atual. por Newton Silveira e Denis Borges Barbosa......op. cit. Vol. I. Parte I. pp. 257/258.

103 BASTOS, Aurélio Wander. Dicionário de Propriedade Industrial e Assuntos Conexos. Rio de Janeiro. Ed. Lúmen Júris. 1997. p. 217.
} 
Thiago Jabur Carneiro

que preleciona citado jurista, a proteção legal será apenas concedida para os produtos ou serviços oriundos de determinados segmentos comercial ou industrial, sendo irrelevante o mercado como um todo. Assim, o titular não poderá impedir que terceiros registrem a marca para produtos originários de segmento de comércio ou indústria distintos daquele por ele, titular, praticado.

Elucidativas se fazem as palavras de Gama Cerqueira, ao lecionar que a nota mais importante atinente ao princípio em apreço é, sobretudo, evitar que o consumidor, principal alvo da marca, seja conduzido a erro. Assevera o ilustre tratadista:

\begin{abstract}
Assim, para decidir se dois produtos diferem suficientemente entre si, de modo a permitir-se, em ambos, o emprego da mesma marca, não basta para verificar se pertencem a classes diferentes, nem se são suscetíveis de se substituírem e serem aceitos um pelo outro pelo consumidor; mas é necessário verificar, principalmente, se o comprador pode ser induzido em engano ${ }^{104}$, dada a afinidade dos produtos, supondo que ambos provêm do mesmo fabricante cuja marca conhece. Se o critério legal não comporta exceções quando se trata de produtos incluídos na mesma classe, o mesmo não se verifica quando se trata de classes diferentes. (grifou-se) 105
\end{abstract}

A exceção aplicável ao princípio da especificidade se dá nos casos da marca de alto renome que, como visto, reside naqueles signos cujo registro assegura proteção especial, em todos os ramos de atividade, em território nacional ${ }^{106}$. Na sistemática da Lei

\footnotetext{
${ }^{104}$ Nesta esteira afiança o Superior Tribunal de Justiça ao formar o entendimento que “(....) evitar repetições ou imitações que levem terceiros, geralmente o consumidor a engano. De outro lado, cumpre observar a natureza da mercadoria. Produtos diferentes, perfeitamente identificáveis e inconfundíveis, podem, porque não levam aquele engano, apresentar marcas semelhantes." (STJ. MS 328/DF, Rel. Min. Luiz Vicente Cernicchiaro, Primeira Seção, julgado em 24/04/1990, DJ 21/05/1990, p. 4421).

${ }^{105}$ CERQUEIRA, João da Gama. Tratado da Propriedade Industrial. $3^{\mathrm{a}}$ ed. atual. por Newton Silveira e Denis Borges Barbosa......op. cit. Vol. I. Parte I. p. 258.

106 Este posicionamento acerca da vasta amplitude da marca de alto renome é avalizado pelos tribunais estaduais e cortes superiores pátrias, conforme se expõe. “Apelação. Ação de Indenização. Marca Notória. Utilização sem licença do titular. Sanção civil devida. Percentual da remuneração. Arbitramento. Recurso parcialmente provido. 1. O titular de marca notória registrada atualmente marca de alto renome tem direito do seu uso e gozo em todo território nacional e para qualquer atividade. 2. A utilização de marca notória, sem a devida licença do titular, constitui ilícito civil sancionável pela via da indenização. 3. Tratando-se de grandezas diferentes representadas por bens móveis e imóveis, é necessário que seja arbitrado o percentual de remuneração do titular da marca notória não respeitada. 4. Apelação conhecida e parcialmente provida." (TJ/MG. Apelação Cível n. ${ }^{\circ}$ 2.0000.00.363750-1/000(1). Rel. Des. Caetano Levi Lopes. Julg. 04 set. 02). Este entendimento foi confirmado pelo Colendo Superior Tribunal de Justiça, consoante REsp 662.917/MG, Rel. Ministro FERNANDO GONÇALVES, QUARTA TURMA, julgado em 25/11/2008, DJe 09/12/2008 RT vol. 882, p. 142.
} 
n. 5.772/1971, tomava lugar o "registro especial" para as marcas de alto renome. Hodiernamente, contudo, não há mais o registro especial, que nos tempos da lei anterior, intitulava-se "registro de marca notória".

Por força do art. 125, da Lei 9.279/96, “à marca registrada no Brasil considerada de alto renome será assegurada proteção especial, em todos os ramos de atividade". Neste sentido, José Tinoco Soares esclarece, de forma concisa e elucidativa que, enquanto que a marca notória tem proteção especial assegurada ao seu ramo e atividade, a marca de alto renome tem proteção assegurada a todos os ramos de atividade, em território nacional ${ }^{107}$.

Ricardo Negrão, didaticamente, estabelece a seguinte comparação analítica entre a marca de alto renome e a marca notória: As marcas de alto renome "são as notoriamente conhecidas no Brasil, em toda a sua extensão e têm proteção especial em todos os ramos de atividade. Trata-se de inovação brasileira prevista no artigo 125 do CPI, sem regulação similar na Convenção Unionista". Por seu turno, as marcas notórias "são as notoriamente conhecidas em seu ramo de atividade e estão previstas na Convenção da União de Paris, no artigo 6 bis, inciso 1, e reguladas pelo art. 126 do CPI. Gozam de proteção especial, independetemente de estarem previamente depositadas ou registradas no Brasil". ${ }^{108}$

Presentemente, compete ao INPI, sem que se proceda a "registros especiais", a declaração expressa no tocante à determinada marca poder ter a rubrica de "alto renome" ou não ${ }^{109}$. Deste modo, o titular deverá encaminhar à autarquia retro citada um pedido para que esta sopese se a marca pleiteada deve ser chancelada como especial ou não. No evento de o INPI assim demarcar, poderá o titular da marca se opor a outras marcas idênticas ou similares em qualquer ramo de atividade. São exemplos clássicos de marca de alto renome: Nike, Coca-Cola, Brastemp, Bradesco etc.

A jurisprudência pátria é farta ao discorrer sobre o princípio da especificidade. $\mathrm{O}$ Colendo Superior Tribunal de Justiça, versando a respeito do tema, tem afirmado,

\footnotetext{
${ }^{107}$ Cf. SOARES, José Carlos Tinoco. Lei de Patentes, Marcas e Direitos Conexos. Lei 9.279 de 1996. ob. cit. p. 206

${ }^{108}$ Cf. NEGRÃO, Ricardo. Direito Empresarial - Estudo Unificado. São Paulo: Ed. Saraiva. 2008. p. 114.

${ }^{109}$ Cf. BARBOSA, Cláudio Roberto. Propriedade Intelectual: introdução à propriedade intelectual como informação. Rio de Janeiro: Elsevier, 2009. pp. 142/143.
} 
incisivamente, que o direito marcário pátrio encontra-se intrinsecamente arraigado ao princípio da especificidade, pelo qual o signo tão somente irradia efeitos no que tange aos produtos ou serviços da respectiva classe de registro ${ }^{110}$.

Por fim, cumpre anotar, no que tange à indenização pela violação de direito marcário, o posicionamento firmado pelo Colendo Superior Tribunal de Justiça. Este pretório tem-se inclinado ao entendimento de que não merece prosperar a tese de ofensa ao artigo 927 do Diploma Civil, no que toca à prova material do dano, mormente quando o núcleo da discussão residir no uso indevido de marca alheia. Extrai-se deste juízo a lição de que, no direito marcário, com amplo respaldo na Lei 9.279/96, não se faz obrigatória a demonstração da prova material do dano, mas tão somente a comprovação do ilícito ocasionado $^{111}$. O uso indevido de marca de titularidade de outrem sempre se presume lesivo a quem a lei confia a titularidade ${ }^{112}$.

\footnotetext{
${ }^{110}$ Impõe-se trazer à colação ementa matriz concernente ao tema, cuja lição segue transcrita: “ (....) $I-O$ direito marcário brasileiro vincula-se ao princípio da especificidade, segundo o qual a marca produz efeitos somente em relação a produtos ou serviços da respectiva classe de registro. Entretanto, a própria lei de regência traz exceção a regra, disciplinando que a marca notória, declarada em registro próprio, goza de proteção em todas as classes. II - A proteção legal tem por escopo resguardar o consumidor adquirente do produto, crédulo da procedência comum dos bens, sobretudo em razão do grande potencial econômico das empresas que detém a titularidade da marca notória. (Resp n. ${ }^{\circ}$ 50.609/MG, Rel. Ministro Sálvio Figueiredo Teixeira, Quarta Turma, julgado em 06/05/1997, p. 25543). Convém esclarecer terminologia, de acordo com a sistemática da Lei n. ${ }^{\circ}$ 9279/96. O julgado externa o entendimento que a "marca notória, declarada em registro próprio, goza de proteção em todas as classes". Sucede, todavia, que a marca notória somente é protegida no ramo específico de atividade. Com fulcro no artigo 125 da Lei 9.279/96, à marca de alto renome, e não notória, será assegurada proteção especial, em todos os ramos de atividade. Devemo-nos sempre nos atentar à nova terminologia adotada pela nova Lei de 1996, posto que, pelo artigo 67 do revogado CPI, a marca notória no Brasil, registrada nos termos e para os efeitos daquele diploma legal, tinha assegurada proteção especial em todas as classes.
}

${ }^{111}$ Recurso Especial n. ${ }^{\circ}$ 662.917/MG. Quarta Turma. Superior Tribunal de Justiça. Rel. Min. Fernando Gonçalves. Julg. em 25 nov. 2008; Recurso Especial n. ${ }^{\circ}$ 101.118/PR. Quarta Turma. Superior Tribunal de Justiça. Min. Rel. Sálvio de Figueiredo Teixeira. Julg. em 02 março de 2000.

${ }^{112}$ Recurso Especial n. ${ }^{\circ}$ 510.855/GO. Quarta Turma. Superior Tribunal de Justiça. Min. Rel. César Asfor Rocha. Julg. em 09 set. 2003. 


\section{II.6 FUNÇÕES DESEMPENHADAS}

Tema bastante explorado pela doutrina nacional e estrangeira concerne às funções exercidas pela marca. Este assunto se apresenta relevante, sobretudo pelo fato de que quanto mais funções estiver revestida a marca, mais expressivo e mais cauteloso deverá se fazer o contrato de licença de uso de marca, tema central do presente estudo.

Conforme oportunamente indicado, a marca, nos primórdios de sua criação, tinha o intuito de indicar a origem ou procedência da mercadoria.

Com contornos diferenciados, porém não se desvencilhando, por todo, da função primordial das marcas, como indicadora de origem, Newton Silveira ${ }^{113}$, com extrema sapiência, procede à clarividente adaptação de tal função aos tempos modernos.

Destarte, pode-se depreender, a partir do ensinamento disseminado pelo insigne jurista, que o sinal de origem não mais se refere à procedência ou local onde fora produzido os produtos, como ocorria na Idade Média com as corporações de ofício. Esta função indicadora possui, atualmente, o objetivo de indicar quem é o empresário responsável por aquela fabricação. Assim, a indicação do produto, através de sua marca, denota que aquele produto foi produzido sob inteira responsabilidade deste ou daquele proprietário. Desta forma, conferindo um caráter notadamente protecionista ao consumidor, Newton Silveira afiança o cunho de indicação de origem da marca, porém sob novos moldes, o qual tem por objetivo a proteção do consumidor em decorrência de eventuais abusos cometidos pelos empresários ${ }^{114}$.

113 SILVEIRA, Newton. A propriedade intelectual e a nova lei de propriedade industrial (Lei 9279 de 14/05/1996). São Paulo: Ed. Saraiva. 1996. p. 24/25.

${ }^{114}$ Sobre a quem se destina a lei marcária, se para atender o interesse privado (do empresariado) ou se para atender o interesse público (consumidor), é imperioso registrar o entendimento de Gama Cerqueira. Conforme magistério do reconhecido tratadista, "Não se contesta certamente, o caráter misto das leis sobre marcas, que se inspira tanto nos interesses de ordem privada como nos de ordem pública; mas destes só cogita o legislador na medida em que podem ser prejudicados pelos interesses de ordem privada. Não se despreza, pois, mas também não se coloque o interesse do consumidor acima dos interesses do comércio e da indústria, porque a lei é feita para a garantia destes [interesse privado]. Os interesses do público são resguardados por outras leis [ex. Código de Defesa do Consumidor], que reprimem as fraudes e falsificações, fora do campo da concorrência desleal, que é o domínio das marcas industriais" (Cf. CERQUEIRA, João da Gama. Tratado da Propriedade Industrial. $3^{\mathrm{a}}$ ed. atual. por Newton Silveira e Denis Borges Barbosa......op. cit. Vol. I. Parte I. p. 243). 
Gama Cerqueira, por seu turno, leciona que as marcas, em sua essência, ostentam dupla função: (i) individualização de produtos e artigos e (ii) distinção de produtos sobre os quais são apostos as marcas de outros inseridos no mesmo nicho de mercado. Adicionalmente, o tratadista em comento advoga que a individualização e distinção do produto ou serviço não mais se reportam a sua origem, mais sim ao produto em si mesmo $^{115}$, de tal sorte que a marca passará a ter função econômica, podendo até ser cedida ou licenciada, independentemente da manutenção ou da cessão do estabelecimento. Em que pese a dupla função acima externada, ainda reconhece o jurista que a função identificadora possui mais impacto do que a função de distinguibilidade do sinal ${ }^{116}$.

P.R. Tavares Paes ${ }^{117}$, convergindo para o ideal corroborado por Carvalho de Mendonça ${ }^{118}$ e Gama Cerqueira, se atêm à função identificadora da marca. Esta posição, contudo, não se apresenta uníssona na doutrina. Stephen Ladas $^{119}$ assinala que a característica de distintividade da marca pode derivar tanto da natureza da marca, como do uso que é feito dela. No entanto, é importante realçar que o citado doutrinador estrangeiro enfatiza que a função da marca tem cunho distintivo mais acentuado do que sua característica identificadora.

Para este posicionamento inclina-se Maitê Cecília Moro, ao lecionar que, em que pese as considerações trazidas à baila por Gama Cerqueira, a função distintiva é mais usualmente verificada do que a função identificadora ${ }^{120}$.

\footnotetext{
115 Este entendimento é corroborado com base nos ensinamentos difundidos por Breuer Moreno, para quem "la marca identifica com el producto que distingue y, desde luego, cuanto mayor es la difusión y aceptación de esse producto, mayor valor adquire para su titular. Simultáneamente, la marca sirve para propender a esa difusión, pues que es facilmente recordata pela clientela". (Cf. MORENO, P.C. Breuer. Tratado de Marcas de Fábrica y Comercio. Buenos Aires: Jesús Menéndez, 1937. n. 19)

116 "Os letreiros luminosos que enfeitam as cidades modernas, a publicidade impressa e, sobretudo, a intensa propaganda radiofônica impõem tiranicamente à nossa vista (...) o nome ou a marca dos produtos, colocando, assim a função identificadora acima de sua função meramente distintiva. Pode-se dizer, pois, que antigamente, a marca distinguia os produtos, indicando-lhes a origem. Hoje, distingue-os, identificando-os, dando-lhes individualidade própria”. (Cf. CERQUEIRA, João da Gama. Tratado da Propriedade Industrial. $3^{\mathrm{a}}$ ed. atual. por Newton Silveira e Denis Borges Barbosa......op. cit. Vol. I. Parte I. p. 242).

${ }^{117}$ PAES, P.R. Tavares. Propriedade Industrial. $2^{\mathrm{a}}$ ed., revista e ampliada. São Paulo. Saraiva. 1987. p. 14.

${ }^{118}$ MENDONÇA, José Xavier Carvalho de, Tratado de Direito Comercial Brasileiro. 1957. ob. cit., p. 217.

119 LADAS, Stephen. Patents, trademarks and related rights - National and Internation Protection. Cambridge: Harvard University Press, 1975. vol II, p. 1043.

${ }^{120}$ MORO, Maitê Cecília Fabbri. Direito das Marcas. ob. cit. p. 36.
} 
Os diplomas legais marcários nacional e estrangeiro igualmente enfatizam mais o caráter distintivo da marca ao seu caráter identificador ${ }^{121}$. Vejamos:

O artigo 15.1, do Acordo TRIPS ${ }^{122}$, reza, in verbis:

Qualquer sinal, ou combinação de sinais, capaz de distinguir bens e serviços de um empreendimento daqueles de outro empreendimento, poderá constituir uma marca. Estes sinais, em particular palavras, inclusive nomes próprios, letras, numerais, elementos figurativos e combinação de cores, bem como qualquer combinação desses sinais, serão registráveis como marcas. Quando os sinais não forem intrinsecamente capazes de distinguir os bens e serviços pertinentes, os Membros poderão condicionar a possibilidade do registro ao caráter distintivo que tenham adquirido pelo seu uso. Os Membros poderão exigir, como condição para registro, que os sinais sejam visualmente perceptíveis.

O artigo 122 da Lei 9.279/76 enfatiza, de igual modo, o caráter distintivo adstrito à marca, ao prescrever que "são suscetíveis de registro como marca os sinais distintivos visualmente perceptíveis'.

Outra função desempenhada pela marca, porém que se apresenta controvertida na doutrina, é a função de indicação de qualidade. Há corrente doutrinária que ministra a tese de que as marcas indicam a qualidade dos produtos por elas representados. Cite-se, nesta esteira, a anotação de Gutierrez Carrau ${ }^{123}$, que indica que a marca está intrinsecamente ligada à qualidade do produto, dando exemplo de que o sujeito que freqüenta o MC'Donalds fora dos Estados Unidos tem plena consciência de que o alimento ingerido na franquia não provém do país de origem da marca, porém credita qualidade

\footnotetext{
${ }^{121}$ Idem, Ibidem, p. 37.
}

${ }^{122}$ O Acordo TRIPs (Trade Related Aspects of Intellectual Property Rights) é um tratado Internacional, integrante do conjunto de acordos assinados em 1994 que encerrou a Rodada Uruguai e criou a Organização Mundial do Comércio. Também chamado de Acordo Relativo aos Aspectos do Direito da Propriedade Intelectual Relacionados com o Comércio (ADPIC), tem o seu nome como resultado das iniciais em inglês do instrumento internacional. O TRIPs foi criado com o escopo de "reduzir distorções e obstáculos ao comércio internacional e levando em consideração a necessidade de promover uma proteção eficaz e adequada dos direitos de propriedade intelectual e assegurar que as medidas e procedimentos destinados a fazê-los respeitar não se tornem, por sua vez, obstáculos ao comércio legítimo". Definição extraída do preâmbulo do Acordo TRIPs. ( http://www.wto.org/english/tratop_e/trips_e/trips_e.htm). Acessado em $10 / 11 / 2008$.

${ }^{123}$ CARRAU, Juan Manuel Gutierrez. Manual teórico-práctico de marcas. Motevidéo: Fundación de Cultura Universitária, 1997. p. 19. 
àquele alimento como se do país de origem fosse proveniente. Com fulcro neste entendimento, Carrau afiança que a marca é um indicador da qualidade do produto.

Corrente doutrinária diversa, capitaneada por Newton Silveira, dissemina a tese de que a marca não é um "sinal de garantia de qualidade, senão na medida em que o empresário deseje manter o padrão de qualidade dos produtos por ela assinalados, a fim de que não caiam em descrédito"124.

Função outra identificada, a partir da leitura da obra de Carvalho de Mendonça ${ }^{125}$, consiste na função de credibilidade e perenidade que expressam as marcas em relação aos produtos ou serviços que representam. Conforme preleciona o comercialista, as marcas, via de regra, tencionam manter no tempo e no espaço as vantagens e credibilidade do aviamento e da reputação do industrial, inibindo, assim, que o consumidor seja ludibriado e, ao mesmo tempo, afiançando ao consumidor que os produtos por ele adquiridos são de extrema confiança. Tal função, até certo ponto, confunde-se com a função de indicação de qualidade, função esta, repise-se, rechaçada por Newton Silveira, conforme acima esposado.

A necessidade perene de se consolidar uma marca, por diversos meios de comunicação, na mente dos consumidores, potenciais adquirentes dos produtos ou serviços e terceiros, faz surgir o conceito de marketing. Este posicionamento do sinal no âmbito dos interesses do público consumidor intitula-se, internacionalmente, branding, tendo, como resultado, a maximização do valor do bem intangível em estudo de forma estimável na relação de concorrência.

Neste sentido, impõe-se mencionar que a função da marca de marketing ou branding implica, decerto, efeitos positivos, como também negativos, àqueles que buscam no marketing internacional disseminar suas marcas arraigadas à qualidade dos produtos ou

\footnotetext{
124 SILVEIRA, Newton. A propriedade intelectual e a nova lei de propriedade industrial (Lei 9279 de 14/05/1996). São Paulo. Saraiva. 1996. p. 24.

125 MENDONÇA, J.X. Carvalho de. Tratado de Direito Comercial Brasileiro. 2 ed. Rio de Janeiro. Ed. Freitas Bastos. 1934. p.216.
} 
serviços disponibilizados, conforme melhor discurso de Cláudio R. Barbosa ${ }^{126}$, o qual assinala, textualmente:

\begin{abstract}
A índole internacional da propriedade intelectual acompanha a própria atuação internacional da empresa que se dá em diferentes terrritórios e jurisdições, aproveita as eficientes campanhas de marketing feitas internacionalmente e, ao mesmo tempo, pode incorporar passivos (e outros aspectos negativos) associados ao nome. É possível afirmar que a comunicação e a informação não têm filtros contra externalidades associadas ao nome, como ocorreu, por exemplo, em episódio no qual a simples utilização da marca "Panasonic" atribuiu responsabilidade à sua subsidiária brasileira ${ }^{127}$.
\end{abstract}

Similarmente à função de marketing, acima ventilada, cumpre-nos mencionar a função de propaganda da marca. Para Waldemar Ferreira, esta função está íntrinsecamente conectada à função econômica da marca, a qual será aditante examinada. Com extremo brilhantismo preleciona o douto comercialista, in litteris:

\begin{abstract}
Ademais disso, o proprietário efetua a propaganda de artigos, assim por sua originalidade, quanto por efeito de sua publicidade. Campanha publicitária bem orientada e melhor executada é de eficácia incostestável. O que se anuncia é a marca; mas o que se vende é o produto. Raridade não é, todavia, que os papéis se invertam, ao cabo de propaganda persistente e que os consumidores passem a comprar os produtos por causa de suas marcas, tanto prestígio que elas adquirem.(grifou-se) ${ }^{128}$
\end{abstract}

Newton Silveira, por igual, sinaliza para a "função de propaganda da marca".

Esta função representa o impacto publicitário ensejado pelo sinal tutelado pelo direito da

126 BARBOSA, Cláudio Roberto. Propriedade Intelectual: introdução à propriedade intelectual como informação. Rio de Janeiro: Elsevier, 2009. pp. 157.

${ }^{127}$ No citado caso, a Panasonic do Brasil Ltda., subsidiária brasileira, foi condenada a indenizar consumidor que havia adquirido produto (filmadora) da empresa norte-americana, Panasonic, a despeito de o produto ter sido comprado em território alienígena. $\mathrm{O}$ argumento capital utilizado pela Corte Superior para determinar a reparação civil consistiu na confiança que consumidor depositou na marca internacional "Panasonic", sob o viés da globalização, independente do local e empresa da qual o produto fora adquirido. (Cf. Recurso Especial n. ${ }^{\circ}$ 63.981/SP. Quarta Turma. Superior Tribunal de Justiça. Rel. Min. Aldir Passarinho Júnior. Julg. em 11 abril 2000). Imperioso citar que esta decisão se quedou mantida, posteriormente, em sede de ação rescisória proposta pela Panasonic do Brasil Ltda., na tentativa de reverter decisão anterior do STJ, com supedâneo no artigo 485, V, do CPC (violação de disposição literal de lei). (Cf. Ação Rescisória n. ${ }^{\circ} 2.931$ SP. Quarta Turma. Superior Tribunal de Justiça. Rel. Min. Castro Filho. Julg. em 24 ago. 2005).

${ }^{128}$ FERREIRA, Waldemar. Tratado de Direito Comercial. São Paulo: Ed. Saraiva. 1962.Vol. 6.pp. 267 /268. 
propriedade industrial. Consoante preleciona o comercialista, "a marca representa o elo entre o produto e o consumidor exercendo, desta sorte, não apenas função de diferenciação e identificação em relação ao produto, mas também se manifestando como força de atração e sugestão" 129 .

Há que se trazer à baila, bem assim, a função informacional da marca, já que o sinal, ante o aludido predicado, dispõe de manifesta inclinação em recepcionar e transmitir informações (aptidão de operar como "signo"), o que capacita a migração da mensagem da relação de consumo inaugural para outras relações futuras, mantendo-se, de tal sorte, os atributos informacionais originais. ${ }^{130}$

Porém, uma das funções, contudo, mais acentuadas e que surtirá impacto determinante na disseminação dos contratos de licença de uso de marca, reside na função econômica ínsita às marcas.

Com efeito, é uníssono o entendimento doutrinário acerca da função econômica que assumem as marcas, mormente quando inseridas em um contexto onde a globalização e o célere dinamismo ínsito às relações capitalistas regem a economia mundial, tendo como resultado imediato a proteção nacional e internacional das idéias e bens incorpóreos formadores do fundo de empresa.

Para Carvalho de Mendonça, as marcas "assumem valiosa função econômica, garantindo o trabalho e o esforço humano, representando fator do tráfego e tornando-se elemento de êxito e de segurança às transações" ${ }^{131}$.

Conforme assinalado por Vianes ${ }^{132}$, na esfera econômica, a marca é vista como "um símbolo da economia moderna".

${ }^{129}$ Cf. SILVEIRA, Newton. A Marca “Stolichnaya” in SILVEIRA, Newton; SILVEIRA, Wilson (org.). Estudos e Pareceres de Propriedade Intelectual. Rio de Janeiro: Ed. Lúmen Juris. 2008. p. 174.

${ }^{130}$ Cf. BARBOSA, Cláudio Roberto. Propriedade Intelectual: introdução à propriedade intelectual como informação. op. cit. pp. 151-161.

${ }^{131}$ Idem, Ibidem. p. 217.

${ }^{132}$ VIANES, Plaquette de l'exposition sur ler marques. Beaubourg. 1977, apud Chavanne e Burst, Droit de la proprieté industrielle. 4 ed. Paris, 1993, p. 460 Apud LOUREIRO, Luiz Guilherme. A lei de propriedade industrial comentada. ob. cit. p. 233. 
P.R. Tavares Paes ${ }^{133}$, por igual, abaliza que as marcas vêm, gradualmente, assumindo importante função na economia contemporânea. A título exemplificativo do alento econômico deste signo, o jurista em referência faz menção à "Coca-Cola" cujo valor de avaliação em meados dos anos de 1990 atingia o suntuosa cifra de US\$ 39,5 bilhões.

No ano de 2009, apenas para efeitos ilustrativos e com o escopo de se trazer à baila e com lastro em números reais, a expressiva representatividade que exerce a função econômica da marca no mercado mundial, fora divulgado o ranking das dez marcas mais valiosas do mundo com os seus correspondentes valores de mercado, o qual entendemos oportuno abaixo reproduzir ${ }^{134}$ :

\begin{tabular}{|c|c|c|c|c|c|c|}
\hline $\begin{array}{l}2008 \\
\text { Rank }\end{array}$ & $\begin{array}{l}2009 \\
\text { Rank }\end{array}$ & MARCA & $\begin{array}{l}\text { PAÍS DE } \\
\text { ORIGEM }\end{array}$ & $\begin{array}{l}\text { RAMO DE } \\
\text { ATIVIDADE }\end{array}$ & $\begin{array}{c}2009 \\
\text { Valor da } \\
\text { Marca(Bilhões } \\
\text { de Dólares) }\end{array}$ & $\begin{array}{c}\text { Alteração } \\
\text { no Valor } \\
\text { da Marca }\end{array}$ \\
\hline 1 & 1 & CaGola & Estados Unidos & Bebidas & 68,734 & $3 \%$ \\
\hline 2 & 2 & 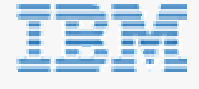 & Estados Unidos & Computação & 60,211 & $2 \%$ \\
\hline 3 & 3 & Microsoft & Estados Unidos & Computação & 56,647 & $-4 \%$ \\
\hline 4 & 4 & & Estados Unidos & Diversos (Eletrônicos) & 47,777 & $-10 \%$ \\
\hline
\end{tabular}

${ }^{133}$ PAES, P.R. Tavares. Nova Lei da Propriedade Industrial. Ob. cit. p. 83.

134 Fonte: Interbrand <http://www.interbrand.com/best_global_brands.aspx?langid=1000> Acessado em 10/10/2009. A Interbrand é a empresa líder mundial em consultoria de marca. Foi fundada em 1974, possuindo escritórios em mais de 30 cidades em mais de 20 países no mundo todo e clientes entre as empresas mais respeitadas. (website oficial <www.interbrand.com>). Na metodologia utilizada para a eleição do ranking das maiores marcas do mundo (“Best Global Brands 2009”), da Business Week/Interbrand, cada marca precisa obter pelo menos um terço dos seus lucros fora do seu país de origem, ser reconhecida fora da sua base de clientes e ter dados de marketing e financeiros disponíveis ao público. Esta metodologia avalia o valor da marca da mesma forma que qualquer outro ativo corporativo é avaliado: com base em quanto ela terá a probabilidade de render para a empresa no futuro. A Interbrand utiliza-se de uma combinação de projeções de analistas, documentos financeiros de empresas e a sua própria análise qualitativa e quantitativa para chegar ao valor líquido atual dos lucros em questão. 


\begin{tabular}{|c|c|c|c|c|c|c|}
\hline $\begin{array}{l}2008 \\
\text { Rank }\end{array}$ & $\begin{array}{l}2009 \\
\text { Rank }\end{array}$ & MARCA & $\begin{array}{l}\text { PAÍS DE } \\
\text { ORIGEM }\end{array}$ & $\begin{array}{l}\text { RAMO DE } \\
\text { ATIVIDADE }\end{array}$ & $\begin{array}{c}2009 \\
\text { Valor da } \\
\text { Marca(Bilhões } \\
\text { de Dólares) }\end{array}$ & $\begin{array}{l}\text { Alteração } \\
\text { no Valor } \\
\text { da Marca }\end{array}$ \\
\hline 5 & 5 & NOKIA & Finlândia & Eletrônicos & 34,864 & $-3 \%$ \\
\hline 8 & 6 & & Estados Unidos & Restaurantes & 32,275 & $4 \%$ \\
\hline 10 & 7 & & Estados Unidos & Serviços de Internet & 31,980 & $25 \%$ \\
\hline 6 & 8 & QDTOYOTA & Japão & Automóveis & 31,330 & $-8 \%$ \\
\hline 9 & 7 & mem & Estados Unidos & Computação & 30,636 & $-2 \%$ \\
\hline 9 & 10 & & Estados Unidos & Entretenimento & 28,447 & $-3 \%$ \\
\hline
\end{tabular}

Irretorquivelemente, para se construir uma marca forte, o posicionamento do empresário deve ser diferenciado em relação aos seus concorrentes posto que a marca deve, necessariamente, transparecer credibilidade para seus diversos públicos. Uma marca forte transmite sempre uma mensagem clara e consistente. Ela recebe constantes investimentos para manter e melhorar o contato com seu público.

No que tange à função econômica do bem intangível em estudo, merecem destaque, por igual, as marcas nacionais, as quais são, assim como as estrangeiras, desejadas por empresários emergentes e potenciais licenciados. 
Admissível trazer a cotejo estudo recente realizado pela consultoria BrandAnalytics/Millward Brown ${ }^{135}$, com 180 marcas brasileiras, indicando as marcas mais valiosas do Brasil, bem como seu valor de mercado.

Nesta esteira, os números abaixo traduzem, de forma decisiva, a importância econômica que pode assumir uma marca em determinados segmentos do mercado, estimulando, por certo, o empresariado a, cada vez mais, introduzir-se em operações de licenciamento em detrimento de se lançar, impetuosamente, e por intermédio de marca novel, no concorrido mercado contemporâneo.

\begin{tabular}{|c|c|c|c|}
\hline & MARCA & $\begin{array}{c}\text { VALOR } \\
\text { EM MILHÕES (R\$) }\end{array}$ & VARIAÇÃO ENTRE 2008 E 2009 \\
\hline (1) & BRADESCO & 12.064 & 9 \\
\hline (2) & ITAÚ & 9.878 & 9 \\
\hline (3) & BANCO DO BRASIL & 8.444 & 19 \\
\hline (4) & SKOL & 4.084 & 23 \\
\hline (5) & NATURA & 3.966 & 7 \\
\hline (6) & PETROBRÁS & 2.308 & -17 \\
\hline (7) & BRAHMA & 2.019 & -30 \\
\hline
\end{tabular}

${ }^{135}$ Fonte: <http://www.brandanalytics.com.br/site.htm>Acesso em 28 ago. 2009. O ranking colacionado na presente tese é confeccionado, anualmente pela consultoria de marcas especializada em análise estratégica BrandAnalytics/Millward Brown. A sociedade Millward Brown foi criada em 1974, é líder global na área de pesquisas de mídia, comunicação, consumo, audiência, e valor ou equity de marcas e está presente no Brasil desde 2000. Está presente, outrossim, em 43 países com mais de 75 escritórios. 


\begin{tabular}{|c|c|c|c|}
\hline (8) & ANTARCTICA & 1.741 & -11 \\
\hline (9) & UNIBANCO & 1.691 & 3 \\
\hline (10) & PERDIGÃO & 1.129 & 9 \\
\hline
\end{tabular}

O estudo em comento investiga mais a fundo o impacto econômico das marcas ao aferir a expressiva participação que este bem incorpóreo pode atingir no valor de mercado das companhias.

Pode-se depreender do quadro abaixo reproduzido ${ }^{136}$ que, em alguns casos, a participação da marca margeia a metade do valor integral de mercado da companhia, o que demonstra a expressiva significância que este intangível pode alcançar.

\begin{tabular}{|c|c|c|}
\hline MARCA & $\begin{array}{c}\mathbf{2 0 0 7} \\
\text { (\% DO VALOR DE MERCADO) }\end{array}$ & $\begin{array}{c}\mathbf{2 0 0 8} \\
\text { (\% DO VALOR DE MERCADO) }\end{array}$ \\
\hline NATURA & $44,8 \%$ & $48,9 \%$ \\
\hline HAVAIANAS & ---- & $45,3 \%$ \\
\hline BOMBRIL & ----- & $43,0 \%$ \\
\hline PORTO SEGURO & $27,7 \%$ & $29,0 \%$ \\
\hline ANHANGUERA & - & $18,3 \%$ \\
\hline
\end{tabular}

A metodologia de cálculo utilizada pela BrandAnalytics/MillwardBrown ${ }^{137}$ para

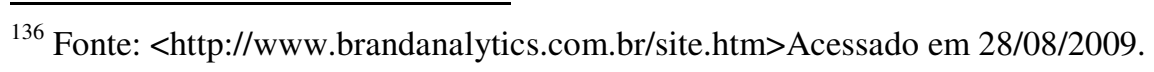


balizar o valor das marcas nacionais fundamentou-se nos seguintes eventos: (i) análise financeira; (ii) análise de demanda; (iii) análise de força de marca e (iv) avaliação da marca. Conveniente se faz demonstrar a seguir, de forma sintética, a denotação de cada evento para melhor compreensão da metodologia utilizada.

A análise financeira consiste na diferença entre o valor de mercado da companhia e o valor de seus ativos tangíveis. O resultado desta diferença corresponderá ao valor dos ativos intangíveis, corporificados em: capital humano, tecnologia, sistemas de distribuição, sistemas de produção, base de clientes, patentes, marcas e fórmulas.

Na análise de demanda, foram utilizadas as informações da BrandZ $Z^{\mathrm{TM}} 138$ com o fito de se segregar a importância da marca em relação aos outros intangíveis. Esta pesquisa, de natureza quantitativa, tem o desígnio de entender o grau de afinidade em que os consumidores se conectam a uma marca. Desta feita, há aqueles consumidores que possuem uma ligação mais emocional com as marcas, ao passo que há outros que mantêm uma relação mais racional com este bem intangível, buscando, sobretudo, preço e localização. Amparado nesta metodologia, busca-se estimar o papel das marcas na geração de resultados da empresa.

Na análise de força da marca, o que se mensura é a taxa que reflete o risco da marca a partir da análise de sua força. A base de dados utilizados confunde-se, outrossim, com aquela apresentada pela Brand $Z^{\mathrm{TM}}$. Portanto, marcas mais fortes trazem consigo maior estabilidade do que a média verificada no mercado e possuem, de tal sorte, menor risco de desvalorização. São considerados os seguintes elementos na análise da força: participação de market-share, qualidade do suporte de comunicação e risco do setor de atuação. Com base nesta análise, se verifica se uma marca tem maior ou menor risco.

\footnotetext{
${ }^{137}$ Fonte: <http://www.brandanalytics.com.br/site.htm>Acessado em 28 ago. 2009.

138 Fonte: <http://www.brandz.com/output/> Acesso em 28/08/09. BrandZ é uma pesquisa realizada mundialmente pela Millward Brown, sendo a maior base de dados sobre o relacionamentos dos consumidores com as marcas. São dez anos de mercado, um milhão de consumidores entrevistados e 50.000 marcas comparadas em 31 paises compreendendo consumidores finais em 443 categorias. No Brasil, foram realizadas cerca de 12.800 entrevistas em 32 categorias das principais cidades brasileiras. As informações recolhidas demonstram um retrato de como as marcas são realizadas financeiramente, como elas são percebidas pelo público, que categoria de marca que eles correspondem e, além disso, qual o seu potencial de crescimento.
} 
Por fim, o valor da marca é o resultado da atualização dos lucros futuros exclusivos a ela pela taxa de desconto que reflete seu risco.

Ainda no que tange à função econômica, uma das funções mais importantes do signo em estudo, forçoso destacar os ensinamentos colacionados pela professora Maitê Moro, abalizando-se no legado do jurista português Manuel de Mello ${ }^{139}$ :

Uma empresa dona de uma marca, especialmente, de uma marca notória, tem um ativo muito valioso em suas mãos. Ativo esse que pode ter valor muitas vezes maior do que o valor do resto do patrimônio material da empresa. $O$ valor atribuído à marca dependerá da força de seu poder de evolução, da atratividade que exerce no público. Esse valor não é fácil de ser medido, mas não pode deixar de ser reconhecido. (grifou-se)

Faz-se imperiosa a exposição das inteligentes ponderações confeccionadas por William M. Landes e Richard A. Posner ${ }^{140}$ sobre a função econômica que exerce a marca sob o ponto de vista do consumidor, portanto, sob a ótica de um interesse eminentemente público.

Com efeito, entendem os conspícuos economistas que as marcas fortes reduzem os custos do consumidor, os estimulando a consumir os produtos por elas representados, evitando, de tal sorte, o desperdício e a decepção do consumidor com outros produtos. Sob esta perspectiva, o consumidor, ao se deparar com uma marca de sua confiança, por representar produtos de qualidade, economiza com pesquisas, bem como gasta menos tempo $^{141}$ e dinheiro na procura de produtos de qualidade. È o chamado "custo social" das $\operatorname{marcas}^{142}$.

${ }^{139}$ MELLO, Manuel de. A importância da função de marketing nas empresas. Marketeer - Revista de Marketing, Comunicação e Vendas, Porto (Portugal), ano III, n. 19, p. 1, jan. 1998 Apud MORO, Maitê Cecília. Direito das Marcas. ob. cit. p. $42 / 43$.

${ }^{140}$ LANDES, William M.; POSNER, Richard A. The economic structure of Intellectual Property Law. London. The Beolknap Press of Harvard University Press. 2003. p. 167-175.

${ }^{141}$ Com este entendimento, sob o ponto de vista do marketing empresarial, Marcos Paulo de Almeida Salles assenta que "marca reduz o tempo e o esforço requeridos do cliente para procurar os produtos na prateleira, ou reforça a escolha do cliente, garantindo o nível de qualidade". (SALLES, Marcos Paulo de Almeida. $O$

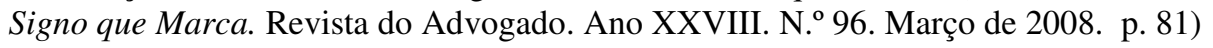

${ }^{142}$ Neste sentido, a marca, quando de confiança do consumidor, o protege contra gastos e decepções com produtos sem qualidade. Este é o entendimento corroborado por Landes e Posner: "The consumer will not be 
Nesse sentido, William M. Landes e Richard A. Posner prelecionam que o consumidor paga uma "taxa de segurança" pela marca utilizada, a qual geralmente se opera com marcas insertas no rol das marcas de qualidade. Esta "taxa de segurança" é, por certo, benéfica para o consumidor, posto que este deixará de gastar com outros produtos (supostamente com qualidade inferior), economizando, portanto, tempo e dinheiro. Com o objetivo de explicar o valor adicional que o consumidor paga pela marca de um determinado produto, os autores em comento apresentam a seguinte equação ${ }^{143}$ : "Preço Cheio do Produto $=($ Preço $)+($ Custos de Pesquisa $) "$.

Os "custos de pesquisa", os quais se refletem na "taxa de segurança" (preço adicional que o consumidor paga pela marca), podem ser representados sem, contudo, a eles se limitar, por:

informação prestada pelo empresário no que tange às características da marca e produto. Desta feita, temos que quanto mais informações são prestadas, menor será o custo que o consumidor terá com pesquisa, portanto maior será o valor daquela marca;

extensão da marca: quanto mais curta for a marca, maior será o custo do consumidor em pesquisar sobre aquela marca e produto correspondente. A contrariu sensu, quando mais extenso, transparente, elucidativo e condizente com a realidade ${ }^{144}$ for o sinal utilizado pelo produtor para representar seu produto, maior será a potencial produtividade daquela marca em reduzir os custos do consumidor.

interested in the formula as such but in the actual manufactured product that he will be consuming, and he may therefore be willing to pay a premium for greater assurance that the product will br actually manufactured to the specifications of the formula. Trademarks enable him to economize on a real cost because the spends less time searching to get the quality he wants." (LANDES, William M.; POSNER, Richard A. ob. cit. p. 174.)

${ }^{143}$ Idem, Ibidem. pp.174/175.

144 Convém repisar, neste sentido, um dos elementos essenciais ínsitos à marca, qual seja o princípio da veracidade, que prescreve, como outrora estudado, que a marca deve ser honesta, com indicação da origem e qualidade verdadeira sobre os produtos, evitando que o consumidor seja induzido a erro. Assim, o princípio da veracidade assume especial importância, não somente no que tange aos requisitos de admissibilidade para o registro da marca, mas para a função econômica que exerce a marca sobre o consumidor. Com efeito, quanto mais verossímil for a marca, maior será seu valor no mercado, porquanto mais confiança terá de seu consumidor alvo. 
Ainda no que atine à relação entre marca e captação de clientes, elucidativas se fazem as palavras do professor Marcos Paulo de Almeida Salles ${ }^{145}$, que prescreve, in verbis, que a "marca é um sinal dotado de uma volumetria de intangíveis que a fazem ser o elemento fundamental da catequese do cliente".

Ante a demonstração do valor econômico da marca e da forte relação que este sinal, em muitos casos, guarda com o consumidor, faz-se imperiosa a edição, à exaustão, de leis nacionais e internacionais ${ }^{146}$ que protejam o titular, sob pena das principais sociedades empresárias nacionais e internacionais, cuja marca é um valor tido como inestimável, estarem fadadas a inúmeras fraudes decorrentes de medidas derivadas de atos de concorrência desleal e, por via de consequiência, ao insucesso, afetando, portanto, as economias de seus países de origem e implicando em intensos prejuízos à economia mundial.

Portanto, a proteção jurídica das marcas está intimamente atrelada ao desenvolvimento econômico dos países, de tal sorte que a ausência de proteção, neste sentido, implicará em consequiências, decerto, deletérias ao desenvolvimento dos tecidos econômico, tecnológico e social ${ }^{147}$.

Paralelamente à função econômica da marca, há que se ressaltar a função social que deve, permanentemente, estar arraigada ao sinal em estudo. Neste sentido, convém fazer referência a Darcy Arruda Miranda Júnior. Consoante melhor doutrina propugnada pelo comercialista, não devemos nos esquecer que a tutela legal conferida à utilização da marca excede os interesses primeiros do seu titular, visando a alcançar toda a “coletividade". Deste modo, além de proteger os direitos dos empresários, impede que o

${ }^{145}$ SALLES, Marcos Paulo de Almeida. O Signo que Marca. Revista do Advogado. Ano XXVIII. N. 96. Março de 2008 p. 77.

${ }^{146}$ Conforme preleciona Carvalho de Mendonça, “(...) esta lei, conhecida como lei de marcas, é uma forma de defesa do industrial e do comerciante e do seu estabelecimento contra os atos de concorrência desleal; é o apoio ao trabalho, à honestidade e à capacidade industrial ou comercial contra outros abusos; é o serviço de segurança ao público, o consumidor; é, em suma, conforme dissemos, uma providência de ordem pública". (MENDONÇA, J.X. Carvalho de. Tratado de Direito Comercial Brasileiro. 2 ed. 1934. ob. cit. p. 220.)

147 "If the Law does not prevent it [brands], free riding may destroy the information capital embodied in a trademark, and the prospect of free riding may therefore eliminate the incentive to develop a valuable trademark in the first place" (LANDES, William M.; POSNER, Richard A. The economic structure of Intellectual Property Law. London. The Beolknap Press of Harvard University Press. 2003. p. 168). 
consumidor seja ludibriado como resultado da similaridade de duas marca, "adqurindo um produto por outro". São estes os objetivos que embasam a tutela legal ${ }^{148}$.

Na mesma medida, conforme legado de Julio Ledesma ${ }^{149}$, a marca deve atender a sua finalidade social, de tal sorte que o consumidor não seja prejudicado em decorrência de relações jurídicas paralelas, a exemplo do contrato de licença de marca, consumadas entre o titular da marca e terceiros. Com efeito, o jurista argentino assinala que a marca tem por desígnio: (a) guiar o consumidor quando da seleção de produtos para o consumo, sobretudo aqueles de qualidade e que são conhecidos pelo público; (b) permitir ao consumidor que este reconheça os vícios e qualidades do produto a ser comprado; (c) facilitar a construção de relações comerciais de confiança entre os produtores ou comerciantes e os consumidores.

Sobre a função social, Newton Silveira ${ }^{150}$, remetendo-se ao jurista peruano Carlos Alejandro Guerrero ${ }^{151}$, em ensaio sobre as diferentes funções exercidas pelas marca desde o início de sua evolução histórica, avaliza que e a função moderna da marca supera o princípio da territorialidade e vai além do princípio da especialidade, porque se conecta mais estritamente ao conteúdo essencial do direito das marcas, com conceitos que repousam na repressão à concorrência desleal e na proteção do consumidor.

A jurisprudência nacional, há tempos, acolhe esta corrente doutrinária (atinente à retro citada função moderna da marca). O conceito de que a tutela legal atribuída à marca deve, por igual, compreender os interesses do consumidor não é apenas doutrinário. A própria jurisprudência, há muito, tem sinalizado para este entendimento.

\footnotetext{
${ }^{148}$ Cf. MIRANDA JÚNIOR, Darcy Arruda. Curso de Direito Comercial. $6^{\text {a }}$ ed. rev., atual e aum. São Paulo: Saraiva. 1987. vol. 1. p.161.

${ }^{149}$ LEDESMA, Julio C. Funcion Social de Las Marcas de Fabrica y de Comercio. Buenos Aires. Ed. Valério Abeledo. 1953. p.86.

${ }^{150}$ SILVEIRA, Newton. Sinais Distintivos da Empresa. ...op. cit. p. 5.

${ }^{151}$ GUERREIRO, Carlos Alejandro Cornejo. in CARVALHO, Patrícia Luciane de (coord.). Propriedade Intelectual - Estudos em homenagem à professora Maristela Basso. Vol. 2. $1^{\mathrm{a}}$ ed. Curitiba: Juruá Editora, 2008, p. 103-123.
} 
Em 1984, o então Tribunal Federal de Recursos do Rio de Janeiro decidiu, com extrema perspicácia, que "a proteção legal do uso da marca, interessa imediatamente ao titular do registro e, mediatamente, a toda a coletividade. O Poder Público, quando toma a si a defesa da propriedade industrial, preserva, a par dos direito individuais, a boa-fé do consumidor a fim de não ser, pela semelhança enganosa, induzido a comprar um produto por outro. É, portanto, basicamente, pelo critério do homem comum, equivalente ao bonus pater familiae do direito civil, que há de pautar-se a avaliação das querelas de reprodução ou imitação de marcas"

Mais recentemente, em valioso voto emitido pelo Ministro Waldemar Zveiter, restou cristalina que "a proteção da marca tem por escopo reprimir a concorrência desleal e evitar a possibilidade de confusão ou dúvida, e o locupletamento com esforço e labor alheios" "153. Latreando-se neste voto, o Ministro Sálvio de Figueiredo Teixeira, por igual, aduziu em em seu voto vencedor, em sede de Recurso Especial não conhecido, que "segundo doutrina e jurisprudência sedimentadas, a proteção da marca tem por objetivo a repressão à concorrência desleal, buscando evitar a possibilidade de confusão do consumidor que adquire determinado produto ou serviço pensando ser outro, bem como o locupletamento com esforço alheio" ${ }^{\prime 154}$.

Por fim, assinalamos, em um contorno notadamente coevo, e com fundamento nas operações mercadológicas em constante efervescência no mercado gloabalizado moderno, a função progenitora, expansionista ou multiplicadora exercida por marcas pujantes no mercado. Sob este aspecto, tem a marca, mormente aquelas que galgam espaços significativos nos mercados nos quais se encontram inseridas, o predicado de ensejar a criação de oportunidades, objetivando a concepção de outras marcas, concebidas dentro de uma mesma estrutura empresarial de administração e produção.

\footnotetext{
152 Ac. un. Da $5^{\text {a }}$ Turma do TRF, de 15.02.1984, na Ap. 58.301-RJ, Rel. Min. Pedro da Rocha Acioli, DJU. 24 maio de 1984. p. 8145. (Cf. MIRANDA JÚNIOR, Darcy Arruda. Curso de Direito Comercial.......op. cit. pp. 161/178).

${ }^{153}$ Superior Tribunal de Justiça. REsp 62770/RJ, Rel. Ministro Waldemar Zveiter. Terceira Turma. Julgado em 06/05/1997, DJ 04/08/1997, p. 34739.

${ }^{154}$ Superior Tribunal de Justiça. REsp 40.190/RJ, Rel. Ministro Sálvio de Figueiredo Teixeira. Quarta Turma. Julgado em 19/08/1997, DJ 29/09/1997, p. 48207.
} 
Com efeito, o empresário moderno tem se valido de marcas vigorosas, perante as classes A e B, para a idealização e concepção de outras marcas, com o escopo precípuo de conquistar as classes menos abastadas, tais quais as classes C e D. Ante esta função progenitora, pois, o empresário intenciona conquistar classes com um poder aquisitivo mais baixo, compostas por família com renda mensal inferior, mas que representam mais da metade da população de determinada região, país ou continente.

Demais disso, esta estratégia se mostra promissora, posto que empresas com marcas fortes no mercado, ao disseminar outras marcas, com o fito de penetrar nas classes menos favorecidas, acabam por ganhar escala de produção, tornando mais rentável a utilização da capacidade de produção das fábricas, recorrendo-se, ao mesmo tempo, à mesma estrutura de distribuição das mercadorias gravadas com as chamadas primeira marca.

A título figurativo, colacione-se três exemplos da função progenitora exercida pelas marcas, a saber: (a) A Starbucks Corporation divulgou que lançará, inicialmente nos Estados Unidos, uma segunda marca de café mais barata (Seattle's Best Coffe), com o fim de atrair consumidores que tiveram seu poder aquisitivo minado pela crise financeira mundial de 2009; (b) uma das maiores empresas de chocolates, a CRM, detentora da marca de chocolates de luxo Kopenhagen, visando galgar espaços no mercado povoado pelo público consumidor inserido nas classes $\mathrm{C}$ e $\mathrm{D}$, optou pela concepção de uma nova marca, a Brasil Cacau, com produtos variando entre 30\% e 50\% mais baratos em relação àqueles chocolatados chancelados com a marca Kopenhagen; (c) há um ano no mercado, com uma segunda marca de maquiagem, intitulada Intense, a empresa $O$ Boticário já possui, no ano de 2010, 69 itens sob esse novo "guarda-chuva" tendo ampliado, por igual, o número de produtos. Desta sorte, a diferença entre o preço dos produtos da marca Intense (segunda marca) e Boticário (primeira marca) é expressiva, chegando, por vezes, a 100\%. Exemplificatiamente, enquanto o batom cravado com a marca Boticário custa, no varejo, $\mathrm{R} \$ 22,90$, aquele designado pela marca Intense, do mesmo empresário, sai por R \$9,90. ${ }^{155}$

\footnotetext{
${ }^{155}$ DE CHIARA, Márcia. Empresas apostam em $2^{a}$ marca para classe C - Estratégia é cada vez mais usada em vários tipos de produtos, como chocolates e torneiras. O Estado de São Paulo, São Paulo, 20 de jun. 2010. Caderno Economia e Negócios. p. B4. (também disponível em: <http://www.estadao.com.br/estadaodehoje/20100620/not_imp569206,0.php>. Acesso em 21 jun. 2010).
} 


\section{II.7 A MARCA À LUZ DA LEI 9.279/96: ASPECTOS RELEVANTES}

Por certo, são extensos os aspectos e características atribuídos às marcas, em consonância com os ditames consignados na Lei da Propriedade Industrial (Lei 9279/96). Colacionamos, a seguir, de modo objetivo, os principais pontos abordados pela Lei em comento no que tange à proteção dos sinais em estudo.

\section{(I) Registro:}

Inicialmente, convém destacar que a propriedade do signo em estudo é adquirido posteriormente ao registro perante a entidade governamental competente para tanto: Instituto Nacional de Propriedade Industrial (INPI). Neste sentido, reza a letra do artigo 129 da Lei 9.279/96.

Art. 129. A propriedade da marca adquire-se pelo registro validamente expedido, conforme as disposições desta Lei, sendo assegurado ao titular seu uso exclusivo em todo o território nacional, observado quanto às marcas coletivas e de certificação o disposto nos arts. 147 e 148.

$\S 1^{o}$ Toda pessoa que, de boa fé, na data da prioridade ou depósito, usava no País, há pelo menos 6 (seis) meses, marca idêntica ou semelhante, para distinguir ou certificar produto ou serviço idêntico, semelhante ou afim, terá direito de precedência ao registro.

$\S 2^{\circ} \mathrm{O}$ direito de precedência somente poderá ser cedido juntamente com o negócio da empresa, ou parte deste, que tenha direta relação com o uso da marca, por alienação ou arrendamento.

Cumpre assinalar, ab initio, que, no direito moderno, há dois sistemas legislativos de registros. O primeiro sistema denomina-se sistema declarativo, pelo qual o direito resulta do primeiro uso e o registro serve apenas como uma simples presunção de propriedade. Na outra vertente, há sistemas legislativos que se inclinam para a utilização do sistema atributivo, pelo qual apenas o registro concederá ao titular de uma marca todas as prerrogativas previstas em lei, principalmente aquelas cujo conteúdo é a proteção contra a concorrência desleal. 
O sistema brasileiro de registro de marcas é considerado, essencialmente, como um sistema atributivo de direito, em contra posição ao sistema norte americano, o qual se insere no sistema declarativo ${ }^{156}$. Neste diapasão, o direito à propriedade da marca, no Brasil, somente se aperfeiçoa com o registro do sinal pelo INPI, a despeito de alguns poucos juristas ainda elegerem o sistema declarativo, e outros indicarem o sistema misto $^{157}$, como passíveis de aplicação no sistema marcário vigente.

Dessarte, temos que, em consonância ao dispositivo legal retro transcrito, no Brasil, a propriedade da marca decorre do registro efetivado pelo INPI. Por tal razão, não é demais afirmar que o sistema pátrio de registro marcário caracteriza-se como um verdadeiro sistema atributivo.

Contudo, em cristalina oposição à assertiva de que o sistema nacional de registro de marca consiste em um sistema atributivo, a Colenda Corte Superior assinalou, em decisão isolada, que "vige no Brasil o sistema declarativo, que prioriza aquele que primeiro fez o uso da marca, constituindo o registro no órgão competente mera presunção, que se aperfeiçoa pelo seu uso"158.

A declaração acima do Superior Tribunal de Justiça emana de litígio, cujo objeto central da contenda residiu em polêmica acerca da possibilidade ou impossibilidade de uso de marca alheia, à luz do princípio da caducidade. A inutilização da marca culminou com a declaração expressa do INPI de "caducidade". Com efeito, ao Recurso Especial fora dado provimento, pois se considerou caduca marca inutilizada por 5 anos. Aludida decisão, decerto paradigmática, foi embasada, com acerto capital, nos artigos 142, inciso III e 143,

\footnotetext{
${ }^{156}$ No sistema Americano, o uso da marca legitima os direitos de seu titular. Não há a necessidade de registrá-la perante o USPTO (INPI Americano). No entanto, as autoridades americanas, e aqui, até certo, ponto reconhecendo a eficácia do sistema atributivo, recomendam o registro federal, devido às vantagens que este registro ocasionará ao titular, como: conhecimento do público, presunção legal de titularidade, facilidade para ingressar com ação judicial perante as cortes federais, o uso do registro americano para se ter uma base para registro em outros países. Fonte: USPTO (INPI norte americano). (<http://www.uspto.gov/web/offices/tac/doc/basic/register.htm>). Web Site acessado em 20/11/2008.

${ }^{157}$ Há autores que entendem que o sistema brasileiro seria misto com predominância do sistema atributivo, em decorrência da exceção prevista no parágrafo $1^{\circ}$, do artigo 129. Cf. BARBOSA, Denis Borges. Direito de Precedência ao Registro de Marcas in Usucapião de Patentes e Outros Estudos de Propriedade Intelectual, Rio de Janeiro: Ed. Lumen Juris, 2006, p. 4; e MORO, Maitê. Direito das Marcas. ob. cit. p. 54.
}

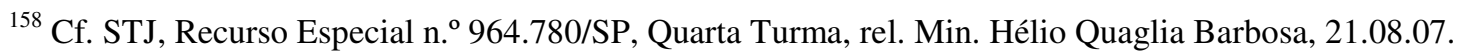


incisos I e II, da Lei 9279/96. No que diz respeito à aludida consideração, nada a divergir, especialmente porque acertadamente fundamentada.

Não obstante, posicionamo-nos em sentido contrário a um dos fundamentos consignado nesta recente decisão emanada do Tribunal Superior. Mencionada dissonância reside, essencialmente, na afirmação externada pelo STJ de que "vige no Brasil o sistema declarativo".

Tal asseveração, por certo, merece aprofundada reflexão, pois impropriamente aplicada. Afirmar, de forma peremptória, que impera no Brasil o sistema declarativo representa negar vigência ao artigo 129, da Lei 9279/96. Ministramos, de outra sorte, tese diametralmente oposta àquela externada pela Corte em exame.

Desta sorte, consideramos o sistema brasileiro de registro marcário genuinamente atributivo, comportando, no entanto, exceções mínimas, ao absorver determinados elementos provenientes, originariamente, de um sistema declarativo. Dentre estes poucos elementos de natureza "declarativa", verdadeiras reservas do sistema atributivo pátrio, podemos citar: (a) o parágrafo primeiro, do artigo 129, que concede o direito de primazia ao registro àqueles que, de boa-fé, na data da prioridade ou depósito, já usavam no país, há no mínimo 6 meses, marca idêntica ou semelhante, para distinguir ou certificar produto ou serviço idêntico, semelhante ou afim; e (b) os artigos 142, inciso III, e 143, da Lei 9279/96, cujos comandos prescrevem que o titular perderá o direito de propriedade sobre a marca registrada se esta for inutilizada pelo prazo de 5 anos. Esta hipótese última consubstancia efeito declarativo negativo dentro de um sistema macro inserido no sistema atributivo.

Ante este entendimento, é conclusivo assinalar que o sistema brasileiro é, predominantemente, atributivo, com ressalvas procedentes do sistema declarativo. Convém mencionar, outrossim, que o sistema nacional não é misto ${ }^{159}$, porque apenas admite exceções oriundas do sistema declarativo. Híbrido seria se, proporcionalmente, comportasse institutos provenientes de ambos os sistemas sob investigação. Porém, conforme fartamente ponderado, não é o que ocorre. O sistema atributivo, reitere-se,

\footnotetext{
${ }^{159}$ Para Gama Cerqueira, as exceções admitidas ao sistema predominantemente atributivo acabam por tornar este sistema um "sistema híbrido". (Cf. CERQUEIRA, João da Gama. Tratado da Propriedade Industrial. $3^{\mathrm{a}}$ ed. atual. por Newton Silveira e Denis Borges Barbosa......op. cit. Vol. II. Tomo II.. Parte III. pp. 83/84).
} 
apenas admite ínfimas exceções provenientes do sistema que lhe faz oposição. Impende-se destacar, neste aspecto, que a tese ora advogada apresenta-se juridicamente pujante, porquanto calcada em doutrina ${ }^{160}$ e jurisprudência ${ }^{161}$ majoritárias.

Em que pese, entretanto, a constituição da propriedade sobre determinada marca através do registro conferido pela autoridade competente, é cogente trazer à tona o instituto da marca de fato, instituto este que decorre de construção doutrinária ${ }^{162}$.

Aqueles signos distintivos, disseminados pelo empresariado, identificados pelo consumidor de uma determinada região, porém não registrados pelo INPI, são reconhecidos como marcas de fato. Tais sinais distinguem-se de outros sinais apostos sobre os mesmos produtos ou serviços pela notoriedade que exercem sobre determinado segmento consumidor. Registre-se, neste particular, que a marca de fato passa a ser reconhecida em decorrência da excelência e credibilidade emprestada ao produto colocado no mercado e não pelo registro conferido pelo INPI. Ademais, vale mencionar que estes tipos de marca têm como área territorial de atuação aquela região (estrita) em que há a recepção por parte do consumidor.

Do exposto, e considerando ser o sistema pátrio um sistema atributivo, as marcas de fato somente podem ser contrapostas, administrativa e judicialmente, contra marcas do mesmo gênero. Esclareça-se, exemplificativamente: se uma marca de fato aposta sobre um tênis é difundida em Belo Horizonte, naquela região não poderá haver a mesma marca de fato para o mesmo produto. Não há óbice, contudo, de que se verifique a presença da mesma marca (de fato) em outro estado ou região do território nacional, posto que não restará configurado o desvio ou confusão de clientela, elementos estes autorizadores da concorrência desleal, como corolário da atuação em mercados consumidores distintos.

\footnotetext{
160 Ver também: SOARES, José Carlos Tinoco. Lei de Patentes, Marcas e Direitos Conexos. op. cit. pp. 213/214; STRENGER, Irineu. Marcas e Patentes. 2a ed. São Paulo: Ed. LTr. 2004, p. 44; NETO, Abílio; CORREIA, Miguel J.A. Pupo. Propriedade Industrial - Legislação Anotada. Lisboa: Ed, Petrony. 1982, pp. 70-72.

${ }^{161}$ Neste sentido, ver: (a) TRF2, Apelação Cível n. ${ }^{\circ}$ AC 422866 RJ, $1^{\text {a }}$ Turma Especializada, rel. Juiz Federal Aluísio Gonçalves de Castro Mendes ; (b) TRF2, Apelação Cível n. ${ }^{\circ} 301083,1^{\text {a }}$ Turma Especializada, rel. Juíza Federal Márcia Helena Nunes, 27 de julho de 2005; (c) TJSC, Apelação Cível n. 69426 SC, $2^{\text {a }}$ Câmara de Direito Comercial, rel. Des. Pedro Manoel Abreu, 06 de março de 2003; (d) TJSP, Apelação Cível, $4^{\mathrm{a}}$ Turma de Direito Privado, rel. Des. Barbosa Pereira, 11 de março de 1999.
}

162 SILVEIRA, Newton. A propriedade intelectual e a nova lei de propriedade industrial (Lei 9279 de 
Em sentido antagônico, as marcas de fato não podem ser contrapostas às marcas registradas, estas últimas amplamente salvaguardadas pelo sistema legal marcário brasileiro. Saliente-se, pois, que as marcas de fato somente podem ser evocadas sob o manto do parágrafo $1^{\circ}$, do artigo 129 , para efeitos de preferência quanto ao registro. Ante este mandamento legal, o usuário de boa-fé que explorava a marca, há pelo menos 6 meses, tem direito de precedência no registro. Depreende-se deste dispositivo que o usuário de boa-fé não terá a prerrogativa de continuar se utilizando a marca (de fato) sem registro. Ele deverá apresentar o pedido para registrar sua marca, até então "de fato", ao INPI. Ademais, necessitará apresentar este pedido no prazo, improrrogável, de 60 dias subseqüentes à publicação do pedido da marca concorrente, que é o prazo assinalado em lei para oposições (art. 158 da Lei $9.279 / 96)^{163}$.

Portanto, se o usuário de boa-fé nada fizer, ou seja, não se opuser em 60 dias como prescreve a lei, perderá o direito de se utilizar daquela marca, cujo registro será concedido ao peticionário concorrente posterior. Assim sendo, o proprietário da marca registrada pode se insurgir contra o titular da mesma marca, mas de fato, aposta no mesmo produto ou serviço (princípio da especificidade), por este estar se utilizando do sinal registrado, ainda que o titular da marca registrada não venda, nem intencione comercializar, seus produtos na mesma região em que o titular da marca de fato desenvolva suas atividades há muitos anos.

Reitere-se, por fim, que o registro marcário tem âmbito nacional, ainda que a marca não seja disseminada em todas as regiões do país. Com efeito, no Brasil, vigora o princípio da anterioridade, uma das diretrizes basilares do direito marcário nacional e internacional. Por este princípio, se houver conflito entre marcas similares representando produtos ou servicos congêneres, encontrará abrigo legal aquele sinal que houver sido registrado em um primeiro momento.

Afirmamos que o aludido princípio é uma das diretrizes basilares também do direito marcário internacional, porque este princípio é rigidamente observado até mesmo por aqueles países que aderiram o Protocolo de Madri, sistema internacional de marcas,

14/05/1996). São Paulo. Saraiva. 1996. pp. 29-34.

163 Estatui o artigo 158, caput, da Lei 9.279/96, verbis: "Protocolizado, o pedido será publicado para apresentação de oposição no prazo de 60 (sessenta) dias”. 
através do qual o registro realizado no escritório de marcas de um dos países membros estende-se para os demais países integrantes do Protocolo. Portanto, na hipótese de um empresário registrar sua marca, isoladamente, em qualquer país (independemente se este país adote ou não o sistema internacional de registro), a proteção de seu sinal deverá ser rigorosamente observada no território em que obteve o registro, à luz do princípio da anterioridade.

A propósito da importância internacional do princípio da anterioridade, merece destaque caso paradigmático que ora se apresenta. A empresa brasileira titular da marca de cachaça "5l" procedeu ao registro de sua marca nos seguintes países: Portugal, Espanha, Reino Unido e Dinamarca. Em momento posterior, outra empresa brasileira decidiu registrar a marca de cachaça "61 Nossa Alegria" na União Europeia, através do sistema regional de marcas (marca comunitária europeia). O Instituto de Harmonização do Mercado Interno (IHMI), órgão europeu responsável pela outorga de registro de marcas no âmbito da União Europeia (registro regional), concedeu o registro da marca "61" para que a empresa titular brasileira (concorrente direta da empresa que comercializava a cachaça “51”) a utilizasse em toda a Uniao Europeia. Diante deste cenário, e sentindo-se lesada, a empresa que detém o registro da marca "51" recorreu ao Tribunal Geral da União Europeia, obtendo, assim, a decretação de nulidade do registro da marca "61 Nossa Alegria".

Em síntese, o Tribunal Europeu posicionou-se no sentido de que a empresa titular da marca "51" havia registrado aquela marca em um primeiro momento, inclusive em países que são partes integrantes da União Europeia (princípio da anterioridade). Aliado ao princípio da anterioridade, o Tribunal Europeu ministrou a tese seguinte: a empresa titular da marca "61" imitou a marca "51", o que poderia induzir o consumidor em erro ou mesmo confundi-lo, gerando a chamada "concorrência desleal". O Tribunal avaliou a confusão (na modalidade imitação, e não contrafação) com amparo nos seguintes elementos: (i) visual: "51" e "61” são visualmente semelhantes; (ii) sonoro/fonético: tanto nas línguas portuguesa, espanhola e inglesa, as sonoridades destes dois números são semelhantes; e (iii) conceitual: ambas as marcas traduzem o mesmo conceito (representam o mesmo produto). ${ }^{164}$ 


\section{(II) Classificacão das Marcas:}

Em síntese, a Lei 9.279/96, em seu artigo 123, prevê as seguintes marcas, com as respectivas funções:

(a)

Marca de Produto - são as marcas utilizadas para distinguir produtos de outros idênticos, semelhantes ou afins;

(b) Marca de Serviço ${ }^{165}$ - são os sinais utilizados para distinguir serviços de outros idênticos, semelhantes ou afins ${ }^{166}$.

(c) Marca de Certificação - tem o escopo de atestar a conformidade de um produto ou serviço com determinadas normas ou especificações técnicas, notadamente quanto à qualidade, natureza, material utilizado e metodologia empregada ${ }^{167}$.

(d) Marca Coletiva - é sinal que tem por objetivo a identificação de produtos ou serviços provenientes de membros de um determinado grupo ou entidade.

=ALLTYP $\&$ numaff $=\&$ ddatefs $=3 \&$ mdatefs $=9 \&$ ydatefs $=2010 \&$ ddatefe $=10 \&$ mdatefe $=9 \&$ ydatefe $=2010 \&$ nom usuel $=\&$ domaine $=\&$ mots $=\&$ resmax $=100 \&$ Submit=Rechercher $>$ Acesso em 30 de julho de 2010.

${ }^{165}$ Conforme entendimento corroborado pelo prof. Newton Silveira, esta foi uma categoria nova introduzida pela legislação marcária vigente, reconhecendo que se as marcas representativas dos produtos são avaliadas positiva ou negativamente pelo público em decorrência de sua qualidade, os serviços também deverão o ser, por meio de sua marca, ainda que o serviço seja delegado a terceiros. (cf SILVEIRA, Newton. A propriedade intelectual e a nova lei de propriedade industrial (Lei 9279 de 14/05/1996). ob. cit..p. 25).

166 "Nem todos os países reconhecem a existência da marca de serviço, já prevista no art. $6^{\circ}$ da Convenção de Paris (na França foi reconhecida, pela primeira vez, na lei 31/12/1964)" (cf. LOUREIRO, Luiz Guilherme de A.V. A Lei de Propriedade Industrial Comentada. ob. cit. p. 235).

167 No Brasil, a marca de certificação de maior procura é a marca "ISO”, que corresponde à sigla de organização internacional de normalização que congrega mais de 20 países no mundo. Vem do grego IGUALDADE. O que se espera é que os países sigam as mesmas normas para facilitar o comercio e relacionamento entre eles. No Brasil a ISO é representada pela ABNT - Associação Brasileira de Normas Técnicas. O ISO 9001 representa o conjunto de requisitos que tem como objetivo orientar as empresas no sistema de gestão da qualidade, com o objetivo de satisfazer os clientes, busca a melhoria continua e assegurar a competitividade de empresa. 
Muito embora ainda não tenha tido recepção pelo ordenamento jurídico pátrio, trazemos à baila nova espécie de marca utilizada, com recorrência, na Europa e, principalmente, nos Estados Unidos, país do qual se originou.

Este novo conceito é conhecido como Marques de Maison ("marca de casa") e tem a finalidade de representar não somente um produto, porém a empresa que o produziu ${ }^{168}$. Com efeito, a empresa tem a prerrogativa de depositar uma espécie de "marca guardachuva" para identificá-la como empresa detentora da titularidade da marca de uma vasta gama de produtos distintos (titular da universalidade dos produtos), sem prejuízo do registro de seus produtos ou serviços devidamente protegidos nas classes ou ramos de atividades específicos a eles correspondentes.

\section{(III) Formas de Apresentacão:}

As marcas dispõem de inúmeras formas de apresentação. Importa aclarar, de acordo com a lei brasileira, que não se pode proteger sinais que não sejam visualmente perceptíveis. O som, ou ainda um aroma, não encontram respaldo na legislação marcária nacional. Configuram-se como principais características de cada forma ${ }^{169}$ :

(a) Marca Nominativa - consiste no sinal constituído apenas por palavras, ou combinação de letras e/ou algarismos, sem apresentação fantasiosa;

(b) Marca Mista - consiste no sinal que combina elementos nominativos e figurativos;

(c) Marca Figurativa - consiste no sinal constituído por desenho, imagem, formas fantasiosas em geral;

\footnotetext{
${ }^{168}$ Cf. LOUREIRO, Luiz Guilherme de A.V. A Lei de Propriedade Industrial Comentada. ob. cit. p. 237.

169 Classificação das formas marcárias extraída diretamente do sítio oficial do INPI. <http://www.inpi.gov.br/menu-esquerdo/marca/marca/oculto/dirma_oqueemarca4>. Acessado em $10 / 11 / 2008$.
} 
(d) Marca Tridimensional - consiste no sinal constituído pela forma plástica distintiva e necessariamente incomum do produto, dissociada de efeito técnico.

\section{(IV) Vigência:}

De acordo com o artigo 133 da Lei 9.279/76, o registro da marca terá validade pelo período de 10 anos, a contar da data da concessão expedida pelo INPI. O direito à marca, ao contrário do que ocorre com a patente, é inexaurível, obviamente se atendidas todas as exigências legais e nenhuma infração for cometida ao ordenamento jurídico brasileiro.

A lei prescreve, igualmente, que a renovação ocorrerá por períodos sucessivos, devendo o titular, contudo, se atentar para as formalidades legais para que não seja subtraído da marca que sempre se utilizara ${ }^{170}$.

Vale lembrar, conforme dicção do artigo 143 da Lei em referência, que a abstenção quanto à utilização da marca registrada dará ensejo à caducidade do registro, a requerimento de qualquer pessoa com legítimo interesse se, decorridos cinco anos da sua concessão, na data do requerimento, forem verificados os eventos seguintes: (a) o uso da marca não tiver sido iniciado no Brasil; ou (b) o uso da marca tiver sido interrompido por mais de cinco anos consecutivos, ou se, no mesmo prazo, a marca tiver sido usada com modificação que implique alteração de seu caráter distintivo original, tal como constante do certificado de registro.

\footnotetext{
${ }^{170}$ Neste sentido, o titular deverá se ater à burocracia legal de, conforme prescrito no parágrafo $1^{\circ}$, do art. 133, da Lei 9279/96, formular o pedido durante o último ano de vigência do registro, instruído com o comprovante do pagamento da respectiva contribuição. Impende-se registrar, outrossim, que se o titular deixar de pedir a prorrogação nos 6 meses subseqüentes à expiração da validade, perderá ele o direito à prorrogação, devendo fazer novo registro e passar por todo o tramite burocrático e moroso perpetuado pelo INPI.
} 
Sobre a caducidade, impõe-se registrar as lições ministradas por Pouillet ${ }^{171}$, ao discorrer acerca da função social da marca. Neste sentido, Pouillet condena o monopólio sobre um sinal que não venha a ser utilizado. Este ato, por si só, atenta contra sua função social. Ademais, o contínuo ato omissivo encetado pelo titular do registro não deve dar azo à afirmação de que o emprego efetivo do sinal nos produtos fabricados pelo concorrente consistiria em flagrante lesão ao direito marcário. Portanto, não há que se falar em proteção jurídica a um sinal ocioso que nenhuma função possua, a não ser vagar no mundo jurídico desprovido de qualquer eficácia sócio-econômica.

Conforme magistério de Rubens Requião ${ }^{172}$, "a caducidade por desuso será ilidida caso se prove que a falta de uso decorreu de impedimento legítimo". Esta afirmação resulta do parágrafo $1^{\circ}$, inciso II, do artigo 143 da Lei 9.279/96, que preceitua, textualmente: "Não ocorrerá caducidade se o titular justificar o desuso da marca por razões legítimas". O Superior Tribunal de Justiça, ao interpretar o dispostivo em estudo, mostrou-se ríspido em

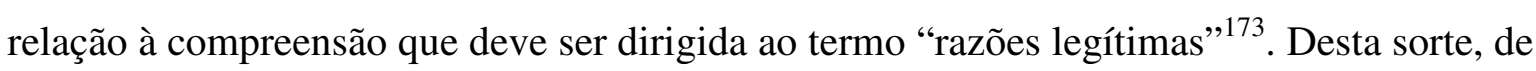
acordo com o pretório, as causas pelas quais o titular tenha deixado de utilizar sua marca devem ser fundadas em argumentos sólidos e persuasivos extraídos da realidade concreta que, inescapavelmente, impeça que o titular proceda ao uso manso e pacífico de seu sinal. Registre-se, neste particular, iluminada fundamentação emitida pelo saudoso Ministro Carlos Alberto Menezes, in litteris:

Em seguida, examino a questão em torno da caducidade. De fato, a caducidade pode dar-se de ofício se não houver a utilização da marca, salvo motivo de força maior. Isso não se discute, porquanto é texto expresso de lei. Não tem espaço, portanto, a questão da legitimidade da recorrida para pedir a

${ }^{171}$ POUILLET, E. Traité des marques de fabrique et de la concurrence déloyale en tous genres. $4^{\mathrm{a}}$ ed. Paris, Ed. Marchal et Billard, 1898. p. 146.

${ }^{172}$ REQUIÃO, Rubens. Curso de Direito Comercial. São Paulo. Saraiva. 2003. vol 1. 25 ed. p. 262.

173 Anote-se voto do Relator Ministro Nilson Naves, em que se externou que "'se não quis a embargada fabricar e comercializar seus produtos, através da sociedade brasileira na qual está, pelo menos em parte, travestida, poderia, perfeitamente, ter efetivado importações através da Zona Franca de Manaus, adaptando-se à sistemática imposta pela política econômica brasileira'” (STJ. $3^{\mathrm{a}}$ Turma. REsp no 33.759/RJ, DJ de 24/10/94). O Rel. Ministro Ari Pargendler, por igual, assinalou que "o acórdão mostrou que por mais de um meio seria possível utilizar-se da marca no Brasil, muito embora vedada a importação dos produtos que ela distingue. Assim, a fabricação pela empresa aqui sediada e de que a recorrente detém noventa e oito por cento do capital. Acrescentou argumentos, tirados da sentença proferida em outro caso, mencionando a viabilidade de importação pela Zona Franca de Manaus”. E, mais: “Essas possibilidades existiam e não se pode afirmar tenha havido violação da lei, por parte do julgado recorrido, quando as teve como capazes de

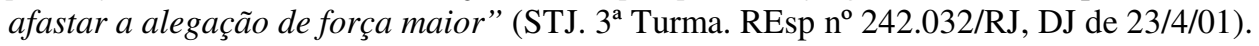


declaração de caducidade, se não houve a efetiva utilização da marca, como reconhecido pelo acórdão considerando os elementos disponíveis nos autos. Restaria verificar a alegação de força maior. O acórdão, como já vimos, entendeu que não haveria como identificar essa força maior em decorrência de vedação transitória de importação de determinados produtos, porque a marca não foi deferida para produtos importados, adiantando que se houve “impedimento à importação, bem como interesse na manutenção do registro, caberia à empresa se valer de outros mecanismos que viabilizassem sua utilização, o que poderia ser feito até mesmo por meio de concessão do uso da marca, o que, como visto acima, não se comprovou ter ocorrido com a $2^{a}$ Ré" (fl. 576). O bem armado recurso especial contradiz esse fundamento afirmando que existe comprovação da vedação da importação de produtos importados, além da falta de uso resultar também do descumprimento do contrato pela recorrida. Essa parte final não está no acórdão, que não tratou do descumprimento de contrato pela recorrida. Mas não desafiou o especial o fundamento de que a marca não foi deferida para produtos importados, com o que esse obstáculo estaria prejudicado. (grifou-se) ${ }^{174}$

Ainda no escólio de Rubens Requião, a marca deverá ser utilizada por completo, devendo condizer, fidedignamente, com as classes consignadas no certificado concedido. Haverá a possibilidade de se decretar a "caducidade parcial", se evidenciado que a marca registrada em várias classes, somente fora utilizada em relação a algumas.

A título ilustrativo, apresentamos a hiótese seguinte: uma sociedade empresária que atua no ramo da construção civil decide registrar sua marca " $\mathrm{X}$ " em duas classes de serviço: uma de desenvolvimento de projetos de arquitetura e a outra de construção civil. Verificado que a sociedade, com mais de cinco anos de constituição regular, tão somente prestou o serviço de construção civil, poderá ser decretada a "caducidade parcial" no que toca à marca concernente ao serviço jamais desempenhado pela construtora, consubstanciado no serviço de desenvolvimento de projetos de arquitetura.

\section{(V) Crimes contra as marcas:}

A lei 9.279/96 é explícita quanto à criminalização em decorrência da transgressão de suas disposições normativas. Indubitavelmente, a criminalização de lesões à lei sob comento deve se fazer presente, sobretudo quando nos deparamos, com recorrência, com a

174 REsp 649.261/RJ, Rel. Ministro Carlos Alberto Menezes Direito. Terceira Turma. Julgado em 06/03/2007, DJ 16/04/2007, p. 183. Acórdão 2303128. página 8 de 9. 
apropriação indevida de ideias alheias, o que, por certo, acaba por ensejar o desestímulo do empresariado em investir em pesquisa e desenvolvimento, comprometendo, por conseguinte, diretamente o desenvolvimento de uma nação.

Sob esta óptica, a criminalização do uso indevido da marca é imprescindível para a disseminação segura e protetiva dos contratos de licença de uso de marca e do empresariado que neste instrumento contratual busque alicerçe para se tornar sólido no mercado econômico contemporâneo.

Convém, igualmente, trazer à baila os ensinamentos de Carvalho de Mendonça ${ }^{175}$, que aclara:

É na sanção penal que reside, senão a única, a mais sólida e forte garantia do direito da marca registrada, cujo contrafator ou falsificador, violando a propriedade alheia, merece o tratamento do ladrão. Defendendo sua propriedade, produto do trabalho e da capacidade, o titular da marca registrada presta o maior dos serviços, porque defende, ao mesmo tempo, o crédito público, a saúde pública, ou, melhor o interesse público, evitando que a má-fé e o ardil triunfem na concorrência mercantil. A lei, sob esse ponto de vista, que é de natureza penal, define e precisa aqueles atentados. (grifou-se)

Desta sorte, encontra-se inserto no capítulo III ${ }^{176}$, da Lei 9279/96, que incorre em crime contra a marca aquele que: reproduz indevidamente marca alheia, altera a marca registrada por terceiro, importa produto assinalado com marca ilicitamente reproduzida e ainda utiliza-se em seus produtos de marca alheia.

Os crimes contra as marcas são igualmente contemplados no extenso rol de espécies de crimes de concorrência desleal, mormente nos incisos III e IV do artigo 195 da

${ }^{175}$ MENDONÇA, J.X. Carvalho. Tratado de Direito Comercial Brasileiro. $2^{\text {a }}$ ed. vol. V. Livro III. Rio de Janeiro. Ed. Freitas Bastos. 1934. p. 215

${ }^{176}$ Cf. Artigos 189 e 190 da Lei 9279/96, que prescrevem, in verbis: "Art. 189. Comete crime contra registro de marca quem: I - reproduz, sem autorização do titular, no todo ou em parte, marca registrada, ou imita-a de modo que possa induzir confusão; ou II - altera marca registrada de outrem já aposta em produto colocado no mercado. Pena - detenção, de 3 (três) meses a 1 (um) ano, ou multa." "Art. 190. Comete crime contra registro de marca quem importa, exporta, vende, oferece ou expõe à venda, oculta ou tem em estoque: I - produto assinalado com marca ilicitamente reproduzida ou imitada, de outrem, no todo ou em parte; ou II - produto de sua indústria ou comércio, contido em vasilhame, recipiente ou embalagem que contenha marca legítima de outrem. Pena - detenção, de 1 (um) a 3 (três) meses, ou multa”. 
Lei 9279/96, os quais assinalam que cometem crime de concorrência desleal, sujeito à pena de detenção de três meses a um ano, aqueles que empregarem meios fraudulentos, com o desígnio de desviar, em proveito próprio ou alheio, clientela de concorrente, bem como aqueles que se utilizarem de marcas alheias cujo resultado gerado seja a confusão entre os produtos ou estabelecimentos.

\section{(VI) Nulidade do registro marcário:}

Por força do artigo 165 da Lei 9279/96, serão considerados nulos os registros marcários concedidos em desconformidadade com a lei, nomeadamente se concedidos em desacordo com o artigo 124 do diploma industrial.

Cumpre assinalar que esta nulidade poderá ser total ou parcial, sendo considerada parcial quando um dos segmentos de um mesmo registro estiver em dissonância com a legislação vigente, enquanto a outra parte do registro estiver em plena conformidade com a lei. Exeplificando: um mesmo signo, de um mesmo titular, é registrado em duas classes diferentes "X" e "Y". Na classe "X", havia outro signo idêntico registrado e, na classe "Y", não havia qualquer outro sinal idêntico ou semelhante registrado. No caso hipotético apresentado, será declarada a nulidade parcial da marca, recaindo esta constrição apenas sobre o uso da marca na classe "X", subsistindo o registro na classe "Y".

No evento do empresário houver registrado sua marca, em determinado segmento de atividade, em país estranegiro signatário da Convenção da União de Paris, ele poderá, no Brasil (que é país signatário da CUP), pleitear, através de ação judicial, a adjudicação judicial do registro, nos termos do no art. $6^{\circ}$ septies (1) daquela Convenção ${ }^{177}$.

A declaração de nulidade é considerada ex tunc, pois que produzirá efeito a partir da data do depósito do pedido no INPI, conforme reza o artigo 167 da Lei 9.279/96.

\footnotetext{
${ }^{177}$ Cf. Art. $6^{\circ}$ septies (1) da CUP: “Se o agente ou representante do titular de uma marca num dos países da União pedir, sem autorização deste titular, o registro dessa marca em seu próprio nome, num ou em vários desses 78 países, o titular terá o direito de se opor ao registro pedido ou de requerer o cancelamento ou, se a lei do país o permitir, a transferência a seu favor do referido registro, a menos que este agente ou repres entante justifique o seu procedimento"
} 
Aquele que tenha interesse na nulidade de marca registrada por terceiro, poderá reivindicar seu direito, pelo processo administrativo de nulidade ou por ação judicial declaratório de nulidade autônoma. No primeiro caso, a nulidade do registro poderá ser declarado, de ofício, pelo INPI, quando esta autarquia, sem que haja provocação de terceiros, aponte para a lesão ao disposto em lei. Alternativamente, o processo de nulidade administrativa poderá ocorrer mediante o requerimento de terceitos com legítimo interesse, no prazo de 180 dias contados da expedição do certificado de registro. Reza o artigo 170 e seguintes, que o titular será intimado para se manifestado no prazo de 60 dias. Há que se resaltar que o processo de nulidade deverá transcorrer, a despeito de eventual extinção do registro.

A possibilidade de processo administrativo perante o INPI não elimina a promoção da ação judicial de nulidade, perante a Justiça Federal, por que de direito. Conforme prescrevem os artigos 173 e seguinte da Lei 9.279/96, esta ação poderá ser intentada tanto pelo órgão de registro (INPI), bem como por qualquer pessoa que tenha legítimo interesse. A prescrição para a propositura desta ação se dá em 5 (cinco) anos. Há que se ressaltar que, somente para ação declaratória de nulidade de marca, há prazo prescricional. Isto porque, tanto para a patente (invenção e modelo de utilidade), quanto para o desenho industrial, não há que se falar em prazo prescricional, considerando que a ação judicial de nulidade pode ser proposta pelo INPI ou por terceiro interessado a qualquer tempo ${ }^{178}$. Quando do término da ação, em decorrência da publicação do trânsito em julgado, o INPI promoverá a anotação no registro da marca que estava sob litígio para que terceiros possam ter ciência da nulidade declarada ou do registro mantido.

Igualmente com o que se sucede com a ação de nulidade de registro, preceitua o artigo 225 do diploma industrial que prescreve em 5 anos o prazo para a propositura da ação indenizatória para a reparação de lesão causada ao direito de pripriedade industrial (marca). A legislação se quedou silente sobre a indicação do prazo prescricional para impedir ou interditar perpetração do esbulho realizado contra o titular da marca ou contra

\footnotetext{
${ }^{178}$ Sobre a prescrição para ação de nulidade de patente, colacione-se art. 56 da Lei 9.279/96: “A ação de nulidade poderá ser proposta a qualquer tempo da vigência da patente, pelo INPI ou por qualquer pessoa com legítimo interesse". Concernente à prescrição no que diz respeito à ação de nulidade do desenho industril, cite-se o art. 118 da Lei 9279/96, que preceitua: "aplicam-se à ação de nulidade de registro de desenho industrial, no que couber, as disposições dos arts. 56 e 57 ".
} 
aqueles por este legitimados (licenciado ou cessionário). Ante esta omissão, o professor Rubens Requião entende ${ }^{179}$, com base na máxima de que o Còdigo Civil é fonte comum ao Direito Privado, que o prazo prescricional para se promover este tipo de ação será de 10 anos, ante o teor do artigo 205 do diploma civil ${ }^{180}$.

\section{II.8 DIFERENÇAS ENTRE MARCA E NOME EMPRESARIAL}

Convém trazer à lume dessemelhanças pontuais verificadas entre a marca e o nome empresarial, ambos categorizados como bens incorpóreos tutelados pelo ordenamento jurídico pátrio, porém agasalhados por regimes legais diferentes. Neste diapasão, a marca, objeto nuclear desta tese, encontra-se nomeadamente disiciplinada pela Lei 9.279/96. O nome empresarial, por seu turno, submete-se à tutela legal disciplinada pelo Código Civil Brasileiro, mais precisamente entre os artigos 1.155 e 1.168 do aludido Diploma Legal. Com efeito, para que se compreendam as principais distinções entre os referidos bens imateriais, os quais, embora muito próximos, não se confundem, faz-se necessária análise preliminar conceitual acerca do nome empresarial.

Inauguralmente, impõe-se anotar duas modalidades distintas de nome empresarial, a saber: a firma e a denominação. A firma pode ser individual ou social (igualmente conhecida como "razão social"). A firma individual se identifica com o nome do comerciante particular. Este comerciante materializa-se na pessoa física que, ao desenvolver determinada atividade empresarial, utiliza-se, obrigatoriamente, de seu nome para apresentar seu "nome empresarial", ou seja, aquela expressão que será reconhecida pelo público consumidor.

${ }^{179}$ Cf. REQUIÃO, Rubens. Curso de Direito Comercial. São Paulo: Saraiva, 2003. vol. 1. 25 a ed. atual. pp. $260 / 261$.

${ }^{180}$ Cf. Art. 205 do Código Civil Brasileiro: "A prescrição ocorre em dez anos, quando a lei não lhe haja fixado prazo menor". 
A firma social ou razão social tem por condão particularizar algumas sociedades empresárias (pessoas jurídicas). Ocorre, a título ilustrativo, com um supermercado, constituído na forma de sociedade empresária limitada, cujos sócios sejam João Pires e Pablo Nunes e que cuja firma ou razão social seja Pires e Nunes Supermercado Ltda.

Consoante o artigo 1.158 do Código Civil, as sociedades limitadas podem ser identificadas ou pela razão social, quando o nome empresarial e o nome de seus sócios se confundem, ou ainda pela denominação social, quando o nome empresarial não guarda relação com o nome dos sócios, porquanto se identifica com um nome alegórico, arbitrariamente eleito pelos sócios da sociedade. Convém mencionar que, enquanto nas sociedades limitadas há a faculdade de decisão entre razão social ou denominação social, nas sociedades anônimas, por óbvio, não há a possibilidade de se recorrer à firma ou razão social.

Não há que se confundir denominação social com nome de fantasia (título de estabelecimento). Enquanto o primeiro identifica-se como uma das modalidades de "nome empresarial", remetendo à figura da pessoa física ou jurídica empresária, o segundo, também conhecido como título de estabelecimento, remete ao lugar onde os serviços são prestados ou os produtos são oferecidos pelo empresário ou sociedade empresária. Onde ocorre o encontro do empresário com a sua clientela. Exemplo: Denominação Social: Companhia Brasileira de Distribuição. Nome de Fantasia (título de estabelecimento): Pão de Açúcar. ${ }^{181}$

Cumpre trazer à colação, ainda, que, ao contrário do nome empresarial, não há registro do nome de fantasia (ou “insígnia”) ${ }^{182}$. A proteção legal deste decorre apenas do artigo 194 da Lei de Propriedade Industrial, inciso V, que prescreve constituir crime de concorrência desleal: usar, indevidamente, nome comercial, título de estabelecimento ou insígnia alheios ou vender, expor ou oferecer à venda ou ter em estoque produto com essas referências Pena - detenção, de 1 (um) a 3 (três) meses, ou multa".

\footnotetext{
${ }^{181}$ Nesse sentido, ver: VALERI, Giuseppe. Manuale di Diritto Commerciale. Firenze: Casa Editrice Dottore Carlo Cya, 1950, v. II, p. 30; Também: REQUIÃO, Rubens. Curso de Direito Comercial. 25 ed. São Paulo: Saraiva. Vol I. p. 289.

${ }^{182}$ O Direito Brasileiro insere-se no mesmo grupo da Itália, daqueles países que não adotam o registro de nome de fantasia. (Cf. VALERI, Giuseppe. Manuale di Diritto Commerciale. Firenze: Casa Editrice Dottore Carlo Cya. 1950., v. II, p. 31).
} 
No tocante às distinções entre a marca e o nome empresarial, sob o prisma do princípio da especialidade e, como corolário, do alcance de proteção projetado, tem-se que, enquanto que o âmbito de compreensão do abrigo legal ao nome empresarial (predicado material da tutela) poderá ser estendido por todo o território nacional, naturalmente, no evento de tal extensão ser requerida junto à Junta Comercial de cada estado da unidade federativa (órgão competente de registro do nome empresarial) ${ }^{183}$, o âmbito de proteção à marca é concedida, de uma só vez, e por todo o território nacional, pelo Instituto Nacional de Propriedade Industrial (INPI), órgão competente de registro marcário. José Carlos Tinoco Soares discorda deste posicionamento, no concernente à proteção territorial regional do nome empresarial. Segundo o industrialista, "no plano fático, pode-se considerar esta limitação territorial (estadual) inócua, pois o ofendido poderá se valer das normas que regulam a leal concorrência para reprimir o uso indevido de seu nome empresarial, a qualquer título, ex vi do disposto no inc. V, do art. 124 e no inc. III do art. 195 da Lei n. 9.279/96" ${ }^{184}$.

Demais disto, parte considerável da doutrina ${ }^{185}$ ministra a tese de que, enquanto que a proteção ao nome empresarial é universal, abarcando, inclusive, aquelas atividades não desempenhadas pelo titular do registro ${ }^{186}$, a proteção conferida à marca limita-se apenas àquelas classes nas quais os produtos ou serviços do titular foram registrados no INPI, com arrimo no princípio da especialidade, ora em estudo. Por outro lado, impende-

${ }^{183}$ Cf. Art. 1.166 do Código Civil Brasileiro: "A inscrição do empresário, ou dos atos constitutivos das pessoas jurídicas, ou as respectivas averbações, no registro próprio, asseguram o uso exclusivo do nome nos limites do respectivo Estado"

${ }^{184}$ Cf. SOARES, José Carlos Tinoco. Nome Comercial “versus” Marca. in ABRÃO, Eliane Yachoub (org.). Propriedade Imaterial: direitos autorais, propriedade industrial e bens de personalidade. São Paulo: Ed. Senac São Paulo. 2006. p. 37.

${ }^{185}$ Cf. REQUIÃO, Rubens. Curso de Direito Comercial. $25^{\mathrm{a}}$ ed....op. cit. p. 231; BERTOLDI. Marcelo M.; RIBEIRO, Márcia Carla. Curso Avançado de Direito Comercial. $5^{\text {a }}$ ed. rev. e atual. São Paulo: Ed. Revista dos Tribunais. 2009. p. 126; NEGRÃO, Ricardo. Manual de Direito Comercial e de Empresa. $3^{\mathrm{a}}$ ed. São Paulo: Saraiva, 2003, v. 1, p. 195; SILVEIRA, Newton. A Propriedade Intelectual e as Novas Leis Autorais. $2^{a}$ ed. São Paulo: Revista dos Tribunais. 1982. p. 17; VERÇOSA. Haroldo Malheiros Duclerc. Curso de Direito Comercial. $2^{a}$ ed. rev e atual. São Paulo: Malheiros, 2008. vol. 1. p. 296.

${ }^{186}$ Neste particular, cite-se preleção de Sérgio Campinho, que assinala, textualmente: "Deve-se registrar que o sistema protetivo do nome empresarial vem pautado em dois princípios: a tutela da clientela e a tutela do crédito do empresário. (...) Em razão desse cenário é que a proteção não se restringe ao ramo de atividade do empresário, como ocorre no Direito Marcário." (CAMPINHO, Sérgio. O Direito de Empresa à Luz do Novo Código Civil. $10^{\mathrm{a}}$ ed. rev. e atual. de acordo com a Lei Complementar n. ${ }^{\circ}$ 128/2008. Rio de Janeiro: Ed. Renovar. 2009, p. 355.) 
se mencionar que parcela adversarial da doutrina ${ }^{187}$, ainda que minoritária, porém a qual nos filiamos, preleciona que a proteção do nome empresarial circunscreve-se tão apenas àquela(s) atividade(s) efetivamente praticada(s) pelo seu titular, sendo crível a terceiros requerer registro com o mesmo nome empresarial, contanto que desenvolvam atividades distintas daquelas praticadas pelo primeiro titular ${ }^{188}$.

Não é razoável que um nome empresarial registrado seja protegido para aquelas atividades que não sejam por ele compreendidas. Significaria estender uma proteção desproporcional e delimitar o direito de outrem de se utilizar daquele mesmo nome empresarial para atividades dessemelhantes. Com o desígnio de lastrear fundamentadamente esta afirmativa, recorremos à mesma argüição utilizada para a promoção e patrocínio do princípio da especialidade no direito marcário, com a diferença residindo no fato de que, enquanto o registro do nome empresarial objetiva tutelar o empresário ou sociedade empresária (fabricante, comerciante ou prestador de serviço), o registro da marca tem por finalidade precípua tutelar o produto ou serviço oferecido pelo empresário. Porém, cumpre mencionar que, em ambos os casos, a proteção deve ser relativizada, não englobando aqueles segmentos e nichos não explorados pelo empresário ou penetrados por seus produtos ou serviços.

A propósito do termo do registro, ou predicado temporal da tutela, impõe-se anotar que o prazo de duração do registro de marca é de dez anos, podendo ser renovado, ilimitada e sucessivamente, pelo titular. Já o prazo de duração concedido à proteção do nome empresarial, é ilimitado, não prescindindo de renovação e provação pelo seu titular. Coincide, pois, com a duração da sociedade.

No que toca à possibilidade de alienação, a marca pode ser cedida ou licenciada. $\mathrm{O}$ nome empresarial, por seu turno, ex vi do artigo 1.164 do Código Civil Brasileiro, não pode ser objeto de alienação. No caso de aquisição de estabelecimento, reza o parágrafo

\footnotetext{
${ }^{187}$ Cf. FAZZIO JÚNIOR, Waldo. Manual de Direito Comercial. São Paulo: Ed. Atlas. 2007. p. 58;

${ }^{188}$ Nesse sentido, colacione-se trecho de ementa de acórdão hodierno exarado pelo STJ: “Tutela do nome comercial entendida de modo relativo. $O$ registro mais antigo gera a proteção no ramo de atuação da empresa que o detém, mas não impede a utilização de nome em segmento diverso, sobretudo quando não se verifica qualquer confusão, prejuízo ou vantagem indevida no seu emprego" (REsp n. 262.643-SP. Terceira Turma do Superior Tribunal de Justiça. Julg. Em 09 março 2010). Ver também: Recurso Extraordinário. Rel. Min. Sydney Sanches. Primeira Turma do Superior Tribunal de Justiça. Julg. Em 26 fev. 1991.
} 
único do aludido dispositivo, que se o contrato autorizar, a adquirente deverá utilizar o nome do alienante, precedido do seu próprio, com a qualificação de sucessor.

Por fim, no caso de existência de colidência entre nome empresarial e marca, recentemente manifestou o Colendo Superior Tribunal de Justiça ${ }^{189}$ que, em princípio, os elementos que integram o nome empresarial devidamente arquivado na Junta Comercial, não podem ser posteriormente registrados, a título de marca, a não ser que assim seja procedido pelo titular da denominação ou por terceiros que tenham o consentimento deste $^{190}$.

Convém indicar o artigo 124, inciso V, da Lei 9.279/96, dispositivo este que assinala como sendo sinais não registráveis como marca: reprodução ou imitação de elemento característico ou diferenciador de título de estabelecimento ou nome de empresa de terceiros, suscetível de causar confusão ou associação com estes sinais distintivos.

Nesta senda, posicionamo-nos no sentido de que, em caso de colidência entre nome empresarial e marca, poderá ser registrada a marca, com a mesma disposição de denominação social previamente registrada na Junta Comercial por outrem, contanto que as atividades desenvolvidas pelos titulares do registro sejam cristalinamente desiguais. Isto porque, conforme acima sublinhado, o artigo 124, inciso V, da Lei 9279/96, não permite a reprodução ou imitação de nome empresarial de terceiros, porém com a ressalva expressa de que a marca que se busque o registro não cause confusão ou associação com os sinais distintivos registrados por outrem em tempo pretérito, ou seja, não implique conflito com as atividades desempenhadas pelo titular do registro antecedente na Junta Comercial.

\footnotetext{
${ }^{189}$ Ver: (i) Recurso Especial n. 1.082.734-RS. Rel. Min. Luis Felipe Salomão. Quarta Turma do Superior Tribunal de Justiça. Julg. Em 03 set. 2009; (ii) AgRg no REsp 757880/RS, Rel. Min. João Otávio de Noronha, Quarta Turma do Superior Tribunal de Justiça. julg. eem 04 fev. 2010; (iii) Recurso de Apelação n. ${ }^{\circ}$ 994.05.096655-1. 1 a Câmara de Direito Privado. TJSP. Rel. Des. Elliot Akel. Julg. em 13 abril de 2010.

190 Este entendimento segue o mesmo posicionamento jurisprudencial firmado em momento anterior à publicação da Lei 9279/96, ou seja, sob a égide da Lei 5.772/71. Registre-se ementa: "Em havendo colidência entre marca e nome comercial, prevalece este se foi levado a registro na Junta Comercial em data anterior à da marca junto ao INPI. Observância do art. 65 do então vigente Código de Propriedade Industrial (Lei 5.772/71), que veda o registro como marca de título de estabelecimento ou nome comercial" (Apelação Cível n. 98.02.31.069-7. Tribunal de Justiça do Rio de Janeiro. D.J.U. 17 set. 2001)
} 
Por outro lado, sob o mesmo argumento conflitivo acima esposado, e com embasamento no princípio da especialidade, não é direito do empresário ou sociedade empresária proceder ao registro de nome empresarial na Junta Comercial, cujos elementos colidam com aqueles elementos que permeiam marca previamente registrada pelo INPI, especialmente no âmbito de circunscrição dos produtos ou serviços chancelados pelo INPI. Portanto, na confrontação entre nome empresarial e marca, radicados no mesmo ramo de atividade, deve imperar o princípio da anterioridade, não importando se o registro anterior tenha sido outorgado pelo INPI ou pela Junta Comercial do Estado competente. Aquele que obteve, inauguralmente, o certificado de registro, passando a ter sobre o bem imaterial a propriedade, tem a chancela estatal de se insurgir contra o uso encetado por terceiros no mesmo ramo de atividade, a exceção das marcas de alto renome, conforme adiante delineado $^{191}$.

Há que se ter em mente que, tanto no que pertine à proteção do nome empresarial, quanto no que concerne à proteção da marca, o objeto central da tutela deve consubstanciar-se na salvaguarda jurídica do bem imaterial, de modo que se reprima qualquer ato de concorrência desleal ${ }^{192}$ se evite, por igual, qualquer possibilidade de confusão do público consumidor, quando da aquisição de um determinado produto ou serviço.

Apresentamos, a título ornamental, o seguinte caso exemplificativo: Sociedade Empresária " $A$ " registrou na Junta Comercial a denominação social "XYZ Produtos Alimentícios Ltda". Posteriormente, cinco anos mais tarde, a Sociedade Empresária "B" procedeu ao registro, perante o INPI, da marca ' $X Y Z$ ', na classe de calçados, sobretudo porque tem como atividade capital a fabricação e comercialização de sapatos. Ante o exposto, questiona-se: pode a Sociedade Empresária "A", que detém o registro da denominação social "XYZ Produtos Alimentícios Ltda." perante a Junta Comercial,

${ }^{191}$ Cf. GONÇALVES NETO. Alfredo de Assis. Manual de Direito Comercial. $2^{\mathrm{a}}$ ed. Curitiba: Juruá. 2000, p. 217.

${ }^{192}$ Segundo prelecionava o insigne Carlos Alberto Bittar, "o nome da pessoa jurídica desfruta de instrumento de amparo específico, tanto na lei citada, como na propriedade industrial e, em particular, no âmbito da teoria da concorrência desleal, onde se pode obviar o uso indevido por concorrente, destinado a criar confusão com sua empresa, para captação de clientela (...) (Cf. BITTAR, Carlos Alberto. Os Direitos de Personalidade. $3^{\text {a }}$ ed. São Paulo: Ed. Forense. 1999. p. 128) 
concedido preteritamente ao registro da marca de sapatos ' $X Y Z$ ', concedido pelo INPI, insurgir-se contra a Sociedade Empresária "B”?

Face à tese acima delineada, a Sociedade Empresária "A" não possui fundamento jurídico para obstar que a Sociedade Empresária "B" permaneça titular da marca "XYZ", porém esta excepcionalidade aplica-se apenas àquele caso especifico em que não fazia presente o conflito entre o núcleo da atividade praticada pela Sociedade Empresária "B" (sapatos) com o núcleo da atividade desenvolvida pela Sociedade Empresária "A" (alimentos). Por certo, se a Sociedade Empresária "B" tentasse registrar a marca "XYZ" na classe alimentícia, estaria agindo em flagrante violação à lei marcária, nomeadamente ao artigo 124, inciso V, combinado com o artigo 195, inciso V, da Lei 9279/96.

Oportuno realçar que este entendimento não se aplica aos casos envolvendo as marcas de alto renome. Aqui, não prevalece o princípio da especificidade ${ }^{193}$. Portanto, o registro outorgado sob a rubrica de marcas de alto renome, pelo contorno universal de seu registro em território nacional, obsta que sejam registrados nomes empresariais (pela Junta Comercial), bem como marcas (pelo INPI), insígnias etc que sejam colidentes com a marca de alto renome, ainda que tais registros se verifiquem em classes diversas daquela cuja tutela estatal fora adquirida pelo titular original ${ }^{194}$.

\footnotetext{
${ }^{193}$ TOMAZETTE, Marlon. A proteção ao nome empresarial . Jus Navegandi, Teresina, ano 10, n. 1062, 29 maio 2006. Disponível em: <http://jus2.uol.com.br/doutrina/texto.asp?id=8456>. Acesso em 20 set. 2009.

${ }^{194}$ Nesse sentido, ver: (i) Recurso Especial n. ${ }^{\circ}$ 658.702/RJ, Rel. Ministro Jorge Scartezzini, Quarta Turma do Superior Tribunal de Justiça, julgado em 29/06/2006, DJ 21/08/2006; (ii) Embargos de Declaração no Recurso Especial n. ${ }^{\circ}$ 50609/MG, Rel. Ministro Sálvio de Figueiredo Teixeira. Quarta Turma do Superior Tribunal de Justiça. julgado em 11/12/1997, DJ 02/02/1998; (iii) Embargos Infringentes em Apelação Cível n. ${ }^{\circ}$ 94.02.22597. TRF $2^{\text {a }}$ Região - $1^{\text {a }}$ Seção -Rel. Des. Federal Tânia Heine, julg. 09/05/2002: "Administrativo. Registro de Marca. Proibição de uso da marca em denominação social de outra empresa. (...) Notoriedade [alto renome] da marca "All Star" reconhecida dentro da mesma classe, calcada em documentos e prova pericial realizada nos autos (art. $6^{\circ}$ bis da Convenção de Paris). IV - Proibição de uso da marca na denominação social de "All Star Artigos Esportivos Ltda." se insere na competência da Justiça Federal, questão reconhecida, inclusive, pelo Tribunal de Justiça do Estado de São Paulo, no caso concreto (...)" .
} 


\section{CONSIDERAÇões INICIAIS ACERCA do CONTRATO dE LICENÇA DE USO DE MARCA: ACEPÇÃo JURÍDICA E IMPORTÂNCIA ECÔNOMICA}

\section{III.1 ACEPÇÃO JURÍDICA DO CONTRATO DE LICENÇA DE USO DE MARCA}

O contrato de licença de uso de marca é uma das espécies do gênero contrato de transferência de tecnologia ${ }^{195}$. Conforme restará adiante demonstrado, é regulamentado pela Lei 9279/96, pelo Ato Normativo n. ${ }^{\circ}$ 135/97 e pelo Código Civil em vigor no que lhe for pertinente.

Ab initio, é oportuno trazer à colação o contrato de cessão de marca. Este contrato, de forma alguma, se confunde com o contrato de licença. Entretanto, é importante que seja brevemente delineado, pois que ambos os contratos têm o mesmo objeto de direito industrial - a marca - a despeito da forma indubitavelmente dessemelhante como esta propriedade industrial é disposta por seu titular em ambos os negócios jurídicos.

O contrato de cessão de uso de marca destaca-se, essencialmente, pela transferência ${ }^{196}$, a título oneroso e definitivo, da propriedade (ou, para alguns autores, monopólio exclusivo do poder de uso sobre a propriedade) de determinada marca. Ademais, conforme adiante aduzido, o contrato de cessão equivale ao contrato de venda $e$ compra $^{197}$, assim como o contrato de licença equipara-se ao contrato de locação de bens

\footnotetext{
${ }^{195}$ Consoante prescrição do artigo 2 do Ato Normativo INPI n. ${ }^{\circ} 135$, de 15 de abril de 1997, encontram-se inseridos nos instrumentos de transferência de tecnologia, os seguintes contratos: de licença de direitos (exploração de patentes ou de uso de marcas) e os de aquisição de conhecimentos tecnológicos (fornecimento de tecnologia e prestação de serviços de assistência técnica e científica), e os contratos de franquia.

196 "Le contrat de cession de marque est celui par lequel le titulaire d'une marque transfère à un tier en tout ou partie les droits de propriété qu'il détient sur elle" (PLASSERAUD, Yves. DEHAUT, Martine e PLASSERAUD, Claude. Marques. Creation, valorisation e protection. Paris: Edition Francis Lefebvre. 1994. p. 151).

${ }^{197}$ Idem. Ibidem. p.151.
} 
móveis. Ou ainda, nos dizeres de Alexandre Gnocchi ${ }^{198}$, a cessão é uma "alienação"., ao passo que que a licença corresponde a uma "autorização de uso ou exploração". Sintetiza o jurista: “a cessão está para a licença, como a propriedade está para a posse”.

A lei 9.279/96 ${ }^{199}$, segundo a dicção dos artigos 134 e 135, assinala que, tanto o pedido de registro, quanto o próprio registro, poderão ser cedidos, em caráter definitivo, desde que o cessionário esteja em plena consonância com os requisitos legais para requerer tal registro. A condição sine qua non para a conclusão do negócio celebrado inter partes reside, necessariamente, no fato de que os produtos ou serviços sejam idênticos, semelhantes ou afins, sob pena de o negócio jurídico ser invalidado.

Não há que se falar, pois, em cessão de marca para a aposição em produtos ou serviços dessemelhantes gerados ou prestados pelo cessionário. Tal fato, notadamente, viria na contramão do sistema de registro marcário, o qual celebra, via de regra e sem contabilizar as exceções consubstanciadas nas marcas de alto renome (cuja proteção especial é assegurada em todos os ramos de atividade), que as marcas somente serão protegidas em seu ramo de atividade ou serviço, nenhum outro além. Eis o princípio da especificidade.

Esclareça-se, bem assim, que o "novo" direito de propriedade industrial, corporificado na Lei 9.279/96, largamente alicerçada na Convenção de Paris (CUP) ${ }^{200}$ e no $T_{R I P S^{201}}$, inovou ao permitir a alienação da marca, via cessão, sem que com esta estivesse

${ }^{198}$ GNOCCHI, Alexandre. Licenças e Roialties no Brasil. São Paulo. Ed. Revista dos Tribunais, 1960. p. 07.

199 “Art. 134. O pedido de registro e o registro poderão ser cedidos, desde que o cessionário atenda aos requisitos legais para requerer tal registro. Art. 135. A cessão deverá compreender todos os registros ou pedidos, em nome do cedente, de marcas iguais ou semelhantes, relativas a produto ou serviço idêntico, semelhante ou afim, sob pena de cancelamento dos registros ou arquivamento dos pedidos não cedidos".

${ }^{200}$ O art. $6^{\circ}$ quater, da Convenção de Paris (CUP), assim reza: (1) Quando, de acordo com a legislação de um país da União , a cessão de uma marca não seja válida sem a transmissão simultânea da empresa ou estabelecimento comercial a que a marca pertence, bastará, para que essa validade seja admitida, que a parte da empresa ou do estabelecimento comercial situada nesse país seja transmitida ao cessionário com o direito exclusivo de fabricar ou vender os produtos assinalados com marca cedida. (2) Esta disposição não impõe aos países da União a obrigação de considerarem válida a transmissão de qualquer marca cujo uso pelo cessionário fosse, de fato, de natureza a induzir o público em erro, particularmente no que se refere à proveniência, à natureza ou às qualidades substanciais dos produtos a que a marca se aplica.

201 Neste sentido, cite-se o artigo 21 do Acordo sobre aspectos dos Direitos da Propriedade Intelectual Relacionado ao Comércio (TRIPS), ipsis literis: "Os Membros poderão determinar as condições para a concessão de licenças de uso e cessão de marcas, no entendimento de que não serão permitidas licenças 
atrelado seu respectivo estabelecimento. Importa repisar que o Código de Propriedade Industrial de 1945 vedava, de modo expresso, que a marca fosse alienada de forma segregada de seu respectivo estabelecimento ${ }^{202}$.

Neste sentido, impõe-se reproduzir nota do professor Newton Silveira, em atualização da obra prima Tratado da Propriedade Industrial de João da Gama Cerqueira, verbis: "Permanece pertinente a observação do autor [João da Gama Cerqueira] no sentido de que, com a transferência da marca, o cedente não está impedido de explorar o mesmo ramo de atividade, desde que se utilize de marcas diferentes. Conforme ressaltado anteriormente, a transferência da marca não implica a alienação do estabelecimento comercial" 203 .

Por certo, esta inovação é de enorme valia, porquanto as relações interempresariais hodiernas se apresentam com acentuado dinamismo, e os empresários, em circunstâncias diversas, alienam marcas já construídas e robustas no mercado em que se fazem representadas, com a finalidade de investir em novas marcas, sem, contudo, se desvencilhar de seus estabelecimentos. Deste modo, a construção de uma marca pujante para sua posterior alienação (cessão) passa a ser um novo negócio de expressiva importância a ser considerado pelos empresários modernos.

Imcumbi-nos proceder, adiante, à distinção entre o contrato de cessão e o contrato de licença de uso de marca. Remo Franceschelli ${ }^{204}$ assinala que a cessão implica o desvencilhamento da marca em relação ao titular, em benefício do cessionário, ao passo

compulsórias e que o titular de uma marca registrada terá o direito de ceder a marca, com ou sem a transferência do negócio ao qual a marca pertença".

${ }^{202}$ Rezava o art. 143 do Código de Propriedade Industrial de 1945 (Revogado), in litteris: “A propriedade de marca, título de estabelecimento, insígnia e expressão ou sinal de propaganda pode ser alienada por ato intervivos, ou transferida em virtude de sucessão legítima ou testamentária, desde que o seja simultâneamente com o respectivo gênero de indústria ou de comércio'.

${ }^{203}$ CERQUERIA, João da Gama. Tratado da Propriedade Industrial. Ed. atualizada por: Newton Silveira e Denis Borges Barbosa. Rio de Janeiro: Ed. Lumen Júris. 2010. Vol. II. Tomo II. Parte III. p. 133.

204 "È anche da distinguere, poi, tra cessione e licenza, avendosi cessione quando anche la titolarità del marchio è transferita con riguardo a, e dentro, un dato ordinamento giuridico; avendosi invece licenza quanto la titolarità rimane nel cedente, e nel cessionario vengono trasmesse determinate facoltà d'uso anche publicitario, di godimento, di defesa giudiziale, ma comunque un diritto, che, rispeto a quello del cedente, resta a contenuto minore". (FRANCESCHELLI, Remo. Sui Marchi Di Impresa. Milano. Dott A. Giuffrà Editore. 1988. p. 368) 
que a licença de uso constitui, estritamente, o direito que o licenciado tem de se utilizar da marca por um determinado período de tempo (direito de uso ou exploração por prazo determinado ou indeterminado da marca disponibilizada). Assim, na licença remanesce a primordial titularidade da marca com o licenciante ${ }^{205}$. Paul Roubier preleciona que na licença dá-se tão-somente a concessão do direito de exploração, sendo que o direito de propriedade da marca remanesce com o licenciante (titular), o qual não teve a intenção de transferir aludido direito real. Na cessão, por seu turno, opera-se a renúncia, integral ou parcial, do direito de propriedade ${ }^{206}$.

Após sinalizada a principal diferença entre ambos os contratos, tornemos ao privativo exame da acepção jurídica do contrato de licença de uso de marca. A doutrina apresenta-se, predominantemente, unânime ao definir o conceito de licença, com pequenas nuances nas conceituações disseminadas pelos juristas que sobre este tema tiveram a oportunidade de se debruçar.

João da Gama Cerqueira ${ }^{207}$, José da Silva Pacheco ${ }^{208}$ e Rubens Requião ${ }^{209}$ definem a licença como uma autorização de uso da marca que o titular do sinal outorga a terceiros. Similarmente, Paul Roubier ${ }^{210}$, Alexandre Gnocchi ${ }^{211}$, Francis Lefebvre ${ }^{212}$ e Giuseppe

${ }^{205}$ Compartilham, por igual, deste entendimento: J. X. Carvalho de Mendonça, Tratado de Direito Comercial Brasileiro, vol. V, $1^{a}$ parte., $2^{\mathrm{a}}$ ed., Rio, 1938. p. 332 e segs; Thomas Braun, Precis des Marques de Fabrique et de Commerce, Bruxelles, 1936. p. 140.

${ }^{206}$ ROUBIER, Paul. Le Droit de la Propriété Industriellle. Paris : Recueil Sirey, 1952. Vol.II. p. 143.

207 CERQUEIRA, João da Gama. Tratado da Propriedade Industrial. $3^{\mathrm{a}}$ ed. atual. por Newton Silveira e Denis Borges Barbosa......op. cit. Vol. II. Tomo II.. Parte III. p. 146

${ }^{208}$ PACHECO, José da Silva. Tratado de Direito Empresarial: Empresário: pessoa e patrimônio. vol. 1. São Paulo. Saraiva. 1979. p. 565.

209 REQUIÃO. Rubens, Curso de Direito Comercial. 23ª ed. vol.1. São Paulo: Ed. Saraiva. 1998. p. 154

${ }^{210}$ De forma concisa, Roubier define a licença em comparação com a cessão do uso de marca. Com efeito, preleciona o eminente tratadista, in verbis: "Par la cession, il y a abandon, em tout ou en partie, du droit de monopole lui-même; par la licence, il y a simplesment concession de la jouissance du droit.” (ROUBIER, Paul. Le Droit de La Propriété Industrielle. $5^{\mathrm{a}}$ ed. vol.III-IV. Paris. Ed. Du Recueil Sirey. 1954. p. 261)

${ }^{211}$ GNOCCHI, Alexandre. Licenças e Roialties no Brasil. São Paulo: Ed. Revista dos Tribunais, 1960. p. 05.

212 "Le contrat de licence est une convention aux terms de laquelle le titulaire d'une marque accorde à une personne physique ou morale le droit d'exploiter la dite marque" (Yves PLASSERAUD. Martine DEHAUT e Claude PLASSERAUD. Marques. Creation, valorisation e protection. Paris. Edition Francis Lefebvre. 1994. p. 160). 
Sena ${ }^{213}$ convergem para o entendimento no sentido de que a licença da propriedade da marca, por seu titular, a terceiros, a título temporário, seria uma concessão de direito de uso. Luiz Leonardos ${ }^{214}$ alarga o conceito, ao ventilar a possibilidade de licenciamento para a marca cujo pedido de registro tenha sido efetuado, malgrado ainda não ter sido deferido pela autoridade marcária competente. Define, por igual, a licença como cessão do direito de uso, no qual se mantém conservada a propriedade ${ }^{215}$ do bem intangível disponibilizado.

A concessão de direito ao uso da marca, como um ato positivo, em conformidade com os ensinamentos difundidos pelos juristas ingleses Neil Wilkof e Daniel Burkitt ${ }^{216}$, reside na idéia fundamental de que esta licença decorre, em sua essência, de uma das caraterísticas basilares da propriedade intelectual, consubstanciada na tese de que o direito de propriedade intelectual é um direito negativo. Portanto, é razoável afirmar que a concessão da licença implica a positivação de um direito essencialmente negativo direcionada pelo seu proprietário ou titular a determinadas pessoas físicas ou jurídicas. A partir deste ato positivo do titular, o direito negativo passará a ser detido, em tese, pelo licenciado, que poderá exercê-lo perante terceiros.

Newton Silveira ${ }^{217}$, inovando na definição do instituto em apreço, aclara que a licença de uso representa a "renúncia ao direito exclusivo por parte do titular em benefício do licenciado, podendo ser expressa ou tácita, a título gratuito ou oneroso, exclusiva ou não exclusiva". Ademais, ainda conforme lição deste comercialista, "na licença existe a

213 “ Può definirsi come contratto di licenza quello com cui il titolare del brevetto attribuisce ad altri, verso corrispettivo, il diritto di utillizare l'invenzione, senza trasferire la titolaritá del brevetto". (SENA. Giuseppe. I Diritti Sulle Invenzioni e Sui Modelli Industriali. Milão. Dott. A. Giuffrè Editore. 1976. p. 320)

${ }^{214}$ LEONARDOS, Luiz. O Contrato de Licença para Exploração de Privilégio de Invenção e para o Uso de Marca - Tentativa de Análise Jurídica. In: ROSA, Rosa Cioni (coord.). Anuário da Propriedade Industrial. São Paulo: 1978, Ano II, Número 2, p. 3.

215 Jean-Jaques Burst ao analisar o contrato de licença para exploração de bem imaterial aponta, por igual, para direito de gozo do bem licenciado, com a preservação, pelo titular, de sua propriedade. (BURST, JeanJacques. Breveté et Licencie. Paris: Ed. Librairies Techniques. 1970. p. 17).

216 WILKOF, Neil e BURKITT, Daniel. Trademark Licensing. $2^{\mathrm{a}}$ ed. Londres. Ed. Thomson, Sweet \& Maxwell, 2005. p. 221.

${ }^{217}$ SILVEIRA, Newton. Licença de Uso de Marca e Outros Sinais Distintivos. São Paulo: Ed. Saraiva. 1984. p. 66. 
simples concessão do exercício do direito e dela resulta que o titular do registro conserva para si, em princípio, o direito de exploração"218.

Com efeito, é imperioso ressaltar que, antes mesmo de o titular atuar positivamente, sob o manto da autorização ou concessão de direito que lhe é próprio, ele procede à atuação negativa, corporificada justamente na renúncia de seu direito, ainda que a título temporário.

Anote-se, por fim, que corrente doutrinária majoritária, capitaneada pelo eminente Gama Cerqueira $^{219}$, vale-se dos princípios de licença de uso de patente para o delineamento da licença do uso de marca.

\section{III.2 IMPORTÂNCIA ECONÔMICA DO LICENCIAMENTO DO USO DE MARCA}

Conforme exposto no capítulo introdutório, a contribuição ao estudo jurídico do contrato de licença de uso de marca justifica-se por duas razões paritárias: uma de cunho jurídico e a outra de cunho notadamente econômico. A primeira razão, de cunho jurídico, repousa no fato de inexistir, no ordenamento jurídico vigente, regulamentação expressa mais aprofundada sobre este contrato de direito industrial, o qual, de acordo com a matéria que será examinada em capítulo oportuno desta tese, é considerado contrato atípico misto. A segunda razão para o estudo deste tipo de contrato é de cunho econômico e consiste na importância determinante que assume a operação econômica do licenciamento de uso de

\footnotetext{
${ }^{218}$ CERQUERIA, João da Gama. Tratado da Propriedade Industrial. Ed. atualizada por: Newton Silveira e Denis Borges Barbosa. Rio de Janeiro: Ed. Lumen Júris. 2010. Vol. II. Tomo II. Parte III. p. 134.

219 Ao discorrer acerca da terminologia concernente à licença, Gama Cerqueira remete-se ao Código de Propriedade Industrial - CPI - de 1945, cujo parágrafo $2^{\circ}$ do artigo 147 do citado diploma legislativo, externava a figura do "concessionário da licença". Ademais, ainda na esteira do precioso legado deixado pelo renomado comercialista, expressões equivalentes, tais quais: contrato de exploração de marca, de locação, de licença, são utilizadas, com recorrência, pelos diversos sistemas legislativos e correntes doutrinárias para a definição de licença de marca. (Cf. CERQUEIRA, João da Gama. Tratado da Propriedade Industrial. $3^{\mathrm{a}}$ ed. atual. por Newton Silveira e Denis Borges Barbosa......op. cit. Vol. II. Tomo II.. Parte III. pp. 146/147.).
} 
marca no mercado globalizado hodierno, que, conforme restará adiante demonstrado neste capítulo, movimenta cifras bilionárias.

Por certo, o licenciamento do uso da marca impacta diretamente na economia e desenvolvimento de um país e, por conseguinte, em sua capitalização. Neste sentido, imperioso faz-se colacionar os ensinamentos de P.R. Tavares Paes ${ }^{220}$, ao lecionar, in litteris:

No concernente ao desenvolvimento tecnológico, há uma vinculação entre a marca e o desenvolvimento da tecnologia de um país, pois o licenciamento de marcas nem sempre acontece isoladamente. Na maior parte das vezes, faz parte de um contrato de transferência de tecnologia, o uso de patentes. Fique certo que a marca está intimamente vinculada ao desenvolvimento técnico e tecnológico de um país." (grifou-se)

Saliente-se, outrossim, o magistério de Alexandre Gnocchi que assinala a licença, sui generis, como um dos institutos do direito industrial de maior expressividade, mormente pelo fato de ser um instrumento distribuidor de tecnologia mundo afora, procedendo ao "nivelamento industrial dos povos" 221.

Na outra vertente, pautando-se em uma análise microeconômica, e sob o prisma da perspectiva empresarial, é irretorquível o profundo impacto do licenciamento da marca na receita gerada pelas sociedades licenciadoras e licenciadas. Sob esta óptica, e calcando-se em teorias de marketing, de comunicação, econômicas e de gerenciamento de marcas, estudiosos das áreas econômica, de administração e publicidade ${ }^{222}$ procederam à confecção de tese peculiar concernente ao tema, sobretudo com foco na importância econômica e em face do mercado consumidor do licenciamento do uso da marca.

220 PAES, P.R., TAVARES, Nova Lei da Propriedade Industrial. Lei 9.279, de 14.05.1996., São Paulo: Ed. Revista dos Tribunais, 1996. p. 82.

${ }^{221}$ GNOCCHI, Alexandre, Licenças e Roialtes no Brasil, São Paulo: Ed. Revista dos Tribunais, 1960, p. 9.

${ }^{222}$ O presente subcapítulo é pautado, essencialmente, no estudo produzido pela Universidade de São Paulo (FEA), confeccionado pelo professor Dr. Edson Crescitelli em co-autoria com Adriana Stefanini, cujo tema consiste em: "O Licenciamento de Marcas. Estudo de Caso: Mattel do Brasil - Marca Barbie". $<$ www.ead.fea.usp.br/Semead/10semead/sistema/resultado/trabalhosPDF/48.pdf>. Sítio acessado em 20 out. 2008. 
Com fundamento no estudo realizado por Edson Crescitelli ${ }^{223}$, os experts em marketing admitem quatro alternativas para o crescimento de empresas em determinados segmentos mercadológicos.

O primeiro, denominado penetração no mercado, se dá quando a empresa almeja o aumento de suas vendas, através da implementação de políticas mais agressivas. A segunda alternativa, intitulada desenvolvimento de mercado, se opera quando a empresa insere-se em novos mercados para, então, aumentar as vendas de suas mercadorias. A terceira alternativa, conhecida como desenvolvimento de produto, se dá quando a sociedade empresária produz melhorias em seus produtos ou mesmo oferece produtos novos, com o desígnio de alargar seu mercado consumidor. A quarta possibilidade para a tentativa de crescimento denomina-se diversificação e se encerra com a migração para novos segmentos, o que significa que novos produtos passam a ser produzidos e novos mercados passam a ser adentrados.

Ainda na esteira do que nos ensina Crescitelli, o "licenciamento é uma oportunidade de desenvolvimento de mercado, desenvolvimento de produtos e diversificação". Destarte, o licenciamento da marca passa a nortear muitas empresas que almejam ingressar em novos segmentos sem que, para tanto, tenham de envidar grandes esforços, aqui representado pela construção e consolidação da marca na mente do público consumidor.

Note-se que o licenciamento pode ocorrer por diversas razões, sendo moldado aos interesses do empresariado que o aciona. Desta forma, ele pode ser usado por algumas empresas com o fito de agregar valor ao produto. De modo diverso, outras empresas preferem utilizá-lo para a ampliação de seu portfólio, com a divulgação de produtos sazonais, nova linha de personagens de desenhos animados, novos membros de jogos eletrônicos etc.

Ademais, a tendência para a segmentação de mercado faz-se cada vez mais patente. O consumidor não mais se contenta com os mesmos produtos, sempre buscando a evolução e, principalmente, a aquisição segura e confiável de novos produtos. O licenciamento

${ }^{223}$ CRESCITELLI, Edson, "O Licenciamento de Marcas. Estudo de Caso: Mattel do Brasil - Marca Barbie"... op. cit. p. 3. 
apresenta-se, pois, como instrumento hábil e de extrema eficácia, não apenas para promover a aproximação entre a empresa licenciada e seu correspondente mercado consumidor, como, igualmente, para conquistar a confiança e conseqüente fidelização deste público alvo.

Sob o prisma da estratégia de mercado, o licenciamento assume grande importância no "posicionamento". Para Al Ries ${ }^{224}$, o "posicionamento" de um produto consiste não apenas na singularidade mercadológica criada por um determinado produto, através de sua marca, porém na forma como ele, produto conjugado com sua marca, é inserido no intelecto do consumidor, de tal sorte que lá seja afixado, culminando com a fidelização do consumidor ao produto consumido.

Nesta esteira, as marcas assumem importância especial para conquistar o mercado consumidor para o qual são direcionadas, de tal sorte a cativá-lo, fidelizá-lo e, por via de conseqüência, resguardar a empresa contra políticas agressivas impetradas por empresas concorrentes. Assim se dá a consolidação e crescimento das margens de lucros.

O impacto econômico do licenciamento consiste no fato de que a marca passa a ser utilizada em vários segmentos de mercado, na medida em que vai sendo proliferada pelo licenciante. Com efeito, a marca, antes reconhecida por causa do produto, passa por um profundo processo de inversão. Assim, se antes a marca se destacava pela qualidade do produto a ela intrínseco, agora o contrário se opera, i.e., o produto passa a ser reconhecido e consumido primeiro pela marca e, depois, pela sua qualidade.

Novamente, impende-se registrar o posicionamento adotado por Cerscitelli ${ }^{225}$, ao discorrer acerca da força do licenciamento como eficaz ferramenta de marketing:

O licenciamento como ferramenta de marketing traz numerosas vantagens, como a transferência de valores da marca para a linha de produtos, os menores investimentos na criação e desenvolvimento de novas marcas e a redução do tempo para se chegar ao varejo, bem como os esforços de comunicação. Para

\footnotetext{
${ }^{224}$ RIES AL e TROUT, Jack. Posicionamento. A Batalha por sua Mente. São Paulo: Prenice Hall, 2002. pp. $37-49$.

${ }^{225}$ CRESCITELLI, Edson, ob. cit. p. 13.
} 
empresas de grande porte, o licenciamento gera a diversificação do portfólio, a entrada em novos segmentos e o faturamento adicional. No caso de pequenas $e$ médias empresas, ocorre ainda um reposicionamento da estratégia da empresa e de sua precificação, uma vez que ela pode aumentar sua margem quando oferece um produto diferenciado acoplado a uma marca forte. Já os licenciadores procuram empresas alinhadas com o posicionamento de suas marcas, empresas líderes em seus segmentos, com distribuição nacional, solidez financeira, transparência, associação de longo prazo, cuidado com o uso da marca e inovação.

Diante do exposto, são irretorquíveis os profundos efeitos econômicos causados pelo licenciamento de uso de marca no mercado mundial, servindo como verdadeiro atalho para a conquista de determinado mercado consumidor e, em concomitância, servindo como evento fomentador à edificação de sistemas jurídicos mais bem aparelhados tecnicamente, sobretudo na ambiência do direito da propriedade intelectual ${ }^{226}$.

\section{III.2.1 LICENCIAMENTO DO USO DE MARCA NO MUNDO 227}

O impacto do licenciamento, principalmente do uso de marca, é bastante expressivo na economia mundial. São geradas cifras elevadíssimas, nomeadamente com o licenciamento de marcas notórias. Destacam-se como protagonistas, no cenário econômico mundial, as seguintes modalidades de licenciamento: estilistas de moda, marcas corporativas, marcas esportivas, personalidades, personagens, marcas universitária, dentre outras, como: causas célebres (Greeepeace, Combate ao Câncer, Unicef), eventos esportivos e sociais (Jogos Olímpicos, Copa do Mundo, Shows) e lugares (Walt Disney

\footnotetext{
${ }^{226}$ Sobre a edificação da ordem jurídica em torno da ordem econômica, oportuno colacionar melhor lição de Balmes Vega Garcia, com arrimo na doutrina weberiana, ao discorrer sobre as relações existentes entre direito e economia: “(...) d. a garantia jurídica está a serviço direito dos interesses econômicos, e não o contrário, ou seja, o modo de produção de uma comunidade solicita e desenvolve determinadas tecnologias, condicionando as relações sociais e gerando um mundo jurídico que o ordene, organize, garanta e assegure, e quando não é este o caso os interesses econômicos não os fatores mais poderesos na formação do direito (...)” (cf. GARCIA, Balmes Vega. Direito e Tecnologia: Regime Jurídico da Ciência, Tecnologia e Inovação. São Paulo: LTr, 2008. p. 61-64)

${ }^{227}$ Este subcapítulo é calcado na apresentação de dados estatísticos expostos por Charlles Riotto, presidente internacional da LIMA - International Licensing Industry Merchandisers' Association, na Exposição do Licenciamento (EXPOLIC), em São Paulo, no dia 4 de abril de 2005. RIOTTO, Charlles. O licenciamento no mundo: uma visão geral. Artigo publicado em 04 de abril de 2005. Disponível em $<$ http://www.abral.org.br/default.asp?tp=1\&pag=noticia/licenciamento.htm>. Acesso em 20 out. 2008.
} 
World, Aspen, Universal Studios). Os dados estatísticos que abaixo seguem representam fiéis indicadores da importância deste negócio jurídico na economia mundial ${ }^{228}$.

Anualmente, a LIMA - Associação Internacional do Licenciamento de Propriedade Intelectual $^{229}$, promove estudo específico, povoado por informações estatísticas voltadas para o segmento norte-americano de licenciamento. Este estudo é fruto do profundo trabalho realizado por pesquisadores das universidades de Harvard e Yale. O estudo estatístico que a seguir se esboça externa os resultados obtidos ao final do ano de 2003.

Impõe-se registrar que os royalties pagos pelos fabricantes, para os direitos de licenciamento de produtos, consistiram em US\$ 5.8 bilhões somente nos Estados Unidos. Ademais, a receita alcançada no mercado de varejo totalizou US\$ 104 bilhões.

Ainda na esteira do estudo apresentado pela LIMA, somente o licenciamento de produtos com temas esportivos, como: tênis, camisetas, calças, bermudas, moletons, raquetes etc, foi responsável por US\$ 807 milhões em royalties, no ano em que foi confeccionado o estudo acima referenciado, o que representa US\$ 14,5 bilhões em vendas, no varejo. O licenciamento deste ramo cresceu $12,4 \%$ em relação aos dois anos antecedentes. É notório, pois, o fato que estes produtos acabaram se tornando referência de moda, principalmente para esportistas no mundo todo.

${ }^{228}$ DIESENDRUCK, Elcan. Com Licença. São Paulo: Nobel, 2000. pp. 40-50.

229"LIMA" é a associação internacional sem fins lucrativos dos licenciadores, licenciados e todos aqueles que tenham interesse direto ou indireto no mercado de licenciamento de propriedade intelectual. A associação foi fundada em 1985, contando, atualmente, com mais de 1.000 associados, representados por companhias e pessoas físicas envolvidos no mercado de licenciamento de marcas e propriedades intelectuais, como agentes e proprietários; industriais; produtores, consultores, vendedores, advogados, contadores etc, contando com escritórios espalhados nos principais centros econômicos mundiais (Nova Iorque, Londres, Munique, Tóquio, e Pequim) A "LIMA" tem por objetivo principal: estabelecer um padrão que reflita aproximação ética e profissional do mercado de licenciamento. A principal fonte de informação é a indústria. Esta associação internacional tem ainda por objetivo comunicar informações atuais sobre o mercado de licenciamento, incluindo dados estatísticos, elevação ou diminuição da taxa de licenciamento, avaliação dos motivos ensejadores de tais modulações etc. para seus associados. Estas informações, via de regra estudadas com acuidade, são encaminhadas aos associados por publicações, boletins, jornais, seminários, conferências e relatórios digitais. Em síntese, tem a Associação Internacional o desígnio de acompanhar as oscilações do mercado de licenciamento, transferindo as informações aos associados, para que estes se situem no mercado de licenciamento podendo adotar esta ou aquela postura, em consonância com as informações, interpretações e conclusões emitidas pela LIMA. Sitio oficial: <www.licensing.org>. Acesso em 30 out. 2008. 
Adicionalmente, em consonância com o estudo sobre o qual fora pautado o presente subcapítulo, grandes marcas esportivas, como "Nike", "Adidas", "Mizuno", dentre outras, estão diversificando seu mercado alvo, passando, doravante, a buscar a dilatação de seu mercado consumidor, ou seja, passando apenas de jovens e adultos para mulheres, crianças e até bebês.

Fora, igualmente, constatado que inúmeras lojas norte-americanas comercializam produtos licenciados, cujo objeto central se materializa na marca corporativa. Tal setor é responsável por US\$1,06 bilhões em pagamento de royalties, representando, por seu turno, a expressiva cifra de US\$ 18 bilhões nas vendas realizadas sob a modalidade do varejo. Dentre os exemplos mencionados, no que pertine ao estudo sobre o impacto econômico mundial do licenciamento, merecem destaque roupas da marca HarleyDavidson, itens de coleção da Coca-Cola, carrinhos para bebês da Jeep, lentes da Kodak para óculos e sorvetes da Starbucks.

Como resultado da presença do licenciamento de marca no mercado mundial, é razoável convergir para o entendimento de que os consumidores compreendem com maior celeridade e segurança o valor e a qualidade das marcas licenciadas e se sentem mais confortáveis para adquirir produtos que representam uma expansão de pessoas ou empresas confiáveis (titulares da marcas licenciadas). Alicerçado nesta filosofia, o segmento da marca corporativa cresceu, no ano de 2003, 9,2\% nas vendas no varejo, em comparação aos dois anos pregressos. Ademais, as áreas de crescimento compreendem, desde modestos artigos para a moradia, até peças automotivas e materiais para construção civil.

Há que se ressaltar, outrossim, a elevação nas vendas de roupas cujo estilo e uso são cristalinamente endossados por celebridades. Este fato decorre do irrefutável culto às celebridades perseguido pela grande maioria da população jovem dos principais centros econômicos mundiais. Anote-se, igualmente, que os produtos licenciados não somente referem-se à área de vestuário, expandindo-se, também em larga escala, para produtos no segmento de perfumes. O estudo sob análise concluiu que marcas de celebridades, como Britney Spears, Beyonce, Paris Hilton etc. são incomparavelmente mais comercializadas e mundialmente reconhecidas do que aquelas marcas em estágio ainda embrionário. Comprovando esta informação, no ano de 2004, os royalties, nos retro mencionados 
segmentos, renderam US\$ 848 milhões, e as vendas destas marcas no varejo atingiram o impressionante dígito de US\$15,3 bilhões.

Analisando-se o mercado de produtos licenciados, à vista do mercado de entretenimento, o estudo sob análise confirmou que tal mercado remanesce como o maior segmento na área de licenciamento gerando $43 \%$ do total de vendas da indústria, ou, em números reais, US\$ 2,5 bilhões de dólares em royalties, e ainda cerca de 44 bilhões de dólares das vendas no varejo. Este nicho compreende propriedades e personagens de filmes, da televisão, de jogos interativos e de outras fontes de entretenimento. O estudo aponta que, neste mercado, sobretudo em relação ao licenciamento da marca personagem para utilização em um filme cinematográfico, por exemplo, o sucesso da receita decorrente do faturamento é diretamente proporcional ao sucesso que o filme faz nas bilheterias. Tanto é assim que filmes marcantes como: Homem Aranha, Batman, Guerras nas Estrelas, Sherlock Holmes, 007 - James Bond, geraram e continuam resultando bilhões de dólares aos licenciadores da marca "personagem”.

Fenômeno por igual interessante reside no licenciamento do nome de escritores falecidos mundialmente reconhecidos. Depois de consagrados no mercado literário e editorial, os nomes ("marcas") dos escritores acabam figurando em capas de livros concebidos, redigidos e lançados em momento póstumo ao falecimento destes. O norteamericano Sidney Sheldon, por exemplo, um dos novelistas e romancistas contemporâneos de sucesso universal, com mais de 300 milhões de livros vendidos em todo o mundo, mesmo após sua morte, prossegue tendo seu nome sobreposto em capas de livros em cujas idealização, redação, revisão e edição não tivera a oportunidade de participar. Este licenciamento é fruto da vontade dos herdeiros e editores de manter a chama da marca de seus ascendentes acesa neste nicho de mercado, isto sem fazer alusão à intenção dos sucessores e editores em angariar expresiva receita advinda deste proveitoso negócio jurídico realizado a título oneroso ${ }^{230}$.

\footnotetext{
${ }^{230}$ Oportuno colacionar trechos extraídos do periódico Veja em matéria articulada sobre o licenciamento póstumo do nome de escritores de sucesso: “(...) A Senhora do Jogo, novo romance de Sidney Sheldon, foi escrito, na verdade, por uma autora bem menos conhecida, Tilly Bagshawe. É um expediente da indústria editorial para manter viva a marca de autores de sucesso que já morreram. (...) Um autor de best-sellers consagra-se fixando seu nome como uma marca comercial. Herdeiros e editores de escritores de sucesso encontraram, nos últimos anos, um meio de manter esse nome forte no mercado: contratam escritores para continuar a obra do morto. (...) Em geral, o escritor que leva adiante a marca de um best-seller já provou sua competência em livros assinados só com o prórpio nome - mas sem alcançar vendas realmente expressivas. A oportunidade de se associar a um morte ilustre é muito sedutora para esses autores de
} 
Dando seqüência à análise do licenciamento da marca no mundo, a associação internacional de licenciamento (“LIMA”) procedeu à investigação do mercado de licenciamento no Japão, decisivamente considerado como o mercado mais significativo na Ásia. A indústria de licenciamento, no Japão, em 2005, estava estimada em 27 bilhões de dólares, no varejo, sendo que o mercado de entretenimento representa 55\% (US\$15 bilhões) desse total.

Com efeito, e como estratégia de marketing, lojas norte-americanas e japonesas comercializam livros e produtos licenciados na mesma seção. O fenômeno "Harry Potter" é um exemplo marcante do sucesso quanto à aplicação desta estratégia de conjugação de produtos para a atração do mercado consumidor.

Ainda ponderando o mercado de entretenimento, os jogos eletrônicos geram receitas milionárias para os licenciadores. Sob esta perspectiva, jogos para televisão e computadores estão compreendidos nos segmentos, decerto, mais lucrativos, pois a Sony e a Nintendo lançaram novas plataformas, que lograram êxito nos primeiros anos desta década, fazendo com que os fornecedores dos jogos lançassem novos produtos. Destarte, personagens que atraíram o público infanto-juvenil, tais quais: Pokemon, Dragon Ball e Mario Bros foram ícones das maiores vendas já registradas neste segmento, levando a um acréscimo de $33 \%$ no licenciamento de personagens para jogos, desde 2002. O estudo em referência indica que esta tendência deve permanecer, pois que os jogos eletrônicos portáteis se tornaram mais populares, não apenas entre as crianças, mas também entre adultos de 20 a 40 anos, os quais conviveram com estes personagens em suas fases pueris.

segundo escalão. E eles não se importam com o fato de o nome mais proeminente na capa pertencer a um escrito que não digitou uma só linha do texto. (...)." (TEIXEIRA, Jerônimo. Vivos para Sempre. Revista Veja, São Paulo, Ed. Abril. Edição 2149. Ano 43 - n. ${ }^{\circ} 4.27$ de jan. 2010. pp. 122/123) 


\section{III.2.2 LICENCIAMENTO DO USO DE MARCA NO BRASIL}

Em meados do século XX, a receita gerada com o licenciamento saltava os olhos do empresariado estrangeiro e demonstrava a tendência para a solidificação deste segmento no país. Em consonância com o relato prestado por Alexandre Gnocchi ${ }^{231}$, o Brasil pagava, a título de royalties, quantias elevadíssimas, sendo que, em 1955, foram pagos US\$ 196 milhões; em 1956, US\$ 275 milhões de dólares e, no ano seguinte, US\$ 350 milhões. Dentre os mercados para os quais os royalties eram direcionados, merecem destaque: Estados Unidos, com 52\%; Suíça, com 17\%; França com $11 \%$ e outros com $20 \%$.

O mercado do licenciamento de marcas chegou com força tamanha que os valores enviados para o exterior em 1957 (US\$ 350 milhões), sob a forma de pagamento de royalties, já excedia o custo brasileiro com a importação de bens indispensáveis, como petróleo, trigo, fretes e seguros.

Atualmente, de acordo com as informações divulgadas pela ABRAL - Associação Brasileira de Licenciamento ${ }^{232}$, o empresariado brasileiro, em muitos segmentos, passa a migrar da antiga posição de licenciado para licenciador. Todavia, embora evoluído, ainda permanece distante dos valores angariados no mercado de licenciamento insculpido nos principais centros econômicos mundiais, tais quais Estados Unidos, Alemanha, Japão, dentre outros.

${ }^{231}$ GNOCCHI, Alexandre, Licenças e Roialtes no Brasil, São Paulo, Ed. Revista dos Tribunais, 1960, pp. 8991. Relato prestado com fundamento em informações extraídas diretamente das Revistas <A Visão $>$, de 15 de janeiro de 1959, p. 19 e <Desenvolvimento e Conjuntura>, Rio de janeiro, n. 6, p. 49 e seg.

232 Os dados apresentados neste capítulo foram extraídos e encontram-se disponibilizados no sítio da Associação Brasileira de Licenciamento, cujo escopo visa congregar todas as partes que trabalham, direta ou indiretamente, com o licenciamento de Marcas, Personagens, Celebridades, Clubes Esportivos e outras formas de licenciamento. Ademais, ABRAL assinou, em 16/05/2007, um acordo de cooperação com a LIMA - International Licensing Industry Merchandisers' Association, através do qual passa a fazer parte da mais poderosa entidade de licenciamento do mundo, com sede em Nova York e escritórios em Londres, Munique, Tóquio e Xangai, e a ter acesso aos 1.100 associados da LIMA, que dará todo apoio e know-how para abertura das portas do comércio internacional para as empresas brasileiras de licenciamento. In $O$ Setor de Licenciamento. Disponível em <http://www.abral.org.br/default.asp?tp=3\&pag=menu/setor.htm>. Acesso em 20 out. 2009. 
Impõe-se registrar que o Brasil dispõe de cerca de 900 marcas licenciadas e 550 licenças disponíveis distribuídas entre 80 agências licenciadoras, que geram expressivos impactos sócio-econômicos ao país. Isto porque estas empresas acabam por gerar 1200 empregos diretos, e que, por óbvio, acarreta na geração de centenas de milhares de empregos indiretos, distribuídos nas indústrias que geram os produtos licenciados, embalagens, propaganda, além daqueles indivíduos que são contratados para proceder ao trabalho de distribuição, entrega e venda dos produtos licenciados ao consumidor final no varejo.

No ano de 2007, o faturamento alcançou 3 bilhões de reais ao mercado revendedor em geral. O Brasil dispunha de, aproximadamente, 450 licenças disponíveis, com royalties variando entre 4 a 12\%, com média aproximada de 6\%. Ademais, segundo informações oficiais prestadas pela ABRAL, o mercado teve um impactante crescimento de $6 \%$.

A estimativa realizada para os anos de 2008 e 2009 apresentou-se com elevado grau de otimismo, sendo que para 2008 a ABRAL aquilatou faturamento de 3 bilhões e 200 milhões de reais, com royalties variando de 6 a 14\%, portanto valorizado se comparado com o ano de 2007. No ano de 2009, o faturamento do setor foi de 4 bilhões e 200 milhões de reais ao mercado revendedor em geral. Havia, aproximadamente, 450 licenças disponíveis, com royalties variando entre 4 a 14\%, com média aproximada de $6 \%$. O mercado cresceu cerca de $6 \%$ em comparação com os anos anteriores.

Estão compreendidos entre os maiores licenciantes nacionais: Mattel do Brasil, Disney do Brasil, Imagine Action, Dalicença, Maurício de Sousa Produções, Warner Bros, dentre outros. O licenciamento mais freqüente praticado no Brasil concerne à licença de personagens, tais quais: Turma da Mônica, Looney Tunes, Batman, Barbie, Mickey e outros, bem como licenciamento de nomes ("marcas") de personalidades, as quais permitem a aposição de seus nomes/marcas em produtos e serviços das mais diversas naturezas. De acordo com pesquisa elaborada pela Veja, periódico semanal de abrangência nacional, personalidades nacionais auferiram milhões de reais com o licenciamento de suas marcas para a aposição em uma vasta gama de produtos diferenciados.

Para fins estatísticos, convém registrar as vultosas quantias auferidas pelas principais personagens nacionais, em decorrência do licenciamento de seus nomes 
(marcas), no ano de 1997: (a) Angélica: licenciou seu nome para aposição em 250 produtos (esmaltes, brinquedos, sandálias etc.). Faturou, em 1997: R\$ 75 milhões; (b) Eliana: licenciou seu nome para aposição em 80 produtos (bonecas, jogos, calçados etc.). Faturou, em 1997: R\$ 45 milhões; (c) Gugu: licenciou seu nome para aposição em 46 produtos (travesseiros, brinquedos, jogos etc.). Faturou, em 1997: R\$ 35 milhões. ${ }^{233}$

Ainda sob o ponto de vista econômico, a ABRAL reconhece que o desenvolvimento de negócios, pautados no licenciamento, tem, a cada dia, acenado para outros novos negócios. Estes novos negócios são realizados através do uso de marca ou imagem de celebridades, astros de televisão, esportistas famosos, estilistas, escolas de samba, artistas plásticos, que decidem ceder seus nomes, imagens, prestígio e "marca" para a difusão de novos produtos.

No Brasil, os desenhos animados e programas infantis transmitidos na televisão, sejam em canais aberto, sejam em canais fechados, dão ensejo ao licenciamento de seus personagens. A título ilustrativo, a associação de personagens famosos à rede de supermercado agrega valor e dão oportunidade a numeroso aumento das vendas.

O licenciamento alastra-se hodiernamente para os mais diversificados ramos de entretenimento. Profissionais que atuam neste nicho de mercado sentem a presença marcante dos efeitos que o licenciamento de marca vem acarretando nas empresas e na economia nacional.

Além daqueles setores tradicionais, que já vinham praticando o licenciamento, os clubes de futebol brasileiros, por igual, se encontram inseridos neste próspero processo empresarial, objetivando, especialmente, que a sua marca gere renda adicional como conseqüência natural do licenciamento, na esteira do que, há muito tempo, já vem sendo praticado pelos principais clubes europeus.

Neste aspecto, anote-se, a título exemplificativo, estudo realizado pela empresa Crowe Horwath RCS, o qual ponderou o valor das marcas dos principais clubes de futebol

\footnotetext{
${ }^{233}$ SANCHES, Neuza. Show Biz: A Marca da Loira. Revista Veja, São Paulo, pp. 126/127, 29 abr. 1998. $<$ http://www.veja.com.br/acervodigital/home.aspx>. Acesso em 04 de março de 2009.
} 
do Brasil ${ }^{234}$. Para precificar as marcas, o estudo embasou-se em fatores como: receitas com publicidade, interesse dos patrocinadores, maior envolvimento dos torcedores nos negócios do clube, venda de ingressos para os jogos e mídia. A avaliação feita das marcas dos três maiores clubes nacionais, representados, respectivamente, por Flamengo, Corinthians e São Paulo, supera os R 500 milhões cada, tendo, estes bens intangíveis, obtido um crescimento de $115 \%$ no período compreendido entre os anos de 2003 e $2009^{235}$.

É forçoso concluir, pois, que a valorização que ora se apresenta acaba por impactar incisivamente na importância e disseminação dos contratos de licenciamento das marcas dos times de futebol de maior notoriedade, em velocidade igual ou ainda superior à dissiminação dos contratos de licenciamento de marcas de grande notoridade em outros segmentos, tais como alimentício, automobilístico, eletrônico, de vestuários etc.

Denote-se, outrossim, que o consumidor está disposto a pagar mais caro por um produto vinculado a um personagem famoso, como o personagem "Rei Leão", por exemplo. Além do mais, aquelas empresas que aderem ao licenciamento de produtos, em geral, obtêm retorno financeiro mais célere, mormente por trabalhar com uma marca ou celebridade reconhecida e da confiança do público.

O licenciamento de marca pode, em uma de suas resultantes, se apresentar como remédio ativo àquelas pessoas jurídicas que margeiam o colapso, passando a ser, portanto, potente mecanismo propulsor destas fragilizadas sociedades de reencontro ao mercado.

O legislador pátrio elencou os seguintes meios de recuperação judicial, cosoante dispõe o artigo 50 da Lei $11.101 / 05^{236}$ :

\footnotetext{
${ }^{234}$ PAIXÃO, Anelso. Marcas que valem uma fortuna. O Estado de São Paulo, São Paulo, 27 de dez. 2009. Caderno Esportes, p. E1.

235 O artigo também apresenta o ranking mundial das marcas de clubes de futebol, tendo como cinco primeiras as marcas de titularidade dos clubes seguintes: Manchester United (R\$ 3.204 bilhões); Real Madrid (R\$ 2.408 bilhões); Arsenal (R\$ 2.136 bilhões); Bayern de Munique (R\$ 1.975 bilhões); Luverpool (R\$ 1.797 bilhões). (Idem, Ibidem. p. E1)

${ }^{236}$ A Lei 11.101, de 09 de fevereiro de 2005, regula a recuperação judicial, a extrajudicial e a falência do empresário e da sociedade empresária.
} 
(i) concessão de prazos e condições especiais para pagamento das obrigações vencidas ou vincendas;

(ii) cisão, incorporação, fusão ou transformação de sociedade, constituição de subsidiária integral, ou cessão de cotas ou ações, respeitados os direitos dos sócios, nos termos da legislação vigente;

(iii) alteração do controle societário;

(iv) substituição total ou parcial dos administradores do devedor ou modificação de seus órgãos administrativos;

(v) concessão aos credores de direito de eleição em separado de administradores e de poder de veto em relação às matérias que o plano especificar;

(vi) aumento de capital social;

(vii) trespasse ou arrendamento de estabelecimento, inclusive à sociedade constituída pelos próprios empregados;

(viii) redução salarial, compensação de horários e redução da jornada, mediante acordo ou convenção coletiva;

(ix) dação em pagamento ou novação de dívidas do passivo, com ou sem constituição de garantia própria ou de terceiro;

(x) constituição de sociedade de credores;

(xi) venda parcial dos bens;

(xii) equalização de encargos financeiros relativos a débitos de qualquer natureza, tendo como termo inicial a data da distribuição do pedido de 
recuperação judicial, aplicando-se inclusive aos contratos de crédito rural, sem prejuízo do disposto em legislação específica;

(xiii) usufruto da empresa;

(xiv) administração compartilhada;

(xv) emissão de valores mobiliários;

(xvi) constituição de sociedade de propósito específico para adjudicar, em pagamento dos créditos, os ativos do devedor.

O rol de possibilidades acima indicado pelo art. 50 da Lei de Falências, discriminando os meios para o exercício da recuperação judicial é de grande valia. Em que pese as alternativas acima aludidas não serem taxativas, entedemos que o legislador perdeu uma grande oportunidade, ao quedar-se silente quanto à menção expressa do licenciamento de bens intangíveis - incluindo-se a marca - como significativa fonte de geração de receita e efetivo meio de recuperação de uma sociedade empresária às margens do estado falimentar.

A despeito do silêncio verificado no art. 50, no que pertine à menção expressa do licenciamento de marca como meio de recuperação, o devedor deverá, no âmbito do art. 53 da legislação falimentar, apresentar, em sessenta dias, plano de recuperação judicial, a ser submetido ao crivo de seus credores, sob pena de convolação em falência. Neste plano, além da viabilidade econômica e laudo econômico-financeiro, o devedor deverá discriminar, minuciosamente, os meios de recuperação a serem empregados, conforme reza o artigo 50 da citada lei.

Nesta esteira, tem-se verificado, em casos capitais, a aprovação, por credores, de planos de recuperação, cujo pilar de sustenção reside, precisamente, no licenciamento de marca como fonte primeira de recuperação judicial da sociedade. Naturalmente, as aprovações de planos calcados nesta modalidade de regeneração se operam apenas em relação àquelas pessoas jurídicas cujas marcas possuem de médio a elevado valor de 
mercado e fulminante capacidade de atração perante seu correspondente mercado consumidor.

Caso notório que demonstra, com propriedade, tudo o quanto acima delineado corresponde à sociedade empresária titular da marca Zoomp, já há mais de três décadas figurando como uma das marcas mais expressivas no setor de vestuário, especialmente nos segmentos de calças jeans e trajes para adolescentes. Este ícone da moda brasileira foi criado em 1974 e, nos últimos anos, fora acometida por uma grave crise financeira. No início de 2009, havia tido a falência decretada pela impontualidade no cumprimento de obrigações constantes de um dos muitos acordos extrajudiciais que houvera subscrito.

Consoante informação veiculada pelo periódico Valor Econômico ${ }^{237}$, o total da dívida com trabalhadores e credores alcançava, em meados de 2009, o montante de $\mathrm{R} \$ 26$ milhões. Os débitos fiscais, por seu turno, somavam R \$ 91 milhões.

Após o decreto da bancarrota, a sociedade empresária em estudo conseguiu reverter tal situação por meio da apresentação de um plano de recuperação judicial, o qual foi deferido por unanimidade de seus credores. Uma das razões fundamentais, pela qual os credores foram conduzidos à adesão ao plano oferecido pela Zoomp, consistiu na real possibilidade de injeção de investimento e geração de receita por meio do licenciamento da afamada marca de jeanswear ${ }^{238}$.

Impõe-se fazer referência a outro caso de expressiva repercurssão nacional e internacional $^{239}$, à luz da utlização da marca como forma de soerguimento da sociedade

${ }^{237}$ KOIKE, Beth. Credores Aprovam Plano da Zoomp. Jornal Valor Econômico. São Paulo. Ano 10. Edição de 20 setembro 2009. p. B4.

238 Cite-se, textualmente, parecer do gestor Carlos Valmer, da Global Capital, então administradora da Zoomp, acerca do licenciamento da marca como elemento de fundamental relevância para a aprovação do plano de recuperação judicial de uma sociedade empresária cuja falência já havia sido decretada: " $A$ aprovação do plano de recuperação abre caminho para que a Zoomp seja vendida ou tenha sua marca licenciada. Tivemos seis interessados, entre investidores e grupos de moda, em adquirir ou licenciar a marca, conhecida pelo raio amarelo. Antes do plano ser aprovado, a negociação não era possível, mas agora isso já pode acontecer. A entrada de um novo investidor na grife poderia ser feita por meio de uma aquisição parcial ou total do capital e também por meio de um licenciamento de 10 ou 12 anos da marca, podendo haver uma opção de compra da grife após esse período”. (KOIKE, Beth. Credores Aprovam Plano da Zoomp. In Jornal Valor Econômico. B4. 20/09/2009).

${ }^{239}$ MADUREIRA, Daniele. Justiça homologa plano da Gradiente. Jornal Valor Econômico. São Paulo. Ano 11. Número 2513. 25 maio 2010. p. A2. 
empresária ou, ao menos, como significativa fonte de receita para pagamento de credores, em cenário de crise econômico-financeira. Citado acontecimento reside na homologação judicial da recuperação extrajudicial concedida à Gradiente. Neste episódio, os credores, com a chancela do Poder Judiciário ${ }^{240}$, aprovaram o pedido de recuperação, alicerçando-se, principalmente, no arrendamento de parcela dos ativos pertecentens à sociedade empresária Gradiente Eletrônica S/A para a Companhia Brasileira de Tecnologia Digital $(C B T D)$ como forma de cumprimento de parte da agenda de reestruturação da sociedade em crise. Desta sorte, a Gradiente, de acordo com o plano homologado, comprometeu-se a proceder ao arrendamento de sua fábrica e de sua pujante marca "Gradiente", com o propósito primeiro de pagar seus credores. A CBDT, por seu turno, comprometeu-se a proceder à resinserção da marca Gradiente no mercado nacional a partir do segundo trimestre de 2010.

Gustavo Sardinha, ao discorrer sobre a utilização da marca como expediente para uma sociedade afastar-se de uma crise, no âmbito da recuperação judicial, faz alusão, a título ilustrativo, à operação entabulada entre a Varig e a VarigLog, em que esta adquiriu algumas unidades produtivas daquela, em cuja transação, parte dos ativos foram adquiridos por valor relativamente reduzido, incluindo-se a marca "Varig", a qual possui, decerto, grande valor de mercado, mesmo em tempos de crise. Neste aspecto, e por força do artigo 60, parágrafo único da Lei $11.101 / 2005^{241}$, os adquirentes não levaram consigo os passivos trabalhistas, tributários e aqueles decorrentes de acidente de trabalho. ${ }^{242}$

Este dispositivo deve ser interpretado em consonância com o artigo 54 da Lei 11.101/05. Saliente-se, de tal modo, que os trabalhores não ficarão desamparados em decorrência dos efeitos emergentes do artigo 60 retro mencionado. Pelo contrário. Terão maiores de chances de recebimento de seus créditos, uma vez que, pelo artigo 54 acima referenciado, o plano de recuperação judicial não poderá prever prazo superior a 1 (um)

\footnotetext{
$2402^{\mathrm{a}}$ Vara de Falências e Recuperações Judiciais. Fórum João Mendes Jr. Capital do Estado de São Paulo. TJSP. Processo n. ${ }^{\circ}$ 100.09.346208-4. Juiz Dr. Caio Marcelo Mendes Oliveira. Sentença emitida em 24 de maio de 2010.

${ }^{241}$ Cf. Artigo 60, Parágrafo Único da Lei 11.101/05: “O objeto da alienação estará livre de qualquer ônus e não haverá sucessão do arrematante nas obrigações do devedor, inclusive as de natureza tributária, observado o disposto no $\S 1^{\circ}$ do art. 141 desta Lei."

${ }^{242}$ SARDINHA, Gustavo Augusto Hanum. Marca Comercial: Quanto Vale a Sua? Avaliação estratégica de marcas, aspectos legais e contábeis e casos práticos. Curitiba: Ed. Juruá, 2009. pp.111-114.
} 
ano para liquidação dos créditos derivados da legislação do trabalho ou decorrentes de acidentes de trabalho vencidos até a data do pleito de recuperação judicial. Demais disso, em conformidade com o parágrafo único do mencionado artigo de lei, o plano não poderá estabelecer prazo superior a um 30 dias para a quitação, até o limite de cinco salários mínimos por trabalhador, dos créditos de natureza restritamente salarial que tenham vencidos 3 (três) meses anteriores ao pedido de recuperação judicial. Por conseguinte, a cessão ou licença de marca, agregada ou não a filiais ou unidades produtivas, culmina com a arrecadação de maior receita à sociedade recuperanda, de modo a emprestar-lhe maiores recursos para o adimplemento de seus débitos, especialmente aqueles de cunho trabalhista.

Diante do exposto, e conforme largamente demonstrado, o licenciamento no Brasil impacta não só na economia nacional, como também, e igualmente em grandes proporções, na sociedade civil, a qual acaba sendo diretamente favorecida com a conseqüente: manutenção das fontes produtoras; preservação da empresa em sua função social; estímulo à atividade econômica; geração de empregos, renda e oportunidades de mercado; impactando, como efeito, na melhoria significativa da qualidade de vida das pessoas. 


\section{A Nova Ordem do Direito Privado e a Unificação dos Contratos Civis E EMPRESARIAIS: EvoluÇão do DireITo COMUM INCIDENTE SOBRE O CONTRATO DE LiCENÇa De USO DE MARCa}

É uníssono o entendimento doutrinário de que o advento do Código Civil de 2002 deu ensejo à unificação do direito obrigacional, particularmente no que concerne às regras e princípios gerais contratuais, determinando-se, desta sorte, uma nova ordem dos contratos.

Neste aspecto, mitigou-se o discurso, que antes era largamente disseminado, no sentido de distinguir os contratos civis dos contratos empresariais. Talvez, no estágio atual em que se encontra o direito pátrio, possa-se fazer esta distinção apenas para fins didáticos e metodológicos. Porém, presentemente, sobretudo com a unificação do direito obrigacional (gênero do qual o direito contratual é espécie), o que verdadeiramente existem são os contratos privados, sob uma nova ótica. Esta nova ordem encontra-se consubstanciada na lente do direito privado comum, ambos (contrato civil e empresarial) se sujeitando a princípios e diretrizes comuns emanados de uma mesma fonte normativa, naturalmente se respeitando as particularidades de cada tipo de contrato, especialmente quando da regulamentação específica concebida por legislação extravagante. Nesta nova era dos contratos, estão incluídos, portanto, os contratos empresariais e, por ser espécie deste gênero, também são integrados nesta nova ambiência contratual os contratos de licença de uso de marca, objeto central da presente tese.

Passemos adiante à análise: (i) da evolução do direito privado, sob a ótica do fenômeno da publicização do direito privado; (ii) da evolução do direito comercial, à luz do direito contratual empresarial e, por fim, (iii) da unificação das obrigações, trazendo-se à colação fonte de disciplinamento jurídico comum aos contratos civis e empresariais (gênero do qual são espécies os contratos de licença de uso de marca). 


\section{1 FENÔMENO DA PUBLICIZAÇÃO DO DIREITO PRIVADO}

Inauguralmente, é oportuno tecer algumas considerações atinentes à dicotomia existente entre os direitos público e privado.

No sistema jurídico romano, o Direito Público pautava-se, essencialmente, no conjunto de normas reguladoras das relações entre Estados, assim como das relações entre Estado e privados. Ademais, conforme ensinamentos propugnados por Thomas Marky ${ }^{243}$, do direito público emanam as normas de caráter público (ius cogen), representadas por aquelas normas cogentes, cuja disposição é imperativa, não podendo, portanto, serem alteradas por livre disposição das partes. A título ilustrativo, Marky utiliza-se do exemplo do contrato de venda e compra através do qual as partes poderiam dispor livremente acerca do preço. No entanto, não poderiam elas suprimi-lo, por se tratar de elemento indispensável à venda e compra ${ }^{244}$.

O Direito Público, em consonância com a doutrina moderna, corresponde àquele Direito cujo corpo normativo regulamenta os "interesses gerais da coletividade" 245 . Nesta esteira, a ele cabe a regulamentação: (i) do Estado, por intermédio do Direito Constitucional; (ii) das atividades do estado e seus órgãos derivados contra outros órgãos públicos ou privados, pessoas jurídicas de direito público ou privado, seus funcionários etc, fazendo-o por meio do Direito Administrativo; (iii) da organização judiciária e, por fim, porém não se limitando a, (iv) do Direito Penal ${ }^{246}$.

\footnotetext{
${ }^{243}$ MARKY, Thomas. Curso elementar de direito romano. 8. ed. São Paulo. Saraiva. p. 1995. p. 15/16.

${ }^{244} \mathrm{O}$ ordenamento civil pátrio, igualmente, reveste-se de sistema normativo misto calcado na disposição de normas cogentes ou dispositivas. Assim, no caso do contrato de venda e compra, assim como ocorria no sistema romano, deve obrigatoriamente dispor de um preço, ainda que o mesmo seja livremente pactuado pelas partes contratantes. Desta forma, prescreve o art. Art. 481: "Pelo contrato de compra e venda, um dos contratantes se obriga a transferir o domínio de certa coisa, e o outro, a pagar-lhe certo preço em dinheiro".

${ }^{245}$ MONTEIRO, Washington de Barros. Curso de Direito Civil - Parte Geral, São Paulo, 1958, p. 13. Apud RODRIGUES, Silvio. Direito Civil - Parte Geral. São Paulo. Saraiva. 1998. vol. I. $28^{a}$ ed. ver., p. 7.

${ }^{246}$ RODRIGUES, Silvio. Direito Civil - Parte Geral. São Paulo. Saraiva. 1998. vol. I. $28^{a}$ ed. ver., p. 7.
} 
Miguel Reale ${ }^{247}$, uma das maiores autoridades da história do Direito brasileiro, define, com extrema perceptibilidade, o Direito Público sob dois prismas distintos. Com relação ao conteúdo objeto da relação jurídica, Reale esclarece que o Direito será de caráter público, quando o interesse a ser tutelado pelo direito for geral, ou seja, da coletividade, público ${ }^{248}$. Por outro lado, e agora no que tange à forma de relação, o saudoso jurista admite que o Direito, por igual, será considerado "Público" quando a relação entre os agentes de direito for, geralmente, de subordinação.

Desta tese, contudo, não partilha Caio Mário da Silva Pereira ${ }^{249}$, o qual corrobora o entendimento que, não obstante a maioria das relações entre Estado e particulares configura-se como uma relação hierárquica, há muitas outras em que é notória a ausência de relação hierárquica, posto que Estado e particular são colocados em patamares nivelados. É o que ocorre nos contratos de negócios celebrados entre o Estado e pessoa jurídica de direito privado. Neste caso, não se pode descartar as normas de direito privado, por se tratar de uma relação pela qual os interesses das partes são horizontalmente sopesados.

O Direito Público, em sua essência, é aquele que rege as relações jurídicas em que o Estado seja parte. Ademais, pode ser considerado como Direito Público Externo e Direito Público Interno. O Direito Público Externo reflete-se no direito internacional, o qual pode ser público ou privado. Público, quando regular as relações entre estados; Privados, quando regulamentar a norma aplicável ao conflito existente entre nacionais e estrangeiros ${ }^{250}$. O Direito Público Interno compreende disposições normativas de cunho constitucional, administrativo, tributário, processual, penal e internacional privado.

\footnotetext{
${ }^{247}$ REALE, Miguel. Lições Preliminares de Direito. 24. ed. São Paulo. Saraiva. 1998. p. 342-344.

${ }^{248}$ A título ilustrativo, o prof. Reale faz referência ao Direito Penal, justificando que este se insere no rol de Direito Público posto que tem por escopo imediato a tutela do interesse geral. Assim, por exemplo, a norma que veda a apropriação indevida de um bem de outrem está, na realidade, não apenas cuidando do bem (interesse) de um particular, porém do interesse geral. A norma penal, ao mesmo tempo, que tutela um bem individual, assume um caráter repressor, de tal sorte que o indíviduo não a infrinja contra qualquer membro da sociedade civil. (Idem, Ibidem. p. 343).

${ }^{249}$ PEREIRA, Cáio Mário da Silva. Instituições de Direito Civil. 19 ${ }^{\text {a }}$ ed. v.1. Rio de janeiro. Ed. Forense. 1998. p.12.

${ }^{250}$ As normas de direito internacional privado encontram-se indicadas, porém sem que haja a exaustão, na Lei de Introdução ao Código Civil. mormente nas letras dos artigos $8^{\circ}$ e seguintes.
} 
Delineado, em breves linhas, o âmbito de atuação do Direito Público, cuidemos, com mais acuidade, do Direito Privado, ramo este sobre o qual se encontra alicerçado o objeto desta tese.

O Direito Romano definia o Direito Privado como o conjunto de normas regulamentadoras das relações entre particulares ${ }^{251}$. O direito dispositivo, emanado do Direito Privado, estabelece preceitos cuja essência consiste na livre iniciativa das partes quando da formação de relação jurídicas umas com as outras.

Miguel Reale ${ }^{252}$, ao definir o Direito Privado, assim como o faz ao individualizar o Direito Público, o assinala sob dois paradigmas. Assim, categoriza o Direito Privado, em relação ao conteúdo ou objeto da relação jurídica, como aquele que regula, de imediato, o interesse privado. Adicionalmente, classifica o Direito Privado, no que concerne à forma de relação, como aquele que regula a relação jurídica entre sujeitos de direito, porém de forma coordenada ${ }^{253}$.

O Direito Privado, conforme dissemina o professor Silvio Rodrigues ${ }^{254}$, prescreve as normas que regerão os interesses particulares entre os sujeitos de direito, regulando vasto rol de relações intersubjetivas, tais quais: as relações familiares; as obrigações que, reciprocamente, estabelecem os indivíduos, sejam estas obrigações decorrentes de contratos celebrados pelos sujeitos, seja em decorrência de ilícito cometido, dando ensejo à responsabilidade civil prevista no Código Civil; direitos reais sobre bens corpóreos etc.

O Direito Privado perfaz-se no conjunto de normas que regulam, em caráter imediato, os interesses de cunho privado nas relações jurídicas entre indivíduos que se

251 "Publicum ius est quod as statum rei Romanae spectat, privatum quod ad singulorum utilitatem pertinet (Inst. 1.1.4 - D. 1.1.1.2). (Cf. MARKY, Thomas. Curso Elementar de Direito Romano. ob. cit. p. 15/16.)

${ }^{252}$ REALE, Miguel. Lições Preliminares de Direito.... op. cit. p. 343.

${ }^{253}$ Exemplificativamente, Reale aponta a relação jurídica entre comprador e vendedor, pela qual há, de forma cristalina, a configuração de relação entre privados em que o vendedor tem a obrigação de entregar a coisa em perfeitas condições, ao passo que o comprador deve pagar, com pontualidade, o preço ajustado com o vendedor. Reale aponta, ainda, a relação institucional, de caráter eminentemente público, como, por exemplo, ocorre no caso em que o Tribunal Eleitoral chama os eleitores ás urnas. Não há igualdade nesta relação. O Estado apresenta-se como soberano e o eleitor como súdito que deve respeitar a decisão estatal.

${ }^{254}$ RODRIGUES, Silvio. Direito Civil-Parte Geral. vol .1. ob. cit. p. 8. 
relacionem em um mesmo patamar. De tal sorte, integram o Direito Privado: (i) o Direito Civil, o qual regulamenta, em sua essência, os direitos e deveres dos indivíduos; (ii) Direito Comercial, que tem por objetivo precípuo a regulamentação da atividade do empresário, e que se encontra, em parte, incorporado ao Direito Civil ${ }^{255}$; e (iii) Direito do Trabalho, que regula as relações travadas entre empregador e empregado, agasalhando normas cujo objeto consiste na proteção do trabalhador, bem como na organização do trabalho e da produção.

A despeito da segregação metodológica presente na dicotomia existente entre o Direito Público e o Direito Privado, porém diante da celeridade e complexidade crescentes relativas à formação das mais distintas relações jurídicas entre os indivíduos, tem-se reconhecido a chamada "publicização do direito privado". Captaneados por Cáio Mário da Silva Pereira ${ }^{256}$, os autores que ministram esta teoria ponderam que o Estado passa a ser chamado a intervir nas relações privadas, que antes detinham cunho flagrantemente liberal, porém agora devem se consumar sem que o interesse alheio seja ilegalmente lesado.

O fenômeno da publicização do direito privado passa a ser verificado em muitos diplomas legais. Com o advento desta evolução do ordenamento jurídico, o Estado passa a intervir, seja através de interferência direta, seja por meio de edições de legislações reguladoras, no âmbito do direito privado.

A título ilustrativo do acima exposto, impõe-se mencionar o Código de Defesa do Consumidor $^{257}$ e a Legislação Antitruste ${ }^{258}$, que têm o desígnio de proteger juridicamente a

\footnotetext{
${ }^{255}$ Para o professor Silvio Venosa, o Direito Público é dividido em interno e externo. Objetivamente, o direito público interno abarca o direito constitucional, o direito administrativo, o direito tributário, o direito penal, o direito processual civil e penal, ao passo que o direito público externo agasalha o direito internacional público e privado. O direito privado, por seu turno, abrange o direito civil e o direito comercial. (Cf. VENOSA, Silvio. História do Direito Civil. Disponível em $<$ http://www.silviovenosa.com.br/direito_civil >. Acesso em 20 março 2010).

${ }^{256}$ PEREIRA, Caio Mário da Silva. Instituições de Direito Civil. ob. cit. p. 14.

257 O Código de Defesa do Consumidor, instituído pela lei 8.078, de 11 de setembro de 1990, reza, logo em seu artigo inaugural, que a relação entre fornecedor e consumidor deve obedecer as "normas de proteção e defesa do consumidor, de ordem pública e interesse social, nos termos dos art. $5^{\circ}$, inciso XXXII, 170, inciso V, da Constituição Federal e art. 48 de suas Disposições Transitórias".

${ }^{258}$ Com fito similar ao diploma consumerista, a legislacao antitruste, introduzida pela Lei 8.884 , de 11 de junho de 1994, visa interferir na relação entre particulares, se de tal relação conflitar com o interesse geral. Destarte a Lei Antitruste "dispõe sobre a prevenção e a repressão às infrações contra a ordem econômica, orientada pelos ditames constitucionais de liberdade de iniciativa, livre concorrência, função social da
} 
parte economicamente inferior nas relações jurídicas, de modo que esta parte "hiposuficiente" não seja lesada, em razão do maior poderio econômico da parte contratante adversa.

Cite-se, por igual, a Lei 9.279/96 (Lei da Propriedade Industrial). Seu artigo $2^{\circ}$ assinala que a proteção dos direitos relativos à propriedade industrial será efetuada em conformidade com o interesse social e o desenvolvimento tecnológico do Brasil.

O diploma legal ventilado, muito embora exteriorize normas expressas concernentes à tutela dos interesses privados e de repressão à concorrência desleal ${ }^{259}$, também tem por objetivo garantir a proteção do interesse social e impedir que terceiros (a exemplo dos consumidores) sejam prejudicados, especialmente em razão da contrafação dos direitos industriais tutelados pelo aludido diploma legal. Neste aspecto, o artigo 191 da Lei 9279/96, indica que a reprodução ou imitação, de modo que possa induzir (terceiros) em erro ou confusão, armas, brasões ou distintivos oficiais nacionais, estrangeiros ou internacionais, sem a necessária autorização, no todo ou em parte, em marca, título de estabelecimento, nome comercial, insígnia ou sinal de propaganda, ou usar essas reproduções ou imitações com fins econômicos, bem como vender, expor à venda, ou oferecer produtos assinalados com estas marcas contrafeitas, são atos chancelados como crimes cometidos por meio de marca, titulo de estabelecimento e sinais de propaganda, dando azo à penalização do agente contrafator.

A "publicização" e "interferência estatal" nas relações privadas, ocorrida no diploma em estudo, também podem ser sentidas nos dispositivos que versam sobre a caducidade do direito industrial pelo desuso ou mesmo sobre o licenciamento compulsório, este último no caso das patentes.

propriedade, defesa dos consumidores e repressão ao abuso do poder econômico" (art. $1^{\circ}$ ).

${ }^{259}$ O professor Newton Silveira, no que diz respeito à conccorência desleal, sinaliza para a distinção entre normas de direito privado (concorrência desleal e ilícita) e as normas de direito público ("abuso de poder econômico"). As normas de direito privado são objeto do artigo 195 da Lei 9279/96. Por seu turno, as normas de direito público, da Lei de Repressão ao Abuso do Poder Econômico (Lei 8884/94) . (SILVEIRA, Newton. A propriedade intelectual no novo código civil brasileiro. Disponível em <http://www.silveiraadvogados.com.br/show_artigo.php?id=52>. Acesso em 10 fev. 2010.) 
No primeiro caso, ante o teor do artigo 143, da Lei 9279/96, em atendimento ao interesse social e, particularmente, de terceiros que almejem se utilizar de marca em desuso, o titular decairá do direito de usufruir sua marca, bem como de dispor do sinal que detinha em seu poder, se o uso da marca não tiver sido iniciado no Brasil, após 5 anos da concessão do registro; se o uso da marca tiver sido interrompido por mais de 5 anos consecutivos; ou ainda se marca, também no prazo de 5 anos sucessivos, tiver sido usada com modificação que resulte alteração substancial de seu conceito visual distintivo original.

No segundo caso, ainda mais acentuada é a "interferência estatal" e a "publicização do direito privado". Opera-se com o licenciamento compulsório. Por força do artigo 68 da Lei 9278/97, o titular da patente deverá, obrigatoriamente, licenciar patente cujo direito esteja sob sua titularidade, se exercer os direitos dela decorrentes de forma abusiva ou, por meio dela, praticar abuso de poder econômico, comprovado nos termos da lei, seja por decisão emanada das autoridades administrativas, seja por decisão emitida do Poder Judicial. Anote-se que o Estado passa a intervir na relação entre privados, a partir do momento em que obriga um particular a licenciar determinada patente para outro particular que tenha manifesto interesse em explorá-la, mediante o pagamento de royalties ao licenciante. Este negócio jurídico firmado entre particulares, corroborado de forma mandatória, é concebido como fruto da ingerência estatal, com amparo nos valores capitais sobre os quais se mantém alicerçada a lei industrial: o interesse social e o desenvolvimento tecnológico do país.

É patente, pois, presença do fenômeno da publicização do direito privado no diploma industrial.

É importante anotar, com efeito, a nova ordem do direito privado. Sob esta nova ordem, convém assinalar que o direito privado não deixará de ser essencialmente privado, porque remanescerá regulando as relações jurídicas entre os particulares. No entanto, a intervenção do Estado, em casos específicos e disciplinados em lei, será necessária para que os interesses dos próprios particulares e de terceiros não sejam lesados contra legem. Consiste tão apenas na disseminação de preceitos e diretrizes já consagrados na Carta Magna Brasileira. Esta nova ordem, pois, é perfeitamente aplicável ao direito industrial, a exemplo da tutela da marca e do próprio contrato de licença de uso de marca. 
Por fim, o Código Civil de 2002, conforme restará adiante demonstrado, é um dos diplomas legais mais marcantes no que diz respeito ao fenômeno da publicização do direito privado. Neste tocante, o diploma civil vigente, a despeito de ter o escopo de regular as relações entre privados (relações entre civis e interempresariais), trouxe à tona princípios capitais de caráter eminentemente público, tais quais, princípio da boa-fé objetiva, princípio da função social do contrato, princípio da vedação da onerosidade excessiva, princípio da justiça material e equivalência material, dentre outros.

\section{2 RELAÇÃO ENTRE DIREITO CIVIL E DIREITO COMERCIAL}

O Direito Civil, conforme preleciona Miguel Reale, consiste no Direito que disciplina "o modo de ser e de agir das pessoas, com abstração de sua condição social, muito embora exercendo funções ou atividades diferenciadas"260. O Direito Comercial, por seu turno, disciplina as relações decorrentes das atividades empresariais ${ }^{261}$.

Em que pese as definições correspondentes a cada direito, remetemo-nos, por ser de suma importância para os fins do presente estudo, à co-relação existente entre ambos. Conforme exaustivamente delineado, direito civil e direito comercial são ramos de um mesmo tronco, o direito privado.

O Direito Civil, contudo, não é fonte do Direito Comercial. No entanto, por se apresentar como direito comum, é perfeitamente aplicável a todas as relações de direito privado (seja entre civis, seja entre empresários), naturalmente naquilo que não contrariar legislação especial. De tal modo, portanto, temos que o Direito Civil incide sobre as

\footnotetext{
${ }^{260}$ REALE, Miguel. Lições Preliminares de Direito. ob. cit. p. 359.

${ }^{261}$ Assim como ocorrera com o Código Civil de 2002, conforme será oportunamente demonstrado, no direito romano não havia diferenciação entre Direito Civil e Direito Comercial. Havia apenas um direito privado cujo objetivo era confeccionar regramento para a relação entre privados. Ademais, as matérias de ordem privada estavam contidas no jus civile ou no ius gentium, que dizia respeito aos estrangeiros.
} 
relações de Direito Comercial (e empresarial), sobretudo na ausência de lei especial que regulamente, com a devida completude, determinadas matérias deste ramo do Direito ${ }^{262}$.

O Direito Civil se constitui, pois, como direito comum que alimenta todos os outros demais ramos do direito, incluindo-se neste extensivo rol o Direito Comercial, especialmente quando da ausência de normas específicas regulamentadoras destes outros segmentos do direito. Nesta esteira, assinala Caio Mário da Silva Pereira, in verbis:

\begin{abstract}
Embora o direito civil se tenha como um dos ramos do direito privado, a rigor é bem mais do que isto. Enfeixa os princípios de aplicação corrente, de aplicação generalizada e não restritiva à matéria cível. É no direito civil que se aprende a técnica jurídica mais característica de um dado sistema. (....) Nele se situam princípios que a rigor não lhe são peculiares nem exclusivos, mas constituem normas gerais que se projetam a todo o arcabouço jurídico: o direito civil enuncia regras de hermenêutica, os princípios relativos à prova dos negócios jurídicos. (....) O Direito Civil não é apenas uma das divisões do direito privado, mas continua sendo o direito comum, em razão de compreender todo um conjunto de regras relativas às instituições de direito privado, aos atos e às relações jurídicas. (grifou-se)
\end{abstract}

Desta forma, não obstante se verifique a distinção entre os sujeitos de direito, i.e., o Direito Civil regulamenta a relação entre civis, ao passo que o Direito Comercial disciplina a relação entre empresários (antigos comerciantes), é irretorquível o fato de que as regras civis são consideradas regras de direito comum, as quais não têm âmbito de atuação restrito apenas ao Direito Civil, pois que se alongam, por igual, a outros ramos do direito, tal qual o Direito Comercial ${ }^{263}$.

Ainda nesta esteira, conforme preleciona Carlos Alberto da Mota Pinto, muito embora os Direitos Civil e Comercial se apresentem como ramos distintos do direito privado, onde o primeiro se apresenta como comum, e o segundo como especial, é certo

\footnotetext{
${ }^{262}$ REQUIÃO, Rubens. Curso de Direito Comercial. $23^{\text {a }}$ ed. ob. cit. p. 27.

${ }^{263}$ Neste sentido, registrem-se os eternos ensinamentos de Miguel Reale, que pondera: "No amplo domínio do Direito Privado destaca-se o Direito Civil como Direito Fundamental ou "Direito Comum" a todos os homens, no sentido de disciplinar o modo de ser e de agir das pessoas, com abstração de sua condição social, muito embora exercendo funções ou atividades diferenciadas. Desse tronco comum abrem-se ramos, com características próprias, como o Direito Comercial ou Agrário" (REALE, Miguel. Lições Preliminares de Direito. ob. cit. p. 359).
} 
que, nos casos em que a legislação especial comercial se fizer omissa, será perfeitamente aplicável o Direito Civil, sendo este, portanto, fonte subsidiária do Direito Comercial ${ }^{264}$.

\section{3 UNIFICAÇÃO DO DIREITO DAS OBRIGAÇÕES NO BRASIL}

Se a matéria em torno da unificação do direito privado é controvertida, o entendimento acerca da unificação do direito obrigacional, pelo novo diploma civil, certamente não o é. Imbuído deste espírito realista no que tange à unificação do direito privado, Miguel Reale ${ }^{265}$, com despretensão e extrema lucidez, assinala, in verbis:

É preciso corrigir, desde logo, um equívoco, que consiste em dizer que tentamos estabelecer a unidade do direito privado. Esse não foi o objetivo visado. $O$ que na realidade se fez foi consolidar e aperfeiçoar o que já estava sendo seguido no país, que era a unidade dos direitos das obrigações. Como o Código Comercial de 1850 se tornara completamente superado, não havia mais questões comerciais resolvidas à luz do Código de Comércio, mas sim em função do Código Civil. (grifou-se)

Conforme adiante delineado, a unificação do direito das obrigações e, por conseguinte, dos contratos civis e empresariais, com a entrada em vigor do Código Civil de 2002, passa a assumir especial importância para o presente estudo, posto que o contrato de licença de uso de marca é, via de regra, um contrato empresarial ${ }^{266}$, cujas regras e princípios gerais norteadores encontram-se unificados no Código Civil de 2002, conforme poderá se vislumbrar nos capítulos vindouros.

\footnotetext{
${ }^{264}$ PINTO, Carlos Alberto da Mota. Teoria Geral do Direito Civil. 4. ed. atual. por Antônio Pinto Monteiro e Paulo Mota Pinto. Coimbra. Ed. Coimbra. 2005. p. 47.

${ }^{265}$ REALE, Miguel. Visão Geral do Projeto de Código Civil”. Revista Literária de Direito. 23/8-13. Ano 4. São Paulo, maio-junho/1998. p.10. (grifou-se)

${ }^{266}$ De acordo com a sistemática empresarial consagrada no "novo" código civil, são contratos empresariais (e não mais contratos mercantis) aqueles cujas partes contratantes são empresários ou sociedades empresárias. Pelo art. 966, do novo diploma civil, é empresário ou sociedade empresária aquele que "exerce profissionalmente atividade econômica organizada para a produção ou a circulação de bens ou de serviços".
} 
A incidência da "nova" legislação civil sobre o contrato em exame, conforme se notará, não se opera apenas em relação aos princípios sociais que permeiam a nova codificação civil, mas também se sucede em relação à regulamentação jurídica (algumas delas novéis em comparação com o Código Civil de 1916) disciplinadora do contratos de locação de coisas móveis, cujas disposições normativas serão, à luz do princípio da analogia, aplicáveis aos contratos de licença de uso de marca.

O tema em estudo certamente não é novel na doutrina, jurisprudência e, igualmente, na legislação nacional e estrangeira.

No ano de 1841, a Suíça unificou o direito das obrigações. Em 1942, foi a vez da Itália sistematizar em um único código as legislações civil e comercial. ${ }^{267}$

No Brasil, a unificação somente foi celebrada no ano de 2002. Convém destacar, contudo, que não faltaram tentativas no sentido de se proceder à unificação do direito privado e, principalmente do direito das obrigações, para por fim à segregação entre os diplomas civil e comercial.

Em 1859, Augusto Teixeira de Freitas, foi o primeiro idealista a elaborar projeto de lei concernente à unificação do direito privado $^{268}$. O inolvidável jurista propagava a idéia de que era injustificável a segregação concebida entre Direito Civil e Direito Comercial, porquanto a vida jurídica era permeada de atos comerciais ou não comerciais, ou seja, podiam consistir na busca do lucro ou outra razão existencial ${ }^{269}$.

\footnotetext{
${ }^{267}$ Remetendo-se ao ordenamento jurídico italiano, Frederico Viana Rodrigues, assinala que, com a unificação do direito privado no sistema jurídico italiano, ocorreu "a última etapa evolutiva do Direito Comercial nos países de tradição romanística, consagrando a teoria da empresa, pela qual o Direito Comercial mais uma vez sofre alargamento do seu campo de abrangência, deslocando seu objeto do ato de comercio para o ato de empresa". (cf. RODRIGUES, Frederico Viana. Direito de Empresa no Novo Código Civil. Rio de Janeiro. Ed. Forense. 2004. p. 24).

${ }^{268}$ Embora majoritária, não é uníssono o ideal de unificação do direito obrigacional. Rubens Requião, citando Cesare Vivante, advoga ser ilusória referida unificação se a falência permanecer como instituto especificamente mercantil. Para o renomado jurista, faz-se inviável a unificação enquanto perdurar tratamento desigual entre o empresário civil e o empresário comercial, da sociedade civil e da sociedade comercial, no que concerne à insolvência. Desta feita, completa Requião que se se deseja realizar unificação completa a falência deve ser estendida para comerciantes e não comerciantes. Em contrário, a unificação é meramente pro forma, mantendo-se a dicotomia no código codificado. (cf. REQUIÃO, Rubens. Curso de Direito Comercial. 2003. $1^{\circ}$ vol. Ob. cit. p. 23/24)
}

${ }^{269}$ HANUAGGE, Vinicius Elias. Nótulas sobre a unificação do direito privado brasileiro. Revista de Direito Empresarial. Curitiba. N. 7. 286 p. jan/jun 2007. p. 11/31. 
Após mencionada unificação ter sido considerada prematura, em 1912, Inglez de Souza, ao qual fora atribuída a tarefa de elaborar o Código Comercial, acabou por agremiar emendas legislativas de tal sorte a transformá-las em um "Código de Direito Privado". Em 1941, foi apresentado o Código das Obrigações pelos juristas Orozimbo Nonato, Philadelpho Azevedo e Hahnemann Guimarães ${ }^{270}$. Novamente, agora em 1943, na II Conferência Interamericana de Advogados, cujo evento fora realizado no Rio de Janeiro, Benedito Costa Neto, calcando-se nos princípios erigidos na proposta de Teixeira de Freitas, apresenta proposta de unificação do direito privado.

Após alguns anos, formou-se nova comissão de juristas, agora formada por eminentes experts como Orlando Gomes e Caio Mário da Silva Pereira, para a elaboração de projeto de lei com o desígnio de se editar um novo Código Civil concomitantemente à confecção de um Código das Obrigações, pela qual seriam unificadas as obrigações de ordem civil e comercial. No entanto, o anteprojeto apresentado acabou por não lograr êxito $^{271}$.

Em 1972, uma última comissão de juristas ${ }^{272}$ foi formada sob a coordenação do memorável professor Miguel Reale. O anteprojeto apresentado era permeado por 1.063 emendas. Em 1984, o Código fora aprovado na Câmara e, em seguida, retransmitido para o Senado, casa em que foi aprovado com a inserção de 332 emendas.

Por fim, em janeiro de 2002, foi promulgado o "novo" Código Civil Brasileiro, instituído pela Lei Federal n. ${ }^{\circ}$ 10.406, de 10 de janeiro de 2002, oriundo do Projeto de Lei n. ${ }^{\circ} 634 / 75$ retro mencionado. O novo códex, por certo, trouxe à baila tema que, há tempos,

\footnotetext{
${ }^{270}$ Neste projeto, os juristas exaltavam a necessidade da unificação dos direitos das obrigações. Na exposição de motivos, foram externadas as seguintes considerações: "Recebendo a incumbência de atender à modificações operadas por leis posteires, seguir as modernas tendências do direito, mitigar os excessos de individualismo, incompatíveis com a ordem jurídica dos tempos que correm, e reduzir a dualidade de princípios aplicáveis aos negócios civis e mercantis, em prol da unificação de preceitos, que devem reger as relações de ordem privada, a Comissão considerou que mais urgente seria a execução do trabalho no que tocasse ao problema obrigacional" (cf. REQUIÃO, Rubens. Curso de Direito Comercial. 25 ed. 2003. ob. cit. p. 23).

${ }^{271}$ HANNUAGE, Vinicius Elias. Nótulas sobre a unificação do direito privado brasileiro. ob. cit. p. 27.

${ }^{272}$ Esta comissão era formada por eminentes juristas, como José Carlos Moreira Alves, Agostinho de Arruda Alvim, Clóvis do Couto e Silva e Torquato Castro, encarregados, respectivamente, da elaboração dos livros: Parte Geral, Direito das Obrigações, Atividade Negocial, Direito das Coisas, Direito de Família e Direito das Sucessões.
} 
tramitava nas casas legislativas nacional, bem como nos anais de Direito Civil disseminados pelas mais diversas correntes doutrinárias, consubstanciado na unificação de grande parte do direito privado nacional, mormente no que tange à matéria obrigacional. Com efeito, ficara expressamente revogado o Código Civil anterior e derrogado o Código Comercial $^{273}$.

O prof. Miguel Reale ${ }^{274}$ assinala que os direitos e deveres dos indivíduos são projetados em suas obrigações e nos contratos celebrados entre eles. Ademais, reconhece que o Código Civil de 2002 promoveu, de forma cristalina e irrefutável, a fusão das obrigações civis com as empresariais ${ }^{275}$.

Convém registrar, paralelamente à fusão do direito obrigacional, a recepção do Direito de Empresa pelo Código Civil, ratificando a unificação de grande parte do direito privado $^{276}$.

Hodiernamente, verifica-se pacificada na legislação e doutrina pátrias a unificação do direito privado obrigacional, fazendo-se o direito das obrigações ecoar, de forma uníssona, nos âmbitos do Direito Civil e Comercial.

${ }^{273}$ Reza o art. Art. 2.045 do Código Civil: "Revogam-se a Lei no 3.071, de 1o de janeiro de 1916 - Código Civil e a Parte Primeira do Código Comercial, Lei no 556, de 25 de junho de 1850". A parte primeira do Código Comercial tratava dos "comerciantes em geral". Impõe-se destacar que a parte segunda ("comércio marítimo") continua vigente, posto que a parte terceira ("das quebras") já havia sido revogada pela primeira LF da república e a parte final do Código Comercial (título único: da administração da justiça nos negócios e causas comerciais) houvera sido revogada pelo Código de Processo Civil de 1939. (cf. NERY JUNIOR, Nelson. Código Civil Comentado. $6^{\text {a }}$ ed. São Paulo. Ed. Revista dos Tribunais, 2008. p. 779).

${ }^{274}$ REALE, Miguel. Visão Geral do Projeto de Código Civil. Disponível em: <www.miguelreale.com.br>. Acesso em 10 nov. 2008.

${ }^{275}$ Reale suprime o termo "atividade comercial" por considerá-la ultrapassada, ainda quando, com respaldo no ordenamento jurídico italiano, o legislador nacional recepcionou a teoria da empresa em detrimento da teoria do comércio.

${ }^{276}$ Neste sentido, clarifica Reale acerca da grande novidade do Código Civil, refletida no direito de empresa. Destarte, registre-se o legado do renomado jurista: "Em seguida ao Direito das Obrigações, passamos a contar com uma parte nova, que é o Direito de Empresa. Este diz respeito a situações em que as pessoas se associam e se organizam a fim de, em conjunto, dar eficácia e realidade ao que pactuam. O Direito de Empresa não figura, como tal, em nenhuma codificação contemporânea, constituindo, pois, uma inovação original” (cf. REALE, Miguel. Visão Geral do Projeto de Código Civil. Disponível em: <www.miguelreale.com.br>. Acesso em 10 nov. 2008) 
$\mathrm{Na}$ legislação brasileira, o direito das obrigações, já com a nova disposição calcada na unificação do direito privado, encontra-se compreendido entre os artigos 233 até 965 do Código Civil, englobando, bem assim, os contratos (princípios gerais e contratos em espécie), tema este que será tratado com mais afinco no capítulo adiante.

O tema da unificação do direito privado, com ênfase ao direito das obrigações é recorrente em grande parte da doutrina nacional. Os doutrinadores, correntemente, enfatizam a necessidade da unificação do direito das obrigações, posto que os princípios gerais atinentes à matéria ora referendada são irradiados de maneira uniforme para as relações civis e para as relações empresariais (antigas relações comerciais).

Portanto, não haveria razão de ser a distinção entre ambos se o que está sob o foco da legislação é a obrigação, de cunho civil ou comercial, a ser cumprida pelas partes, sejam estas corporificadas por sujeitos de direito no âmbito civil ou sujeitos de direito no âmbito comercial $^{277}$. Há que se realçar, conforme assinala Fran Martins ${ }^{278}$, que tanto os civis como os empresários assumem obrigações, cuja fonte das regras aplicáveis a estas obrigações é a mesma, materializada em lei única uniformizadora do direito privado.

Francisco Amaral ${ }^{279}$, alicerçando-se nos pensamentos de autores de notável saber jurídico, como Teixeira de Freitas, Carvalho de Mendonça, Lacerda de Mendonça, Lacerda de Almeida, Carvalho Mourão, Inglez de Souza, Waldemar Ferreira, Francisco Campos, dentre outros, assinala que o Código Civil, de fato, procedeu à unificação do direito das obrigações, erigindo-se, doravante, como Lei Padrão, embora não "global" do direito privado. Acrescenta o jurista, contudo, que, não obstante tenha havido a unificação do direito das obrigações, resta mantida a autonomia científica e didática do Direito Civil e Comercial, não mais sendo este, contudo, matéria especial.

\footnotetext{
${ }^{277}$ Neste sentido, pertinente assinalar o conceito tecido por Valdemar Ferreira, ao sentenciar que não é o direito civil que é comum a civis e empresários. Na realidade, o direito das obrigações é que deve ser uno e a um quanto ao outro. FERREIRA, Valdemar. Instituições de Direito Comercial, $4^{\mathrm{a}}$ ed., $3^{\circ}$ vol., t. I. São Paulo. Ed. Max Limonad. 1954. p. 6.

${ }^{278}$ MARTINS, Fran. Contratos e Obrigações Comerciais. $9^{\mathrm{a}}$ ed. Rio de Janeiro. Ed. Forense. 1998. pp. 7-9.

${ }^{279}$ AMARAL, Francisco. Direito Civil: introdução. $7^{\mathrm{a}}$ ed. Rio de Janeiro: Ed. Renovar, 2008. p. 174.
} 
Ainda sobre a unificação do direito obrigacional, merecem destaque as sapientes palavras do mestre Cáio Mário da Silva Pereira ${ }^{280}$, verbis:

\begin{abstract}
Não se compreende, na verdade, que um mesmo fenômeno jurídico, e.g., a compra e venda, seja submetido a duas ordens de disciplinas, destacando-se conceitualmente a compra e venda mercantil e a compra e venda civil; que se sujeite a regras diferentes a prescrição em matéria civil e em matéria comercial

O que há de prevalecer, e neste ponto nenhuma transigência é possível no plano dogmático, é a unificação do direito obrigacional. Neste caso, o mesmo código compreenderá, além da teoria do negócio jurídico, a disciplina das obrigações em geral, os contratos (teoria geral e suas várias espécies), a declaração unilateral de vontade, enriquecimento sem causa, responsabilidade civil, títulos de crédito e a matéria atinente à atividade empresarial. (grifou-se)
\end{abstract}

Revelem-se, também, os admiráveis legados deixados por Pontes de Miranda ${ }^{281} \mathrm{e}$ Clóvis V. de Couto e Silva ${ }^{282}$, os quais anteviram a unificação do direito das obrigações, admitindo expressamente que não há elemento que distinga a obrigação de cunho civil daquela de cunho empresarial (antigo comercial).

Nelson Nery Jr. ${ }^{283}$, João Augusto da Palma ${ }^{284}$ e Marcia Mallmann Lippert ${ }^{285}$ admitem, por igual, a unicidade do direito obrigacional com o advento do novo diploma civil.

${ }^{280}$ PEREIRA, Cáio Mário da Silva. Instituições de Direito Civil. vol. 1. ob. cit. p. 18.

${ }^{281}$ MIRANDA, Francisco Cavalcanti Pontes de. Tratado de Direito Privado. Rio de Janeiro. Ed. Borsoi. 1954. vol. 22. p.7.

${ }^{282}$ COUTO E SILVA, Clóvis V. do. A obrigação como processo. São Paulo. Ed. José Bushatsky, 1976.

${ }^{283}$ Nelson Nery Júnior admite, categoricamente, que o Código Civil brasileiro "adotou parcialmente a tese monista, unificando o direito das obrigações ". Ademais, prescreve o eminente civilista que " a opção do legislador foi no sentido de reunir num mesmo sistema as atividades empresariais como prolongamento dos direitos das obrigações" (cf. NERY JUNIOR, Nelson. Código Civil Comentado. 6a ed. São Paulo. Ed. Revista dos Tribunais, 2008. p. 779-781).

284 "Se nos outros ramos do direito privado, persiste a busca da distinção entre direito civil e comercial, no direito das obrigações a discussao está superada. A unificação do direito obrigacional é realidade aceita tanto pelos doutrinadores quanto pelos legisladores" (cf. PALMA, João Augusto da. Novo Código Civil e Comercial. São Paulo. Ed. Ltr. São Paulo. 2005. p.11/12).

${ }^{285}$ LIPPERT, Márcia Mallmann. A Empresa no Código Civil - Elemento de Unificação do Direito Privado. São Paulo. Ed. Revista dos Tribunais. 2003. p. 105. 
Em que pese a distinção dos sujeitos das obrigações (civis e empresários), ambas são permeadas dos mesmos elementos essenciais calcados na singularidade de um mesmo preceito: relação de débito e crédito entre dois sujeitos de direito, não importando se as obrigações são de natureza civil ou comercial, haja vista que os deveres e direitos de dar e receber se fazem patentes nas duas ambiências citadas.

Esclareça-se, por fim, que as regras do Código Civil, no tocante à matéria das obrigações e, por via de consequiência, dos contratos, valem em relação às "matrizes" e "princípios gerais", pois, conforme melhor lição de Miguel Reale, "nada impede que do tronco comum se alonguem e se desdobrem, sem se desprenderem, ramos normativos específicos, que, com aquelas matrizes, continuam a compor o sistema científico do Direito Civil ou Comercial"286.

Demonstrada a unificação do direito obrigacional e, por conseguinte, do direito contratual $^{287}$, consubstanciando a chamada nova ordem dos contratos, em que os contratos civis e empresariais passam a ser disciplinados juridicamente por regras comuns emanadas de um "mesmo tronco" ou "mesma fonte normativa" (Código Civil ou Direito Comum ${ }^{288}$ ), sem que, contudo, seja desconsiderada legislação especial pertinente, passemos à ánalise do regime jurídico incidente sobre o Contrato de Licença de Uso de Marca - contrato empresarial, classificado como contrato atípico misto - sujeito aos preceitos e dispositivos normativos enraizados na Lei 9.279/96 e no Código Civil de 2002.

\footnotetext{
${ }^{286}$ REALE, Miguel. O Projeto do Novo Código Civil. São Paulo. Saraiva. 1999. p. 56.

${ }^{287}$ Pertinente colacionar os ensinamentos de João da Gama Cerqueira a respeito da aplicação subsidiária do direito civil aos contratos de licenças: "Sendo omisso o contrato quanto aos direitos e obrigações das partes, as suas relações regulam-se pelo direito comum no que for compatível com a natureza especial do contrato (...) (Cf. CERQUEIRA, João da Gama. Tratado da Propriedade Industrial. $3^{a}$ ed. atual. por: Newton Silveira e Denis Borges Barbosa. op. cit......Vol. II. Tomo I. Parte II. p. 174).

${ }^{288}$ REALE, Miguel. O Projeto do Novo Código Civil. São Paulo. Saraiva. 1999. p. 56.
} 


\section{REgIME JURÍdico InCIDENTE SOBRE O CONTRATO de LICENÇA DE USO DE MARCA}

Adiante, serão ponderados os pontos basilares concernentes à teoria geral e princípios que regem os contratos empresariais, à guisa da legislação, jurisprudência e doutrinas pátrias e alienígenas, mormente pelo fato de o contrato de licença de uso de marca, objeto central da presente tese, inserir-se em tal categoria, submetendo-se, com efeito, ao regime jurídico dos contratos desta natureza ${ }^{289}$. Serão tracejados os pontos elementares dos contratos empresariais, conforme regulamentação do diploma civil vigente, face à unificação do direito obrigacional exposto no capítulo antecedente.

Impõe-se reiterar que se há controvérsia no que tange à unificação do direito privado, em sua universalidade, apresenta-se, indubitavelmente, mansa e pacífica nos tribunais e correntes doutrinárias pátrios, a ideia de que houve a unificação do direito obrigacional no novo códex.

Os contratos caracterizam-se como "fonte mediata" das obrigações. Para Orlando Gomes, as obrigações emanam de fontes imediatas e fontes mediatas ${ }^{290}$. Ainda segundo o civilista em apreço, as fontes imediatas são as leis. Por seu turno, as fontes mediatas, condições que estipulam o nascimento das obrigações, constituem em circunstâncias (fatos ou situações) capazes de gerar efeitos no mundo jurídico. Desta feita, são considerados "fatos constitutivos de obrigações". Com efeito, os contratos, como negócios jurídicos, são

\footnotetext{
${ }^{289}$ Silvio de Salvo Venosa, ao delinear acerca das regras aplicáveis aos contratos, precipuamente àqueles contratos que carecem de regulamentação específica, assevera que "A heterogeneidade do universo contratual salienta que a importância mais uma vez decantada da teoria geral dos negócios jurídicos, em primeiro plano, e da teoria geral dos contratos, em segundo, ambas, no entanto, com crucial importância para o deslinde dos fenômenos dos vários contratos e negócios jurídicos. No exame de cada contrato em particular, não havendo regra específica, o intérprete deverá recorrer à teoria geral". (VENOSA, Sílvio de Salvo. Direito Civil: Contratos em espécie e responsabilidade civil. São Paulo. Atlas. 2001. vol.3. p. 24)
}

${ }^{290}$ GOMES, Orlando. Obrigações. $13^{\mathrm{a}}$ ed. Rio de janeiro. Forense. 2000. pp. 25-29. 
espécies solidamente reconhecidas como fontes geradoras de obrigações estando, portanto, incluídos no gênero "direito das obrigações".

Extremamente elucidativos são os dizeres de Orlando Gomes ${ }^{291}$, cuja melhor doutrina reza:

\begin{abstract}
Os negócios jurídicos constituem a mais abundante fonte de obrigações.
(...)Os fatos constitutivos de obrigações negociais são: a) os contratos; b) os atos coletivos; c) os negócios unilaterais; d) a promessa unilateral.
\end{abstract}

Os mais importantes são, inquestionavelmente, os contratos. Constituem a fonte por excelência das obrigações. Seu estudo, objeto da parte especial do Direito das Obrigações, abrange a exposição dos princípios gerais que os disciplinam e o exame dos tipos definidos na lei. (grifou-se)

Consoante amplamente discorrido na doutrina, pacificado nos tribunais e codificado pelo Diploma Civil vigente, os contratos civis e empresariais (antigos contratos mercantis) - classe na qual se insere os contratos de licença de uso de marca - foram submetidos a um mesmo diploma legal, em que pesem as particularidades de cada tipo contratual, bem como eventuais legislações extravagantes que sobre os contratos empresariais possam recair $^{292}$.

Nesta acepção, o diploma civil, sob o ponto de vista principiológico e como sendo a regulamentação jurídica apta a preencher as lacunas deixadas pela legislação privada extravagante, passa a ser a legislação aplicável aos contratos empresariais (contratos em que os dois contratantes são empresários). Obviamente, em havendo legislação extravagante que discorra acerca de um determinado contrato empresarial, sobre este

${ }^{291}$ GOMES, Orlando. Obrigações. 13 ${ }^{\mathrm{a}}$ ed. Rio de janeiro. Forense. 2000. p. 30.

292 A definição contratos mercantis ou comerciais foi substituída por contratos empresariais, haja vista a recepção da teoria da empresa pelo novo diploma legal. Desta feita serão contratos empresariais aqueles contratos celebrados entre empresários, que com fundamento no artigo 966 do Código Civil, são aqueles que exercem "profissionalmente atividade econômica organizada para a produção ou a circulação de bens ou de serviços". Registre-se, outrossim, que a teoria dos atos de comércio, inspirada na concepção francesa no sentido de indicar as atividades especificamente praticadas pelos comerciantes foi suprimida pela "teoria da empresa", onde não mais importa o gênero de atividade desenvolvida pelo indivíduo ou sociedade, mas sim a forma como ele a desenvolve, de tal sorte que se a atividade econômica for praticada com organização e tiver por desígnio a produção ou circulação de bens ou serviços, será o sujeito ou sociedade enquadrado como empresário. (REQUIÃ̃O, Rubens. Curso de Direito Comercial. vol .1. 25 a ed. São Paulo. Saraiva. 2003. p. 35-45). 
prevalecerá a legislação especial, aplicando-lhe o Código Civil apenas em caráter subsidiário e naquilo que lhe for pertinente.

O presente capítulo terá por desígnio o delineamento acerca da teoria geral dos contratos e dos princípios incidentes sobre os contratos atípicos ou inominados, à luz do Código Civil vigente, contratos estes sob cujo manto se submete grande parte dos contratos empresariais, incluindo-se neste inesgotável rol o contrato de licença de uso de marca que, conforme será adiante verificado, muito embora esteja previsto em legislação específica, não se encontra regulamentado em sua plenitude, tendo de se recorrer, inevitavelmente, ao regime jurídico dos contratos civis e empresariais, disciplina geral esta corroborada e exteriorizada pelo Diploma Civil em vigor.

Os contratos atípicos, em cuja classe se insere o contrato objeto deste estudo, serão objeto de apreciação do presente capítulo. Esta categoria de contrato alcançou notável importância para a sistemática em exame, haja vista que tais contratos, sobretudo aqueles em que não há expressa regulamentação prescrita por legislação extravagante, serão submetidos ao regime dos princípios e teoria geral dos contratos, exteriorizados pela legislação civil, como, por igual, serão subjugados ao regramento daquelas espécies contratuais que lhe sejam análogas.

Assim, convém registrar que, com a edição da legislação civil de 2002, o legislador pátrio reeditou figuras contratuais, antes aventadas pelo Código de 1916, bem como inovou ao trazer ao sistema jurídico positivo figuras contratuais originais ${ }^{293}$. Quando da reedição das espécies contratuais que já haviam sido disciplinadas pelo Código Civil de 1916 (revogado), o legislador: (i) manteve o regramento integral de espécies contratuais disciplinadas no diploma civil anterior; (ii) inovou completamente, trazendo à lume nova regulamentação para as figuras contratuais reeditadas; e, por fim, (iii) manteve a maioria dos elementos jurídicos constantes do regramento previsto no Código anterior, trazendo, todavia, algumas inovações no bojo da nova legislação civil. Esta última mutação foi a que

\footnotetext{
${ }^{293}$ O Código Civil de 2002 regulamentou os seguintes contratos civis e empresariais, os quais se encontram compreendidos entre os artigos 481 e 853 do citado diploma legal: Compra e Venda (art. 481); Troca ou Permuta (art. 533), Doação (art. 538), Locação de Coisas (art. 565), Empréstimo (art. 579), Prestação de Serviço (art. 593), Empreitada (art. 610), Depósito (art. 627), Mandato (art. 653), Comissão (art. 693), Agência ou Distribuição (art. 710), Corretagem (art. 722), Transporte (art. 730), Seguro (art. 757), Constituição de Renda (art. 803), Jogo e Aposta (art. 814), Fiança (art. 818), Transação (art. 890).
} 
se operou com o contrato de locação de coisas - contrato análogo direto ao contrato de licença de uso de marca remunerado - em que se manteve boa parte do regramento consignado no diploma anterior, trazendo-se à tona novos dispositivos normativos. Estas inovações normativas serão demonstradas quando do estudo da incidência das regras do contrato de locação de coisas sobre o contrato de licença de uso de marca, adiante.

O contrato de agência ou distribuição é a prova cabal e instrumento que simboliza, de forma inconteste, a unificação do direito contratual civil e empresarial materializada na nova codificação. Neste sentido, assenta Humberto Theodoro Junior ${ }^{294}$ :

\begin{abstract}
Dessa conceituação legal, deduz-se que o contrato de agência envolve: a) relação entre empresários, dentro da circulação mercadológica de bens e serviços; (...) c) o objetivo do contrato não é um negócio determinado, mas uma prática habitual, de sorte que entre as partes se estabelece um vínculo duradouro (não eventual); d) a representação importa atos promovidos por uma das partes à conta da outra, configurando, portanto, um negócio de intermediação na prática mercantil de interesse do representado. (grifou-se)
\end{abstract}

Entretanto, ainda que o legislador envidasse esforços sobre-humanos com o escopo precípuo de prever ou tipificar todos os contratos que refletem as relações civis e empresariais, tal encargo seria, por certo, inalcançável. O universo das relações jurídicas intersubjetivas é, incontestavelmente, mais complexo do que as previsões legais contempladas pelos mais diversificados tipos de diplomas legais que integram a malha do complexo ordenamento jurídico nacional.

A massificação das relações intersubjetivas, sob o ponto de vista sociológico, faz com que os jurisconsultos e profissionais que atuam na área jurídica, sejam compelidos a envidar imensuráveis esforços para o desenvolvimento de negócios jurídicos particulares dos mais variados tipos, cujos instrumentos contratuais delineiem, ao máximo, as relações jurídicas dos indivíduos que nestes instrumentos figuram como partes ou agentes contratuais. Nesta esteira, conforme acima refletido, os operadores do direito passam, indiferentemente da posição profissional que ocupem no universo jurídico, a figurar como constantes criadores do direito.

\footnotetext{
294 JUNIOR, Humberto Theodoro. Do contrato de agência e distribuição no Novo Código Civil. Artigo public. Em 29/09/2005. Disponível em: $<$ http://www.mundojuridico.adv.br/sis_artigos/artigos.asp?codigo=645>. Acesso em 12 nov. 2008.
} 
Entretanto, em que pese a liberdade dos operadores no que concerne à concepção, por vezes engenhosa, de contratos civis e empresariais não previstos no Código Civil ou legislação extravagante (contratos atípicos), certos princípios gerais devem obrigatoriamente ser respeitados.

O legislador concedeu, assim, poderes aos instrumentadores do direito contratual, porém simultaneamente os restringiu, de tal sorte que os princípios basilares do direito contratual, e que guarnecem os civis, os empresários e todo o tecido social envolto às relações intersubjetivas, não sejam lesados.

Adiante, realizar-se-á estudo analítico, de sorte a demonstrar a atipicidade dos contratos de licença de uso de marca e o disciplinamento jurídico que recai sobre esta "espécie" contratual. Serão noticiados, outrossim, à luz do regime jurídico incidente sobre o contrato em exame, as diretrizes e princípios gerais que sobre esta figura contratual devem ser aplicados, com fundamento em construções doutrinárias desenvolvidas por atores de importante atuação no cenário jurídico contratual.

Serão, ademais, extraídas sínteses analíticas das obras estudadas, com o fito de serem alcançados resultados conclusivos no que tange às regras gerais aplicáveis aos contratos atípicos - mais especificamente aos contratos de licença de uso de marca, sobretudo em conformidade com os ditames exteriorizados pelos legisladores e colaboradores da legislação civil vigente.

\section{V.1 A ATIPICIDADE DO CONTRATO DE LICENÇA DE USO DE MARCA}

A classificação jurídica existente entre contratos típicos e atípicos segue a distinção histórica instaurada pelo Direito Romano, que distinguia os contratos entre nominados e inominados. Tal distinção consistia, precipuamente, na existência ou não de nomen iuris próprio. O elevado grau de formalismo no Direito Romano não permitia, de início, proteção aos contratos tidos como inominados (atípicos). ${ }^{295}$ Desta forma, os contratos

${ }^{295}$ Cf. JUNIOR, Nelson Nery e NERY, Rosa Maria de Andrade, Código Civil Comentado e Legislação Extravagante, $3^{\text {a }}$ ed. Revisada e ampliada, p. 374, jun. 2005. 
nominados obstaculizavam, de certo modo, a validade de qualquer acordo que não estivesse admitido pelo costume e consolidado segundo o Direito Romano, ficando os contratos que não estivessem inseridos naquele delimitado rol de contratos nominados desprovidos da proteção jurídica correspondente.

Hodiernamente, todavia, a segregação entre contratos típicos e atípicos perfaz-se, predominantemente, na vinculação que certo tipo de contrato tem ou não tem com as figuras contratuais exteriorizadas pelo Código Civil ou Legislação Extravagante.

Cumpre salientar, ainda, que o contrato típico não apenas possui uma denominação meramente ilustrativa (nomen iuris), como também deve ser elaborado dentro daqueles preceitos normativos apresentados pelo Código Civil ou legislação extravagante ${ }^{296}$. Desta forma, as regras e preceitos contratuais devem estar em plena conformidade com as regras positivadas explicitamente prescritas, sob pena de ser declarada a nulidade do contrato.

Ao lado dos contratos típicos, ainda existem os contratos típicos formados com cláusulas atípicas. Tal afirmação reside no fato de que há contratos que são tipificados, ou seja, estão devidamente regulamentados pelo ordenamento jurídico (códigos ou legislação extravagante), porém que se encontram igualmente munidos de cláusulas atípicas, ou seja, cláusulas que não estão regulamentadas pelo sistema legal pátrio.

Para efeitos ilustrativos, o mestre Orlando Gomes ${ }^{297}$ enumera aqueles instrumentos que se encontram inseridos no rol de contratos de tal natureza: (i) venda de controle acionário. Este é um contrato de "venda e compra", devidamente tipificado pelo Código Civil, porém com cláusulas atípicas (controle acionário), mesmo porque envolve complexas questões societárias que devem ser mencionadas quando da formação deste contrato; (ii) locação de um terreno para afixação de "outdoor"; (iii) locação intuitu

\footnotetext{
${ }^{296}$ Nelson Nery Júnior afiança este entendimento, prelecionando que não basta ao contrato ter apenas um nome, porém ele deve possuir regramento específico prescrito pelo ordenamento jurídico, seja pelo Código Civil, seja por legislação específica. Podemos depreender, a partir das lições disseminadas por Nery, que não basta que a lei apenas faça referência a determinados contratos. Para que estes, sejam considerados típicos, a lei deve, necessariamente, regulamentá-los, tal qual, ocorre, a título exemplificativo, com os contratos de venda e compra no código civil. (JÚNIOR, Nelson Nery e NERY, Rosa Maria de Andrade. Código Civil Comentado. $6^{\text {a }}$ ed. São Paulo. Ed. Revista dos Tribunais. 2008. p. 495).
}

${ }^{297}$ GOMES, Orlando. Contratos. $22^{\mathrm{a}}$ ed. Rio de Janeiro. Ed. Forense. 2000. p. 108. 
personae de casa para o empregado morar enquanto perdurar a relação de emprego. Neste caso, vale a ressalva que este contrato de locação, não obstante tutelado pela Lei do Inquilinato, permeia-se por cláusulas essencialmente atípicas e que, de certo modo, até contrariam certas previsões dispostas na Lei do Inquilinato ${ }^{298}$. (iv) contratos de joint venture $^{299}$; e (v) contratos de informática, dentre outros.

Contrario sensu, são considerados contratos atípicos aqueles negócios jurídicos bilaterais ou plurilaterais que criem, alterem, regulamentem e extingam direitos e deveres de caráter patrimonial, que não estejam sujeitos a disciplinamento jurídico específico expresso no Código Civil ou ainda em legislação extravagante. Desta feita, estes contratos, categorizados como atípicos, devem ser celebrados com fundamento no princípio basilar contratual da autonomia da vontade privada. Ademais, conforme bem preleciona o insigne professor Washington de Barros Monteiro, "os contratos inominados [ou atípicos] resultam, em geral, da fusão de dois ou mais tipos de contratos previstos na lei". 300

Em síntese, os contratos atípicos são figuras novas, cuja regulamentação é fruto da vontade das partes, sendo-lhes aplicados diversos elementos de contrato típicos no que lhes for pertinente.

Exemplo clássico de contrato atípico é o "Contrato Sobre Exploração da Lavoura de Café", cujo entendimento jurisprudencial converge para um contrato composto de elementos de contratos de locação de serviços, empreitada, arrendamento e parceria agrícola, ou ainda o "Contrato de Hospedagem”, contrato misto de locação de coisa, de depósito e prestação de serviço.

\footnotetext{
${ }^{298}$ Em síntese, a locação para Locatário empregado é aquela em que a figura do Locador se confunde com a figura do empregador e destina-se a uso residencial do empregado e de sua família, em razão do emprego. Esse tipo de locação exige contrato que contenha cláusula específica (cláusula atípica) registrando que a locação somente vigerá enquanto o Locatário trabalhar para o Locador. Exige ainda que haja valor efetivamente pago ou descontado, a título de aluguel. O desconto pode ser efetuado na folha de pagamento ou pode ser cobrado normalmente como em qualquer outra situação. O que importa é que a locação tenha relação com o emprego, e as condições da locação sejam formalmente estabelecidas.

${ }^{299}$ Assenta Luis Olavo Baptista que os "contratos de joint venture são criados a partir de um acordo-base em torno do qual gravitam os contratos satélites, sendo seus objetivos realizados por um órgão de gestão e controle que pode ser uma pessoa física ou jurídica, mandatária, formal como uma sociedade por ações, ou informal, como o gerente de um consórcio". (MAGALHÃES, José Carlos de \& BAPTISTA, Luiz Olavo. Arbitragem comercial. Rio de Janeiro: Freitas Bastos, 1986, p. 59).
}

${ }^{300}$ MONTEIRO, Washington de Barros. Apud DOWER, Nélson Godoy Bassil, Curso Moderno de Direito Civil, Contratos e Responsabilidade Civil, $3^{\mathrm{a}}$ edição, São Paulo: Ed Nelpa. 2007. p. 24. 
Reitere-se, ainda, que não há diferença quanto à forma de tratamento direcionada aos contratos. Tal afirmação reside no fato de que o contrato, por si só, faz lei entre as partes (pacta sunt servanda), não tendo significância se eles são classificados em típicos ou atípicos.

No que tange à distinção entre os contratos típicos e atípicos, preleciona, com extrema vivacidade, Álvaro Villaça Azevedo ${ }^{301}$ :

Os contratos típicos recebem do ordenamento jurídico uma regulamentação particular, e apresentam-se com um nome, ao passo que os atípicos, embora possam ter um nome, carecem de disciplina particular, não podendo a regulamentação dos interesses dos contratantes contrariar a lei, a ordem pública, os bons costumes e os princípios gerais de direito.(grifou-se)

A professora Giselda Fernandes Novaes Hironaka, perfilhando o mesmo entendimento disseminado por Álvaro Villaça Azevedo, esclarece, com brilhantismo, verbis:

\begin{abstract}
Nesse passo, levanto pedido de licença para registrar, desde logo, a inconveniência e o desacerto de se prosseguir, doutrinaria e dogmaticamente, com aquela posição que sempre deu, como sinônimas as expressões inominado e atípico. Sob nenhuma hipótese desconsidero tal crítica, eis que a atipicidade de um contrato não se traduz pelo fato de ter ele, ou não, um nomem juris, mas sim pelo fato de não estar devidamente regulamentado em lei.

Reconhece-se com freqüência cada vez mais acentuada que contratos há que têm nome e nem por isso são nominados-típicos já que, para que assim fossem considerados, estariam a exigir a presença de um regramento legislativo específico. Fico com a melhor e dominante doutrina para admitir que é preferivel se referir, nestes casos, a contratos típicos e a contratos atípicos, em lugar de nominados e inominados.

Assim, é contrato típico aquele que a lei regulamenta, estabelecendo regras especificas de tratamento e lhe concedendo um nomem juris.

A seu turno, portanto, contrato atípico é aquele não disciplinado pelo ordenamento jurídico, embora lícito, pelo fato de restar sujeito às normas gerais do contrato e pelo fato de não contrariar a lei, nem os bons costumes, nem os princípios gerais de direito. Pouco importa se tem ou não um nome, porque este não é a característica da sua essência conceitual; seu traço característico próprio é o fato de não estar sujeito a uma disciplina própria. ${ }^{302}$
\end{abstract}

${ }^{301}$ AZEVEDO, Álvaro Villaça. Teoria geral dos contratos típicos e atípicos. São Paulo: Atlas, 2002. p. 132.

${ }^{302}$ HIRONAKA, Giselda Fernandes Novaes. Contrato: estrutura milenar de fundação do direito privado renovando a crise e renovando princípios, no início do vigésimo primeiro século, ao tempo da transição legislativa brasileira. Disponível em <http://www.flaviotartuce.adv.br/secoes/artigosc.asp> Acesso em 20 set. 2010. 
Os contratos atípicos classificam-se em contratos atípicos puros (ou singulares) ou contratos atípicos mistos. Conforme preleciona Álvado Villaça, "os contratos atípicos singulares são figuras atípicas, consideradas individualmente. Os contratos atípicos mistos apresentam-se: (a) com contratos ou elementos somentes típicos; (b) com contratos ou elementos somente atípicos; (c) com contratos ou elementos típicos e atípicos",303

Segundo a melhor lição de Silvio de Salvo Venosa ${ }^{304}$, são contratos atípicos puros (ou singulares) aqueles que não guardam qualquer semelhança com qualquer outra espécie de contrato tipificada no Código Civil. Neste caso, importa muito o fundamento destes tipos de contrato, que devem ser interpretados de acordo com os princípios gerais de direito geral e de direito contratual.

Ademais, pouco recorrente se faz a presença, no ordenamento jurídico nacional, dos contratos atípicos puros, posto que, com notável freqüência, os instrumentos contratuais não regulamentados em lei, se valem de dispositivos outros previstos para a regulamentação de contratos análogos ${ }^{305}$, os quais se submetem, em geral, à disciplina legal do Diploma Civil ou de legislação extravagante.

Não há que se confundir os contratos atípicos coligados com os contratos atípicos mistos. São duas figuras, certamente, dissonantes. Conforme ilação extraída da primorosa obra de Álvaro Villaça Azevedo, os contratos coligados, dois ou mais, conservam sua individualidade própria, ficando as contratações autônomas distintas configuradas em um único instrumento, porém conectadas por um interesse econômico peculiar. Por outro lado, no que toca aos contratos atípicos mistos, inúmeras são as avenças adicionadas e que se agremiam de maneira indissolúvel, não tendo, cada uma das avenças, vida própria, se

\footnotetext{
${ }^{303}$ AZEVEDO, Álvaro Villaça. Teoria geral dos contratos típicos e atípicos. São Paulo: Atlas, 2002. p. 138.

${ }^{304}$ VENOSA, Sílvio de Salvo, Direito Civil, Teoria Geral das Obrigações e Teoria Geral dos Contratos,

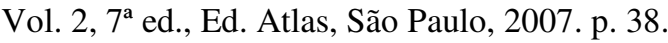

305 Cumpre-nos destacar, na esteira da unificação do direito privado obrigacional, o princípio da analogia previsto no art. $4^{\circ}$ da Lei de Introdução do Código Civil. Em conformidade com a dicção do mencionado dispositivo que "quando a lei for omissa, o juiz decidirá o caso inspirado na analogia, nos costumes e nos princípios gerais de direito". Muito embora esta regra seja direcionada à aplicação da legislação pelo magistrado em caso de omissão legal ao deparar-se com o caso concreto, corroboramos a tese de que a analogia é um princípio arraigado ao novo diploma civil, podendo, portanto, ser igualmente utilizada pelos operadores de direito contratual para a confecção dos contratos atípicos. Portanto, ratificamos o entendimento de que é muito pouco recorrente a presença dos contratos atípicos puros no sistema jurídico contratual.
} 
individualmente considerada naquele contexto contratual. Está-se diante de uma “contratação única, complexa e indivisível" 306.

Na definição do professor Nelson Nery Júnior, os contratos mistos intitulam-se “contratos complexos"307, considerando que elementos de diversas espécies contratuais codificadas coexistem em um mesmo instrumento contratual, o qual tem por desígnio operação econômica unitária, ou seja, objetivo econômico distinto daquelas espécies contratuais das quais foram extraídos os elementos para a corroboração do contrato misto.

Mister se faz esclarecer, ainda segundo a lição do professor Nery Jr., que os contratos mistos não se confundem com a figura da união de contratos. Nesta figura, há a soma de contratos em um único instrumento. No mais, a exclusão de um dos contratos não prejudica a continuidade do outro ${ }^{308}$. No contrato atípico misto, por seu turno, a complexidade alcançada é de tal sorte que a exclusão de alguns elementos contratuais pode vir a afetar toda a estrutura e natureza do contrato.

Interessante faz-se mencionar a definição que o mestre Silvio Venosa atribui aos contratos atípicos mistos ${ }^{309}$. Ele os define como "mosaico contratual", haja vista a interdependência existente entre os elementos contratuais. Venosa assinala que uma avença pode depender de outra ou uma avença pode até mesmo excluir outra nos contratos atípicos mistos. Exemplificando, o civilista aponta o evento da venda casada, que ocorre quando o contratante vende um equipamento de informática (hardware) e cede gratuitamente os programas de utilização (software). Aqui, em cristalina demonstração de interdependência de elementos contratuais (contrato atípico misto), somente existe a cessão gratuita do programa, porque ocorreu a compra e venda do hardware. Deste modo, a cessão depende intrinsecamente da compra e venda.

\footnotetext{
${ }^{306}$ AZEVEDO, Álvaro Villaça. Teoria geral dos contratos típicos e atípicos. São Paulo: Atlas, 2002. p. 138

${ }^{307}$ Cf. JUNIOR, Nelson Nery e NERY, Rosa Maria de Andrade. Código Civil Comentado e Legislação Extravagante, $3^{\mathrm{a}}$ ed. Revisada e ampliada, p. 374, jun. 2005, São Paulo.

${ }^{308}$ Segundo a lição de Silvio Venosa: "existem contratos que se unem, pinçando disposições de mais de um contrato. Distingue a doutrina a união externa dos contratos da ligação de contratos independentes entre si. A união meramente externa liga contratos independentes que se unem unicamente sob o ponto de vista material. Poderá haver, por exemplo, um comodato de moveis dentro de uma locação de imóvel. São dois os contratos que contigencialmente se apresentam no mesmo instrumento”. (VENOSA, Sílvio de Salvo. Direito Civil, Teoria Geral das Obrigações e Teoria Geral dos Contratos, Vol. 2, $7^{\mathrm{a}}$ ed. ob. cit. p. 381)

${ }^{309}$ VENOSA, Sílvio de Salvo, ob. cit. p. 381.
} 
Os contratos atípicos mistos são, com freqüência, vislumbrados pelos tribunais pátrios $^{310}$, os quais consideram que a definição da natureza jurídica do instrumento contratual irradiará efeitos diversos no mundo jurídico. Conclui-se, pois, que a definição da natureza jurídica de certo contrato terá impacto de cunhos teórico e prático.

Ante a teoria dos contratos atípicos acima exposta, convergimos para a atipicidade do contrato de licença de uso de marca, o enquadrando na modalidade dos contratos atípicos mistos.

Deste posicionamento, contudo, não compartilham os professores Jacques Labrunie e Maitê Cecília Fabri Moro, para quem o contrato em apreço é contrato típico, “já que a Lei 9.279/96 o disciplina" ${ }^{311}$. Da teoria da atipicidade do contrato de licença de uso de marca também não partilha Alexandre Gnocchi, para quem estas espécies de contrato de licença são consideradas contratos típicos de direito industrial ${ }^{312}$. Ademais, muito embora este autor reconheça que estes tipos de contrato guardem certa semelhança com os contratos de locação e que sobre eles recaiam a teoria geral dos contratos, tais contratos não se confundem com aqueles instrumentos de natureza civil ou comercial.

Por fim, curvando-se à corrente acima ventilada, Gabriel Di Biasi considera o contrato de licença de marca como um "contrato típico, em que os pressupostos e

\footnotetext{
310 Pertinente trazermos à colação julgados nos quais há a apreciação dos contratos atípicos e suas conseqüentes implicações jurídicas. "Contrato Atípico Misto. Acórdão que considera constituírem contratos de compra e venda e comodato "uma unidade essencial", apesar do seccionamento puramente formal do negócio jurídico. Descumprimento do Contrato. Condenação á multa com exclusão de perdas e danos. Redução da Multa. Inexistência de dissídios com julgado que não a reduziu em caso de obrigação negativa descumprida. Recurso Extraordinário conhecido em parte e não provido”. Apelação Cível. Factoring. Contrato de Fomento Mercantil. Garantias Contratuais. Admissibilidade. O contrato de fomento mercantilfactoring - tem natureza de contrato misto e atípico. Mista porque presta serviços e compra créditos mercantis. Atípica porque compra créditos e não mercadorias. 2. A cessão de crédito é o meio de transmissão dos títulos de crédito adquiridos do cedente-faturizado pelo cessionário-faturizador. 3. A factor, através do ato de cessão, fica investida de todos os direitos de agir em nome próprio na cobrança da dívida. 4. É lícita a exigência de garantias no contrato de fomento mercantil. 5. O princípio da autonomia da vontade se alicerça na ampla liberdade contratual que permite a fixação de normas aplicáveis aos contratos de fomento mercantil pelos pactuantes. 6. Admite-se a condição de pro-solvendo do faturizado, conforme permitido pelo artigo 296, do NCC. 7. O fim social ou teleológico da legislação de factoring é incentivar e permitir que a iniciativa privada se desenvolva”. (STF, $1^{\mathrm{a}} \mathrm{T}, \mathrm{RE} 79562-\mathrm{SP}$, rel. Min Rodrigues Alckimin, v.u., j. 10.2.1976 - RTJ 77/884. Site <www.stj.gov.br>; Acesso em 20 set. 2009)

311 MORO, Maitê Cecília Fabri; LABRUNIE, Jacques. Contrato de Licença de Uso de Marca e suas Particularidades. in PEREIRA JR., Antônio Jorge; JABUR, Gilberto Haddad (coord.). Direito dos Contratos. São Paulo: Ed. Quartier Latin, 2006. p. 235.
}

${ }^{312}$ GNOCCHI, Alexandre. Licenças e Roialties no Brasil. ob. cit. p. 07. 
requisitos dos contratos especificados no Código Civil, especialmente os arts. 565 e 578 do referido Código, incidem sobre essa modalidade de locação, respeitadas as características peculiares dos bens imateriais e o tratamento dispensado pela Lei 9.279/96"313.

Apresentada corrente contrária, passemos, respeitosamente, à fundamentação de nosso posicionamento acerca da atipicidade do contrato sub examine:

A lei 9279/96, em seu artigo 139, de forma pontual, lacônica e simples, apresenta a seguinte e única redação para os contratos de licença de uso de marca: "o titular de registro ou o depositante de pedido de registro poderá celebrar contrato de licença para uso da marca, sem prejuízo de seu direito de exercer controle efetivo sobre as especificações, natureza e qualidade dos respectivos produtos ou serviços". Ademais, o referido artigo de lei prevê, em seu parágrafo único, que "o licenciado poderá ser investido pelo titular de todos os poderes para agir em defesa da marca, sem prejuízo dos seus próprios direitos”. O ato normativo INPI n. ${ }^{\circ}$ 135/97, também laconicamente, faz menção ao contrato em exame (juntamente com outros contratos de transferência de tecnologia), ao assinalar, em seu artigo 3, que "os contratos deverão indicar claramente seu objeto, a remuneração ou os "royalties", os prazos de vigência e de execução do contrato, quando for o caso, e as demais cláusulas e condições da contratação".

Temos, portanto, que o contrato de licença de uso de marca é nominado, porque mencionado em lei. Porém, diante de tudo o que fora acima exposto, é atípico, porque carece de regulamentação correspondente pormenorizada. Não é demais repisar, na esteira do que ministram os professores Alvaro Villaça Azevedo, Silvio Venosa e Giselda Hironaka, dentre outros, que a mera nominação da espécie contratual não é elemento caracterizador de sua tipicidade. É imperioso o disciplinamento jurídico mais apurado para que o contrato seja classificado como tal. Ademais, a ausência de regramento mais aprofundado sobre determinado contrato é fato inconteste que o remete à classificação de contrato atípico. É exatamente o que se sucede com o contrato de licença de uso de marca. Como visto, o regramento jurídico expresso (tipicidade) que incide sobre esta espécie contratual é absolutamente lacônico e genércio, não se podendo falar em contrato típico. A

${ }^{313}$ Cf. DI BIASI, Gabriel. A Propriedade Industrial: Os Sistemas de Marcas, Patentes, Desenhos Industriais e Transferência de Tecnologia. $3^{\mathrm{a}}$ ed. rev. e atual. Rio de Janeiro: Ed. Forense. 2010. p. 376) 
prova cabal desta afirmação repousa no fato que a "regulamentação expressa" deste tipo de contrato esgotou-se, de forma rasa, em apenas um parágrafo do texto de lei (acima).

Não há que se falar, desta sorte, em regulamentação desta figura contratual pela Lei 9.279/96, conforme perpetram alguns juristas, porquanto o aludido diploma que regula o direito da propriedade industrial apenas lhe faz menção, extremamente sucinta, sem proceder a qualquer forma de regulamentação ou disciplinamento que, de alguma forma, possa inseri-lo no rol dos contratos típicos.

Portanto, concluímos que o contrato de licença de uso de marca é contrato atípico misto. "Contrato atípico", pelas razões e fundamentos acima mencionados (carência de regulamentação específica mais acurada sobre a matéria). "Misto", conforme restará adiante demonstrado, porque possui elementos típicos, como atípicos. "Elementos típicos" pois que extraídos do artigo 139, e Ato Normativo INPI n..$^{\circ}$ 135/97, retro transcritos, contratos análogos típicos (especialmente contrato de locação de coisas), e princípios gerais e cláusulas específicas do Código Civil. "Elementos atípicos", porque se consubstanciam nas cláusulas e condições não disciplinados (tipificados) em lei, competindo ao intérprete do direito a concepção destes elementos no âmbito do contexto contratual. Os elementos atípicos, a exemplo, da forma de pagamento pelo licenciamento da marca, eleição de clásula de arbitragem, cláusulas de confidencialidade, obrigações da partes, dentre outras cláusulas e condições com caracteres de atipicidade, serão oportunamente estudados na presente tese.

Demonstrada a atipicidade do contrato de licença de uso de marca, passemos à análise do regramento jurídico incidente sobre este contrato de direito industrial interempresarial. 


\section{V.2 DISCIPLINAMENTO JURÍDICO APLICÁVEL AO CONTRATO DE LICENCA DE USO DE MARCA (CONTRATO ATÍPICO MISTO)}

Concebida a tese da atipicidade do contrato de licença sob investigação, impõe-se sinalizar para as possíveis regras jurídicas a serem aplicadas ao contrato sub examine, classificado como verdadeiro contrato atípico misto, o que, conforme analisado na presente tese, carece de uma normatização positivada, muito embora esteja vinculado a princípios gerais e outras fontes jurídicas .

Compete, $a b$ initio, realização de acautelada investigação concernente às regras aplicáveis aos contratos atípicos lato sensu, para, após, procedermos à análise das regras incidentes sobre os contratos de licença de uso de marca. Como regra basilar do disciplinamento jurídico dos contratos atípicos, é imperioso registrar o preceito contido no artigo 425 do Código Civil vigente, que aponta ser "lícito às partes estipular contratos atípcos, observadas as normas fixadas neste Código". 314

Diante do artigo acima colacionado, pode-se depreender, através de um exercício hermenêutico, que o legislador pátrio outorgou aos particulares o poder de confeccionar contratos que não estejam prescritos (positivados). Eis o ponto de partida e regra basilar para os contratos atípicos. Neste ponto, pode-se inferir que o Código Civil, ainda que timidamente, fez menção aos contratos atípicos, lhes direcionando regras genéricas de formação.

O legislador pátrio, sob um ponto de vista teleológico, muito mais se preocupou em determinar princípios genéricos aos contratos atípicos do que "regras" hermeticamente fechadas, como o fez com os contrato típicos. O Código Civil vigente, neste sentido, desvencilhou-se do tecnicismo exacerbado presente no diploma revogado, para promover

\footnotetext{
${ }^{314}$ Tramita no Congresso Nacional Brasileiro, há mais de seis anos, projeto de lei (atualmente n. ${ }^{\circ}$ 276/2007), de autoria do Dep. Léo Alcântara, para se alterar, dentre outros dispositivos do Código Civil, a redação do Artigo 425 do Código Civil, que passaria a ter a seguinte disposição: "É lícito às partes estipular contratos atípicos, resguardados a ordem pública, os bons costumes e os princípios gerais de direito, especialmente o princípio de que suas obrigações são indivisíveis, formando um só todo (NR)."
} 
princípios sociais equalizadores das relações jurídicas e cláusulas abertas que emprestem maior flexibilidade aos operadores do direito, seja para a concepção de contratos (especialmente atípicos), seja para a aplicação da lei ao caso concreto.

A possibilidade de se conceber contratos "novos", cujas cláusulas e condições podem ser livremente fixadas, contanto que "observadas as normas [gerais] fixadas" no diploma civil, resulta na concepção de um novo conceito principiológico passível de aplicação em todos os contratos atípicos, o qual ousamos intitular princípio liberal limitado. Esta denominação refere-se ao fato de que os contratos atípicos são disciplinados não somente pelas normas gerais aplicáveis a todos os contratos, mas também pela livre confecção de cláusulas pelas partes (princípio liberal da autonomia da vontade privada); pelas disposições atinentes ao contrato típico com o qual venha a oferecer maior analogia ou proximidade; e pelos princípios das modalidades que o compõem (restrição da liberdade contratual àqueles dispositivos normativos codificados, ainda que o sejam em outras espécies contratuais).

Reteire-se, outrossim, que a qualificação jurídica do contrato não se restringirá à denominação que sobre ele incidir, mas se caracterizará em razão dos elementos que o encerrem, de maneira a direcioná-lo a uma espécie jurídica ou outra.

Extremamente elucidativa se apresenta a sempre moderna obra do professor Orlando Gomes, em sua cristalina tese acerca da disciplina jurídica aplicável aos Contratos Atípicos, conforme restará a seguir demonstrado ${ }^{315}$. Ao conceber sua teoria, este contratualista discorre sobre a evolução histórica concernente às três correntes doutrinárias que versam sobre esta temática. No entanto, impõe-se registrar que o entendimento do professor baiano é de que há, de fato, regras aplicáveis aos contratos atípicos (sempre lembrando que é modalidade de contrato com a qual o contrato desta tese se identifica), concomitantemente em que são aplicados os princípios gerais do Direito Contratual.

Assim sendo, Orlando Gomes celebra três teorias que versam sobre o tema, quais sejam:

\footnotetext{
${ }^{315}$ GOMES, Orlando. Contratos, $12^{\mathrm{a}}$ edição, $3^{\mathrm{a}}$ tiragem. Rio de Janeiro: Ed. Forense. 1990. pp. 111-117.
} 
(i) teoria da combinação. Esta teoria admite que é possível retirar elementos do contrato, os isolando, para aplicar-lhes a respectiva disciplina legal. No entanto, há ríspidas críticas contra esta teoria, porquanto os elementos de um contrato, principalmente contratos atípicos, não são justapostos, mas, ao contrário, compenetrados e soldados uns aos outros. Desta forma, não é possível retirar elementos contratuais, sem que sua estrutura seja por isto abalada.

(ii) teoria da absorção. A segunda corrente doutrinária apresenta a chamada teoria da absorção. Esta teoria parte do pressuposto de que, em todo contrato misto, há um elemento preponderante ao qual se subordinam todos os outros, como se o elemento principal atraísse, absorvesse, os elementos secundários e cujas regras dos elementos principais fossem aplicadas aos elementos secundários. A grande falha apresentada nesta teoria, segundo o entendimento de Orlando Gomes, reside no fato de que, em um contrato atípico misto, não se pode falar em preponderância de elementos, mas sim de equivalência, o que impossibilitaria a absorção, conforme externado pela corrente acima.

(iii) teoria da aplicação analógica. Consoante melhor convencimento de Orlando Gomes, esta teoria é aquela que mais se aproximaria aos contratos atípicos, haja vista que tal teoria alicerça-se, fundamentalmente, na proximidade dos contratos atípicos com aqueles contratos típicos semelhantes. O problema, contudo, ocorre quando não há qualquer semelhança entre um contrato atípico formulado e qualquer outro contrato típico prescrito em lei. Assim, neste caso, aplicar-se-ão os princípios gerais de direito contratual, anteriormente ventilados na presente tese.

Após a apresentação, em síntese, das principais teorias que versam sobre a questão das regras aplicáveis aos contratos atípicos, Orlando Gomes converge para o entendimento a seguir reproduzido: 
pelas próprias partes. O problema simplifica-se, com efeito, pelo emprego correntio do princípio da autodisciplina dos contratos. Os estipulantes de um contrato atípico costumam regular mais explicitamente seus efeitos, porque sabem que inexistem regras supletivas de sua vontade. Além disso, os usos que vão se formando, se não adquirem, para logo, o valor de fonte normativa, auxiliam o intérprete e o aplicador do Direito”. 316 (grifou-se)

Faz-se relevante acrescentar, à luz dos elucidativos ensinamentos de Washington de Barros Monteiro $^{317}$, remetendo-se a Louis Josserand, que os operadores do direito, ao confeccionar, analisar e, eventualmente, julgar os instrumentos contratuais atípicos (não regulamentados ou insuficientemente disciplinados por lei), devem se alicerçar nos seguintes preceitos:

(i) Princípios Gerais. As cláusulas e preceitos gerais de direito contratual $^{318}$, hodiernamente insculpidos no novo diploma civil. Desta tese compartilha o professor Haroldo Verçosa, ao ministrar que o Direito Comercial é por todo permeado de contratos atípicos que podem ou não vir a se tornar contratos típicos, por força de legislações extravagantes. Ademais, ensina o eminente comercialista que os princípios gerais de direito, e aqui remetemo-nos aos princípios gerais de direito contratual, serão acionados naquelas relações jurídicas não antevistas pelo legislador. Por igual, embasando-se no artigo $4^{\circ}$ da Lei de Introdução ao Código Civil, entende que as leis civis são fontes subsidiárias do Direito Comercial, sobretudo quando da ausência de normas empresariais para disciplinar determinadas relações jurídicas de cunho empresarial;

(ii) Fiel Autonomia da Vontade. A vontade das partes contratantes tal qual manifestada, expressando, de maneira mais condizente com a realidade, o que de fato se intencionou com a celebração do instrumento jurídico e, por fim;

(iii) Contratos Análogos. As disposições aplicáveis aos contratos típicos, i.e., regulamentados por legislação civil ou extravagante, que maior analogia guardem com os

\footnotetext{
${ }^{316}$ GOMES, Orlando, op. cit. pág. 116.

${ }^{317}$ MONTEIRO. Washington de Barros. Curso de Direito Civil. Direito das Obrigações. 14 ${ }^{\mathrm{a}}$ ed. São Paulo. Ed. Saraiva. $1979.5^{\circ}$ vol. $2^{\mathrm{a}}$ parte. p. 30.

318 Cf. VERÇOSA, Haroldo Malheiros Duclerc. Curso de Direito Comercial. 2 $2^{\mathrm{a}}$ ed. São Paulo: Ed. Malheiros. 2008. pp. 61/65.
} 
contratos atípicos em composição. O saudoso mestre, professor Antônio Junqueira de Azevedo, ao estudar os contratos atípicos, adverte que esta espécie contratual "não é contrato típico, não estando diretamente submetido às regras específicas de nenhum modelo legal, e sim às regras gerais dos contratos - ao que, na dogmática jurídica, se denomina teoria geral dos contratos - e às regras cabíveis por analogia”,319.

Este fundado posicionamento encontra guarida também na jurisprudência nacional, a qual se inclina à tese de que os contratos atípicos ( e portanto, os contratos de licenca de uso de marca) devem ser contemplados: pela disciplina legal dos contratos análogos; de conformidade com os princípios gerais do direito contratual e, também, pela livre apreciação do juiz $^{320}$.

É irretorquível, portanto, o caráter detalhista e minucioso que deve ser atribuído aos contratos atípicos. Vale lembrar que, na prática, é muito pouco provável que os operadores do direito sejam capazes de conjeturar, com precisão e plenitude, todas as cláusulas representativas de um negócio jurídico, precipuamente em um contrato atípico.

Contudo, é imperioso afirmar que quanto mais lacunoso for um contrato empresarial atípico, maiores serão as chances de advirem litígios judiciais (que recaiam sobre aqueles contratos lacunosos). Destarte, os efeitos deletérios de um contrato lacunoso que possa possivelmente dar ensejo a litígios judiciais, estender-se-ão não somente aos agentes contratuais, que terão de esperar por longos anos para terem seus direitos tutelados pelo Estado, como igualmente a todo o tecido econômico.

\footnotetext{
${ }^{319}$ AZEVEDO, Antônio Junqueira de. Novos Estudos e Pareceres de Direito Privado. São Paulo: Saraiva, 2009. p. 139.

${ }^{320}$ Foi acórdão pioneiro, sobre este tema, aquele cujo relator era o eminente Min. José Carlos Moreira Alves, então ministro do Supremo Tribunal Federal (Cf. RE 811.052/SP, 2 ${ }^{\text {a }}$ Turma. J. 17 out. 1975). Colacione-se, por igual, trecho elucidativo de ementa extraída de julgado proferido pelo Superior Tribunal de Justiça. "Direito Privado. Concessão de Revenda com Exclusividade. Resolução unilateral. Reponsabilidade Indenizatória. Contratos Atípicos. Princípios gerais do direito obrigacional e contratual. Recurso não conhecido. Consoante a doutrina, os contratos atípicos devem ser apreciados não apenas pela disciplina legal dos contratos afins, mas: primeiro, pela analogia; segundo, de acordo com os princípios gerais do direito obrigacional de contratual; terceiro, pela livre apreciação do juiz." (REsp 5680/SC, Rel. Ministro SÁLVIO DE FIGUEIREDO TEIXEIRA, QUARTA TURMA, julgado em 13/11/1990, DJ 10/12/1990, p. 14812).
} 
Com o desígnio de consolidar a tese acima externada, registrem-se os pensamentos de Caio Mário da Silva Pereira ${ }^{321}$, ao assinalar que o patrocínio de um contrato atípico exige das partes contratantes o zelo de descerem pormenores acentuados, porque na sua disciplina legal falta a sua regulamentação específica. Na solução de eventuais demandas, resultantes deste contexto, o julgador ou intérprete terá de invocar, em auxílio do conteúdo das cláusulas próprias, os regramentos relativos ao contrato típico mais próximo, e isto nem sempre é trabalho fácil, porque a ocupação de "zona grísea", entre mais de um, sugere às vezes aproximações várias, nenhuma das quais dotadas de pura limpidez.

Assinale-se, por igual, lição de Álvaro Villaça Azevedo ${ }^{322}$, que define o contrato atípico como um contrato livre, onde a liberdade de contratar deva ser exercida nos limites da lei, certo de que este livre arbítrio "há que condicionar-se, emoldurando-se na lei, para ser liberdade condicionada, não ser liberdade escravidão, instrumento dos que atuam de má-fé, em detrimento da própria sociedade".

Alicerçando-se na teoria concebida por Orlando Gomes e no legado deixado por Washington de Barros Monteiro, com lastro na melhor doutrina de Louis Josserand, bem como na tendência jurisprudencial pátria moderna, acima externados, o contrato de licença de uso de marca, o qual rotulamos como contrato atípico misto, submeter-se-á ao seguinte regime jurídico:

(i) Princípios Gerais de Direito Contratual. As cláusulas e preceitos gerais de direito contratual, atualmente consagrados pelo Código Civil vigente, conforme restará adiante demonstrado. Desta sorte, conforme serão analisados no capítulo subseqüente, incidirão sobre o contrato de direito industrial em exame os elementos essenciais informadores da teoria geral dos contratos (capacidade das partes; objeto possível, lícito, determinado e determinável; forma prescrita e não defesa em lei etc.), bem como os princípios sociais norteadores das relações obrigacionais, como, por exemplo, princípio da função social do contrato, princípio da boa-fé objetiva, princípio do pacta sunt servanda, princípio da vedação da onerosidade excessiva, dentre outros.

\footnotetext{
${ }^{321}$ PEREIRA, Caio Mário da Silva, Instituições de Direito Civil - Contratos, vol. III, p. 61, 12 $2^{\mathrm{a}}$ ed., Ed. Forense, Rio de Janeiro, 2005.

${ }^{322}$ AZEVEDO, Álvaro Villaça de, ob. cit. p.142.
} 


\section{(ii) Elementos típicos extraídos do diploma que regula a propriedade} industrial e de ato normativo correspondente. Consoante examinado anteriormente, o contrato de licença de uso de marca é laconica e insuficientemente diciplinado pela Lei 9.279/96 (Lei da Propriedade Industrial), podendo-se afirmar, inclusive, que praticamente não há regulamentação expressa que incida sobre esta éspecie contratual, havendo somente a proclamação de breves diretrizes e concisas permissões das quais pode se valer o titular do registro. Desta feita, a lei em comento, em seu artigo 139 e parágrafo - único artigo que versa sobre o contrato objeto desta tese - apenas autoriza o titular ou depositante do pedido a celebrar o contrato em estudo, podendo, por igual, exercer controle efetivo sobre as esepcificações, natureza e qualidade dos respectivos produtos ou serviços. Permite também, se o licenciante assim autorizar, que o licenciado seja investido dos poderes para agir em defesa da marca. Este diploma não se inclina, portanto, à regulamentação desta espécie contratual. $\mathrm{O}$ ato normativo INPI n. $^{\circ}$ 135/97, (I), 3, também de forma extremamente abreviada e precária, sinaliza que o contrato de licença de direito (incluindose o de uso de marca), para que seja efetuado seu registro perante o INPI, indique, declaradamente: seu objeto, a remuneração ou os "royalties", os prazos de vigência e de execução do contrato, quando for o caso, e as demais cláusulas e condições da contratação.

(iii) Contratos análogos. Sobre o contrato de licença de uso de marca, embasando-se na bem fundamentada teoria da aplicação analógica, incidirão as regras e disposições normativas aplicáveis àqueles contratos típicos, i.e., regulamentados pela legislação civil ou extravagante, que maior analogia guardem com esta espécie contratual. Com efeito, conforme posição doutrinária dominante, adiante demonstrada, os contratos mais "próximos" do contrato objeto central da presente tese, são: o contrato de locação de coisas (para os contratos de licença de uso de marca remunerado), cujo regramento encontra-se compreendido entre os artigo 568 e 578 do diploma civil vigente; e o contrato de comodato (para os contratos de licença de uso de marca não remunerado), cujos dispositivos encontram-se inseridos entre os artigos 579 e 585 do Código Civil Brasileiro. 
Asin Singh e Julie le Bars ${ }^{323}$ prelecionam que o Código Civil francês irradia efeitos sobre o contrato de licença de uso de marca. No ordenamento jurídico francês, o contrato de licença pode se valer das regras aplicáveis aos contratos de locação de bens, contrato este considerado como o mais próximo, e portanto, análogo, ao contrato sub examine. Com efeito, grande parte dos direitos e obrigações, tanto do licenciador, como do licenciado, decorre de normas aplicáveis à locação de bens móveis.

Luís M. Couto Gonçalves, ao estudar o contrato de licença de marca no direito lusitano, sinaliza para sua natureza manifestamente obrigacional. O jurista português submete este negócio jurídico ao regime do direito das obrigações e indica como regramento subsidiário ao Código de Propriedade Industrial português (CPI) o disciplinamento regulamentador do contrato de locação $o^{324}$ (que se encontra consignado no Código Civil português).

O sistema brasileiro segue os modelos francês e português, especialmente ao eleger o contrato de locação de coisas como o contrato análogo ao contrato de licença de uso de marca. A primeira evidência que conduz a doutrina a afirmar de que o contrato de locação é considerado "contrato referência" do contrato de licença em exame repousa no artigo $5^{\circ}$ da Lei 9.279/96, ao indicar que, para os efeitos legais, os direitos de propriedade industrial são considerados bem móveis.

Gama Cerqueira (remetendo-se a Ramella, Allart e Pouillet) ${ }^{325}$, Yves Plasseraud ${ }^{326}$, Luiz Guilherme de A.V. Loureiro ${ }^{327}$, Paul Roubier ${ }^{328}$, Luiz Leonardos ${ }^{329}$, dentre outros,

\footnotetext{
${ }^{323}$ Asim Singh é advogado militante na área da propriedade intelectual e sócio do escritório de advocacia, em Paris, "Sokolow, Carreras \& Associés". Julie le Bars é sócio do escritório "Nataf, Fajgenbaum \& Associes". Ambos escreveram o capítulo 15 - A French Law View of Trade Mark Licensing da obra "Trademark Licensing”. in WILKOF, Neil e BURKITT, Daniel. Trademark Licensing. $2^{\mathrm{a}}$ ed. Londres. Ed. Thomson, Sweet \& Maxwell, 2005. p. 270 e ss.

${ }^{324}$ GONÇALVES, Luís M. Couto. Manual de Direito Industrial: Patentes, Marcas, Concorrência Desleal. $2^{a}$ ed. rev. e aumentada. Coimbra: Almedina. 2008. pp. 359-361

${ }^{325}$ Idem. Ibidem. p. 438.

326 “Regime Juridique - le contrat de license de marque s'analyse comme um "contrat de loug” soumis au droit commun at regi par les articles 1709 et suivants du Code civil” (Yves PLASSERAUD. Martine DEHAUT e Claude PLASSERAUD. Marques. Creation, valorisation e protection. op. cit. p. 161)

${ }^{327}$ LOUREIRO, Luiz Guilherme de A.V. Loureiro. A Lei de Propriedade Industrial Comentada. Lei $n^{\circ}$ 9.279 de 14 de maio de 1996). São Paulo. Lejus. 1999. p. 274 e ss.
} 
elegem o contrato de locação de bens móveis (intitulado no Código Civil como locação de coisas) o instrumento de referência e analogia com fulcro no qual os contratos de licença de uso de marca remunerados serão confeccionados.

Luiz Guilherme Loureiro, ao comparar o contrato de licença com o contrato de locação de coisas, traz à colação importante distinção entre o contrato objeto deste estudo e o contrato de representação ou agenciamento, instrumento este tipificado pelo Código Civil. Consoante leitura feita pelo comercialista, no contrato de representação, o titular autoriza terceiro a vender produtos com a sua marca. Impõe-se registrar que, no contrato de representação ${ }^{330}$, os produtos são fabricados ou os serviços são prestados pelo titular da marca. Por seu turno, no licenciamento, a marca é licenciada pelo titular para que esta seja aposta nos produto ou serviços que serão produzidos e oferecidos pelo licenciado, e não pelo licenciador.

Contrario sensu, na possibilidade de a licença ser concedida a título gratuito, igualmente aproveitando-nos da teoria da aplicação analógica, o contrato socorrer-se-á dos dispositivos previstos no contrato de comodato $^{331}$, cujos comandos encontram-se insculpidos no Diploma Civil vigente.

Neste sentido, impõe-se transcrever valioso ensinamento externado por Sílvio de Salvo Venosa ${ }^{332}$, ao asseverar, com notável propriedade: “os bens incorpóreos, suscetíveis de uso e posse, como o direito autoral, a patente de invenção, o nome ou marca comercial, a linha telefônica e outros, também podem ser dados em comodato". (grifou-se)

\footnotetext{
${ }^{328}$ ROUBIER, Paul. Le Droit de la Propriété Industrielle. ob. cit. pp. 285-286.

${ }^{329}$ LEONARDOS, Luiz. O Contrato de Licença para Exploração de Privilégio de Invenção e para o Uso de Marca - Tentativa de Análise Jurídica. op. cit. p. 44.

${ }^{330}$ Os contratos de agência ou distribuição foram tipificados com o advento do novo diploma civil, cujo artigo 710 prescreve que: "pelo contrato de agência, uma pessoa assume, em caráter não eventual e sem vínculos de dependência, a obrigação de promover, à conta de outra, mediante retribuição, a realização de certos negócios, em zona determinada, caracterizando-se a distribuição quando o agente tiver à sua disposição a coisa a ser negociada." Ressalte-se que tanto a coisa quanto a marca a esta aposta são de inteiro domínio de seu titular, não tendo, em nenhum momento, o distribuidor direito sobre aquela marca.
}

${ }^{331}$ Cf. FIGUEIREDO, Paulo Roberto, A Propriedade Industrial, 1978, p. 123. apud LEONARDOS, Gabriel Francisco. Tributação da Transferência de Tecnologia. Rio de Janeiro: Forense, 2001. pp. 88-89.

${ }^{332}$ VENOSA, Sílvio de Salvo.Direito Civil, Contratos em Espécie, $7^{\mathrm{a}}$ ed., São Paulo: Ed. Atlas. 2007. vol. 3. p. 170. 
Precisa é a lição extraída da obra de Gabriel Francisco Leonardos ${ }^{333}$, ao abordar o aproveitamento de regras insculpidas no diploma civil nos contratos de licença de uso de marca, sejam estes celebrados a título oneroso ou gratuito:

(...) Tal contrato [licença de uso de marca] pode ser caracterizado, se oneroso, como um contrato de locação de bem móvel, regido, como tal, pelos arts. 1.188 a 1.199 [correspondentes aos arts. 565 ao art. 578 do Código Civil de 2002], ou, se gratuito, como um contrato de comodato, sujeito aos arts. 1.248 a 1.255 [correspondentes aos arts. 579 ao art. 585 do Código Civil de 2002] do Código Civil. Naturalmente, tais dispositivos do Código Civil são aplicáveis apenas quando não forem incompatíveis com as regras especiais previstas no Código de Propriedade Industrial. (grifou-se)

Portanto, assim como se opera a sobreposição do contrato de locação de bens móveis ao contrato de licença de marca remunerado, naqueles contratos em que a marca for licenciada, a título gratuito, aplicar-se-á, além da lei marcária naquilo que lhe for pertinente, em caráter análogo, o Contrato de Comodato ${ }^{334}$, cujos dispositivos encontramse compreendidos entre os artigos 579 e 585 do Código Civil. Impõe-se salientar que as regras contidas no "novo" Código Civil, em relação ao comodato, acompanham, quase que integralmente, as diretrizes antes existentes no Código Civil de $1916^{335}$.

(iv) Fiel Autonomia da Vontade. Por igual, e não menos importante, o contrato de licença celebrado no âmbito marcário será disciplinado, em meio a elementos emprestados de outras espécies contratuais regulamentadas (elementos típicos), pela vontade das partes contratantes, tal qual manifestada, expressando, de maneira mais condizente com a realidade, o que de fato se intencionou com a celebração do instrumento jurídico.

O regime da fiel autonomia da vontade, onde as partes contratantes livremente pactuam o que melhor lhes aprouver, naturalmente nos limites das balizas legais

\footnotetext{
${ }^{333}$ LEONARDOS, Gabriel Francisco. Tributação da Transferência de Tecnologia. Rio de Janeiro: Forense, 2001. p. 90.

${ }^{334}$ Consoante dispõe o art. 579 do Código Civil, o comodato se apresenta como contrato de empréstimo gratuito de coisas não fungíveis.

${ }^{335}$ WALD, Arnoldo. Direito Civil: contratos em espécie; vol. 3. $18^{\text {a }}$ ed. São Paulo: Saraiva, 2009. p. 190.
} 
(diretrizes, cláusulas gerais e princípios sociais informadores dos contratos), é o que remete este tipo de contrato atípico à categoria de contrato atípico misto. Isto porque as partes convencionarão condições não mencionadas em lei, confeccionando, como decorrência, cláusulas consideradas atípicas, ou seja, não regulamentadas por qualquer código ou legislação extravagante inserido no ordenamento jurídico vigente.

Por tal razão, afirma-se que o contrato de licença de uso de marca consubstancia verdadeiro contrato atípico misto: porque formado por elementos típicos (elemento extraídos da lei que regula a propriedade industrial e de contratos típicos análogos) e elementos atípicos (livremente regulamentados pelas partes - dentro das balizas legais não encontrando menção ou disciplinamento no sistema legal vigente, como decorrência de sua atipicidade) $)^{336}$.

\section{V.3 PRINCÍPIOS GERAIS DE DIREITO CONTRATUAL INCIDENTES SOBRE O CONTRATO DE LICENÇA DE USO DE MARCA}

Com o advento do Código Civil vigente, a derrogação do Código Comercial, no que tange à sua parte primeira e, por via de conseqüência, com a unificação do direito obrigacional (e contratual), os princípios gerais de direito contratual passaram a incidir, de modo decisivo, sobre os contratos civis e empresariais. Desta sorte, o presente capítulo trará à colação conceitos capitais de cada um dos principais princípios sociais informadores do Código Civil que recaem diretamente sobre o contrato de licença de uso de marca (verdadeiro contrato empresarial atípico misto, conforme acima demonstrado).

Após, quando da análise pormenorizada dos elementos, condições e cláusulas que integram o contrato em estudo, examinar-se-á a aplicação pontual e concreta dos princípios gerais adiante apresentados à espécie contratual objeto da presente tese.

\footnotetext{
${ }^{336}$ Cf. AZEVEDO, Álvaro Villaça. Teoria geral dos contratos típicos e atípicos. São Paulo: Atlas, 2002. p.
} 138. 
Impende-se repisar, inicialmente, que o que difere essencialmente um contrato civil de um contrato empresarial são as partes envolvidas na relação jurídica, em um primeiro plano, e a atividade praticada, objeto do contrato, em um segundo plano. De tal sorte, se as partes contratantes forem empresárias, e a atividade regulada for empresária ${ }^{337}$, será o contrato empresarial. Se forem civis, e a atividade regulada for civil, será o contrato civil. Certamente, há regras particulares para cada tipo de contrato. No entanto, e o que será de grande valia para a presente tese, serão os princípios gerais ou regras de interpretação ${ }^{338}$ do direito contratual que irradiarão efeitos, tantos nos contratos civis, como nos empresariais, rol este no qual se encontra inserido o contrato de licença de uso de marca.

Consoante lição de Waldírio Bulgarelli ${ }^{339}$, a unificação do direito das obrigações em um único código (Código Civil), ainda que esvazie, de certa forma o Direito Comercial, induz à formação de princípios gerais contratuais perfeitamente aplicáveis aos contratos empresariais.

Bulgarelli assevera que são características importantes direcionadas pelo direito contratual, então consagradas pelo Código Civil vigente: (i) informalidade: com vista a dar maior celeridade aos negócios empresariais, o Código Civil se manifesta acerca da importância que deve ser dada à aparência e boa-fé nos contratos em relação à disposição literal das cláusulas contratuais; (ii) uniformização de procedimentos: os procedimentos e normas civis acabam por uniformizar as operações empresariais, nos âmbitos nacional e internacional.

\footnotetext{
${ }^{337}$ Novamente, convém reiterar o entendimento no sentido de que o diploma civil veio a consagrar a "teoria da empresa" em detrimento da "teoria dos atos de comércio", de tal sorte que ao nos remetermos às atividades empresárias, nos referimos à forma da exploração da atividade, i.e., se a atividade, à guisa do artigo 966 do Código Civil de 2002, tem fins de lucro e é praticada de forma organizada para a produção e circulação de bens ou serviços, será vitalmente considerada empresária, sendo o contrato, por conseguinte, considerado empresário. Contrario sensu, sendo a atividade de natureza civil, será o contrato classificado como contrato civil.

${ }^{338} \mathrm{O}$ termo regras de interpretação como sendo diretrizes dos contratos civis e empresariais é utilizado por Waldírio Bulgarelli, ao assinalar as inovações trazidas pelo Código Civil vigente, no âmbito do direito obrigacional, em que, segundo escólio do jurista, se sobressai a função social do contrato, probidade e boa-fé objetiva. (BULGARELLI, Waldírio. Tratado de Direito Empresarial. $3^{\text {a }}$ ed. São Paulo. Ed. Atlas S.A. 1997. pp. 213/214).
}

${ }^{339}$ BULGARELLI, Waldírio. Contratos Mercantis. $14^{\mathrm{a}}$ ed. São Paulo. Atlas. 2001, pp. 46-56. 
Os princípios contratuais aplicáveis aos contratos civis e empresariais, e, portanto, aos contratos de licença de uso de marca, podem ser verificados ao longo das disposições normativas constantes do Diploma Civil vigente. Os principais princípios estão compreendidos entre os artigos 421 e 426 do Código Civil. Assim vejamos aqueles princípios de maior importância e que devem ser constantemente aplicados quando da formatação e conclusão do contrato empresarial sub examine:

(i) Princípio da Autonomia da Vontade ${ }^{340}$. O licenciante e o licenciado, partes contratantes no contrato de licença, devem dispor de ampla, ainda que não seja ilimitada, liberdade para contratar e formular as cláusulas contratuais que constituirão o contrato de licença de uso de marca. As normas cogentes deverão, contudo, ser respeitadas. Assim sendo, o legislador civil, ao prever tal princípio contratual, o fez moderadamente, utilizando-se de outro princípio, mencionado no item (ii) abaixo, e que tem por escopo a delimitação da autonomia da vontade, de tal sorte que terceiros e o tecido social, como um todo, não sejam lesados.

(ii) Princípio da Supremacia da Ordem Pública. Este princípio contratual determina que a autonomia da vontade não poderá se confrontar com os ditames insculpidos na lei positivada, a moral, os usos e costumes. Os elementos retro citados devem acompanhar a autonomia privada, determinando, por conseguinte, as fronteiras da liberdade contratual.

Consoante magistério de Álvaro Villaça Azevedo ${ }^{341}$, o contrato de licença de uso de marca, considerado contrato atípico misto, muito embora possa ser livremente delineado pelas partes contratantes, deve respeitar os ditames legais, não podendo se sobrepor aos princípios e normas cogentes que permeiam o sistema jurídico vigente ${ }^{342}$, sob pena de

\footnotetext{
${ }^{340}$ Cf. Art. 421 do Código Civil: "A liberdade de contratar será exercida em razão e nos limites da função social do contrato".

${ }^{341}$ AZEVEDO, Álvaro Villaça, ob. cit. p. 144

${ }^{342}$ Registre-se acórdão emitido pelo extinto $2^{\circ}$ Tribunal de Alçada Cível, hoje Tribunal de Justiça do Estado de São Paulo: “As disposições legais invocadas pelo embargante não infirmam o acórdão, porque o negócio jurídico não se rege apenas pela vontade das partes, mas também pelas normas de ordem pública, entre as quais a que confere o direito à revisão contratual" (extinto $2^{\circ}$ TACivSP, $10^{\mathrm{a}}$ Câmara de Direito Privado. EDcl 653999 - 1/7, rel. Nestor Duarte, v.u., j. 22/10/2003).
} 
haver intervenção estatal, por intermédio do Poder Judiciário. Com efeito, propugna, textualmente, o mencionado jurista:

O acanhamento de nossa legislação, no campo dos contratos típicos e atípicos, choca ante a intensidade da liberdade privada, que se nos coloca pela frente no âmbito contratual.

É verdade que a convenção faz lei entre as partes, mas a própria lei há que conter os limites dessa livre estipulação privada no sistema contratual, para que não fique esse sistema ao arbítrio das convenções, sem a indispensável intervenção do Estado, para diminuir, cada vez mais, os abusos, a fim de que, assim, se realize o fim do Direito, que é a Justiça, depois da Ordem e Segurança sociais. (grifou-se)

(iii) Obrigatoriedade do Contrato. De acordo com este princípio, o contrato de licença de uso de marca corrobora lei entre as partes. As cláusulas contratuais devem, portanto, ser obedecidas, sendo que o descumprimento dará ensejo a indenizações e ações judiciais movidas pela parte inocente contra a parte culpada. É o chamado "pacta sunt servanda" (os pactos devem ser respeitados).

Washington de Barros Monteiro ${ }^{343}$ avaliza o entendimento que as partes devem cumprir "fielmente" aquilo que fora entre elas pactuado, sob pena de a parte inadimplente sofrer execução patrimonial no valor que deveria adimplir, mas não o fez. De Plácido e Silva ${ }^{344}$ converge para o mesmo ideal no que pertine ao princípio da força obrigatória dos contratos.

O mestre Orlando Gomes ${ }^{345}$ define o princípio em apreço, assinalando que "estipulado validamente seu conteúdo, vale dizer, definidos os direitos e obrigações de cada parte, as respectivas cláusulas têm, para os contratantes, força obrigatória".

\footnotetext{
${ }^{343}$ MONTEIRO. Washington de Barros. Curso de Direito Civil: Direito das Obrigações - 2. ${ }^{\text {a }}$ parte. $27^{\mathrm{a}}$ ed. São Paulo, Saraiva. 1994. v. 5. p. 9.
${ }^{344}$ Segundo os ensinamentos corroborados por De Plácido e Silva, a partir do momento em que o contrato passe a irradiar efeitos no mundo jurídico, as partes, devem, necessariamente, se manter "obedientes" às cláusulas em contrato estipuladas. Somente assim o contrato será pontualmente cumprido. (SILVA, De Plácido. Vocabulário Jurídico. 14. ed. Rio de Janeiro: Forense, 1998. p. 569).

${ }^{345}$ GOMES, Orlando. Contratos. 17. ed. Rio de Janeiro: Forense, 1997. p. 36. 
Os tribunais pátrios, com recorrência, pronunciam-se a respeito do princípio sob análise. Com efeito, as cortes nacionais têm firmado entendimento no sentido de que, nos contratos privados (como é o caso do contrato em análise), devem ser observados, de forma concatenada, os princípios da autonomia da vontade, da supremacia da ordem pública e da obrigatoriedade do contrato, de tal sorte que a negligência de um dos contratantes em adimplir o que dele esperado, gerará à outra parte o direito de rescindir o contrato e pleitear os danos decorrentes da inadimplência encetada pelo contratante insolvente ${ }^{346}$.

(iv) Princípio da Intangibilidade dos Contratos. Segundo este princípio, que guarda intrínseca relação com o princípio da obrigatoriedade, o contrato de licença de uso de marca, uma vez formado e subscrito entre licenciante e licenciado, não poderá ser alterado unilateralmente.

Quanto à imutabilidade do contrato, Orlando Gomes ${ }^{347}$ afiança que o conteúdo do contrato não é passível de modificação judicial. Os mencionados juristas advogam a tese de que a modificação do conteúdo do contrato, gerada pelas vias judiciais, somente poderá ocorrer para a decretação da nulidade, resolução do instrumento ou ainda por motivo outro previsto em lei, porém jamais com o fito de alterar a matéria consentida e consignada em contrato com fulcro no princípio da livre autonomia da vontade.

Resta, pois, demonstrado que o contrato de licença de uso de marca tem alicerçe no princípio da força vinculante dos contratos ou pacta sunt servanda. Por esta diretriz, prescreve-se, com incontestável clareza, que licenciante (titular da marca) e licenciado

\footnotetext{
${ }^{346}$ Vale registrar o julgado a seguir colacionado, o qual, com meridiana, clareza estampa a essencialidade de alguns dos princípios basilares do direito contratual abaixo, cuja ementa prescreve, in verbis: "Ação de Cobrança Civil. Obrigações. Contrato de Prestação de Serviços. Diferença de Pagamentos. Adicional de periculosidade. Ação improcedente. Nos contratos privados vigem os princípios da autonomia da vontade, da supremacia da ordem pública e a obrigatoriedade do contrato ou da pacta sunt servanda. $O$ descumprimento contratual gera, para o inadimplente, a obrigação de reparar o dano causado e, para o prejudicado, o direito de rescindir a avença configurado o cumprimento contratual, nada há o que indenizar, tratando-se de forma normal de sua extinção (...)(grifou-se) (in Apelação Cível № 597146372, Terceira Câmara Cível, Tribunal de Justiça do RS, Relator: Luiz Ari Azambuja Ramos, Julgado em 30/10/1997. Disponível em <http://www.tj.rs.gov.br/site_php/jprud2/ementa.php> Acesso em 20/11/2008).

${ }^{347}$ Ao sopesar o princípio da obrigatoriedade dos contratos cotejado com o princípio da força vinculante dos contratos, leciona Orlando Gomes: "se ocorrem motivos que justificam a intervenção judicial em lei permitida, há de realizar-se para decretação da nulidade ou da resolução do contrato, nunca para a modificação do seu conteúdo". (GOMES, Orlando. Contratos. 17. ed. Rio de Janeiro: Forense, 1997. p. 36).
} 
(receptor do direito de uso de marca), devem, necessariamente, ser submetidos às cláusulas e preceitos contratuais por eles consentidos. Ademais, os dispositivos pactuados não são passíveis de alteração unilateral ou mesmo estatal, a não ser que para a declaração de nulidade, resolução ou motivo outro com amplo respaldo no arcabouço legal.

(v) Probidade e Boa Fé Objetiva. Celebra o artigo 422 do Código Civil ${ }^{348}$ que "os contratantes são obrigados a guardar, assim na conclusão do contrato, como em sua execução, os princípios de probidade ${ }^{349}$ e boa-fé".

Por este princípio, licenciante e licenciado, ao contratarem, devem agir com boa fé, no pré-contrato, no contrato e no pós-contrato. Conforme asseguram, em caráter dominante, a doutrina e a jurisprudência, agir com boa fé significa agir com lealdade, sem a intenção de ludibriar a parte contrária, ser transparente quanto àquelas informações que estão e aquelas que não estão expressas em contrato.

A boa-fé objetiva coincide com a regra de conduta padrão adotada e reconhecida pela sociedade, esperada de um homem correto, honesto e leal ${ }^{350}$. Não verificada a boa-fé objetiva, o magistrado, como já vem sendo correntemente sentenciado, poderá desconsiderar certas cláusulas ou até mesmo todo o contrato, ainda que nele contenha cláusulas contratuais contrárias a esta decisão judicial.

A legislação civil, além de ter feito referência expressa ao instituto da boa-fé objetiva, o fez de modo abrangente, de tal sorte que o espírito da boa-fé deve estar naturalmente imbuído nas partes contratantes ${ }^{351}$, inclusive nas tratativas preliminares que

\footnotetext{
${ }^{348}$ A boa-fé é igualmente mencionada no art. Art. 113 do CC que prescreve, ipsis literis, que "os negócios jurídicos devem ser interpretados conforme a boa-fé e os usos do lugar de sua celebração".

${ }^{349}$ Ressalte-se a natureza jurídica atribuída pelos civilistas à probidade, conforme pode ser depreendido do enunciado extraído da Jornada IV STJ 363, que assinala "os princípios da probidade e da confiança são de ordem pública, estando a parte lesada somente obrigada a demonstrar a existência da violação". Disponível em <http://www.tj.rj.gov.br/cedes/enunciados_jornada_direito_civil.htm>. Acesso em 30/11/2008.

${ }^{350}$ Nos dizeres do prof. Venosa: "A boa-fé objetiva, por outro lado, tem compreensão diversa. O intérprete parte de um padrão de conduta comum, do homem médio, naquele caso concreto, levando em consideração os aspectos sociais envolvidos. Desse modo, a boa-fé objetiva se traduz de forma mais perceptível com uma regra de conduta, um dever de agir de acordo com determinados padrões sociais estabelecidos e reconhecidos”. (VENOSA, Sílvio de Salvo.Direito Civil, Teoria Geral das Obrigações e Teoria Geral dos Contratos, $7^{\text {a }}$ ed., São Paulo: Ed. Atlas. 2007. vol. 2. p. 347).

${ }^{351}$ Nelson Nery Junior e Rosa Maria de Andrade Nery assinalam que a boa-fé deve ser presumida (presunção
} 
antecederem à celebração do contrato de licença de uso de marca. Enraizada em tal assertiva, a Colenda Corte Superior pacificou entendimento de que a boa-fé objetiva deve ser observada, por igual, na fase das tratativas preliminares, logo quando da confecção das primeiras minutas contratuais que antecederem à assinatura do contrato principal ${ }^{352}$.

Adicionalmente, consoante ilação extraída dos ensinamentos de Giselda Hironaka $^{353}$ e Álvaro Villaça Azevedo ${ }^{354}$, a boa-fé objetiva deve ser igualmente observada após o termo final consignado no instrumento contratual ${ }^{355}$.

Imprescindível esclarecer que a boa-fé objetiva, tema correntemente discorrido pela doutrina moderna dominante, não é um tema novel na legislação estrangeira.

O instituto sob análise já fora recepcionado pelas legislações civis de ordenamentos jurídicos estrangeiros que, decerto, exercem profunda influência na construção e constante mutação do ordenamento nacional.

júris tantum), de tal sorte que aquele que alegar a má-fé da parte contrária deverá fazer a comprovação de tal alegação. (cf. JÚNIOR, Nelson Nery e NERY, Rosa Maria de Andrade. Código Civil Comentado. $6^{a}$ ed. São Paulo. Ed. Revista dos Tribunais. 2008. p. 513).

${ }^{352}$ Desta feita, prescreve a ementa do julgado em comento, in verbis: "a minuta contratual já integra uma fase da relação obrigacional, vista esta como um processo que se inicia nas tratativas preliminares e se estende até para depois de cumprido o contrato, no ensino de Clóvis do Couto e Silva". (in Superior Tribunal de Justiça, $4^{\text {a }}$ Turma, REsp n. ${ }^{\circ}$ 300129-RJ, rel. Min. Ruy Rosado de Aguiar, v.u., j. 04/09/2001. DJU 29/10/2001. Disponível em <www.stj.gov.br>. Acesso em 28/11/2008).

${ }^{353}$ Para Giselda Hironaka, “a boa-fé objetiva é, indubitavelmente, a mais célebre dos princípios contratuais positivados pelo novo código civil. A boa-fé sempre deve estar presente nas negociações que antecedem a conclusão do negócio, na sua execução, na produção continuada de seus efeitos, na conclusão e na sua interpretação e deve prolongar-se até mesmo para depois de concluído o negócio contratual, se necessário”. (HIRONAKA, Giselda, in Novo Código Civil brasileiro - o que muda na vida do cidadão. Seminário realizado na Câmara dos Deputados em 04/06/02. Disponível em <www2.camara.gov.br/conheça/ouvidoria/seminários/1partecodigocivil.html>. Acesso em 30 nov. 2009.

354 Pragmaticamente, ao discorrer sobre a boa-fé objetiva no pós-contrato, Villaça esclarece que "após a extinção do contrato, existem também deveres, que devem ser respeitados pelos contratantes, como, por exemplo, o dever de não divulgar informações sigilosas de que tomem conhecimento, segredos profissionais, de fabricação de produtos, fórmulas secretas e que devam manter-se sob reserva. Qualquer divulgação desses e de outros fatos, por um dos contratantes, pode causar sérios prejuízos ao outro" (VILLAÇA, Álvaro. $O$ Novo Código Civil Brasileiro: tramitação; função social do contrato; boa-fé objetiva; teoria da imprevisão e, em especial, onerosidade excessiva (laesio enormis). in DELGADO, Mário Luiz e ALVES, Jones Figueiredo (Coord.). Questões Controvertidas no Novo Código Civil. Vol.2. Ed. Método.São Paulo 2004. p. 15.) 
Dentre as legislações civis estrangeiras que proclamaram mencionado instituto, merecem destaque ${ }^{356}$ :

(a) o Código Civil Alemão (BGB), que prescreve em seu artigo 242 que "o devedor está obrigado a executar a prestação como exige a boa-fé, em atenção aos usos e costumes";

(b) o Código Civil Italiano de 1942, que reza em seu artigo 1.337, que os contratantes devem "comportar-se segundo a boa-fé no desenvolvimento das tratativas e formação dos contratos".

(c) o Código Civil Português de 1967, que preceitua que "quem negocia com outrem para conclusão de um contrato deve, tanto nas preliminares, como na formação dele, proceder segundo as regras da boa-fé, sob pena de responder pelos danos que culposamente causar à outra parte".

O próprio ordenamento jurídico brasileiro, muito embora não houvesse recepcionado o princípio da boa-fé objetiva na legislação civil, houvera feito por intermédio de legislação extravagante, a exemplo do Código de Defesa do Consumidor ${ }^{357}$.

Portanto, esta figura, antes mesmo de sua positivação pelo atual Diploma Civil, já havia sido absorvida pela legislação e jurisprudência pátrias, seja em relação aos contratos típicos, como em relação aos contratos atípicos (classe na qual se inserem os contratos de licença de uso de marca).

\footnotetext{
${ }^{356}$ AZEVEDO, Álvaro Villaça. O Novo Código Civil Brasileiro: tramitação; função social do contrato; boafé objetiva; teoria da imprevisão e, em especial, onerosidade excessiva (laesio enormis). ob. cit. p. 15.

${ }^{357}$ Prescreve o art. $4^{\circ}$, inciso III c/c art. 51, do Diploma Consumerista, instituído pela Lei 8.078/90, ipsis literis :"Art. 4 A Política Nacional das Relações de Consumo tem por objetivo o atendimento das necessidades dos consumidores, o respeito à sua dignidade, saúde e segurança, a proteção de seus interesses econômicos, a melhoria da sua qualidade de vida, bem como a transparência e harmonia das relações de consumo, atendidos os seguintes princípios: (.....) "III - harmonização dos interesses dos participantes das relações de consumo e compatibilização da proteção do consumidor com a necessidade de desenvolvimento econômico e tecnológico, de modo a viabilizar os princípios nos quais se funda a ordem econômica (art. 170, da Constituição Federal), sempre com base na boa-fé e equilíbrio nas relações entre consumidores e fornecedores". "Art. 51. São nulas de pleno direito, entre outras, as cláusulas contratuais relativas ao fornecimento de produtos e serviços que: (...) IV - estabeleçam obrigações consideradas iníquas, abusivas, que coloquem o consumidor em desvantagem exagerada, ou sejam incompatíveis com a boa-fé ou a eqüidade."
} 
Muito embora reconheça a importância do instituto da boa-fé objetiva, Judith Martins $\operatorname{Costa}^{358}$ define este princípio como aberto e como um dispositivo eficiente a cargo do magistrado, o qual deverá aplicá-lo casuisticamente, de acordo com a oportunidade e conveniência. Neste sentido, elucida a civilista:

(...) o princípio da boa-fé objetiva "constitui uma disposição normativa que utiliza, no seu enunciado uma linguagem de tessitura intencionalmente "aberta", "fluida" ou "vaga", caracterizando-se pela ampla extensão de seu campo semântico. Esta disposição é dirigida ao juiz de modo a conferir-lhe um mandato (ou competência) ${ }^{359}$ para que, à vista dos casos concretos, crie, complemente ou desenvolva normas jurídicas, mediante o reenvio para elementos cuja concretização pode estar fora do sistema; estes elementos, contudo, fundamentarão a decisão, motivo pelo qual não só resta assegurado o controle racional da sentença como, reiterados no tempo fundamentos idênticos, será viabilizada, através do recorte da racio decidendi, a ressistematização destes elementos, originariamente extra-sistemáticos, no interior do ordenamento jurídico.

A jurisprudência nacional, crescentemente, festeja o indigitado princípio, assinalando que o ordenamento jurídico brasileiro, tal como concebido hodiernamente pelo Código Civil, exige das partes contratantes comportamento escorreito em todas as instâncias da relação negocial, isto é, nas fases de tratativa, formação, execução e conclusão do contrato. Inegavelmente, a aludida conduta exemplar deverá ser rigorosamente observada pelo licenciante e pelo licenciado, tanto na fase que anteceder, como nas fases de execução, conclusão e pós-término do negócio jurídico envolvendo a licença de uso de marca.

Neste contexto, a boa fé objetiva, verdadeira diretriz de procedimento, estabelecida no artigo 422 do Código Civil, reveste-se da função geradora de deveres tangenciais ou acessórios, como o de prestar informações acuradas e o de colaborar para que a relação entabulada não dê ensejo a lesões ou desapontamentos para uma das partes. Este princípio norteador da conduta humana, integra, como corolário, a essência do contrato naquilo em

\footnotetext{
${ }^{358}$ MARTINS-COSTA, Judith. A boa-fé no direito privado: sistema e tópica no processo obrigacional. São Paulo: Revista dos Tribunais, 1999. p. 335

${ }^{359}$ Neste sentido, impende-se colacionar o enunciado da Jornada I STJ 26, que prescreve: “ A cláusula geral contida no CC 422 impõe ao juiz interpretar e, quando necessário, suprir e corrigir o contrato segundo a boafé objetiva, entendida como exigência de cumprimento leal dos contratantes". Disponível em $<$ http://www.tj.rj.gov.br/cedes/enunciados_jornada_direito_civil.htm>. Acesso em 30/11/2008.
} 
que o instrumento for omisso, em decorrência de um imperativo de eticidade, de modo a inibir o emprego de subterfúgios ou interesses outros daqueles expressos no instrumento representativo de negócio jurídico formalizado e subscrito pelas partes contratantes ${ }^{360}$.

Ilustrativamente, o princípio da boa-fé objetiva (em sua feição pré-contratual e no que toca ao dever de "prestar informações acuradas"), no plano do contrato de licença de uso de marca, pode ser observado nas tratativas preliminares à conclusão do contrato. Assim ocorre quando o licenciante tem a obrigação de apresentar ao potencial licenciado marca de sua titularidade com avaliação real de mercado. Com base nesta avaliação, poderão ser aferidas bases remuneratórias eqüitativas a serem estabelecidas em um eventual contrato de licenciamento que venha a ser firmado. Se o licenciante não proceder de forma leal e transparente, estará transgredindo seu dever de prestar informações acuradas para a boa conclusão do negócio jurídico projetado.

Exemplificando-se: em 2008, a marca de uma construtora fora avaliada em R\$ 1.000.000,00 (hum milhão de reais). No entanto, após o enfrentamento de uma profunda crise mundial financeira, verificou-se: (a) a depreciação de grande parte dos ativos da construtora, incluindo os intangíveis; e (b) flagrante acréscimo de seu passivo. Por conseguinte, no ano de 2010, após nova avaliação de mercado realizada por empresa especializada, a pedido da própria construtora, sua marca foi avaliada em $\mathrm{R} \$ 500.000,00$ (quinhentos mil reais), portanto 50\% menos do que valia em 2008. Nas tratativas précontratuais, realizada no final do ano de 2010, e após a nova avaliação, o licenciante, ardilosamente, apresenta ao licenciado a avaliação de 2008, e não a mais recente, correspondente ao ano de 2010. A partir da análise do valor de mercado da marca atingido em 2008, então, os contratantes decidiram pelo licenciamento e pela estipulação de valor mensal pré-fixado, que seria cobrado a título de contraprestação (royalty) pelo licenciamento ocorrido.

No caso hipotético que ora se expõe, é patente a violação ao princípio da boa-fé objetiva. À guisa deste preceito, era de se esperar que o licenciante apresentasse ao

\footnotetext{
${ }^{360}$ Cf. REsp n. ${ }^{\circ}$ 910389/RN, Rel. Ministro Sidnei Beneti, Terceira Turma do Superior Tribunal de Justiça. julgado em 25/05/2010, DJe 18/06/2010; REsp n. ${ }^{\circ}$ 953.389/SP, Rel. Ministra Nancy Andrighi. Terceira Turma do Superior Tribunal de Justiça. Julgado em 23/02/2010, DJe 15/03/2010; REsp n.. 830.526/RJ, Rel. Ministra Nancy Andrighi. Terceira Turma do Superior Tribunal de Justiça. Julgado em 03/09/2009, DJe 29/10/2009.
} 
licenciado a avaliação mais recente (depreciada) de 2010. Entretanto, ele assim não o fez, induzindo o licenciado a erro, sobretudo no que tange ao valor consentido a título remuneratório. Portanto, é forçoso concluir, à luz do princípio ora ponderado, que o licenciante e licenciado devem agir com a mais estrita probidade e boa-fe $e^{361}$.

O indigitado princípio da boa-fé objetiva é instituto de aplicação universal, porquanto verificado em outros ordenamentos jurídicos. A título ilustrativo, cumpre trazer à baila aplicação deste princípio, por sistema alienígena, em contrato em que houve licenciamento de uso de marca.

Com efeito, a corte australiana, a exemplo do que vem sendo praticado pelos tribunais pátrios, tem, com recorrência, aplicado o princípio da boa-fé objetiva implícita (implied term of good faith) em contratos empresariais, muito embora tal princípio não tenha sido expressamente ventilado pelas partes contratantes quando da confecção do instrumento contratual. Mencione-se, assim, caso capital apreciado pelo Poder Judiciário australiano, inaugurador de precedente naquele país, cujo litígio instaurado teve como protagonistas duas redes de lanchonete de reconhecimento internacional: Burger King Co. e Hungry Jack's ${ }^{362}$.

O caso que ora se apresenta, de franquia e desenvolvimento de negócios (e portanto licenciamento de marca), foi apreciado pela alta corte australiana (New South Wales Court of Appeal), em 21 de junho de 2001. Reporta-se ao litígio entre Burger King, gigante cadeia norte-americana de lanchonete, e sua correspondente franquia australiana, Hungry Jack's. Em sua essência, este caso diz respeito à quebra de um contrato de franquia e

${ }^{361}$ O tema da boa-fé nos contratos de licença, embora consagrado no novo diploma civil, já fora enfrentado pela doutrina. Conforme leciona de Alexandre Gnocchi, "importante é saber como deveria se comportar o roialte, nos casos de contrato de licença em que se constate que o roialte pago não constituiu o preço do progresso. As hipóteses são duas: de boa-fé e de má-fé na relação contratual de licença. Podemos, por exemplo, ter patenteado algo e, com a patente celebramos, com terceiros um contrato de licença, passando a receber o roialte da exploração. Mais tarde, entretanto vimos a saber que o "invento" foi inventado antes, em qualquer país estrangeiro. É caso de boa-fé. E essa boa-fé ficará provada, se as partes, ao terem ciência da invalidade da patente, derem por nulo o contrato de licença, requerendo o titular, ao Departamento Nacional da Propriedade Industrial, o imediato cancelamento da patente. A permanência da licença e da patente provará má-fé e será fraude à lei ao Estado. No casos de má-fé, o roialte deve ser entregue ao estado e por este destinado a um Fundo de Pesquisas Científicas ou a um Fundo de Auxílio ao Inventor”. (GNOCCHI, Alexandre. Licenças e Roialties no Brasil. op. cit. p.p. 224/225)

362 Burger King Corporation v Hungry Jack's. in Wikipedia - The Free Encyclopedia. Disponivel em $<$ http://en.wikipedia.org/wiki/Burger_King_Corporation_v_Hungry_Jack\%27s> Acesso em 20 de dez. 2009. 
desenvolvimento de negócios (Development Agreement) entre as empresas acima aludidas, bem como à tentativa da Burger King em encerrar o contrato antecipadamente (resolução), alegando descumprimento de obrigações pela Hungry Jack's. A corte de apelação, todavia, determinou que a Burger King não poderia encerrar antecipadamente o contrato, por algumas razões, uma das quais consistia no fato de que este término corresponderia à quebra do princípio da boa-fé, implícito ao contrato, mormente em função das inúmeras ações encetadas pelo Burger King para, propositada e ardilosamente, pleitear a resolução contratual.

Em síntese, o contrato prescrevia que a Hungry Jack's tinha o dever contratual de, em determinada região do território australiano, implementar quatro novas franquias por ano, sob pena de resolução contratual por inadimplemento. Esta obrigação, naturalmente, somente seria concretizada após a indispensável concordância da franqueadora Burger King, a qual, impende-se destacar, não mais intencionava manter relações comerciais com a parte adversa, dado que pretendia, por conta própria, difundir seu negócio na Austrália. No entanto, não encontrava meios de encerrar o contrato, sem ter de pagar indenização milionária à Hungry Jack's, pela extinção antecipada do contrato. Diante deste cenário, a Burger King, com o escopo de dar ensejo à resolução contratual, começou, de má-fé e deliberadamente, a negar aprovações financeiras e operacionais para a abertura de novos restaurantes (franquias). Esta atitude forçada foi considerada pela corte como ilegítima à perseguição dos interesses contratuais e, principalmente, como subterfúgio utilizado pela Burger King para prejudicar e obstaculizar as operações da Hungry Jack’s na Austrália, de modo a tomar toda aquela operação para si.

Abalizando-se no exemplo acima, verifica-se que a tendência internacional, no que toca aos contratos envolvendo o licenciamento de marca, prende-se ao entendimento de que a boa-fé objetiva deverá ser ininterruptamente observada pelas partes contratantes. Esclareça-se que este preceito deverá nortear a relação entre licenciador e licenciado, ainda que: (i) tal princípio não seja ventilado no instrumento ou; (ii) as cláusulas contratuais se posicionem de forma contrária ao indigitado princípio.

Diante do acima examinado, concluímos ser de vital importância que, nas relações jurídicas em que haja o licenciamento do uso de marca, os direitos e deveres assumidos pelos contratantes (incluindo-se aqueles anexos ou laterais, não expressos em contrato, 
porém inatos a ele) sejam implementados, executados, operados, observados e concluídos, em estrita consonância com o princípio da boa-fé objetiva, festejado pelo artigo 422 do Código Civil Brasileiro.

(vi) Princípio da Relatividade. O contrato de licença de uso de marca, em tese, e desde que não resulte prejuízos a terceiros, só terá eficácia (gerará direitos e deveres) entre as partes contratantes. Desta forma, assim como ocorre na relação de pesos e contrapesos verificada entre os princípios da autonomia da vontade e supremacia da ordem pública, há a mesma relação de compensação entre os princípios da relatividade e função social do contrato, conforme abaixo descrito.

(vii) Princípio da Função Social do Contrato. O princípio da função social do contrato representa outro princípio de direito contratual de elevado quilate ao qual o contrato de licença de uso de marca deverá se subsumir. $\mathrm{O}$ artigo 421 do Código Civil celebra, em concomitância, dois princípios basilares informadores do direito contratual vigente. $\mathrm{O}$ primeiro reside na autonomia da vontade, supra delineada. $\mathrm{O}$ outro, que será doravante examinado, repousa no princípio da função social do contrato.

Tem-se edificado conceitos de que a função social do contrato é uma extensão da função social da propriedade, mencionada à exaustão na Carta Suprema ${ }^{363}$. Neste sentido, muito embora a Carta Magna tenha se omitido em relação à expressão "função social do contrato", é certo que o constituinte teve a intenção de fazê-lo, ainda que de forma “oblíqua", "tangencial” e "implícita"364.

\footnotetext{
363 “Art. $5^{\circ}$ Todos são iguais perante a lei, sem distinção de qualquer natureza, garantindo-se aos brasileiros e aos estrangeiros residentes no País a inviolabilidade do direito à vida, à liberdade, à igualdade, à segurança e à propriedade, nos termos seguintes: (...) XXIII - a propriedade atenderá a sua função social”; "Art. 186. A função social é cumprida quando a propriedade rural atende, simultaneamente, segundo critérios e graus de exigência estabelecidos em lei, aos seguintes requisitos: (...)"Art. 182. A política de desenvolvimento urbano, executada pelo Poder Público municipal, conforme diretrizes gerais fixadas em lei, tem por objetivo ordenar o pleno desenvolvimento das funções sociais da cidade e garantir o bem- estar de seus habitantes (..) § $2^{\circ}$ - A propriedade urbana cumpre sua função social quando atende às exigências fundamentais de ordenação da cidade expressas no plano diretor". "Art. 170. A ordem econômica, fundada na valorização do trabalho humano e na livre iniciativa, tem por fim assegurar a todos existência digna, conforme os ditames da justiça social, observados os seguintes princípios: (...) III - função social da propriedade".

${ }^{364}$ Cite-se, neste sentido, o raciocínio jurídico tecido pelo magistrado João Hora Neto: “(...) Uma vez entendida que a propriedade representa o segmento estático da atividade econômica, não é desarrazoado entender que o contrato, enquanto segmento dinâmico, implicitamente também está afetado pela cláusula da função social da propriedade, pois o contrato é um instrumento poderoso de circulação da riqueza, ou melhor, da própria propriedade. (cf. NETO, João Hora. O Princípio da Função Social do Contrato no Novo Código Civil. Disponível em <http://jus2.uol.com.br/doutrina/texto.asp?id=8262>. Acesso em 28/11/2008.
} 
Por este princípio, materializado em uma cláusula geral, o contrato de licença de uso de marca deverá exercer uma função social, função esta que acaba por delimitar a liberdade de contratar.

Na sociedade contemporânea, um contrato, seja ele empresarial ou civil, poderá afetar não somente as partes contratantes, como igualmente, e nocivamente, terceiros.

Exemplo clássico, no Direito Comercial, que ilustra referido princípio é representado pelas fusões e aquisições. Estas reorganizações societárias podem afetar terceiros, sobretudo sob o ponto de vista do Conselho Administrativo de Defesa Econômica (CADE) ${ }^{365}$, que tem a função de avaliar os atos de concentração de mercado, atos estes materializados em instrumentos contratuais específicos, submetidos à legislação societária extravagante.

Desta feita, se tais contratos afetarem terceiros, facultará ao CADE intervir, com o escopo de desconstituir aquele contrato previamente corroborado entre as partes contratantes. O CADE deve, em caráter preliminar, analisar a função social do contrato, sopesando se, ao exercer a autonomia da vontade privada, os contratantes estão tendo vantagem desmedida em detrimento do tecido social. Exemplo ocorre, quando há a fusão de duas empresas do setor da aviação civil, com intuito manifestamente monopolístico do setor em que atuam. Resta claro que a fusão mencionada acarretará controle de mercado, de tal sorte que os consumidores sairão notadamente prejudicados, em decorrência de aumentos abusivos no valor da tarifa da passagem área, sobretudo pela manifesta ausência de concorrência leal com outras empresas que no mesmo ramo atuem.

Portanto, a lei autoriza o CADE a aprovar ou rejeitar a fusão. O CADE admitirá a operação apenas se considerar que a sociedade civil dela possa ser beneficiada. Com efeito, serão aprovadas operações cujos contratos atinjam sua função social, conforme prescrito pelo artigo 421 do diploma civil em vigor.

\footnotetext{
${ }^{365}$ O CADE (Conselho Administrativo de Defesa Econômica) é a última instância, na esfera administrativa, responsável pela decisão final sobre matéria concorrencial. Foi instituído pela lei 8.884/94. Impõe-se registrar, mormente em consonância com os princípios norteadores insculpidos no artigo $1^{\circ}$ da Lei 8.884, a função social dos contratos que passam pelo crivo da autarquia em estudo.
} 
Cumpre salientar que este princípio pode ser considerado um dos alicerces contratuais aplicáveis ao Direito Obrigacional e Empresarial e um grande desafio aos magistrados, principalmente quando se depararem com contratos sobre os quais paira a desconfiança e a temeridade de lesão ao tecido social. Segundo a melhor lição de Silvio de Salvo Venosa, "a função social do contrato avalia-se, portanto, na concretude do direito, como apontamos. Todo esse quadro deve merecer deslinde que não coloque em risco a segurança jurídica, um dos pontos fulcrais mais delicados das denominadas cláusulas abertas. Esse será o grande desafio do aplicador do Direito deste século" ${ }^{366}$.

Giselda Hironaka admite que o papel do estado, no que tange à intervenção nos contratos que lesem a sociedade civil, passa a assumir especial importância no contexto atual, cujas presenças dos liberalismos econômico e jurídico vigentes devem ser atenuadas $^{367}$.

O Estado passa, pois, a intervir naquelas relações intersubjetivas perniciosas, com o desígnio precípuo de, como resultado deste tolhimento da autonomia da vontade desenfreada, poder albergar os interesses dos socialmente indefesos ou enfraquecidos.

O princípio da função social do contrato, que irradia seus efeitos diretamente sobre o contrato objeto desta tese, tem a finalidade de obstar que as partes se sirvam cega e interminavelmente do princípio da autonomia da vontade. Com efeito, o contrato de licença de marca não pode ser utilizado para o cometimento de abusos que impliquem lesões a terceiros, posto que, de acordo com a elocução do artigo 187 do Código Civil, "também comete ato ilícito o titular de um direito que, ao exercê-lo, excede manifestamente os limites impostos pelo seu fim econômico ou social, pela boa-fé ou pelos bons costumes" 368 .

\footnotetext{
366 VENOSA, Silvio de Salvo, Op. Cit. p. 349.

${ }^{367}$ HIRONAKA, Giselda Maria Fernandes Novaes. A função social do contrato. Direito Civil: estudos. Belo Horizonte: Ed. Del Rey. 2000. p. 109.

${ }^{368}$ Cf. REALE, Miguel. Função Social do Contrato. Disponível em <http://www.miguelreale.com.br/>. Acesso em 30 jan. 2010.
} 
Por fim, impõe-se enumerar as diretrizes (ou enunciados ${ }^{369}$ ) definidas pelo Colendo Superior Tribunal de Justiça acerca do tema em referência:

Enunciado n. ${ }^{\circ}$ 21: a função social do contrato prevista no art. 421 do novo Código Civil constitui cláusula geral, que impõe a revisão do princípio da relatividade dos efeitos do contrato em relação a terceiros, implicando a tutela externa do crédito.

Enunciado n. ${ }^{\circ}$ 22: a função social do contrato prevista no art. 421 do novo Código Civil constitui cláusula geral, que reforça o princípio de conservação do contrato, assegurando trocas úteis e justas.

Enunciado n. ${ }^{\circ}$ 23: a função social do contrato prevista no art. 421 do novo Código Civil não elimina o princípio da autonomia contratual, mas atenua ou reduz o alcance desse princípio, quando presentes interesses meta-individuais ou interesse individual relativo à dignidade da pessoa humana. (grifou-se) ${ }^{370}$

Contudo, há que se ressaltar que, muito embora o princípio da função social tenha lugar nos contratos de licença de uso de marca (contrato empresarial), sua aplicação deve se dar de forma seletiva e apenas quando for realmente imprescíndivel à correção de alguma lesão desmedida e injustificável ocasionada a terceiros. Isto, naturalmente após verificadas as circunstâncias do caso concreto, e avaliando-se, cautelosamente, os elementos intrínsecos e extrínsecos à relação jurídica concebida pelas partes contratantes, sob pena de se gerar insegurança jurídica para o empresariado e provocar efeitos deletérios a todo o tecido econômico nacional. Além, obviamente, de repelir o investimento externo, também como resultado da insegurança gerada aos entes estrangeiros, pela eventual aplicação desenfreada da citada cláusula geral pelo Poder Judiciário. Jamais podemos nos olvidar que o predicado capital dos contratos é o seu atributo econômico, haja vista que

\footnotetext{
${ }^{369}$ Os enunciados aprovados pelo Conselho da Justiça Federal e Superior Tribunal de Justiça "representam um indicativo para interpretação do Código Civil e significam o entendimento majoritário das comissões temáticas constituídas em número de quatro: Parte Geral e Direito das Coisas, Direito das Obrigações e Responsabilidade Civil, Direito de Empresa e Direito de Família e Sucessões". Disponível em $<$ http://www2.cjf.jus.br/portal/publicacao/engine.wsp?tmp.area=115>. Acesso em 10 jun. 2009.

${ }^{370}$ Os enunciados ora enumerados foram aprovados na Jornada de Direito Civil, STJ, no período de 11 a 13 de setembro de 2002, promovida pelo Centro de Estudos Judiciários do Conselho da Justiça Federal - CJF, no período de 11 a 13 de setembro de 2002, sob a coordenação científica do Ministro Ruy Rosado, do STJ. Disponível 
este instituto tem o escopo de promover a circulação de riquezas e robustecer a economia de uma nação.

Neste particular, o professor Haroldo Malheiros Duclerc Verçosa, ao rechaçar a aplicação indiscriminada do príncipo da função social aos contratos empresariais, faz referência a julgado paradigmático de relatoria da Ministra Nancy Andrighi, em capítulo de sua tese de livre docência, que intitula: “A visão da Jurisprudência. uma pá de cal na visão socialista da função Social do contrato",371.

De conformidade com trecho extraído de voto proferido pela Ministra Nancy Andrihi, acolhido por unanimidade pela Terceira Turma Julgadora do Superior Tribunal de Justiça:

\begin{abstract}
"A função social infligida ao contrato não pode desconsiderar seu papel primário e natural, que é o econômico. Este papel não pode ser ignorado, a pretexto de cumprir-se uma atividade beneficente. Ao contrato incumbe uma função social, mas não de assistência social. Por mais que o indivíduo mereça tal assistência, não será no contrato que se encontrará remédio para tal carência. $O$ instituto é econômico e tem fins econômicos a realizar, que não podem ser postos de lado pela lei e muito menos pelo seu aplicador. A função social não se apresenta como objetivo do contrato, mas sim como limite da liberdade dos contratantes em promover a circulação de riquezas ${ }^{372}$ (grifou-se)
\end{abstract}

No julgado citado, o Recurso Especial foi acolhido, por unanimidade, restabelecendo-se a sentença de primeiro grau. Com efeito, decidiu-se que o contrato de venda e compra de soja para entrega futura, com preço pré-fixado, não poderia ser revisado, sob o pretexto da variação cambial e sob o argumento de que o vendedor teve de suportar prejuízo ou lucro menor do que o projetado. A revisão pleiteada teve como fundamento a variação do valor de mercado da soja, quando a mercadoria seria entregue ao comprador, porquanto o preço ficou abaixo do que aquele fechado quando da subscrição do contrato, em razão de uma "drástica" variação cambial. O contrato subscrito foi um

\footnotetext{
${ }^{371}$ VERÇOSA, Haroldo Malheiros Duclerc. O Código Civil de 2002 e a Crise do Contrato - Seus Efeitos nos Contratos Mercantis (Aspectos Relevantes). Tese para Concurso de Livre-Docência para o Departamento de Direito Comercial da Faculdade de Direito da Universidade de São Paulo. São Paulo. 2009. p. 125.

372 Recurso Especial n. ${ }^{\circ}$ 803.481/GO. Terceira Turma. Superior Tribunal de Justiça. Rel. Min(a). Nancy Andrighi. Julg. em 28 jun. 2007. Relatório e Voto n. ${ }^{\circ}$ 3139931. p. 9 de 11.
} 
contrato notadamente empresarial. Ambas as partes tinham conhecimento e assumiram os riscos a ele inerentes.

Embasando-se neste entedimento, a turma julgadora posicionou-se no sentido da aplicação restritiva do princípio da função social ao contrato empresarial, sinalizando que "a função social não se apresenta como objetivo do contrato, mas sim como limite da liberdade dos contratantes em promover a circulação de riquezas". No mais, externou interpretação no sentido de que contratos empresariais de execução continuada ou diferida são contratos em que as partes assumem riscos e, por tal razão, os contratantes devem incluir em suas prestações todos os custos que poderão incorrer, tanto os resultantes dos próprios termos do contrato, livre flutuação cambial, frete, seguro etc, como aqueles oriundos das condições extrínsecas ao negócio. Portanto, não há como se acolher a tese de que, tendo calculado erroneamente as circusntâncias acima mencionadas, ou, pior, estando arrependida com o preço previamente ajustado no ato da celebração do negócio jurídico, a parte tenha a pretensão, com amparo no princípio da função social do contrato, pleitar a resolução do contrato.

(viii) Principio da Vedação da Onerosidade Excessiva (Artigos 317 e 478 do Código Civil Brasileiro).

Antes mesmo de sua positivação, pelo atual Código Civil, doutrina e jurisprudência brasileira já se inclinavam à aplicação deste princípio, conforme sustenta Luiz Gastão Paes de Barros Leães. Assim se manifestou o jurista, ao emitir parecer em favor de uma sociedade anônima que havia firmado contrato empresarial de mútuo com outra sociedade empresária. Segundo o ilustre comercialista, "a doutrina e a jurisprudência brasileiras vêm admitindo, cada vez de forma mais ampla, como causa de resolução ou modificação dos contratos comutativos de execução diferida, continuada ou periódica, a onerosidade excessiva, que, em virtude de acontecimento extraordinário e imprevisível, sobrevenha, dificultando ao extremo o cumprimento de obrigação de um dos contratantes" ${ }^{\text {,373 }}$. Tendo-se em vista que os contratos de licença de uso de marca são contratos empresariais

\footnotetext{
${ }^{373}$ LEÃES, Luiz Gastão Paes de Barros. Pareceres. São Paulo: Ed. Singular. 2004. vol. 1. p. 1.098.
} 
comutativos e de execução continuada, o conceito acima externado aplica-se, perfeitamente, ao contrato objeto desta tese.

O artigo 317 do Código Civil Brasileiro reza que "quando, por motivos imprevisíveis, sobrevier desproporção manifesta entre o valor da prestação devida e o do momento de sua execução, poderá o juiz corrigi-lo, a pedido da parte, de modo que assegure, quanto possível, o valor real da prestação".

Por seu turno, o artigo 478 do mesmo Diploma Legal estatui: "nos contratos de execução continuada ou diferida, se a prestação de uma das partes se tornar excessivamente onerosa, com extrema vantagem para a outra, em virtude de acontecimentos extraordinários e imprevisíveis, poderá o devedor pedir a resolução do contrato. Os efeitos da sentença que a decretar retroagirão à data da citação".

Estes dispositivos, conforme será pontualmente examinado, apresentam-se como de grande valia para os contratos de licença de uso de marca, principalmente pelo fato de que este tipo de contrato, via de regra, está permeado de preceitos densos e complexos interligados entre si. Neste sentido, o ordenamento jurídico, pelo Poder Judiciário, pode desconsiderar regras que, de início, tenham sido avalizadas pelas partes contratantes como “cláusulas hermeticamente fechadas” não passíveis de modificações pelos contratantes.

Consoante os mandamentos extraídos dos artigos 317 e 478 do Código Civil vigente, nos instrumentos contratuais de execução prolongada (ou continuada), se a obrigação de uma das partes tornar-se demasiadamente onerosa, em função de grande vantagem auferida pela outra parte contratante, como resultado de eventos extraordinários e de difícil previsibilidade, a parte devedora terá a prerrogativa legal de requerer a resolução do contrato. Acrescente-se, por igual, que os efeitos irradiados pela sentença serão retroativos à data em que o credor for citado.

Há uma particularidade, contudo, deste princípio, se comparado aos demais acima enumerados. Enquanto que a maioria dos outros princípios deve ser observada a partir do momento da composição contratual, o principio da vedação da onerosidade excessiva deve ser observado após o decurso temporal, ou seja, após a assinatura do instrumento contratual. 
Depreende-se da leitura do artigo 478 do Diploma Civil que este princípio aplica-se aos contratos de execução continuada ou diferida, cujos negócios jurídicos dependem de evento futuro e cujos cenários econômicos que o envolvem são inesperados. É forçoso apontar, pois, a existência de uma lacuna temporal, que tem como marco inicial o instante da celebração do contrato, prolongando-se até o efetivo cumprimento da obrigação, lapso temporal este em que deve vir à tona o fato excepcional, totalmente estranho ao conhecimento das partes. É exatamente este o caso do contrato de licença de uso de marca, considerado, em sua essência, como um contrato de execução continuada e, portanto, passível de aplicação do artigo em análise. Esta espécie contratual é assim considerada porque a marca é licenciada contra o pagamento de prestação periódica como forma de remuneração deste licenciamento, até o evento do termo final estipulado por licenciante e licenciado.

O fato excepcional resulta em excessiva onerosidade a uma das partes, contrariando o ambiente inaugural das negociações. Por via de conseqüência, este evento inesperado implica vantagem excessiva de uma parte à custa de uma desvantagem desproporcional e injustificada da outra parte, configurando "enriquecimento ilícito" e dando ensejo à quebra de um princípio basilar do Direito Contratual: princípio da isonomia ou equilíbrio contratual $^{374}$.

Neste tocante, um dos temas de maior repercussão doutrinária e jurisprudencial diz repeito ao termo "acontecimentos imprevisíveis", mencionado no artigo 478 do diploma civil. O paradigma desta discussão reside nos efeitos deletérios acarretados pela "inflação". Quando se verifica inflação desmedida e imprevisível após a celebração de determinado contrato, questiona-se a plausibilidade de aplicação ou não do artigo 478, com o escopo de se proceder à revisão do contrato, em decorrência da desproporção extraordinária do cumprimento ao qual fica submetida uma das partes contratantes.

\footnotetext{
374 O prof. Álvaro Villaça de Azevedo, inclusive, elaborou uma minuta de anteprojeto de lei para regulamentação geral dos contratos atípicos, apresentando, para tanto, normas de caráter geral que objetivam coibir os excessos de liberdade prejudiciais ao equilíbrio econômico dos contratantes. Destarte, o artigo $4^{\circ}$ do citado anteprojeto externa a redação seguinte: "Art. $4^{o}$ - As partes devem utilizar-se do contrato atípico, segundo sua função social, observando os princípios da boa-fé objetiva, desde o momento anterior à formação do contrato até o posterior a sua extinção: o princípio da igualdade entre os contratantes, e, principalmente, o da onerosidade excessiva para que não ocorra enriquecimento injusto ou indevido".
} 
Impende-se registrar que não há entendimento pacificado na jurisprudência e doutrina no que pertine a esta problemática. Álvaro Villaça ${ }^{375}$ afirma que os tribunais pátrios não têm recepcionado a cláusula da revisão de contrato (rebus sic stantibus) em casos de "inflação". Não se apresentando partidário deste entendimento e trazendo à colação julgados em sentido contrário, Nelson $\mathrm{Nery}^{376}$ aponta que, muito embora a inflação seja um evento de fácil previsibilidade, a jurisprudência pátria tem admitido que os contratos sejam modificados quando índices inflacionários ou variações de preço estrondosos venham a "desnaturar a obrigação", de tal sorte que a parte prejudicada não logre êxito quanto ao adimplemento de sua obrigação.

Compartilhamos do ideal corroborado por Villaça ${ }^{377}$, quando defende, incisivamente, a exclusão do termo "imprevisíveis" do artigo 478. De fato, o que importa é o desequilíbrio contratual decorrente de circunstâncias cristalinamente desvencilhadas dos atos e vontades de cada uma das partes contratantes: irretorquivelmente, está é tônica do princípio da onerosidade excessiva.

Advogar a tese de que o contrato somente pode ser revisado, com fulcro no princípio da onerosidade excessiva, tão somente quando verificadas circunstâncias imprevisíveis, significa lesar flagrantemente direito alheio, abalando a segurança jurídica nacional e, por via de conseqüência, desestimulando futuras contratações. Até porque a grande maioria dos eventos futuros é previsível, ainda que seja improvável a sua ocorrência. Significa, outrossim, ir na contramão do sistema privado vigente, que rechaça, veementemente, o enriquecimento sem justa da causa de uma parte em detrimento do infortúnio alheio.

375 VILLAÇA, Álvaro. O Novo Código Civil Brasileiro: tramitação; função social do contrato; boa-fé objetiva; teoria da imprevisão e, em especial, onerosidade excessiva (laesio enormis). in DELGADO, Mário Luiz e ALVES, Jones Figueiredo (Coord.). Questões Controvertidas no Novo Código Civil. Vol.2. Ed. Método. São Paulo 2004. p. 20.

${ }^{376}$ Cite-se os seguintes julgados: (i) "STJ, $4^{\text {a }}$ turma, REsp 73370-AM, rel. Min. Ruy Rosado de Aguiar, v.u., j. 21.11.1995, DJU 12.2.1996"; e (ii) "STJ, 4 Turma, REsp 135151-RJ, rel. Min Ruy Rosado de Aguiar, v.u., j. 08.10.1997, DJU 10.11.1997) (cf. JÚNIOR, Nelson Nery e NERY, Rosa Maria de Andrade. Código Civil Comentado. $6^{a}$ ed. São Paulo. Ed. Revista dos Tribunais. 2008. p. 511).

${ }^{377}$ VILLAÇA, Álvaro. O Novo Código Civil Brasileiro: tramitação....ob. cit. p.p.23-29. 
Ante este debate, aventuramo-nos a argüir que a inflexibilidade do dispositivo normativo tal como se nos apresenta, dá ensejo à insegurança jurídica e econômica e, por conseguinte, implica diretamente a redução das atividades e contratações empresariais, encetando, decerto, conseqüências deletérias ao tecido econômico pátrio.

De forma esclarecedora, Villaça assinala que o ordenamento jurídico com a rigidez apresentada pelo artigo 478 ("teoria da imprevisão") acaba sendo autofágico, posto que se faz complexa a revisão em torno dos contratos firmados entre o Governo Brasileiro e alguns Bancos Internacionais. Ora, se o Brasil adota a teoria da imprevisão, como discutir perante os bancos e organizações internacionais os contratos internacionais (em que o Brasil figura como devedor), com base nas flutuações cambial e financeira ordinárias e, portanto, "previsíveis" e com base na onerosidade excessiva? Certamente, seria um contrasenso: aplica-se, internamente, uma norma, enquanto se rechaça a aplicação desta mesma norma nas relações exteriores em que o Governo figura como parte.

Visando à interpretação para a flexibilização do contestado termo "motivos impresíveis", foram editados, pelo Conselho da Justiça Federal e Superior Tribunal de Justiça, dois enunciados de suma importância, aos quais podem os magistrados se socorrer para que se extraia aproveitamento mais razoável dos artigos 317 e 478 do Código Civil. Com efeito, o Enunciado 17, aprovado pela I Jornada de Direito Civil, estabelece que "a interpretação da expressão "motivos imprevisíveis", constante do art. 317 do novo Código Civil, deve abarcar tanto causas de desproporção não previsíveis, como também causas previsíveis, mas de resultados imprevisíveis" (grifou-se). Por seu turno, o Enunciado 175, aprovado pela III Jornada de Direito Civil, estatui: “ A menção à imprevisibilidade e à extraordinariedade, insertas no art. 478 do Código Civil, deve ser interpretada não somente em relação ao fato que gere o desequilíbrio, mas também em relação às consequiências que ele produz" (grifou-se).

Contudo, com base nos mesmos fundamentos outrora examinados quando do estudo do princípio da função social do contrato, o princípio da onerosidade excessiva deve ser aplicado aos contratos de licença de uso de marca (contrato empresarial) com extrema cautela e aprofundada fundamentação. Não poderá ser aplicado indiscriminadamente. Não deverá ser aplicado em larga escala, como decorre das relações civis ou de consumo, em que, muitas vezes, as partes não estão equiparadas, porque estão 
situadas em diferentes patamares na relação jurídica estabelecida. Tudo isto para que, conforme pontuado quando da apreciação do princípio da função social do contrato, não se gere incerteza jurídica. Para que o empresariado não se sinta desestimulado a contratar. Para que não prejudique a ordinária fluidez e dinamismo ínsitos ao mercado. Para que não comprometa o livre funcionamento do mercado, o qual tem como fundamento basilar a livre iniciativa, com atenuadas intervenções estatais.

Este entendimento tem sido agasalhado pelo Superior Tribunal de Justiça, conforme se depreende de julgado modelo, cujo trecho do voto aprovado à unanimidade (extraído do Recurso Especial outrora citado, de relatoria da Min. Nancy Andrighi) segue adiante transcrito:

\begin{abstract}
A regra acerca da onerosidade excessiva, ou seja, a revisão do contrato, somente é admitida se a superveniência do acontecimento que torna excessivamente onerosa a prestação de uma das partes se apresente como equivalente a uma extrema vantagem para o outro contratante e seu advento fosse extraordinário e imprevisível.
\end{abstract}

No particular, os eventos que teriam influído no valor da prestação devida pelo recorrido não eram extraordinários tampouco imprevisiveis. Ademais, o aumento do preço da saca de soja à época de sua entrega não torna excessivamente oneroso o negócio para o vendedor, tampouco proporciona à recorrente uma extrema vantagem. $O$ produtor, ao fixar $\boldsymbol{O}$ preço, certamente foi cauteloso em nela computar seus gastos e um lucro razoável, de modo que, em vez de experimentar prejuízo com a alienação antecipada assegurou um lucro. O negócio foi lucrativo para o vendedor, embora seu lucro fosse menor do que seria se em vez de tê-lo vendido no ano anterior o tivesse alienado em março a maio do ano seguinte. Assim, os requisitos do negócio ser excessivamente oneroso para uma das partes e vantajoso para a outra, em decorrência de um acontecimento extraordinário e imprevisível, reclamados pelo artigo 478 do CC/02, inexistem na hipótese e, portanto, inexiste ofensa a tal dispositivo legal.

(...)Enfim, os riscos assumidos pelas partes quanto à variação do preço da mercadoria decorrem da própria natureza do contrato de venda e compra de safra futura a preço certo.(grifou-se) ${ }^{378}$

Desta feita, como decorrência das sucessivas demandas direcionadas à apreciação do Poder Judiciário, restou firmada, na IV Jornada de Direito Civil, o Enunciado n. ${ }^{\text {3 } 366,}$

${ }^{378}$ Recurso Especial n. ${ }^{\text {o }}$ 803.481/GO. Terceira Turma. Superior Tribunal de Justiça. Rel. Min(a). Nancy

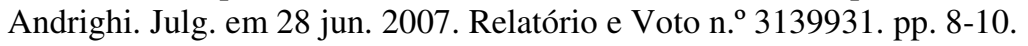


cujo teor consiste na mitigação dos efeitos do artigo 478 do Código Civil em relação aos contratos empresariais. De acordo com a mencionada diretriz interpretativa, "o fato extraordinário e imprevisível causador de onerosidade excessiva é aquele que não está coberto objetivamente e pelos riscos próprios da contratação",379. Justifica o autor deste enunciado, o professor Paulo Roque Khouri, que "o regime da onerosidade excessiva superveniente não pode ser acionado diante de uma simples oscilação econômica para mais ou para menos do valor da prestação". Ainda segundo o mencionado jurista, "essa oscilação encontra-se coberta pelos riscos próprios da contratação compreendida pelos riscos próprios do contrato" 380 .

Os limites da aplicação do princípio da onerosidade excessiva aos contratos de licença de uso de marca serão adiante melhor analisados, especialmente quando do exame dos efeitos dos royalties pré-fixados nesta espécie de contrato empresarial.

Saliente-se, por fim, a possibilidade de revisão judicial, com fundamento no artigo 479 do Código Civil ${ }^{381}$. Desta forma, se conjuntamente ponderados os dispositivos 478 e 479 do diploma civil, pode-se depreender que verificada a onerosidade excessiva, poderá a parte requerida propor o reequilíbrio contratual, em respeito ao princípio da conservação do contrato. Sucede, todavia, que se a contratante ré se mantiver silente quanto à confecção de acordo para a reformulação contratual, poderá o juiz resolver o contrato ${ }^{382}$.

\footnotetext{
${ }^{379}$ IV Jornada de Direito Civil. Organização: Ministro Ruy Rosado de Aguiar Jr.. Brasília: CJF, 2007. 2 v. Disponível em <http://www.jf.jus.br/cjf/cej-publ/jornadas-de-direito-civil-enunciados-aprovados>. Acesso em 10 out. 2010.

380 KHOURI, Paulo R. Roque. A revisão judicial dos contratos no Novo Código Civil, Código do Consumidor e Lei 8.663/1993. São Paulo: Atlas. 2006. p. 157.

381 “Art. 479. A resolução poderá ser evitada, oferecendo-se o réu a modificar eqüitativamente as condições do contrato".

382 J. M. Othon Sidou. A revisão judicial dos contratos e outras figuras jurídicas. $2^{\mathrm{a}}$ ed. Rio de Janeiro.Forense. 1984. p. 120 Apud AZEVEDO, Álvaro Villaça de. O Novo Código Civil...ob cit. p. 27.
} 


\section{V.4 ANÁLISE DOS CONTRATOS DE LICENÇA DE USO DE MARCA À LUZ DA TEORIA DA APLICAÇÃO ANALÓGICA}

Conforme examinado nos capítulos sobre a atipicidade e disciplinamento jurídico do negócio jurídico em exame, incidirão sobre o contrato de licença de uso de marca, embasando-se na bem fundamentada teoria da aplicação analógica, e sem prejuízo dos princípios gerais de direito contratual e fiel autonomia da vontade, as regras e disposições normativas aplicáveis àqueles contratos típicos que maior analogia guardem com esta espécie contratual, o que, no vertente caso, são representados por: contrato de comodato (para os contratos de licença de uso de marca não remunerados), cujos dispositivos encontram-se inseridos entre os artigos 579 e 585 do Código Civil Brasileiro; e contrato de locação de coisas (para os contratos de licença de uso de marca remunerados), cujo regramento encontra-se compreendido entre os artigo 568 e 578 do diploma civil vigente.

\section{V.4.1 CONTRATO DE LICENÇA DE USO DE MARCA NÃO REMUNERADO CONSOANTE A APLICAÇÃO DOS DISPOSITIVOS NORMATIVOS INCIDENTES SOBRE O CONTRATO DE COMODATO}

Conforme demonstrado, quando do estudo da incidência da tese da aplicação analógica, na possibilidade de a licença ser concedida a título gratuito, o contrato socorrerse-á dos dispositivos previstos no contrato de comodato ${ }^{383}$, cujos comandos encontram-se insculpidos no Diploma Civil vigente.

O contrato celebrado a título gratuito é utilizado, com recorrência, como subterfúgio para que o titular não perca a titularidade da marca. No entanto, é imperioso evidenciar, ao contrário do que ocorria em outras legislações, não obstante a marca seja licenciada, para que não se opere a caducidade do bem imaterial licenciado, este deve ser efetivamente utilizado.

\footnotetext{
${ }^{383}$ Cf. FIGUEIREDO, Paulo Roberto, A Propriedade Industrial, 1978, p. 123. apud LEONARDOS, Gabriel Francisco. Tributação da Transferência de Tecnologia. Rio de Janeiro: Forense, 2001. pp. 88-89.
} 
Acerca dos aspectos e elementos jurídicos concernentes ao contrato de licença não remunerado, é forçoso destacar que esta espécie contratual, a despeito de ser verificada com pouca reccorência nas relações empresariais, é admissível e amplamente avalizada pela doutrina que sobre este tema se debruça.

Em conformidade com a lição exarada por Paul Roubier ${ }^{384}$, o contrato de licença é o instrumento jurídico através do qual o titular concede o monopólio de exploração sobre uma marca para outrem, sendo que esta espécie contratual, na grande maioria dos casos, é celebrada a título oneroso. Conclui-se, pois, que é perfeitamente possível a celebração de contratos de licença a título gratuito, muito embora não seja com recorrência verificado na praxis comercial.

O presente subcapítulo terá o condão de ponderar as principais questões incidentes sobre esta modalidade contratual, sendo que questões outras, sem embargo de poderem irradiar efeitos sobre a espécie em estudo, deverão ser mensuradas nas investigações realizadas sobre o contrato de licença de marca remunerado.

O contrato de comodato espelha-se, quase que em sua integralidade no contrato de locação de bens móveis, com nevrálgica restrição de que, enquanto no contrato de locação há a presença obrigatória de cláusula remuneratória, no contrato de comodato não há contraprestação pela utilização do bem oferecido em comodato.

O ponto nodal, conseqüentemente, entre o contrato de locação e o contrato de comodato é o elemento da gratuidade, componente basilar deste último instrumento. Assim, o caráter oneroso do primeiro opõe-se ao "caráter gracioso" do segundo ${ }^{385}$.

Diante destas premissas, e à guisa do princípio da analogia, passemos à análise do contrato de licença de uso de marca não remunerado face aos subsídios e elementos emprestados pelo contrato de comodato.

\footnotetext{
384 ROUBIER, Paul. "Licences et Exclusivités" in Annales de Droit Comercial Français, Etranger et International. Paris: Tomo 45. p. 289.

385 Cf. JUNIOR, Nelson Nery e NERY, Rosa Maria de Andrade, Código Civil Comentado e Legislação Extravagante, $3^{\mathrm{a}}$ ed. Revisada e ampliada. São Paulo: Ed. Revista dos Tribunais. 2005. p. 432.
} 
Alicerçando-se, portanto, em profundas investigações legais e doutrinárias concernentes aos componentes e dispositivos ínsitos ao contrato de comodato, temos que o contrato de licença de marca não remunerado é unilateral, porquanto gera obrigações para apenas uma das partes, consubstanciada na pessoa do licenciado. No entanto, conforme magistério de Caio Mário da Silva Pereira ${ }^{386}$, esta espécie contratual pode vir a se tornar bilateral imperfeita, na medida em que o licenciado contrair obrigações decorrentes de eventos posteriores à relação jurídica originária.

A gratuidade deste tipo de contrato é elemento capital, sem o qual, tal espécie pode restar desnaturada. Assim o é pelo fato de que apenas o licenciado aufere vantagens e proveitos do uso do bem imaterial licenciado. Importa ressaltar, contudo, que o licenciado tem o dever de suportar eventuais taxas e emolumentos para a manutenção do registro.

Caio Mário adverte que se tem admitido, no comodato, a instituição do chamado "comodato modal" 387 . Utilizando-se desta figura para aplicação ao contrato de licença em estudo, temos que o licenciador poderá impor certas condições ao licenciado, desde que tais imposições não se revistam de caráter de "contraprestação" 388 . Com efeito, o licenciador pode dispor, gratuitamente, de marca de sua titularidade, sem exigir contraprestação, porém demandando que o licenciado faça uso efetivo de sua marca, com o intuito de se evitar a caducidade do direito sobre o sinal.

O titular terá, pois, a faculdade de prever em contrato que o licenciado se utilize apenas da marca licenciada, sendo-lhe defeso recorrer ao emprego de outras marcas que não aquela do licenciante. A exigência de que o sinal seja usado, de forma exclusiva, não significa contraprestação e, assim, não desnatura a gratuidade do contrato não remunerado, conforme afiança os juristas Silvio Venosa ${ }^{389}$ e Carlos Roberto Gonçalves ${ }^{390}$, ao examinarem o contrato de comodato.

\footnotetext{
${ }^{386}$ PEREIRA, Cáio Mário da Silva. Instituições de Direito Civil. 12ª ed. Rio de Janeiro: Forense, 2006. p. 341.

${ }^{387}$ Id., Ibidem. p. 342.

${ }^{388}$ GONÇALVES, Carlos Roberto. Direito Civil Brasileiro. Vol. 3: contratos e atos unilaterais. $3^{\mathrm{a}}$ ed. São Paulo: Ed. Saraiva, 2007, p. 311.
}

${ }^{389}$ VENOSA, Silvio de Salvo. Direito Civil: Contratos em Espécie. Vol.3. $7^{\mathrm{a}}$ ed. São Paulo: Ed. Atlas S.A. 2007. pp. 177/178. 
No que tange à formalidade, é imperioso reconhecer um dos poucos pontos dissonantes entre a licença gratuita e o comodato. Tal assertiva reside no fato de que o contrato de licença de marca gratuito deve ser reduzido a termo, por escrito, com a conseqüente averbação no Instituto Nacional de Propriedade Industrial ${ }^{391}$, para que produza efeitos perante terceiros. O comodato, por seu turno, é informal, não tendo forma prescrita em lei. Destarte, não depende de forma específica. Conforme preleção propugnada por Washington de Barros Monteiro $^{392}$, pode ser convencionado oralmente ou por escrito, sendo, se verbalmente convencionado, passível de comprovação por meio de testemunhas.

O elemento da temporariedade aplicável ao comodato é, por igual, extensivo ao contrato de licença gratuito. O prazo pode ser determinado ou indeterminado, de acordo com o consentimento dos contratantes. No evento de o prazo não restar convencionado, em consonância com a interpretação feita a partir do comando extraído do artigo 581 do Código Civil, a licença da marca se operará pelo período necessário para o uso concedido.

Pode-se depreender, a partir do magistério de Vitor Frederico Kumpel ${ }^{393}$, que a licença gratuita tem uma finalidade, não podendo o licenciador exigir a restituição do bem imaterial disponibilizado, a qualquer tempo, o que denota que o titular da marca terá de aguardar o uso da marca em conformidade com a sua finalidade.

Registre-se, neste aspecto, lição de Caio Mário Pereira da Silva ${ }^{394}$, que ministra a tese de que o comodante (leia-se, licenciador) tem, conforme o princípio da razoabilidade, prerrogativa de reclamar a coisa (leia-se marca) a qualquer tempo, se o contrato houver sido celebrado por prazo indeterminado, assim como se o bem tiver sido utilizado de acordo com o estabelecido pelas partes contratantes.

\footnotetext{
${ }^{390}$ GONÇALVES, Carlos Roberto. Direito Civil Brasileiro. op. cit. pp. 311/312.

${ }^{391}$ Prescreve, in verbis, o art. 140 da Lei 9279/96: “O contrato de licença deverá ser averbado no INPI para que produza efeitos em relação a terceiros".

392 MONTEIRO, Washington de Barros. Curso de Direito Civil-Direito das Obrigações (2a parte). $35^{\mathrm{a}}$ ed. São Paulo: Ed. Saraiva, 2007. pp. 200/201.

${ }^{393}$ KUMPEL, Vitor Frederico. Direito Civil 3 - Direito dos Contratos. São Paulo: Ed. Saraiva, 2005. p.193

394 PEREIRA, Cáio Mário da Silva. Instituições de Direito Civil. 12ª ed. Rio de Janeiro: Forense, 2006. p. 344.
} 
Não obstante, ressalta o eminente civilista, esta situação não se confunde com o “precário”395, instituto típico do Direito Romano, em que a reserva de recobrar a coisa poderia ser exercida a todo e qualquer tempo, sendo irrelevante qualquer prazo em relação ao bem unilateral e gratuitamente disponibilizado. Portanto, a licença da marca, se pudesse ser exigida a qualquer tempo pelo titular, e ao seu livre arbítrio, por certo, perderia completamente seu sentido jurídico e acepção econômica. Por tal motivo, assiste razão o dispositivo inserto no artigo 581 do diploma civil.

A título ilustrativo, valhamo-nos do exemplo seguinte: Tício Ltda. licencia marca de camiseta esportiva denominada "Névius", de sua titularidade, para Caio Ltda. Logo no primeiro mês, o licenciado Caio Ltda. determina a aposição da marca licenciada "Névius" em um lote de dez mil camisetas esportivas de sua fabricação, para posterior lançamento no mercado nacional. No caso hipoteticamente apresentado, de acordo com a essência do art. 581 do CC, Tício Ltda. (licenciador) não poderá extinguir o contrato antes que as camisetas sejam disponibilizadas no mercado, não podendo, outrossim, inibir que Caio comercialize aquele determinado lote, pois que a marca, tal como disponibilizada, deve atender sua finalidade, qual seja potencializar as vendas dos produtos para os quais fora aposta, ainda que o seja de forma limitada e em determinado período de tempo.

Cumpre frisar, outrossim, acerca da inexistência do contrato de licença gratuito "perpétuo" 396 . Se for eviterno, deixa de ser licença gratuita e passa a ser cessão a título gratuito, assim como o comodato "perpétuo" deixa de ser comodato e se transforma em doação.

Da análise da segunda parte do artigo 581 do Código Civil, conclui-se, em caráter análogo, que o licenciador, se demonstrar "necessidade imprevista e urgente", poderá requerer ao juiz que suspenda o uso e gozo do sinal licenciado, antes de terminado o prazo convencional, ou que se determine pelo uso outorgado.

\footnotetext{
${ }^{395}$ FIUZA, César. Direito Civil Completo. $11^{\text {a }}$ ed. Belo Horizonte: Ed. Del Rey, 2008, p. 528.

${ }^{396}$ Cf. PEREIRA, Cáio Mário da Silva. Instituições de Direito Civil. 12a ed. op. cit. p. 344; DINIZ, Maria Helena. Curso de Direito Civil Brasileiro. 3. Teoria das Obrigações Contratuais e Extracontratuais. $23^{\mathrm{a}}$ ed. op. cit. p. 327.
} 
Silvio Rodrigues ${ }^{397}$ adverte que, neste caso, há clara colidência de interesses. O interesse do comodante (licenciador) de ter de reaver seu bem, em decorrência de acontecimento imprevisto e urgente que não pôde antever; e o interesse do comodatário (licenciado) de se utilizar do bem gratuitamente recebido pelo prazo determinado ou presumido. Como resultado de tal embate, conclui o civilista que deve prevalecer o interesse do "dono".

No entanto, abalizando-se na melhor doutrina de Ricardo Fiúza ${ }^{398}$, é de grande cautela que o licenciado preconize pela inserção de cláusula penal ressarcitória quando da confecção do contrato de licença. Esta prudência, decerto, lhe será de grande valia, sobretudo se o titular conseguir reaver a marca licenciada, por força de decisão judicial, antes da exaustão do tempo determinado ou presumido, e naturalmente se tiver demonstrado necessidade urgente e imprevista. É o que ocorre no caso de o licenciado ter dispendido vultosos recursos para a produção de um material em razão da marca licenciada, porém não poder ter tido a oportunidade de usá-la, conforme planejado. É razoável que por isto seja ressarcido, ainda que o titular tenha reavido o bem, com amplo respaldo legal.

O contrato de comodato e, por extensão, o contrato de licença de marca gratuito, é intuitu personae ${ }^{399}$. Assim o é, posto que o caráter personalíssimo norteia a relação jurídica estabelecida, não podendo o objeto da licença ser cedido a terceiro ou sublicenciado ${ }^{400}$. Naturalmente, se o contrato dispuser de forma contrária, o contrato deixará de ser intuitu personae, facultando ao licenciado a possibilidade de sublicenciar o bem imaterial gratuitamente recebido.

\footnotetext{
${ }^{397}$ RODRIGUES, Silvio. Direito Civil: dos contratos e das declarações unilaterais de vontade. Vol. 3. $27^{\mathrm{a}}$ ed. São Paulo: Saraiva. 2000. pp. 247/248.

${ }^{398}$ FIUZA, César. Direito Civil Completo. op. cit. p. 528.

${ }^{399}$ DINIZ, Maria Helena. op. cit. p. 326; PEREIRA, Cáio Mario. op. cit. p. 343; KUMPEL, Vitor Frederico. op.cit. p.191;

${ }^{400}$ Registre-se preleção de Serpa Lopes ao estudar o contrato de comodato. Afiança o civilista: “(...) por isso é um contrato incedivel a terceiros, a menos que o comodante [titular] nisto consista". (LOPES, Miguel Maria de Serpa. Curso de Direito Civil. Vol. 4. $9^{\mathrm{a}}$ ed. Rioa de Janeiro: Ed. Freitas Bastos. 2000. p. 321).
} 
Na omissão do contrato, se o licenciado, na pessoa de seu administrador ou sócio, disponibilizar a terceiro marca licenciada a título gratuito, seja através de cessão, seja por intermédio da modalidade do sublicenciamento, incorrerá nas penas do crime de estelionato, insculpidas no artigo 171 do Código Penal Brasileiro ${ }^{401}$.

Apreciados os atributos dos contratos de licença de uso de marca gratuito, passemos ao exame dos requisitos subjetivos e objetivos desta espécie contratual. Segundo dispõe a primeira parte do art. 139 da Lei 9279/96, tanto o titular de registro, quanto mero depositante do pedido de registro, poderão celebrar contrato de licença para uso da marca.

Neste tocante, merece destaque advertência erigida por parte da doutrina ${ }^{402}$ acerca da prerrogativa de administrador judicial de sociedade em recuperação judicial ou massa falida em dispor de bem (material ou imaterial) destas estruturas em recuperação ou em liquidação. $\mathrm{O}$ artigo 580 do diploma civil prevê que os administradores de bens alheios não poderão dar em comodato, sem autorização especial, os bens confiados à sua guarda ${ }^{403}$.

Note-se que este dispositivo é perfeitamente aplicável ao contrato de licença em investigação, e possui total fundamento e justificativa de ser. Tem o condão de evitar que aqueles que administram sociedades em recuperação ou mesmo falidas possam retirar proveito pessoal, em decorrência da disposição, arbitrária, de bens (no caso em tela, imaterial) que lhe são confiados. Desta forma, por não figurarem como proprietários dos bens que lhe são temporariamente entregues, os administradores não poderão, sem autorização especial, retirar do estabelecimento empresarial bens que causem o descréscimo do valor patrimonial do acervo em liquidação. Com efeito, não lhes é lícito proceder ao livre licenciamento da marca (muitas vezes um dos elementos mais valiosos

\footnotetext{
${ }^{401}$ Reza o art. 171 (Estelionato), do Código Penal Brasileiro: “Obter, para si ou para outrem, vantagem ilícita, em prejuízo alheio, induzindo ou mantendo alguém em erro, mediante artifício, ardil, ou qualquer outro meio fraudulento: Pena - reclusão, de um a cinco anos, e multa. (...) $\$ 2^{o}$ - Nas mesmas penas incorre quem: Disposição de coisa alheia como própria I - vende, permuta, dá em pagamento, em locação ou em garantia coisa alheia como própria (...)”;

${ }^{402}$ KUMPEL, Vitor Frederico. op. cit. 193; PEREIRA, Cáio Mario. op. cit. p. 343.

${ }^{403}$ Impõe-se reproduzir preciosos ensinamentos de Washington de Barros Monteiro a respeito da limitação em apreço. Afirma, o insigne jurista: “Os administradores judiciais (...) não são proprietários e, no entanto, podem constituir comodato acerca dos bens sujeitos à sua guarda, desde que autorizados” (MONTEIRO, Washington de Barros. Curso de Direito Civil - Direito das Obrigações (2a parte). $35^{\text {a }}$ ed. op. cit. p. 204)
} 
do estabelecimento empresarial), somente podendo fazê-lo mediante a necessária autorização do empresário titular da marca ou do magistrado da causa.

Deste modo, na eventualidade de a sociedade titular ou depositante da marca estar sob a gestão de administrador judicial, facultará ao administrador judicial conceder o licenciamento da marca, tão somente se tal ato jurídico for aprovado pelos sócios e/ou determinado pelo juiz.

Ainda na esteira da legislação do comodato, investiguemos os efeitos jurídicos decorrentes do contrato de licença gratuita, estudando-se, para tal fim, as obrigações pertinentes ao licenciado e ao licenciador.

Cumpre-se estabelecer, ab initio, as obrigações fundamentais do licenciado receptor do bem imaterial a título gratuito. Decorre de interpretação do artigo 582 do Código Civil que o licenciado tem o dever de conservar o sinal recebido, como se dele fosse. O uso do bem é personalíssimo, não podendo o licenciado ceder ou mesmo sublicenciar a marca. Caio Mário ${ }^{404}$ adverte que não basta um "cuidado elementar". O insigne jurista recorre ao Direito Romano para afirmar que aquele direito não se satisfazia com a diligência deu um "pai de família", mas sim com a diligência superior ao bonus pater família $^{405}$. O Código Civil não se apresenta, contudo, com tamanha rigidez. Porém, cria mecanismos de segurança, de maneira a blindar os direitos do comodante (licenciador).

Pelo exame dos artigos 582 e 583, sobrepostos ao contrato de licença, o licenciado deve preservar, como sua própria fosse, a marca licenciada, não tendo o direito de empregá-la em desacordo com o estipulado no contrato de licença, sob pena de responder por perdas e danos.

O segundo dever do licenciado corresponde ao emprego da marca conforme a sua natureza ou destinação, comando este igualmente inserto no artigo 582 do CC. Desta

\footnotetext{
${ }^{404}$ PEREIRA, Cáio Mário da Silva. ob cit. pp. 344/345.

405 "In rebus commodatis talis diligentia praestanda est qualem quisque deligentissimus pater famílias suis rebus adhibet” in Digesto, liv., XIII, tit. VI, fr. 18, apud PEREIRA, Cáio Mário da Silva. op. cit. pp.344/345.
} 
forma, conforme outrora anotado, o sinal licenciado não poderá ser utilizado em contrariedade à sua destinação ou natureza. Assim, uma marca originariamente registrada na classe referente a sapatos não poderá ser utilizada pelo licenciado em produtos cosméticos. Neste caso exemplificativo, é notório que a marca foi utilizada em absoluta dissonância com a sua natureza ou destinação, devendo o licenciado responder por perdas e danos pela infração legal cometida ${ }^{406}$.

Outro dever do licenciado é indenizar o licenciador no evento daquele remanescer usando a marca licenciada após consumado o prazo assinalado em contrato ou mesmo após ter recebido notificação resilitória naqueles casos em que o contrato fora celebrado por termo indeterminado. Consoante interpretação do artigo 582, o licenciado constituído em mora, além de por ela responder, pagará, até deixar de usar, royalties referente ao sinal licenciado, remuneração esta arbitrada pelo licenciador.

Da constituição em mora e pagamento de "aluguel" (royalties), decorrem observações pertinentes abalizadas pela melhor doutrina pátria. Vitor Frederico Kumpel ${ }^{407}$ e Caio Mário ${ }^{408}$ repreendem o termo "aluguel” usado pelo legislador na redação do artigo 582 do CC em relação ao licenciado constituído em mora. Para os civilistas, a despeito do dilpoma civil mencionar "aluguel", o termo adequado seria "multa", que corresponderia a remuneração que seria devida se o contrato passasse a ser remunerado. Adicionalmente, a licença gratuita não pode se converter automaticamente em licença remunerada.

Outra observação importante apontada por Cáio Mário ${ }^{409}$, no que diz respeito ao dispostivo supra mencionado, recai sobre a questão do arbitramento do valor devido pelo uso da marca depois de expirado o período pré-determinado no contrato de licença gratuito. Pelo comando do artigo 582, entende-se que o valor da remuneração (royalty)

\footnotetext{
${ }^{406}$ Em relação à penalidade pelo uso inadequado do bem disponibilizado, Washington de Barros Monteiro indica a maior rigidez dos romanos, os quais aplicavam sanções civil e penal pela infração verificada. A sanção penal era aplicada em razão de os romanos considerarem este ato como "furto simples o abuso do comodato". (MONTEIRO, Washington de Barros. Curso de Direito Civil - Direito das Obrigaçães $\left(2^{a}\right.$ parte). $35^{\text {a }}$ ed. ob. cit. p. 206)

${ }^{407}$ KUMPEL, Vitor Frederico. op. cit. p. 194.

${ }^{408}$ PEREIRA, Cáio Mário da Silva. op. cit. p.346.

${ }^{409}$ Idem. Ibidem. p.346.
} 
deverá ser livremente fixado pelo licenciador (na redação da lei, pelo comodante). O valor, por ser arbitrado em caráter penalizatório, poderá ser superior ao valor cobrado se o contrato de licença em comento remunerado fosse. No entanto, conforme adverte Cáio Mário, esta fixação não pode ser manifestamente abusiva ${ }^{410}$. Se assim for, através da aplicação analógica do artigo 413 do CC, poderá o juiz, na eventualidade de o titular ser acionado pelo licenciado, reduzir equitativamente o valor da multa pecuniária, levando-se em consideração a natureza e a finalidade do negócio. Aqui, estamos diante de uma das inúmeras aplicações pontuais do princípio da vedação da onerosidade excessiva ao contrato de licença de uso de marca.

A fixação do valor penalizatório, ao qual a lei denomina erroneamente de “aluguel”, pode ser arbitrada pelo titular na petição inicial ou mesmo no curso da ação em função das provas produzidas, inclusive pericial, se o valor for contestado pelo réu ${ }^{411}$.

Sobre a modalidade exigida para a constituição em mora, o art. 397 do Código Civil é impositivo ao afirmar que o inadimplemento da obrigação, positiva e líquida, no seu termo, constitui de pleno direito em mora o devedor. Ademais, na ausência de termo convencionado, reza o dispositivo em comento que a mora se constituirá mediante interpelação judicial ou extrajudicial.

Este comando é avalizado pela jurisprudência pátria, a qual tem admitido duas hipóteses concernentes à constituição em mora: a primeira consiste naquelas relações jurídicas cujo prazo fora previamente determinado pelos contratantes. Neste caso, não há a necessidade de qualquer tipo de interpelação para constituição do licenciado em mora. Findo o prazo consignado em contrato, diante da desídia do licenciado, estará este automaticamente constituído em mora, podendo o titular, de forma direta, promover a ação judicial cabível $^{412}$. A segunda hipótese consiste nas relações em cujo instrumento não fora

\footnotetext{
${ }^{410}$ Fiúza adverte que não se pode perder de vista que o valor arbitrado pelo comodante [titular] tem natureza de pena, portanto, ainda que não seja excessivo, deve ser mais alto do que um "aluguel" convencional. (FIUZA, César. Direito Civil Completo. op. cit. p. 529).

${ }^{411}$ VENOSA, Silvio de Salvo. op. cit. p. 176.

${ }^{412}$ Assim posiciona-se o STJ a respeito da matéria: “(..)O comodato com prazo certo de vigência constitui obrigação a termo, que dispensa qualquer ato do credor para constituir o devedor em mora (mora "ex re"), nos termos do que dispõe o art. 960 do Código civil [CC/1916 e que corresponde ao art. 397 do CC/02/].(REsp 71.172/SP, Rel. Min. Sálvio de Figueiredo Teixeira, Quarta Turma, julgado em 18/11/1997, DJ 21/09/1998 p. 165)
} 
avençado prazo determinado para o término da relação jurídica. Neste caso, deverá o titular constituir o licenciado em mora, podendo fazê-lo judicialmente, extrajudicialmente ou até oralmente $^{413}$. Há doutrinadores ${ }^{414}$ e jurisprudência consolidada ${ }^{415}$ que ministram a tese de que a citação pode ser considerada como interpelação, contanto que seja concedido prazo razoável para a restituição na hipótese de concessão de liminar.

O licenciado obriga-se, por igual, a responder pelos riscos do bem imaterial que passou a ficar sob os seus cuidados ${ }^{416}$. Aplica-se, neste caso, o princípio da boa-fé objetiva no momento da execução do contrato. Desta forma, deverá responder perante o titular pelo mau uso da marca licenciada, sobretudo se do sinal se utilizou indevidamente. Exemplificativamente: "A" licencia para "B" determinada marca de chocolate. "B", após ter aposto a marca de chocolate em seus produtos, passa a comercializá-los. Os produtos disponibilizados por "B" no mercado, já com a marca licenciada, apresentam-se impróprios para o consumo, acabando por contaminar milhares de consumidores. Como resultado deste fatídico evento, oriundo da desídia de "B", a marca de titularidade de "A" passa a ter valor de mercado, em um curtíssimo espaço de tempo, reduzido pela metade do que valia na data da subscrição do contrato de licenciamento.

No caso hipotético que ora se apresenta, é cristalino que o valor da marca licenciada foi depreciado em decorrência, única e exclusivamente, da desídia do licenciado, que deveria ter se certificado sobre a qualidade dos produtos que estava disponibilizando no mercado e substituí-los por outros em perfeitas condições de consumo. E deveria fazê-lo em tempo hábil, de sorte a evitar qualquer lesão à imagem da marca licenciada. Por tal motivo, é certo que o licenciado deverá indenizar o titular da marca se algum dano causou ao bem que houvera sido disponibilizado a título gratuito.

\footnotetext{
${ }^{413}$ Conforme lição ministrada por Washington de Barros Monteiro, "a constituição em mora do comodatário depende de interpelação, que não exige, todavia, forma especial; até verbal ela pode ser" (MONTEIRO, Washington de Barros. op. cit. p. 208).

${ }^{414}$ VENOSA, Silvio de Salvo. Direito Civil: Contratos em Espécie. op. cit. p. 176; e ALVES, Jones Figueiredo in ASSUNÇÃO, Alexandre Guedes Alcoforado; MALUF. Carlos Alberto Dabus; FIGUEIRA JR., Joel Dias. Código Civil Comentado. $6^{\mathrm{a}}$ ed. Coord. Regina Beatriz Tavares da Silva. São Paulo: Saraiva, 2008. p. 533.

${ }^{415}$ STJ, $3^{\text {a }}$ T., REsp 25.298/SP, Rel. Min. Cláudio Santos, Dj, 16/11/1992; e TJ/SP, Apel. Civ. n. o 0836768-6, 26/05/2003, $5^{\text {a }}$ Cam., Rel. Juiz Alberto Mariz de Oliveira.

${ }^{416}$ KUMPEL, Vitor Frederico. ob. cit. p. 194.
} 
Contrariu sensu, o licenciado não responderá por perdas e danos que se originarem de acontecimentos que venham, de alguma forma, prejudicar o bem imaterial licenciado. Recorrendo-se ainda ao exemplo acima, se o valor da marca concedida por "A" foi depreciado por "B" por fatores extrínsecos à vontade e aos atos por ele praticados, "B" não deverá ressarcir "A" pela desvalorização da marca cedida. De tal modo, exemplificativamente, não há que se falar em responsabilidade do licenciado por perdas e danos se, no período em que houve o licenciamento, o mundo imergiu em grave crise econômica e financeira, incidente sobre os mais diversificados ramos econômicos, fazendo com que a marca licenciada, avaliada em US\$ 1 milhão quando do licenciamento, passasse a valer US\$ 250 mil após cinco meses de subscrito o contrato de licença gratuito. Eis um claro exemplo de caso acidental externo e inesperado que desobriga o licenciado a indenizar o licenciador pelo dano verificado ao bem imaterial disponibilizado.

Após discorrer acerca da desvalorização da marca, impõe-se examinar evento inverso, em que a marca licenciada venha a valorizar-se como efeito do bom uso realizado pelo licenciado. A partir de exame do legado de Washington de Barros Monteiro ${ }^{417}$, ao investigar o comodato, concluímos que o licenciado terá direito aos "frutos" decorrentes da valorização da marca, ou seja, terá direito de ser monetariamente recompensado por tal valorização, na seguinte conjectura:

(a) o licenciado houver contribuído para esta valorização, seja pela hábil e eficiente divulgação do bem licenciado, seja pelo oferecimento de produtos ou serviços os quais, pela notória qualidade, tenham arrebatado o consumidor e/ou ampliado o mercado para o qual fora originariamente destinado; e, sobretudo,

(b) na hipótese da mencionada remuneração ter sido expressamente consignada em contrato, em que pese argumentação adversa propugnada por parte da doutrina, esta capitaneada por Carlos Alberto Bittar ${ }^{418}$, corroborando o entendimento de que “(..) $o$ comodatário [licenciado] tem, em contraposição [às obrigações estipuladas em lei],

\footnotetext{
${ }^{417}$ MONTEIRO, Washington de Barros. Curso de Direito Civil - Direito das Obrigações (2a parte). $35^{\mathrm{a}}$ ed. op. cit. p. 206.

${ }^{418}$ BITTAR, Carlos Alberto. Curso de Direito Civil. Vol. 2. Rio de Janeiro: Forense Universitária, 1994. p. 719.
} 
direitos sobre benfeitorias necessárias e úteis, direitos aos interditos e outros, pois recebe o bem, dele retirando as utilidades próprias e nos limites convencionados".

Partilhamos, contudo, da tese advogada pelos juristas Washington de Barros Monteiro e Silvio Venosa, no sentido de que é essencial que o licenciado se atenha à inserção de cláusula, no contrato, prevendo participação nos "frutos" da valorização do sinal licenciado e outros eventuais benefícios decorrentes do uso da marca licenciada gratuitamente, após o término do prazo contratual. Isto para evitar que sejam erigidas controvérsias, podendo ser o licenciado, injustamente, preterido da recompensa decorrente da valorização da marca, valorização esta fruto de grande trabalho e esforço envidados pelo próprio licenciado ${ }^{419}$.

Por fim, para rematar as obrigações do licenciado, remetemo-nos ao estudo do artigo 585 do Código Civil. Por este dispositivo, se houver dois ou mais licenciados para um mesmo sinal, todos ficarão solidariamente responsáveis para com o licenciador. Consoante dicção do artigo 265 do CC, "a solidariedade não se presume; resulta da lei ou da vontade das partes".

Logo, em sendo a marca licenciada para o uso de duas pessoas jurídicas distintas, o que ocorre principalmente quando as duas pertencem ao mesmo grupo econômico, qualquer uma delas responderá por eventuais danos acarretados ao bem licenciado, independentemente de qual tenha sido a licenciada que deu azo à infração legal e/ou contratual. Saliente-se, outrossim, que a responsabilidade não será proporcionalmente compartilhada no evento de ambos os licenciados terem dado causa à infração.

Qualquer licenciado poderá ser acionado para responder integralmente pelo dano verificado, ainda que a lesão tenha sido cometida pelo outro não demandado. Após, entretanto, e via ação de regresso, poderá o licenciado condenado acionar o outro, de fato culpado, conforme a letra do artigo 283 do CC, que prescreve: "o devedor que satisfez a dívida por inteiro tem direito a exigir de cada um dos co-devedores a sua quota, dividindo-

\footnotetext{
${ }^{419}$ Registre-se, neste aspecto, valiosas palavras de Silvio Venosa: "Na falta de autorização, o comodatário não pode assenhorear-se dos frutos da coisa. Essa permissão poderá até mesmo ser tácita e decorrer dos usos e costumes, mas não pode estar ausente. Aqui, como em todos os contratos, deve-se ter em mente a boafé objetiva, em paralelo com a subjetiva” (VENOSA, Silvio de Salvo. Direito Civil: Contratos em Espécie. Vol.3. $7^{a}$ ed. São Paulo: Ed. Atlas S.A. 2007. pp. 174)
} 
se igualmente por todos a do insolvente, se o houver, presumindo-se iguais, no débito, as partes de todos os co-devedores".

O licenciador, por seu turno, tem como deveres fundamentais ${ }^{420}$, nos contratos de licença de uso de marca não remunerado ou gratuito:

(a) assegurar que o licenciado faça uso manso e pacífico da marca licenciada, não podendo perturbar o uso e gozo do bem, a não ser que dele necessite, em caráter imprevisto e emergencial, o que deverá ocorrer apenas mediante autorização judicial, de acordo com o art. 581 do CC;

(b) informar ao licenciado sobre eventuais ações judiciais, administrativas ou qualquer outro ato que venha a prejudicar o uso manso e pacífico do sinal licenciado;

(c) pagar despesas extraordinárias que decorram da utilização da marca. Concernente a este dever, é imperioso que o contrato de licença preveja expressamente se as custas periódicas correspondente a taxas e emolumentos para a renovação da marca serão suportadas pelo seu titular, o que é mais natural, ou pelo licenciado. Jones Figueiredo Alves $^{421}$ ministra a tese que as despesas ordinárias para a manutenção do bem, devem ser custeadas pelo comodatário [licenciado], ainda que o titular pague e depois demande reembolso do comodatário $(\text { licenciado })^{422}$

(d) indenizar o licenciado por vício oculto que, dolosamente, haja omitido, desde que, por força de tal vício possa o licenciado ser prejudicado.

\footnotetext{
${ }^{420}$ KUMPEL, Vitor Frederico. op. cit. 195; PEREIRA, Cáio Mario. op. cit. p. 346. FIUZA. Cesar. op. cit. p. 529.

${ }^{421}$ ALVES, Jones Figueiredo in ASSUNÇÃO, Alexandre Guedes Alcoforado; MALUF. Carlos Alberto Dabus; FIGUEIRA JR., Joel Dias. Código Civil Comentado. $6^{\mathrm{a}}$ ed. Coord. Regina Beatriz Tavares da Silva. São Paulo: Saraiva, 2008. p. 535.

${ }^{422}$ Nesse sentido, aponta o julgado seguinte: “ São devidos os encargos decorrentes de comodato, tais como cotas condominiais e imposto predial, procedendo a sua cobrança contra o comodatário para reembolso do que despendeu o comodante” (TACRJ, AC 10.214/95 (Reg. 966-3), 4ª C., Rel. Juiz José Rondeau, j. em 14/03/96)
} 
Ilustrativamente: o titular licencia marca cujo registro expirou e não foi renovado dentro do prazo legal ou ainda licencia bem que sobre ele incidem certas constrições judiciais. Naturalmente, o licenciado poderá vir a ser prejudicado, especialmente se tiver produzido produtos ou prestado serviços confiando no uso manso e pacífico do sinal recebido.

No que tange à extinção do contrato de licença de uso de marca celebrado a título gratuito, valemos-nos das causas que ensejam o término do contrato de comodato, quais sejam:

(a) expiração do prazo pré-estabelecido. O contrato de licença se extinguirá no dia seguinte à data final convencionada no instrumento, obviamente, no evento de ter sido avençado pacto com prazo determinado;

(b) advento do prazo do uso do bem, de acordo com o fim para o qual foi licenciado. Conforme acima amplamente exposto, se não houver prazo determinado préestabelecido, o licenciador poderá reclamar a devolução da marca licenciada após período necessário para o uso concedido. Assim reza o art. 581 do CC. Naturalmente, esta questão pode ser de complexidade elevada ou reduzida, dependendo do que constar da cláusula versando sobre o objeto do contrato. Portanto, quanto mais delimitada for a cláusula contratual neste aspecto, menores serão os problemas que o titular terá para reaver a marca licenciada. Diante de controvérsia entre titular e licenciado a respeito do tempo necessário para o uso concedido, competirá ao juiz fixar termo e/ou condições para o término do prazo;

(c) resolução contratual. Conforme será adiante delineado, o titular tem o direito de terminar o contrato antecipadamente ao prazo avençado, pleiteando do licenciado as perdas e danos decorrentes do inadimplemento contratual, sobretudo em razão do uso inadequado $^{423}$ do bem imaterial recebido.

${ }^{423}$ GONÇALVES, Carlos Roberto. Direito Civil Brasileiro. op. cit. p. 319. 
Este descumprimento reside, na grande maioria das vezes, no fato de o licenciado usar a marca em desconformidade com o estipulado em contrato. Assim poderá ser, por exemplo, no evento de o licenciado usar a marca em produtos ou serviços diferentes daqueles pactuados entre as partes contratantes; ou se continuar usando a marca mesmo após o término do prazo previamente consentido; ou se ceder a marca à outrem; ou se sublicenciar a marca não podendo fazê-lo; dentre violações outras aptas a ensejar a resolução do contrato por parte do titular da marca.

Nestes casos, além de resolvido o contrato, deverá o licenciado indenizar o titular da marca, em razão da flagrante ofensa ao art. 187 do Código Civil, que reza que "também comete ato ilícito o titular de um direito que, ao exercê-lo, excede manifestamente os limites impostos pelo seu fim econômico ou social, pela boa-fé ou pelos bons costumes"

(d) resilição unilateral. Pode o titular da marca encerrar o contrato de licença antes do prazo expresso ou presumido, e de forma injustificada, desde que autorizado pelo juiz, que somente o fará se o licenciador demonstrar necessidade imprevista e urgente $^{425}$. $\mathrm{O}$ licenciado, por seu turno, poderá, a qualquer tempo, encerrar o contrato, se o bem que foi obtido em seu interesse passou a lhe desinteressar após certo período de tempo ${ }^{426}$;

(e) distrato. Ocorre quando licenciador e licenciado, de comum acordo, decidem extinguir o contrato antes mesmo de findo seu prazo pré-estabelecido ou convencional;

\footnotetext{
${ }^{424}$ Idem, Ibidem. p. 320.

${ }^{425} \mathrm{O}$ colendo Superior Tribunal de Justiça, na esteira do preceito legal, tem se posicionado no sentido de que a resilição unilateral, nas relações de comodato, somente é possível se demonstrada necessidade imprevista e urgente por parte do comodante. "Civil. Comodato por prazo indeterminado. Retomada do imóvel. Se o comodato não tiver prazo convencional, presumir-se-lhe-á o necessário para o uso concedido, salvo necessidade imprevista e urgente do comodante (CC, art. 1.250). 2. Processo Civil. Reintegração de Posse. Medida Liminar. A só notificação do comodatário de que já não interessa ao comodante o empréstimo do imóvel é insuficiente para que o juiz determine a imediata reintegração de posse; ainda que deferida a medida liminar, deve ser assegurado o prazo necessário ao uso concedido sem perder de vista o interesse do comodante, para não desestimular a benemerência. Recurso especial conhecido em parte e, nessa parte, provido. (REsp 571.453/MG, Rel. Ministro Ari Pargendler, Terceira Turma, julgado em 06/04/2006, DJ 29/05/2006 $\quad$ p. 230) Disponível em $<$ http://www.stj.jus.br/SCON/jurisprudencia/doc.jsp?livre=notificacao+comodato $\& \& b=A C O R \& p=t r u e \& t=\&$ $1=10 \& \mathrm{i}=2 \#>$. Acesso em 30/09/09.

${ }^{426}$ Neste sentido, avaliza a professora Maria Helena Diniz, ao estudar as causas ensejadoras da extinção do contrato de comodato: “(...) b) o comodatário poderá, a qualquer tempo, resilir tal negócio porque, se foi contraído em seu interesse, não está obrigado a conservar o objeto de cujo uso se desinteressou" (DINIZ. Maria Helena. op. cit. p. 333)
} 
(f) falência do licenciado. No caso de ser decretada a falência do licenciado, o contrato de licença se quedará automaticamente extinto, tendo o titular da marca o direito de, imediatamente, "reavê-la"427.

(g) extinção do registro marcário. Na hipótese de o registro não ser renovado ou ser extinto por ato administrativo ou judicial, o contrato de licença será considerado, automaticamente, encerrado pela perda de seu objeto central;

Por fim, cumpre sinalizar, en passant, para a possibilidade da promessa de licença de marca não remunerada. Abalizando-se na melhor doutrina ministrada por Silvio de Salvo Venosa ${ }^{428}$, ao investigar o contrato de comodato, inclinamo-nos à conclusão a seguir apresentada: considerando que não há previsão no ordenamento jurídico pátrio concernente à regulamentação de instrumento jurídico que verse sobre promessa de licença de marca, a título gratuito, há a possibilidade de se criar contrato atípico apresentando este perfil. $\mathrm{O}$ ponto nevrálgico deste instrumento reside em sua inexecução. Na esteira do que preleciona Venosa, levando-se em consideração a diretriz geral do pré-contrato, ou contrato preliminar, temos que o promitente titular da marca não está obrigado a licenciar a marca prometida, por ser de sua propriedade. Não obstante, o jurista assegura que, no evento de o titular não cumprir com o prometido, deverá pagar multa (se prevista em contrato) ou indenizar o promitente licenciado pelas perdas e danos por este suportados.

\section{V.4.2 CONTRATO DE LICENÇA DE USO DE MARCA REMUNERADO CONSOANTE A APLICAÇÃO DOS DISPOSITIVOS NORMATIVOS INCIDENTES SOBRE O CONTRATO DE LOCAÇÃO DE COISAS}

Após investigado o contrato celebrado a título gratuito, adentremos à esfera do contrato de licença de uso de marca remunerado, à luz da teoria da aplicação analógica.

\footnotetext{
${ }^{427}$ VENOSA, Silvio de Salvo. Direito Civil: Contratos em Espécie. op. cit. p.175.

${ }^{428}$ VENOSA, Sílvio de Salvo.Direito Civil, Contratos em Espécie, 7 a ed., São Paulo: Ed. Atlas. 2007. vol. 3. p. 171 .
} 
Passemos, pois, ao exame dos elementos do contrato de locação de coisas que sobre a espécie contratual objeto desta tese irradiam efeitos.

Com relação às obrigações concernentes ao titular e ao licenciado, impõe-se reconhecer que os deveres dos contratantes seguirão, em grande parte, aqueles abalizados no capítulo que se debruçou sobre o contrato de licença de marca não remunerado, com a crucial reserva de que, nos contratos em estudo (remunerados), o licenciado terá o dever de adimplir pontualmente os valores pré-convencionados junto o titular da marca, sob pena de resolução contratual por inadimplência obrigacional.

Oportuno apontar magistério de Luiz Leonardos ${ }^{429}$, o qual assinala, na esteira das principais autoridades sobre o assunto, capitaneadas por Gama Cerqueira, os principais deveres que devem ser cumpridos pelos contratantes. Reitere-se que são aplicados aos contratos de licença de uso marca remunerado os dispositivos inerentes aos contratos de locação de coisas, compreendidos entre os art. 565 a 578 do Código Civil vigente, harmonizados com a regulamentação prevista em legislação especifica (Lei 9279/96 e Instrução Normativa INPI 135/97). Passemos, pois, à análise destes dispositivos sobrepostos à espécie contratual em comento.

Nos termos do artigo 566 do Código Civil, configuram obrigações do titular/licenciante: disponibilizar ao licenciado a marca licenciada, em estado de servir ao uso a que se destina, e a mantê-la nesse estado, pelo tempo do contrato, salvo disposição contratual diversa; garantir ao licenciado, durante o tempo do contrato, o uso pacífico do bem intangível disponibilizado ${ }^{430}$. A garantia do uso pacíficio coincide com a validade do registro, título que assegura a prerrogativa do uso.

\footnotetext{
${ }^{429}$ LEONARDOS, Luiz. O Contrato de Licença para Exploração de Privilégio de Invenção e para o Uso de Marca...op. cit. pp. 49-53.

${ }^{430}$ Este dispositivo segue o teor do artigo 1719 do Código Civil Francês, o qual estatui que o locador tem o dever de garantir que o locatário desfrute, mansa e pacificamente, do bem locado, ao longo de todo o prazo licenciado.
} 
Ante o exposto, registros nulos ou sujeitos à caducidade serão imprestáveis ao propósito a que se destinam, porquanto não serão oponíveis em relação a terceiros que poderão livremente se utilizar do bem $^{431}$;

Depreende-se do comando inserto no art. 567 do Código Civil que, se durante o período de licença, a marca se deteriorar (desvalorizar-se), sem culpa do licenciado, terá este o direito de pleitear redução proporcional dos valores pagos a título de royalties, ou mesmo resolver o contrato, caso a marca não mais sirva para o fim ao qual originariamente se destinava. Este artigo deve ser interpretado à luz do princípio da onerosidade excessiva, princípio este que será adiante investigado com maior acuidade.

Com lastro no artigo 568 do Código Civil, o licenciador terá o dever de proteger o licenciado contra terceiros que prejudiquem ou pretendam molestar o uso manso e pacífico do bem disponibilizado, devendo, por igual, responder pelos seus vícios ou defeitos anteriores à subscrição do instrumento de licenciamento. Os vícios redibitórios e defeitos ocultos serão objetos de apreciação mais acurada, quando da investigação dos dispositivos contratuais que intergram o negócio jurídico de direito industrial em análise.

Remetemo-nos ao artigo 569 do Código Civil, o qual entendemos pertinente colacionar, para corroborar nossa tese de que, no evento de o licenciante, exercendo seu poder fiscalizador, evidenciar, de forma patente, a não exploração da marca pelo licenciado ou, conforme leitura do dispositivo civil supra indicado, não servir-se o licenciado da marca para os usos convencionados ou presumidos, o contrato em apreço poderá ser resolvido com o escopo de se evitar o perecimento do direito correspondente ao sinal concedido, em consequiência de seu desuso, ex vi dos artigos 142 e 143 da Lei $9.279 / 96^{432}$. Colacione-se, neste sentido, o dispostivo civil em exame:

\footnotetext{
${ }^{431}$ Cf. LEONARDOS, Luiz. O Contrato de Licença para Exploração de Privilégio de Invenção e para o Uso de Marca...op. cit. p. 50.

${ }^{432}$ Cf. Artigos 142 e 143 da Lei 9.279/96. “Art. 142. O registro da marca extingue-se: (...) III - pela caducidade; Art. 143 - Caducará o registro, a requerimento de qualquer pessoa com legítimo interesse se, decorridos 5 (cinco) anos da sua concessão, na data do requerimento: I - o uso da marca não tiver sido iniciado no Brasil; ou II - o uso da marca tiver sido interrompido por mais de 5 (cinco) anos consecutivos, ou se, no mesmo prazo, a marca tiver sido usada com modificação que implique alteração de seu caráter distintivo original, tal como constante do certificado de registro".
} 
Art. 569. O locatário é obrigado:

I - a servir-se da coisa alugada para os usos convencionados ou presumidos, conforme a natureza dela e as circunstâncias, bem como tratá-la com o mesmo cuidado como se sua fosse; (grifou-se) $(\ldots \ldots . .$.

A resolução do contrato de licença de uso de marca opera-se nos casos em que umas das partes não cumprir com suas obrigações, por inadimplemento contratual. Assim, com fulcro no artigo 474 do diploma civil, a resolução poderá ser tácita, necessitando da interpelação judicial, ou ainda expressa, caso em que o contrato deverá prever cláusula resolutiva expressa. Nesta última hipótese, temos que, no caso de inexecução do contrato por uma das partes, o contrato restará automaticamente resolvido, não necessitando, portanto, de pronunciamento judicial. Com efeito, é forçoso reconhecer que a abstenção quanto ao uso da marca, conforme presumido pelas partes contratantes - leia-se "uso indevido" - conduz à caracterização, com clareza, de uma infração obrigacional, dando ensejo, desta sorte, à rescisão contratual, sob a modalidade resolução, por parte do titular da marca.

A esta inteligência têm-se rendido os tribunais brasileiros, ao se debruçarem sobre casos cujo objeto central reside na resolução contratual, fruto da utilização indevida da marca licenciada ${ }^{433}$. Imperioso faz-se trascrever trechos de magistral acórdão extraído do Tribunal de Justiça do Estado de São Paulo, alicerçado em precioso voto paradigmático emitido pelo eminente Desembargador Francisco Loureiro, decisão esta que resguarda os interesses do licenciante, ao mesmo tempo em que salvaguarda os direitos do consumidor $^{434}$ :$$
\text { (...) }
$$

Na lição clássica de João da Gama Cerqueira, apoiado em Carvalho de Mendonça "a lei não visa proteger a simples combinação de emblemas ou de palavras, mas proteger o direito, resultado do trabalho, da capacidade, da inteligência e da probidade do industrial ou do comerciante" (CERQUEIRA,
}

\footnotetext{
${ }^{433}$ Registre-se, neste aspecto, decisão extraída do TJ/RJ: "Marca comercial. Contrato de licença. Rescisão em razão do uso indevido da marca. Venda de refeições a quilo que enfraquece o nome comercial. Violação de cláusula contratual objeto de notificação. Direito do titular do registro de zelar pela reputação da marca registrada. Incidência dos artigos 130, III, e 139 da Lei Federal 9.279. Desnecessidade de perícia se não há reconvenção discutindo o valor mercantil da marca. Preliminar rejeitada. Apelação desprovida" (Apelação Cível n. ${ }^{\circ}$ 2006.001.69.224. 10ª Câmara Cível. TJ/RJ. Rel. Des. Bernardo Moreira Garcez Neto. Julg. em 11 de abril de 2007).

${ }^{434}$ Apelação Cível n. ${ }^{\circ}$ 521.406-4/7-00. Quarta Câmara de Direito Privado. TJ/SP. Rel. Des. Francisco Loureiro. Julg. em 05 de março de 2009. Disponível em: <www.tj.sp.gov.br>.
} 
João da G., Tratado da Propriedade Industrial, Vol. 2, $2^{a}$ ed., RT, São Paulo, 1982, p. 758).

(...) Assim é que, embora a ré esteja autorizada a explorar a marca, deve fazê-lo em estrita conformidade aos padrões exigidos pela autora.

O fundamento do reclamo da autora parece ter sido a insistência do autor em explorar a marca de forma totalmente incompativel com os serviços prestados pela rede $\mathrm{Mr}$. Sheik. A ré, por gozar da qualidade de exploradora original da marca, insiste em seu direito de fazê-lo de forma distinta daquela exigida das franquias recentes da empresa autora. Oferece serviços e produtos que destoam dos demais estabelecimentos que exploram a marca e não obedece normas de apresentação da loja e funcionários.

Não se conforma a autora com o comportamento da ré, que entende ser prejudicial ao bom nome que atualmente goza a marca.

Tanto a empresa autora, como todas as empresas franqueadas, têm trabalhado ao longo dos anos para tornar a marca Mr. Sheik não apenas conhecida dos consumidores, mas sinônimo de um padrão de qualidade de produtos $e$ serviços. A conduta da empresa ré de explorar a marca de forma alheia aos demais estabelecimentos gera evidente prejuizo a trabalho conjunto realizado pela autora e demais licenciados ao uso da marca.

(...) a quebra na expectativa repercute imediatamente em prejuízo a todos os estabelecimentos e não apenas àquela da ré.

Evidencie-se, aliás, que a teoria da aparência, quotidianamente aplicada em nossos Tribunais, autoriza ao consumidor até mesmo a acionar a empresa autora por conta dos atos praticados pela ré. A tolerância da autora ao exercício de atividade incompatível sob a mesma denominação ser-lhe-ia em todo prejudicial.

(...)

Em suma, correta a sentença que acolheu o pedido inicial a ré a se abster de usar a marca MR SHEIK em suas lojas.

Apenas os fundamentos do acolhimento do pedido é que são distintos, porque se fundam não na exclusvidade do uso da marca, mas sim na violação do padrão de qualidade e de imagem por parte da ré. (...) (grifou-se)

Ante o acima exposto, temos que, no evento de o licenciado utilizar-se da marca licenciada de forma contrária à pactuada, ou de forma distinta para a qual se destina, ou ainda se ela for depreciada, desvalorizada ou tiver sua imagem distorcida perante o público consumidor por manifesto abuso do licenciado, terá o titular da marca o direito de, além de resolver o contrato, exigir perdas e danos ${ }^{435}$. A ação pertinente a ser promovida pela parte lesada consiste na Ação de Rescisão Contratual cumulada com Indenização, pelo rito ordinário $^{436}$.

Sob inspiração do art. 569 do Código Civil, o licenciado tem como obrigações:

\footnotetext{
${ }^{435}$ Cf. Art. 570 do Código Civil Brasileiro.

${ }^{436}$ TARTUCE, Flávio. Direito Civil. ob. cit. p. 222.
} 
(i) conforme acima exposto, servir-se da marca licenciada para os usos convencionados ou presumidos, conforme a natureza dela, classes em que se encontra registrada e as circunstâncias, bem como tratá-la com o mesmo cuidado como se sua fosse. Este dever denota que o licenciado terá de coligar a marca recebida em seus produtos ou serviços, apenas em relação à(s) classe(s) em que o sinal fora registrado pelo titular no Instituto Nacional de Propriedade Industrial;

(ii) realizar o pagamento pontual dos valores estipulados no contrato de licença, a título de royalties, nos prazos ajustados, e, em falta de ajuste, segundo o costume do lugar ${ }^{437}$;

(iii) a levar ao conhecimento do licenciante as turbações de terceiros, que se pretendam fundadas em direito ${ }^{438}$;

(iv) findo o licenciamento, restituir (deixar de usar) o bem imaterial ao qual teve acesso por determinado período de tempo, no estado em que o recebeu, salvas as depreciações econômicas naturais ao uso regular, extrínsecas à vontade e aos atos encetados pelos licenciado quando de sua utilização. A recusa quanto à abstinência de uso após o termo final, concederá ao titular o direito de promover as medidas judiciais e administrativas pertinentes, indicando, dentre outros argumentos, atos de contrafação ensejados pelo licenciado descumpridor $^{439}$.

No que pertine ao termo do contrato, o titular não poderá, antes da expiração do prazo, reaver o bem disponibilizado. Caso o faça, deverá indenizar o licenciado pelas perdas e danos verificados. O licenciado, por igual, não terá a faculdade de restituir a

${ }^{437}$ Asin Singh e Julie le Bars, com inspiração no artigo 1729 do Código Civil Francês (contrato de locação), indicam que o licenciado tem o dever de cumprir com todas as obrigações admitidas em contrato de licença, utilizando-se da marca da forma como previamente pactuada, bem como adimplindo os royalties ("aluguel") acordados com o licenciador ("locador"), dentre outras obrigações assumidas. (Cf. WILKOF, Neil e BURKITT, Daniel. Trademark Licensing...op. cit. p. 270 e ss.)

${ }^{438}$ Luiz Leonardos aponta que desta obrigação advém reflexo direto no direito do licenciado. De tal modo, informando ao licenciante as violações praticadas por terceiros, o titular deverá tomar as medidas cabíveis para que o licenciado faça uso manso e pacífico da marca licenciada. (LEORNADOS, Luiz. op. cit. p. 52).

${ }^{439}$ Idem, Ibidem. p.52. 
marca previamente ao exaurimento do prazo. Se o fizer, deverá pagar, proporcionalmente, a multa pré-ajustada em contrato. Em ambos os casos, se o dever de compensar o licenciamento pelo tempo que faltar constituir indenização flagrantemente abusiva, poderá o magistrado fixar bases mais razoáveis de indenização ${ }^{440}$. Este dispositivo, em que se verifica a patente aplicação do princípio da vedação da onerosidade excessiva ao contrato de licença de uso de marca, é novel, não encontrando, portanto, correspondência no Código Civil revogado de 1916.

Cumpre salientar, bem assim, que o licenciado terá o direito de reter a marca, ou seja, continuar utilizando-a, enquanto não for devidamente ressarcido pela inadimplência contratual praticada pelo titular, consubstaciada no ato de pleitear a devolução antecipada do bem imaterial, em flagrante lesão à clausula relativa ao termo de contrato ${ }^{441}$. Esta regra trazida à tona pelo Diploma Civil, por igual, é inovadora, por não encontrar correspondência na legislação civil revogada.

Acrescente-se, ainda, que o licenciado também poderá exercer o direito de retenção da marca, no evento de ter realizado investimentos expressivos visando à valorização do bem imaterial recebido em licença. Denote-se, contudo, que esta regra somente é aplicável na hipótese de o titular ter consentido expressa e favoravelmente à realização, pelo licenciado, de tais investimentos objetivando a maximização do valor econômico da marca ${ }^{442}$.

O contrato de licença de uso de marca pode ser fixado por prazo determinado ou indeterminado $^{443}$. Se for por tempo determinado, cessará de pleno direito quando do encerramento do prazo estipulado em contrato, independentemente de prévio aviso ou notificação por qualquer dos contratantes. Ademais, se expirado o prazo, e o licenciado

\footnotetext{
${ }^{440}$ Cf. Art. 572 do Código Civil Brasileiro.

${ }^{441}$ Cf. Art. 571 do Código Civil Brasileiro.

${ }^{442}$ Cf. Art. 578 do Código Civil Brasileiro.

443 O INPI advoga a tese da impossibilidade de se prever "prazo indeterminado" para o licenciamento do uso da marca. Está cláusula seria, segundo esta autarquia, nula de pleno direito, porquanto infactível. Ademais, ainda segundo o INPI, o contrato de licença de uso de marca pode ser estabelecido por prazo determinado ou por prazo em que vigorar o registro do sinal. Este, contudo, não é o nosso entendimento, pois que, uma vez expirado o registro da marca, o contrato de licença não mais existirá em decorrência da perda de seu objeto, podendo-se falar nos tradicionais termos antagônicos "prazo determinado" e "prazo indeterminado".
} 
continuar se utilizando da marca, sem que haja qualquer manifestação do titular, presumirse-á prorrogado o licenciamento, com base nos mesmos valores originalmente consentidos pelos contratantes. Neste caso, o contrato passará a ser por prazo indeterminado ${ }^{444}$.

Na hipótese de o licenciado não cessar o uso da marca, mesmo após ter sido notificado, ele deverá pagar ao licenciante valor por este arbitrado. É forçoso ressaltar, de acordo com o art. 575 do Código Civil, que, se o valor arbitrado pelo titular for abusivo, o juiz poderá reduzi-lo, devendo considerar, contudo, que o aludido valor terá natureza penalizatória, mais do que meramente remuneratória. Estamos diante de mais um novel dispositivo, que não encontra correspondência no Código Civil revogado, em que se verifica a evidente incidência do princípio da vedação da onerosidade excessiva sobre o contrato de licença de uso de marca.

Portanto, pelo artigo 575 do Código Civil, se o licenciado não obedecer ao mandamento inserto na notificação enviada pelo licenciante e continuar se utilizando da marca licenciada, após o termo final do contrato, poderá o licenciante arbitrar o royalty correspondente, conforme valor que entender mais adequado, sem prejuízo do valor devido pelo dano ocasionado pelo licenciado infrator. Repise-se, entretanto, que se o valor do royalty for manifestamente excessivo, terá o juiz a possibilidade de reduzi-lo equitativamente.

Exemplificativamente, suponha-se que licenciante e licenciado firmaram contrato de licença e uso de marca, pelo termo de 3 anos, com valor de royalty mensal pré-fixado em R \$ 100.000,00. Após o decurso de prazo, contudo, o licenciado remanesceu utilizandose do signo licenciado, mesmo após notificado pelo licenciado para que se abstivesse de fazê-lo. Inconformado com tamanho menoscabo, o titular/licenciante deliberou pelo estabelecimento de "novo aluguel", o fixando em R\$200.000,00. No exemplo ora oferecido a título didático, poderá o juiz reduzir o aluguel arbitrado de forma equitativa, conforme comando normativo inserto no parágrafo único do artigo 575, sem se desprender, todavia, do seu caráter sancionador. Assim, sem prejuízo dos danos ocasionados pelo uso ilegal da marca, a serem apurados de forma independente, pode o juiz fixar o valor do

${ }^{444}$ Cf. Arts. 573 e 574 do Código Civil Brasileiro. 
“novo aluguel” em R \$ 150.000,00, tendo-se em mente o caráter penalizatório da norma em apreço.

Sob a orientação do art. 576 do Código Civil, em sendo cedida a marca durante o termo do licenciamento, o cessionário não terá o dever de comprir com as disposições contratuais, se no instrumento obrigacional não estiver expressamente estabalecida cláusula de vigência na hipótese de alienação, bem como se o contrato não houver sido registrado pela autoridade competente (INPI) ${ }^{445}$. Por tal razão, é de grande valia que os operadores do direito se atenham a este dispostivo ao confeccionar o contrato de licença de uso de marca, sob pena de os direitos do licenciado sucumbirem em conseqüência da cessão do bem intangível que houvera recebido, a título de licenciamento.

\section{V.5 OS CONTRATOS DE LICENÇA DE USO DE MARCA À LUZ DO PRINCÍPIO DA FIEL AUTONOMIA DA VONTADE}

A Lei 9.279/96, em seu artigo 139, brevemente regulamentado pelo Ato Normativo INPI $n^{\circ} 135$, emprestou maior abertura ao contrato de licença de uso de marca, à vista do princípio da fiel autonomia da vontade. Não impôs às partes contratantes (licenciante e licenciado) cláusulas essenciais e condições mínimas do negócio juridico a constar do instrumento obrigacional. Tal afirmação se faz por conta do cotejo resultante da atual legislação industrial (art. 139) com o antigo Código de Propriedade Industrial, cujo artigo 90 delineava os requisitos mínimos que deveriam fazer constar do do contrato em estudo, como: (a) indicação do número do pedido ou registro a ser explorado; (b) condições da remuneração; bem como (c) dever de o titular exercer controle efetivo sobre as especificações $^{446}$.

\footnotetext{
${ }^{445}$ Preceitua o artigo 140, da Lei 9.279/40, que o "contrato de licença deverá ser averbado no INPI para que produza efeitos em relação a terceiros".

${ }^{446}$ A título comparativo, importante se faz a transcrição do artigo 90 da legislação precedente ao diploma atual, sobretudo com vistas a aclarar os pontos divergentes entre uma legislação e outra.: "Art. 90. O titular de marca ou expressão ou sinal de propaganda poderá autorizar o seu uso por terceiros devidamente estabelecidos, mediante contrato de exploração que conterá o número do pedido ou do registro e as
} 
O contrato de licença, sob os moldes da lei vigente, apresenta-se, pois, mais flexível, sobretudo se comparado com o instrumento que era disciplinado pela Lei 5.772/81. Contudo, com a acentuação da unificação do direito contratual trazida pelo novo diploma civil, a fiel autonomia das partes contratantes, ao lado da aplicação analógica dos contratos, continua plenamente aplicável, porém mitigada pelas cláusulas e princípios gerais de direito contratual de alcance mais abrangentes, o que, de certo modo, acaba conferindo maior segurança jurídica às partes contratantes.

Portanto, ante a atipicidade mista da espécie contratual sob exame, conjugada aos princípios gerais de direito contratual e aos elementos típicos emprestados de contratos análogos (contrato de locação de coisas e contrato de comodato), a fiel autonomia da vontade das partes contrantes é elemento jurídico decisivo que incide sobre os contratos de licença de uso de marca. As partes se encontram livres (dentros das balizas legais e princípios gerais de direito) para confeccionar as cláusulas que melhor antender seus interesses. A fiel autonomia da vontade é o terceiro elemento da tríade formadora do contrato de licença. Ademais, não há que se falar em hierarquia dos três elementos substanciais ensejadores do contrato em exame, mas sim em sua conjugação unidimensional. Tal assertiva repousa no fato de que os princípios gerais de direito, a aplicação analógica dos contratos de locação e comodato e, por fim, a fiel autonomia da vontade, se aplicam, de forma alinhavada e harmoniosa, à figura contratual em estudo.

Adotamos, neste aspecto, melhor entendimento do italiano Giuseppe Sena ${ }^{447}$, no sentido de que a aplicação pura da teoria da aplicação analógica aos contratos de licença não pode ser utilizada indiscriminadamente, sendo que o operador do direito deve ser zeloso ao aplicar elementos e interpretações extraídas de instrumentos análogos ao contrato em comento, se valendo, essencialmente, do princípio da autonomia da vontade, sob os

condições de remuneração, bem como a obrigação de o titular exercer controle efetivo sobre as especificações, natureza e qualidade dos respectivos artigos ou serviços. $1^{\circ}$ A remuneração será fixada com observância da legislação vigente e das normas baixadas pelas autoridades monetárias e cambiais. $2^{\circ} A$ concessão não poderá impor restrições à industrialização ou à comercialização, inclusive à exportação. $3^{\circ}$ $O$ contrato de exploração, bem como suas renovações ou prorrogações só produzirão efeito em relação a terceiros depois de julgados conforme e averbados pelo Instituto Nacional da Propriedade Industrial. (...)" (grifou-se)

${ }^{447}$ SENA. Giuseppe. I Diritti Sulle Invenzioni e Sui Modelli Industriali. ob. cit.. p. 321. 
contornos dos princípios gerais de direito contratual, em oposição à confiança cega e/ou exacerbada no princípio da analogia.

No contrato de licença de uso de marca, a fiel autonomia da vontade assume importância ainda maior, ao analisarmos o trecho de redação final do Ato Normativo INPI n. ${ }^{\circ}$ 135/97, abaixo colacionado, que concede às partes contratantes a liberdade de confeccionar a maior parte das "cláusulas e condições da contratação". Estamos diante da chamada liberdade contratual.

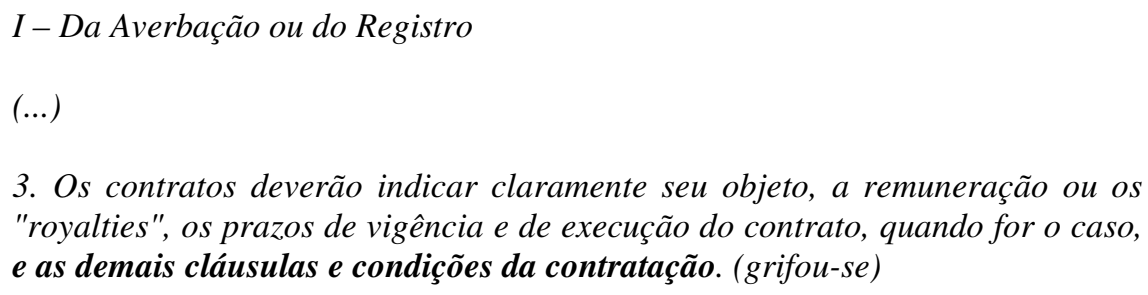

Adiante, será realizado estudo do perfil e elementos jurídicos (típicos e atípicos) que integram o contrato de licença de uso de marca, à luz da fiel autonomia da vontade, acolhida pelo ordenamento jurídico pátrio, e sólido amparo na melhor doutrina e jurisprudência nacionais.

\section{V.5.1. MODALIDADES DE CONTRATO DE LICENÇA DE USO DE MARCA}

No que pertine às possíveis modalidades de licença, elemento essencialmente atípico desta espécie contratual, temos que a licença poderá ser exclusiva ou não exclusiva; limitada ou ilimitada. Merece realce a dissonância doutrinária a respeito da natureza jurídica da licença, balizada em função da modalidade adotada pelos contratantes. 
Neste aspecto, consoante magistério de Pontes de Miranda ${ }^{448}$, Túlio Ascarelli ${ }^{449}$ e Dieter Pfaff ${ }^{450}$, enquanto a licença exclusiva confere ao licenciado direito real e absoluto erga omnes, a licença não-exclusiva confere ao recpetor da marca tão somente direito pessoal (obrigacional). Luiz Leonardos ${ }^{451}$ e Paul Roubier ${ }^{452}$ encabeçam, contudo, corrente doutrinária antagônica, partidária da tese de que a licença de uso de marca, independentemente da modalidade eleita pelas partes, representa direito pessoal. Com efeito, para estes juristas, não há que se cogitar direito real, mormente pelo fato de que há puramente uma concessão de direito de uso, e não de propriedade. Não obstante o licenciado detenha o poder de uso absoluto do bem, o direito de propriedade remanesce com o titular, o qual deverá reavê-lo quando do término do prazo ou no evento de rescisão contratual.

Extrai-se destes dois mandamentos adversos conclusão híbrida para a qual convergimos. Neste sentido, o contrato de licença de uso de marca, celebrado sob o manto da exclusividade, e que confira ao licenciado todos os poderes para agir em defesa da marca $^{453}$, se apresenta como direito obrigacional permeado de elementos imanentes ao direito real. Consubstancia-se em direito obrigacional, uma vez que o contrato de licença constitui-se em fonte geradora de obrigação. Compõe-se de elementos de direito real, pois que, a partir do momento em que o licenciado é investido de poderes para agir contra todos em defesa da marca, ele passa a revestir-se das prerrogativas inatas ao direito de propriedade, corroborando um direito de uso in rem.

Superado o exame das divergências doutrinárias acerca da natureza jurídica do contrato em apreço, cumpre salientar que o ordenamento jurídico pátrio adota as mesmas modalidades de licenciamento que aquelas acolhidas pelos principais sistemas jurídicos

\footnotetext{
448 MIRANDA, Francisco Cavalcanti Pontes de. Tratado de Direito Privado. Rio de Janeiro. Ed. Borsoi. 1956. vol. 16. p.351.

449 ASCARELLI, Tullio. Teoria della Concorrenza e dei Beni Immateriali. Milão: Giuffrè, 1956, pp. 426435.

${ }^{450}$ PFAFF, Dieter. Conflict of Law Aspects of License Contracts in Germany and Socialist Countries. In International Reviews of Industrial Property and Copyright Law, vol. 8, n.1, pp. 29/30.

${ }^{451}$ LEONARDOS, Luiz. op. cit. p. 42.

${ }^{452}$ ROUBIER, Paul. Le Droit de La Propriété Industrielle. op. cit. . 290-292.

${ }^{453}$ Cf. Art. 139, parágrafo único, da Lei 9279/96.
} 
alienígenas (italiano ${ }^{454}$, francês ${ }^{455}$, germânico ${ }^{456}$, estadosunidense es7 $^{457}$ e britânico ${ }^{458}$ ). Desta sorte, acompanhando os modelos propugnados pelos citados sistemas estrangeiros, o ordenamento interno admite as seguintes modalidades de contrato de licença de uso de marca: (i) "com exclusividade" ou "sem exclusividade"; (ii) abrangente (no caso do Brasil, nacional) ou limitada a determinada região; (iii) por prazo determinado ou indeterminado; (iv) total ou parcial.

O comercialista Giuseppe Sena ${ }^{459}$, ao discorrer sobre as modalidades de contrato de licença, no sistema italiano, preleciona que as licenças podem ser exclusiva ou não exclusiva; de duração ilimitada ou de duração limitada.

Neste aspecto, a lei nacional quedou-se silente, devendo as partes se remeter ao princípio da autonomia da vontade, consagrada no artigo 421 do Código Civil, para dispor qual será a modalidade de negócio jurídico entre elas adotada.

Nos contratos de licença não-exclusiva, o licenciado é autorizado apenas a servir-se da marca licenciada. Não tem o direito de se opor contra terceiros, ainda que contrafatores, competindo este direito de oposição exclusivamente ao licenciante, titular do direito ${ }^{460}$. Aqui, impõe-se mencionar a prerrogativa que o titular tem de conceder "licenças

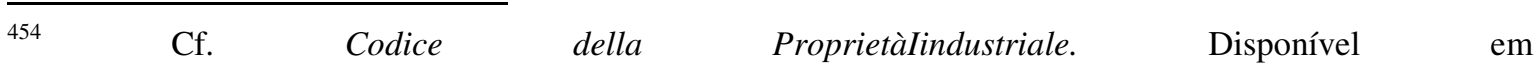
$<$ http://www.camera.it/parlam/leggi/deleghe/testi/05030dl.htm>. Acessado em 15 set. 2009.

455 Cf. Code de La Propriété Intellectuelle. Disponível $\mathrm{em}$ <http://www.legifrance.gouv.fr/html/codes_traduits/cpialtext.htm>. Acesso em 20 nov. 2009.

456 Cf. German TradeMark Law. Capítulo 5 - "As Marcas como objeto de propriedade” Disponível em < http://www.markenagentur.de/guide/markg1d.htm\#teil25> Acesso em 12 out. 2009.

${ }^{457}$ PROGOFF, Susan. Understanding the Intellectual Property License. Nova Iorque (EUA): Practising Law Institute, 2004. p. 12.

${ }^{458}$ Cf. Trade Marks Act 1994. Chapter 28 - Chapter 31. O Trade Marks Act 1994 é a lei que rege as marcas nos países membros do Reino Unido e da Ilha de Man. Esta legislação implementa diretiva comunitária anterior que constitui o enquadramento para as leis de marca de todos os estados membros da UE, e revoga lei anterior, consubstanciada no Trade Marks Act 1938. (Cf. CHRISTIE, Andrew; GARE. Stephen. Blackstone's Statutes on Intellectual Property. $10^{\mathrm{a}}$ ed. Nova Iorque: Oxford University Press. 2010. pp. 330/331)

459 “(...) concedere licenze a terzi, e contratti di licenza semplice o non esclusiva; contrati di licenza di durata illimitada (uguale cioè alla residua durata del brevetto) e contratti di licenza limitati nel tempo (...)" (Cf. SENA. Giuseppe. I Diritti Sulle Invenzioni e Sui Modelli Industriali. Milão. Dott. A. Giuffrè Editore. 1976. p. 320);

${ }^{460}$ SILVEIRA. Newton. Licença de Uso de Marca. op. cit. p. 67. 
múltiplas" ${ }^{461}$ a várias pessoas físicas ou jurídicas ${ }^{462}$, restritas ou não a certas regiões do território nacional. Neste tocante, Newton Silveira define que, nas licenças não exclusivas, há um "fracionamento do direito entre titulares diversos" 463 .

Por outro lado, a licença pode ser exclusiva, caso em que o licenciante não pode autorizar que terceiro se utilize de sua marca, a não ser o licenciado que por ela remunera. Outrossim, convém registrar que, neste tipo de restrição, salvo se no contrato restar consignado de modo diverso, o próprio licenciante deve se eximir de utilizar a marca licenciada ${ }^{464}$. Na esteira do que prelecionam os juristas franceses SINGH e BARS, e como não há qualquer vedação na norma interna quanto a esta modalidade, faz-se possível a celebração de licenciamento exlcusivo "com reservas" 465 . Neste caso, o licenciador, no contrato com exclusividade, poderá, juntamente com o licenciado, usufruir o bem intangível licenciado. Esta possibilidade é largamente admitida pelo ordenamento jurídico brasileiro, conforme advoga o professor Newton Silveira, para quem a licença de uso de marca pode ser "extensiva a vários licenciados", caso em que "o titular do registro poderá reservar para si o direito de uso da marca, bem como o de conceder outras licenças a terceiros" ${ }^{466}$. Temos, portanto, a modalidade de licença exclusiva com reservas. Sucede, contudo, que este dispositivo somente terá validade, se expressamente consignado no instrumento contratual de licenciamento. Ante a ausência do mencionado dispositivo na relação jurídica com exclusividade, o licenciador não poderá continuar se utilizando da marca que houvera licenciado.

461 CERQUEIRA, João da Gama. Tratado da Propriedade Industrial. $3^{\mathrm{a}}$ ed. atual. por Newton Silveira e Denis Borges Barbosa......op. cit. Vol. II. Tomo I.. Parte II. p. 174.

462 "La licence peut être non exclusive. Dans cette hypothèse, le concedant se reserve la possibilité d'accorder à plusieurs personnes physiques ou morales le droit d'expliter sa marquee. Faute de stipulation contraire expresse dans le contrat, la licence de marquee concèdèe est reputèe être non-exclusive" (Yves PLASSERAUD. Martine DEHAUT e Claude PLASSERAUD. Marques. Creation, valorisation e protection. op. cit. p. 163).

${ }^{463}$ SILVEIRA. Newton. Licença de Uso de Marca.... op. cit. p. 05.

${ }^{464}$ LOUREIRO, Luiz Guilherme de A.V. Loureiro. A Lei de Propriedade Industrial Comentada. Lei $n .^{o}$ 9.279 de 14 de maio de 1996). São Paulo. Lejus. 1999. p. 275.

${ }^{465}$ WILKOF, Neil e BURKITT, Daniel. Trademark Licensing. ......op. cit. p. 270 e ss.

${ }^{466}$ CERQUERIA, João da Gama. Tratado da Propriedade Industrial. Ed. atualizada por: Newton Silveira e Denis Borges Barbosa. Rio de Janeiro: Ed. Lumen Júris. 2010. Vol. II. Tomo II. Parte III. pp. 133/134. 
Naturalmente, a onerosidade e custo expendido pelo licenciado serão balizados em consonância com a modalidade de contrato eleita pelas partes. A licença exclusiva acaba por tornar a contraprestação ao licenciado mais dispendiosa, haja vista que ele terá exclusividade na utilização do sinal licenciado pelo titular, o qual não poderá autorizar aquele uso a terceiros. O sistema jurídico francês ${ }^{467}$ reconhece que o contrato deve mencionar expressamente que a licença é exclusiva. Em havendo omissão contratual, a transferência será considerada não exclusiva.

Neste sentido, o licenciado deve se ater ao dispositivo da exclusividade, de modo a evitar que seu investimento não seja devidamente recompensado, principalmente em razão da concorrência realizada por terceiros licenciados que da mesma marca venham a se utilizar.

Sobre a questão da exclusividade, sinalize-se para a aplicação do princípio da boafé objetiva (em sua fase pré-contratal), o que, conforme anteriormente examinado, é princípio que irradia efeitos diretos sobre a espécie contratual em exame. Com respaldo no artigo 422 do Diploma Civil: (i) se a partes, nas tratativas pré-contratuais, consentiram que a licença se daria a título exclusivo; e (ii) se as condições e investimento realizado tiverem se coadunado com um contrato de licença exclusiva, mas por uma razão ou por outra, não tenha sido expressamente consignada em contrato a aludida exclusividade, tem o licenciado prejudicado a prerrogativa de discutir o contrato em face do licenciante, com amplo respaldo no princípio social de direito contratual acima exposto.

Conforme demonstrado na presente tese, considerando que os contratos de licença de uso de marca subordinam-se, subsidiariamente, ao regramento contido no código civil e, como corolário, aos princípios gerais do direito contratual neste diploma consignados, é de grande valia que o operador do direito bem desenvola os "considerandos", à luz do princípio da boa-fé objetiva, antes de adentrar ao conteúdo do contrato, de maneira a demonstrar, de forma inequívoca, as reais intenções das partes.

A importância desta engenharia contratual reside no fato de que, por alguma razão, algumas das intenções das partes contratantes podem não ser refletidas no bojo do

\footnotetext{
${ }^{467}$ Yves PLASSERAUD; DEHAUT, Martine. op. cit.. p. 163.
} 
instrumento obrigacional. Por tal razão, é de grande importância a elaboração de preâmbulo que demonstre o verdadeiro interesse das partes em relação ao negócio por elas entabulado $^{468}$. Desta sorte, convém colacionar lição externada por Juliana B. Viegas:

O Novo Código Civil baseia-se em princípios e fundamentos abertos, que têm grande influência na validade e na exeqüibilidade dos contratos (...)

Ora, nos "considerandos" iniciais de um contrato podem-se incluir declarações gerais cuja finalidade pode ser a de indentificar qual o interesse de cada um das partes no contrato, e qual o equilíbrio que se busca entre os direitos e obrigações expressos pelo contrato. ${ }^{469}$ (grifou-se)

Ainda no que tange às modalidades, os contratos em apreço podem se limitar a certa região ou irradiarem efeitos por todo o território nacional. Saliente-se, conforme oportunamente demonstrado, que as marcas obedecem ao princípio da territorialidade. Portanto, com exceção das marcas notoriamente conhecidas, os contratos de licença somente poderão assegurar juridicamente a proteção (em seu limite máximo) dentro do território nacional.

Seria, certamente, inexeqüível, e viria na contramão do sistema marcário internacional, que titular de marca ordinária registrada no Brasil, licenciasse sua marca a determinado licenciado (nacional ou estrangeiro), para que este fizesse uso do sinal distintivo, por exemplo, nos Estados Unidos, sob a artificiosa alegação do licenciante de que a marca registrada no território brasileiro também irradiaria efeitos registrários no sistema jurídico norte-americano, onde outra marca (semelhante àquela registrada no Brasil), porém de outro titular, para o mesmo produto ou serviço, já estivesse sendo utilizada antes da subscrição do contrato de licenciamento no Brasil.

No vertente caso, novamente resta patente a flagrante violação ao princípio da boafé objetiva (dever de lealdade e probidade) por parte do licenciante, que tendo

\footnotetext{
${ }^{468}$ Registre-se, neste aspecto, o artigo 112 do Código Civil, que primou pela real intenção das partes contratantes em oposição à redação disposta no instrumento contratual, verbis: "Art. 112. Nas declarações de vontade se atenderá mais à intenção nelas consubstanciada do que ao sentido literal da linguagem".

${ }^{469}$ VIEGAS, Juliana Laura Bruna. Contrato de Licenciamento de Marcas. in JABUR, Wilson Pinheiro; DOS SANTOS, Manoel J. Pereira (coord). Propriedade Intelectual - Contratos de Propriedade Industrial e Novas Tecnologias. São Paulo: Ed. Saraiva, 2007. p.97.
} 
conhecimento acerca do princípio da territorialidade, claramente o violou, induzindo o licenciado a erro ${ }^{470}$.

Ainda na esteira do que prescreve o princípio da boa-fé objetiva, a qual, repise-se, deve ser observado pelas partes contratantes, inclusive em momento ulterior à conclusão do termo consignado no instrumento contratual, Gama Cerqueira ${ }^{471}$ assinala que comete infração contratual o licenciado que explora o signo fora da região pré estabelecida contratualmente. Ademais, acrescenta o insigne tratadista que infringe o contrato e, portanto, o princípio acima ministrado, o licenciado que continua a explorar o signo após o termo final do contrato.

Superada a questão territorial do instrumento em apreço, cumpre-nos salientar o prazo de vigência que deverá restar consignado no instrumento de licença. Doutrinadores nacionais $^{472}$ e estrangeiros ${ }^{473}$ preterem os usuais termos antagônicos determinado/indeterminados, originariamente ínsitos aos contratos em geral. Segundo estes autores, para os contratos sob análise, o prazo pode ser determinado ou pelo prazo de duração do privilégio.

O conceito "prazo em que perdurar o privilégio", em oposição ao usual termo "prazo indeterminado", não se mostra consistente, porque o término da validade do registro e a ausência de sua renovação, implicam, juridicamente, a perda do objeto do contrato, objeto este que se apresenta como pilar estrutural do instrumento jurídico sob análise. Desta forma, entendemos ser perfeitamente aplicável o conceito prazo

\footnotetext{
${ }^{470}$ Pertinente trazer à baila o artigo 166, do Código Civil vigente, ao versar sobre a nulidade dos negócios jurídicos, incluindo-se, aqui o instrumento contratual objeto da presente dissertação. Destarte, assinla o mencionado dispositivo, in verbis: "é nulo o negócio quando: Art. 166. É nulo o negócio jurídico quando: I celebrado por pessoa absolutamente incapaz; II - for ilícito, impossível ou indeterminável o seu objeto; III - o motivo determinante, comum a ambas as partes, for ilícito; IV - não revestir a forma prescrita em lei; $\mathrm{V}$ - for preterida alguma solenidade que a lei considere essencial para a sua validade; VI - tiver por objetivo fraudar lei imperativa; VII - a lei taxativamente o declarar nulo, ou proibir-lhe a prática, sem cominar sanção; VIII celebrado por pessoa absolutamente incapaz; IX - for ilícito, impossível ou indeterminável o seu objeto" e o artigo 168 .

${ }^{471}$ Cf. CERQUEIRA, João da Gama. Tratado da Propriedade Industrial. $3^{\text {a }}$ ed. atual. por: Newton Silveira e Denis Borges Barbosa. op. cit......Vol. II. Tomo I. Parte II. pp 175-178.

${ }^{472}$ Idem. Ibidem. p. 174.

${ }^{473}$ Yves PLASSERAUD. Martine DEHAUT e Claude PLASSERAUD. Marques. Creation, valorisation e protection. ob. cit. p. 164.
} 
indeterminado aos contratos de licença de uso de marca, onde a extinção do registro, automaticamente, acarretará o encerramento do contrato, em decorrência da perda de seu objeto nuclear.

Faz-se imperioso ressaltar a evolução da função do contrato de licença de marca no ordenamento jurídico nacional. Nos primórdios da instituição deste instrumento no sistema pátrio, a função da licença era exclusivamente evitar que a marca caducasse. Com efeito, a entidade estrangeira que pretendesse expandir seus negócios e, por via de conseqüência, sua marca pelo mundo, incluindo o Brasil, com fundamento no princípio da territorialidade, aqui registrava a marca e a licenciava para evitar que o signo caducasse.

Portanto, se antes tal instrumento tinha por objetivo unicamente evitar o perecimento do signo, agora não mais exerce esta função. Neste aspecto, são luminosos os artigos 143 e 144, da Lei 9.279/96 $6^{474}$, os quais assinalam, com meridiana clareza, que a marca caducará, no evento de verificada a ausência de seu uso efetivo pelo prazo de cinco anos consecutivos. Com efeito, sem embargo da marca estar licenciada, se o licenciado dela não fizer uso pelo prazo acima indicado, o titular da marca poderá ser destituído desta propriedade industrial. Reportamo-nos aos dizeres de Alexandre Gnocchi ${ }^{475}$, o qual aclara que "uma licença não atuada acarreta perda da propriedade".

Saliente-se, outrossim, que a licença poderá ser total ou parcial. Será total, quando o titular licenciar sua marca para todos os produtos ou serviços para os quais seu sinal esteja previamente registrado no INPI. Contrariu sensu, será parcial, quando o titular proceder ao licenciamento de sua marca apenas em relação a determinados produtos ou serviços para os quais seu sinal tenha sido registrado, e não para todos eles. Titulares de

\footnotetext{
${ }^{474}$ Pertinente colacionarmos os dispositivos insertos nos artigos 143 e 144, os quais apontam para a caducidade da marca tão somente pelo seu desuso, não sendo relevante o fato de a marca estar licenciada ou não. Prescrevem, neste sentido, mencionados artigos: "Art. 143 - Caducará o registro, a requerimento de qualquer pessoa com legítimo interesse se, decorridos 5 (cinco) anos da sua concessão, na data do requerimento: I - o uso da marca não tiver sido iniciado no Brasil; ou II - o uso da marca tiver sido interrompido por mais de 5 (cinco) anos consecutivos, ou se, no mesmo prazo, a marca tiver sido usada com modificação que implique alteração de seu caráter distintivo original, tal como constante do certificado de registro. $\S 1^{\circ}$ Não ocorrerá caducidade se o titular justificar o desuso da marca por razões legítimas. $\S 2^{\circ} \mathrm{O}$ titular será intimado para se manifestar no prazo de 60 (sessenta) dias, cabendo-lhe o ônus de provar o uso da marca ou justificar seu desuso por razões legítimas. Art. 144. O uso da marca deverá compreender produtos ou serviços constantes do certificado, sob pena de caducar parcialmente o registro em relação aos não semelhantes ou afins daqueles para os quais a marca foi comprovadamente usada".
}

${ }^{475}$ GNOCCHI, Alexandre. Licenças e Roialties no Brasil. op. cit. p. 217. 
marcas pujantes podem, estrategicamente, se valer do contrato de licença parcial, com o intuito de licenciar suas marcas para que outras empresas a utilizem em outros produtos ou serviços que não sejam produzidos ou prestados, original e habitualmente, pelos titulares. Indubitavelmente, esta modalidade de negócio acaba por evitar a caducidade da marca para determinados produtos ou serviços, ao mesmo tempo em que torna aquela marca ainda mais valorizada economicamente, sobretudo em relação a diferentes nichos de mercados que não aqueles que o titular está enraizado e afeito a atuar ${ }^{476}$.

Por fim, no que tange à possibilidade de outorga de sublicença, a doutrina ${ }^{477}$ é categórica ao preconizar que ao licenciado não é facultado sublicenciar o signo originariamente licenciado, se esta possibilidade não estiver prevista em contrato. Perfilha este posicionamento os principais sistemas marcários estrangeiros, tais como: italiano, francês, americano, britânico, germânico, espanhol e português. Isto porque mencionado contrato é considerado como intuitu personae, da mesma forma como o é seu contrato análogo (contrato de locação de coisas). Em virtude do predicado da pessoalidade, inato ao contrato de licença, a marca não pode ser, nem licenciada, tampouco cedida, sem a expressa e necessária aquiescência de seu titular.

\section{V.5.2 ESTUDO DOS DISPOSITIVOS JURÍDICOS INTEGRANTES DOS CONTRATOS DE LICENÇA DE USO DE MARCA}

No que pertine aos dispositivos ou cláusulas essenciais que devem restar consignados nos contratos de licença remunerado, com o fim de garantir a segurança

\footnotetext{
${ }^{476}$ Anote-se, neste aspecto, lição do jurista italiano Marco Ricolfi, verbis: "La licenza, esclusiva e parziale, può innanzitutto concernere beni non affini a quelli offerti sul mercato da altri licenziatari (o dallo stesso licenziante).È il caso della Ferrari, quando essa affidi la produzione e la vendita degli orologi o di telefoni cellulari muniti del suo marchio ad imprese licenziatarie diverse; ed in generale dei c.d. contratti di merchandising, ove il soggetto che abbia portato un segno all'affermazione iniziale procede alla sua valorizzazione come marchio in campi molto diversi dall'utilizzazione primaria, di regola stipulando una pluralità di contratti con imprese già presenti nei diversi settori di riferimento". (Cf. AUTERI, Paolo (et. al). Diritto Industriale - Proprietà Intellectuale e Concorrenza. $3^{\mathrm{a}}$ ed. G. Giappichelli Editore: Torino, 2009. p. $143)$.

${ }^{477}$ Cf. CERQUEIRA, João da Gama. Tratado da Propriedade Industrial. $3^{\mathrm{a}}$ ed. atual. por: Newton Silveira e Denis Borges Barbosa. op. cit......Vol. II. Tomo I. Parte II. p. 177; GNOCCHI, Alexandre. Licenças e Roialties no Brasil. op. cit. p. 218.
} 
jurídica das partes contratantes, José Carlos Tinoco Soares ${ }^{478}$ e José da Silva Pacheco ${ }^{479}$ indicam que licenciante e licenciado devem se coadunar com as formalidades legais, prevendo em contrato, ao menos, os elementos essenciais a seguir delineados:

\begin{tabular}{|c|c|}
\hline CLÁUSULAS & ОВJETO \\
\hline PARTES & Qualificação de licenciante e licenciado ${ }^{480}$. \\
\hline OBJETO & $\begin{array}{l}\text { Indicação da marca registrada (certificado } \\
\text { emitido pelo INPI) ou pedido de registro } \\
\text { (protocolo feito no INPI, pelo futuro titular da } \\
\text { marca). }\end{array}$ \\
\hline REGISTRO & $\begin{array}{l}\text { O número do registro ou do pedido e de sua } \\
\text { data. É importante fazer mencionar em contrato } \\
\text { qual dos contratantes será o responsável pelo } \\
\text { registro e por eventuais renovações da licença, } \\
\text { haja vista que para cada renovação } \\
\text { (aditamento) do contrato de licença se faz } \\
\text { necessário novo registro (averbação) perante o } \\
\text { INPI. }\end{array}$ \\
\hline
\end{tabular}

${ }^{478}$ SOARES, José Carlos Tinoco. Lei de Patentes, Marcas e Direitos Conexos. Lei 9.279 de 1996. São Paulo. Ed. Revista dos Tribunais. 1997. p. 227.

${ }^{479}$ PACHECO, José da Silva. Tratado de Direito Empresarial: Empresário: pessoa e patrimônio. vol. 2. São Paulo. Saraiva. 1979. p.p. 569/570.

${ }^{480}$ Quanto à qualificação, as partes devem estar devidamente qualificadas, ou seja, deve estar descrito no contrato: (i) o nome completo da pessoa jurídica titular do registro ou do pedido, seu endereço e localidade, inscrição no Cadastro Nacional de Pessoas Jurídicas, nome e cargo do representante legal do licenciante e (ii) nome completo da pessoa jurídica que fará uso da marca licenciada, seu endereço e localidade, inscrição no Cadastro Nacional de Pessoas Jurídicas, nome e cargo do representante legal do licenciante. É judicioso que as partes contratantes solicitem uma a outra que, no ato da assinatura do contrato, sejam apresentados os estatutos ou contratos sociais com o desígnio de se verificar se as informações constantes da minuta contratual se coadunam com as qualificações e poderes consignados nos atos constitutivos da licenciante e licenciada. 


\begin{tabular}{|c|c|}
\hline EXCLUSIVIDADE & $\begin{array}{l}\text { Determinar, expressamente, se a licença é } \\
\text { exclusiva ou não exclusiva. Repise-se que, na } \\
\text { omissão do contato, a licença será considerada } \\
\text { "não exclusiva", tendo o licenciante a } \\
\text { faculdade de conceder "licenças múltiplas", } \\
\text { conforme outrora examinado. }\end{array}$ \\
\hline CLASSE DE PRODUTO OU SERVIÇO & $\begin{array}{l}\text { A classe em que estão enquadrados os produtos } \\
\text { ou serviços representados pelo sinal licenciado. }\end{array}$ \\
\hline $\begin{array}{c}\text { USO ACOMPANHADO DA MARCA DO } \\
\text { LICENCIADO }\end{array}$ & $\begin{array}{l}\text { Uso de outras marcas: conter expressamente a } \\
\text { faculdade de o licenciado, se julgar } \\
\text { conveniente, fazer, por igual, uso de marca ou } \\
\text { propaganda própria acompanhada da marca ou } \\
\text { propaganda licenciada. }\end{array}$ \\
\hline PODER DE CONTROLE & $\begin{array}{l}\text { O direito de o titular do registro poder exercer } \\
\text { controle efetivo sobre as especificações, } \\
\text { natureza e qualidade dos respectivos produtos } \\
\text { ou serviços }^{481} \text {. }\end{array}$ \\
\hline USO EFETIVO & $\begin{array}{l}\text { A obrigatoriedade }{ }^{482} \text { de o licenciado usar } \\
\text { efetivamente a marca, sob pena de seu } \\
\text { perecimento, com fundamento no artigo } 139 \text { da } \\
\text { Lei } 9.279 / 96^{483} \text {; }\end{array}$ \\
\hline
\end{tabular}

${ }^{481}$ Luiz Guilherme Loureiro assevera que as partes contratantes podem prever em contrato que os produtos fabricados ou serviços prestados pelo fabricante, licenciado, devem observar um mínimo de qualidade. (LOUREIRO, Luiz Guilherme de A.V. Loureiro. A Lei de Propriedade Industrial Comentada. Lei n. $^{\circ} 9.279$ de 14 de maio de 1996. São Paulo. Lejus. 1999. p. 275).

482 Conforme magistério de Paul Roubier, o uso da marca é mais do que um direito do licenciado, mas sim um dever que deve ser cumprido. "Lê licencie ne doit pás être considere seulement comme ayant lê droit, mais encore comme ayant l'obligation d'exploiter" (ROUBIER, Paul. Le Droit de la Propriété Industrielle. ob. cit. p. 281)

483 De igual modo ao verificado no ordenamento jurídico brsaileiro, convém trazer à colação que o ordenamento jurídico francês impõe ao licenciado o dever deste explorar a marca sob pena de se verificar a sucumbência do direito a ela adstrito. Assim: "pars ailleurs dans certains cas, le concèdant peut s'être interdit lui-même d'exploiter lar marquee. Dans cette hypothèse, le licencie qui n'exploite pás gele indûment l'exploitation de la marque, et fait encourir au titulaire le risque d'une action en déchéance”. (Yves PLASSERAUD. Martine DEHAUT e Claude PLASSERAUD. Marques. Creation, valorisation e protection. ob. cit. p. 167). 


\begin{tabular}{|c|c|}
\hline VIGÊNCIA & $\begin{array}{l}\text { O prazo de vigência do contrato, que poderá ser } \\
\text { determinado ou indeterminado. Imperioso } \\
\text { lembrar que o decurso do prazo do registro da } \\
\text { marca ou sua caducidade, por qualquer dos } \\
\text { motivos previsto em lei, implicará a perda do } \\
\text { objeto do contrato e, portanto, no término da } \\
\text { relação jurídica contratual. Ademais, com } \\
\text { fulcro no art. } 576 \text { do Código Civil, é de grande } \\
\text { valia que se preveja expressamente que o } \\
\text { contrato remanescerá vigente no evento de a } \\
\text { marca ser cedida a terceiros (cessionários), a } \\
\text { que título for, durante todo o termo consignado } \\
\text { no contrato de licença de uso de marca } 484\end{array}$ \\
\hline REMUNERÇÃO (ROYALTY) & $\begin{array}{l}\text { Determinar o valor a ser pago como contra- } \\
\text { prestação pela utilização da marca. }\end{array}$ \\
\hline FORMA DE PAGAMENTO & $\begin{array}{l}\text { Determinar a forma de pagamento do valor } \\
\text { consentido pelas partes. }\end{array}$ \\
\hline TERRITÓRIO & $\begin{array}{l}\text { Estabelecer a região em que será utilizada a } \\
\text { marca. Ou seja: se a marca será utilizada } \\
\text { nacional ou regionalmente; }\end{array}$ \\
\hline SUBLICENCIAMENTO & $\begin{array}{l}\text { Consignar a possibilidade de sublicenciamento. } \\
\text { Convém reiterar que, na ausência de previsão } \\
\text { expressa acerca da possibilidade de } \\
\text { sublicenciamento, por ser um contrato “intuitu } \\
\text { personae”, não tem o licenciado o direito de } \\
\text { licenciar a marca licenciada a terceiros; }\end{array}$ \\
\hline FORO & $\begin{array}{l}\text { Designar o foro de solução de conflito (judicial } \\
\text { ou arbitragem). }\end{array}$ \\
\hline
\end{tabular}

${ }^{484}$ Sobre a cessão da marca, na vigência do contrato de licença, o jurista francês Tardieu Guigus assemelha este mecanismo ao contrato de arrendamento mercantil (leasing). Com efeito, no evento de o bem arrendado ser vendido, o comprador passará a ser o "novo arrendador" em relação à parte adversa que recebeu o bem (licenciado), tendo, a partir de tal momento, todos os deveres e obrigações que antes possuía o vendedor. (GUIGUS, Tardieu, JCL Marques. 7400. par. 87. apud WILKOF, Neil e BURKITT, Daniel. Trademark Licensing. $2^{\mathrm{a}}$ ed. Londres. Ed. Thomson, Sweet \& Maxwell, 2005. pp. 373 e ss) 
As cláusulas ora assinaladas são tidas como essenciais pela doutrina, sobretudo para a confecção de um contrato de licença que garanta o mínimo de segurança jurídica às partes contratantes. No mais, as partes estão livres para confeccionar outras cláusulas, contanto que tais dispositivos, elaborados à luz ds princípios da autonomia da vontade, função social do contrato e boa-fé objetiva, não venham a confrontar com as disposições legais, usos e costumes, albergados pelo princípio da supremacia da ordem pública ${ }^{485}$.

Conforme acima delineado, o objeto do contrato examinado nesta tese consiste na marca registrada ou no pedido de registro (depósito) ${ }^{486}$ encaminhado ao INPI. Portanto, também é admissível a possibilidade de licenciamento de marca cujo registro ainda não tenha sido concedido (licenciamento da solicitação do pedido), ou, conforme entendimento da doutrina pátria, licença de marca futura ${ }^{487}$. Entretanto, cumpre salientar que o indeferimento do pedido de registro de marca implicará, naturalmente, a caducidade da licença.

Luiz Leonardos ${ }^{488}$ assinala que a marca registrada, objeto do contrato de licença, não pode apresentar defeitos que inviabilize seu uso regular ou acarrete decréscimo de seu valor econômico. Neste caso, lhes serão aplicadas as normas relativas aos vícios redibitórios, compreendidas entre os arts. 441 a 446 do Código Civil Brasileiro.

Portanto, se a marca, objeto capital do contrato de licenciamento, apresentar vícios ocultos que interfiram em sua regular utilização, terá o licenciado o direito de rejeitá-la, redibindo (anulando) o contrato, podendo, alternativamente, permanecer utilizando a marca

\footnotetext{
${ }^{485}$ Na lição do processualista e especialista em arbitragem Carlos Alberto Carmona, "o legislador prestigiou, no que se refere à arbitragem, o princípio da autonomia da vontade, que - na visão dos internacionalistas caracterizaria a possibilidade de exercerem as partes, livremente, a escolha da legislação à qual queiram submeter-se, limitada tal escolha, de um lado, pela noção de ordem pública e, de outro, pelas leis imperativas" (CARMONA. Carlos Alberto. Arbitragem e Processo - um comentário à Lei 9.307/96, São Paulo, Malheiros, 1998, p. 61)

${ }^{486}$ A German Trademark Law prevê que o titular da marca poderá licenciá-la, a despeito do sinal não estar registrado no órgão de registro competente. Com efeito, há possibilidade de o titular da marca licenciá-la, ainda que seu direito tenha sido edificado tão somente a partir do uso ou notoriedade da marca. Cf. German TradeMark Law. Capítulo 5 - "As Marcas como objeto de propriedade" Disponível em < http://www.markenagentur.de/guide/markg1d.htm\#teil25> Acesso em 12 out. 2010.

${ }^{487}$ Cf. BARBOSA, Denis Borges. Proteção das Marcas: Uma Perspecitva Semiológica. Rio de Janeiro: Ed. Lúmen Juris. 2008. p. 404

${ }^{488}$ LEONARDOS. Luiz. op. cit. pp. 48-49.
} 
mediante abatimento do preço. Dentre os vícios ocultos que podem recair sobre o bem imaterial em destaque, podemos citar como exemplo: (a) avaliação irreal da marca; (b) registro total ou parcialmente nulo ou inexsitente; (c) registros sujetos a caducidade; (d) dentre outros vícios impercptíveis em um primeiro momento, mas que podem, por igual, comprometer a utilização para os fins aos quais se propôs o licenciado.

Caso o licenciante tenha cognição acerca do defeito oculto da marca disponibilizada, deverá, além de restituir o que recebeu em contraprestação pelo bem licenciado, indenizar o licenciado em perdas e danos. Entretanto, se não tinha conhecimento acerca do defeito, deverá tão somente restituir o valor recebido cumulado com as despesas do contrato, nos termos do art. 443 do Código Civil.

Destaque-se, outrossim, que se a marca estiver registrada em classe diferente daquela que houvera sido indicada em contrato pelo licenciante, estamos diante de caso de inadimplemento contratual, e não de vício oculto ${ }^{489}$.

O prazo para o exercício do direito redibitório é decadencial ${ }^{490}$. O licenciado poderá anular o contrato ou exercer seu direito de abatimento no preço no termo de 30 dias, a partir da data da celebração do instrumento jurídico. Se, contudo, o licenciado somente tiver conhecimento do dano em momento ulterior à subscrição do contrato, o prazo será contado do momento em que o licenciado tiver ciência em diante, sendo que o prazo máximo é de 180 dias ${ }^{491}$. Estes prazos não serão contados em havendo cláusula de garantia. Porém, insta salientar que, neste caso, o adquirente terá de denunciar o defeito ao alienante nos 30 dias seguintes ao seu descubrimento, sob pena de decadência ${ }^{492}$.

\footnotetext{
489 "Entrega de coisa diversa da contratada. No caso de vício redibitório, o contrato é cumprido de maneira imperfeita, pois a coisa tem defeito oculto que a torna imprópria ao uso a que se destina ou lhe diminui o valor. Já no caso de entrega de coisa diversa, o contrato é descumprido, caracterizando inadimplemento e não defeito oculto (RT 657/102)" (Cf. JUNIOR, Nelson Nery e NERY, Rosa Maria de Andrade, Código Civil Comentado e Legislação Extravagante, $3^{\text {a }}$ ed. op. cit. p. 394.).

${ }^{490}$ Cf. Art. 444 do Código Civil Brasileiro.

${ }^{491}$ Cf. Art. 445, $\S 1^{\circ}$, do Código Civil Brasileiro. Neste sentido, registre-se, Jornada III STJ 174: "Art. 445: Em se tratando de vício oculto, o adquirente tem os prazos do caput do art. 445 para obter redibição ou abatimento de preço, desde que os vícios se revelem nos prazos estabelecidos no parágrafo primeiro, fluindo, entretanto, a partir do conhecimento do defeito". Disponível em $<$ http://daleth.cjf.jus.br/revista/enunciados/IIIJornada.pdf>. Acesso em 20 out. 2009.

${ }^{492}$ Cf. Art. 446 do Código Civil Brasileito.
} 
Os dispositivos normativos que versam sobre a evicção, compreendidos entre os artigos 447 e 457 do Código Civil Brasileiro, são, por igual, aplicáveis ao contrato em estudo, e em especial ao seu objeto (a marca $)^{493}$. A evicção, segundo alocução do professor emérito da Universidade Federal de Juiz de Fora, Paulo Nader ${ }^{494}$, se opera quando o adquirente de coisa móvel ou imóvel, em contrato oneroso, perde o direito de propriedade, posse ou uso, integral ou parcialmente, em decorrência de ato administrativo de desapropriação, ou sentença judicial, devido a fato pretérito ou contemporâneo à aquisição.

Com efeito, o licenciante da marca deverá responder pela evicção, no evento de ter contra si decisão administrativa, geralmente emanada do INPI, ou decisão judicial (fruto de ação de nulidade ou reivindicatória), retirando-lhe o direito de propriedade sobre a marca licenciada, por competir a terceiro a propriedade sobre o bem disponibilizado.

O art. 448 do Código Civil faculta aos contratantes a possibilidade de estabelecer cláusulas, no sentido de reforçar, diminuir ou excluir a responsabilidade pela eviccção. No entanto, a despeito da presença de cláusula expressa que desobrigue o titular de responsabilidade, o licenciado terá o direito de recompor seu patrimônio com o preço que pagou pelo licenciamento. Aplica-se este dispositivo na hipótese de o licenciado não ter tido conhecimento do risco da evicção ou, ainda, se dele informado, não o assumiu ${ }^{495}$.

Em sendo verificada a evicção, salvo previsão contratual diversa, o licenciado terá direito, além da restituição integral do preço ou das quantias que pagou: à indenização pelas despesas dos contratos, pelos prejuízos que diretamente resultarem da evicção; às custas judiciais; e aos honorários do advogado por ele constituído ${ }^{496}$. O preço, seja a evicção total ou parcial, será o do valor da coisa, na época em que se evenceu, e proporcional ao desfalque sofrido, no caso de evicção parcial. Esclareça-se, ainda, que o

\footnotetext{
${ }^{493}$ Cf. LEONARDOS, Luiz. op. cit. p. 48.

${ }^{494}$ NADER, Paulo. Curso de Direito Civil-Obrigações. São Paulo: Forense, 2005. vol. 2. p. 129.

${ }^{495}$ Nelson Nery e Rosa Maria de Andrade Nery asseguram que este dispositivo tem a finalidade precípua de evitar que o alienante [licenciante], que recebeu o valor devido, se locuplete às custas do alienatário [licenciado]. (JUNIOR, Nelson Nery e NERY, Rosa Maria de Andrade, Código Civil Comentado e Legislação Extravagante, $3^{\text {a }}$ ed. op. cit. pp. 396/397).

${ }^{496}$ Cf. Art. 450 do Código Civil Brasileiro.
} 
licenciante terá este dever, muito embora a marca licenciada tenha seu valor de mercado deteriorado, exceto se houve dolo do licenciado para esta degradação do valor.

Aplicando-se interpretação extensiva do art. 453 do Código Civil ao contrato em comento, deduz-se que se o licenciado houver feito investimentos para melhoria da marca licenciada (ex.: realização de investimentos em insumos mais refinados para a melhoria na qualidade dos produtos ou serviços; e injeção de vultosas quantias em marketing), estes investimentos também deverão ser indenizados pelo licenciante.

A evicção parcial, no domínio da licença marcária, se sucede quando uma marca licenciada para duas classes distintas, por força de decisão judicial ou administrativa, sofre subtração, passando a ter amparo legal, conferido pelo INPI, em apenas uma das classes. $\mathrm{Na}$ outra classe, o licenciante perde a titularidade da marca, em razão do sinal já ter sido anteriormente registrado por terceiro, que tinha o direito originário de propriedade sobre o bem imaterial.

No evento da evicção ser parcial, o licenciado poderá optar entre a rescisão do contrato e a restituição de parte do preço contratado (royalties) correspondente ao desfalque sofrido. Se esta restituição, contudo, não for considerável, caberá direito à indenização $^{497}$.

Condição para poder exercitar o direito que da evicção lhe resulta, o licenciado deverá notificar do litígio o licenciante imediato, ou qualquer dos anteriores, quando e como lhe determinarem as leis do processo. Não atendendo o licenciante à denunciação da lide, e sendo manifesta a procedência da evicção, pode o licenciado deixar de oferecer contestação, ou usar de recursos. Por fim, insta salientar que não pode o licenciado demandar pela evicção, se tinha plena cognição de que a marca disponibilizada não pertencia ao licenciante ou estava sob discussão judicial ou administrativa ${ }^{498}$.

Superada a questão da evicção incidente em contratos de licenciamento de uso de marca, passemos à análise do uso acompanhado da marca licenciada com a marca própria

\footnotetext{
${ }^{497}$ Cf. Art. 455 do Código Civil Brasileiro.

${ }^{498}$ Cf. Arts. 456 e 457 do Código Civil Brasileiro.
} 
do licenciado. As partes poderão prever contratualmente que o uso da marca licenciada será acompanhado da marca própria do licenciado. Em verdade, o licenciado não poderá ser privado de utilizar sua própria marca acompanhada da marca licenciada. Neste sentido, convém trazemos à colação a inteligência do artigo 132 da Lei 9279/96, o qual reza, in litteris: "O titular da marca não poderá: I - impedir que comerciantes ou distribuidores utilizem sinais distintivos que lhes são próprios, juntamente com a marca do produto, na sua promoção e comercialização; II - impedir que fabricantes de acessórios utilizem a marca para indicar a destinação do produto, desde que obedecidas as práticas leais de concorrência. (...)".

Este dispositivo, utilizado com recorrência, é de uso permitido pela legislação. Também é verificado na praxis contratual do ordenamento jurídico norte-americano. Ademais, tem se mostrado de grande eficiência. Intitula-se co-licença, tradução do termo original anglo-saxão co-branding. Com supedâneo neste comando contratual, o licenciado utiliza-se de sua marca conjugada à marca licenciada pelo titular. Esta fusão de sinais tem por escopo principal reunir o atributo positivo de uma marca à característica acentuada da outra, de sorte a manter o público consumidor já fiel aos produtos ou serviços do licenciado e, concomitantemente, atrair nova corrente de consumidores, mormente aquele público antes leal aos produtos e serviços representados pela marca licenciada ${ }^{499}$.

Ao exame da cláusula remuneratória. No tocante à cláusula remuneratória que compõe os Contratos de Licença de Uso de Marca, traçando-se breve histórico comparativo com o diploma revogado, é imperioso trazer à tona o dispositivo inserto no artigo $1^{\circ}$, do artigo 90 do extinto Código de Propriedade Industrial (Lei Federal 5.772/71), o qual assinalava que a remuneração seria abalizada em estrita conformidade com a legislação vigente à época e em consonância com as normas baixadas pelas autoridades monetárias e cambiais. No que pertine à regulamentação baixada pelas autoridades cambiais, Newton Silveira ${ }^{500}$ indica a Portaria do Ministério da Fazenda n. ${ }^{\circ}$ 436/58, a qual estabelecia o teto de $1 \%$ pela exploração das marcas.

De extrema lucidez e coerência se mostra o entendimento corroborado por

\footnotetext{
${ }^{499}$ Cf. DIESENDRUCK, Elcan. Com Licença. op. cit. p. 56.

${ }^{500}$ SILVEIRA, Newton. Licença de Uso de Marca e Outros Sinais ...op. cit. p. 70.
} 
Gnocchi $^{501}$, ao assinalar, em tom notadamente crítico, o absurdo de se pré conceber legalmente o valor a ser pago a título de royalty. Segundo o eminente jurista, o valor deve ser idealizado em função da importância da marca no mercado. Ademais, o valor da marca não é passível de ser pré-determinado por lei, mesmo porque há marcas cujas remunerações, em sede de contrato de licença, devem ser mais expressivas em razão de sua significância econômica e impacto gerado sobre o mercado consumidor, ao passo que, há marcas outras, embrionárias, que sequer apresentam valor de mercado. Portanto, o jurista conclui que o royalty legalmente pré-concebido de $1 \%$ constituiria uma "dedução indevida, em prejuízo da economia nacional”, de sorte que apenas os titulares de marcas com valores expressivos acabavam sendo premiados com o royalty.

Perfilha este entendimento Newton Silveira ${ }^{502}$, ao ministrar a tese de que o valor da marca resulta do uso e de sua repercussão diante da clientela, sendo que o valor do signo em apreço é válido, irretorquivelmente, "pelo que representa para o público", e não o que representa em si mesmo.

Com o advento da Lei 9.279/96, o corpo normativo disciplinador dos direitos sobre a propriedade industrial deixou de prever mínimo ou máximo legal de remuneração ou royalties $^{503}$. Preleciona Rubens Requião, ao debruçar-se sobre a remuneração em contrato de licença, que houve uma libertação, no campo da legislação da propriedade industrial, cabendo o controle fiscal e cambiário a outro segmento. Para o jurista paranaense, a lei vigente que regulamenta a propriedade industrial foi proclamada sob um manto menos protecionista e burocrático e, portanto, mais flexível, de modo que o contrato de licença de uso de marca passoum a ser disciplinado sob um viés mais liberal, também em seu aspecto

${ }^{501}$ GNOCCHI, Alexandre. Licenças e Roialties no Brasil. op. cit. p. 232.

${ }^{502}$ SILVEIRA, Newton. Licença de Uso de Marca e Outros Sinais Distintivos. op. cit. p. 69.

503 " $<$ Royalty $>$ n. a percentage of gross or net profit or a fixed amount per sale to which a creator of a work is entitled which is determined by contract between the creator and the manufacturer, publisher, agent and/or distributor. Inventors, authors, movie makers, scriptwriters, music composers, musicians and other creators contract with the manufacturers, publishers, movie production companies and distributors, as well as producers and distributors for a license to manufacture and/or sell the product, who pay a royalty to the creator based on a percentage of funds received. Should someone use another person's creation either purposely or by mistake, the user could be found liable to the creator for all profits on the basis of copyright or patent infringement, which usually is far more than a royalty. However, a creator does not have to license his/her creation to anyone". (in Law.Com Dictionary. Disponível em <http://dictionary.law.com/default2.asp?typed=royalties\&type=1> Acesso em 10 abril 2009. 
remuneratório. Neste sentido, imperioso colacionar lição do comercialista em estudo, a seguir textualmente reproduzido

\begin{abstract}
A Lei n. ${ }^{\circ} 9.279 / 96$ abandonou as regras severas do antigo Código, que versavam sobre os contratos de exploração de marca e conseqüente pagamento de royalties, com que se pretendia supostamente defender a economia nacional da exploração de empresas estrangeiras, que poderiam se utilizar do royalty gerado pelo contrato para remeter disfarçadamente lucros ao exterior. Houve a liberalização, ao menos no campo da legislação da propriedade industrial, cabendo o controle fiscal e cambiário a outro campo. (grifou-se) 504
\end{abstract}

Com efeito, a remuneração deve ser livremente fixada pelas partes, em acordância ao princípio da livre autonomia da vontade, consagrado no novo diploma civil.

Assim como ocorre na locação de bens móveis, as partes são livres para pactuar a forma de remuneração. A despeito de as regras do contrato de locação de coisas irradiarem efeitos sobre o contrato de licença, evidencie-se a diferenciação entre royalties, aluguéis e juros, solidamente arquitetada por José Luiz Bulhões Pedreira ${ }^{505}$. Preleciona o jurista que a diferenciação entre os três conceitos reside no objeto para o qual cada remuneração se projeta, ou seja, no elemento central do qual advém cada retribuição. Desta feita, o aluguel remunera o capital investido em bens materiais; os juros retribuem o capital financeiro e os royalties, por fim, consistem no pagamento do capital aplicado "em direitos" ou bens incorpóreos. Acrescenta, ainda, que a receita obtida pelo licenciamento, consubstanciada nos royalties, não guardam relação direta com a receita obtida pela empresa como corolário de sua produção de bens ou serviços, posto que esta última receita caracteriza "lucro operacional", sem embargo da faculdade de a sociedade licenciar a marca ou se valer de marca licenciada mediante pagamento de contraprestação.

\footnotetext{
${ }^{504}$ REQUIÃO, Rubens. Curso de Direito Comercial. 25 ed. São Paulo: Saraiva, 2003. vol. 1. p. 266.

${ }^{505}$ PEDREIRA, José Luiz Bulhões. Imposto de Renda. Rio de Janeiro: APEC Editora, 1969, pp. 9-6.
} 
Ex vi do artigo 318 do Código Civil Brasileiro ${ }^{506}$, o pagamento da remuneração consentida pelas partes contratantes, nos contratos de licença de uso de marca, deve estar previsto em moeda nacional.

O Código Civil revogado, de cunho notadamente mais liberal, permitia expressamente o pagamento em moeda estrangeira ${ }^{507}$. Com efeito, o artigo 947 do Código de 1916, assegurava às partes o exercício pleno da livre autonomia da vontade, sinalizando a licitude em se determinar que o pagamento fosse efetuado em moeda nacional ou estrangeira. Adicionalmente, prescrevia que o devedor, no evento de se estipular pagamento em moeda estrangeira, poderia eleger, na data do adimplemento, entre o pagamento na espécie designada no título ou o seu equivalente em moeda corrente no lugar da prestação, ao câmbio do dia do vencimento. Não havendo cotação nesse dia, prevaleceria a imediatamente anterior.

Com o advento do fluxo forçado da moeda nacional, consagrado pelo Decreto Lei

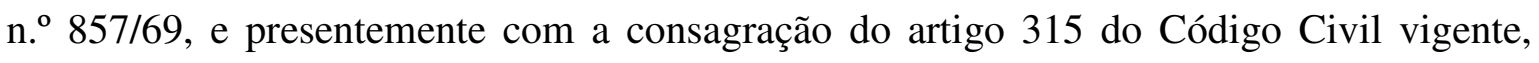
somente os pagamentos realizados em moeda nacional passaram a dar ensejo à liberação das partes contratantes em relação às obrigações contratualmente assumidas.

A interpretação ao artigo 315, acima mencionado, deve ocorrer de forma restrita, de modo que deve ser invalidada tão somente a cláusula obrigacional que estipule o pagamento da dívida em moeda estrangeira, não se desdobrando esta compreensão à disposição contratual que recorre à moeda estrangeira apenas como padrão de conversão, quando do momento do pagamento ${ }^{508}$.

A Suprema Corte Brasileira tem nos proporcionado a seguinte interpretação aos dispositivos que versam sobre a questão remuneratória em relações obrigacionais: faculta-

\footnotetext{
${ }^{506}$ Reza o art. 318 do Código Civil Brasileiro, que "são nulas as convenções de pagamento em ouro ou em moeda estrangeira, bem como para compensar a diferença entre o valor desta e a moeda nacional, excetuados os casos previstos na legislação especial".

${ }^{507}$ Conforme art. 947 do CC de 1916: “O pagamento em dinheiro, sem determinação da espécie, far-se-á em moeda corrente no lugar do cumprimento da obrigação. $\S 1^{\circ}$ É, porém, licito às partes estipular que se efetue em certa e determinada especie de moeda, nacional, ou estrangeira”.

${ }^{508}$ Cf. OLIVEIRA, James Eduardo. Código Civil anotado e comentado: doutrina e jurisprudência. Rio de Janeiro: Ed. Forense, 2009. p. 266.
} 
se às partes a contratação em moeda estrangeira, desde que os contratantes expressamente estabeleçam que o pagamento será efetuado por meio da respectiva conversão em moeda nacional. Portanto, ante o curso forçado de moeda nacional, é defeso ao credor se recusar a receber o pagamento da dívida em "reais", sendo que o momento da conversão em moeda nacional é o da data do adimplemento da dívida e não o da propositura da ação judicial contra o devedor ${ }^{509}$.

Nesta esteira, o entendimento corroborado pela jurisprudência pátria é consistente ao consagrar o princípio da equivalência em moeda nacional ${ }^{510}$. Tal princípio consiste na previsão contratual cujo valor concernente à contraprestação é previsto em moeda estrangeira, porém o pagamento é realizado em moeda nacional.

Conclui-se, portanto, que os contratos de licença de uso de marca, cujo pagamento será realizado internamente, poderão ter seus royalties previstos em moeda nacional ou estrangeira, à luz do princípio da fiel autonomia da partes. Esta proposição valida-se, contudo, tão somente no evento de as partes expressamente contratarem que o pagamento se realizará por meio da respectiva conversão em moeda nacional, na data do adimplemento parcial ou total da obrigação contraída pelo devedor. Neste sentido, a partir da interpretação da impossibilidade de pagamento em moeda estrangeira, porém da possibilidade de equivalência com moeda estrangeira, registre-se, a título exemplificativo, cláusula que pode ser utilizada pelos operadores do direito ao confeccionarem contratos de licença: "Do Pagamento: Pelo uso da marca licenciada, objeto do presente instrumento, o

\footnotetext{
${ }^{509}$ Colacionem-se, neste aspecto, dois julgados paradigmáticos sobre a contratação em moeda estrangeira: (i) "Em muitas decisões, esta Corte tem admitido a contratação em moeda estrangeira, desde que o pagamento seja efetuado em moeda nacional" (STJ, Resp. 397.398/SP, $3^{\mathrm{a}}$ T., rel. Min. Carlos Alberto Menezes Direito, DJU 24.02.2003, p.223); (ii) "Desde que expressamente previsto que o pagamento realizar-se-á por meio da respectiva conversão em moeda nacional, é vállida a contratação em moeda estrangeira, consideradas as peculiaridades do processo. A obediência ao curso forçado da moeda nacional implica na proibição do credor se recusar a receber o pagamento da dívida em reais e faz surgir a conclusão de que o momento da conversão em moeda nacional é o do pagamento da dívida e não o do ajuizamento da execução.”(STJ,REsp. 647.672/SP, $2^{\text {a }}$ Seção, Rel. Min. Nancy Andrighi, DJU 20.08.2007, p. 234)

${ }^{510}$ Oportuno colacionar o posicionamento do Colendo Superior Tribunal de Justiça a respeito da matéria em comento, cuja ementa segue reproduzida: "Civil. Ação de Cobrança. Contrato de Compra e Venda em Moeda Estrangeira. Possibilidade desde que o pagamento se efetive pela conversão em moeda nacional, arts. $1^{o}$ do Decreto Lei $n^{\circ} 857 / 69$ e $6^{o}$ da Lei $n .^{\circ}$ 8.880/94. 1. É legítimo contrato de compra e venda celebrado em moeda estrangeira, desde que o pagamento se efetive pela conversão em moeda nacional. 2. Recurso especial não reconhecido.” (grifou-se) (STJ. REsp n. ${ }^{\circ}$ 799832/PR. 2005/0195576-8. Rel. Min. João Otávio de Noronha. Quarta Turma. Julgado em 08/04/2008. DJe 28/04/2008).
} 
licenciado pagará, mensalmente, ao licenciante o equivalente, em Reais (moeda nacional), a US\$ 50.000,00 (cinqüenta mil dólares norte-americanos)”.

Sobre as diversas alternativas de remuneração dos contratos de licença de uso de marca, Susan Progoff, ao examinar o ordenamento jurídico estadosunidense, estabelece que a contraprestação pelo uso do sinal disponibilizado em caráter temporário pode consistir $\mathrm{em}^{511}$ :

valor cheio (paid up license), quando o licenciado remunera, logo quando do início do contrato, montante integral para a utlização do sinal;

(ii)

valor fixo mínimo (minimum royalty), o que corresponde ao montante mínimo a ser pago, periodicamente (mensal, trimestral, semestral, anual etc), pelo licenciado ao licenciador. Alicerçando-se em decisão judicial da corte norte americana, Susan Progoff ${ }^{512}$ assevera que no caso de préfixação de remuneração mínima, não se pode concluir que o contrato de licença dispõe, implicitamente, de preceito prevendo que o licenciado envidará seus melhores esforços no uso da marca, dado que o pagamento de valor mínimo, por si só, denota segurança ao licenciador;

(iii) valor variável (running royalty), em que o licenciado remunera o licenciador proporcionalmente ao montante variável obtido com a venda dos produtos ou serviços aliados ao sinal licenciado. Assinale-se, neste sentido, preciosa definição disseminada por Andrew J. Sherman, atinente aos royalties variáveis. Segundo o autor, as "fórmulas de royalties variam largamente, podendo ser baseadas na receita bruta, na receita líquida, no lucro líquido, em valor fixo por produto licenciado vendido, em um pagamento mínimo a ser, periodicamente, feito ao licenciador ou, além disso, pode se abalizar em um escalonamento com o escopo de se

\footnotetext{
${ }^{511}$ Cf. PROGOFF, Susan. Understanding the Intellectual Property License. Nova Iorque (EUA): Practising Law Institute, 2004. pp. 20/21.

512 "If the licensee pays a minimum royalt, courts may not infer that the license agreement also implicitly contains a best efforts clause. In such a situation, the minimum royalty payment protects the licensor from the possibility that the licensee will fail to use reasonable or best efforts. Emerson Radio Corp. v. Oroin Sales, Inc., 243. F. 3d 159 (3d. Circ. 2001) (Idem. Ibidem. p. 35)
} 
conceder incentivos ao licenciador como recompensa de sua performance positiva" ${ }^{, 13} \mathrm{e}$, por fim;

valor mínimo fixo aliado a valor variável (percentual) sobre a receita auferida pelo licenciado com a venda dos produtos ou serviços.

Similarmente, no ordenamento jurídico nacional, licenciante e licenciado poderão prever: (i) uma porcentagem sobre a receita auferida pelo licenciado com a venda dos produtos ou serviços por ele oferecidos ao mercado; (ii) uma porcentagem ou valor fixo por unidade fabricada ou vendida ou por serviço prestado; (iii) um valor fixo periódico pela utilização da marca $^{514}$; ou ainda, (iv) a combinação de valores fixos com percentagens variáveis de acordo com a quantidade de produtos vendidos ou serviços prestados. Ademais, conforme bem observa João da Gama Cerqueira, costuma-se fixar valor mínimo fixo, o qual não guarda relação com o valor variado ${ }^{515}$. Sucede, entretanto, que os valores pré-fixados devem se coadunar com o valor e imagem da marca no mercado, com os produtos ou serviços as serem oferecidos, e com as possibilidades que uma parte tem de pagar e a outra de receber ${ }^{516}$.

Concernente à terceira alternativa de remuneração, consistente no pagamento de um valor fixo periódico pela utilização da marca, merece especial apreciação a aplicação do

\footnotetext{
${ }^{513}$ Cf. SHERMAN, Andrew J. op. cit. p. 365. (tradução livre).

${ }^{514}$ Sobre as possíveis formas de pagamento de royalties, em contratos de licença de uso de marca, Giuseppe Sena prescreve: “(...) contratti di licenza Il cui corrispettivo è costituito da uma somma versata uma tantum e contrati di licenza con um canone por esempio annuale o percentuale rispetto al fatturato del prodotto (si parla correntemente di royalties o di redevances." (Cf. SENA. Giuseppe. I Diritti Sulle Invenzioni e Sui Modelli Industriali. Milão. Dott. A. Giuffrè Editore. 1976. p. 320)

515 Neste sentido, convém reproduzirmos a justificativa apresentada por Gama Cerqueira para o estabelecimento de piso fixo desvencilhado do pagamento variável. Assim reza o ilustre tratadista, in verbis: "Costuma-se, também, fixar um pagamento mínimo independente da retribuição contratada, ou correspondente ao mínimo de produção fixada, como garantia ao titular da patente [ou marca] contra a falta de exploração da patente ou nos casos de exploração reduzida". Importa lembrar que Gama Cerqueira utilizase dos mesmos princípios aplicáveis aos contratos de licença de patente, para estudar os contratos de licença de uso de marca. (Cf. CERQUEIRA, João da Gama. Tratado da Propriedade Industrial. $3^{\mathrm{a}}$ ed. atual. por: Newton Silveira e Denis Borges Barbosa. op. cit......Vol. II. Tomo I. Parte II. pp. 174/175)

516 SOARES, José Carlos Tinoco. Lei de Patentes, Marcas e Direitos Conexos. Lei 9.279 de 1996. op. cit.. pp. $227 / 228$.
} 
princípio da onerosidade excessiva sobre o contrato de licença de uso de marca (contrato de execução continuada ${ }^{517}$ ).

Conforme aclarado em capítulo oportuno, este princípio, consubstanciado na teoria da imprevisão, assinala que o contrato poderá ser rescindido, em existindo fato superveniente que traga vantagem excessiva para uma das partes em face de manifesto e expressivo prejuízo à parte adversa. No entanto, tal rescisão somente se opera, se o fato superveniente for extraordinário e de complexa previsão. Esta teoria encontra-se arraigada à cláusula "rebus sic stantibus", que assinala que a relação jurídica deve perdurar enquanto remanescer a situação fática que lhe deu ensejo.

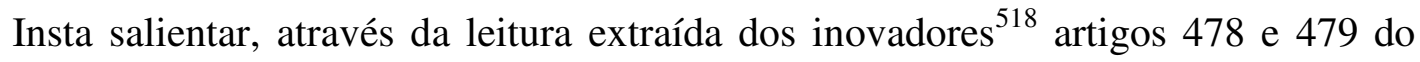
diploma civil vigente, que mencionada legislação não autorizou a revisão do contrato pelo juiz. Por tais dispositivos, pode-se extrair que o juiz pode tão somente resolver a relação jurídica consagrada entre as partes, não podendo, ex officio, equilibrá-la ou revisá-la. Poderá apenas fazê-lo se provocado, i.e., na hipótese de o réu insurgir-se contra a demanda resolutória proposta pelo autor em cuja contestação seja apresentada proposta alternativa, de tal modo a permitir que o contrato seja reformatado, em suas bases, com fulcro nas novas condições oferecidas pelo réu e que o juiz, necessariamente, as tenha como suficientemente eqüitativas a evitar a resolução do contrato.

Aplicando-se este dispositivo ao instrumento contratual sub examine, imaginemos que tenha sido firmado contrato de licença de uso de marca, pelo qual o titular licencia, a título exclusivo, sua marca para determinado cosmético " $\mathrm{X}$ " e para determinado perfume "Y", ambos fabricados por terceiro. Vamos imaginar, ainda, que este contrato tenha sido fixado pelo prazo de 3 anos, com valor mensal fixo pré-fixado de R\$100.000,00 (cem mil reais), para a utilização da mesma marca, registrada para os dois produtos acima mencionados. No entanto, após 12 meses de contrato, tenha sido editada legislação específica proibindo a fabricação e a comercialização do cosmético "X”, em todo o

\footnotetext{
${ }^{517} \mathrm{O}$ contrato de licença de uso de marca representa contrato de execução continuada, porque as prestações são continuamente adimplidas pelas partes contratantes. Desta sorte, o uso contínuo da marca é assegurado pelo licenciante, ao passo que as prestações são adimplidas periodicamente pelo licenciado, em contraprestação à aludida utilização do bem imaterial disponibilizado pelo titular do direito.
}

${ }^{518}$ Estes dispositivos normativos não encontram correspondência no Código Civil de 1916 (revogado). 
território nacional, pois que este produto, após a realização de testes, fora considerado nocivo à saúde. Sendo que $60 \%$ do lucro obtido pelo licenciado era extraído da comercialização do cosmético "X”, pergunta-se: pode o licenciado, com amparo na princípio da vedação à onerosidade excessiva, pleitear judicialmente a resolução (ou revisão se a parte contrária assim consentir) do contrato de licença de uso de marca, com fundamento no artigo 478 do Código Civil?

Passemos à análise deste caso, à luz dos elementos extraídos do artigo 478 do Diploma Civil. Primeiramente, temos que o contrato de licença de uso de marca em tela é contrato de execução continuada ou diferida. Na hipótese erigida, é patente a quebra do ponto de equilíbrio contratual. É de se notar que a prestação do licenciado, após a publicação da lei proibindo a comercialização do cosmético "X", tornou-se excessivamente onerosa, com extrema vantagem para o titular da marca. Isto porque, se o titular ainda estivesse comercializando o produto embargado, seria ele quem suportaria os "prejuízos", fruto do óbice legal. E como o titular licenciou a marca também para aquele produto, ele passou a lucrar em detrimento do licenciado, porquanto, a despeito da aludida proibição legal, os royalties não deixaram de ser devidos e pagos pelo licenciado, por força do contrato de licença, que fez lei entre as partes. Por fim, é razoável admitir que a lei proibindo a produção e comercialização daquele produto (produto este que já vinha ocupando espaço no mercado ao longo de 10 anos) representa evento extraordinário e imprevisível.

Sobre o conceito de evento extraordinário e imprevisivel, Luiz Guilherme Loureiro assinala que "é preciso que os eventos extraordinários e imprevisíveis sejam de âmbito geral (...)". Ainda afirma o jurtista que "o acontecimento tem caráter de generalidade quando muda as condições de todo um mercado ou de todo um segmento de relações, como é o caso da greve de um determinado setor da indústria, o advento de lei que proíba a produção ou comercialização de determinado produto ou substância ou eventos naturais de extrema gravidade, dentre outros exemplo" 519 .

Ante os argumentos externados, e respondendo-se à questão acima proposta, é razoável concluir que o licenciado, na hipótese que ora se levanta, tem fundamento jurídico

${ }^{519}$ Cf. LOUREIRO, Luiz Guilherme. Contratos no Novo Código Civil. $2^{\mathrm{a}}$ ed. São Paulo; Ed. Método. 2004. pp. $267 / 268$. 
para pleitear judicialmente a resolução (ou revisão se a parte contrária assim consentir) do contrato de licença de uso de marca, com fundamento no artigo 478 do Código Civil.

Por outro lado, este autor é partidário do posicionamento de que a aplicação do princípio da vedação da onerosidade excessiva somente tem lugar, no contrato de licença de uso de marca, quando, e tão somente quando, os eventos que afetarem o equilíbrio contratual forem extraordinários e se encontrarem dissociados do risco natural intrínseco a este tipo de relação jurídica empresarial. Demais disto, a obrigação de uma das partes deve passar a ser enormemente onerosa com extremado benefício para a outra.

Com efeito, o contrato de licença de uso de marca, por ser um contrato empresarial e, portanto, um contrato de risco, não poderá ser "revisado", simplesmente porque houve desproporção das prestações assumidas, em decorrência da alteração "esperada" de fatores econômicos extrínsecos ao contrato, porém que, de alguma forma, tenham impactado no equilíbrio econômico inicialmente alcançado pelas partes.

Tendo-se em mente este conceito, apresentemos o seguinte cenário ilustrativo, para reflexão.

Imaginemos que tenha sido firmado contrato de licença de uso de marca, pelo prazo de 5 anos, com valor mensal fixo pré-fixado, alternativamente à fixação de valor abalizado em porcentagem sobre a receita auferida ou mesmo sobre o lucro alcançado. $\mathrm{O}$ valor pré-fixado entre as partes contratantes foi fixado em conformidade com a receita mensal média, atinente ao produto comercializado, obtida pelo titular no período dos 3 anos consecutivos anteriores à assinatura do instrumento.

Imagine-se, entretanto, que após dois anos de contrato, em decorrência de uma crise mundial inciada no sexto mês de contrato, a receita mensal média, proveniente do produto comercializado, tenha caído 35\%. Considerando que: (a) a receita mensal média havia sido utilizada como parâmetro para o estabelecimento do valor mensal fixo da licença; (b) o licenciado esperava que tivesse lucro; (c) o licenciado, após dois anos de contrato, e em razão da grave crise mundial, teve lucro ínfimo, muito aquém do projetado, Ante esta conjectura, questiona-se: pode o licenciado, com amparo na princípio da vedação à onerosidade excessiva, pleitear judicialmente a resolução (ou revisão se a parte contrária 
assim consentir) do contrato de licença de uso de marca, com fundamento no artigo 478 do Código Civil?

No caso hipotético que ora se apresenta, entendemos que não há como pleitear a resolução ou revisão do contrato, como efeito da ausência de lucro para o licenciado, e a presença de lucro para o licenciante, este último como resultado do pagamento dos royalties mensais pré-fixados. Isto porque o contrato firmado é um contrato empresarial e carrega consigo os riscos críveis a ele inerentes. Deste modo, assim como o licenciado poderia ter lucros exorbitantes, no hipótese de a economia estar hiperaquecida, também poderia ter prejuízos acentuados, como resultado do desaquecimento abrupto do mercado. Repise-se: são os riscos inatos à atividade empresarial. Diz respeito à álea normal do negócio entabulado pelas partes.

É neste particular que preleciona Humberto Theodoro Júnior, cujas palavras seguem adiante transcritas:

\begin{abstract}
Nos jogos dos fenômenos econômicos há sempre um certo risco de não se alcançar o lucro ou o resultado projetado pelo contratante. Há modificações por assim dizer normais e previsiveis nas cirunstâncias que envolvem a pactuação do contrato e que, quase sempre, não serão as mesmas da época de seu cumprimento. Muitas vezes, aliás, é para se garantir contra tais mutações que a parte é levada a contratar. Somente quando as variações são muito profundas, ao ponto de acarretar uma onerosidade muito maior do que aquela que se poderia rozoavelmente prever, é que a parte cuja responsabilidade negocial foi efetivamente atingida teria condições de pretender a revisão do contrato ainda por cumprir. (grifou-se).
\end{abstract}

Ainda neste sentido, convém colacionar esclarecedor magistério da professora Paula A. Forgioni, verbis:

Novamente, será preciso cuidado para que o texto do novo Código Civil não seja aplicado de forma tal a neutralizar as vantagens competitivas normais $e$ desejáveis do mercado. Em linguagem mais tradicional, poderíamos falar na "normal álea do negócio", que parece ter sido ignorada pelo novo diploma em alguns aspectos. Além da questão da lesão, lembre-se a disciplina da onerosidade excessiva, positivada nos arts. 478 e seguintes. Ao contrário do art. 1.467 do Codice Civile, nosso diploma não contemplou expressamente as hipóteses em que a excessiva onerosidade subsume-se à "álea normal do contrato". Ora, terá sido ignorada a "incerteza sobre a margem dos prejuízos ou do lucro superveniente", que, em tal caso, presumir-se-ia "matéria de risco 
Na mesma medida, pondera Cáio Mário da Silva Pereira, para quem "nunca haverá lugar para a aplicação da teoria da imprevisão naqueles casos em que a onerosidade excessiva provém da álea normal e não do acontecimento imprevisto, como ainda nos contratos aleatórios, em que o ganho e a perda não podem estar sujeitos a um gabarito determinado" ${ }^{521}$.

Há que ficar claro, pois, que este princípio, assim como outros princípios sociais cujos efeitos são irradiados sobre o contrato de licença de uso de marca, sobre esta modalidade de contrato empresarial deve ter incidência branda e seletiva. Não se espera que seja aplicado de modo indiscriminado, em em larga esclada, à luz da teoria maximalista, como ocorre em relações outras em que há partes situadas em diferentes patamares, a exemplo das relações de consumo. Especialmente para que não se gere insegurança jurídica nas relações empresariais. Para que o empresariado não se sinta desestimulado a contratar e a promover a circulação de riquezas (fundamento e escopo maior dos contratos). Para que o empresário também não fique ao desabrigo. E, por fim, para que a economia não sofra danos irremediáveis ou de morosa reparação. Portanto, conforme sinalizado nos exemplos acima confrontados, para que se observe a aplicação do princípio da onerosidade excessiva, as circustâncias extrínsecas ao contrato devem ser, de fato, extraordinárias, conduzindo uma das partes à vantagem excessiva contra o elevado prejuízo da parte contratante adversa.

Este posicionamento tem sido reverberado pela Corte Superior. Em recente julgado, de relatoria do Min. Luis Felipe Salomão, apreciou-se a alteração de valores em contratos de venda e compra de soja para entrega futura, à luz da teoria da imprevisão. O comprador consentiu juntamente com o produtor, quando do fechamento do contrato, $\mathrm{R} \$ 25,00$ por saca de $60 \mathrm{~kg}$ de soja. Todavia, um ano após a subscrição do contrato, já quando da entrega

\footnotetext{
${ }^{520}$ FORGIONI. Paula Andréa. Interpretação dos Negócios Empresariais. in FERNANDES, Wanderlei (coord.). Fundamentos e Princípios dos Contratos Empresariais. $1^{a}$ ed. Série GV Law. São Paulo: Saraiva. 2007. pp.75-155.

${ }^{521}$ PEREIRA, Cáio Mário da Silva. Instituições de direito civil. $11^{\mathrm{a}}$ ed. Rio de Janeiro: Forense, 2003, v. III, p. 167.
} 
do produto, o valor de mercado da aludida saca era de $\mathrm{R} \$ 35,00$. O vendendor pleiteou, então, a rescisão ou revisão do contrato, sob o argumento de que, com a significante valorização do produto, por fatores múltiplos, ele, vendedor, haveria por demais se onerado. Pautou sua defesa, essencialmente, na teoria da imprevisão.

A despeito do acolhimento desta tese pelo Tribunal de Justiça do Estado de Goiás, a Colenda Corte Superior deicidiu que a venda antecipada da soja assegura a obtenção de lucros razoáveis, previamente identificáveis, tornando o contrato protegido contra o declínio repentino no preço do produto. Para o STJ, não haveria como se recorrer ao princípio da onerosidade excessiva, pois que não houve prejuízo para o produtor/vendedor, mas tão apenas a obtenção de um lucro aquém daquele que teria, na eventualidade de a venda se aperfeiçoar em momento futuro. Até porque este mercado, em sua essência, é flutuante e está constantemente sujeito a todos os riscos intrínsecos à oscilação de preço do produto (soja).

A jurisprudência do Superior Tribunal de Justiça, em eventos análogos, sustentou o mesmo entendimento:

Comercial. 1. Compra e Venda de Safra Futura a Preço Certo. A compra e venda de safra futura, a preço certo, obriga as partes se o fato que alterou o valor do produto agrícola (sua cotação no mercado internacional) não era imprevisível. 2. Cédula de Produto Rural. A emissão de cédula de produto rural, desviada de sua finalidade típica (a de servir como instrumento de crédito para o produtor), é nula. Recurso especial conhecido e provido em parte. ${ }^{522}$

Civil. Contrato. Venda. Safra Futura. Soja. Cotação. Mudança. Alteração e Resolução da Avença. Impossibilidade. 1 - A venda de safra futura, a preço certo, em curto espaço de tempo, há de ser cumprida pelas partes contratantes. Alterações previsíveis na cotação do produto (soja) não rendem ensejo à modificação da avença ou à sua resolução. Precedentes deste Tribunal. 2 Recurso especial não conhecido ${ }^{523}$.

Ainda no aspecto remuneratório, impõe-se identificar outro princípio de direito contratual de grande autoridade: o princípio da função social (em sua eficácia externa) do

\footnotetext{
${ }^{522}$ Recurso Especial n. ${ }^{\circ}$ 722130/GO. Rel. Ministro Ari Pargendler. Terceira Turma do Superior Tribunal de Justiça. Julg. em 15 dez. 2005. DJ 20/02/2006 p. 338.

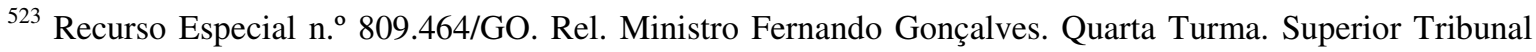
de Justiça. Julg. em 10/06/2008, DJe 23/06/2008 RT vol. 876 p. 161.
} 
contrato, insculpido no artigo 422 do Código Civil. Deste modo, o contrato de licença de uso de marca deve preencher sua função social. Para tanto, conforme assinala José Carlos Tinoco Soares ${ }^{524}$, ao produto sobre o qual incidirá a marca licenciada, não poderá ser imposto preço de venda incompatível com aquele praticado pelo mercado. O comercialista acrescenta que o valor remuneratório, cobrado pelo licenciante a título de royalty, deverá ser razoável, de tal sorte que não somente as partes tenham benefícios erigidos do contrato celebrado, como, por igual, o consumidor não seja prejudicado em função do contrato concluído.

Exemplificativamente, o princípio da função social do contrato (no caso da estipulação de remuneração) pode restar transgredido, quando as partes fixarem valores de royalties extremamente elevados, de tal sorte que o licenciado repasse este valor ao consumidor, que poderá ficar demasiadamente onerado em decorrência de um contrato celebrado inter partes, do qual não teve qualquer participação. Na vertente hipótese, temos que o preço a ser praticado pelo licenciado passará a ser extremamente elevado e não condizente com os preços de mercado. Portanto, imprescindível se faz uma intervenção ao contrato tendo-se por desígnio o restabelecimento de sua função social.

No tocante à função social do contrato de licença, impõe-se assinalar, outrossim, que este princípio encontra-se intrinsecamente conectado ao artigo 173 , parágrafo $4^{\circ}$, da Carta Magna pátria ${ }^{525}$. Deste modo, temos, que tanto o artigo 422 do Código Civil, como o artigo 173, parágrafo $4^{\circ}$ da Constituição Pátria, visam à defesa dos agentes extrínsecos aos contratos de licença, de tal sorte que eles não venham a ser prejudicados por atos arbitrários, lançados às margens da lei, que resultem em abuso de poder econômico ou concorrência desleal, fruto da autonomia da vontade descomedida perpetrada pelas partes contratantes.

\footnotetext{
${ }^{524}$ SOARES, José Carlos Tinoco. Lei de Patentes, Marcas e Direitos Conexos...op. cit. p. 227.

525 Assinala a Carta Magna Brasileira, em seu art. 173, parágrafo $4^{\circ}$, o qual prescreve, in verbis: "Ressalvados os casos previstos nesta Constituição, a exploração direta de atividade econômica pelo Estado só será permitida quando necessária aos imperativos da segurança nacional ou a relevante interesse coletivo, conforme definidos em lei. (...) $\S 4^{\circ}$ - A lei reprimirá o abuso do poder econômico que vise à dominação dos mercados, à eliminação da concorrência e ao aumento arbitrário dos lucros".
} 
O abuso de poder econômico, fruto de eventuais contratos de licença, é frontalmente combatido pelo TRIPS, cuja colação do artigo 40 se faz de extrema importância para fins do presente estudo:

\title{
SEÇÃO 8: CONTROLE DE PRÁTICAS DE CONCORRÊNCIA DESLEAL EM CONTRATOS DE LICENCGAS
}

\author{
ARTIGO 40
}

1. Os Membros concordam que algumas práticas ou condições de licenciamento relativas a direitos de propriedade intelectual que restringem a concorrência podem afetar adversamente o comércio e impedir a transferência e disseminação de tecnologia.

2. Nenhuma disposição deste Acordo impedirá que os Membros especifiquem em suas legislações condições ou práticas de licenciamento que possam, em determinados casos, constituir um abuso dos direitos de propriedade intelectual que tenha efeitos adversos sobre a concorrência no mercado relevante. Conforme estabelecido acima, um Membro pode adotar, de forma compativel com as outras disposições deste Acordo, medidas apropriadas para evitar ou controlar tais práticas, que podem incluir, por exemplo, condições de cessão exclusiva, condições que impeçam impugnações da validade e pacotes de licenças coercitivas, à luz das leis e regulamentos pertinentes desse Membro. (...) (grifou-se)

No que atine às limitações legais do licenciamento de marca, D. Carter ${ }^{526}$ preleciona que, na Austrália, na esteira do que ocorre em outros sistemas jurídicos, é ilegal, à luz da lei concorrencial daquele país (Trade Practices Act/1974), que o contrato contenha dispositivos que fixem preços e que obriguem o licenciado a se vincular a um determinado fornecedor de produtos. Esta ilegalidade, contudo, será desconsiderada (passando-se à legalidade), especialmente no evento das referidas imposições serem estabelecidas com o escopo precípuo de o licenciador exercer seu poder de controle sobre as operações do licenciado, poder este expressamente avalizado em lei ${ }^{527}$.

\footnotetext{
${ }^{526}$ CARTER, D. in Trademark Licences or Goodbye Goodwill. Florence. Open Forum Papers. 21-24 october 1998. Paper: FLO/2.5. < http://www.ficpi.org/library/florence98/goodwill.html> Acesso em 20 de dez. de 2009.

${ }^{527}$ Neste sentido, imperioso transcrever seção do Trade Practises Act que excepciona a possibilidade de fixação de preços e vinculação do licenciado a terceiros, por força do contrato: "Trade Practices Act 1974 Sect 51 - Exceptions - (...) A contravention of a provision of this part other than section $46,46^{a}$ or 48 shall not be taken to have been committed by reason of : (...) (c) the inclusion in a contract, arrangement or understanding between: (i) the registered proprietor of a trade mark other than a certification trade mark; and (ii) a person registered as a registered user of that trade mark under Part IX of the Trade Marks Act 1955 or a person authorized by the contract to use the trade mark subject to his or her becoming registered as such a registered user; of a provision to the extent that it relates to the kinds, qualities or standards of goods bearing the mark that may be produced or supplied, or the giving effect to the provisions to that extent. (..)”
} 
No Brasil, o artigo 29, $\S 2^{\circ}$, da revogada Lei 5.772/71 (antigo Código de Propriedade Industrial), proclamava que ao contrato de licenca era vedada a imposição de ressalvas, a que título fosse, que resultasse na delimitação à: (a) comercialização e exportação do produto portador da marca licenciada; e (b) importação de insumos necessários à sua fabricação.

A doutrina nacional, por igual, sustenta a necessidade perene de controle, combatendo, com veemência, as práticas de concorrência desleal e abuso de poder econômico em contratos de licença de uso de marca. Luiz Leonardos assinala:

(...). Mas não pode a licença determinar restrições às vendas dos produtos fabricados ou às exportações dos mesmos, nem fixar-lhes os preços ou incluir qualquer cláusula que restrinja a sua comercialização ou vincule à licença à aquisição de insumos provenientes do titular ou de fonte por este indicada. (grifou-se)

Reportamo-nos, igualmente, à lição ministrada por José da Silva Pacheco, que prescreve, com fundamento na Lei $8.884 / 94^{528}$, que o contrato de licença não pode conter dispositivos contratuais que infrinjam os mandamentos insertos na lei que dispõe sobre a repressão às infrações contra a ordem econômica.

Com efeito, na esteira do que propugna o tratadista em referência, não devem restar consignadas em contrato cláusulas que impliquem expressa ou tacitamente, a restrição ou mesmo impedimento de fabricação ou comercialização de produto ou serviço identificado pela marca licenciada ${ }^{529}$, sobretudo dispositivos contratuais que:

(i) regulem, alterem ou limitem a produção, venda, preço, distribuição, bem como a contratação de pessoal e a reserva ou a distribuição de mercados ou

\footnotetext{
${ }^{528}$ José da Silva Pacheco remete-se à Lei 4.137/67, revogada pela Lei 8.884/94, para enumerar as matérias que não podem ser ponderadas em um contrato de licença de uso de marca, sob pena de flagrante lesão ao principio da função social e conseqüente prejuízo a todo o tecido sócio-econômico. (PACHECO, José da Silva. Tratado de Direito Empresarial: Empresário: pessoa e patrimônio. vol. 2. São Paulo. Saraiva. 1979. p.p. 570/571)

${ }^{529}$ SILVEIRA, Newton. Licença de Uso de Marca e Outros Sinais Distintivos. op. cit. pp.. 70/71.
} 
a exclusão de algum deles, exceto se legislação ou ato internacional dispuser em sentido contrário;

(ii) obriguem ou condicionem a compra de insumos ou materiais do titular/licenciante ou de outros fornecedores por ele indicados;

(iii) impeçam, alterem ou bloqueiem as atividades de desenvolvimento tecnológico do licenciado;

(iv) impeçam o licenciado de discutir, administrativamente ou em juízo, a titularidade obtida ou solicitada pelo licenciante;

(v) dispensem o titular/licenciante de responder, administrativamente ou em juízo, ações promovidas por terceiros, cujo conteúdo tenha relação direta ou indireta com o objeto do contrato de licença;

(vi) transfiram ao licenciado a obrigação de manter o direito de propriedade industrial, conferido pelo registro.

Naturalmente, a imposição de preços e quantidade de venda pelo licenciante ao licenciado traz implicações, decerto, deletérias a todo o tecido social e econômico. Social, pelo fato de que o consumidor sofrerá com a oscilação irregular dos preços de mercado no que pertine a um dado produto ou serviço. Sob o prisma econômico, temos que o princípio da livre concorrência, insculpido no artigo 170 da Carta Suprema ${ }^{530}$, será flagrantemente lesado com a pré-fixação de preços cominada pelo licenciante ao licenciado.

Deste modo, é manifesto que os dispositivos acima enumerados não podem ser estipulados nos contratos de licença de uso de marca, sempre visando à preservação da

\footnotetext{
${ }^{530} \mathrm{O}$ artigo 170, previsto da Constituição Federal de 1988 tem por desígnio estabelecer as diretrizes que devem se fazer prevalecer na introdução, desenvolvimento e conclusão das atividades econômicas no Brasil. Reza o mencionado dispositivo: "Art. 170. A ordem econômica, fundada na valorização do trabalho humano e na livre iniciativa, tem por fim assegurar a todos existência digna, conforme os ditames da justiça social, observados os seguintes princípios:I - soberania nacional;II - propriedade privada;III - função social da propriedade;IV - livre concorrência; $\mathrm{V}$ - defesa do consumidor (...). Parágrafo único. É assegurado a todos o livre exercício de qualquer atividade econômica, independentemente de autorização de órgãos públicos, salvo nos casos previstos em lei".
} 
função social e econômica do instrumento contratual em apreço, em beneficio de todo o tecido social e econômico que o circundam.

Há casos, contudo, em que o licenciamento da marca deixa de ser o objeto central de análise para verificação da existência ou não de atos de concentração para se tornar uma possível alternativa àquelas operações inter-empresariais em que há notória concentração de mercado, que, portanto, deve ser mitigada pelos órgãos de defesa econômica.

Desta forma, quando duas sociedades empresariais, detentoras de marcas líderes em um determinado segmento, decidem unir esforços e, por conseguinte, acabam por concentrar poder em certo mercado, tem-se como opção à manutenção da indigitada concentração o licenciamento de uma das marcas líderes (de titularidade de uma das empresas conectadas) a terceiros. Este licenciamento, por determinado termo, tem o condão de promover a preservação da livre concorrência (principio econômico informador da Carta Suprema) em oposição ao aumento, manifestamente ilegal, do "poder de mercado" consumado pelas partes envolvidas na operação. ${ }^{531}$

A título ilustrativo, convém registrar síntese conclusiva de parecer emitido pela Secretaria de Acompanhamento Econômico (SEAE), em 29 de junho de 2010, atinente à fusão de duas marcas líderes do setor alimentício, especialmente do ramo de carne in natura (peru): SADIA e PERDIGÃO. A SEAE opinou que a aludida fusão, se fosse aprovada pelo CADE, daria ensejo à cristalina concentração de mercado, prejudicando, de forma flagrante, os concorrentes de ambas as empresas. Em uma das alternativas apontadas pela SEAE, visando à manutenção desta operação, as empresas teriam de licenciar, por pelo menos cinco anos, uma de suas principais marcas (Sadia ou Perdigão), sendo que este licenciamento deveria ser acompanhado da alienação do conjunto de ativos produtivos correspondentes à participação de mercado detida pela marca objeto da licença, tendo-se em consideração à média dos 03 anos anteriores à operação.

531 Cf. Parecer n. ${ }^{\circ}$ 06510/2010/RJ COGCE/SEAE/MF. Ato de Concentração n ${ }^{\circ}$ 08012.004423/2009-18. Requerentes: Perdigão S/A e Sadia S/A. Ministério da Fazenda. Secretaria de Acompanhamento Econômico. Em 29 de junho de 2010. Disponível em: <http://www.seae.fazenda.gov.br/destaque/parecer-seae-ac-08012004423-2009-18-perdigao-e-sadia>. Acesso em 05 jul. 2010. 
Prosseguindo-se no estudo dos dispositivos que integram o contrato de licença de uso de marca, e ainda à luz da investigação da função social enraizada a esta figura contratual de direito industrial, os operadores do direito vêm, crescentemente, desenvolvendo novos mecanismos de ligação entre as partes contratantes e os agentes ou tecido social extrínsecos ao contrato celebrado. Estes mecanismos encontram-se consubstanciados nas chamadas cláusulas sociais. Mencionados dispositivos contratuais têm por escopo resguardar direitos de terceiros que do contrato não tenham participado, de tal sorte que a inobservância destas "cláusulas sociais" poderá dar azo à rescisão contratual, sem prejuízo do valor devido ao proprietário da marca, a título de perdas e danos.

Cite-se, neste aspecto, segundo descreve John Jennings ${ }^{532}$, a presença de cláusulas sociais em alguns contratos de licenças subscritos em território norte-americano. Com efeito, muitas universidades daquele país, como condição essencial para a concessão da licença do uso de sua marca, exigem que o licenciado filie-se à organização protetora dos direitos dos trabalhadores. Mencionada condição garante que quaisquer produtos oferecidos ou serviços prestados pelo licenciado, portando a marca do licenciador, tenham sido realizados dentro da estrita legalidade e de modo seguro, em respeito às leis e práticas trabalhistas locais.

Esta cláusula é de notável inteligência, pois que a agência protetora dos direitos trabalhistas, nos Estados Unidos, denominada Fair Labor Association (FLA), procede ao monitoramento das condições de trabalho nas instalações, alojamentos, abrigos e adjacências dos licenciados em todo o mundo. Assim o faz como forma de representação de seus membros (licenciadores da marca), fiscalizando, deste modo, se os licenciados estão adimplentes ou não, no tocante à cláusula social a qual aderiram ao subscreverem o contrato de licenciamento.

Insta repisar, sob esta perspectiva, a eficiência do dispositivo social em estudo, mormente pelo fato que surtirá efeitos e compreenderá não apenas o monitoramento em território restrito (estadosunidense), mas em todo o mundo.

\footnotetext{
532 JENNINGS, John. University Trademark Licensing: Creating Value Through a "Win-Win" Agreement. WIPO. Disponível em: <http://www.wipo.int/sme/en/documents/uni_trademark_licensing.html>. Acesso em: 30 jan. 2010.
} 
Ante o apresentado, e analisando-se o Contrato de Licença de Uso de Marca, à luz do ordenamento jurídico interno, temos que o licenciante pode determinar ao licenciado cláusulas atípicas, de cunho social e de preservação de interesses difusos e coletivos, que tenham por objeto a salvaguarda de interesses:

(i) Trabalhistas. Por esta cláusula, o licenciante impõe ao licenciado que este cumpra com todos os deveres trabalhistas consignados no diploma trabalhista, sendo responsável pelas conseqüências decorrentes do não cumprimento das leis trabalhistas;

(ii) Segurança e Medicina do Trabalho. Estipulando-se esta cláusula, o licenciante exige que o licenciado observe a legislação concernente à medicina do trabalho, obedecendo, para tanto, as normas e regulamentos emanados das legislações locais e federal, sendo, por conseguinte, integralmente responsável pelo seu não cumprimento;

(iii) Terceiros Protegidos pela Lei (Responsabilidade Social). Por este dispositivo, o licenciado se obriga a respeitar a proibição de trabalho noturno, perigoso ou insalubre, a menores de dezoito e de qualquer trabalho a menores de dezesseis anos, salvo na condição de aprendiz, a partir de quatorze anos, em estrita conformidade com o artigo $7^{\circ}$, inciso XXXIII da Constituição Federal do Brasil;

(iv) Meio Ambiente. Por esta "cláusula social", o licenciado se obriga a não desrespeitar a constituição federal, bem como a legislação infraconstitucional ambiental em vigor, devendo, para tanto, mas não se limitando a: (a) desenvolver técnicas de atuação que não lesem o patrimônio ambiental; (b) adquirir todas as autorizações ambientais, dentro da estrita legalidade; (c) se furtar ao lançamento de qualquer tipo de poluente condenado pela legislação vigente na atmosfera, rios, lagos, lençóis freáticos etc; (d) respeitar todas as normas e exigências, tais quais, mas não se limitando a, da Secretaria de Estado do Meio Ambiente, da Companhia de Tecnologia de Saneamento Ambiental (CETESB), do Instituto Brasileiro do Meio Ambiente e dos Recursos Naturais Renováveis (IBAMA), do Conselho 
Nacional do Meio Ambiente (CONAMA), do Conselho de Defesa do Patrimônio Histórico, Artístico, Arqueológico e Turístico do Estado de São Paulo (CONDEPHAAT) e de outros Órgãos Governamentais afins; (e) manter o licenciante informado, sempre que, a preparação, execução ou término do objeto contratado possa, potencialmente, envolver possível ofensa ao meio ambiente, inclusive delineando os métodos escolhidos e motivando os riscos a serem incorridos, responsabilizando-se o licenciado pelos danos gerados ao meio ambiente advindos da execução do objeto contratado.

(v) Livre Concorrência. Estipulando-se esta cláusula, o licenciante obriga-se a observar os ditames constitucionais e infraconstitucionais atinentes ao exercício da livre concorrência, furtando-se: (a) ao abuso de poder econômico que vise à dominação dos mercados; (b) à eliminação da concorrência; e (c) aumento arbitrário dos lucros, tudo com amplo respaldo no Diploma Supremo e Lei Federal n. ${ }^{\circ} 8.884 / 94$, conforme oportunamente discorrido no presente capítulo.

Examinadas as cláusulas sociais, passemos ao exame da cláusula de disposição de inventário remanescente. Assim, na hipótese do licenciamento de uso de marca, para a aposição em produto, é de bom termo que as partes estabeleçam o destino do "inventário remanescente", ou seja, daqueles produtos conjugados à marca licenciada, que tenham deixado de ser comercializados após o término do prazo contratual.

Temos assim que, em certas ocasiões, findo o licenciamento, o licenciado acaba por manter consigo, ou sob suas dependências, estoque de mercadoria aliada à marca licenciada, cujo êxito de venda não fora logrado ao longo do período do contrato. Para estes eventos, e com o intuito de se evitar conflitos no pós-contrato, a comercialista norteamericana Susan Progoff ${ }^{533}$ adverte para a necessidade de se consignar no instrumento contratual o destino dos produtos remanescentes.

Faculta-se as partes, segundo a jurista norte-americana, consentir quanto à liquidação do inventário remanescente, mesmo após o encerramento do contrato, contanto que o

\footnotetext{
${ }^{533}$ Cf. PROGOFF, Susan. Understanding the Intellectual Property License. Nova Iorque (EUA): Practising Law Institute, 2004.. p. 41.
} 
licenciado não aliene os produtos com desconto ou os venda a outlets (lojas que procedem à liquidação de determinados produtos). $\mathrm{O}$ objetivo deste dispostivo é evitar a concorrência entre terceiros que venham a adquirir os produtos com desconto e os produtos ordinariamente comercializados no mercado, pelo titular, e sem desconto. Ademais, o contrato pode prever disposição estabelecendo quantidade pré-determinada de produtos licenciados passíveis de comercialização pelo licenciado após o termo final do contrato. Intenciona-se, com este dispositivo, impedir que o licenciado torne, ardilosamente, seu estoque acima do razoável (overstocking), com a finalidade de vender produtos licenciados após o prazo convencionado entre as partes.

Alternativamente, na eventualidade de ser permitida a liquidação, no pós-contrato, Progoff preconiza que este período seja devidamente especificado e delimitado pelo licenciador. Outra alternativa prevista na doutrina americana repousa na possibilidade de o licenciado eliminar todo o estoque remanescente após o término do prazo contratual.

Por fim, o que entendemos como uma alternativa decerto razoável, reside na possibilidade de o licenciador adquirir todo o inventário remanescente. Neste caso, preconiza-se que o licenciador inclua em contrato fórmula para fixação de preço dos produtos remanescentes, de sorte que, nem o titular, nem o licenciado, sejam prejudicados.

A despeito de não ser considerada essencial ao contrato de licença de uso de marca a cláusula penal merece apreciação, pois que representa dispositivo de grande valia à promoção da segurança jurídica às partes contratantes do negócio jurídico em estudo. A regulamentação deste dispositivo se encontra compreendida entre os artigos 408 a 416 do Código Civil. Deste modo, a parte que descumprir as obrigações consignadas em contrato, terá de pagar a outra a multa prevista em contrato.

Temos, assim, que o licenciante e o licenciado devem se manter alinhados às cláusulas pactuadas, sob pena de a parte culpada ter de pagar à parte inocente multa rescisória, à luz do instituto da cláusula penal. Neste tocante, quanto à aplicação incidente sobre os contratos de licença, merecem destaque dois dispositivos inseridos na lei civil. 
O primeiro reside no artigo 413 do Código Civil ${ }^{534}$. Por este dispositivo, o licenciado pode questionar judicialmente a cláusula penal, no evento de a obrigação ter sido parcialmente cumprida ou se o valor arbitrado, em sede de cláusula penal, for flagrantemente excessivo, em comparação com a natureza e impacto econômico do negócio consentido pelas partes. Impõe-se registrar que este comando normativo guarda relação de extrema proximidade com o artigo 575, parágrafo único do Código Civil, que regulamenta o contrato de locação de coisas (contrato análogo ao contrato de licença). Ambos os dispositivos preceituam que, não obstante as partes tenham consentido quanto à cláusula penal ou valor da licença, dispõe o juiz de plenos poderes para revisar a indenização fixada unilateralmente ou em contrato, se concluir que o valor fixado, no âmbito indenizatório, não se apresenta equânime.

Exemplificativamente, imagine-se que licenciante e licenciado tenham fixado o valor de $\mathrm{R} \$ 120.000,00$ (cento e vinte mil reais), a título de cláusula penal, em contrato para a licença de uso de marca para o período de 1 ano. No oitavo mês, contudo, o licenciado se torna inadimplente, se abstendo, por via de conseqüência, a pagar os royalties fixos pré-concebidos em $\mathrm{R} \$ 10.000,00$ (dez mil reais) mensais, devidos ao titular da marca. O licenciante, por seu turno, ingressa em juízo com o escopo de executar o valor integral consignado na cláusula penal consentida pelos contratantes.

Na hipótese em tela, embasando-se no artigo 413 do Código Civil, pode o juiz reduzir o valor, em caráter equitativo, tendo-se em mente dois conceitos elementares: o primeiro consistente no fato de a obrigação principal ter sido parcialmente cumprida; o segundo residente no fato de que o valor consignado na cláusula penal consubstanciou montante excessivamente elevado e em total desconformidade com a natureza, finalidade

\footnotetext{
${ }^{534}$ Prescreve o art. 413, do Código Civil, in verbis: "A penalidade deve ser reduzida eqüitativamente pelo juiz se a obrigação principal tiver sido cumprida em parte, ou se o montante da penalidade for manifestamente excessivo, tendo-se em vista a natureza e a finalidade do negócio". Cumpre salientar a inovação trazida por este dispositivo em relação ao seu artigo correspondente (art. 924) do CC de 1916, o qual conferia ao magistrado poderes para reduzir proporcionalmente (e não equitativamente) a multa estipulada para o caso de mora ou inadimplemento. Doravante, e atendendo ao principio da função social do contrato, tem o juiz maiores poderes para estabelecer as balizas penalizatórias em caso de descumprimento contratual. (Neste sentido, ver também SIMÃO, José Fernando. A Lei do Inquilinato e o Novo Código Civil. Questões Polêmicas: A Redução da Multa. Disponível em <http://www.professorsimao.com.br/artigos_simao_a_\%20lei_do_inquilinato_01.htm>. Acesso em 20 jan. 2010)
} 
do negócio e proveito econômico extraído do negócio jurídico celebrado pelas partes contratantes.

Registrem-se os efeitos irradiados ao contrato em exame por um segundo dispositivo "penal", materializado no artigo 416 do Código Civil. Assim, conforme se pode depreender do caput do mencionado dispositivo, não se faz necessária a prova de prejuízo para que a parte lesada, em decorrência do inadimplemento obrigacional, faça jus à multa civil. Sob este prisma, merece apreciação o parágrafo único do artigo de lei mencionado, considerado dispositivo novel, porque não encontra correspondência no Diploma Civil revogado. Prescreve o aludido comando que, não obstante o prejuízo exceda o valor previsto na cláusula penal, não é facultado ao credor exigir indenização suplementar se assim não foi expressamente convencionado em contrato. Ademais, no evento de o licenciante e licenciado tiverem expressamente convencionado indenização suplementar, a pena pecuniária constatante da cláusula penal valerá como mínimo da indenização, cabendo à parte prejudicada comprovar o prejuízo excedente.

Portanto, é judicioso e altamente recomendável que licenciante e licenciado contratem expressamente que a pena consentida pelas partes não se fará satisfatória, no caso de a parte prejudicada demonstrar que o valor oriundo do prejuízo por ela experimentado é superior ao valor penal consentido pelas partes.

Passemos à apreciação da cláusula de arbitragem, a qual tem sido utilizada, com recorrência, nos contratos de licença de uso de marca. Neste tocante, convém assinalar as vantagens da arbitragem nos contratos de propriedade industrial, que são instrumentos cujos objetos centrais (marcas, patentes, tecnologia etc.), em tese, podem ser dispostos ${ }^{535}$ pelos contratantes, tendo as partes, com efeito, a prerrogativa de prever a cláusula sob análise no instrumento contratual por elas celebrado ${ }^{536}$.

\footnotetext{
${ }^{535}$ No que pertine aos direitos que podem ser objetos passíveis de cláusula arbitral, consigne-se, in literis, o artigo inaugural da Lei 9.307/96 (Lei da Arbitragem): "Art. $1^{\circ}$ As pessoas capazes de contratar poderão valer-se da arbitragem para dirimir litígios relativos a direitos patrimoniais disponíveis".

${ }^{536}$ EICHIN-AMARAL. Pedro. Arbitragem Internacional em Propriedade Intelectual. in Revista Brasileira de Arbitragem ${ }^{\circ}{ }^{\circ}$ 13. São Paulo. Editora Thonson/IOB. Jan-Mar. 2007. pp. 7-23.
} 
Dentre as principais vantagens ${ }^{537}$ de se eleger a cláusula arbitral nos contratos de licença de uso de marca, assumem especial importância: (i) confidencialidade; (ii) celeridade e (iii) especialidade.

Pela confidencialidade, temos que tão somente licenciante e licenciado terão acesso ao procedimento arbitral e às informações dele constantes, ao contrário do que se sucede no processo judicial, em que a coletividade tem acesso ao litígio, o que acaba por prejudicar a imagem e reputação construída pelas partes contratantes perante o mercado. Adicionalmente, há que se ressaltar que a publicidade de um litígio (naturalmente dependendo de sua complexidade) pode, potencialmente, refletir na confiança dos investidores em relação às pessoas jurídicas litigantes, bem como no valor de mercado atribuído aos intangíveis dos contratantes sub judice.

No que pertine ao benefício da celeridade $e^{538}$, imperioso destacar que a arbitragem, não obstante tenha para sua implantação e desenvolvimento um custo mais elevado, se comparado com o processo judicial, encerra-se, ordinariamente, em curto prazo de tempo, tendo a parte prejudicada seus interesses tutelados satisfatoriamente.

Conforme bem pondera Eichin-Amaral ${ }^{539}$, há casos em que um dos contratantes pleiteia extinção antecipada do contrato em decorrência de falta grave incorrida pelo outro contratante. Porém, diante da longa morosidade do Poder Judiciário, a tutela pleiteada é apenas concedida após o término do contrato. Portanto, é forçoso concluir que a aplicação da cláusula arbitral em contratos de propriedade industrial se faz extremamente benéfica para ambos os contratantes.

Outro expressivo proveito de se utilizar a cláusula em comento consiste no fato de que as decisões tomadas, em sede de juízo arbitral, são emitidas com a célere assistência de

\footnotetext{
${ }^{537}$ ANDRIGHI, Fátima Nancy. A arbitragem: solução alternativa de conflitos. Revista da Escola Superior da Magistratura do Distrito Federal, n. 2, p. 149-173, maio/ago.

538 "Não se pode negar, em princípio, que a arbitragem tem condições de superar o processo estatal em termos de rapidez. Sabendo-se que as partes podem escolher o procedimento a seguir, fica claro que muitos atos poderão ser simplificados a cada caso para evitar a demora inútil" (CARMONA, Carlos Alberto. A arbitragem no Código de Processo Civil Brasileiro. Tese de Doutorado apresentada à Faculdade de Direito da Universidade de São Paulo. São Paulo. 1990, p. 72)

${ }^{539}$ Idem. Ibidem. p. 20.
} 
peritos que sobre o tema têm conhecimentos alargados. Em que pese o respeitável conhecimento dos magistrados pátrios, os árbitros eleitos pelas partes são, em tese, profundos conhecedores no assunto, mormente quando se trata de temas de elevada tecnicidade envolvendo elementos e conceitos de propriedade industrial.

Por fim, é imperativo mencionar outras cláusulas gerais que se fazem importantes à confecção do contrato de licenciamento de uso de marca, sob o manto da lei civil e marcária vigentes. Dentre elas, merecem destaque: (a) forma de comunicação entre as partes (via mensagem eletrônica, fax, carta registrada com AR ou outro meio eleito pelas partes); (b) possibilidade ou não de cessão do contrato a terceiros; (c) cláusula de inexistência de relação de emprego entre as partes; (d) o idioma oficial eleito por contratantes com domicílio em diferentes jurisdições. No caso do contrato redigido em idioma estrangeiro, é imprescindível a apresentação de uma tradução ao INPI; (e) a forma como se darão os aditamentos entre as partes, que geralmente ocorre escrituralmente e deve ser, necessariamente, subscrito pelas partes; (f) se um do contratantes for estrangeiro, é imprescindível que sua firma seja reconhecida por Notário Público, com subseqüente ratificação pelo Consulado Brasileiro (“consularização”). Não há a necessidade de cumprimento desta formalidade se o domicílio de um dos contratantes consisitir em país com o qual o Brasil tenha Acordo de Cooperação em Matéria Judiciária; (g) assinatura de duas testemunhas 540 .

\section{V.6 REGISTRO DO CONTRATO DE LICENÇA DE USO DE MARCA NO INSTITUTO NACIONAL DE PROPRIEDADE INDUSTRIAL (INPI)}

Sobre o tema, convém indicar que o Brasil posiciona-se de modo análogo, naturalmente respeitando as diferenças peculiares a cada ordenamento jurídico, aos sistemas jurídicos da Venezuela, Colômbia, China Continental, Hong Kong, Egito, França $^{541}$, Reino Unido, México dentre outros sistemas.

\footnotetext{
${ }^{540}$ Cf. VIEGAS, Juliana L. B. Contrato de Licenciamento de Marcas....op. cit. pp. 120-122.

541 "Le contrat doit être publié au Registre national des marques afin d'être opposable aux tiers" (Yves PLASSERAUD. ob. cit. p. 164).
} 
No que pertine aos registros dos contratos de licença e transferência de tecnologia, oportuno colacionar a síntese do estudo de direito estrangeiro, exteriorizado, com extrema perceptibilidade, por Juliana B. Viegas. A comercialista em exame apresenta a postura dos diversos ordenamentos jurídicos no que concerne à obrigatoriedade ou não do registro do instrumento sob investigação.

Nesta esteira, temos o mapeamento a seguir delineado: América Latina. México: até 1991, a aprovação e registro dos contratos de licença eram obrigatórios. Após 1991, o registro tornou-se facultativo e somente para tornar o contrato válido perante terceiros. $\mathrm{O}$ processo de registro não implica exame de todas as cláusulas contratuais. Pode-se apresentar uma versão resumida do contrato. Argentina: $\mathrm{O}$ registro é facultativo, mas quando feito confere vantagem fiscal às partes. As cláusulas contratuais não são examinadas, porquanto o registro é efetuado para fins meramente informativos. Colômbia: Para que tenha validade perante terceiro, os contratos de licença precisam ser registrados. Se os contratos forem onerosos, devem ser igualmente registrados perante o Incomex para fins fiscais. Em geral, as cláusulas contratuais não são revisadas. Chile: Os contratos devem ser averbados à margem dos respectivos registros, para que tenham validade perante terceiros. Tailândia: O registro do contrato de licença de marca é obrigatório para assegurar que haja o controle de qualidade, para fins de proteção do consumidor. O órgão de registro tem poderes para determinar que as partes alterem o instrumento com o desígnio de se garantir o controle de qualidade. China: O registro é necessário em nível nacional (INPI chinês) e regional. No nível regional ou provincial o contrato é rigorosamente examinado e as partes poderão ser convocadas a alterar cláusulas contratuais para cumprimento do que determinado pela autoridade competente. Austrália: Não se faz necessário o registro para efeitos de proteção da propriedade intelectual, para efeitos cambiais ou fiscais. Rússia: Há a necessidade do registro perante o Rospatent (órgão competente para registro de propriedade industrial e contratos correspondentes). Saliente-se, ainda, que as licenças de marcas são sujeitas a exigência de que os bens fabricados sob a marca licenciada tenham a mesma qualidade, tendo o licenciante o dever de exercer o controle de qualidade. União Européia: Não há diretivas da EU que obriguem os países membros ao registro de contratos de licença de marcas para fins fiscais ou cambiais. Na Inglaterra, por exemplo, o registro não se faz obrigatório. Egito: O contrato 
de licença de uso de marca deve ser registrado perante o órgão competente. Não há, contudo, revisão de cláusulas contratuais ${ }^{542}$.

Houve expressiva evolução no que atine ao contrato de licença de uso de marca no Brasil. O comando inserto no artigo 29 do revogado Código de Propriedade Industrial (CPI), de cunho notadamente intervencionista e burocrático, reflexo do momento político ditatorial, protecionista e paternalista ao qual estava submetido o Brasil, previa que a concessão da licença somente seria operada se devidamente revestida das formalidades legais, bem como das condições de remuneração e de todas as características ínsitas ao objeto da licença. Reitere-se, outrossim, que a remuneração paga a título de royalty deveria ser fixada em estrita conformidade com as legislações e normas baixadas pelas autoridades monetárias e cambiais.

No ordenamento jurídico vigente, conforme dicção do artigo 140 da Lei $9.279 / 96^{543}$, os contratos de licença deverão ser simplesmente averbados no Instituto Nacional de Propriedade Industrial (INPI) para que possam produzir efeitos perante terceiros, não havendo mais a necessidade de se falar em confecção de contrato em estrita conformidade com legislações e normas baixadas pelas autoridades monetárias e cambiais. Com efeito, o comando insculpido no artigo 140 da Lei ora referendada dispõe acerca da produção de efeitos do contrato de licença perante terceiros.

Há que se mencionar posicionamento de corrente minoritária, no sentido de que a tutela antecipada, em sede de ação de busca e apreensão, pode ser concedida em favor do licenciado, ainda que o contrato de licença não tenha sido registrado no INPI $^{544}$. Neste sentido, convém transcrever trecho de decisão emitida pela Corte Estadual de São Paulo, verbis: “ (...) Convém registrar que o acórdão não é incoerente ao admitir a eficácia do

\footnotetext{
${ }^{542}$ VIEGAS, Juliana L. B. Efeitos da Averbação de Contratos no INPI. in "XX Seminário da Propriedade Intelectual. Proteção da Tecnologia e das Criações Intelectuais no II Milênio. Anais 2000”. São Paulo. Public. ABPI - Associação Brasileira da Propriedade Intelectual. 2000. pp. 90-94.

${ }^{543}$ Reza, in literris, o Art. 140, da Lei 9.279/96: “O contrato de licença deverá ser averbado no INPI para que produza efeitos em relação a terceiros. $\$ 1^{\circ} \mathrm{A}$ averbação produzirá efeitos em relação a terceiros a partir da data de sua publicação. $\$ 2^{\circ}$ Para efeito de validade de prova de uso, o contrato de licença não precisará estar averbado no INPI."

${ }^{544}$ Trecho extraído do voto vencedor do Rel. Des. Ênio Zuliani. Acórdão registrado sob o n. ${ }^{\circ} 00488158$, pp. 8/9. Apelação Cível n. ${ }^{\circ}$ 128.569-4/4. Terceira Câmara de Direito Privado. TJ/SP. Rel. Des. Ênio Santarelli Zuliani. Julg. em 30 jul. 2002. Disponível em <www.tj.sp.gov.br>.
} 
contrato de licença, para efeito de emitir tutela interdital, sem a averbação no INPI (acolhimento do pedido principal ou de abstenção do comércio clandestino) e, ao mesmo tempo, expedir condenação, tendo, como data, justamente a averbação no INPI, porque são consequiências distintas do contrato. Resguardar a exclusividade da marca contra a concorrência desleal é uma função natural do contrato de licença, porque é próprio do escopo da contratação, conforme explicado no voto condutor, enquanto a indenização por ato ilícito depende da averbação no INPI, para efeito de subordinar o patrimônio do terceiro. Dai a distinção (...)"

Contrariu Sensu, os tribunais pátrios, majoritariamente, têm concedido tutela antecipada em favor do licenciado, apenas na circunstância de o contrato de licença houver sido registrado pelo INPI. O principal argumento e elemento condicionador sob os quais se alicerça a jurisprudência pátria, para a concessão da aludida antecipação, lastreia-se no registro do contrato de licença de marca pelo INPI (art. 140), momento este a partir do qual os efeitos resultantes do contrato são imediatamente sentidos por terceiros. Assim, impõe-se repisar que o licenciado apenas poderá demandar contra terceiros contrafatores, além de preenchidos os requisitos da legitimidade ativa ad causam, após a necessária averbação do contrato de licença de uso de marca pelo INPI. ${ }^{545}$

Este, também, é o entendimento disseminado pela doutrina majoritária ${ }^{546}$. Assinala José Carlos Tinoco Soares:

Na realidade, o contrato de licença para a exploração de marca por terceiro,
estabelecido entre empresa estrangeira e nacional ou apenas entre duas
empresas nacionais, para todos os efeitos, precisa ser firmado entre as partes.
Em ambos os casos, para que seja integralmente válido em relação a terceiros, e
isto se dará notadamente quando o titular da marca tiver que defendê-la
perante o Poder Judiciário, terá que ter essa primeira formalidade. Não
obstante esse contrato seja elaborado, assinado, com as firmas reconhecidas
(sob legalização consular, se proveniente de licenciante estrangeiro), e, muitas
vezes até submetido ao Cartório de Títulos e Documentos elou ao Registro Civil
das Pessoas Jurídicas, deverá ser encaminhado ao INPI para a necessária e

${ }^{545}$ Neste sentido, ver: (a) Recurso Especial n. ${ }^{\text {6 }}$ 606.443-SP, $3^{\text {a }}$ Turma, Superior Tribunal de Justiça, Rel. Min. Castro Filho. Julgado em 05 de fev. 2004. Disponível em <www.stj.gov.br>: (b) Agravo de Instrumento n. ${ }^{\circ}$ 460.464-4/7-00, 4ª Câmara de Direito Privado, TJ/SP, Rel. Des. Maia da Cunha. Julg. 25 de out. 2006. Disponível em <www.tj.sp.gov.br>.

${ }^{546}$ Cf. LOUREIRO, Luiz Guilherme. A Lei da Propriedade Industrial comentada, São Paulo, LEJUS, 1999, págs. 278/281; e LOBO, Thomaz Thedim. Introdução à nova Lei de Propriedade Industrial, São Paulo: Ed. Atlas, 1997. pp. 103/104. 
indispensável verificação, processamento e conseqüente averbação. Somente a partir da aprovação pela averbação e conseqüente publicação na Revista da Propriedade Industrial é que produzirá efeitos no tocante a terceiros. ${ }^{547}$

Comporta advertência, contudo, o fato de que os efeitos inter partes são gerados tão logo o instrumento contratual seja subscrito entre o titular da marca e o licenciado, independendo, neste caso, do pedido de registro ou mesmo publicação do deferimento do registro do contrato pelo órgão competente.

Por outro lado, como dito, a averbação do contrato perante o INPI, muito embora não seja condição de validade e eficácia entre licenciante e licenciado, é condição sine qua non para que o contrato gere efeitos perante terceiros, incluindo-se aqui as autoridades fiscais e monetárias. Como corolário, os royalties pagos pelo licenciado ao licenciante, sob o manto da legislação fiscal, somente poderão ser deduzidos pelo licenciado, se o contrato estiver devidamente averbado no INPI. Igualmente, sob o véu da legislação cambiária, as remessas de divisas para o exterior somente serão passíveis de realização, no evento de o instrumento em análise estiver devidamente averbado pelo INPI.

Dentre as legislações fiscais e cambiárias que fazem menção à averbação do contrato de licença pelo INPI, merecem destaque: Lei n. ${ }^{\circ} 3.470 / 58$, artigo 74 , parágrafo $3^{\circ}$; Lei n. ${ }^{\circ} 4.131 / 62$, artigo 12, parágrafo $2^{\circ}$. Lei 4.506/64, artigo 71, “f”, 1; Parecer Normativo n. ${ }^{\circ}$ 76, de 1976, que prevê a dedução das despesas incorridas antes da averbação mas dentro do prazo do contrato; Lei n. ${ }^{\circ} 8.383 / 91$, artigo 50; Lei n. ${ }^{\circ} 8.661 / 93$, artigo $4^{\circ}$, inciso VI; Decreto 949/93, artigo 13, inciso VI; Ato Normativo 135/97, n. ${ }^{\circ}$, item 2 - norma que versa que o INPI procederá à averbação dos contratos; Carta Circular n. ${ }^{\circ}$ 2.798/98 do Banco Central do Brasil, artigos $2^{\circ}$ e $9^{\circ}$; e Decreto 3.000/99, artigos 353, parágrafo único, e 355 , parágrafo $3^{\circ}$ (dedutibilidade a partir da averbação no INPI $)^{548}$.

\footnotetext{
547 Cf. SOARES, José Carlos Tinoco. Lei de Patentes, Marcas e Direitos Conexos, São Paulo: Editora Revista dos Tribunais, 1997, pp. 228/229.

${ }^{548}$ Esta elucidativa compilação das normas de propriedade industrial e, principalmente, normas fiscais e cambiárias foi apresentada por Ornub Couto Bruno, no XX Seminário da Propriedade Intelectual, para ministrar a tese de que não é a Lei de Propriedade Industrial que torna o registro compulsório, mas sim a legislação fiscal e cambial brasileira. (BRUNO, Ornub Couto. Efeitos da Averbação de Contratos no INPI. in "XX Seminário da Propriedade Intelectual. Proteção da Tecnologia e das Criações Intelectuais no II Milênio. Anais 2000”. São Paulo. Public. ABPI - Associação Brasileira da Propriedade Intelectual. 2000. p. 97).
} 
No tocante à possibilidade de dedução de royalties no que diz respeito ao licenciamento de marcas, Denis Barbosa ${ }^{549}$ sustenta que os royalties são dedutíveis na medida em que representem despesa operacional para a prática da atividade empresarial. Ademais, conforme preleciona o comercialista, apenas serão passíveis de deduções as contraprestações atinentes ao prazo em que o direito, objeto da licença devidamente regularizada, vigorar. Conclui, por fim, que não são dedutíveis a remuneração paga por marca extinta, bem como não há que se falar em dedução de royalties referentes a: (a) períodos não consignados no instrumento de licença; (b) quando não exista licença; ou ainda (c) quando não exista licença regularizada (averbada no INPI).

Ainda sobre a dedutibilidade de royalties, o professor Newton Silveira ${ }^{550}$ apontava, antes da edição da Lei 9.279/96, que o contrato de licença com exclusividade, celebrado entre a matriz no exterior e sua subsidiária no Brasil, não concedia à licenciada controlada a vantagem da dedutibilidade fiscal. Neste sentido, Gabriel Francisco Leonardos justifica, com precisão, a motivação das autoridades fiscais brasileiras para a regulamentação da dedutibilidade ou não dos valores remetidos a título de royaties, como contraprestação à utilização de tecnologia (gênero no qual se inclui a marca para fins da legislação de propriedade industrial em vigor) de outrem:

Uma das principais razões para a criação de controles governamentais sobre os contratos de transferência de tecnologia a partir da década de 1950 foi o elevado valor de remessas ao exterior sobre a rubrica de transferência de tecnologia. Sendo tais remessas despesas dedutiveis para a empresa pagadora, era evidentemente mais conveniente remeter tais valores a título de transferência de tecnologia que a título de lucros. Havia, portanto, a convicção de que os pagamentos por tecnologia, notadamente quando em favor de empresa coligada ou do sócio controlador, eram uma forma de distribuição disfarçada de lucros. 551

Com efeito, conforme se pode inferir do comando inserto no artigo 71, da Lei $4.506 / 1964^{552}$, a dedução de despesas com royalties será admitida:

\footnotetext{
${ }^{549}$ BARBOSA, Denis Borges. Tributação da Propriedade Industrial e do Comércio de Tecnologia, Edição do INPI e da Ed. Revista dos Tribunais. 1983. pp. 4/5.

${ }^{550}$ SILVEIRA. Newton. Licença de Uso de Marca..... op. cit. p. 73.

${ }^{551}$ LEONARDOS, Gabriel Francisco. Tributação da Transferência de Tecnologia.... op. cit. p. 128.

552 A Lei 4.506 de 30 de novembro de 1964 dispõe sobre o imposto de renda e proventos de qualquer natureza.
} 
(A) quando necessárias para que o contribuinte mantenha a posse, uso ou fruição do bem ou direito que produz o rendimento; e

(B) se o aluguel ou royalty não constituir aplicação de capital na aquisição do bem ou direito, nem distribuição disfarçada de lucros de pessoa jurídica.

Por outro lado, não são dedutíveis, à luz do referido dispositivo:

(i) os "royalties" pelo uso de patentes de invenção, processos e fórmulas de fabricação ou pelo uso de marcas de indústria ou de comércio, quando:

(i.1) pagos pela filial no Brasil de sociedade com sede no exterior, em benefício da sua matriz;

(i.2) pagos pela sociedade com sede no Brasil a pessoa com domicílio no exterior que mantenha, direta ou indiretamente, controle do seu capital com direito a voto;

(ii) os "royalties" pelo uso de marcas de indústria e comércio pagos ou creditados a beneficiário domiciliado no exterior:

(ii.1) que não sejam objeto de contrato registrado no Banco Central do Brasil e que não estejam de acordo com o Lei da Propriedade Industrial; ou

(ii.1) cujos montantes excedem dos limites periodicamente fixados pelo Ministro da Fazenda para cada grupo de atividade ou produtos, segundo o grau de sua essencialidade, de conformidade com a legislação específica sobre remessas de valores para o exterior.

Extrai-se, da leitura do aludido dispositivo, rígidas restrições à dedutibilidade de royalties remetidos ao exterior. De outra parte, não são dedutíveis, entre os residentes no Brasil, os royalties pagos a sócios ou dirigentes das empresas, e aos seus parentes ou dependentes. 
O coeficiente percentual para a dedução dos royalties como despesas operacionais deverá, considerando-se as ressalvas legais, coincidir com o limite máximo de $5 \%$ da receita líquida das vendas dos produtos fabricados ou vendidos. Ademais, esta percentagem deverá ser definida e revista, periodicamente, mediante ato expedido pelo Ministro da Fazenda, o qual considerará os tipos de produção ou atividades reunidos em grupo, segundo o grau de essencialidade, para a definição do percentual aplicável ao caso concreto $^{553}$. Atualmente, ainda se encontra em vigor a Portaria/MF n. ${ }^{\circ} 436$, de 30 de dezembro de 1958, que estabelece o coeficiente percentual máximo de dedutibilidade de $1 \%$ (um por cento), em decorrência do uso de marcas, em qualquer tipo de produção ou atividade, e quando o uso da marca ou nome não seja decorrente da utilização de patente, processo ou fórmula de fabricação ${ }^{554}$.

A Portaria/MF n. ${ }^{\circ}$ 436/58 ventila que as porcentagens de dedutibilidade (no caso do licenciamento do uso de marca, de 1\%) incidirão sobre a receita bruta dos produtos fabricados ou vendidos. No entanto, com o advento do Decreto-Lei n. ${ }^{\mathbf{1}} 1.730 / 79^{555}$, os coeficientes máximos de dedutibilidade passaram a ser aplicados sobre a receita líquida, e não mais sobre a receita bruta dos produtos fabricados ou vendidos. Consoante o item 4 , da IN n. ${ }^{\circ}$ 51/78, expedida pela Secretaria da Receita Federal, entende-se por receita líquida de vendas: "a receita bruta da vendas e serviços, diminuídas: (a) das vendas canceladas, (b) dos descontos e abatimentos concedidos incondicionalmente e (c) dos impostos incidentes sobre as vendas"

${ }^{553}$ Registre-se, neste sentido, os artigos 352 a 355 do Regulamento do Imposto de Renda/99 e Portaria do Ministério da Fazenda n. 436/58; PACHECO, José da Silva. Tratado de Direito Empresarial: Empresário: pessoa e patrimônio. vol. 2. São Paulo. Saraiva. 1979. pp. 552/553).

554 Neste sentido, afirmam, com propriedade, os tributaristas Hiromi Higuchi, Fábio Higuvhi e Celso Higuchi, verbis: "a Portaria n. ${ }^{\circ}$ 436/58 limitou em 1\% do produto fabricado ou vendido a dedutibilidade dos royalties pagos pelo uso de marca de indústria ou comércio, em qualquer tipo de produção ou atividade. Assim, as pessoas jurídicas só podem deduzir, na apuração do lucro real, o royalty de $1 \%$ sobre a receita líquida dos produtos vendidos, nos casos de uso de marcas, símbolodos ou personagens, para calçados, vestuário etc. O limite de dedutibilidade não altera ainda que sejam pagos $1 \%$ para uso da marca e $9 \%$ ou 14\% a qualquer outro título." (Cf. HIGUCHI, Hiromi; HIGUCHI, Fábio Hiroshi; e HIGUCHI, Celso Hiroyuki. Imposto de Renda das Empresas - Interpretação e Prática. atual. até. 10.01.2009. São Paulo: IR Publicações, 2009. p. 380)

${ }^{555}$ Prescreve o artigo $6^{\circ}$, do Decreto-Lei 1.730/79: "O limite máximo das deduções, estabelecido no artigo 12 da Lei $\mathrm{n}^{\circ}$ 4.131, de 3 de setembro de 1962, será calculado sobre a receita líquida das vendas do produto fabricado ou vendido".

${ }^{556}$ Cf. HIGUCHI, Hiromi; HIGUCHI, Fábio Hiroshi; e HIGUCHI, Celso Hiroyuk. Imposto de Renda ... op. cit. pp. 372/373. Ver também: NEVES, Silvério das; VICECONTI, Paulo E. V.; e SILVA JR., Francisco 
Ainda no que diz respeito aos efeitos do contrato registrado pelo INPI, é oportuno reiterar que o instrumento jurídico somente produzirá efeitos perante terceiros em momento ulterior à publicação da averbação do instrumento na Revista da Propriedade Industrial ${ }^{557}$. Até este acontecimento, o contrato somente produzirá efeito entre as partes (licenciante e licenciado).

Inclusive, tem-se acolhido, no âmbito judicial, a tese de que a indenização que deverá ser paga pelo contrafator deverá ser contada, apenas a partir da averbação do contrato de licença de uso de marca no INPI, ainda que mencionado contrato tenha sido subscrito por licenciador e licenciado em momento pretérito. De acordo com acórdão emitido, em sede de Recurso de Apelação, pela Corte do Estado de São Paulo, “a indenização que os artigos 208 e 209 da Lei 9279/76 permitem, não poderá ser calculada desde 1993 [ data da subscrição do contrato ], como requerido, porque, para valer diante de terceiros, o contrato de licença necessita da averbação no INPI, e isso faz com que o marco desencadeante da liquidação coincida com a data do contrato averbado, exatamente $1^{\circ}$ de setembro de 1998, como consta de fl. 311", 558 (grifou-se).

Oportuno assinalarmos, no âmbito registrário, celeuma espinhoso que tem sido suscitado pela doutrina. A legislação sobre os registros do contrato de licença é, certamente, lacunosa. O ato normativo INPI n. ${ }^{\circ}$ 135/97, oportunamente mencionado no presente estudo, estabelece apenas cláusulas essenciais que devem restar consignadas em contrato, para efeitos de averbação, não fazendo menção a cláusulas outras estipuladas pelos contratantes. Ademais, o artigo 140 da Lei 9279/96 é cristalino quanto à averbação para que o instrumento gere efeitos jurídicos perante terceiros. $\mathrm{O}$ cerne da celeuma erigida pela doutrina reside no comportamento adotado pelo INPI ao registrar os contratos em comento.

Aguiar da. Curso prático de imposto de renda pessoas jurídica e tributos conexos (CSLL, PIS e COFINS). $14^{a}$ ed. rev. e ampl. São Paulo: Frase Editora, 2009. pp. 288-291.

${ }^{557}$ A Resolução 117/2005 instituiu a Revista Eletrônica da Propriedade Industrial - RPI como único órgão destinado a publicar os atos, despachos e decisões relacionados às atividades da autarquia. Consoante dispõe o artigo $3^{\circ}$ da mencionada Resolução, é livre e sem qualquer custo o acesso à Revista Eletrônica da Propriedade Industrial, a qual estará permanentemente disponibilizada no sítio do INPI (www.inpi.gov.br). (Disponível em <http://revista.inpi.gov.br/Resolucao_117_05.pdf>Acesso em 20/12/2008).

${ }^{558}$ Trecho extraído do voto vencedor do Rel. Des. Ênio Zuliani. Acórdão registrado sob o n. ${ }^{\circ} 00488158$, pp. 8/9. Apelação Cível n. ${ }^{\circ}$ 128.569-4/4. Terceira Câmara de Direito Privado. TJ/SP. Rel. Des. Ênio Santarelli Zuliani. Julg. em 30 jul. 2002. Disponível em <www.tj.sp.gov.br>. 
Questiona-se: teria o INPI a competência de adentrar a todo o conteúdo do contrato ou não? Tal autarquia deve-se se restringir apenas ao registro para fins meramente informativos, apenas verificando se constam do contrato as cláusulas essenciais prescritas pelo Ato Normativo INPI 135/97?

Juliana Viegas ${ }^{559}$ assinala, em tom notadamente crítico, que o INPI tem-se portado como se o Código de Propriedade Industrial de 1971 não houvesse sido revogado. Tal assertiva reside no fato de que esta autarquia remanesce se atendo a minúcias e externando exigências e entraves que a ela não compete fazê-lo, adotando, de tal sorte, a política intervencionista anteriormente praticada e que não mais se coaduna com os ditames do "novo" diploma da propriedade industrial.

Assim, a jurista conclui que, sob o véu da nova lei, o INPI deve se ater apenas à averbação ou registro do contrato de licença para fins meramente de ciência a terceiros, assim como teleologicamente visado pelo legislador ao idealizar e conceber o artigo $140 \mathrm{da}$ LPI.

Deste entendimento parece compartilhar o Superior Tribunal de Justiça. Em 2010, discutiu-se sobre a competência para apreciação de caso, cujo objeto central da contenda repousava na revisão de cláusula de royalties em contrato de licença de patente, em razão de manifesta onerosidade excessiva. Conforme se relatou, a sociedade licenciada promoveu ação judicial contra a sociedade licenciante, com o fito de obter revisão de algumas cláusulas contratuais, entre as quais a cláusula de royalties, com amparo na teoria da imprevisão (rebus sic standibus).

O Tribunal Regional Federal admitiu a defesa ministrada pela recorrida de que o julgamento do litígio competia apenas à Justiça Estadual e não à Justiça Federal. Isto porque o INPI, muito embora proceda à edição de regulamentos internos concernente aos contratos de direito da propriedade industrial, não se fazia parte legítima para atuar no feito. Demais disto, conforme fundamentação exarada pelo Tribunal Estadual, ao INPI

\footnotetext{
${ }^{559}$ VIEGAS, Juliana L. B. Efeitos da Averbação de Contratos no INPI. in "XX Seminário da Propriedade Intelectual. Proteção da Tecnologia e das Criações Intelectuais no II Milênio. Anais 2000”. São Paulo. Public. ABPI - Associação Brasileira da Propriedade Intelectual. 2000. p. 94.
} 
apenas compete à averbação de registros de contratos de licença, em estrita consonância com os aspectos formais (e não materiais) do negócio jurídico entabulado pelas partes. Não pode, desta sorte, adentrar ao mérito do contrato. Não tem competência para julgar cláusulas contratuais livremente estipuladas pelas partes.

Com este mesmo entendimento, a Corte Superior endossou a tese arquitetada pelo Tribunal de Regional Federal. Para o Min. Sidnei Beneti, "a única intervenção esperada do INPI, na ação de revisão do contrato, é extraprocessual, mera providência relativa a registro". Mais adiante, em seu voto, o qual fora acolhido à unanimidade pela turma julgadora, o Ministro Beneti assinala: "De fato, outro desfecho não poderia ter a discussão senão a de que a competência para o julgamento do presente feito é mesmo da Justiça Estadual”. E arremata: “A par da ausência de interesse jurídico do INPI (não há na espécie indagação relevante sobre algum tema de Direito Marcário), as partes discutem pagamento pelo uso de patente relativa à fabricação de CD e DVD. A demanda é de natureza eminentemente patrimonial e estritamente privada, não havendo mesmo a necessidade de atuação do INPI no feito" ${ }^{\circ 60}$.

Desta opinião, contudo, não compartilha Ornurb Couto Bruno ${ }^{561}$, o qual exime o INPI das críticas que lhes são frontalmente direcionadas acerca de seu exacerbado intervencionismo, apontando que esta autarquia acaba sendo compelida à prática de atitudes burocráticas e cartoriais que resultam, não da Lei 9.279/96, mas dos comandos insculpidos na legislação tributária e cambial, posto que na ausência deste registro, não se faz possível a dedutibilidade das despesas pagas e a remessa de divisas ao exterior a título de royalties.

\footnotetext{
${ }^{560}$ Recurso Especial 1046324/RJ, Rel. Ministro Sidnei Beneti, Terceira Turma do Superior Tribunal de Justiça. julgado em 14/09/2010, DJe 24/09/2010.Documento n. 6208862 . Rel. e Voto. pp. 6 e 7 de 8.

${ }^{561}$ BRUNO, Ornub Couto. Efeitos da Averbação de Contratos no INPI. in "XX Seminário da Propriedade Intelectual. ob. cit.. p. 97.
} 


\section{V.7 LEGITIMIDADE DO LICENCIADO PARA AGIR EM DEFESA DA MARCA}

No que atine à legitimidade para agir perante terceiros, a doutrina apresenta-se bipolarizada. Corrente doutrinária capitaneada pelos sapientes Gama Cerqueira ${ }^{562}$ e Rubens Requião $^{563}$ assinala que a averbação de contrato de licença no INPI, naquelas relações jurídicas em que a concessão seja exclusiva, concede ao licenciado, se o titular assim consentir, poderes para que aquele ingresse em juízo. Este ingresso dá-se com o objetivo de se proceder à defesa da marca contra eventuais usurpadores, facultando ao licenciado, igualmente, pleitear a anulação de eventuais autorizações concedidas pelo titular a terceiros, como remédio processual à infração do conteúdo estabelecido em contrato que contenha cláusula de exclusividade.

Impõe-se mencionar corrente jurisprudencial que se inclina à tese de que o licenciado, muito embora não seja o titular da marca, tem plenos poderes para ingressar em juízo em defesa da marca e do direito próprio ${ }^{564}$. Em julgado emitido pelo Tribunal de Justiça do Distrito Federal, proferido em 2005, o Des. Rel. Benito Tiezi indeferiu a argüição de ilegitimidade ativa sucitada, corroborando, portanto, o entendimento de que a licenciada tinha legitimidade ativa para ingressar em juízo contra terceiros. Assim considerou porque, pela análise do contrato acostado aos autos, ainda que não houvesse a

${ }^{562}$ Cf. CERQUEIRA, João da Gama. Tratado da Propriedade Industrial. $3^{\mathrm{a}}$ ed. atual. por: Newton Silveira e Denis Borges Barbosa. op. cit......Vol. II. Tomo I. Parte II. p. 176.

${ }^{563}$ REQUIÃO. Rubens, Curso de Direito Comercial. 25a ed. vol.1. São Paulo. Ed. Saraiva. 2003. p. 265.

${ }^{564}$ O Tribunal de Justiça do Estado de São Paulo, ao apreciar a importação paralela e a licença de marca, sinaliza para a possibilidade de o licenciado ingressar em juízo para proceder à defesa da marca licenciada. Convém registrar a síntese do julgado em comento: “(...)Na verdade, a agravante é concessionária de exclusividade na importação de produtos da empresa nipônica referida no relatório e, no curso do processamento do presente agravo, restou verossímil até mesmo por confissão da agravada, que esta andou importando, em atividade paralela à da agravante, os produtos da Makita [sociedade matriz japonesa que licenciou sua marca para sua subsidiária brasileira], que é a sobredita empresa do Japão, embora se escuse na boa-fé quanto a essa prática. (...) Além dessa afirmação, a aludida verossimilhança autorizativa da antecipação da tutela se mostra na cópia da nota fiscal de fl. 217, pela qual restou demonstrado que a agravada, ainda que se lhe admita a boa-fé, está vendendo os produtos de que a agravante detém a exclusividade de distribuição no Brasil. Como a pretensão da recorrente é obter, pela antecipação da tutela jurisdicional a determinação de que a recorrida cesse a importação das mercadorias objeto do processo, bem assim a busca e apreensão, para fins de repatriamento, das peças já importadas, é de ser-lhe deferida a pretensão, sob as penas da lei, sem prejuízo do prosseguimento da ação em curso e do desfecho correspondente, com as conseqüências que dele advierem em favor ou desfavor de qualquer das partes" (TJSP, Agravo de Instrumento n. ${ }^{0}$ 080.264-4/4-00/São Paulo, $8^{a}$ Câmara de Direito Privado, rel. Ricardo Brancato, 03 de fevereiro de 1999). 
outorga expressa de poderes para a defesa da marca, a licenciada estava autorizada a utilizar a marca licenciada, possuindo, desta sorte, exclusividade na comercialização dos produtos conjugados à marca licenciada e, portanto, legítimo interesse em se insurgir (processualmente) contra terceiros, em razão do uso indevido da marca licenciada no território do Distrito Federal. ${ }^{565}$

Deste entendimento não perfilha a doutrina encabeçada por José Tinoco Soares ${ }^{566}$, a qual advoga que somente o titular da marca (licenciante) poderá ingressar em juízo perante terceiros. Esta corrente divergente alicerça-se, essencialmente, no artigo $6^{\circ}$, do Código de Processo Civil, o qual reza que "ninguém poderá pleitear, em nome próprio, direito alheio, salvo quando autorizado por lei”. A possibilidade de, em um primeiro momento, apenas o titular poder ingressar com ação em defesa da marca licenciada (de sua propriedade) é, por igual, considerada pelo sistema marcário canadense. Este regime legal estabelece que, no evento de a marca licenciada se encontrar ameaçada por atos de terceiros, o licenciado notificará o licenciador para que, como titular do sinal, promova as medidas cabíveis em relação a qualquer problema que afete seus interesses. Se o proprietário nada fizer, após dois meses de ter sido demandado, a lei prescreve que poderá o licenciado fazê-lo em seu próprio nome como se titular da marca fosse $\mathrm{e}^{567}$.

No sistema português, coforme dicção do artigo 32, (4), do Código de Propriedade Industrial $^{568}$, o licenciado tem, "salvo estipulação em contrário", e para todos os efeitos legais, as faculdades outorgadas ao titular (licenciante). Depreende-se deste dispositivo que

565 “(...) 1 Se a empresa concessionária está autorizada a utilizar a marca da empresa concedente, possuindo exclusividade na comercialização de veículos, peças e assessórios no âmbito do Distrito Federal, sustenta legítimo interesse em se opor ao uso indevido desta marca por outras empresas. (...). (TJ/DF. Apelação Cível n. ${ }^{\circ}$ 2004.01.1.019151-6. Terceira Turma Cível. Rel. Des. Benito Tiezzi. Julg. em 24 out. 2005)

${ }^{566}$ SOARES, José Carlos Tinoco. Lei de Patentes, Marcas e Direitos Conexos. Lei 9.279 de 1996. ob. cit.. p. 228.

567 O sistema canadense se posiciona de forma alternativa, de acordo com dispositivo adiante transcrito (Trade-marks Act - R.S., 1985, c. T-13 ) in verbis: "Licences 50 (3). Subject to any agreement subsisting between an owner of a trade-mark and a licensee of the trade-mark, the licensee may call on the owner to take proceedings for infringement thereof, and, if the owner refuses or neglects to do so within two months after being so called on, the licensee may institute proceedings for infringement in the licensee's own name as if the licensee were the owner, making the owner a defendant. R.S., 1985, c. T-13, s. 50; 1993, c. 15, s. 69; 1999, c. 31, s. 211(F)" Disponível em < http://www.wipo.int/wipolex/en/text.jsp?file_id=125519>. Acessado em 17 set. 2009.

568 Código da Propriedade Industrial português. $\quad$ Disponível em <http://www.portolegal.com/CodPropriedadeIndustrial2003.htm>. Acess em 10 jul. 2010. 
o licenciado goza de legitimidade ativa para ingressar em juízo contra terceiros, em defesa da marca licenciada. De acordo com o artigo referenciado, esta legitimidade é decorrência natural do contrato, sendo que este direito apenas não remanescerá no evento de as partes, em comum acordo, estipularem que apenas o licenciante terá legitimidade para agir em defesa da marca perante terceiros.

No ordenamento jurídico britânico ${ }^{569}$, o licenciado exclusivo tem direitos e remédios processuais como se cessionário fosse. Assim, em contrato de licença de uso de marca, celebrado a título exclusivo, o titular poderá outorgar ao licenciado, nos termos do contrato, os mesmos direitos e remédios processuais objetivando o combate à repressão de infrações ocorridas após a concessão da licença, sendo esta, portanto, equiparada à cessão. Ante este consentimento expresso do titular, ao licenciado é facultado ingressar em juízo, em seu próprio nome, contra terceiros que estejam usurpando, de alguma forma, a marca licenciada.

No sistema alemão, no que toca ao direito de ação, o licenciado poderá promover medidas judiciais contra terceiros, em decorrência de infração da marca licenciada, tão somente se o titular assim consentir. Ademais, objetivando ser indenizado pelos danos suportados, o licenciado tem o direito de intervir em ações judiciais promovidas pelo titular da $\operatorname{marca}^{570}$.

O ordenamento jurídico pátrio segue os modelos concebidos pelos sistemas britânico e germânico. Com efeito, é marcante a presença de corrente jurisprudencial pátria posicionando-se no sentido de que o licenciado tão somente poderá ingressar em juízo, em defesa da marca licenciada, na hipótese de o contrato de licença expressamente prever tal possibilidade. Esta tese foi corroborada, sobretudo, com arrimo no paráragrafo único, do

${ }^{569}$ Cf. Trade Marks Act 1994. Part I, 31 (1). O Trade Marks Act 1994 é a lei que rege as marcas nos países membros do Reino Unido. 31 Exclusive licensee having rights and remedies of assignee. Colacione-se Part I, 31 (1), literris: "(1)An exclusive licence may provide that the licensee shall have, to such extent as may be provided by the licence, the same rights and remedies in respect of matters occurring after the grant of the licence as if the licence had been an assignment. Where or to the extent that such provision is made, the licensee is entitled, subject to the provisions of the licence and to the following provisions of this section, to bring infringement proceedings, against any person other than the proprietor, in his own name" (Cf. CHRISTIE, Andrew; GARE. Stephen. Blackstone's Statutes on Intellectual Property. $10^{\text {a }}$ ed. Nova Iorque: Oxford University Press. 2010. p. 331)

570 Cf. German TradeMark Law. Capítulo 5 - “As Marcas como objeto de propriedade” Disponível em < http://www.markenagentur.de/guide/markg1d.htm\#teil25> Acesso em 20 de maio de 2010. 
artigo 139, da Lei 9279/96. Este dispositivo permite ao licenciante a possibilidade (ou não) de conferir ao licenciado todos os poderes, inclusive judiciais, para agir em defesa da marca.

Neste particular, merece trancrição trecho de voto vencedor, emitido pelo Rel. Des. Tasso Caubi Soares Delabary, do Tribunal de Justiça do Estado do Rio Grande do Sul, mormente pela riqueza de argumentos trazidos à lume:

\begin{abstract}
“(...) Ora, pelo regime de locações de coisas indicado pela doutrina referida, prevê o art. 566, II, que o locador é obrigado a garantir, durante o tempo do contrato, o uso pacífico da coisa, além de dispor o art. 569, III, que o locatário é obrigado a levar ao conhecimento do locador as turbações de terceiros, que se pretendam fundadas em direito, resultando, daí, que o locatário/licendiado, não pode defender a coisa como se sua fosse, mas deverá direcionar eventuais turbação ao uso da marca ao seu titular.
\end{abstract}

Além disso, conforme previsão expressa da Lei n. 9279/96 - Lei de Patentes -, art. 139, o titular de registro ou o depositante de pedido de registro poderá celebrar contrato de licença para uso da marca, sem prejuízo de seu direito de exercer controle efetivo sobre as especificações, natureza e qualidade dos respectivos produtos ou serviços, acrescentando o parágrafo único que: "O licenciado poderá ser investido pelo titular de todos os poderes para agir em defesa da marca, sem prejuízo dos seus próprios direitos.

Desta forma, a licenciada SADIA não tem legitimidade ativa para demandar a proteção das marcas objeto da licença (nugget, nuggets e chicken nuggets). Como supra transcrito, o contrato de licença é suficientemente claro em apontar que a Mc Donald's Corporation continuaria "responsável por manter as ditas marcas em vigor", dispondo, ainda, que em qualquer ataque às marcas a "LICENCIADA não tomará qualquer iniciativa, mas comunicará prontamente o assunto à LICENCIANTE.

Nestas condições, considerando que a licenciante das marcas não está nos autos, carece a demandante SADIA de legitimidade para demandar autonomamente a proteção das marcas licenciadas (...) (grifou-se $)^{571}$

Convém indicar, do mesmo modo, outros julgados proferidos sob contornos estritamente legalistas, pois que, com arrimo no parágrafo único, do artigo 139, apenas permitem o licenciado a ingressar em juízo, na eventualidade de o contrato de licença de uso de marca expressamente prever tal possibilidade (leia-se, expresso consentimento do titular do registro marcário). A saber:

${ }^{571}$ Apelação Cível n. ${ }^{\text {7 } 7001750772 . ~ 9 a ~ C a ̂ m a r a ~ C i ́ v e l . ~ T J / R S . ~ R e l . ~ D e s . ~ T a s s o ~ C a u b i ~ S o a r e s ~ D e l a b a r y . ~ J u l g . ~}$ em 11 jul. 2007. Disponível em <www.tj.rs.gov.br>. 
(...) A Autora é parte legítima para figurar no pólo ativo da demanda, pois o instrumento que materializou o contrato de licença, fez constar em seu item 4.07, fls. 63, a autorização para a propositura da ação, a fim de resguardar direitos. 572

“Processual Civil. Cautelar. Ilegitimidade Ativa. Licença para Uso de Marca. Impõe-se o reconhecimento da ilegitimidade ativa da autora, porquanto, nos termos do contrato de licença para uso de marcas firmado entre a licenciante e a licenciada, esta deve obter autorização daquela para poder conduzir os processos relativos à violação da marca. Ausência de documento a demonstrar a investidura legal prevista no, parágrafo único, do art. 139 da Lei $n^{o}$ $9.279 / 96 " .573$

“(...) 0 art. 139, parágrafo único, da Lei 9279/1996, autoriza o licenciado a defender a exclusividade ou privilégio comercial da marca, o que foi autorizado por licença, desde que se proceda a averbação no INPI (art. 140). 0 mesmo ocorre com a licença de patente (art. 61, § único). A apelante cumpriu essas formalidades, consoante se verifica do documento de fls. 311/312, que deverá ser lido em conjunto com o contrato de fls. 42/47, traduzido de forma oficial e inscrito na JUCESP (licença concedida pela Nintendo Of América Inc. Playtronic, antiga denominação da Gradiente Entertainment, para exploração das marcas citadas). (... $)^{574}$

Tem-se, pois, a partir deste entendimento formado pelos pretórios, que o licenciado terá legimitidade ativa para atuar em defesa da marca licenciada, sem que, para tanto, tenha de acionar o licenciante. No entanto, cumpre clarificar que este direito subjetivo se opera tão somente se o licenciante (titular da marca), em contrato, expressamente acenar para tal prerrogativa.

No entanto, a despeito do sistema legal, pelo artigo 139, parágrafo único, da Lei 9.279/96, e da jurisprudência, conforme acima exposto, sinalizarem para a possibilidade da legitimidade ativa do licenciado, tão-somente no evento de o titular da marca desta forma expressamente consentir, convém apontar construção de teoria pautada no princípio da analogia que possa conduzir doutrinadores, magistrados e legisladores à reflexão mais aprofundada acerca da matéria.

\footnotetext{
572 Trecho extraído do voto vencedor do Rel. Des. Natan Zelinschi de Arruda (p. 02). Apelação Cível n. ${ }^{\circ}$ 0.209.575-4/1-00. Quarta Câmara de Direito Privado. TJ/SP. Rel. Des. Natan Zelinschi de Arruda. Julg. em 24 ago. 2006. Disponível em <www.tj.sp.gov.br>.

${ }^{573}$ Ementa extraída do Agravo de Instrumento n. ${ }^{0} 70021049358,5^{\text {a }}$ Câmara Cível, TJ/RS. Des. Rel. Leo Lima. Julg. em 24 de out. 2007. Disponível em <www.tj.rs.gov.br>.

574 Trecho extraído do voto vencedor do Rel. Des. Ênio Zuliani. Acórdão registrado sob o n. ${ }^{\circ} 00488158$, pp. 3/4. Apelação Cível n. ${ }^{\circ}$ 128.569-4/4. Terceira Câmara de Direito Privado. TJ/SP. Rel. Des. Ênio Santarelli Zuliani. Julg. em 30 jul. 2002. Disponível em <www.tj.sp.gov.br>.
} 
Esta teoria consubstancia-se, essencialmente, na aplicação do princípio da analogia a dois contratos de direito de propriedade intelectual: contrato de edição e contrato de licença de uso de marca a título exclusivo.

Orlando Gomes assinala que "a edição propriamente dita é o contrato pelo qual o autor de obra literária concede, contra remuneração à outra parte, o direito exclusivo de reproduzi-la e divulgá-la"575. Segundo a melhor doutrina de Fábio Maria de Mattia, entende-se por contrato de edição o negócio jurídico em que o autor de uma obra literária transfere seu direito patrimonial ao editor, para que este reproduza e dissemine a obra, tendo esta licença, como característica peculiar a "exclusividade com que é investido o editor nesta utilização" contrato de edição é a exclusividade, e não a cessão, com o qual é frequentemente confundido" ${ }^{577}$.

O artigo $5^{\circ}$, inciso X, da Lei de 9.610/98 (Lei de Direito Autoral) estatui que o editor é a "pessoa física ou jurídica à qual se atribui o direito exclusivo de reprodução da obra e o dever de divulgá-la, nos limites previstos no contrato de edição". Ademais, consoante o mesmo diploma legal, o contrato de edição é o instrumento jurídico, mediante o qual "o editor, obrigando-se a reproduzir e a divulgar a obra literária, artística ou científica, fica autorizado, em caráter de exclusividade, a publicá-la e a explorá-la pelo prazo e nas condições pactuadas com o autor" ${ }^{278}$.

Acerca da legitimidade do editor para agir perante terceiros, Fábio Maria de Mattia, alicerçando-se na doutrina do italiano Alfredo Arienzo, aponta que, no contrato de edição, o editor é empossado do ius prohibitionis concernente ao autor, de modo que aquele, como licenciado exclusivo, tem o direito de obstar terceiros, inclusive, o próprio autor (licenciante), a usufruir da obra disponibilizada ${ }^{579}$, nas formas e sob as condições

\footnotetext{
${ }^{575}$ GOMES, Orlando. Contratos. Rio de Janeiro: Forense, 1975. p. 479.

${ }^{576}$ DE MATTIA, Fábio Maria. O Autor e o Editor na Obra Gráfica - Direitos e Deveres. São Paulo: Ed. Saraiva. 1975. p. 22

577 ABRÃO, Eliane Yachouh. Direitos de Autor e Direitos Conexos. São Paulo: Editora do Brasil, 2002. p. 135.

${ }^{578}$ Cf. Artigo 53 da Lei 9.610/98 (Lei de Direitos Autorais).

${ }^{579}$ Em conformidade com o saudoso professor da Faculdade de Direito da Universidade de São Paulo, “o
} 
contratualmente estabelecidas. Contrariu sensu, acrescenta o jurista que, no caso de "licenças simples", o licenciado "tem a simples faculdade positiva de gozar da obra, mas não de modo exclusivo, e, pois, em concorrência com o autor ou algumas pessoas às quais o autor concedeu ou poderá conceder direitos exclusivos, ou, apenas, igual licença" ${ }^{\text {"580. }}$.

A doutrina acima abalizada, respeitante à legitimidade processual ativa ínsita ao editor, teve acolhida pela Lei 9.610/98, cujo artigo 63, § $1^{\circ}$, estatui que "na vigência do contrato de edição, assiste ao editor o direito de exigir que se retire de circulação edição da mesma obra feita por outrem”. Temos, portanto, que o editor, como sendo o licenciado exclusivo para a utilização da obra do autor, tem legitimidade ativa plena para ingressar em juízo perante terceiros e, também, em face do próprio autor, ainda que este direito não tenha sido previa e expressamente consignado no instrumento contratual de edição.

Ante o exposto, é crível afirmar que o contrato de edição afigura-se como um contrato de licença exclusiva em que o editor tem exclusividade absoluta na utilização da obra que lhe foi entregue pelo autor, na forma e sob as condições assinaladas em contrato. O contrato de licença de uso de marca, celebrado a título exclusivo, afigura-se, por igual, como um contrato em que o licenciado tem exclusividade absoluta na utilização da marca que lhe foi disponibilizada pelo titular da marca. Faz-se pertinente, pois, a analogia entre estes dois contratos de propriedade intelectual, de modo que, apesar de apresentarem objetos distintos de propriedade intelectual (em um, dá-se a licença exclusiva da obra, enquanto que, no outro, dá-se a licença exclusiva da marca), ambos possuem os mesmos contornos jurídicos, decorrentes dos elementos e dispositivos jurídicos similares que os integram.

Respaldando-se, desta sorte, no princípio da analogia, seria de grande razoabilidade admitir que os contratos de licença de uso de marca, celebrados a título exclusivo, possibilitassem ao licenciado da marca, ainda que sem o expresso consentimento do licenciante, o direito de ingressar em juízo contra o titular e terceiros, em defesa da

editor recebe uma proteção que lhe assegura a possibilidade de agir judicialmente de maneira autônoma, pois, lhes são conferidos poderes fundados no contrato e limitados pela destinação deste. Estas faculdades constituem o direito de edição o qual se opõe a terceiros e ao próprio autor. A doutrina descreve o direito de ação como um direito real ou quase real". (DE MATTIA, Fábio Maria. O Autor e o Editor na Obra Gráfica.....op. cit. p. 27).

${ }^{580}$ DE MATTIA, Fábio Maria. O Autor e o Editor na Obra Gráfica.....op. cit. p. 26. 
marca usurpada, tal qual ocorre com os contratos de edição (contrato de licenciamento de obra a título exclusivo).

Outro argumento pertinente, nesta linha de inteligência, seria emprestar ao contrato de licença de uso de marca exclusivo dispositivo de segurança semelhante àquele característico ao contrato de locação de bens imóveis, consubstanciado nas ações possessórias. Estas ações podem ser promovidas contra terceiros diretamente pelo locatário, contra eventuais turbações ${ }^{581}$ ou esbulhos que recaiam sobre o bem alugado, sem a necessária anuência do locador.

Isto porque, o licenciado exclusivo, tal qual ocorre com o locatário, pode sofrer embaraço ao seu livre exercício de uso da marca licenciada. Assim, o recurso pelo licenciado a este dispositivo protetivo permitido ao locatário de bens imóveis, poderia lhe possibilitar o ingresso direto em juízo contra terceiros que, eventualmente, estivessem restringindo ou prejudicando, de alguma forma, o uso exclusivo do bem imaterial licenciado. Esta prerrogativa conferida ao licenciado, seguramente, lhe possibilitaria maior agilidade na defesa de seus interesses ("marca licenciada"), principalmente em Ações de Busca e Apreensão de mercadorias contrafeitas, em que se exige a máxima confidencialidade e celeridade possível, ao contrário do que ocorre quando se tem de recorrer, previamente, ao licenciante (titular da marca) para que este promova as devidas medidas judiciais contra terceiros usurpadores da marca (procedimento este mais moroso, burocrático e ameaçador dos direitos imediatos do licenciado).

Por certo, a construções doutrinárias ora apontadas, sobretudo aquela alicerçada no contrato de edição, em que pese estarem na contramão do sistema legal vigente, merecem reflexão mais aprofundada pelos edificadores e operadores do direito, de modo a possibilitar alterações substanciais no sistema jurídico marcário vigente e, assim, impedir o aviltamento de direitos importantes dos quais deveriam ser investidos os licenciados, tão apenas em defesa daquilo que lhes fora disponibilizado, contra o pagamento de justa remuneração.

\footnotetext{
${ }^{581}$ Conforme preleciona Orlando Gomes, turbação "é todo ato que embaraça o livre exercício da posse, haja ou não dano, tenha ou não, melhor direito sobre a coisa; há de ser real, isto é, concreta, efetiva, consistente em fatos". (GOMES, Orlando. Direitos Reais. 14a ed com notas de Humberto Theodoro Júnior. Rio de Janeiro: Forense. 1999. p. 90)
} 


\section{V.8 EXTINÇÃO DO CONTRATO DE LICENÇA DE USO DE MARCA}

A extinção do contrato de licença de uso de marca se opera em estrita conformidade com os artigos 472 a 480 do Código Civil Brasileiro, sendo este Diploma, conforme estudado, direito comum aplicável à espécie contratual de direito industrial em exame. Com efeito, o referido contrato será extinto em consequiência dos seguintes eventos: distrato, resilição unilateral ou ainda resolução do contrato por inadimplemento obrigacional de uma das partes.

$\mathrm{O}$ distrato decorre da vontade mútua de licenciante e licenciado em encerrar o contrato de licença previamente ao termo final estipulado no instrumento contratual.

A resilição unilateral decorre da vontade externalizada por uma das partes, antes do término da relação jurídica estabelecida, em não prosseguir com o contrato, operando-se mediante denúncia notificada à outra parte. Ante o teor da primeira parte do caput do artigo 473 do Código Civil Brasileiro, a resilição unilateral se opera nos casos em que a lei, expressa ou tacitamente permitir. Nos contratos firmados por tempo indeterminado, é facultada a qualquer contratante a prerrogrativa de encerrar o contrato a qualquer tempo, mediante denúncia à parte contrária. Esta faculdade é admitida pelo ordenamento jurídico, ainda que não seja expressamente recepcionada por legislação específica positivada ${ }^{582}$. Neste sentido, é imperioso trazer à colação preciosa lição do mestre Pontes de Miranda, o qual assinala:

Nas relações jurídicas duradouras, é preciso que possa ter ponto final o que se concebeu em reticência. Porque relação jurídica duradoura a que não se pudesse por termo seria contrária às necessidades da livre atividade dos

\footnotetext{
${ }^{582}$ Registre-se, neste aspecto, doutrina disseminada por James Eduardo Oliveira, o qual ministra que, nos contratos firmados por tempo indeterminado, qualquer parte pode exercer seu direito de resilição unilateral, considerando que do contrato não existiria outra forma natural de se encerrar o vínculo obrigacional. Para o civilista, "neste tipo de contrato, a resilição unilateral é implicitamente consentida pela ordem jurídica vigente que é avessa à perpetuidade das obrigações. Não depende, pois, de previsão expressa no instrumento negocial o direito de resilir unilateralmente o contrato por prazo indeterminado". (Cf. OLIVEIRA, James Eduardo. Código Civil anotado e comentado: doutrina e jurisprudência...op. cit.. p. 380).
} 
homens. Não bastaria subordiná-la a eventual resolução por inadimplemento ou ao distrato. Daí a figura da denúncia, com que se denuncia, pois resulta de se haver atribuído a algum dos figurantes o direito formativo extintivo, que é o de denunciar. ${ }^{583}$

No caso dos contratos de licença de uso de marca, principalmente em razão de sua atipicidade e subsunção analógica às normas que disciplinam a locação de coisas, o prazo pode ser por tempo determinado ou indeterminado. Ademais, há a permissão tácita à resilição unilateral $^{584}$. Especialmente no evento de a licença de uso ser concedida por tempo indeterminado, poderá qualquer das partes encerrar o negócio jurídico a qualquer momento, denunciando o contrato à parte contrária, sem que, para isto, tenha de indenizar o outro contratante. Esta regra, contudo, comporta uma exceção, ex vi do parágrafo único do artigo 473 do Diploma Civil.

O parágrafo único, do artigo 473, que se aplica tanto para os contratos por prazo indeterminado, como para aqueles firmados por prazo determinado, se apresenta como outro moderno dispositivo trazido à tona com o advento do novo diploma civil, interessando-nos pontualmente, mormente em decorrência do fato de ser aplicável aos contratos de licença de uso de marca.

Conforme comando extraído do parágrafo único do artigo em comento, no evento de uma das partes decidir pela resilição unilateral, onde uma das contratantes tenha realizado investimentos consideráveis para a obtenção do licenciamento da marca, a denúncia unilateral somente produzirá efeito depois de transcorrido prazo compatível com a natureza e o vulto dos investimentos.

Registre-se, nesta senda, a ilação realizada pelo professor José Fernando Simão ${ }^{585}$, ao afiançar que o artigo 473 do Código Civil se coaduna pefeitamente com um dos

\footnotetext{
${ }^{583}$ Cf. MIRANDA, Francisco Cavalcanti Pontes de. Tratado de Direito Privado. atual. por Vilson Rodrigues Alves. Campinas: Bookseller. 2003. tomo XXV. p. 338.

584 “O art. 567 dá, na verdade, um direito potestativo ao locatário não culpado pela deterioração da coisa alugada, qual seja, pedir a redução proporcional do aluguel ou resolver o contrato. A faculdade concedida pela lei é tecnicamente a resilição unilateral ou denúncia” (LOPEZ, Teresa Ancona. Comentários ao Código Civil. São Paulo: Saraiva, 2003, vol. 7, p. 19).
}

${ }^{585}$ SIMÃO, José Fernando. Direito Civil: contratos. 2a ed. São Paulo: Ed. Atlas, 2007 - (série leituras jurídicas); v. 5. pp. 81/82. 
princípios basilares da nova ordem social: a função social do contrato. Ademais, na esteira do que preleciona o civilista, o contrato deve ser vantajoso para ambos os contratantes, sendo que, se um contratante beneficiar-se em detrimento da outra parte, inobservado estará o princípio da função social do contrato.

Depreende-se, pois, que, se comprovado que o investimento realizado para aquela licença ainda não fora, ao menos, recuperado, mesmo após decurso de prazo exíguo estipulado em contrato, detém o magistrado a prerrogativa de decidir pela não resilição do contrato de licença, ainda que a cláusula resilitória tenha, de início, sido expressamente consentida por licenciante e licenciado ${ }^{586}$. De forma concisa e esclarecedora, o civilista ora referenciado delineia o seguinte cenário, in litteris:

\begin{abstract}
(...) situação em que determinada empresa firma contrato pelo qual se torna autorizada de uma marca de eletrodomésticos para realizar serviços de reparos e fazer substituições de equipamentos que estão no prazo de garantia. Prevê o contrato o prazo de dois anos para vigência e a faculdade de denúncia mediante um aviso prévio de 30 dias, após o prazo contratual. Entretanto, prevê o contrato que esta autorizada deverá realizar investimentos para a divulgação da marca, bem como para a instalação do estabelecimento. Findos os dois anos de contrato, em razão do vulto de investimentos, a empresa autorizada ainda não obteve qualquer lucro com o contrato. Se a outra empresa exercer seu direito de resilir o contrato unilateralmente, a autorizada poderá pedir a suspensão dos efeitos da resilição até que o contrato lhe garanta um mínimo de lucro.(grifou-se)
\end{abstract}

O sistema brasileiro, por certo, guarda relação de similaridade com o ordenamento francês. Com relação a este última sistema, SINGH e BARS assinalam que o prazo de vigência da licença poderá ser determinado ou indeterminado. Na hipótese de o prazo ser determinado, nenhuma das partes poderá, no curso normal da relação jurídica concebida, encerrar o contrato. Neste caso, a parte inocente deverá ser indenizada. Se o prazo do contrato for, contudo, por período indeterminado, qualquer das partes poderá denunciar o contrato, contanto que notifique o outro contratante com prazo de antecedência "razoável". A "razoabilidade", segundo os juristas franceses em estudo, variará em consonância com fatos e circunstância do caso concreto, devendo ser considerados a duração do contrato até

${ }^{586}$ Cf. SIMÃO, José Fernando. Direito Civil: Contratos ....op. cit. p. 83. 
o momento da renúncia; a dependência econômica e a possibilidade de se encontrar outro contratante. $^{587}$

As condições acima ventiladas são preocupações evidentes perpetuadas pelos doutrinadores franceses, assim como correntemente ocorre com os juristas brasileiros, de sorte a evitar que uma parte seja prejudicada, principalmente em relação aos investimentos realizados não recuperados, contra o enriquecimento e benefício desproporcional, logrado pela outra parte.

A terceira forma de extinção do contrato de licença de uso de marca repousa na resolução por inadimplemento obrigacional. Depreende-se da interpretação do artigo 474 do Código Civil que o contrato de licença poderá prever cláusula resolutiva ou não. No evento de haver previsão expressa desta cláusula, a inexecução de qualquer obrigação contratual implicará a extinção do contrato, sem prejuízo de a parte prejudicada pleitear indenização da parte inadimplente ${ }^{588}$. Nesta primeira hipótese, o encerramento do contrato de licença se operará de pleno direito, de modo que não há a necessidade de interpelação judicial $^{589}$. Na outra vertente, se licenciante e licenciado não houverem expressamente consignado no instrumento a possibilidade de resolução por inadimplemento contratual, a extinção do vínculo obrigacional somente ocorrerá mediante interpelação judicial.

Ante o exposto, o contrato de licença de marca poderá ser: (i) resilido, se o contrato for por prazo indeterminado ou se houver previsão contratual expressa indicando que uma das partes poderá desfazer o contrato unilateralmente, imotivadamente e a título arbitrário; ou (ii) resolvido, no caso de uma das partes infringir uma das cláusulas contratuais. Neste segundo caso, o inadimplemento de um dos dispositivos consignados em contrato sujeitará a parte culpada ao dever de ressarcir a parte inocente por perdas e danos

\footnotetext{
${ }^{587}$ Cf. WILKOF, Neil e BURKITT, Daniel. Trademark Licensing.....op. cit. p. 270 e ss.

${ }^{588}$ Prescreve o artigo 475 do Código Civil Brasileiro que "a parte lesada pelo inadimplemento pode pedir a resolução do contrato, se não preferir exigir-lhe o cumprimento, cabendo, em qualquer dos casos, indenização por perdas e danos".

589 Segundo alocução de Paulo Nader, "caracterizada a resolução expressa, a parte lesada não carece de ajuizamento de ação judicial, salvo de optar por excigir o cumprimento da obrigação, pleitear perdas e danos ou formular ambos os pedidos. O litígio judicial pode ser instaurado, contudo, pelo acusado de inadimplência, pretendendo preservar o vínculo contratual, além de exigir o ressarcimento da contraparte, quando, naturalmente, deverá provar o cumprimento de sua obrigação" (Cf. NADER, Paulo. Curso de Direito Civil. $2^{\mathrm{a}}$ ed. São Paulo: Ed. Forense. vol. 3. p. 184)
} 
sofridos, dentre os quais assumem especial importância: os danos materiais, emergentes e lucros cessantes.

Alicerçamo-nos, aqui, na melhor doutrina do civilista Flávio Tartuce ${ }^{590}$ de que a rescisão é gênero das quais são espécies: a resolução (quando há descumprimento do contrato) e a resilição (quando há a dissolução do contrato por vontade bilateral ou unilateral, quando admissível em lei).

Se ponderarmos que o contrato de licença é espécie de contrato de transferência de tecnologia em que há, em tese, investimento de capital, principalmente por parte do licenciado, vislumbramos como remota a possibilidade de se prever contratualmente a resilição unilateral.

Adicionalmente, há que se ressaltar que a extinção, via resolução, neste tipo de contrato, se apresenta com maior constância do que a resilição. Sinalizamos, outrossim, para a impropriedade técnica de se utilizar o termo "direito de resilir", quando da constatação, pelo licenciante, de desuso da marca pelo licenciado. O desuso corresponde ao inadimplemento do contrato, e flagrante violação à Lei 9279/96 (que prescreve o uso efetivo da marca, sob pena de caducidaade), dando azo, na grande maioria dos casos, à resolução e não à resilição.

Por força dos artigos 476 e 477 do Diploma Civil, que versam sobre exceções a contratos não cumpridos, e trazendo ao plano do contrato de licença de uso de marca, qualquer uma das partes não poderá exigir o cumprimento da obrigação de sua contraparte se não houver adimplido o que lhe competia por contrato. Ademais, conforme comando do artigo 477, durante a execução do contrato, a lei faculta ao contratante suspender o cumprimento de sua obrigação, no evento de constatar que sua contraparte sofreu diminuição patrimonial considerável, de modo que comprometa ou torne duvidosa a obrigação da qual houvera se incumbido. Desta sorte, a suspensão da prestação persistirá até que a outra parte cumpra sua obrigação ou forneça garantia suficiente que irá satisfazê-

\footnotetext{
${ }^{590}$ TARTUCE, Flávio. Direito Civil, v.3: Teoria Geral dos Contratos e Contratos em Espécie. $2^{\mathrm{a}}$ ed. São
} Paulo. Ed. Método. 2007. pp. 222-233. 
$1 \mathrm{l}^{591}$. O patrimônio do devedor representa, pois, a segurança de seus credores. Na esfera contratual, se o acervo de bens de um dos contratantes se decompõe a ponto de comprometer ou tornar duvidosa a prestação assumida, o artigo 477 autoriza sua contraparte a suspender o cumprimento de sua prestação até que lhe seja ofeercida garantia de que a obrigação será, de fato, cumprida pelo contratante cujo patrimônio se encontra em processo de decomposição.

Por fim, o contrato de licença de uso de marca poderá ser resolvido (extinto) por onerosidade excessiva. Conforme dicção dos artigos 478 a 480 do Diploma Civil, este acontecimento se opera na hipótese seguinte: se a obrigação de uma das partes se tornar excessivamente onerosa, com elevados benefícios para a outra parte, em razão de eventos extraordinários e imprevisíveis, poderá o devedor pleitear a extinção do contrato, sem que, por isto, tenha de indenizar a parte credora por inadimplemento contratual. Este tema foi oportunamente abordado na presente tese, quando do estudo das diversas formas de remuneração aplicáveis ao contrato sub examine.

591 "Nesta hipótese, a parte que sofreu diminuição do patrimônio poderá exigir do co-contratante o adimplemento de sua prestação, enquanto não cumprir sua obrigação ou oferecer a garantia supra citada. Caso promova a ação judicial com este objetivo, poderá a outra parte apresentar exceção de contrato não cumprido" (Cf. LOUREIRO, Luiz Guilherme. Contratos no Novo Código Civil: teoria geral e contratos em espécie. $2^{\mathrm{a}}$ ed. rev. e atual. São Paulo: Ed. Método, 2004. p. 260). 


\section{O Licenciante E O DeVER de EXecer O CONTROLE DE QUALIDADE SOBRE o Uso da Marca Licenciada: AnÁlise Crítica do Artigo 139 da LeI 9.279/96}

O artigo 90, da revogada Lei 5.772, de 21 de dezembro de 1971, que houvera instituído o Código da Propriedade Industrial, autorizava o licenciamento da marca, por seu titular, a terceiros, mediante a subscrição de "contrato de exploração". Previa, outrossim, que o contrato deveria fazer menção expressa ao número do pedido ou do registro; à forma de remuneração; bem como à "obrigação" (dever) de o titular da marca (licenciante) realizar o controle real sobre as especificações, natureza e qualidade dos respectivos artigos ou serviços.

A Lei 9.279/96, em vigor, que revogou o diploma acima ventilado, eliminou o comando inserto no artigo 90, especialmente o comando que discorria sobre a obrigação do licenciante em realizar o controle efetivo sobre o uso da marca licenciada. Com efeito, a segunda parte do caput da Lei 9.279/96, passou a conferir ao licenciante (titular da marca) o direito de "exercer controle efetivo sobre as especificações, natureza e qualidade dos respectivos produtos ou serviços”. Pelo sistema legal marcário vigente, portanto, o que antes era dever, passou a ser mero direito do titular da marca.

Perfilhamos o entendimento, conforme adiante demonstrado, de que houve acentuado retrocesso da "nova" lei que regulamenta a propriedade industrial, quando em cotejo com o Código de Propriedade Industrial revogado. Este retrocesso, acarretado pelo artigo 139, caput, da lei vigente, será sopesado tendo-se em vista a função social, em sua eficácia externa (perante terceiros que do contrato não tenham participado), da qual deve se revestir o contrato de licença de uso de marca. 
Sobre esta função social, a comercialista Juliana B. Viegas sustenta que é adequado ao licenciante "exercer efetivamente o seu direito de controle sobre a qualidade, natureza, especificações e materiais dos produtos ou serviços assinalados pelas marcas licenciadas" ${ }^{\$ 92}$. No entanto, em que pese a faculdade de o licenciante fiscalizar o produto ou serviço, cuja identificação se dê através da marca licenciada, compartilhamos da opinião, disseminada por Julio C. Ledesma, de que, visando atender à função social do contrato e do próprio signo ${ }^{593}$, o titular tem o dever (e não mero direito) de verificar a qualidade do produto fabricado ou serviço prestado pelo licenciado.

Este "dever" tem a finalidade de evitar que terceiros (principalmente consumidores) que venham a adquirir produto ou serviço conjugado à marca licenciada, sejam, de alguma forma, lesados. Esta lesão se dá em função da queda acentuada da qualidade daquilo que os terceiros estejam adquirindo como consequencia da credibilidade originariamente edificada pelo titular da marca (licenciante), fruto de um processo histórico de consumo.

Conforme oportunamente estudado, uma das funções exercidas pela marca é justamente distinguir os produtos ou serviços, em função de sua qualidade e credibilidade, de produtos ou serviços congêneres disseminados em um mercado de livre concorrência. Evidentemente, o maior prejudicado com a ausência de fiscalização da qualidade do produto ou serviço oferecido pelo licenciado é o consumidor. Vejamos:

O licenciado não poderá trazer à tona produto ou serviço, objetivamente, de má qualidade. Se assim o fizer, prejudicará expressivamente o consumidor que, ilusoriamente, o tenha adquirido, por ter creditado confiança à marca licenciada, e não ao produto ou serviço contraído. Na hipótese referenciada, o consumidor acabará tendo significante prejuízo de ordem financeira e moral, este último alicerçado na decepção de ter sido ludibriado por marca não condizente com a qualidade do produto esperado.

\footnotetext{
${ }^{592}$ VIEGAS, Juliana L. B. Contrato de Licenciamento de Marcas...op. cit. p. 100.

${ }^{593}$ Neste sentido, cite-se o magistério de Julio C. Ledesma, o qual realça o dever do licenciante em fiscalizar a marca licenciada, com o escopo de se atender à função social do sinal disposto. Leciona o mestre argentino: "No puede concebirse, em consecuencia, que un símbolo marcario que ha sido concedido em propriedad para individualizar um producto dado, sirva para distinguir outro que se origina em um medio fabril o comercial distinto, mediante procedimientos técnicos diferente (....) preciso es admitir, cualquiera sea la concepción del intérprete relativa al derecho de propriedad, que los titulares de marca tienen el deber de colaborar a la realización de los fines sociales (...)" (LEDESMA, Julio C. Funcion Social de Las Marcas de Fabrica y de Comercio. Buenos Aires. Ed. Valério Abeledo. 1953. pp. 85-99).
} 
Convém trazer à colação a forma da qual se comportam alguns ordenamentos jurídicos alienígenas, em relação à qualidade que devem ter os produtos ou serviços promovidos pelo licenciado, bem como à necessidade perene de o titular exercer o "controle de qualidade" sobre o uso da marca licenciada.

Muito embora o dever do exercício do "controle de qualidade" não esteja contemplado a fundo pelo diploma marcário português ${ }^{594}$, a doutrina lusitana hodierna, capitaneada por Luís M. Couto Gonçalves ${ }^{595}$, posiciona-se favoravelmente à necessidade de o titular da marca realizar efetivo controle de qualidade, sob pena de, não o fazendo, potencialmente vir a sofrer lesões previstas pela própria lei industrial.

Desta sorte, a licença de uso de marca não consiste apenas na renúncia do licenciante ao seu direito originário de proibir que terceiros se utilizem do sinal de sua titularidade (direito negativo). Mais do que isso, o titular da marca deve, necessariamente, exercer certas faculdades (direito positivo), de modo a evitar que possíveis mazelas acometam o bem intangível de sua propriedade, conforme adiante se elucida.

Ex vi do artigo 269 do Código da Propriedade Industrial português ${ }^{596}$, a caducidade da marca é declarada nas hipóteses a seguir tracejadas: (a) se o bem intangível protegido pelo registro não houver sido objeto de "uso sério" 597 ao longo de cinco anos consecutivos, com exceção à apresentação de justo motivo e sem prejuízo ao disposto no artigo 268 do CPI; (b) se a marca tiver se transformado na designação usual do comércio do produto ou serviço para o qual tenha sido chancelada, como decorrência da atividade ou ausência dela

\footnotetext{
${ }^{594}$ A despeito da ausência de tipificação quanto à forma de controle de qualidade, o sistema português faz menção expressa ao dever do licenciado em manter a qualidade dos produtos ou serviços por ele gerados (aliados à marca licenciada). (Artigo 264 do CPI português).

595 GONÇALVES, Luís M. Couto. Manual de Direito Industrial: Patentes, Marcas, Concorrência Desleal. $2^{\mathrm{a}}$ ed. rev. e aumentada. Coimbra: Almedina. 2008. p. 354.

596 Código de Propriedade Industrial português. Disponível em $<$ http://www.portolegal.com/CodPropriedadeIndustrial2003.htm> Acesso em 20 jul. 2010.

${ }^{597}$ Conforme aclara o artigo 268 do CPI português, considera-se "uso sério da marca": (a) o uso da marca tal como está registrada ou que dela não se distinga senão em elementos que não alterem o seu caráter distintivo, de harmonia com o disposto no artigo $261^{\circ}$, feito pelo titular do registro, ou por seu licenciado, com licença devidamente averbada; (b) o uso da marca, tal como definida na alínea anterior, para produtos ou serviços destinados apenas a exportação; (c) a utilização da marca por um terceiro, desde que o seja sob controle do titular e para efeitos da manutenção do registro.
} 
pelo seu titular; e (c) se a marca se tornar passível de induzir o público a erro, especialmente no que diz respeito à natureza, qualidade e origem geográfica desses produtos ou serviços, quando do uso feito pelo seu titular, ou mesmo por terceiro com o seu consentimento, para aqueles produtos ou serviços para que foi registrada.

Note-se, com efeito, que o licenciante, titular da marca, deve inclinar-se à fiscalização do modo pelo qual seu bem intangível está sendo utilizado pelo licenciado. E este ato positivo deve se operar, não apenas em defesa de interesse próprio do licenciante, corporificado na manutenção do registro de sua propriedade em face de eventual declaração de caducidade, como, de igual forma, em defesa de interesse de terceiros (consumidores) que do contrato de licença não tenham participado. Acrescente-se a isso que a ausência de previsão em contrato acerca da implantação de "controle de qualidade" pelo licenciante pode dar azo à impossibilidade de o titular recorrer ao seu direito de promover medida judicial de contrafação contra o licenciado, na eventualidade deste prejudicar, substancialmente, a qualidade dos produtos ou serviços representados no mercado pela marca licenciada.

Neste senso, é oportuno indicar preleção disseminada por Luís Gonçalves, à luz da doutrina portuguesa ${ }^{598}$ :

É certo que o licenciante e o licenciado são livres de não estabelecerem contratualmente esse controlo, mas essa opção dos contraentes não afasta a aplicação da referida sanção da caducidade, que opera independentemente da vontade das partes por servir interesses diferentes, dos consumidores e dos outros concorrentes, que, logicamente, não são derrogáveis contratualmente. A não estipulação contratual do requisito da qualidade e do respectivo controlo, poderá relevar para outro efeito: para a impossibilidade de o licenciante, fazendo uso do disposto no artigo 264, invocar seu direito de marca para instaurar um processo de contrafação contra o licenciado na hipótese de este alterar, de modo relevante, a qualidade dos produtos ou serviços licenciados. (grifou-se)

Há que se concluir, por conseguinte, a importância direcionada pelo ordenamento jurídico português ao exercício do direito, margeando o conceito de "dever", do licenciante de exercer efetivo controle de qualidade sobre a marca licenciada, sob pena de lesar a

598 GONÇALVES, Luís M. Couto. Manual de Direito Industrial: Patentes, Marcas, Concorrência Desleal.....op. cit. p. 353. 
função social que deve servir o direito de propriedade industrial, como, de igual modo, sob pena de golpear os interesses daqueles que do contrato não tiveram a oportunidade de participar, porém que deste negócio jurídico possam sofrer consequiências imediatas. É o exemplo dos consumidores, os quais têm de pagar pelas mazelas oriundas da negligência contratual propiciada pelo licenciante.

O ordenamento australiano oferece sólidos elementos que embasam a necessidade de se exercer o controle de qualidade decorrente dos contratos de licença de marca. A legislação australiana não se quedou silente em relação a esta matéria, considerando-a como elemento capital a ser sopesado quando da transferência temporária do bem imaterial em referência.

De tal modo, a Seção 8 (1), do Trade Marks Act 1995, estatui que uma pessoa, em geral jurídica, é identificada como "usuária autorizada" de uma marca, se esta pessoa usa tal marca em relação a produtos ou serviços à vista do controle do titular da marca. Acresça-se, ainda, a Seção 8 (2), a qual reza que a utilização de uma marca pelo licenciado será considerada como de "uso autorizado" tão somente se este uso se operar sob o necessário controle do titular.

A doutrina australiana, acaudilhada por Mark J. Davison, Ann L. Monotti e Leanne Wiseman, aponta que a questão central erigida pelo ordenamento jurídico deste país, especialmente no que pertine à validade do licenciamento, concerne ao controle de qualidade efetivado pelo licenciador. Este controle deve ser realizado com tenacidade, para que o público receptor dos produtos comercializados sob o manto da marca licenciada não seja lesado e ludibriado em sua boa-fe $e^{599}$.

Neste aspecto, é imperioso fazer menção à lição perpetrada por Graham J., o qual aponta como de extrema importância, quando o assunto é licenciamento de marca, a satisfação do público consumidor, ao adquirir produto ou serviço do licenciado, como se estivesse obtendo produto ou serviço com as mesmas qualidades e características originariamente apresentadas pelo titular da marca. Acresça-se a isso, conforme afiançado

599 DAVISON, Mark J.; MONOTTI, Ann L. e WISEMAN, Leanne. Australian Intellectual Property Law. Nova Iorque: Cambridge University Press, 2008. pp. 172-173. 
por D. Carter, a existência de forte corrente doutrinária inclinando-se à tese da responsabilidade solidária entre licenciador e licenciado perante o público consumidor, em caso de prejuízo motivado por produto ou serviço vicioso, mormente em decorrência do exercício inadequado de controle de qualidade efetivado pelo licenciador ${ }^{600}$. Daí o porquê ser vital que o controle de qualidade seja realizado, com afinco e com a devida perícia, pelo titular da marca registrada ${ }^{601}$.

O sistema marcário germânico ${ }^{602}$ sinaliza, por igual, para a necessidade de fiscalização da marca licenciada. Estabelece, destarte, que o titular poderá se insurgir contra o licenciado que infringir disposições contratuais concernentes:

(i) ao termo final da vigência da licença;

(ii) às formas como a marca poderá ser usada, em consonância com o registro efetuado. Assim temos, a título exemplificativo, que marca licenciada, cujo registro tenha sido efetuado para classe de venda de material esportivo, não poderá ser usada pelo licenciado para construção civil;

(iii) ao tipo de produtos ou serviços para os quais a licença tenha sido permitida;

(iv) ao local que tenha sido estipulado o usa da marca licenciada;

(v) à qualidade dos produtos gerados ou dos serviços fornecidos pelo licenciado.

${ }^{600}$ CARTER, D. Trademark Licences or Goodbye Goodwill. Open Forum Papers. 21-24 october 1998. Paper: FLO/2.5. < http://www.ficpi.org/library/florence98/goodwill.html> Acesso em 20 de dez. de 2009.

${ }^{601}$ Sob este enfoque, prescreve, in literris, Graham J.: "The really important point is that the public should recognize that the symbol or word in question is being used as a trademark by someone who is responsible for the product being what it is and having the quality which it in fact has(...) This is why it is important that proprietors of trade marks should retain adequate control over the quality of their product and should by careful advertising and use of their marks ensure that the public do not attribute to marks meanings which may lead to confusion." (Graham J. General Eletric Case,[1969] RPC 418, 448 (ChD). Idem. Ibidem. p. 172).

602 Cf. German TradeMark Law. Capítulo 5 - “As Marcas como objeto de propriedade” Disponível em < http://www.markenagentur.de/guide/markg1d.htm\#teil25> Acesso em 12 out. 2009. 
A preocupação do legislador germânico fora cristalina em assegurar que o produto ou serviço fornecido pelo licenciado tenha o mesmo nível qualitativo de excelência do que aqueles preteritamente oferecidos pelo titular. Tal diretriz tem o condão de evitar que terceiros de boa-fé, leia-se consumidores, sejam lesados ao adquirir produto ou serviço oferecido pelo licenciado, tendo-se em mente o grau de qualidade e mesmos atributos daqueles artigos que eram oferecidos pelo genuíno titular licenciador, anteriormente à subscrição do contrato de licença.

O legislador italiano também não se descuidou da segurança do consumidor adquirente de produto ou serviço cuja marca tenha sido objeto de licença. Com efeito, determina o Codice Della Proprietà Industriale que os produtos ou serviços, para os quais a marca tenha sido licenciada, devem manter as mesmas características essenciais, mesmo padrão de excelência e igual nível de qualidade, em cotejo com aqueles produtos ou serviços oferecidos no mercado, pelo titular, antes da celebração do instrumento de licenciamento. Este preceito legal tem a finalidade de evitar que o consumidor seja induzido a erro. Tem a finalidade de impedir, principalmente, que o consumidor adquira determinado produto ou serviço que possua atributos marcantemente inferiores à qualidade inerente aos produtos que eram obtidos diretamente do licenciante ${ }^{603}$.

Ademais, com arrimo na doutrina italiana, é lícito ao licenciante ingressar em juízo e promover a competente ação de contrafação (Azione di Contraffazione) contra o licenciado que não cumprir com as determinações contratuais assumidas, incluindo-se aqueles deveres inerentes à manutenção da qualidade dos produtos oferecidos ou dos serviços prestados pelo licenciado no mercado. Esta medida repressiva é possível, especialmente se a licença é firmada a título não exclusivo, quando haja vários licenciados e, por tal razão, se faça complexo o exercício simultâneo do controle de qualidade, pelo licenciante, sobre todos os licenciados. Segundo lição do jurista italiano Marco Ricolfi, a Azione di Contraffazione representa um remédio jurídico contundente, passível de utilização ao longo da relação contratual, pois que, simultaneamente, tutela objetivamente

\footnotetext{
603 O artigo 23.4, do Código da Propriedade Industrial Italiano, de 2005, ao tratar da licença do uso de marca, prescreve textualmente: "In ogni caso, dal trasferimento e dalla licenza del marchio non deve derivare inganno in quei caratteri dei prodotti o servizi che sono essenziali nell'apprezzamento del pubblico". (Cf. Codice della Proprietà Iindustriale. Art. 23. Trasferimento del Marchio Disponível em $<$ http://www.camera.it/parlam/leggi/deleghe/testi/05030dl.htm>. Acessado em 15/09/09).
} 
a marca (escopo extracontratual) e garante o adimplemento do contrato de licença (escopo contratual). ${ }^{604}$

Tendo-se em vista a "função social do contrato", a perene "proteção ao consumidor" e a tendência seguida pelos sistemas jurídicos externos, reforçamos a tese de que o licenciante tem o poder/dever de proceder à fiscalização do uso da marca recebida, como decorrência do contrato de licença. Este dever, conforme rezava o artigo 90 do CPI revogado, reside, essencialmente, no controle de qualidade a ser exercido sobre os produtos sobre os quais estiver aposta a marca licenciada. De tal modo, o titular/licenciante deverá envidar todos os esforços, em benefício do consumidor, visando à manutenção da qualidade dos produtos ou serviços, através da implementação de planos de ação que visem à prevenção e correção dos vícios encontrados nos produtos ou serviços fiscalizados, na forma como será adiante demonstrada. Na outra vertente, conforme assinala Luiz Guilherme Loureiro, o controle de qualidade deve ser ferramenta utilizada pelo licenciante, com o fito de evitar o perecimento da propriedade da marca, em conseqüência do desuso pelo licenciado ${ }^{605}$.

Ainda no que pertine ao dever de fiscalização da marca licenciada, o professor Newton Silveira ${ }^{606}$, ao discorrer sobre o artigo 90 do revogado Código de Propriedade Industrial, em que tal fiscalização se fazia compulsória, recorre ao ordenamento jurídico estadunidense para advogar a tese de que mencionado dever é de suma importância, a fim de se evitar que o consumidor fique ao desabrigo.

\footnotetext{
${ }^{604}$ Neste aspecto, anote-se lição de Marco Ricolfi, ipisis litteris: "I compiti di controllo del licenziante sono del resto facilitati dalla possibilità di procedere contro il licenziatario che non si attenga alle diverse prescrizioni contrattuali - ivi incluse quelle relative a "la qualità dei prodotti fabbricati e dei servizi forniti dal licenziatario ( $3^{\circ}$ comma dell'art. 23 Cod. E Par. 3 dell'art. 22) - con l'azione di contraffazione. Si tratta di un remedio particolarmente incisivo, esperibile anche in pendenza del rapporto contrattuale, che configura un'ipotesi di concorso dell'azione extracontrattuale a tutela del marchio con quella contrattuale di adempimento del contrato de licenza." (Cf. AUTERI, Paolo (et. al). Diritto Industriale - Proprietà Intellectuale e Concorrenza. $3^{\text {a }}$ ed. G. Giappichelli Editore: Torino, 2009. p. 142).

${ }^{605}$ Para Loureiro, a abstenção quanto à utilização da marca pelo licenciado, enseja ao licenciante o direito de o contrato, com o objetivo de se evitar a caducidade do sinal. (Cf. LOUREIRO, Luiz Guilherme de A.V. A Lei de Propriedade Industrial Comentada. Lei n. ${ }^{\circ} 9.279$ de 14 de maio de 1996. São Paulo. Lejus. 1999. p. 275).

${ }^{606}$ SILVEIRA, Newton. Licença de Uso de Marca e Outros Sinais Distintivos. São Paulo. Ed. Saraiva. 1984. p. 70)
} 
O comercialista, embasando-se no Lanham Act norte-americano, indica decisões exaradas por cortes americanas, cujos comandos exteriorizam a ideia acerca da necessidade de haver controle constante exercido pelo licenciante, com o escopo de se garantir ao consumidor que o produto para cuja marca houvera sido licenciada detenha a mesma qualidade que possuía em momento pretérito ao licenciamento.

Diversas decisões são citadas pelo professor da Faculdade do Largo de São Francisco. Merece destaque, contudo, aquela exarada no caso Gizzi v. Texaco, em que a corte de apelação revogou a decisão de primeira instância que houvera externado ordem sumária eximindo a Texaco - aparente licenciadora - de culpa pelos danos suportados pelos consumidores. Com efeito, a corte de apelação determinou que o processo fosse enviado para análise do júri, para que este julgasse se o licenciador (Texaco) era ou não era civilmente responsável perante o consumidor lesado, o qual se valeu dos serviços prestados por um aparente franqueado/licenciado.

No caso que se apresenta, as motivações que levaram a corte de apelação a reformar a decisão de primeira instância, passando a considerar que fossem feitas investigações mais aprofundadas sobre eventual responsabilidade da aparente licenciadora, repousam nos argumentos a seguir delineados: (i) ausência de garantia na venda do produto pela aparente licenciada; (ii) ausência de garantia no que pertine aos trabalhos efetuados no produto vendido; (iii) responsabilidade subsdiária da aparente licenciadora pelos vícios no produto oferecido e serviço prestado pela aparente licenciada; e, o mais importante, (iv) negligência da aparente licenciadora em permitir que profissionais desqualificados da aparente licenciada realizassem trabalhos no estabelecimento da licenciadora $^{607}$.

Ainda na esteira do que propugna o ordenamento jurídico norte-americano, impende-se discorrer acerca de precioso mecanismo jurídico protetivo de terceiros que não tenham sido parte integrante da relação jurídica concebida por licenciador e licenciado. $\mathrm{O}$ aludido mecanismo de proteção materializa-se na doctrine of apparent authority.

\footnotetext{
607 A íntegra da decisão sob análise encontra-se disponível em: <http://openjurist.org/437/f2d/308/gizzi-vtexaco-inc-giaccio>. Acesso em 03/9/2009.
} 
A doutrina da autoridade aparente pode irradiar efeitos positivos, porquanto albergadores de direitos de terceiros, sobre as relações jurídicas cujo objeto central seja o licenciamento de marca ou franquia, sejam estas relações expressas ou tácitas. Utilizandose deste dispositivo doutrinário e jurisprudencial, os tribunais norte-americanos têm afirmado que o licenciador, naturalmente após análise pormenorizada do caso concreto, pode vir a ser responsabilizado pelos danos que tenham sido gerados a terceiros, como resultado de ações encetadas pelo licenciado ou ente subsidiário.

Convém reigstrar, nesta perspectiva, caso apreciado pela corte estadosunidense, em que McDonald's Inc., titular da marca McDonald's, foi acionado por consumidor que houvera sido lesado por uma das franquias McDonald's (licenciado). Convém exteriorizar entendimento corroborado, com meridiana clareza, pelo juiz Michael Anthony BILANDIC $^{608}$, da corte de apelação de Illinois/Chicago, no que tange à responsabilidade do licenciador decorrente de prejuízos causados pelo licenciado a terceiros. Afiança, com brilhantismo, o magistrado norte-americano:

\begin{abstract}
O contrato de licença assegura que a licenciadora McDonalds tem desenvolvido e opera um sistema de restaurante (....) O Sistema McDonald é operado e é anunciado amplamente dentro dos Estados Unidos da América. O acordo de licença revela que o McDonald Inc. [titular da marca] empenha-se, por meio de seus acordos contratuais, em assegurar que ele, por si só, controle como o público enserga seus restaurantes [licenciados]. O sistema da corporação do McDonald's é descrito como sendo abrangente, de tal sorte que há uma padronização das políticas pelos licenciados. (...) Isto inclue requerer que os franqueados só sirvam comidas e bebidas pré-estabelecidos; que se use somente equipamentos e prédios com "layouts" e "designs" pré-estabelecidos; (...) treinar os profissionais na matriz da empresa; e aderir estritamente aos padrões de qualidade, serviço e limpeza nos restaurantes/franquias em operação. As publicidades nacionais do "McDonald's Inc." (licenciador) também promovem seus sistema, sem distinguir o licenciador dos licenciados. De acordo com estas publicidades nacionais, o público se depara com o mesmo cardápio, marca e ofertas promocionais em todos os restaurantes "McDonald's". Considerando estes fatos, o júri poderia, com razoabilidade, concluir que o "McDonald's Inc.” (licenciador) agiu de tal modo a criar a aparência que ele era proprietário e operava o restaurante do licenciado onde o autor da ação foi supostamente lesionado juridicamente.(grifou-se)
\end{abstract}

${ }^{608}$ Insta salientar que este voto apresentado por BILANDIC foi dissidente no julgamento do caso ora investigado. (BILANDIC, Michael Anthony. Docket No. 79547--Agenda 11--January 1996. REGINALD O'BANNER, Appellee, v. McDONALD'S CORPORATION et al. (McDonald's Corporation, Appellant Opinion filed May 31, 1996.) 
Mencionada doutrina reconhece que o licenciador (principal) será responsável, não somente pela transferência de bem intagível (marca) de sua propriedade ao licenciado, mas igualmente pela autoridade que ele aparenta ceder. Apenas o fato de o licenciador ou franqueador criar a aparência que outrem é seu agente, ainda que não o faça expressamente, dará ensejo à sua co-responsabilização por eventuais danos que seu suposto licenciado venha a causar a terceiros inocentes ${ }^{609}$.

Calcando-se neste preceito, a Corte Superior dos Estados Unidos tem, correntemente, aplicado a doutrina da autoridade aparente com o propósito maior de apurar co-responsabilidades de licenciados, franqueados, holdings e licenciadores, sobretudo quando é patente o uso da mesma marca, nome e anúncios publicitários ${ }^{610}$.

Alberto Echarri e Angel Pendás ${ }^{611}$, ao analisarem o sistema marcário espanhol, com amparo no princípio da analogia, indicam que os deveres e responsabilidades incidentes sobre o licenciante de patente recaem, por igual, sobre o licenciante da marca. Destarte, com fundamento nesta construção doutrinária e, por conseguinte, no artigo 78, da Ley de

${ }^{609}$ Colacine-se, neste sentido, pela meridiana clareza apresentada, voto dissidente emitido pelo magistrado Michael Anthony BILANDIC, na apreciação de apelação promovida por um consumidor contra o MC' Donalds, caso em que o consumidor fora lesado por um dos franqueados e promoveu ação contra o McDonald's Coporation (titular da marca McDonald's). Neste sentido, afirma BILANDIC, in verbis, que: "the apparent agency doctrine recognizes that a "principal will be bound not only by that authority which he actually gives to another, but also by the authority which he appears to give (....) For a franchisor to be vicariously liable for the acts of its franchisee under the apparent agency doctrine, a plaintiff must show that: (1) the franchisor has represented or permitted it to be represented that the party dealing directly with the plaintiff is its agent; and (2) the plaintiff, acting in justifiable reliance on such representations of the franchisor, has dealt with the agent to the detriment of the plaintiff. (...) The first element is satisfied where the franchisor holds itself out as the provider of certain goods and services without informing the patron that the goods and services are provided by another, whom it considers to be a nonagent, such as a franchisee. The element of justifiable reliance is satisfied if the plaintiff relies on the franchisor to provide the goods and services, rather than on the franchisee." (BILLANDIC, Michael Anthony. Docket No. 79547--Agenda 11-January 1996. REGINALD O'BANNER, Appellee, v. McDONALD'S CORPORATION et al. (McDonald's Corporation, Appellant - Opinion filed May 31, 1996). Disponível em <http://bulk.resource.org/courts.gov/states/Ill/79547.txt> Acesso em 05 out. 2009.

${ }^{610}$ Oportuno mencionar alguns casos em que se faz presente a aplicação doutrina da aparência pelo judiciário norte americano, dentre os quais se destacam: Drexel v. Union Prescription Centers, 582 F.2d 781 (3rd Cir. 1978) (applying Pennsylvania law); Matthews v. KFC National Management Co., No 86-1181 (E.D. Pa. November 19, 1986) (unpublished) (applying Pennsylvania law); Fogel v. Hertz Int'l, Ltd., 141 A.D. $2 d$ 375, 529 N.Y.S.2d 484 (1st Dept. 1998). (DeMartino, Douglas L., Pennsylvania Superior Court Expands Vicarious Liability To American Companies For The Actions Of A Wholly-Owned Foreign Subsidiary: The Doctrine Of Apparent Authority)

Disponivel em: <http://www.marshalldennehey.com/CM/DefenseDigest/DefenseDigest619.asp> Acesso em 04 nov. 2009.

${ }^{611}$ ECHARRI, Alberto; PENDAS, Angel. La Transferencia de Tecnología: aplicación e práctica jurídica. Madrid: Fundación Confemetal. 1999. p. 84. 
Patentes (Lei 11/1986), o licenciante será solidariamente responsável com o licenciador pelas indenizações devidas provenientes dos danos e prejuízos causados a terceiros por vícios dos produtos oferecidos ou serviços prestados que estejam conjugados à marca ou pedido de marca licenciado. Por outro lado, a despeito da mencionada solidariedade, ainda socorrendo-se, por construção analógica, à lei de patente espanhola - artigo 78.2 - o licenciante terá direito de regresso contra o licenciado pelo valor que tiver sido demandando. Este regresso deve se operar, naturalmente, no evento de o titular da marca haver, efetivamente, indenizado terceiros prejudicados por produtos ou serviços defeituosos colocados no mercado pelo licenciado. Aponte-se, entretanto, que a aludida possibilidade de regresso não será crível, no ordenamento em apreço, se as partes houverem pactuado de forma contrária; se o licenciante tiver agido de má-fé, ou ainda, dada as circunstâncias específicas do caso, se deva ser ele, licenciante, o responsável a arcar com a totalidade ou parcialidade das indenizações a terceiros lesados.

Valendo-se dos concatenados fundamentos jurídicos que embasam o instituto da doutrina da aparência, acima referenciados, advogamos a tese de que, no Brasil, a utilização da marca deve - e não pode, conforme preconiza a lei marcária vigente - ser fiscalizada pelo titular/licenciante, após a subscrição dos contratos de licença, à luz da preservação da função social do contrato $^{612}$ e do princípio da supremacia da ordem pública.

A despeito do teor da segunda parte do caput, do artigo 139 da Lei 9279/96, entendemos que o licenciante tem o "dever", e não o simples "direito", de fiscalizar o produto representado pelo sinal licenciado, sob pena de o consumidor ser iludido e, por conseqüência, prejudicado, ao contrair algo que não condiz com as expectativas por ele criadas, comparativamente ao produto ou serviço que antes era contraído diretamente do licenciante (titular da marca).

Neste aspecto, o licenciado atua, perante o público, como um verdadeiro "representante" do licenciante, assumindo, de tal modo, a marca deste e se posicionando no

${ }^{612}$ Acrescente-se, não obstante em caráter implícito, que a fiscalização enaltecida pelo insigne comercialista supra mencionado tem, por igual, o fito de permitir que a função social do contrato se mantenha indelével. 
mercado tal como se o último fosse ${ }^{613}$. O predicado capital da função social é, exatamente, obstar que os contratos concluídos entre particulares prejudiquem, de alguma forma, os direitos de terceiros que da contratação não tenham participado.

Nesta linha de inteligência, segundo valiosos ensinamentos propugnados por Ada Pellegrini Grinover, Kazuo Watanabe, dentre outros co-autores do anteprojeto do Código de Defesa do Consumidor ${ }^{614}$, quando o diploma consumerista faz referência a fornecedor, almeja abarcar todos aqueles que integram o ciclo de produção e distribuição, inclusive o fornecedor aparante ${ }^{615}$, materializado naquele que licencia seu nome ou marca no produto final produzido por outrem.

Ainda sobre a responsabilidade do licenciante perante terceiros, e à guisa da teoria da autoridade aparente, posicionamo-nos contrário à confecção de dispositivo contratual, em contrato de licença de uso de marca, que desobrigue o licenciante de qualquer responsabilidade ocasionada por eventuais danos gerados pelo licenciado, com arrimo no artigo 25, parágrafo $1^{\circ}$, do Código de Defesa do Consumidor ${ }^{616}$.

Anote-se, neste aspecto, lição extraída de luminoso acórdão emitido pelo Des. Jânio Machado, alicerçando-se em esclarecedor parecer do procurador de justiça do Estado de Santa Catarina, Dr. André Carvalho, verbis:

613 “(..) De fato, para o regular desenvolvimento desse tipo de operação contratual [licença de uso de marca], é imprescindível a cooperação e a relação de estrita confiança entre as partes, mesmo porque a licenciada atua, perante o público, como uma verdadeira representante da licenciadora, ostentando sua marca e se apresentando no comércio tal como se fosse a última. (..)” (Agravo de Instrumento n. ${ }^{\circ}$ 2005.032375-2. $3^{\text {a }}$ Câmara de Direito Comercial. TJ/SC. Rel. Des. Marco Aurélio Gastaldi Buzzi. Julg. em 31 de ago. 2006).

${ }^{614}$ GRINOVER, Ada Pelegrini, et al. Código Brasileiro do Consumidor: Comentado pelos Autores do Anteprojeto. Rio de Janeiro: Forense Universitária, 1998, pp. 144/145.

${ }^{615} \mathrm{O}$ artigo $3^{\circ}$ do Anteprojeto do Código de Defesa do Consumidor vislumbra três categorias de forncedores, quais sejam: (i) fornecedor real, compreendendo o fabricante, o produtor e o construtor; (ii) fornecedor presumido, assim entendido o importador do produto industrializado ou in natura; (iii) fornecedor aparente, ou seja, aquele que apõe seu nome ou marca no produto final. (GRINOVER, Ada Pelegrini. op. cit. p. 145).

${ }^{616}$ Cf. Código de Defesa do Consumidor (Lei 8.078/90). “Art. 25º - É vedada a estipulação contratual de cláusula que impossibilite, exonere ou atenue a obrigação de indenizar prevista nesta e nas seções anteriores. $\S 1^{\circ}$ Havendo mais de um responsável pela causação do dano, todos responderão solidariamente pela reparação prevista nesta e nas seções anteriores". 
Não bastasse, é também ausente de valor frente aos consumidores a previsão contida na Cláusula VI do contrato firmado entre a agravante [licenciante] e a Sociedade de Educação e Cultura de Criciúma [licenciada], que prevê a ausência de qualquer liame de solidariedade entre as partes.

É o que dispõe o CDC:

"Art. 25. É vedada a estipulação contratual de cláusula que impossibilite, exonere ou atenue a responsabilidade pela reparação prevista nesta e nas seções anteriores.

$\S 1^{o}$ Havendo mais de um responsável pela causação do dano, todos responderão solidariamente pela reparação prevista nesta e nas seções anteriores."

Ora, não seria mesmo razoável a possibilidade de se impor a terceiros, no caso os destinatários finais do serviço, o pactuado pelas empresas em acordo estritametne bilateral. Isto não só porque o pacto entre os titulares não obriga terceiros que deles não participem nem tomem conhecimento, mas também em razão dos consumidores deterem uma vulnerabilidade que lei de ordem pública oferece maior proteção contra estes abusos.

No presente caso, como já se salientou, o consumidor procurou a Sociedade de Educação e Cultura de Criciúma [licenciada] acreditando estar contratando serviços com a agravante [licenciante]. É insofismável a verdade que o consumidor procurou a instituição [licenciada] por esta ostentar a renomada marca, oferecendo a célebre metodologia que inclui material didático impresso com a logomarca da recorrente. Aliás, basta perguntar a qualquer dos alunos qual o nome do curso freqüentado, e a resposta certamente "Objetivo" [marca do licenciante $]{ }^{617}$ (grifou-se)

Portanto, o licenciante, consubstanciado na figura do fornecedor aparente, pode perfeitamente ser acionado pelos consumidores, muito embora os produtos ou serviços tenham sido produzidos e/ou oferecidos pelo licenciado (fornecedor real) ${ }^{618}$. É o que reza a doctrine of apparent authority, acolhida pela presente tese, e exaustivamente disseminada pelo ordenamento jurídico norte-americano, podendo, também, ser aproveitada e acolhida pelo sistema legal brasileiro.

Adicionalmente, impõe-se assinalar que a reconhecida teoria da aparência vem sendo, manifesta e recorrentemente, aplicada pelos tribunais pátrios, os quais, a despeito de

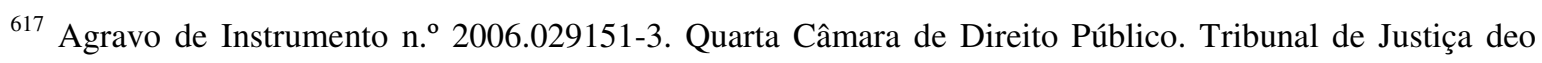
Estado de Santa Catarina. Rel. Des. Jânio Machado. Julg. em 27 de fev. 2008.

${ }^{618}$ IDS - Instituto Dannemann Siemsen de Estudos de Propriedade Intelectual. Comentários à lei da propriedade industrial. Ed. revista e atualizada. Rio de Janeiro: Renovar, 2005. pp. 278-281. 
ainda não ter unificado jurisprudência ${ }^{619}$, têm emitido reiteradas e exímias decisões no sentido de que o licenciante pode sim ser acionado pelo consumidor, sem embargo de não ter com este contratado diretamente, devendo ser responsabilizado civilmente, em decorrência de eventuais danos ocasionados a terceiros, ainda que tais prejuízos sejam fruto de ação encetada tão apenas pelo licenciado e não pelo licenciante ${ }^{620}$. Há, ainda, decisões que vão além: determinam que o licenciante indenize o consumidor pelos prejuízos causados e, no mesmo decisório, concedem ao licenciante o direito expresso de ingressar com ação de regresso contra o licenciado ${ }^{621}$, ou seja, primeiro responsabilizam o licenciante e, após, o licenciado, demonstrando, desta sorte, a colossal reponsabilidade que o licenciante deve, perenemente, manter perante o consumidor, não obstante esteja inoperante no mercado.

Portanto, é imperioso sinalizar para a importância que se deve atribuir ao poder/dever de fiscalização exercido pelo licenciante em relação aos produtos ou serviços conjugados à marca licenciada. Este requisito deve ser questão central a ser sobrelevada, não apenas nos contratos de licença de uso de marca, mas, por igual, em todo sistema jurídico brasileiro. Até porque este dever de fiscalização é conseqüência natural das funções simultâneas atualmente exercidas pela marca, quais sejam: (i) evitar a concorrência deselal; e (ii) proteger o consumidor. Sob este prisma, convém registrar valioso ensinamento do professor Newton Silveira, alicerçando-se em ensaio proferido por Alejandro Cornejo Guerrero, litteris:

619 Oportuno colacionar decisões, minoritárias, posicionando-se em contraposição à tese de coresponsabilidade do licenciante, decorrente de prejuízos gerados pelo licenciado a terceiros: (i) Recurso Especial n. ${ }^{\circ}$ 652069/RS. $3^{\text {a }}$ Turma. Superior Tribunal de Justiça. Rel. Min. Carlos Alberto Menezes Direito. Julg. em 14 de dez. 2006; (ii) Agravo de Instrumento n. ${ }^{\circ}$ 1002406225988-2/001. TJ/MG, Des. Rel. Duarte de Paula. Julg. em 22 de ago. 2007; (iii) Agravo de Instrumento n. ${ }^{\circ}$ 1067209403546-2/0001. 17ª Câmara Cível. TJ/MG. Des. Rel. Luciano Pinto. Julg. em 03 de dez. de 2009; (iv) Apelação Cível n. o 7001286105. Décima Sétima Câmara Cível. TJRS. Des. Rel. Alexandre Mussoi Moreira. Julg. em 11 de out. 2005.

${ }^{620}$ Neste sentido, ver: (i) Apelação Cível n. ${ }^{7}$ 7000952008-1. Nona Câmara Cível. TJ/RS. Rel. Des. Fabianne Breton Baisch. Julg, em 28 de dez. 2005; (ii) Agravo de Instrumento n. ${ }^{\text {7 }}$ 70009653205. Nona Câmara Cível. TJ/RS. Rel. Des. Adão Sérgio do Nascimento Cassiano. Julg em 03 de nov. 2004; (iii) Apelação Cível n. ${ }^{\circ}$ 7095057-3. Vigésima Terceira Câmara de Direito Privado do TJ/SP. Rel. Des. J.B. Franco de Godoi. Julg.

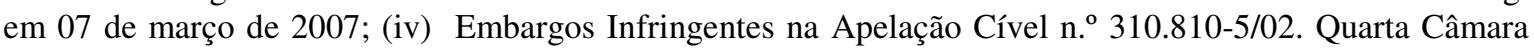
Cível. Tribunal de Alçada de Minas Gerais. Rel. Des. Maria Elza. Julg. em 06 de mar. 2002; (v) Recurso Especial n. ${ }^{\circ}$ 139.400/MG. $4^{\text {a }}$ Turma. Superior Tribunal de Justiça. Rel. Min. César Asfor Rocha. Julg. em 03 de ago. de 2008 .

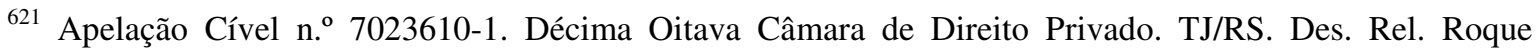
Mesquita. Julg. em 08 de abril de 2008. 
$\mathrm{Na}$ época atual, destaca o autor: “se vá más allá del principio de territorialidad", "se va más allá del principio de especialidad", "se vincula más estrechamente el contenido del derecho de marcas, com nociones como la de competência desleal y protección al consumidor". ${ }^{22}$ (grifou-se)

\section{VI.1 FORMAS DE O LICENCIANTE EXERCER O CONTROLE DE QUALIDADE SOBRE O USO DA MARCA LICENCIADA}

Ante o acima exposto, e partindo-se do pressuposto de que o licenciador tem o poder/dever de proceder ao controle de qualidade, passemos à análise da necessidade e das formas de controle do uso do sinal licenciado, das quais deve se valer o titular da marca, ao longo do prazo em que perdurar a relação jurídica do licenciamento.

Com efeito, passemos à análise deste tópico, à luz dos ordenamentos jurídicos alienígenas, sobretudo em razão de não haver tipificação legal ou qualquer outro tipo de regulamentação concernente a este mecanismo no ordenamento jurídico nacional. Esta ausência de regulamentação resulta na possbilidade do operador do direito interno poder livremente confeccionar dispositivos contratuais (atípicos) neste sentido, abalizando-se em experiências e conceitos extraídos de outros sistemas jurídicos. Por tal razão, é de grande importância o estudo das formas de controle do uso do sinal licenciado, sob a lente dos sistemas jurídicos internacionais.

$\mathrm{O}$ sistema jurídico norte-americano ${ }^{623}$ sinaliza para o controle de qualidade que o licenciador deve exercer sobre os produtos e serviços oferecidos ao mercado pelo licenciado, no que pertine à utilização do sinal disponibilizado ${ }^{624}$.

\footnotetext{
${ }^{622}$ SILVEIRA, Newton. Sinais distintivos da empresa...op. cit. p. 5.

${ }^{623} \mathrm{O}$ contrato de licença de uso de marca, à guisa do ordenamento jurídico norte-americano, não é regulamentado por legislação específica. É fruto dos usos, costumes, princípios gerais, práticas comerciais e contratuais, bem como por singelos subsídios fornecidos pelo Lanhman Act, legislação que versa sobre a proteção marcária federal naquele país.
}

${ }^{624}$ CRETELLA NETO, José. Contrato Internacional de Franchising. Rio de Janeiro: Ed. Forense. 2000. pp. $80 / 81$. 
Preliminarmente, cumpre mencionar que o aludido controle deve se iniciar antes mesmo de as partes firmarem o contrato de licença. Sobre o licenciamento a título exclusivo, Susan Progoff ${ }^{625}$ assinala a importância de o titular efetuar diligências investigativas (due diligencies), na fase antecedente à celebração do negócio jurídico, visando a alargar seu conhecimento acerca da reputação e capacidade do licenciado. Procedendo a tais diligências, o titular poderá se assegurar se o potencial licenciado, ao menos em tese, tem estrutura física, admnistrativa, competência e habilidade para se utilizar adequadamente da marca licenciada, de sorte a não gerar efeitos deletérios à imagem do bem intangível disponibilizado.

Nos Estados Unidos, na ausência de controle de qualidade, modalidade de licença intitulada naked licence, em que se compreende a ação ou omissão do titular em relação à fiscalização do uso do sinal licenciado, a marca, potencialmente, poderá ser declarada "abandonada" pelas autoridades de registro ${ }^{626}$.

Neste sentido, através da leitura do Lanham Act ${ }^{627}$, em consonância com o instrumento investigado no presente estudo, pode-se depreender que o titular (licenciador) perderá seu direito sobre a marca registrada nos seguintes eventos, dentre outros: (a) abandono da marca; (b) se a marca utilizada pelo licenciado não representar fidedignamente os produtos ou serviços para os quais fora registrada a marca originariamente licenciada pelo titular; e (c) se o uso do nome, termo ou dispositivo considerado como uma infração, é um uso, ao contrário do que uma marca, de parte do nome de um indivíduo em seu próprio negócio ou de um termo ou dispositivo que é descritivo e usado legalmente, e de boa-fé, tão somente para descrever bens ou serviços de uma das partes, ou sua indicação geográfica.

\footnotetext{
625 Imperioso colacionar, in verbis, recomendação de conduta de Progoff no que diz respeito às due diligences realizadas na fase pré-contratual ao licenciamento: "Licensor should confirm that licensee has the expertise and resources to market the licensed products in the territories covred by the license. As part of licensor's due diligence, licensor should inquire into licensee's marketing, sales and distribution capabilities throughtout the territory." (Cf. PROGOFF, Susan. Understanding the Intellectual Property License. op. cit. p. 17/18).

${ }^{626}$ Assim se decidiu nos casos seguintes: Barcanerica Int.'l USA Trust v. Tyfield Imps, Inc. 289 F. $3 d 589$ (9th Circ. 2002); Stanfield v. Osborne Indus., Inc., 52 F. $3 d 867$ (10th Circ. 1995); Heaton Enters of Nev., Inc. v. Lang, 7 USPQ2d 1842 (TTAB 1988).

${ }^{627}$ Lanhman Act. 15 USC 1115. Registration on principal register as evidence of exclusive right to use mark; defenses. Disponível em: <http://www.uspto.gov/web/offices/tac/tmlaw2.pdf>. Acesso em 28 jan. 2010.
} 
Por conseguinte, de modo a evitar que o licenciador perca sua titularidade, o contrato sub examine encontra-se afeito à exteriorização de cláusulas versando sobre:

(i)

uso da marca: o licenciador deve especificar o modo do qual a marca será aproveitada em relação aos produtos ou serviços oferecidos, bem como a forma pela qual serão disseminados materiais de publicidade. Adicionalmente, o licenciado deverá requerer a autorização expressa do licenciador, no evento de pretender conferir nova apresentação ao bem imaterial licenciado;

(ii) monitoramento do controle de qualidade: o licenciador poderá prever em contrato o acesso ilimitado às instalações do licenciado, às matérias primas utilizadas para a fabricação dos produtos, aos produtos finais oferecidos, aos trabalhadores, dentre outros acessos para mensurar se o licenciado atende aos padrões de qualidade dos produtos ou serviços oferecidos pelo licenciador. O titular não deve, contudo, efetuar controle exarcerbado, sob pena de o contrato de licença se transformar, ainda que tacitamente, em um contrato de franquia, cujo regime jurídico aplicável é, por certo, diferenciado, submetendo-se o à legislação federal mais severa (Federal Trade Commission Franchise Rule, 16 CFR. Par. 436, et. Seq. 2003). São considerados controles exacerbados ou significant control, conforme aponta, a título exemplificativo, Sosan Progoff ${ }^{628}$ : fornecer treinamento aos empregados do licenciado, exigindo-se que um manual operacional seja devidamente cumprido; exigir que o licenciado adquira matéria-prima de um único forncedor central; exigir que o licenciado anuncie seus produtos de uma ou outra forma; atuar em mercados pré-estipulados etc.

${ }^{628}$ PROGOFF, Susan. Understanding the Intellectual Property License. Nova Iorque (EUA): Practising Law Institute, 2004. pp. 24-26. 
Neste aspecto, é forçoso trazer à baila contribuição à matéria prestada por John JENNINGS $^{629}$, jurista e diretor do setor de pequenas e médias empresas da Organização Mundial da Propriedade Intelectual. Ao investigar o licenciamento de marcas universitárias, sob o manto do regime legal norte americano, Jennings adverte que o controle de qualidade sobre as marcas licenciadas é praticado contumazmente, sendo, por tal motivo, explicitado nos contratos de licença.

Dentre os mecanismos de controle apontados por Jennings, merecem destaque medidas que incluem: (i) a submissão de amostras do produto ao licenciador, previamente à comercialização efetivada pelo licenciado. Andrew J. Sherman, indicando mecanismo de controle ainda mais ríspido e de alta protetividade ao consumidor, assinala que o licenciador deve execer seu poder de vigilância. Este poder deve ser exercido, não apenas em momento prévio à comercialização do produto licenciado, mas ao longo de todo o prazo de vigência do contrato, tendo o titular, a qualquer momento, o direito de requerer ao licenciado que este lhe envie amostras dos produtos representados pela marca licenciada, com a finalidade de se mensurar as características e qualidade deles ${ }^{630}$; (ii) permissão para que o licenciador fiscalize, habitualmente, as premissas do licenciado; e (iii) o direito de o licenciador aprovar qualquer ilustração que envolva a marca licenciada.

É muito comum, em território americano, que o licenciador requeira ao licenciado que a marca utilizada preceda os símbolos “®”,631 ou “TM"632. Estes símbolos têm o escopo

${ }^{629}$ JENNINGS, John. University Trademark Licensing: Creating Value Through a "Win-Win" Agreement. WIPO. Disponível em: <http://www.wipo.int/sme/en/documents/uni_trademark_licensing.html>. Acesso em: 30 jan. 2010.

${ }^{630}$ Cf. SHERMAN, Andrew J. Franchising \& Licensing: Two powerful ways to grow your business in any economy”. 3a ed. Nova Iorquer (EUA): Amacom. 2004, pp. 377/378.

${ }^{631}$ O símbolo “®” denota que marca foi registrada, ao passo que o símbolo "TM" significa que determinado sinal é uma marca que ainda não foi registrada no USPTO (escritório de registro). Vale lembrar que apenas o uso da marca, nos Estados Unidos, garante sua proteção no local em que a mesma é utilizada, não no país inteiro. Exemplificativamente, se a marca estiver em uso em Chicago pela companhia " $X$ ", mas a companhia "Y" de Nova Iorque decidir registrá-la, posteriormente, no USPTO, a marca passará a ser registrada e protegida em todo o país, com exceção daquele local em que fora usada anteriormente (Chicago). (Cf. JENNINGS, John. University Trademark Licensing: Creating Value Through a "Win-Win” Agreement.op. cit.).

632 Cite-se, neste sentido, trecho do dispositivo do Lahmam Act, 15 USC 1115, (b), (6), o qual explicita a validade da marca não registrada em determinada área, uma vez comprovada a utilização pelo seu usuário anteriormente à marca registrada em âmbito federal. Dispõe, in verbis: “(...) Provided, however, That this defense or defect shall apply only for the area in which the mark was used prior to such registration or such publication of the registrant's mark; 
de informar a terceiros que determinado sinal é uma marca (registrada ou apenas em uso), alertando, preventivamente, potenciais infratores ou contrafatores.

Objetivando o alargamento da proteção dos licenciadores e, em certa medida, dos consumidores, Gregory Battersby e Charles Grimes ${ }^{633}$ coligam à cláusula de controle de qualidade do uso de marca licenciada três comandos de considerável eficiência.

O primeiro remete à prerrogativa por parte do licenciador de realizar auditorias periódicas nos livros e documentos contábeis do licenciado. Este mandamento tem a finalidade de evitar que o licenciado deixe de repassar ao licenciador os verdadeiros royalties devidos, sobretudo se esta remuneração for abalizada em percentagem incidente sobre a receita auferida pela venda dos produtos comercializados pelo licenciado.

Ademais, em sendo averiguadas discrepâncias entre valores auditados e os valores efetivamente recebidos, é permitido ao licenciado o recebimento dos juros incidentes sobre esta diferença, bem como multa, se as partes assim houverem consentido. Por fim, as partes podem delimitar que, no evento de ser verificada notável discrepância de valores, o custo de auditoria inicialmente expendido pelo licenciador seja transferido ao licenciado.

O segundo deles concerne à indicação de um prazo contratual relativamente curto. Por esta cláusula, o licenciamento abrangerá período de duração menos extenso do que o usualmente praticado, podendo ser sucessivamente renovado de acordo com a conveniência e vontade dos contratantes. O escopo desta disposição é permitir que o licenciador possa, em tempo hábil de revalorizá-lo, retomar seu bem intangível, cujo valor fora depreciado pela má utilização realizada pelo licenciado. De outra sorte, o prazo fixado deve ser minimamente razoável para que o licenciado recupere o investimento realizado (equipamentos, produção industrial, custos de propaganda, pagamento de royalties mínimos etc.) ${ }^{634}$, naturalmente se ele estiver envidando todos os esforços possíveis para a utilização devida e esperada da marca a qual teve acesso, sob pena de, não o fazendo, o titular ter o direito de resolver o contrato antes do término de seu prazo.

\footnotetext{
${ }^{633}$ Battersby, Gregory J. e Grimes, Charles W.. License Agreements: Forms and Checklists. Nova Iorque (EUA): Aspen Publishers, 2004. 5.02 (B), 5-7/5-11.

${ }^{634}$ Cf. PROGOFF, Susan. Understanding the Intellectual Property License. op. cit. p. 20.
} 
O terceiro comando, de caráter eminentemente protetivo ao licenciador, pertine à pré-fixação de metas. Por esta disposição, o licenciado obriga-se a vender determinada quantia de produtos com a marca licenciada, em um dado período, sob pena, de não o fazendo (underperfoming), poder o licenciador encerrar o contrato, sem o dever de indenizar o licenciado, ou seja, ter o direito de, fundamentadamente, extinguir o contrato por inexecução contratual ${ }^{635}$.

Objetivando bem agasalhar os interesses do titular, é recorrente na doutrina estadunidense comandos expressos que vedam ao licenciado a tentativa de proceder ao registro do bem recebido ou de suas variações, no território de abrangência ou mesmo em território extrínseco àquele previsto no instrumento contratual, durante ou após o termo final do contrato, sem a prévia e necessária permissão do licenciador ${ }^{636}$.

Atinente às formas sob as quais o licenciador exercerá o citado controle, o sistema jurídico australiano inclina-se para as seguintes modalidades:

(i) fiscalização e auditagem dos processos de produção;

(ii) possibilidade de o próprio licenciante produzir os produtos para a distribuição do licenciado; e

(iii) livre acesso às instalações do licenciado.

Adicionalmente às formas acima elencadas, é oportuno trazer à baila modalidades outras de controle e recomendações que podem ser eleitas em contrato, conforme assevera D. Carter. São elas ${ }^{637}$ :

635 “ (...) To address this concern, the licensor should preserve the right to terminate the agreement of the licensee has failed to meet certain milestones, such as, inter alia, the sale of a fixed number of licensed products during a given period." (Battersby, Gregory J. e Grimes, Charles W. License Agreements: Forms and Checklists. op. cit. 5.02 (B), 5-7.)

${ }^{636}$ KAUFMAN, Roy S., Art Law Handbook. Nova Iorque: Aspen Publishers, 2000. p. 78.

637 CARTER, D. Trademark Licences or Goodbye Goodwill. Open Forum Papers. 21-24 october 1998. Paper: FLO/2.5. < http://www.ficpi.org/library/florence98/goodwill.html> Acesso em 20 de dez. de 2009. 
(a) padronização dos materiais de fabricação: as qualidades das matérias primas e métodos de produção podem ser previamente indicados pelo licenciador em contrato. Cumpre anotar, conforme ensinamento de D. Carter, que o licenciador pode manifestamente compelir o licenciado a adquirir matéria prima de sua produção ou de outrem por ele indicado. Esta imposição será admissível, conforme adiante demonstrado, e não irá à contra-mão das leis anticoncorrenciais, apenas no caso da inexistência de outro fornecedor que possua matéria prima com a qualidade e especificações determinadas pelo licenciador ou assemelhadas aos produtos por este originariamente fabricados;

(b) acesso a amostras preliminares: recomenda-se, prioritariamente, que o licenciador tenha acesso ao produto produzido pelo licenciado, antes que ele seja oficialmente oferecido à comercialização;

(c) exigência de amostras periódicas: D. Carter preconiza, por igual, que seja estabelecido em contrato que o licenciador receba, periodicamente, amostras dos produtos comercializados pelo licenciado. Este procedimento tem o condão de permitir que o titular da marca proceda à ánalise do produto, para sopesar se aquilo que está sendo oferecido ao público consumidor remanesce com a mesma qualidade e excelência, em comparação com o produto oferecido em momento pretérito ao licenciamento;

(d) análise prévia de rótulos: todos os rótulos, embalagens e outras formas físicas de exteriorização do sinal devem ser aprovados pelo licenciador previamente à utilização, no mercado, pelo licenciado;

(e) divulgação de materiais promocionais: eventuais materiais promocionais a serem disseminados pelo licenciado devem ser antecipadamente examinados e aprovados pelo licenciador.

(f) registros: o licenciado deve manter os registros de todos os produtos fabricados e/ou comercializados e deve permitir que o licenciador a eles tenha acesso contínuo. Por certo, quando royalties estiverem sendo pagos, o que pode não ocorrer quando a licença é concedida a título gratuito, a previsão de manutenção do registro é de importância determinante. 
Cumpre anotar, outrossim, que o licenciador deverá exercer seu poder de fiscalização de fato, sendo que, poderá, naturalmente dependendo do caso concreto, exercitar esta prerrogativa além das fronteiras contratualmente delineadas ${ }^{638}$.

Ante a análise exposta, é razoável concluir que o licenciante não apenas poderá, como deverá proceder à realização de testes nos produtos ou serviços licenciados, independentemente de fiscalização pelo licenciado. Adicionalmente, impõe-se registrar que o controle de qualidade deverá se operar, igualmente, sobre as peças ou insumos que integram o produto final, bem como sobre o maquinário ou equipamento utilizado para a fabricação daquele produto. Esclareça-se, por fim, que os testes poderão ser realizados em períodos consentidos pelo licenciante e licenciado, de tal sorte que se possa aferir o grau da qualidade esperado pelo titular da marca.

${ }^{638}$ DAVISON, Mark J.; MONOTTI, Ann L. e WISEMAN..... op. cit.. 173. 


\section{- VII -}

\section{DEbates EM TORNO Do LICENCIAMENTO do USO DE MARCA E DA IMPORTAÇão Paralela No Direito Pátrio}

Do exposto no capítulo V.7, pode-se extrair que a legitimidade ad causam exercida pelo licenciado tem sido recepcionada por doutrina e jurisprudência, precipuamente com o fito de se combater frontalmente a importação paralela $^{639}$ praticada por terceiros. Perpetram-se acalorados debates em torno do licenciamento do uso de marca e da importação paralela no Direito Pátrio.

Para alguns doutrinadores, o licenciado, representado por empresa nacional, que licenciou determinada marca de sociedade estrangeira, deve dispor de mecanismos jurídicos eficazes que inibam a importação paralela. Sobre este tipo de importação ilegal, faz-se oportuno assinalar, à luz da legislação da propriedade industrial, que o licenciado deve se contrapor àquele que importa produtos paralelamente, em flagrante violação à concorrência leal, principalmente na hipótese de a licença ter sido concedida a título exclusivo.

Com efeito, o importador que, às margens da lei, rompe as barreiras da exclusividade consentida por licenciante e licenciado, deve ser obstado a internalizar produto cuja distribuição não lhe compete. Ademais, se mantida flagrante ilegalidade, o importador se enriquecerá injustamente, de forma parasitária e em flagrante lesão ao princípio da concorrência leal, aproveitando-se do investimento realizado pelo licenciado, o qual procedeu à construção física de sua rede de distribuição, bem como injetou vultosos

\footnotetext{
${ }^{639}$ A Organização Mundial da Propriedade Intelectual (OMPI) conceitua a importação paralela como sendo a importação de produtos fora dos canais de distribuição contratualmente definidos pelo produtor, titular da marca. (Disponível em <http://www.wipo.int/sme/en/ip_business/export/international_exhaustion.htm>. Acesso em 20 fev. 2010).
} 
investimentos em materiais e canais promocionais para o sucesso de seu negócio. Neste tocante, merece destaque ensinamento difundido por Luiz Henrique do Amaral:

\begin{abstract}
O argumento de que a importação paralela é economicamente salutar, pois estimula a competição e beneficia o consumidor final com preços inferiores é, normalmente, falacioso. Essa atividade paralela nasce de uma vantagem momentânea de preço no exterior, em virtude da qual um importador aproveita os investimentos alheios, trazendo produtos genuínos no país de origem, mas sem consentimento para comercialização no Brasil ou comprometimento com qualquer continuidade de negócio. O consumidor final poderá ter um benefício de preços no curto prazo, mas a sociedade como um todo perde. Essa atividade paralela desorganiza a produção, reduz os impostos, esvazia os investimentos em promoção; e ainda não leva em conta as especificações e exigências do produto no Brasil. Uma maior permissividade com tal prática implica desincentivo à fixação da obra no Brasil, com a exportação de empregos e estímulo ao descaminho." ${ }^{460}$ (grifouse)
\end{abstract}

Tem-se reconhecido, com veemência, que esta conduta ilícita se configura como ato de concorrência desleal, tendo como ato ensejador o desvio de clientela, expressão inserta no comando do artigo 195, inciso III, da Lei 9279/96 $6^{641}$.

No que concerne ao princípio da exaustão no direito marcário, em seus distintos vieses, a Organização Mundial da Propriedade Intelecutal (OMPI) enumera três diferentes tipos de exaustão: (i) exaustão nacional, em que o titular da marca não pode se opor à circulação do produto marcado por ele colocado no mercado doméstico, ou neste mercado introduzido, do exterior, com seu consentimento. Neste caso, pode o titular ou licenciado se opor, inclusive judicialmente, à importação de bens originais comercializados no exterior com base no direito de importação. (ii) exaustão regional. Neste caso, a primeira venda do produto marcado, comercializado pelo titular ou com seu consentimento, esgota quaisquer direitos de propriedade intelectual, não apenas em nível nacional, mas dentro de uma região pré-determinada (ex. Mercosul; União Europeia), não podendo se falar em importação ilícita. (iii) exaustão internacional. Este é o caso mais amplo de exaustão. No

640 AMARAL, Luiz Henrique do. A Questão das Importações Paralelas: Reflexos nos Direitos Autorais. XVIII Seminário Nacional da Propriedade Intelectual - A Nova Lei de Direitos Autorais e a Extensão da Proteção da Propriedade Intelectual. Anais. 1998. São Paulo. ABPI - Associação Brasileira de Propriedade Intelectual. 1998. p. 56.

${ }^{641}$ OIKAWA, Alysson Hautsch. A importação paralela e a licença de marca. in Jornal Valor Econômico, publicado em 19/01/2007, Legislação \& Tributos, p. E2. 
ordenamento jurídico que recorre a este tipo de exaustão, os direitos de propriedade intelectual se findam a partir do instante em que o produto marcado é comercializado pelo titular da marca, ou com seu consentimento, em qualquer parte do mundo. ${ }^{642}$

No Brasil, permite-se, majoritariamente, a exaustão (leia-se "esgotamento") interna ou nacional do direito de marcas, sendo inaplicável, aqui, o princípio da exaustão internacional, a despeito da presença de raríssimas exceções. Aliando-se ao fato de estar consignada na Lei marcária, esta tese encontra-se, por igual, agasalhada por largo filão da doutrina e jurisprudência pátrias, em que pese a presença de doutrinadores que se posicionam em defesa da importação paralela, pois que tal atividade está em perfeita consonância com os princípios da livre iniciativa, valorização do trabalho humano e livre concorrência, diretrizes estas insertas no comando do artigo 170 de nossa Carta Magna.

Neste aspecto, urge externar, mormente pela riqueza de argumentos trazidos a lume, valioso embate doutrinário entabulado entre duas autoridades de irretocável saber jurídico, sobretudo no âmbito do Direito Comercial hodierno.

Em favor do óbice à importação paralela e do acolhimento, pelo ordenamento jurídico nacional, tão somente da exaustão interna, com negação à recepção da exaustão internacional, convém citar os ensinamentos da professora Maristela Basso. Com efeito, a aludida jurista proporciona precioso estudo ${ }^{643}$, sinalizando para as máculas da indigitada importação, pois que esta se opera em flagrante violação aos princípios e diretrizes que permeiam o direito da propriedade industrial, não havendo que se falar em colisão com o artigo 170 da Carta Suprema, especialmente no que toca à livre iniciativa, valorização do trabalho humano e livre concorrência.

Em sentido diametralmente oposto, a internacionalista e catedrática Paula A. Forgioni oferece rico ensaio ${ }^{644}$ em favor da importação paralela e, por via, de conseqüência

${ }^{642}$ Disponível em <http://www.wipo.int/sme/en/ip_business/export/international_exhaustion.htm>. Acesso em 20 fev. 2010.

${ }^{643}$ BASSO, Maristela. A Importação Paralela e o Princípio da Exaustão. Especial Referência às Marcas. in GRAU-KUNTZ, Karin; BARBOSA, Denis Borges (org.) Ensaios sobre o Direito Imaterial - Estudos Dedicados a Newton Silveira. Rio de Janeiro: Ed. Lúmen Juris. 2009. pp. 169-207.

${ }^{644}$ FORGIONI. Paula A. Importações Paralelas no Brasil: a Propriedade Industrial nos Quadrantes dos Princípios Constitucionais. in GRAU-KUNTZ, Karin; BARBOSA, Denis Borges (org.) Ensaios sobre o 
da exaustão nacional e internacional de direito de marcas. Destrincemos, doravante, os argumentos erigidos por cada jurista.

No âmbito constitucional, calcada nos princípios da razoabilidade e da interpretação consistente ${ }^{645}$, Maristela Basso sustenta que não há que se falar em colidência entre o direito magno de propriedade privada e os princípios da livre iniciativa e livre concorrência, porquanto ambos se complementam e se harmonizam, na medida em que se busca o equilíbrio.

Paula Forgioni, de outro lado, argumenta, com supedâneo no artigo 170 da Constituição Federal, que os princípios da livre iniciativa e da livre concorrência devem ser observados, devendo as atividades empresarial e econômica ser restringidas apenas por força de expressa disposição legal, previsão esta que inexiste no ordenamento nacional no que diz respeito às importações paralelas.

Já na arena infraconstitucional, consoante leciona a internacionalista Maristela Bassso, a prática da importação paralela encontra-se, consistemente, vedada por lei. Primeiro porque, de forma análoga aos preceitos legais que disciplinam o direito de patente (art. 6 e seguintes da LPI), ao titular do direito de marca é, por igual, dada a prerrogativa de afastar terceiros da prática de atos que lesem o direito de propriedade, incluindo-se neste rol o direito de excluir terceiros de colocar à venda, vender ou importar ${ }^{646}$ produtos marcados, sem a autorização do titular ou licenciado (concepção negativa). Segundo, porque o artigo 129 da LPI confere ao titular do direito de marca o domínio amplo de usar o bem imaterial de forma exclusiva (concepção positiva). Acresça-se, ainda, que o artigo 130 da LPI, no inciso III, reza que "ao titular da marca ou ao depositante é ainda

Direito Imaterial - Estudos Dedicados a Newton Silveira. Rio de Janeiro: Ed. Lúmen Juris. 2009. pp. 209229.

${ }^{645}$ Conforme Frederick Abbot, o princípio da interpretação consistente significa que a norma de direito interna deve ser interpretada e aplicada de acordo com as obrigações internacionais pertinentes, no evento de existirem indecisões sobre a interpretação que deva ser dada às normas locais. (BASSO, Maristela. A Importação Paralela e o Princípio da Exaustão...op. cit. p. 184.)

${ }^{646}$ Basso argumenta que o conteúdo e a extensão dos direitos de marca e patentes se confundem, com arrimo no mesmo princípio - o poder de impedir do titular de impedir que terceiros não autorizados pratiquem atos atentatórios ao direito de propriedade. Neste sentido, o art. 42, da LPI reza: a patente confere ao seu titular o direito de impedir terceiro, sem o seu consentimento, de produzir, usar, colocar à venda, vender ou importar com estes propósitos. 
assegurado o direito de zelar pela sua integridade material ou reputação". Por fim, a jurista argumenta que o artigo 132, inciso III, da LPI, converge para a proibição da importação de produtos, ainda que estes não sejam falsificados, se não houverem sido introduzidos no mercado nacional com o consentimento expresso do titular ou de seu licenciado exclusivo no Brasil. Em síntese, para a internacionalista, as condições consignadas no art. 132, inciso III, são objetivas, sendo que: “(i) o mercado em questão é o nacional - nível doméstico; (ii) o produto deve ter sido colocado em circulação (no mercado nacional) pelo titular da marca ou com seu consentimento; (iii) o consentimento deve ser claro e inequívoco" ${ }^{647}$.

Sobre a questão da possibilidade de o consentimento ser tácito ou expresso, Luiz Henrique do Amaral sinaliza ser de "boa cautela" que o titular da marca, licenciado ou distribuidor oficial, direcione ao importador paralelo notificação, cujo teor expresse a carência de autorização ou mesmo a recusa expressa do consentimento. Esta notificação prévia remetida ao importador paralelo tem o condão de demonstrar a oposição do titular ou licenciado à prática da importação paralela, de modo a não erigir dúvidas futuras acerca da negativa de consentimento externado pelo titular ${ }^{648}$.

Contrariu sensu, a professora Forgioni adverte não haver, no plano infraconstitucional, dispositivo que obstacularize a prática da importação paralela. Para a jurista, o teor do artigo 129 da Lei 9279/96 não comporta interpretação positiva quanto à exclusividade para a comercialização do bem marcado, depois de colocado no comércio pelo próprio titular da marca, licenciado ou distribuidor oficial. Este dispositivo apenas faz menção à utilização do sinal com o escopo de se diferenciar o produto do concorrente. Conseqüentemente, a comercialização do produto original é livre. Demais disso, depreende-se do comando insculpido no artigo 132, inciso I, que, a partir do instante em que o produto é inserido no fluxo do comércio, o titular da marca não mais pode se contrapor ao seu tráfico subseqüiente ${ }^{649}$.

${ }^{647}$ BASSO, Maristela. A Importação Paralela e o Princípio da Exaustão...op. cit. p. 186.

${ }^{648}$ AMARAL, Luiz Henrique do. "A Exaustão de Direitos e a Importação Paralela na Nova Lei de Propriedade Industrial: A Evolução Judicial". in VIEGAS, Juliana L. B; NUNES, Luiz Antonio Ricco e DANNEMANN, Gert E. (org.). XIX Seminário Nacional de Propriedade Intelectual - A Propriedade Intelectual no Século XXI. São Paulo: ABPI - Associação Brasileira de Propriedade Intelectual. 1999. p 121.

${ }^{649}$ Neste sentido, Paula Forgioni assinala que a aceitação do titular prevista no artigo 132 circunscreve-se apenas à assertiva de que o produto comercializado no território nacional não seja contrafeito. Acrescenta, também, que a Lei Marcária não autoriza o titular da marca obstar que o produto regularmente no mercado venha a ser comercializado por distribuidor autônomo, sendo este integrado ou não à rede oficial de 
Sob outra perspectiva, Maristela Basso anota ter a importação paralela efeitos deletérios sobre o consumidor ${ }^{650}$. Dentre as principais conseqüências nefastas ao público que adquire o produto introduzido no mercado nacional, sob o manto da importação paralela, a jurista elenca: (i) ausência de serviço de atendimento ao consumidor no pósvenda; (ii) variação da fórmula fundamental de região para região; (iii) ausência de recompensa ou garantia; (iv) instrução ou informação sobre o produto incompleta e em língua estrangeira, portanto incompreensível a maior parte dos compradores locais; (v) inobservância dos padrões de importação, como: estocagem, temperatura de manutenção do produto no porto, tempo de transporte etc. Acrescente-se a isso alguns exemplos, quais sejam: (a) brometo em pães, que é admitido em alguns países, é coibido em outros; (b) produtos alimentícios com marcas internacionais podem não ser aceitos em mercados alheios àquele de sua produção, em função da marcante diferença das normas de culinária do país receptor dos produtos, via paralelismo; (c) tocador de DVD adquirido nos Estados Unidos pode ser incompatível com os DVDs comercializados no Reino Unido ou na Austrália; (d) produtos importados paralelamente podem não atender certas normas ambientais do país receptor, haja vista que as leis ambientais do país produtor podem destoar daquelas do país importador; (e) produtos de tecnologia importados paralelamente podem não cumprir as normas previstas pelos órgãos competentes reguladores no Brasil, como Instituto Nacional de Metrologia, Normalização e Qualidade Industrial (INMETRO), Agência Nacional de Telecomunicações (ANATEL) etc ${ }^{651}$.

Sustenta Forgioni, em oposição, que a importação paralela é extremamente benéfica ao consumidor, pois traz consigo predicados virtuosos que implicam o aumento da concorrência local reduzindo, por corolário, os preços, muitas vezes elevados, praticados pelo produtor, licenciado ou distribuidor "oficial". Desta feita, a título

distribuição formatada pelo titular. (FORGIONI, Paula A. Contrato de Distribuição. 2a ed. São Paulo: Ed. Revista dos Tribunais. 2008. pp. 246-248)

\footnotetext{
${ }^{650}$ Neste diapasão, registre-se lição de Gabriel Leonardos, in litteris: “(...) Contra, [as importações paralelas], contudo, percebemos que os consumidores ficam desguarnecidos quanto à natureza, qualidade, garantia, assistência técnica, transporte e acondicionamento do produto e, além disso, inibem-se investimentos que gerem empregos e riquezas para o Brasil" (Cf. LEONARDOS, Gabriel. A Questão das Importações Paralelas: Reflexos nos Direitos Autorais. XVIII Seminário Nacional da Propriedade Intelectual - A Nova Lei de Direitos Autorais e a Extensão da Proteção da Propriedade Intelectual. in VIEGAS, Juliana L. B; NUNES, Luiz Antonio Ricco e DANNEMANN, Gert E. (org.). XIX Seminário Nacional de Propriedade Intelectual - A Propriedade Intelectual no Século XXI. São Paulo: ABPI - Associação Brasileira de Propriedade Intelectual. 1999. p. 126).

${ }^{651}$ Também conforme Luiz Henrique do Amaral. AMARAL, Luiz Henrique do. A Exaustão de Direitos e a
} 
exemplificativo, apresenta o seguinte cenário: empresa $X$ passa a atuar no mercado da empresa Y (ex. mercado brasileiro), adquirindo produtos da empresa produtora Z, esta com atuação em outro mercado (ex.: mercado americano), pelo preço de US\$ 90. A empresa Y, "licenciada oficial" da produtora Z, vende o produto no mercado brasileiro por US\$ 120. A empresa X, importadora paralela, passa a vender este mesmo produto por US\$ 110 . Conclusivamente, para a internacionalista em comento, é inegável que a importação paralela é proveitosa ao consumidor, porquanto força a redução de preços, alijando o monopólio e ceifando possíveis abusos cometidos pelo licenciado ou distribuidor tido como oficial pelo titular da marca.

No que pertine ao desenvolvimentismo, a professora Maristela advoga a tese de que a importação paralela representa verdadeira concorrência desleal, na modalidade "parasitária", e ceifa o desenvolvimento tecnológico nacional. Isto porque pressiona o licenciado a reduzir seus preços, para fazer concorrência aos preços perpetrados pelo importador paralelo, gerando, como corolário, a eliminação de investimentos em pesquisa e desenvolvimento (P\&D), em garantias e serviços ao consumidor, promoção, marketing, informação de distribuição e assitência técnica. Por conseguinte, o consumidor perde serviços e investimentos em melhoria, e o país perde em desenvolvimento tecnológico. No mais, conforme assinalado pela insigne professora, a importação paralela desestimula o licenciado a operar neste segmento, inibindo, por igual, os produtores, titulares de marca e licenciados, a promoverem políticas de redução de preços em áreas continentais carentes, como, por exemplo, na região africana.

Paula Forgioni, por seu turno, assevera que não há lesão ao desenvolvimentismo, no plano nacional, dado que o lucro auferido pelo licenciado ou distribuidor, na grande maioria das vezes, não é revertido para a pesquisa e desenvolvimento. É direcionado apenas para o aumento patrimonial do próprio licenciado em razão dos preços "monopolísticos" leoninamente praticados perante o público consumidor. Neste aspecto, a concorrência praticada pelo importador paralelo é leal, haja vista que encontra guarida nos princípios da livre iniciativa e livre concorrência, insculpidos no artigo 170 da Constituição Suprema, não podendo ser dada como certa a adoção da doutrina privatista da 
propriedade industrial como "poder natural e absoluto" sobre a qual não se refletem as imposições oriundas de sua função social ${ }^{652}$.

Karin Grau-Kuntz abaliza que, tradicionalmente, a jurisprudência nacional majoritária, com arrimo no princípio do direito exclusivo do uso da marca, presente no artigo 129 da Lei 9279/96, posiciona-se refratária à adoção da teoria da importação paralela de produtos marcados ${ }^{653}$. Desta sorte, o ordenamento nacional não acolhe a teoria da exaustão dos direitos de marcas em nível internacional. Conforme preleciona o autor em comento, o uso da marca, obtido por meio de contrato de licenciamento, permite ao licenciado insurgir-se contra aquele que, paralelamente, importa produtos com a mesma marca, sem o consentimento do titular do sinal. Impõe-se apontar, de tal modo, os valiosos ensinamentos de Karin Kuntz e Newton Silveira, ao examinar a matéria, verbis:

Diferentemente da Lei 5.772/71, esta lei [Lei 9.279/96] dispõe que o titular da marca não poderá impedir a livre utilização do produto colocado no mercado "interno" pelo titular ou com o seu consentimento, ressalvado o disposto nos $\S$ $3^{\circ}$ e $4^{\circ}$ do art. 68 (art. 132, III). A regra é expressamente a da exaustão interna para o direito de marcas. Há porém duas exceções a esta regra, nas quais se permitirá a importação paralela por qualquer terceiro, a saber:

- quando o titular de uma patente pratica a importação do objeto da patente;

- quando o licenciado importa, desde que o produto tenha sido colocado no mercado (internacional) diretamente pelo titular da patente ou com o seu consentimento.

Em ambos os casos, a titularidade da marca e o direito de uso exclusivo não poderão ser alegados para impedir a entrada dos produtos paralelamente importados. ${ }^{654}$ (grifou-se)

\footnotetext{
${ }^{652}$ Marcelo Dias Varella acompanha este entendimento ao asseverar que "o titular dos direitos de propriedade intelectual foi remunerado (no mercado estrangeiro) por sua contribuição intelectual. É claro que seus níveis de lucro podem ser mais baixos do que os que ele obteria se pudesse fragmentar os mercados e cobrar um preço mais alto do país importador, mas isso não significa que ele não consiga recuperar seus gastos com pesquisa e desenvolvimento" (VARELLA, Marcelo Dias (org. e co-autor). Propriedade Intelectual e Desenvolvimento. São Paulo: Lex editora, 2005. p. 64)

${ }^{653}$ GRAU-KUNTZ, Karin e SILVEIRA, Newton. A Exaustão do Direito de Marca na União Europeia e o Mercosul. in Revista de Direito Mercantil, Industrial, Econômico e Financeiro. São Paulo: Ed. Malheiros. Ano XXXVI (nova série), n. 106. abril-junho. 1997. 107-127.
}

${ }^{654}$ GRAU-KUNTZ, Karin e SILVEIRA, Newton. op. cit. p. 125. 
Na mesma linha de inteligência, Cláudia Marins Adiers mostra-se partidária deste raciocínio. A autora leciona que a Lei de Marcas e Patentes vigente implantou, no ordenamento jurídico pátrio, comandos que outorgaram ao titular da marca o benefício de obstar a venda de produtos importados para o mercado interno, por terceiros ilegítimos, sem o seu prévio consentimento, mesmo que os produtos marcados sejam "originais", i.e., provenientes da mesma fonte que aqueles produtos oferecidos pelo titular ou por licenciado legitimamente credenciado pelo titular do registro.

A articulista assinala, bem assim, que os artigos 129, 130 e 131 da Lei 9.279/96 conferem aos titulares das marcas o uso exclusivo destes sinais em todo o território nacional, concedendo-lhes o direito de se voltarem contra as violações do direito de propriedade e de exclusividade incorridas por terceiros, assinalando que, no Brasil, prevalece o princípio da exaustão interna para o direito de marca ${ }^{655}$.

Luiz Henrique do Amaral combate frontalmente a importação paralela no Brasil. Anota que, se o próprio titular da marca, que subscreve contrato de licença, com exclusividade e sem reserva, está obstado a atuar no território de atuação do licenciado, é decorrência natural que os importadores também estejam excluídos deste tipo de operação.

Sobre o desenvolvimentismo, o jurista em comento sustenta que o licenciado oficial acaba por ter imensuráveis prejuízos, na eventualidade de ter de concorrer com importadores paralelos que nenhum aporte de capital extra tenham realizado para a satisfação do consumidor no período do pós-venda. Enraiza sua argumentação em precioso litígio em que a Reebok do Brasil ingressou com ação judicial contra a Reebok International acusando esta, inter alia, de não tomar as medidas cabíveis contra os importadores paralelos no Brasil. Em que pese ter sido alcançado acordo nesta demanda, este argumento foi acolhido pelo Tribunal de Justiça do Estado do Rio de Janeiro, sob a razão de que a Reebok International, titular da marca, ao se furtar ao ingresso de medidas contra os importadores paralelos, deu azo à origem de vultosos prejuízos à $R B K$ do Brasil, a qual injetou maciços investimentos e fez dispendiosos planejamentos, que acabaram se tornando insignificantes. Por fim, esta decisão determinou que a licenciante era

\footnotetext{
${ }^{655}$ ADIERS, Cláudia Marins. As Importações Paralelas à Luz do Princípio da Exaustão do Direito de Marca e seus Reflexos nos Direito Contratual e Concorrencial. in Revista da AJURIS. Porto Alegre: Ano XXIX, n. 88. Dez 2002.
} 
responsável pela carência de cautela na fiscalização dos importadores paralelos e, por via de conseqüência, pela totalidade dos lucros conjeturados no "plano de negócios", cujo valor poderia alcançar a substanciosa cifra de US\$ 20 milhões ${ }^{656}$.

A temática em torno da importação paralela é, decerto, controvertida. Em que pese a presença de decisões esparsas minoritárias ${ }^{657}$, a jurisprudência pátria hodierna, na mesma senda da doutrina nacional, apresenta-se, predominantemente, pacífica a respeito do tema, ao abrigar a tese da exaustão interna ou nacional, ao mesmo tempo em que rechaça a exaustão internacional no direito marcário brasileiro. Destarte, os tribunais estabelecidos nos principais centros econômicos brasileiros são contundentes ao sustentar que a importação paralela, via de regra, é vedada pelo ordenamento jurídico interno. Ademais, esta modalidade de importação só poderá ser agasalhada por nosso sistema ante as exceções insertas nos parágrafos $3^{\circ}$ e $4^{\circ}$ do artigo 68 da Lei 9279/96, ou se a importação ocorrer com a aquiescência do titular da marca. Em se verificando a prática da aludida operação em contrariedade às exceções acima referendadas, o uso não autorizado da marca deverá render indenização ao titular ou licenciado, com fulcro nos artigos 207, 208, 209 e 210 da Lei 9279/96.

Neste tocante, merecem destaque decisórios capitais emitidos pelos principais tribunais brasileiros, cujos fragmentos elucidativos dos julgados seguem adiante reproduzidos:

“(...) A importação paralela só se afigura legítima no caso de estar configurada qualquer das exceções previstas no $\$ 3^{\circ}$ e $4^{\circ}$ do artigo 68 da LPI ou se a importação se faz com o consentimento do titular da marca. $O$ uso inconsentido da marca é passível de indenização, na esfera civil, nos termos dos artigos 207, 208, 209 e 210 da lei especial, apurando-se o respectivo valor em liquidação de sentença. "658

\footnotetext{
656 AMARAL, Luiz Henrique do. A Exaustão de Direitos e a Importação Paralela na Nova Lei de Propriedade Industrial: A Evolução Judicial. in XIX Seminário Nacional da Propriedade Intelectual. Anais. 1999. São Paulo: ABPI - Associação Brasileira de Propriedade Intelectual. 1999. pp.118-121.

${ }^{657}$ Nesse sentido, ver: Apelação n. n. 75.002-1 TJSP. RJTJSP. 106/135 (vinho italiano “Bolla”); Apelação n. 90.538.4-3, $3^{\text {a }}$ Câmara de Direito Privado, TJSP, Des. Rel. Carlos Roberto Gonçalves. Julg. em 20 jan 2000 JTJ-Lex 229/136. jul (caso da vodka "Wiborowa”); e mais recentemente Apelação n. ${ }^{\circ}$ 419.571-4/0-00, 4 Câmara de Direito Privado. TJSP. Rel. Des. Enio Zuliani (caso charutos cubanos “Havana”).

658 Apelação Cível n. ${ }^{\circ}$ 2008.00106846, $1^{\text {a }}$ Câmara Cível, TJ/RJ, Des. Myriam Medeiros da Fonseca Costa. Julg. em 21 de out. 2008. Disponível em <www.tjrj.jus.br>. Acesso em 20 nov. 2010.
} 
“(...) Importação e Comercialização de charutos cubanos, realizadas sem o consentimento das requerentes. Ofensa a direitos protegidos pela Lei de Propriedade Industrial. Inteligência dos artigos 129 e 132, da Lei 9279/96. Prática ilícita configurada pela simples importação e comercialização desautorizada, independentemente da autenticidade dos produtos. Abstenção da comercialização mantida. Apelação Provida",659

“(...) Ferindo a importação realizada pela agravante direito protegido pela lei de propriedade industrial, correta a concessão de liminar para determinar a busca e apreensão dos produtos importados pelo importador paralelo sem o consentimento do titular da marca. Agravo não provido. ",660

"Propriedade Industrial - Marcas - Requerente que possui a averbação do acordo de licença de marcas junto ao INPI - Hipótese em que está protegida contra terceiros - Inteligência do art. 140 da Lei 9279/96 - Proibição de "importação paralela" no território nacional - Interpretação "a contrario sensu” do art. 132, III, da Lei $n{ }^{\circ}{ }^{\circ}$ 9279/96 - Abstenção da comercialização dos produtos pela requerida corretamente determinada - Caracterização de ato ilícito - Lucros cessantes devidos - Recurso Desprovido "661

“(...) A proteção à marca goza de garantia constitucional, à luz do contido no art. 5', XXXIX da CF/88. No caso concreto, trata-se de prática comercial de importação solicitada por empresa chilena, de calçados da marca "Dakota" produzidos por empresa sediada no território nacional, sem a devida autorização elou licenciamento da titular da marca registrada no INPI. Infração ao Direito Marcário. Concorrência desleal configurada ante a prática de intermediação da agravante na condição de representante comercial da empresa estrangeira. Aplicação dos art. 129, 130 e $131 \mathrm{c} / \mathrm{c} 132$, III e par. $3^{\circ}$ e $4^{o}$ do art. 68, art. 195, III, todos da Lei de Propriedade Industrial. Recurso Desprovido. "662

Em julgado proferido no ano de $2009^{663}$, a colenda Corte Superior inclinou-se ao aclaramento interpretativo do conceito de "consentimento" externado pelo inciso III, do artigo 132, da Lei de Propriedade Industrial. Ao contrário do que assinalado por alguns juristas $^{664}$, este decisório não teve por finalidade acolher o princípio da exaustão internacional e permitir a importação paralela sem o consentimento do titular da marca.

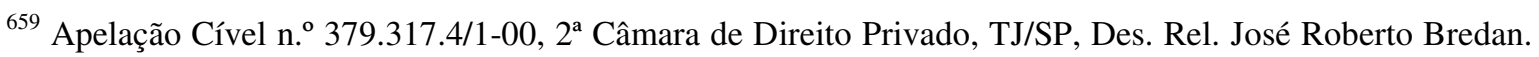
Julg. em 30 set. 2008. Disponível em <www.tj.sp.gov.br>. Acesso em 20 nov. 2010.

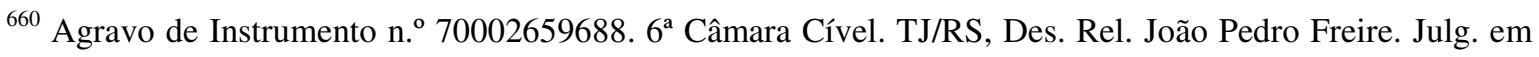
$1^{\circ}$ ago. 2001. Disponível em <www.tj.rs.gov.br>. Acesso em 20 nov. 2010.

${ }^{661}$ Apelação Cível n. ${ }^{o}$ 174.640.4/0 - Campinas, $1{ }^{\text {a }}$ Câmara de Direito Privado, TJ/SP, Rel. Des. Luiz Antonio de Godoy. Julg em 23 jan. 2007. Disponível em <www.tj.sp.gov.br>. Acesso em 20 nov. 2010.

${ }^{662}$ Agravo de Instrumento n. ${ }^{\circ}$ 70010368991, 13 ${ }^{\text {a }}$ Câmara Cível, TJ/RS. Des. Rel. Ângela Terezinha de Oliveira Brito. Julg. em 02 de jun. 2005. Disponível em <www.tj.rs.gov.br>. Acesso em 20 nov. 2010.

${ }^{663}$ Recurso Especial n. ${ }^{\circ} 609.047$ - SP, Quarta Turma. Superior Tribunal de Justiça. Rel. Min. Luis Felipe Salomão. Julg. em 20 out. 2009. Disponível em <www.stj.gov.br>. Acesso em 20 nov. 2010.

664 IGNÁCIO, Laura. STJ Diverge Sobre Importação Paralela. Valor Econômico OnLine. Edição de 20.11.09. Disponível em <http://www.valoronline.com.br>. Acesso em 20.02.10. 
Apenas teve por escopo instruir que a desautorização do detentor da marca precisa ser clara e cabalmente comprovada por aquele que litiga contra o suposto importador paralelo. O consentimento tácito por parte do titular ou licenciado autorizado é satisfatório para que a importação deixe de ser "paralela", contra legem, e passe a ser lícita.

O caso capital retro mencionado encontra-se corporificado em ação ajuizada por empresa produtora de um célebre produto multivitamínico (CENTRUM), sediada no exterior. No pólo ativo da ação, à titular da marca com sede no exterior ainda se uniram a empresa licenciada (titular da marca no Brasil) e a empresa que detinha a exclusividade de produção e comercialização dos produtos em território brasileiro. No pólo passivo da demanda encontrava-se a empresa importadora e exportadora nacional que adquiriu e comercializou este mesmo produto marcado (original), diretamente de terceira importadora brasileira, a qual não fora incluída no aludido litígio, porém estava autorizada pela titular da marca no exterior a distribuir o produto mundo afora.

Os autores da ação argumentaram que a ré estava importando e comercializando o multivitamínico no Brasil, sem a devida e expressa autorização do titular da marca ou de seu licenciado, concorrendo de forma desleal, na modalidade "parasitária", e ferindo, de forma latente, o direito de propriedade industrial dos autores da ação. Por fim, demandaram que a ré se abstivesse de comercializar o aludido produto ou semelhante, sob pena de multa.

Em decisão de primeiro grau, avalizada pelo Tribunal Estadual, o pedido foi julgado improcedente, sob o ensejo de que o direito das autoras não fora violado, pois que o produto foi colocado no mercado nacional, pela ré, de forma lícita, haja vista que esta adquiriu referido "multivitamínico" de importadora brasileira autorizada pela titular da marca. Portanto, a titular da marca no exterior, ao permitir, ou melhor, não desautorizar de forma expressa, que uma de suas importadoras oficiais distribuisse seus produtos à empresa ré, suposta importadora paralela, tacitamente admitiu a comercialização de seus produtos também por esta, ainda que ela não fosse parte integrante de sua "rede oficial de distribuição".

Examinada pelo Superior Tribunal de Justiça, esta decisão foi do mesmo modo ratificada. A corte superior, legitimando o entendimento das instâncias inferiores, coroou a 
tese, amplamente avalizada pela doutrina pátria, da ilicitude da importação paralela sem a ocorrência da autorização do titular da marca ${ }^{665}$. Não obstante, afirmou, in casu, que o consentimento do titular, ainda que tácito e por intermédio de um de seus importadores “oficiais", é mecanismo hábil para tornar a importação paralela lícita. Para tanto, alicerçouse no argumento, antes externado pela corte estadual, de que a recorrida (importadora não exclusiva e ré no processo principal) tinha autorização implícita da titular da marca, posto que houvera adquirido o produto de uma terceira empresa, distribuidora nacional autorizada pela empresa detentora da marca no exterior, e que não estava por esta desautorizada a distribuir o mesmo produto para outras distribuidoras além das fronteiras do país de fabricação do produto.

Firmou, por igual, o entendimento de que a importação paralela passa a ser lícita, na medida em que consentida pelo titular da marca, no exterior, por licenciado ou por quem estava autorizado para tanto, exatamente conforme ocorrido no caso em comento, quando terceira distribuidora, autorizada pela titular da marca a distribuir o produto sem limites fronteiriços, o fez à importadora "não oficial".

Por fim, o Ministro Relator do caso acima referendado, Dr. Luis Felipe Salomão, arremata, com preciosismo, que o ilícito verificado não decorre da importação paralela, podendo ser, talvez, caracterizado como infração de natureza meramente contratual, assinalando, in litteris:

Nesses casos, há, em tese, um ilícito contratual por parte do fabricante do produto, que, em violação ao contrato de distribuição seletiva firmado com o titular do direito à utilização da marca no Brasil, autoriza importação de produtos às outras distribuidoras que também atuam no país. Ou, ainda, por parte do distribuidor agregado no país de origem ou do titular da marca em uma terceira circunscrição geográfica, que, violando o contrato de distribuição seletiva firmado com o fabricante, vende os produtos a outros distribuidores que não atuam naquele território, e não apenas a consumidores finais, como geralmente é o caso em contrato de distribuição seletiva ou exclusiva. ${ }^{666}$ (grifou-se)

665 Conforme trecho sublinhado da ementa sob apreciação: "Propriedade Industrial. Direito de Marcas. Importação paralela de produtos originais sem o consentimento do titular da marca no Brasil. Concorrência Desleal. Inocorrência” (Recurso Especial n. ${ }^{\circ} 609.047$ - SP, Quarta Turma. Superior Tribunal de Justiça. Rel. Min. Luis Felipe Salomão. Julg. em 20 out. 2009).

666 SALOMÃO, Luis Felipe. Recurso Especial n. ${ }^{\circ} 609.047$ - SP, Quarta Turma. Superior Tribunal de Justiça. Rel. Min. Luis Felipe Salomão. Julg. em 20 out. 2009. Acórdão. p. 6/8. 
No caso em tela, não restou demonstrada pelas autoras, ao longo da instrução probatória, a indevida importação paralela realizada pela ré. Bastava às autoras levarem aos autos provas indicativas de que a distribuidora da qual a ré adquiriu o produto marcado estava desautorizada a efetuar esta venda específica. Exemplificativamente, as autoras poderiam demonstrar em juízo que o contrato de distribuição, subscrito entre a titular da marca no exterior e sua distribuidora nacional, não continha em seu bojo comando permissivo no sentido de que a aludida distribuidora "oficial" comercializasse o produto marcado: (a) fora do território contratualmente delimitado; ou (b) para outras empresas que não aquelas contratualmente eleitas pela titular da marca licenciante. No entanto, a despeito de ter esta oportunidade, as autoras não o fizeram, restando caracterizada, pois, a autorização, ainda que tácita, da importação paralela do "multivitamínico".

Ante o exposto, há robusto entendimento de que a importação paralela e a exaustão internacional continuam sendo inadmitidos pelo ordenamento interno, à exceção de quando haja o consentimento do titular, autorização esta que poderá expressa ou ainda tácita (decorrente do contexto das operações comerciais e jurídicas encetadas pelas sociedades empresárias envolvidas), conforme se pôde depreender do caso capital acima apreciado pelo Superior Tribunal de Justiça.

Ademais, há que ser ponderada a tese da negativa de consentimento como mecanismo de combate à importação paralela e à concorrência indesejada. Por esta tese, para maior proteção jurídica do titular da marca e seus distribuidores exclusivos sediados em territórios estrangeiros, faz-se proveitoso ao titular da marca no exterior delimitar, contratualmente, o campo de atuação de seus distribuidores locais e estrangeiros, impedindo que estes vendam o produto marcado para outros distribuidores ou importadores, sobretudo para aqueles com sede no exterior e, especialmente, em países em que já haja distribuidor ou representante exclusivo nomeado pelo titular da marca para a comercialização de seu produto. Este mecanismo apresenta-se eficaz a inibir a chamada concorrência parasitária e evitar, desta sorte, a colidência entre distribuidores múltiplos de diferentes origens, bem como se mostra hábil o suficiente a impedir o nascimento de dispendiosas e vagarosas batalhas judiciais respeitantes à importação paralela.

Em síntese, pois, é altamente proveitoso ao operador do direito prever, expressamente, em contrato firmado pelo titular da marca e seus distribuidores ou 
licenciados: (i) que o licenciado, distribuidor ou importador está desautorizado a vender os produtos marcados fora do território delimitado em contrato ou para empresas que tenham sede, atuem ou exerçam atividades comerciais em territórios alienígenas ao território contratualmente demarcado; ou, alternativamente, (ii) que o licenciado, distribuidor ou importador, somente poderá vender os produtos marcados dentro do território delimitado em contrato e para aquelas empresas e mercado consumidor contratualmente demarcados, ficando o distribuidor impedido de proceder à venda do referido produto para empresas ou mercado consumidor que tenham sede, atuem, ou exerçam atividades empresariais, em territórios estranhos ao território contratualmente demarcado.

Por fim, faz-se oportuno assinalar, através de uma interpretação jurídica lógica decorrente de uma sucessão de contratos de venda, distribuição e importação, que ninguém pode transferir a terceiros mais direitos do que tem ou mais direitos do que aqueles incialmente recebidos. Com efeito, é razoável afirmar que, se um distribuidor ou licenciado não tem poderes para distribuir determinados produtos, que tenham sido contratualmente estabelecidos, fora de um território " $X$ ", é certo que outros distribuidores, subdistribuidores ou importadores, que venham a adquirir os produtos marcados dos primeiros distribuidores aqui citados, também não poderão distribuir ou revender estes mesmos produtos fora do mesmo território " $\mathrm{X}$ ",667.

\footnotetext{
${ }^{667}$ Neste mesmo sentido, cite-se Gabriel Leonardos, o qual aponta uma possível solução para a repartição de mercados e blindagem à importação paralela, verbis: "Então se você quiser repartir mercados e confiar nas leis que reprimem a importacao paralela, como existe no Brasil e na União Europeia, o produto fabricado na Ásia deveria vir com a indicação "Proibida a venda no Brasil". Aí me parece que nenhum importador paralelo poderia, legitimamente, alegar que tinha o consentimento, presumido ou tácito, para importar o produto para o Brasil ou aqui revendê-lo".(LEONARDOS, Gabriel. A Exaustão de Direitos... op. cit. pp. 122-126).
} 


\section{O Contrato De Franquia e a Licença de Uso de Marca}

Malgrado o contrato de franquia não seja objeto central da presente tese, faz-se proveitoso o exame desta espécie contratual, cuja licença de uso de marca se apresenta como um de seus baluartes ${ }^{668}$. Diante de tal assertiva, faz-se pertinente traçar considerações atinentes à matéria que ora se investiga. Demais disto, convém, quando oportuno, trazer à baila as semelhanças e diferenças entre o contrato de franquia e o contrato de licença de uso de marca.

Newton Silveira aponta que o fanchising, naturalmente antes da edição da lei que o disciplina no Brasil, se perfazia com a conjugação de dois contratos, elaborados separadamente: um contrato de licença de uso de marca, o qual era celebrado a título gratuito; e um contrato de prestação de serviços de assistência técnica ${ }^{669}$. No entanto, esta espécie contratual passou a ser disciplinada pela Lei Federal n. ${ }^{\circ} 8.955$, de 15 de dezembro de 1994.

O termo "franquia" origina-se da expressão inglesa franchise, oriunda do verbo francês franchir, cujo significado remete à libertação, concessão de imunidade. Na acepção jurídica do termo, entende-se franquia como a cessão de um direito por seu titular a outrem.

\footnotetext{
${ }^{668}$ Irineu Mariani aponta, textualmente, e de forma peremptória, que "sem registro no INPI e cessão ou licença, não há franchising” (MARIANI. Irineu. Contratos Empresariais: atualizados pelo Código Civil de 2002 e leis posteriores. Porto Alegre: Ed. Livraria do Advogado, 2007. p. 367).

${ }^{669}$ Cf. SILVEIRA, Newton. O Contrato de Franchising. in BITTAR, Carlos Alberto (coord.). Novos Contratos Empresariais. São Paulo: Ed. Revista dos Tribunais. 1990. pp. 157-165.
} 
Historicamente, o contrato de franquia ou franchising surgiu em 1860, nos Estados Unidos, quando a sociedade empresária Singer Sewing Machine, com o desiderato de expandir suas vendas sem, contudo, ter de recorrer a grandiosos investimentos, optou pela concessão de seu negócio, concomitantemente à continuidade da prática de sua atividade, a outros empresários, em diversos pontos do país. A fórmula foi um sucesso, o que açodou outros agentes empresariais a segui-la. Podemos citar, no rol daqueles que deste mecanismo se valeram, empresas como McDonald's, General Mottors, Coca-Cola, Hilton, Pizza Hut, Fiat etc. ${ }^{670}$

Portanto, esta modalidade de negócio jurídico tem por finalidade a disseminação de um negócio bem sucedido, onde, tanto as partes contratualmente acopladas, como terceiros, são diretamente favorecidos: o franqueador, porquanto terá a oportunidade de divulgar seu negócio em ambientes nunca antes desbravados, robustecendo, por tal meio, sua marca e, por corolário lógico, potencializando o valor agregado de seu produto ou serviço; o franqueado, pelo fato de ter acesso à modalidade de negócio pré-concebida, previamente avaliada e bem recepcionada pelo público consumidor, o que acaba por facilitar seu ingresso no mercado e a obtenção de receita mais elevada do que aquela que obteria se houvesse optado por iniciar negócio totalmente novo; por fim, terceiros, leia-se consumidor, pois que serão diretamente beneficiados, como bem aponta Newton Silveira, “da qualidade uniforme de um produto ligado a uma marca conhecida e a métodos já experimentados" $" 671$.

Oportuno colacionar importantes definições doutrinárias atribuídas ao contrato sob investigação.

Consoante ensinamento de Arnoldo Wald, a franquia "é contrato típico, bilateral, oneroso, pelo qual um franqueador cede a franqueado o direito de uso de marca e/ou

\footnotetext{
${ }^{670}$ Cf. VENOSA, Sílvio de Salvo.Direito Civil, Teoria Geral das Obrigações e Teoria Geral dos Contratos, $7^{\mathrm{a}}$ ed., São Paulo: Ed. Atlas. 2007. vol. 2. p. 523; MONTEIRO, Washington de Barros. Curso de Direito Civil: Direito das Obrigações: $2^{a}$ Parte - Dos Contratos em Geral, das Várias Espécies de Contrato, dos Atos Unilaterais, da Responsabilidade Civil. 35 a ed. ver. e atual. Carlos Alberto Dabus Maluf e Regina Beatriz Tavares da Silva. São Paulo: Ed. Saraiva, 2007. v. 5. p.449.

${ }^{671}$ SILVEIRA, Newton. O Contrato de Franchising. in BITTAR, Carlos Alberto (coord.). Novos Contratos Empresariais. op. cit. p. 161.
} 
patente, usualmente com o direito de distribuição exclusiva ou semi-exclusiva de produtos ou serviços (inclui-se o know-how), sem vínculos empregatícios" ${ }^{\text {672 }}$.

Nelson Abrão, por seu turno, delimita a franquia como "o contrato pelo qual o titular de uma marca de indústria, comércio ou serviço (franqueador) concede o seu uso a outro empresário (franqueado), posicionado ao nível da distribuição, prestando-lhe assistência no que concerne aos meios e métodos para viabilizar a exploração dessa concessão, mediante o pagamento de uma entrada e um percentual sobre o volume dos negócios realizados ao franqueado" ${ }^{, 673}$.

O mestre Antônio Chaves apresenta a seguinte definição ao franchising: “o contrato pelo qual uma pessoa assume o compromisso de efetuar a distribuição seletiva de bens de sua fabricação ou de terceiros, ou proporcionar método ou serviços caracterizados por marca registrada a outras que a ela se vinculam, sem dependência, por compromisso de licença, ligação contínua e eventual assistência técnica, para a venda limitada a determinada área geográfica" 674 .

O eminente comercialista Waldírio Bulgarelli, de forma concisa, estatui que a franquia "é a operação pela qual um comerciante, titular de uma marca comum, cede seu uso, num setor geográfico definido a outro comerciante. O beneficiário da operação assume integralmente o financiamento da sua atividade e remunera o seu co-contratante com uma porcentagem calculada sobre o volume dos negócios”.

Irineu Mariani indica que a franquia é "um negócio formatado ou, expressão também usada, um pacote formatado, isso porque o franqueado muito mais do que assinar um contrato, adere a um sistema, sendo que o núcleo está exatamente no formato ${ }^{675}$.

\footnotetext{
${ }^{672}$ WALD, Arnoldo. Direito Civil - Contratos em Espécie. $18^{\mathrm{a}}$ ed., São Paulo: Ed. Sariva. 2009. p. 380.

${ }^{673}$ ABRÃO, Nelson. Da Franquia Comercial - “Franchising”. São Paulo. Ed. Revista dos Tribunais, 1984. p. 13.

674 CHAVES. Antõnio. Lições de Direito Civil - Direito das Obrigações. São Paulo: Ed. Revista dos Tribunais. 1977. p. 348.

${ }^{675}$ MARIANI. Irineu. Contratos Empresariais.....op. cit. p. 366.
} 
Caio Mário da Silva Pereira, de forma pontual, preceitua o franchising como "uma autorização de nome e marca que uma empresa cede a outra com prestação de serviços"676.

Por fim, em sua acepção legal ${ }^{677}$, a franquia empresarial é o sistema pelo qual um franqueador cede ao franqueado: (i) o direito de uso de marca ou patente; (ii) o direito de distribuição exclusiva ou semi-exclusiva de produtos ou serviços pré-determinados pelo franqueador e, ocasionalmente; (iii) o direito de uso de tecnologia de implantação e administração de negócio ou sistema operacional desenvolvidos ou detidos pelo franqueador, contra o pagamento de remuneração direta ou indireta. Há que se ressaltar, outrossim, que esta relação jurídica não caracteriza o vínculo empregatício entre franqueador e franqueado.

Não se encontra pacificado, na doutrina, entendimento pertinente à natureza jurídica do contrato de franquia empresarial.

Doutrina minoritária, capitaneada por Washington de Barros Monteiro, classifica esta espécie contratual como contrato atípico ${ }^{678}$, haja vista que a lei que o disciplina é lacônica e abarca apenas alguns de seus elementos vitais. De outra sorte, corrente doutrinária majoritária, encabeçada por juristas de elevada autoridade, como Waldírio Bulgarelli, Arnoldo Wald e Caio Mário da Silva Pereira, advoga a tese de que este contrato é típico, pelo fato de estar robustamente regulamentado em lei, ainda que não o tenha sido feito à exaustão ${ }^{679}$.

Posicionamo-nos partidários desta última corrente, perfilhando o entendimento de que o fato de o contrato estar disciplinado em lei, por si só, é satisfatório para que seja considerado contrato típico. Impõe-se mencionar que raríssimos, para não dizer nenhum, são os contratos típicos que se encontram regulamentados em sua integralidade, em

\footnotetext{
${ }^{676}$ PEREIRA, Caio Mário da Silva. Instituições de Direito Civil - Contratos. 13 ${ }^{\mathrm{a}}$ ed. Rio de Janeiro: Ed. Forense. 2009. vol. III. p. 517.

${ }^{677}$ Cf. Art. $2^{\circ}$ da Lei 8.955/94.

${ }^{678}$ Cf. MONTEIRO, Washington de Barros. op. cit. p. 450.

${ }^{679}$ Cf. BULGARELLI, Waldírio. op. cit. 523; WALD, Arnoldo. op. cit. 379; PEREIRA, Caio Mário da Silva. op. cit. p. 517.
} 
resposta à totalidade das demandas sociais que o circundam, fruto da constante evolução das complexas relações humanas e empresariais socialmente verificadas. Há, com recorrência, cláusulas estruturais de suma importância para o contrato típico, as quais, contudo, deixam de ser ventiladas por sua correspondente lei tipificadora. Por tal razão, afiliamo-nos à tese de que o contrato previsto em lei, ainda que não o tenha sido feito em sua plenitude, é considerado contrato típico, tal como ocorre com o contrato de franquia, disciplinado pela Lei 8.955/94. O mesmo não se pode afirmar do contrato de licença de uso de marca, objeto central do presente estudo, que é considerado contrato atípico, em sua essência, em face de sua flagrante carência de suficiente regulamentação legal, conforme oportunamente discorrido no capítulo V.

Consoante melhor doutrina de Arnaldo Rizzardo, não obstante a sua tipicidade, o contrato de franquia utiliza-se de dispositivos de outras espécies contratuais, o que o faz tornar-se um contrato híbrido ou complexo. Destarte, aplicam-se ao franchising elementos extraídos dos seguintes contratos: venda e compra, prestação de serviços, licença de uso de marca, comodato, licença de uso de patente, agência, distribuição, cessão de know-how, mandato, comissão, dentre outros ${ }^{680}$.

Na lição de Carlos Roberto Gonçalves ${ }^{681}$, o franqueador determina a forma pela qual o franqueado deverá instalar e atuar, lhe concedendo assistência técnica contínua para o alcance do objetivo de ambas as partes, desiderato este que se encontra materializado na maximização dos lucros e expansão de certo negócio em determinados limites fronteiriços. Desta sorte, as diretrizes estatuídas pelo franqueador compreendem outros tipos de contratos, tais quais: (i) engineering, pelo qual o franqueador realiza o planejamento e concede orientação concernente à implantação do estabelecimento do franqueado $^{682}$; (ii) management, pelo qual o franqueador presta ao franqueado assessoria para treinamento de

${ }^{680}$ Cf. RIZZARDO, Arnaldo. Contratos. $3^{\mathrm{a}}$ ed. Rio de Janeiro: Ed. Forense, 2004. p. 1388; VENOSA, Silvio de Salvo. op. cit. p. 525.

${ }^{681}$ GONÇALVES, Carlos Roberto. Direito Civil Brasileiro - Contratos e Atos Unilaterais. São Paulo: Ed. Saraiva. 2004, vol. 3. p. 663.

682 O prof. Arnoldo Wald faz alusão a duas espécies distintas de engineering: a primeira refere-se ao consulting engineering, a qual se presta como uma verdadeira consultoria técnica, fazendo ao exame de viabilidade e elaboração do projeto industrial; a segunda modalidade corresponde ao comercial engeneering, que engloba não apenas a consultoria para a elaboração do projeto, como a própria instalação e execução deste. (WALD, Arnoldo. op. cit. p. 380). 
pessoal e estruturação da administração do negócio; (iii) marketing, pelo qual o franqueado participa da publicidade, idealizada e realizada pelo franqueador, da marca licenciada.

O contrato em epígrafe tem como características basilares ${ }^{683}$ : (a) bilateralidade, por ser subscrito entre duas partes com interesses distintos em relação ao objeto do contrato; (b) consensual, por depender da manifestação expressa da vontade entre os contratantes; (c) comutatividade, em função da onerosidade recíproca; (d) onerosidade, na medida em que a remuneração é, por força de expressa disposição de lei, exigida pelo franqueador. Neste aspecto, é imperioso registrar que, em contrariedade ao contrato de licença de uso de marca, o qual pode ser gratuito ou oneroso, o contrato de franquia é, obrigatoriamente, oneroso; (e) durabilidade, conquanto o prazo deve restar consignado no instrumento representativo da relação jurídica entre franqueador e franqueado; (f) territorialidade, haja vista que deve prever o território em que o franqueado poderá comercializar os produtos com a marca de titularidade do franqueador; (g) intuitu personae, porquanto as pessoas dos contratantes não podem ceder o contrato a terceiros, sem o consentimento expresso da parte adversa, de modo igual como ocorre com o contrato de licença de uso de marca; (f) formal, conforme dispõe o artigo $6^{\circ}$ da Lei 8.955/94, considerando que a relação deve ser representada, obrigatoriamente, na forma escrita, devendo ser firmado na presença de 2 (duas) testemunhas, sendo que terá validade independentemente de ser levado a registro perante cartório ou órgão público. A subscrição por duas testemunhas porta finalidade de cunho administrativo, porquanto consiste em requisito obrigatório para deferimento do registro pelo INPI.

Rechaçando a assertiva de que a franquia poderia ser caracterizada como contrato de adesão, grande parte da doutrina, em oposição ao entendimento que vem sendo construído pela jurisprudência ${ }^{684}$, advoga a tese de que esta espécie contratual aproxima-se

${ }^{683}$ VENOSA; Silvio de Salvo. op. cit. p. 529.

${ }^{684}$ Impõe-se transcrever decisão recente emitida pelo Tribunal de Justiça do Estado do Rio Grande do Sul: “(...)Contrato. Imposição de Preço pela Franqueadora a ser praticado junto aos consumidores. Ilegalidade não constatada. Contrato de Adesão por Natureza - A objetividade jurídica do contrato de franquia, consubstanciada na concessão a um terceiro do direito de uso de marca ou patente, justifica o caráter adesivo do pacto, mitigando a autonomia de vontade, o que, por si, não conduz à sua nulidade, justamente porque a delimitação vertical das diretrizes contratuais tem como escopo único a garantia do sucesso do empreendimento franqueado. Nessas condições, ao detentor da concessão da franquia não será franqueada qualquer ingerência na elaboração das diretrizes criadas pelo franqueador. Cabe-lhe, apenas, aceitá-las ou

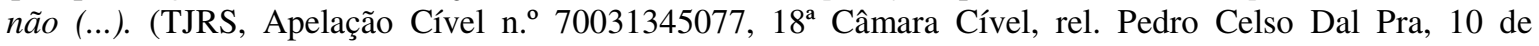
setembro de 2009). 
mais de um "contrato-tipo"685 a um "contrato de adesão", posto que, enquanto neste as cláusulas não são passíveis de negociação, naquele, as partes podem livremente negociar os dispositivos contratuais, em momento anterior à subscrição do contrato principal, com amparo no princípio da autonomia da vontade ${ }^{686}$, mesmo que o franqueado seja obrigado, após a assinatura do instrumento, a seguir diretrizes impostas pelo franqueador.

Ministramos, por igual, o entendimento de que, nos contratos de franquia, a redução do campo de abrangência da autonomia da vontade não implica a eliminação deste princípio. Deve-se, neste aspecto, assinalar que os dispositivos contratuais são perfeitamente passíveis de emenda, previamente à subscrição do contrato, tendo o franqueado a possibilidade de exercer seu direito de recusa à assinatura do instrumento, em não aceitando a imposição de determinadas condições, da mesma forma como, ordinariamente, ocorre em outros contratos empresariais. Esta aplicabilidade não deve ser confundida, contudo, com a ineficácia deste princípio no que tange às diretrizes de operação impostas e, inicialmente, aceitas pelo franqueado. Aqui, sim, há que se ressaltar a inaplicabilidade do princípio em comento.

Ante o exposto, posicionamo-nos, veementemente, na contramão da jurisprudência majoritária que vem sendo construída no sentido de caracterizar o contrato de franquia como um contrato de adesão puro e simples, a despeito do fato, e aqui concordamos integralmente, de o franqueado ter o dever de se vincular às diretrizes impostas pelo franqueador e que foram por aquele aceitas, na ocasião da assinatura do contrato. Ademais, acolher a tese de que o contrato de franquia representa verdadeiro contrato de adesão, induz ao entendimento de que a relação entre franqueador e franqueado equivale à relação de consumo. Este raciocínio se mostra, decerto, inconsistente, na medida em que a própria jurisprudência majoritária tem estabelecido que a relação entre ambas as partes não corrobora relação de consumo ${ }^{687}$.

${ }^{685}$ Cf. ANDRADE, Jorge Pereira. Contratos de Franquia e Leasing. $3^{\mathrm{a}}$ ed. ver. atual. São Paulo: Ed. Atlas, 1998. p. 28.

${ }^{686}$ Conforme preleciona Silvio Venosa: "Não é característica da franquia que o contrato seja sempre de adesão, pois há cláusulas que podem ser livremente discutidas”. (VENOSA, Sílvio de Salvo. Direito Civil, Teoria Geral das Obrigações e Teoria Geral dos Contratos, $7^{\text {a }}$ ed., op. cit. pp. 532/533).

687 “(...) Relação entre o franqueador e franqueado. Lei $n^{\circ}$ 8.955/94. Código de Defesa do Consumidor. Fiança. Exoneração. 1. A relação entre o franqueador e o franqueado não está subordinada ao Código de Defesa do Consumidor (...)" (STJ, Recurso Especial n. 687.322/RJ, $3^{\mathrm{a}}$ Turma, rel. Min. Carlos Alberto Menezes Direito, 21 de setembro de 2006) Ver também: TJSP, Agravo de Instrumento n. ${ }^{\circ} 7343481200,24^{a}$ 
Ante os elementos retro descritos, o contrato em destaque, por sua natureza eminentemente empresarial, deve ser firmado entre empresas. Ademais, tem como componente primordial a licença do uso da marca arraigada à prestação de serviços de assistência técnica, contra o pagamento de remuneração inicial (taxa de filiação) cumulada com royalties resultantes da receita oriunda do volume de negócios alcançado pelo franqueado.

A contrariu sensu dos efeitos que decorrem do contrato de licença de uso de marca, em que o sinal é licenciado de forma simples e destacada ${ }^{688}$, no contrato de franquia, o licenciamento da marca se opera, portanto, de forma conjugada a outros fatores consignados no diploma legal pertinente e que se encontram corporificados: (a) na utilização, pelo franqueado, do know-how adquirido pelo franqueador; (b) bem como na aquisição e distribuição de determinados produtos, em conformidade com a modalidade de negócio pré-formatado e segundo as diretrizes operacionais instituídas pelo franqueador.

É imperioso transcrever as similitudes e diferenças entre o franchising e contrato de licença de uso de marca, apontadas na lição do professor Adalberto Simão Filho:

\begin{abstract}
Pois bem, denota-se, no franchising, uma aproximação com este tipo de contrato [licença de uso de marca], na medida em que, por conceito, se licencia também um comerciante para que este se utilize da marca, expressão ou sinal de propaganda ou, quiçá, de uma patente, mediante um rígido controle do licenciador (franqueador). Entretanto, nestes tópicos residem tão somente os pontos de aproximação, pois, alem destas cessões e licenças, existe a comercialização de produtos, mercadorias ou serviços na forma especificada no contrato, além da sujeição aos preços estipulados. $E$ a sujeição do franqueado ao cabedal das normas técnicas, inerentes ao negócio, em conjunto com a obrigação do franqueador à prestação de assistência específica em níveis diversos, culmina por distanciar os dois institutos [franquia e contrato de licença de uso de marca] que, a princípio, tanto se assemelhavam. $^{689}$ (grifou-se)
\end{abstract}

Câmara de Direito Privado, rel. Salles Vieira, 23 de abril de 2009; TJRJ, Agravo de Instrumento n. ${ }^{\circ}$ 2006.002.20072, 11 a Câmara Cível, rel. Benedicto Abicair, $1^{\text {o }}$ de novembro de 2006. Registre-se também jurisprudência minoritária, que aduz ser de consumo a relação entre franqueador e franqueado. Cf. TJSC, Agravo de Instrumento n. ${ }^{\circ}$ 2007.016920-2, $4^{\text {a }}$ Câmara de Direito Comercial, rel. João Henrique Blasi, 05 de maio de 2008; TJSC, Agravo de Instrumento n. ${ }^{\circ}$ 2006.012583-6, rel. Salim Schead dos Santos, $1^{\text {a }}$ Câmara de Direito Comercial, 19 de março de 2008.

688 Waldírio Bulgarelli assevera que é "justamente, pela prestação desses serviços [técnicos] que o franchising se diferencia da cessão de uso de marca, pura e simples" (Cf. BULGARELLI, Waldírio.... op. cit. p. 527).

${ }^{689}$ SIMÃO FILHO,Adalberto.Franchising:Aspectos Jurídicos e Contratuais. $3^{\text {a }}$ ed. São Atlas SA.1998. p. 37. 
Portanto, ao passo que o contrato de franquia estabelece procedimentos estandardizados, os quais devem ser uniformemente adotados por todos os franqueados, o contrato de licença de uso de marca proporciona maior flexibilidade para convenções, sendo certo que a presença do príncipio da livre autonomia da vontade, especialmente da parte do licenciado, é mais acentuada no segundo negócio jurídico citado.

Fábio Konder Comparato ${ }^{690}$, com sua costumeira precisão, acena que a prestação do serviço ocorrida na franquia empresarial, compreendida pela consultoria técnica prestada pelo franqueador em diversos ramos do negócio (engineering, management e marketing), é o que dissente esta espécie contratual da simples licença de uso de marca. Ante este diferenciação, conclui o jurista que é crível que a remuneração do franchising seja maior do que aquela praticada em relações empresariais, cujo objeto central seja o licenciamento do uso de marca, puro e simples, pois, na franquia, o franqueador deve ser remunerado pelo sinal distintivo licenciado agregado à recorrente consultoria técnica prestada ao franqueado.

É importante mencionar, por igual, que o contrato de franquia não se confunde com o contrato de concessão empresarial, gênero do qual são espécies a Agência e a Distribuição, muito embora a franquia e a concessão possuam elementos em comum.

A concessão empresarial reside, tão somente, na distribuição de produtos ou serviços. Tanto o licenciamento da marca, quanto a eventual prestação de serviços sobre os produtos distribuídos pelo concessionário, neste tipo de relação jurídica, não são os componentes principais do contrato.

Anote-se, também, conforme bem observa Carlos Roberto de Gonçalves ${ }^{691}$, que o concessionário preserva sua individualidade jurídica e mercadológica, o que não ocorre com o franqueado, que detém personalidade jurídica autônoma, todavia não possui reconhecimento empresarial de seu público consumidor, o qual adquire produtos ou

\footnotetext{
${ }^{690}$ COMPARATO, Fábio Konder. Ensaios e Pareceres de Direito Empresarial. Rio de Janeiro: Ed. Forense, 1978. p. 374.

${ }^{691}$ Cf. GONÇALVES, Carlos Roberto. op. cit. p. 663.
} 
serviços do franqueado como se do franqueador estivesse fazendo, desconhecendo, sob este aspecto, a figura e características mercadológicas autônomas do franqueado.

Pode-se extrair da lição acima que, enquanto o concessionário opera com imagem presencial no mercado para o qual se dirige, o franqueado opera sob o véu da imagem do franqueador, passando despercebido perante seu público consumidor. A ausência de individualidade mercadológica, por certo, traz benefícios e malefícios às partes envolvidas e terceiros. Benefícios, porquanto o consumidor adquirirá do franqueado produtos ou serviços, com a percepção de estar fazendo diretamente do franqueador. Malefícios, se o franqueado se mostrar inábil e disseminar no mercado produtos ou serviços com qualidade inferior àqueles originariamente oferecidos pelo franqueador. Por óbvio, neste último caso, o consumidor será ludibriado em sua boa-fé, adquirindo mercadorias que não se coadunam com sua expectativa e os preços praticados.

Insta salientar, entretanto, que a ausência de individualidade mercadológica não retira do franqueado sua autonomia de gestão. Sob este aspecto, o franqueado deve, de forma peremptória, seguir as diretrizes comerciais impostas pelo franqueado, sem, contudo, perder sua total autonomia de gerenciamento administrativo.

Luís Miguel Pestana de Vasconcelos expõe que, uma vez extrapolado o controle realizado pelo franqueador, de sorte a interferir diretamente na gestão interna do franqueado, inclusive exercendo poder de direção direta sobre os empregados deste último, o contrato de franquia poderá se desconfigurar em sua essência. Como seqüela, esta espécie contratual poderá ser considerada como um verdadeiro contrato de trabalho, cuja relação entre franqueador e franqueado passará a ser regida pelas leis trabalhistas, em detrimento dos mandamentos insculpidos na Lei de Franquia ${ }^{692}$.

$\mathrm{Na}$ esteira do estudo acerca do controle realizado em contratos que envolvam licenciamento de uso de marca, oportuno assinalar que, no contrato de licença de uso de marca, se o controle de qualidade for exercido nos moldes, e com similar intensidade, daquele observado em relações empresariais de franquia, o contrato de licença de uso de

${ }^{692}$ VASCONCELOS, Luis Miguel Pestana de. O Contrato de Franquia (Franchising). Coimbra: Almedina, 2000, p. 33. 
marca é passível de ser desnaturado, passando, com efeito, a ser qualificado como contrato de franquia. Destarte, mencionada espécie contratual se sujeitará a regime legal diferenciado aplicável ao franchising, se submetendo, por conseqüência, às disposições consignadas na Lei 8.955/94. A presente tese sobre este tema se debruçou, ao estudar o licenciamento de sinais distintivos, no Direito Estrangeiro e, notadamente, no Direito Norte-Americano ${ }^{693}$.

No franchising , entretanto, a licença do uso da marca, a consultoria técnica, o fornecimento de tecnologia (management, marketing e/ou engineering) ${ }^{694}$ e a eventual prestação de serviços, são elementos de fundamental importância, sem os quais esta espécie contratual torna-se juridicamente inexpressiva. Enquanto na concessão o concessionário é tão somente o intercessor entre o concedente e o consumidor, na franquia, $\mathrm{o}$ franqueado atua diretamente na cadeia produtiva, gerando o produto ou prestando o serviço diretamente ao público consumidor, sob a orientação do franqueador. Comporta repisar, bem assim, que a supervisão e a assitência técnica prestadas pelo franqueador ao franqueado se apresentam como verdadeiros divisores de águas entre o contrato de licença de uso de marca e o contrato de franquia ${ }^{695}$.

Silvio Venosa ${ }^{696}$, na contramão da corrente jurídica tradicional, a qual demarca explicitamente a segregação entre concessão e franquia, proporciona lição inovadora, ao identificar, ainda que de forma discreta, a concessão empresarial (no modo "distribuição") com a "franquia simples", em oposição à outra modalidade de franquia, intitulada pelo jurista de "franquia formatada".

\footnotetext{
${ }^{693}$ Sobre o controle externo verificado no contrato de licença de uso de marca e no contrato de franquia, Irineu Mariani pronuncia-se: “(...) Assemelham-se porque em ambos acontece a autorização, mas diferem-se porque, no contrato de licença, o controle durante a execução se limita à exploração da marca ou patente, enquanto que, no franchising, esse controle ocorre como parte de uma relação mais ampla do "negócio formatado". Como vimos, o franchising é muito mais amplo de que uma licença para exploração de marcas ou patentes." (MARIANI, Irineu. Contratos Empresariais. op. cit. pp. 373).

${ }^{694}$ Cf. WALD, Arnoldo. Direito Civil Brasileiro - Obrigações e Contratos. 13ª ed. ver. e ampl. e atual. Pelo Prof. Semy Glanz. São Paulo, Ed. Revista dos Tribunais, 1998. p. 546.

${ }^{695}$ Cf. BULGARELLI, Waldírio.... op. cit. p. 526;

${ }^{696}$ VENOSA, Silvio de Salvo...... op. cit. pp. 524/525.
} 
Temos, assim, seguindo-se o que propugna Venosa, que a franquia simples, ou "franquia de marca e de produto" reside na autorização que o franqueador concede ao franqueado para que este venda, no mercado, os produtos fabricados pelo cedente e com a marca de titularidade deste. A primeira parte do artigo $1^{\circ}$, da Lei 8.955/94, corrobora esta modalidade, ao prescrever, textualmente, que "a franquia empresarial é o sistema pelo qual um franqueador cede ao franqueado o direito de uso de marca ou patente, associado ao direito de distribuição exclusiva ou semi-exclusiva de produtos ou serviços". Verifica-se, com recorrência, a prática deste tipo de franquia por postos de combustíveis, concessionárias revendedoras de veículos, lojas revendedoras de alimentos e bebidas.

A "franquia formatada" ou business format franchising, de outra parte, consiste em uma concessão plena, sendo, decerto, mais abrangente e, por conseguinte, complexa do que aquela praticada no formato tradicional. O franqueado não tem acesso, simplesmente, ao produto e à marca do franqueador. Mais do que isso, tem acesso a toda a estrutura do negócio. Deve se submeter a um corpo de regras delimitado pelo franqueador. Recebe o direito de utilização: da marca, do nome de fantasia, da estrutura de administração, do formato de negócio, da consultoria técnica, do treinamento oferecido aos empregados etc. Seus empregados obrigam-se a adotar comportamento pré-determinado pelo franqueador, incluindo o vestuário e forma de tratamento empenhado frente ao público consumidor. A remuneração reside no pagamento de uma taxa inicial, intitulada "taxa de filiação", cumulada com o pagamento, pelo período acordado entre as partes, de royalties. Imperioso colacionar esclarecedora definição de Silvio Venosa acerca da franquia complexa:

\begin{abstract}
"O "business format franchising” é uma modalidade de franquia múltipla, eis que nela o franqueador cede a franqueado técnicas comerciais, industriais ou métodos de serviços expostos em "manuais de operações", a marca e o logotipo, o "know-how", assessoria técnica e de treinamento contínuo (jurídica, fiscal, tributária, financeira, de engenharia, pesquisa de localização do ponto-de-venda, marketing, informática), além de prestar serviços de supervisão nas operações de comercialização e de administração geral do franqueado. ${ }^{, 697}$ (grifou-se)
\end{abstract}

Ante o exposto, o licenciamento do uso da marca pode ser verificado em contratos de complexidades distintas, partindo do menos complexo, representado pelo contrato de

${ }^{697}$ Idem, Ibidem. p. 524. 
licença de uso de marca; passando pelo intermediário, corporificado pelo contrato de franquia tradicional; e encerrando no mais complexo, materializado no business format franchising.

A diferença marcante que se apresenta entre o contrato de franquia, na modalidade business format franchising, e o contrato de licença de uso de marca, repousa no fato de que, enquanto naquele contrato, o franqueado se obriga a seguir o padrão e o conceito de negócio delineado pelo franqueador, no contrato de licença, o licenciado se submete tãoapenas à exploração de determinada marca (e não de todo um negócio jurídico), na forma contratualmente configurada pelas partes.

Cumpre destacar, outrossim, as principais modalidades de franchising. Maria Helena Diniz ${ }^{698}$, doutrina sob a qual se inspirou Washington de Barros Monteiro ${ }^{699}$, proporciona três espécies diferentes de contrato de franquia, a saber:

(a) franquia industrial. Por este contrato, o franqueador assume o encargo de fornecer todos os subsídios necessários para que o franqueado edifique e opere complexo fabril com as mesmas características daquele originariamente, por ele, franqueador, implantado. Agregam-se a esta prática industrial: a assistência técnica permanente, a licença de uso da marca, a cessão de know how, a eventual cessão de equipamentos e a eventual licença de uso de patentes. A transmissão, a título temporário, dos direitos das citadas propriedades intelectuais deverá ocorrer mediante declaração expressa emitida pelo franqueado, cujo conteúdo repousará no dever de preservação de todos os segredos de indústria e direitos correlatos. Neste tipo de franquia, e aqui vale grifar a diferença pontual entre este tipo de relação jurídica e aquela corporificada pela concessão empresarial, o franqueado participa de todas as etapas da produção do produto que irá comercializar com a marca licenciada, estágios estes que serão integralmente seguidos sob a orientação do franqueador;

\footnotetext{
${ }^{698}$ DINIZ, Maria Helena. Tratado Teórico e Prático dos Contratos. $4^{a}$ ed. São Paulo, Saraiva, 2002. vol. 4. pp. 53-55.

${ }^{699}$ MONTEIRO, Washington de Barros. op cit. p. 452.
} 
(b) franquia de comércio ou de distribuição. Neste tipo de relação empresarial, o franqueado comercializa produtos que são fabricados pelo franqueador, ou por fornecedor central por ele indicado. Os produtos oferecidos são obrigatoriamente grafados com a marca do franqueador. É bastante comum a utilização desta modalidade de franquia por lojas de grande consumo, principalmente aquelas de vestuário.

(c) franquia de serviços. Nesta relação, o objeto da franquia reside, essencialmente, na licença temporária da marca aliada à determinada forma pela qual é prestado certo serviço. Portanto, o franqueador concede ao franqueado o direito de exercer um serviço perante o mercado consumidor, porém na exata modalidade em que este serviço é originariamente oferecido pelo franqueador. São exemplos: redes de restaurantes, redes de lanchonetes, redes de escolas, redes de cursinhos, redes de hotéis etc.

Acrescente-se às franquias tradicionais acima apontadas outras modalidades de franquia: (a) Pura ou Mista: é pura quando a franquia não combina atividades; por seu turno, é mista quando mescla atividades em um mesmo contrato como, por exemplo, produtos e serviços; (b) Desenvolvimento de Área. Originada da expressão inglesa development franchise. Por esta modalidade, o franqueado opera, em determinado território, tantos estabelecimentos quantos entender necessários, sem a necessidade de firmar contrato novo para cada estabelecimento; (c) Franquia Múltipla. Originado do termo multifranchise. Ao contrário do que ocorre no desenvolvimento de área, neste tipo de negócio jurídico, o franqueado pode operar diversos estabelecimentos de uma mesma rede ou marca, porém, para cada estabelecimento, deverá firmar novo contrato com o franqueador; (d) Córner. A franquia consiste na operação de pequenos pontos comerciais, principalmente, em shopping centers. Estes pontos não guardam relação com lojas propriamente ditas. São facilmente encontrados em lojas de departamento, o que, no Brasil, tem crescido vertiginosamente; (e) Associativa. Ocorre quando o franqueador tem participação societária no fraqueado ou vice-versa. Não há a necessidade de que uma sociedade seja controladora da outra para se verificar a existência desta espécie de franquia; (f) Financeira. Esta modalidade corresponde a um investimento. O franqueado contrata com o franqueador, porém transfere a gestão do negócio para um terceiro. É incomum observá-la na praxis contratual, porquanto o contrato de franquia é intuito personae e a modalidade ora apresentada, de forma antagônica, não é revestida de tal predicado; (g) De Conversão. Ocorre quando o empreendedor de um determinado negócio 
o converte, passando a operar uma franquia no mesmo estabelecimento empresarial em que desenvolvia suas atividades anteriores. No entanto, este estabelecimento passa por uma reformatação, de acordo com normas impostas pelo franqueador. (h) Itinerante. Corresponde à franquia móvel. Comum verificar esta espécie de franchising nas redes de comida, sobretudo comida rápida ${ }^{700}$.

No franchising, a fase pré-contratual é de suma importância. $\mathrm{O}$ artigo $3^{\circ}$ da Lei 8.955/94 estabelece que o franqueador, em momento pretérito ao fechamento do contrato com potencial franqueado, a este deve encaminhar circular de oferta de franquia, por escrito e em linguagem compreensível, contendo informações de cunho obrigatório. Estas informações são explicitamente mencionadas nos 15 incisos do dispositivo acima referendado.

Ante o comando do artigo $4^{\circ}$, da Lei 8.955/94, a circular de oferta deverá ser encaminhada ao interessado em adquirir a franquia no prazo mínimo de dez dias antes de firmado o contrato ou pré-contrato, ou ainda, antes de realizado o pagamento de qualquer valor pelo franqueado ao franqueador. $\mathrm{O}$ descumprimento das condições ora descritas, implicará a anulabilidade do contrato, cumulada com a obrigatoriedade de o franqueador restituir ao franqueado todos os valores pagos, sejam a título de taxa de filiação ou royalties. As importâncias devolvidas deverão estar devidamente corrigidas e com a incidência dos juros legais. A restituição das quantias pagas não obstará que o franqueado acione a máquina judiciária na busca das perdas e danos por ele suportados, sem prejuízo da aplicação das sanções penais ao caso aplicáveis.

Cumpre mencionar que as sanções acima previstas, com supedâneo no artigo $7^{\circ}$ da aludida lei, serão igualmente aplicáveis no caso de o franqueador veicular informações falsas na circular de oferta de franquia.

\footnotetext{
${ }^{700}$ Cf. MARIANI, Irineu. Contratos Empresariais. op. cit. pp. 370-373; Cf. VENOSA, Silvio de Salvo. op. cit. p. 526/527; Cf. SIMÃO FILHO, Adalberto. Franchising. op, cit. pp. 47-50.
} 
Convém ao franqueador, bem assim, inserir, na circular de oferta, medidas preventivas e mecanismos de repressão, no sentido de inibir que o franqueado cause algum tipo de malefício à marca licenciada ${ }^{701}$.

A utilização da marca, no franchising, deve se adequar aos padrões de qualidade estabelecidos pelo franqueador, inclusive devendo se submeter à constante fiscalização que será por este realizada. Esta fiscalização tem o condão de: (a) impedir que a marca licenciada, a qual galgou patamar elevado no mercado, tenha sua imagem prejudicada perante o público consumidor e, por conseqüência, venha a sofrer desvalorização econômica. Por tal razão, segundo anotação de Maria Helena Diniz ${ }^{702}$, o franqueador deve se certificar que o franqueado esteja envidando todos os esforços para preservar a "reputação dos produtos que distribui"; e (b) evitar que ele, franqueador, seja acionado administrativa e/ou judicialmente por dano acarretado pelo franqueado ao consumidor. Tal afirmação encontra-se respaldo no artigo $3^{\circ}$ do Código de Defesa do Consumidor, que define como fornecedor, dentre outros agentes, toda pessoa jurídica que desenvolva atividade de produção, montagem, criação, transformação, exportação, distribuição ou comercialização de produtos ou prestação de serviços. Portanto, o franqueador, especialmente se produzir o produto e distribuí-lo ao franqueado para oferecimento no mercado, poderá ser responsabilizado por eventuais danos gerados ao consumidor.

Ainda na esteira do controle externo realizado pelo franqueador sobre o franqueado, é imperioso trazer ao presente estudo precioso ensaio concebido por Jorge Lobo, com arrimo na melhor doutrina do professor Fábio Konder Comparato ${ }^{703}$.

Preliminarmente, Lobo distingui duas modalidades de grupo de sociedades. A primeira ocorre quando uma sociedade participa do capital da outra sociedade, culminando em uma relação societária integrativa direta entre as sociedades envolvidas. Aqui, a sociedade controladora, aquela que detém maioria no capital social, será responsabilizada pelos danos causados por atos realizados com abuso de poder, à luz dos artigos 116 e 117

\footnotetext{
${ }^{701}$ Cf. VENOSA, Silvio de Salvo. op. cit. p. 532.

702 Cf. DINIZ, Maria Helena. Curso de Direito Civil Brasileiro - Teoria das Obrigações Contratuais e Extracontratuais. $25^{\mathrm{a}}$ ed. reformulada. São Paulo: Ed. Saraiva. vol. 3. p. 751.

${ }^{703}$ Cf. LOBO, Jorge. Contrato de “Franchising”. Rio de Janeiro: Ed. Forense, 2000. pp. 44-51.
} 
do Lei 6.404/76 (Lei das Sociedades Anônimas). A segunda modalidade consiste na "cooperação" entre duas ou mais sociedades, com o desígnio de se alcançar objetivo comum. Neste caso, quedam-se preservadas as personalidades jurídica e patrimonial de cada agente empresarial, muito embora, em grande parte dos casos, haja a nítida presença de sociedade dominante e sociedade dominada, havendo, com efeito, o controle externo de uma sobre a outra. É o que se verifica no franchising.

Segundo Comparato, em sua primorosa obra "O Poder de Controle na $S / A$ "704, ao examinar o sistema de concessão empresarial com exclusividade, a dependência do concessionário em ter o dever de adquirir produtos ou insumos do concedente gera a obrigatoriedade unilateral. O concessionário deve submeter-se a frequente controle externo por parte do concedente, o qual inspecionará: os materiais utilizados na produção; o funcionamento dos equipamentos; os grau de profissionalismo dos profissionais do concessionário; e, por fim, porém não menos importante, se a publicidade e divulgação dos produtos estão sendo realizados em estrita conformidade com as diretrizes impostas pelo concedente. O concessionário tem, igualmente, a obrigação de oferecer assistência técnica após a venda dos produtos. A inobservância de tais mandamentos encetará a resolução contratual, sem prejuízo das sanções civis e penais aplicáveis.

Ante este cenário de austero controle externo verificado na distribuição empresarial com exclusividade, Jorge Lobo afiança, textualmente:

\begin{abstract}
Se é possivel falar-se, quando se trata de concessão de venda com exclusividade, em "grupo econômico de subordinação externa", com muito mais razão quando se cuida de franchising, em que, como vimos (supra capítulo VII, n. 53 e 54), o franqueador, além de ceder o uso da marca do seu produto e o know-how dos servicos de organização de vendas, cede, também, o projeto para construção e reforma das instalações do estabelecimento, mobiliário, cores, maquinaria etc. (engineering), treina o pessoal do franqueado e monta sua organização contábil e administrativa (management) $e$ faz acurado estudo do mercado em potencial, publicidade, vendas promocionais e lançamento de produtos (marketing), permanentemente orientando e fiscalizando as atividades do franqueado, que não atua senão em conformidade com as ordens do franqueador, a quem deve rigorosa obediência, sob pena de infringir o contrato que celebrou e que o obriga a observar e cumprir com as instruções do franqueador sobre sua produção, comercialização, administração e marketing. ${ }^{705}$ (grifou-se)
\end{abstract}

\footnotetext{
${ }^{704}$ Cf. COMPARATO, Fábio Konder. O Poder de Controle na S/A. Rio de Janeiro: Ed. Forense, 1983. pp. $74 / 75$.

${ }^{705}$ Cf. LOBO, Jorge. Contrato de Franchising. op. cit. pp. 49/50.
} 
Do trecho acima transcrito, Lobo arremata $^{706}$ : (i) conforme assinala Comparato, no contrato de concessão de venda, operado sob o manto da exclusividade, verifica-se a formação de grupo econômico com o conseqüente controle externo do concedente sobre o concessionário; (ii) este controle externo, por analogia ao controle realizado entre sociedades financeiramente ligadas em que uma participa do capital da outra, sujeita-se à incidência de aplicação dos artigos 116 e 117 da Lei 6.404/76; (iii) na franquia, especialmente em sua modalidade mais comumente observada, o business format franchising, ocorre controle externo mais ortodoxo do que o praticado na concessão de venda com exclusividade, porquanto franqueador e franqueado formam grupo econômico, tendo o franqueador "deveres e responsabilidades próprios do controlador, inclusive devendo responder por eventuais abusos do poder de controle"; (iv) por analogia, portanto, aplica-se ao controlador os comandos insertos nos artigos 116 e 117 da Lei das Sociedades Anônimas.

Extrai-se, pois, das conclusões acima apontadas, que o franqueador, além de ser solidariamente responsável pelos vícios ocasionados por produtos ou serviços oferecidos pelo fraqueado, sob o prisma do diploma consumeirista, responde, também, pelos danos gerados, em decorrência de atos praticados com abuso de poder de controle. Destarte, com fundamento no artigo 116, parágrafo único, da Lei 6.404/76, o franqueador, revistido na função de controlador, terá deveres e responsabilidades para com o franqueado como, igualmente, terá responsabilidades perante o consumidor, público este para o qual são destinados os produtos ou serviços oferecidos pelo franqueado.

Por analogia ao artigo 117, parágrafo primeiro da Lei 6.404/76, o franqueador cometerá abuso de poder, quando incorrer nos seguintes atos que ora se apresenta em rol não exaustivo: (a) orientar o franqueado para fim estranho ao objeto social ou lesivo ao interesse nacional, ou levá-lo a favorecer outra sociedade, brasileira ou estrangeira; (b) promover atos perante o franqueado, com o intuito de conseguir para si ou para outrem, vantagem indevida, em prejuízo dos concorrentes, outros franqueados e/ou do público consumidor; (c) indicar administrador ou fiscal que sabe inapto, moral ou tecnicamente; (d) induzir, ou tentar induzir, administrador ou fiscal a praticar ato ilegal, ou, descumprindo seus deveres definidos em Lei e no ato constitutivo do franqueado; (e)

\footnotetext{
${ }^{706}$ Idem. Ibidem. p. 51.
} 
aprovar ou fazer aprovar contas irregulares de administradores, por favorecimento pessoal, ou deixar de apurar denúncia que saiba ou devesse saber procedente, ou que justifique fundada suspeita de irregularidade.

Antes de adentrarmos ao contrato de franquia, é cogente assinalar a figura do précontrato, instrumento este utilizado com assiduidade pelo franqueador, com o fito de adquirir conhecimento sobre a aptidão do franqueado, especialmente para que este, ao atuar no mercado, não lesione a imagem da marca e reputação, ao longo de anos, erigida pelo franqueador. Ordinariamente, este contrato preliminar é assinado por curto período de tempo, para, após, e naturalmente na hipótese de ambas as partes estarem satisfeitas com o negócio proposto e experimentado, se firmar o instrumento definitivo ${ }^{707}$.

No que concerne aos dispositivos contratuais do franchising, são indispensáveis as seguintes cláusulas ${ }^{708}$ :

(i) partes contratantes. Deverão ser qualificados em contrato: o franqueador, pessoa física ou jurídica que outorga a licença do uso da marca, juntamente com a cessão de seus produtos ou serviços associados a eventual prestação de serviços (consultoria técnica), e o franqueado, pessoa física ou jurídica que recebe o direito de uso da marca juntamente com consultoria técnica, devendo obedecer, rigorosamente, às normas $\mathrm{e}$ diretrizes impostas pelo franqueador.

(ii) prazo de vigência do contrato. A lei não fixa prazo determinado. Em tese, as partes podem fixar o prazo que melhor lhes aprouver, devendo, no entanto, ter em mente que deve ser afixado prazo condizente com o tamanho do negócio e período necessário para colocá-lo em operação. Na prática, varia de um a cinco anos;

(iii) território, objetivando a delimitação do local de atuação do franqueado. Importante frisar acerca da impossibilidade de utilização de subterfúgios, tais quais televenda ou comércio via malote direcionados a consumidores residentes ou domiciliados em

\footnotetext{
${ }^{707}$ Cf. SIMÃO FILHO, Adalberto. Franchising. op. cit. pp. 59/60.

${ }^{708}$ Cf. DINIZ, Maria Helena. Curso de Direito Civil Brasileiro - Teoria das Obrigações Contratuais e Extracontratuais. op, cit. pp. 752/753; VENOSA, Silvio de Salvo. op. cit. 529; ANDRADE, Jorge Pereira. Contratos de Franquia e Leasing. op. cit. p. 29.
} 
localidade territorial não delimitada em contrato. Desta sorte, o franqueado somente poderá se valer destes mecanismos de comércio de longo alcance, mediante autorização expressa do franqueador ${ }^{709}$;

(iv) exclusividade, cuja finalidade é estabelecer se o franqueado atuará isoladamente ou em conjunto com outros empresários. O artigo $3^{\circ}$, da Lei 8.955/95, estatui que deve restar consignado em contrato se o franqueado terá exclusividade de atuação ou preferência sobre determinado território, e quais as condições o fará. Portanto, a exclusividade não é presumível, devendo estar expressamente indicada no instrumento contratual. No evento de não ventilada, pressupõe-se que não há cláusula de exclusividade, tendo o franqueador a prerrogativa de conceder seu business format a outros franqueados, no mesmo âmbito de atuação do primeiro franqueado. É a chamada "semi-exclusividade". Conforme estudado, da mesma forma ocorre com os contratos de licença de uso de marca.

Irineu Mariani afirma que a "semi-exclusividade" não sugere, ou ao menos não deve implicar, desigualdade de condições face ao público consumidor. Assim, não deve nem o franqueador, muito menos qualquer dos franqueados, promover anúncios e oferecer condições mais benéficas de aquisição dos produtos ou serviços licenciados, quando esta aquisição se opere em uma das franquias da rede, cuja localização se situe em uma mesma região onde atuem diversos franqueados. Este ato representa concorrência interna; violação contratual e lesão ao princípio da função social do contrato em sua eficácia interna. Caracteriza, adicionalmente, um grande contra-senso ao conceito de uniformidade, ínsito ao sistema de franquia, em que se busca estratégia homogênea e benéfica, de forma uníssona, a todos os franqueados da cadeia. Por outro lado, a exclusividade é presumida quanto à distribuição dos produtos, bem como em relação à aquisição da matéria-prima que consubstanciará os produtos que serão comercializados pelo franqueado. $\mathrm{O}$ artigo $3^{\circ}$, inciso XI, da Lei de Franquia, prescreve que o franqueado tem o dever de obter tão somente daqueles fornecedores eleitos pelo franqueador, todo e qualquer bem, serviço ou matériaprima que sejam necessários para a implantação, operação ou administração da franquia ${ }^{710}$;

\footnotetext{
${ }^{709}$ Cf. MARIANI, Irineu. Contratos Empresariais. op. cit. pp. 368/369.

${ }^{710}$ Idem, Ibidem. p. 369.
} 
(v) preço, indicando a taxa de filiação e royalties que deverão ser pagos pelo franqueado ao franqueador.

Adalberto Simão Filho $^{711}$ sinaliza para três tipos de prestação, a saber: (a) pagamento inicial. Refere-se à taxa de filiação, podendo o franqueador incluir neste valor a aquisição ou aluguel de certos equipamentos a serem utilizados pelo franqueado ao longo do prazo contratual; (b) pagamento sobre vendas. Corresponde ao valor percentual cobrado sobre as vendas dos produtos ou serviços prestados pelo franqueado; (c) pagamento a títulos diversos. Equivale aos custos distribuídos entre os franqueados para a manutenção do sistema. Estes valores, em geral, são destinados ao pagamento de campanhas de publicidade. Convém mencionar, outrossim, que o franqueador pode, obviamente antes da assinatura do contrato, estabelecer a formação de fundos de naturezas diversas, cobrando outras taxas de seus franqueados. São exemplos de "outras taxas" as contribuições ou pagamento de percentuais sobre as vendas, tendo como fim precípuo a melhoria do processo de formatação ou criação de novos produtos.

O artigo $3^{\circ}$, inciso VIII e alíneas, da Lei 8.955/94, enumera, a título ilustrativo, encargos remuneratórios ou destinos para os quais deverão ser direcionados os valores aportados pelos franqueados, a saber: “a) remuneração periódica pelo uso do sistema, da marca ou em troca dos serviços efetivamente prestados pelo franqueador ao franqueado (royalties); b) aluguel de equipamentos ou ponto comercial; c) taxa de publicidade ou semelhante; d) seguro mínimo; e e) outros valores devidos ao franqueador ou a terceiros que a ele sejam ligados".

No que diz respeito ao preço, o valor pago pelo franqueado tem o intuito de remunerar, igualmente à licença do uso da marca, a disponibilização de: tecnologia, treinamentos e assistência técnica, promovidos pelo franqueador. No contrato de licença de uso de marca, por seu turno, o preço tem o desígnio de remunerar somente a licença do uso da marca. Excepcionalmente, terá a finalidade de remunerar a exploração de artigos licenciados, bem como eventual publicidade conjunta partilhada entre licenciador e licenciado.

${ }^{711}$ SIMÃO FILHO, Adalberto. Franchising. op. cit. pp. 68/69. 
(vi) quotas de venda. Por este dispositivo, o franqueador exige do franqueado que este venda determinado número de produtos, sob pena de resolução contratual;

(vii) preço de venda dos produtos. O preço de venda, ao consumidor, dos produtos franqueados é, comumente, fixado pelo franqueador. Naturalmente, o franqueador, na fixação do preço, deverá levar em consideração o lucro ao qual fará jus o franqueado. Caso contrário, a franquia não trará nenhum benefício ao franqueado. No mais, no evento de o franqueado almejar alterar o preço pré-estabelecido, em função da ocorrência de certas circunstâncias, deverá postular autorização do franqueador para fazê-lo.

(viii) extinção do contrato. As partes deverão, por fim, eleger os fatos que, se ocorridos, darão causa ao término do contrato. Os contratos de franquia serão extintos:

(a) pelo término do prazo contratualmente estipulado pelas partes;

(b) pelo distrato. Quando ambas as partes, antes do término do prazo convencionado, decidirem, de comum acordo, encerrar o contrato, sem o dever de indenização;

(c) pela resilição unilateral (“denúncia vazia”), injustificada, e a qualquer tempo. Anote-se, contudo, que esta resilição somente será operada na hipótese de tal possibilidade restar expressamente disposta em contrato;

(d) pela resolução unilateral. Quando restar comprovada a inexecução de cláusula contratual por qualquer uma das partes. Sobre a resolução, Maria Helena Diniz ${ }^{712}$ prescreve que o contrato poderá ser resolvido por ato que danifique, indiretamente, a imagem da marca licenciada e o prestígio do produto ou serviço licenciado. Ademais, poderão ser previstos eventos outros ensejadores da resolução contratual, a exemplo da prática de "atos escandalosos" que desprestigiem a imagem alcançada pelo franqueador ao longo de anos ou décadas.

${ }^{712}$ Cf. DINIZ, Maria Helena. Curso de Direito Civil Brasileiro - Teoria das Obrigações Contratuais e Extracontratuais. op, cit. pp. 752/753. 
(e) pela anulabilidade, prevista no artigo $4^{\circ}$, parágrafo único, da Lei de Franquia.

No que pertine à possibilidade de o franqueado pleitear do franqueador, após o término do prazo contratual, indenização decorrente da perda da clientela que ele, franqueado, conquistara ao longo do contrato de franquia, Adalberto Simão Filho ${ }^{713}$, com muita propriedade, aduz: a compensação não será devida, se o franqueado tiver operado em território cujo consumidor já houvera sido atingido pelo franqueador em momento pretérito à subscrição do contrato de franquia. De outra parte, a reparação será devida, no evento de o franqueado, com a sua eficiente gestão, houver angariado clientela, a qual, sem o frutífero trabalho realizado por ele, não seria atingida e conquistada pelo franqueador.

De forma antagônica, se apresenta doutrina capitaneada por Guyenot ${ }^{714}$ e Fauceglia $^{715}$, ao considerar que a omissão, no instrumento contratual, sobre a possibilidade de indenização após o termo final da relação jurídica, não confere ao franqueado o direito de pleitear reparação pela perda da clientela.

Alicerçando-se no artigo 122 do Código Civil vigente, é vedado às partes inserir, no instrumento, condição ou cláusula potestativa. Entende-se como cláusula potestativa aquela que prive de todo efeito o negócio jurídico ou, ainda, aquela que submeta uma das partes "ao puro arbítrio" da outra parte contratante. Não podemos nos olvidar, contudo, acerca da possibilidade de o franqueador alterar, de forma unilateral, algumas diretrizes, ao longo do contrato de franquia, contanto que não o faça de modo arbitrário, de sorte a prejudicar o franqueado. Até porque, o sistema está em constante evolução e carece de modificações recursivas, adequações, ajustes, adaptações à demanda de mercado etc. Reitere-se que estas imposições, visando à evolução do sistema, devem ocorrer com comedimento. Depreende-se, a título ilustrativo, que seria ilícito ao franqueador determinar que o franqueado redefinisse toda a arquitetura e engenharia de seu estabelecimento. Por natural, esta imposição representa verdadeira condição potestativa.

\footnotetext{
${ }^{713}$ Cf. SIMÃO FILHO, Adalberto. Franchising. op. cit. pp. 79/80.

${ }^{714}$ GUYENOT. Que es el franchising? in Concessionaes Commerciales. Buenos Aires: Ediciones Juridicas Europa - America. 1977, p. 79 apud SIMÃO FILHO, Adalberto. Franchising. op. cit. 80.

${ }^{715}$ FAUCEGLIA, Giuseppe. Il franchising: profili sistematici e contratuali. Milão: Dott A.G. 1988. p. 114 apud SIMÃO FILHO, Adalberto. Franchising. op. cit. 80.
} 
Quanto ao registro, assim como ocorre no contrato de licença de uso de marca, o contrato de franquia, de acordo com o artigo 211 da Lei 9.279/96, deverá ser registrado no Instituto Nacional de Propriedade Industrial (INPI), para que passe a gerar efeitos perante terceiros $^{716}$.

No que concerne à magnitude de aplicação da Lei de Franquia, o artigo $8^{\circ}$ da Lei 8.955/94, disciplina que referida lei terá abrangência nacional. Acrescente-se, igualmente, em consonância com o artigo $9^{\circ}$, que, nos casos de subfranquia, os dispositivos previstos na legislação em referência serão, da mesma forma e com a mesma efetividade, aplicados a subfranqueador e subfranqueado, como se franqueador e franqueado respectivamente fossem. Na interpretação realizada por Fernando Netto Boiteux, concernente ao artigo $9^{\circ}$ supra, a lei brasileira de franquia irradia efeitos sobre todas as franquias que ofereçam seu sistema no Brasil, a despeito de o franqueador estar sediado em território estrangeiro, porquanto "o sistema de franquia é o formato que lhe dá o franqueador e, não, o contrato celebrado com o franqueado" 717 .

A possibilidade de subfranqueamento dá ensejo à figura do master franqueado ${ }^{718}$. Este tipo de franqueado tem a permissão de outorgar subfranquias a terceiros interessados dentro das fronteiras delimitadas pelo franqueador.

\footnotetext{
${ }^{716}$ Fernando Boiteux afirma, textualmente, que “(...) Ao mesmo tempo, o registro permitirá ao consumidor determinar com maior precisão eventuais responsabilidades decorrentes da compra que vier a fazer" (BOITEUX, Fernando Netto. Contratos Mercantis. São Paulo: Ed. Dialética. 2001. p. 245/246.)

${ }^{717}$ Idem, Ibidem. p. 245.

${ }^{718}$ Cf. ANDRADE, Jorge Pereira. Contratos de Franquia e Leasing. $3^{\mathrm{a}}$ ed. ver. atual. São Paulo: Ed. Atlas, 1998. p. 27.
} 


\section{- IX -}

\section{CONCLUSÃO}

A importância econômica da propriedade industrial e seus reflexos no ordenamento jurídico galgam patamares nunca antes alcançados. $\mathrm{O}$ desenvolvimento econômico hodierno prescinde, crescentemente, dos bens intangíveis erigidos da criatividade humana, que são tutelados pelo ordenamento jurídico vigente, sem os quais, a economia de uma nação se submeterá ao risco da estagnação. Não devemos nos olvidar, contudo, que este desenvolvimento contínuo só remanescerá vigoroso na medida em que o Direito, através de preceitos e mecanismos jurídicos consistentes, se proponha a guerrear frontalmente situações fáticas ameaçadoras ao sistema econômico e social, de tal sorte que os agentes econômicos patológicos sejam terminantemente punidos pelos seus atos fraudulentos e abusivos, empreendidos em desfavor do interesse da coletividade.

O estudo do Direito Estrangeiro possibilitou-nos concluir que, em diversos países, como: Itália, França, Inglaterra, Alemanha, Portugal, Estados Unidos, Argentina, dentre outros, o contrato de licença de uso de marca é amplamente admitido, com elementos e contornos claramente similares àqueles praticados internamente, conforme restou demonstrado no presente trabalho.

Diante de todo o estudo apresentado, fazem-se pertinentes algumas considerações conclusivas acerca do tratamento dispensado aos contratos de licença de uso de marca, sob a lente da Lei 9.279/96 e sob a égide do Código Civil vigente.

Inicialmente, faz-se imperioso concluir, em oposição à blindagem exacerbada verificada em tempos pretéritos, que a marca, não obstante seja elemento integrante do estabelecimento comercial, dele pode ser segregada, para efeitos de cessão ou licenciamento. Esta possibilidade legal se opera da mesma forma como ocorre no vigente 
sistema marcário italiano $^{719}$, o qual, é importante frisar, submeteu-se à mesma evolução legislativa do que aquela pela qual passou o sistema marcário brasileiro.

Debates espinhosos foram travados pela doutrina nacional e alienígena a respeito do destacamento da marca do estabelecimento comercial correspondente. Em que pese a argumentação contra a segregação do bem incorpóreo em apreço, com fulcro na máxima de que o consumidor poderá restar prejudicado pela produção de produtos ou prestação de serviços cuja qualidade seja aquém daqueles produzidos pelo cedente ou licenciante, não perfilhamos este entendimento.

Ao lado de corrente doutrinária majoritária e, por óbvio, de legislação positivada que assim autoriza, ministramos a tese de que esta segregação é perfeitamente aplicável, mormente com o intuito de dinamizar as relações inter empresariais e impulsionar o empresariado em estágio embrionário que anseia progredir no mercado ao qual se encontra submergido. No tocante à preocupação concernente à salvaguarda do interesse do consumidor, que poderá ser prejudicado, em razão da segregação da marca de seu respectivo estabelecimento, é oportuno registrar que esta apreensão é plausível e será ponderada quando da elaboração das conclusões críticas à lei vigente, conforme adiante demonstrado, porém sob outro prisma.

O valor econômico da marca, a ser aferido a título de licenciamento, deve ser livremente convencionado pelas partes, com arrimo no princípio da autonomia da vontade privada. Ademais, para efeito valorativo, não há que se confundir o valor da marca enquanto inserido no estabelecimento comercial do licenciante e o valor da marca singular, enquanto aposta ao produto ou serviço produzido exclusivamente pelo licenciado. São posições, decerto, distintas e que devem ser sopesadas, sob o manto do princípio da razoabilidade, no momento da negociação em relação ao valor remuneratório a ser fincado

\footnotetext{
719 "La vecchia stesura dell'art. 2573 c.c., prevedeva che il marchio registrato potesse essere transferito soltanto com l'azienda o côn un ramo particolari di essa. Il D. Lgs 4 dicembre 1992 n, 480, nel modificare l'art. 15 della legge sui marchi ed il comma primo dell'articolo 2573 c.c., ha abolito il vincolo con l'azienda, disponendo que il marchio è liberamente tranferible, anche indipendentemente dall'azienda o da un suo ramo particolare (...)” (Cf. BALDUCCI, Daniele. L'Affitto D’Azienda. $3^{\text {a }}$ ed. Milão: Edizioni Fag, 2007.p. 93) Ver também: "Si è recordato che il simultâneo transferimento dell'azienda non è più condizione necessária per il transferimento del marchio" (AUTERI, Paolo (et. al). Diritto Industriale - Proprietà Intellectuale $e$ Concorrenza. $3^{\mathrm{a}}$ ed. G. Giappichelli Editore: Torino, 2009. p. 141)
} 
contra a licença marcária concedida. Tal assertiva decorre da definição jurídica majoritariamente atribuída ao estabelecimento comercial de que este corresponde ao produto final da congregação dos bens corpóreos e incorpóreos. Portanto, o valor do bem imaterial, enquanto inserido no estabelecimento do licenciante, é um, ao passo que é outro no momento em que dele se aparta.

Questão controversa outra atine à definição da natureza jurídica das marcas, o que impactará diretamente no regime jurídico aplicável a este bem incorpóreo. Não obstante sejam apresentadas, com recorrência, a doutrina do direito pessoal, a doutrina dos direitos intelectuais, a teoria dos direitos sobre bens imateriais, e, por fim, a teoria do monopólio sobre a marca, com todo o respeito às citadas doutrinas, alicerçamo-nos no escólio dos eminentes João da Gama Cerqueira, Rubens Requião, Luiz Guilherme Loureiro, dentre outros, como, por igual, no tratamento conferido pelo artigo $5^{\circ}$, inciso XXIX, da Carta Suprema, concluindo que o direito sobre as marcas é notadamente um direito de propriedade. Assim se conclui, especialmente pelo fato de que o titular da marca detém para si todas as prerrogativas inatas ao "direito de propriedade lato sensu", quais sejam, os direitos de usar, gozar e dispor do sinal, ainda que o faça de "forma limitada", e em relação à determinada classe de bens ou serviços.

Como decorrência desta consideração conclusiva, convergimos para o entendimento de que esta modalidade de bem intangível, por via de analogia, submete-se ao regime jurídico de direito real. De tal modo, aos titulares das marcas registradas é facultado usar, gozar e dispor (licenciar) do sinal como melhor lhes aprouver, obviamente obedecendo aos limites dos direitos dos quais são titulares e sem prejuízo do interesse social.

A despeito das inúmeras funções exercidas pela marca, merecem destaque para os fins do presente estudo:

(i) a função individualizadora e distintiva. Em que pese o intenso debate doutrinário acerca do tema, e muito embora a legislação marcária nacional e internacional, esta última representada pelo TRIPS, assinalem apenas a função distintiva, compartilhamos da tese de que ambas são perfeitamente aplicáveis ao signo em comento, paritariamente, i.e., sem a preponderância de uma sobre a outra, posto que o signo tem o condão de tornar únicos os 
atributos do produto ou serviço (função individualizadora), ao mesmo tempo em que os distingue de seus produtos ou serviços congêneres (função distintiva).

Adicionalmente, rechaçamos, com respaldo na melhor doutrina do professor Newton Silveira, o entendimento corroborado de que a marca tem a função de indicação de qualidade, por excelência de sua natureza. Este entendimento não merece prevalecer, posto que a marca somente sinalizará a boa qualidade de um produto ou serviço se, de fato, ele merecer tal credibilidade. Caso contrário, não há que se falar em indicação de qualidade, de forma nata, do bem imaterial em estudo.

(ii) a função social. Muito embora esta função careça de exame mais acurado por grande parte da doutrina, é forçoso concluir que a marca deve atender não somente ao interesse das partes contratantes, mas, por igual, ao interesse do consumidor que nela deposita credibilidade. Tem-se, portanto, que o consumidor não pode restar prejudicado em decorrência da transferência, a título permanente ou temporário, da propriedade da marca, haja vista que uma das funções de maior relevância do sinal sub examine consiste justamente em direcionar o consumidor, de forma segura, a contrair determinado produto ou serviço com a qualidade almejada, de sorte que aquele que venha a adquirir o produto arraigado à marca licenciada tenha cognição plena acerca dos vícios e virtudes do artigo ou serviço contraído ${ }^{720}$.

(iii) a função econômica. Sem esta função, o contrato de licença de uso de marca, conforme contemporaneamente empregado, não teria a importância econômica assumida hodiernamente e, por via de conseqüência, dispensaria tutela mais aprofundada do ordenamento jurídico. Conforme largamente demonstrado, a abalizando-se em seu valor de mercado, as marcas mundiais líderes representam cifras bilionárias. Estes valores de expressiva monta, não apenas no que diz respeito às marcas líderes, mas, ainda que em menores proporções, no que atine a centenas de milhares de marcas nacionais e estrangeiras, impactam diretamente na disseminação dos contratos de licença.

\footnotetext{
720 Este entendimento é consentâneo ao posicionamento perfilhado pelo professor Newton Silveira, para quem "a tutela garantida às marcas produz efeitos que atingem, de forma indireta, os consumidores. Ao conceder ao seu titular proteção contra o rsico de confusão entre sua marca e outra de concorrente, protege-se também o interesse do consumidor que não deve ser ludibriado. (Cf. SILVEIRA, Newton. A Marca “Stolichnaya”.....op. cit.p. 174).
} 
Nesta esteira, conforme exposto na presente tese, o Brasil tem crescido admiravelmente no segmento das licenças marcárias, alcançando, no ano de 2007, aproximadamente 500 licenças, com faturamento correspondente a $\mathrm{R} \$ 3$ bilhões. Tal fato econômico, decerto, demanda pela necessidade imediata de se alcançar mecanismos jurídicos eficazes que alberguem, a contento das partes contratantes e da sociedade, o instrumento contratual objeto do presente estudo.

A despeito da discussão doutrinária incidente sobre a unificação do direito privado pelo Código Civil vigente, faz-se imperioso concluir, pautando-nos na lição disseminada pela corrente majoritária, enraizada na melhor lição do eterno mestre Miguel Reale, que o novo diploma civil trouxe à tona a unidade do direito obrigacional e, por conseguinte, do direito contratual.

Com efeito, considerando o amplo laconismo da Lei 9.279/96 com relação a cláusulas estruturais essenciais, detalhes e pormenores atinentes aos contratos de licença de uso de marca, forçoso remeter este instrumento contratual aos princípios, cláusulas gerais e dispositivos normativos insertos no Código Civil vigente. Assim, impõe-se registrar, a título conclusivo, os ensinamentos do mestre Waldírio Bulgarelli ${ }^{721}$. Leciona o comercialista que os microssistemas jurídicos, materializados nas legislações especiais, tal qual a Lei 9.279/96, são verdadeiras "normas gravitacionais que giram em torno à normação dos códigos [Código Civil], sem com eles se confundirem".

Do mesmo modo, muito embora o contrato de licença seja ventilado pelo artigo 139 da Lei da Propriedade Industrial, não foi devidamente regulamentado, nos levando a concluir, com amparo na tese ministrada por João da Gama Cerqueira, que a espécie contratual em apreço é um contrato atípico misto.

Acrescente-se, outrossim, conforme melhor doutrina de João Marcelo de Lima Assafim $^{722}$, que os contratos de transferência de tecnologia, gênero no qual se enquadra a

\footnotetext{
${ }^{721}$ BULGARELLI. Waldírio. Diretrizes Gerais dos Contratos Empresariais. in BITTAR, Carlos Alberto (coord.). Novos Contratos Empresariais. São Paulo: Ed. Revista dos Tribunais. 1990. p. 22.

${ }^{722}$ ASSAFIM, João Marcelo de Lima. A Transferência de Tecnologia no Brasil: Aspectos contratuais e concorrenciais de propriedade intelectual. Rio de Janeiro: Lumen Juris, 2005. pp. 154/155.
} 
espécie contratual em estudo, são contratos "socialmente típicos"723 e "juridicamente atípicos"724. Esta definição reside no fato que estes contratos são utilizados, com recorrência, pelo empresariado. No mais, a despeito de apresentarem um nomen iuris, não se encontram suficientemente regulamentado pelo ordenamento jurídico brasileiro. Por tal razão, são considerados atípicos.

Desta sorte, com alicerce na teoria da aplicação analógica, perpetuada pelos insignes juristas Louis Josserand, Orlando Gomes, Washington de Barros Monteiro, aos contratos de licença de uso de marca gratuitos são emprestados, quando compatíveis, elementos do contrato de comodato, ao passo que, quando o licenciamento for chancelado sobre a rubrica da remuneração, à relação jurídica serão aplicados, quando cabíveis, os dispositivos do Código Civil incidentes sobre o contrato de locação de coisas. Para o disciplinamento jurídico do contrato objeto desta tese, perfilhamos, portanto, a teoria da aplicação analógica, em que há a proximidade dos contratos atípicos com aqueles contratos típicos semelhantes, arraigada aos princípios basilares norteadores do direito contratual.

Aliado a este conceito, é indispensável que se aplique ao instrumento em análise os princípios gerais de direito contratual, consagrado pela legislação civil em vigor, amplamente delineados na presente tese, dentre o quais merecem destaque: autonomia da vontade em compensação com a função social do contrato; probidade e boa-fé objetiva, supremacia da ordem pública, intangibilidade do contrato e vedação da onerosidade excessiva.

Ditos princípios ou cláusulas gerais representam hábeis ferramentas que o sistema jurídico pátrio fornece, sobretudo ao magistrado, para que este possa aplicar a lei ao caso concreto (no caso em tela, aos contratos de licença de uso de marca), com maior flexibilidade e precisão sem, contudo, se descuidar do príncipios da legalidade, eticidade e moralidade que permeiam o ordenamento jurídico vigente. Remetendo-se ao sapiente

\footnotetext{
${ }^{723}$ Cf. BETTI, Emilio. Teoria Generale del Negozio Giuridico. $2^{\mathrm{a}}$ ed. Nápoles: Edizioni Scientifiche Italiane, 1994. pp. 192 e ss.

${ }^{724}$ O jurista italiano Vincenzo Roppo sinaliza para uma terceira modalidade de contrato: o contrato sociojurisprudencialmente típico. (Cf. ROPPO, Vincenzo. Il contratto in Trattato de Dirito Privato. VER. Giovanni Iudica e Paolo Zatti. Milão: Giufré. 2001. pp. 123 e ss).
} 
jurista italiano Stefano Rodotà, Cláudio Luiz Bueno de Godoy afiança, com profunda perceptibilidade, que a técnica legislativa que concebeu os princípios ou cláusulas gerais, "de um lado, atende justamente, como se revela a pós-modernidade, a uma realidade hipercomplexa, em constante mutação, caracterizada por uma multiplicidade social, ao contrário da norma descritiva, que supõe um futuro contínuo, imutável, ou ao menos estável, de verdades perenes; e, de outro, evita, pela sua mobilidade intrínseca, a exagerada proliferação de normatizações cada vez mais setorizadas, fato legislativo que, embora se repute inexorável, não se pode dar com a assiduidade que grassa, daí sendo provocador, veja-se, de grande insegurança" 725 .

Há que se ressaltar, contudo, que nos filiamos à corrente que defende a aplicação minimalista dos princípios sociais de direito contratual aos contratos de licença de uso de marca, modalidade contratual esta inserida no rol dos contratos empresariais. Assim se defende, porquanto a aplicação maximalista de tais princípios, a exemplo da função social e vedação à onerosidade excessiva, por certo, pode gerar enorme insegurança jurídica ao empresariado e, como corolário, profundo abalo ao bem estar social, mormente em razão da adoção de mecanismos exagerados de defesa, pelos empresários.

Conclui-se, pois, pela defesa da aplicação dos princípios gerais de direito contratual, tal como exposto na presente tese. Até porque, o enquadramento do contrato em análise a estes princípios, é conseqüência natural do próprio sistema hodierno de direito contratual positivado, até que legislação contrária lhe sobrevenha. Entretanto, com todo o respeito àqueles que se opõem a este posicionamento, condena-se a aplicação indiscriminada e maximalista destes princípios aos contratos de licença de uso de marca. Desta sorte, estes princípios gerais de direito contratual (tidos como princípios sociais) não devem ser aplicados com a mesma rigidez do que aquela verificada em relações jurídicas em que as partes encontram-se situadas em patameres desnivelados como ocorre, por exemplo, em algumas relações entre civis e, com recorrência, nas relações de consumo, sob pena de se gerar insegurança jurídica em todo o sistema econômico. E, por assim dizer, desestimular o empresariado a licenciar marca de sua titularidade, bem imaterial que, muitas das vezes, é considerado como um dos ativos mais valiosos do estabelecimento empresarial.

725 GODOY, Cláudio Luiz Bueno. Função Social do Contrato: Os Novos Princípios Contratuais. $2^{\mathrm{a}}$ ed. rev atual. São Paulo: Saraiva. 2007. (coleção prof. Agostinho Alvim. Coord. Renan Lotufo). pp. 192/193. 
Esta linha de inteligência é construída, com amparo no raciocínio de que determinadas normas gerais, tais como função social e resolução por onerosidade excessiva, por exemplo, podem gerar incerteza jurídica se indiscriminadamente aplicadas aos contratos empresariais (gênero no qual se encontra inserido o contrato de licença de uso de marca). Os contratos de licença em estudo são contratos de risco por natureza. Portanto, não podem ser modificados, simplesmente em razão de adversidades naturais decorrentes de alterações triviais verificadas no mercado. Não há que se falar em revisão contratual, com fundamento em qualquer princípio social, se a alteração observada na prestação devida por qualquer um dos contratantes derivar da "álea normal do negócio".

Neste sentido, merece destaque lição ministrada pelo professor Haroldo Malheiros Duclerc Verçosa, crítico austero da submissão dos contratos empresariais às aludidas “cláusulas sociais", para quem "os empresários exercem a sua atividade no plano do risco (que pode ser mensurado), mas detestam o da incerteza (que, por sua própria natureza, se revela um mundo impenetrável)". E assim conclui o comercialista: "E esta atividade deflui inelutavelmente com grande força dos caminhos trilhados pelo Código Civil de 2002, cujo efeito será, certamente, a tomada de medidas defensivas pelos empresários com o surgimento indefectível de efeitos de segunda ordem. Tudo isto tem o preço. E este será pago sempre pela parte mais fraca (que, lá no final da estrada, é sempre o consumidor), a não ser que o operador do direito encontre as adequadas soluções de equilíbrio" ${ }^{\text {,726 }}$.

Nesta mesma linha de inteligência, cumpre citar lição ministada pela também professora da Faculdade de Direito da Universidade de São Paulo, Vera Helena de Mello Franco, que assinala, em tom notadamente crítico, que "quem contrata tem a justa expectativa de perceber determinada contraprestação, sendo esta a razão pela qual contrata. Se assim não ocorre, não tem por quê contratar". Prosseguindo com este raciocício, assinala: “ora, na medida em que o resultado esperado não pode ser garantido [em decorrência da aplicação dos príncipios sociais de direito contratual], inexistem, mais razões para contratar". E arremata: “o respeito ao pacta sunt servanda e a execução do contratado conforme a prática do comércio (ou dos empresários) devem prevalecer, sob

726 VERÇOSA, Haroldo Malheiros Duclerc. O Código Civil de 2002 e a Crise do Contrato - Seus Efeitos nos Contratos Mercantis (Aspectos Relevantes) op. cit.... p. 331. 
pena de se destruir a instituição contrato como instrumento de circulação de riquezas, dada a ausência de segurança jurídica" 727 .

Por outro lado, também não se pode, cegamente, atribuir o prejuízo desproporcional de uma das partes simplesmente ao "risco natural do negócio" (nos contratos empresariais). Se assim for, naturalmente, gerar-se-á segurança jurídica para uma parte do empresariado e insegurança jurídica para a outra parte. Por tal razão, que cada caso, irretorquivelmente, deve ser judiciosamente sopesado. Cada caso deve, assim, ser analisado, à luz dos elementos característicos e eventos especiais que o permeiam, sem que se faça qualquer pré-julgamento; sem que se leve em conta apenas o atributo essencial deste tipo de contrato, o qual consiste na relação de cunho empresarial sujeita aos riscos normais do negócio.

Em julgado proferido em outubro de 2010, pela Corte Superior Brasileira, uma empresa de representação obteve indenização em consequência de uma profunda crise que acometeu a marca da qual esta mesma empresa de representação se valia para se apresentar no mercado. A representante exclusiva da aludida marca promoveu ação indenizatória contra a titular da marca, porque esta sociedade empresária incorreu em má-gestão administrativa, comprometendo sobremaneira a imagem da marca no mercado. A profunda crise na qual imergiu este bem imaterial ensejou a perda de numerosos contratos para a representante, fazendo com que esta ingressasse em juízo pleiteando danos morais e indenização pelos lucros que deixou de obter, em decorrência da desastrosa administração desempenhada pela empresa titular da marca. A titular do registro marcário, por seu turno, advogou a tese de que a redução das vendas de seu representante deu-se em razão da "menor sorte" deste e por conta de "meras vicissitudes do mercado". No entanto, este argumento foi frontalmente repelido pelo Tribunal Estadual, com posterior endosso pelo Superior Tribunal de Justiça, sob o argumento de que "as ilicitudes praticadas pelas empresas acionadas, ao lado de sua desorganização administrativa e contábil, que não se caracteriza como simples má administração, mas sim como manifesta conduta contrária

\footnotetext{
${ }^{727}$ Para a professora da Faculdade de Direito da USP, “a aplicação dos princípios gerais, consubstanciados atualmente no Código Civil, não pode ser vista, quando no terreno dos contratos empresariais, sob a poética luz da tutela aos menos favorecidos. Se existem dúvidas ou obscuridades, estas devem ser supridas conformes os usos e costumes usuais daquela prática negocial,e não conforme a subjetividade particular do julgador (...)" (FRANCO. Vera Helena de Mello. Os Contratos Empresariais e seu Tratamento após o advento do Código Civil de 2002. in Revista de Direito Mercantil, Industrial, Ecônomico e Financeiro. Vol. 15'/152. São Paulo: Malheiros Editores. Jan/Dez. 2009. pp. 44/45)
} 
aos princípios da ética e da boa-fé, é que provocaram os danos reclamados" naquela demanda. $^{728}$

Referente ao registro do contrato de licença de uso de marca, convém concluir que o instrumento contratual deve ser registrado no Instituto Nacional de Propriedade Industrial (INPI) para que tenha eficácia e seja exeqüível perante terceiros. Cumpre assinalar, entretanto, que a ausência deste registro não obsta, de qualquer forma, que o contrato gere efeitos inter partes. São conseqüências geradas pelo registro: (i) exclusividade da utilização do sinal distintivo pelo licenciado, na região contratualmente delimitada (naturalmente, na hipótese de o contrato fazer previsão de licença privativa de uso); (ii) possibilidade de transferência de valores ao exterior, a título de royalties, e o benefício de se proceder à dedutibilidade fiscal destes pagamentos; e (iii) legitimidade para o licenciado ingressar em juízo em defesa da marca (no evento de o contrato de licença desta forma admitir).

$\mathrm{Na}$ matéria referente à legitimidade ativa do licenciado, ante o estudo doutrinário e jurisprudencial realizado, é imperioso concluir que o licenciado terá legimitidade ativa para agir em defesa da marca licenciada, sem que se obrigue a avocar o licenciante, tão-somente na seguinte conjectura: se o licenciante, no contrato de licença de uso de marca, houver expressamente sinalizado para esta prerrogativa. Assim prescreve a Lei 9.279/96, em seu artigo 139, parágrafo único, a qual é endossada por doutrina e jurisprudência majoritárias, conforme já examinado.

No entanto, conforme oportunamente estudado, merece ponderação mais aprofundada, pelos doutrinadores, magistrados e, principalmente, pelos legisladores, o reconhecimento do direito de o licenciado exclusivo agir em defesa da marca, mesmo que sem a anuência contratual expressa por parte do licenciante (titular da marca), o que resultaria na alteração do parágrafo único, do artigo 139, da Lei 9.279/96.

\footnotetext{
${ }^{728}$ Impõe-se transcrever trecho do voto vencedor, emitido pelo Rel. Min. Sidnei Beneti, no qual este Ministro repoduz (o avalizando) trecho do acórdão recorrido (emitido pelo TJBA): “(...) Indagando-se se a repulsa dos produtos Golden Cross pelo mercado decorreu de falta de diligência dos seus dirigentes e de sua ineficiência administrativa, a resposta afirmativa se impõe. Com efeito, não há que se falar em conjuntura do mercado como causa das dificuldades financeiras e do descrédito da Golden Cross junto ao público consumidor, sendo prova contundente disso o fato de que no mesmo período todas as suas concorrentes de porte assemelhado prosperaram e ampliaram sua atuação no mercado" (Recurso Especial n. ${ }^{0}$ 970.708/BA. Terceira Turma. Superior Tribunal de Justiça. Rel. Min. Sidnei Beneti. Julg. em 26 out. 2010. Negado provimento ao Resp. V.U. Voto Vencedor. Doc. n. ${ }^{\circ} 11361631$. Relatório e Voto. pp. 5 e 6 de 11).
} 
Esta reflexão é fruto da investigação comparativa analítica, traçada ao longo da presente tese, entre o contrato objeto central desta tese (celebrado a título exclusivo) e outro contrato de propriedade intelectual análogo: o contrato de edição. Em ambos os negócios jurídicos, há o licenciamento exclusivo para a utilização de um bem imaterial. No primeiro, licencia-se a marca. No segundo, a obra autoral. Ambos possuem mecanismos jurídicos de acentuada similaridade. No contrato de edição, contudo, e com muita felicidade, doutrina e lei reconhecem a possibilidade de o editor (licenciado exclusivo) ingressar com ação contra terceiros que prejudiquem ou cometam infração contra a obra licenciada a título exclusivo, sendo dispensável a anuência do autor. No entanto, no contrato de licença de uso de marca exclusivo, esta prerrogativa somente é admissível, no evento de o licenciante (titular da marca) contratualmente consentir.

Ante as inúmeras similaridades apresentadas entre estes dois tipos de contratos de propriedade intelectual, o citado mecanismo de defesa conferido ao "editor" (legitimidade ativa in natura), por igual, também deveria ser outorgado ao "licenciado exclusivo", nos contratos de licença de uso de marca. Adicionalmente, há que se considerar os mecanismos de proteção da posse, consagrados pelo ordenamento jurídico vigente, de modo que o licenciado exclusivo (similarmente ao possuidor) detenha legitimidade ativa para agir diretamente em defesa da marca que esteja sendo usurpada por terceiros, assim como ocorre nas ações de manutenção de posse, em que o possuidor direto de um bem imóvel (ex. locatário) tem a prerrogativa legal de ingressar em juízo contra terceiros que estejam, de alguma forma, embaraçando o livre exercício da posse do imóvel alugado (turbação).

Por tais razões, merece reflexão mais aprofundada possível alteração do Artigo 139, parágrafo único, da Lei 9.279/96, de sorte que o licenciado exclusivo passe a ter a prerrogativa de ingressar diretamente em juízo contra terceiros, em defesa da marca, sem que, para isto, se faça necessária a anuência contratual do licenciante (titular da marca).

Impõe-se ressaltar que a ausência de autorização para que o licenciado atue em defesa da marca, contudo, não impede que o licenciado atue como assistente do licenciante na defesa de seus direitos sobre a marca licenciada, mesmo que o contrato de licença não preveja tal benfício. Assim se conclui ex vi do artigo 50 do Diploma Processual Civil, o qual estatui, textualmente, que "pendendo uma causa entre duas ou mais pessoas, o 
terceiro, que tiver interesse jurídico em que a sentença seja favorável a uma delas, poderá intervir no processo para assisti-la". No mais, depreende-se do parágrafo único do aludido dispositivo, que o licenciado, figurando como assistente, poderá ingressar em qualquer tipo de procedimento judicial, em qualquer grau de jurisdição, recebendo o processo no estado em que ele se encontrar quando da sua entrada.

No que atine à importação paralela e à exaustão internacional, conforme examinado, há ricos debates em torno deste intrincado tema. Não obstante opiniões contrárias bem fundamentadas, para largo filão da doutrina estas operações remanescem sendo inadmitidas pelo ordenamento jurídico pátrio, à exceção de quando houver o consentimento do titular, autorização esta que poderá, inclusive, ser expressa ou tácita (decorrente do contexto das operações comerciais e jurídicas encetadas pelas sociedades empresárias envolvidas).

Neste sentido, para que se evite qualquer interpretação equivocada acerca da permissão ou não da citada modalidade de importação, parece-nos razoável a aplicação da tese da negativa de consentimento como mecanismo de combate à importação paralela e, consequentemente, à concorrência desleal. Por esta tese, parece-nos aceitável preconizar, para maior proteção jurídica do titular da marca e de seus distribuidores exclusivos sediados em territórios estrangeiros, ser proveitoso ao titular da marca no exterior delimitar, expressa e contratualmente, o campo de atuação de seus distribuidores locais e estrangeiros, impedindo que estes vendam ou alienem o produto marcado para outros distribuidores ou importadores, sobretudo para aqueles que mantenham sede no exterior e, especialmente, em países, regiões ou continentes em que já haja distribuidor(es) ou representante(s) exclusivo(s) nomeado(s) pelo titular da marca para a comercialização de seu produto. Por certo, este mecanismo apresenta-se eficaz a inibir a chamada concorrência parasitária e evitar, desta sorte, a colidência entre distribuidores múltiplos de diferentes origens, bem como hábil o suficiente a impedir o nascimento de dispendiosas e vagarosas batalhas judiciais respeitantes à importação paralela.

Referente à confrontação realizada entre os contratos de franquia e licenciamento de uso de marca, é forçoso ponderar, conclusivamente, que, a despeito da marcante semelhança entre ambos (que reside no licenciamento do uso da marca), são acentuadas as diferenças entre estas duas espécies contratuais. 
Assim, temos as seguintes diferenças:

(i) o contrato de franquia é um contrato típico, pois que tem seu disciplinamento jurídico consignado na Lei 8.955/94 (Lei de Franchising); o contrato de licença de uso de marca, por seu turno, é um contrato atípico misto, considerando que não há disciplinamento legal específico que, minimamente, o regulamente. Desta sorte, conforme estudado, sua regulamentação no mundo jurídico pode ser extraída do diálogo de diplomas legais, tais quais a Lei 9.279/96 e o Código Civil vigente, tendo como regramentos análogos aqueles incidentes sobre o contrato de locação de coisas (quando oneroso) e sobre o contrato de comodotao (quando gratuito);

(ii) no contrato de franquia, o franqueador autoriza o uso de sua marca, permite ao franqueado promover a distribuição privativa de produtos ou serviços, além de transmitir continuamente conhecimentos técnicos (know-how), para que o franqueado opere o negócio com sucesso; no contrato de licença de uso de marca, o licenciante autoriza, sob certas condições, que o licenciado utilize a marca de sua titularidade em produtos ou serviços que, em geral, são produzidos e prestados livremente pelo próprio licenciado. Neste caso, tão-apenas a marca é licenciada. Não há, na grande maioria dos casos, a transferência de conhecimento técnico de know how sobre a fabricação, comercialização ou distribuição de produtos ou serviços;

(iii) no contrato de franquia, o franqueado tem o dever de cumprir com os procedimentos técnicos estandartizados pelo franqueador; já no contrato de licença de uso de marca, o licenciado dispõe de maior mobilidade quanto aos ajustes contratuais, uma vez que tem maior flexibilidade em gerir seu próprio negócio e não deve, ao menos em tese, se submeter ao cabedal de normas técnicas estatuídas pelo licenciante, como ocorre na franquia. Vale frisar que esta maleabilidade não impede que o licenciante exerça, prévia e posteriormente, o controle de qualidade sobre os produtos ou serviços conjugados à marca licenciada que são oferecidos pelo licenciado no mercado;

(iv) no contrato de franquia, há uma maior dificuldade em convergir com os interesses dos potenciais franqueados, especialmente pelo engessamento e uniformização das cláusulas contratuais; já no contrato de licença de uso de marca, há mais agilidade em 
captar um maior número de licenciados, especialmente em decorrência das diferenças regionais, e em razão da maior flexibilidade em alterar as cláusulas contratuais de um contrato que, em regra, não é uniformizado (como ocorre com os contratos de franquia). Com efeito, no contrato de licença de uso de marca, verifica-se maior liberdade do licenciado em ajustar e estabelecer as bases do negócio jurídico; e, por fim,

(iv) em relação ao preço, o valor pago pelo franqueado tem a finalidade de remunerar a licença do uso da marca, bem como dar ensejo à disponibilização, pelo franqueador, de: tecnologia, treinamentos e assistência técnica, promovidos pelo franqueador. No contrato de licença de uso de marca, o preço remunera somente a licença do uso da marca. Excepcionalmente, terá a finalidade de remunerar a exploração de artigos licenciados, bem como, raramente, terá o fim de pagar eventual publicidade conjunta compartilhada entre licenciador e licenciado(s).

Ante as diferenças acima assinaladas, compete ao empresário definir qual o modelo de negócio jurídico pretende adotar, sendo certo que a opção de uma figura contratual ou de outra, apesar de apresentarem objetos nucleares semelhantes, trará impactos e consequiências jurídicas cristalinamente diversas.

Com efeito, a adoção do licenciamento de uso de marca, em que o licenciado tem mais independência para criar e atuar, pode tornar a operação do empresário menos engessada do que a franquia, de modo que aquele modelo de negócio jurídico é mais apto a se afeiçoar aos hábitos, rotinas e diferentes costumes de consumo das diferentes regiões de um país de porte territorial, como é o Brasil. Adicionalmente, ao contrário do que ocorre com a franquia, o licenciamento de uso de marca permite ao licenciado, livremente, optar pelos forncededores e os produtos, de conformidade com suas necessidades, sem que, obrigatoriamente, tenha de recorrer aos fornecedores e artigos oferecidos ou indicados pelo licenciante, como ocorre na franquia. Por derradeiro, enquanto que, na franquia, o franqueado deve se utilizar da marca, em estrito cumprimento às normas estatuídas pelo franqueador, no contrato de licença de uso de marca, o licenciado tem mais liberdade para se utilizar da marca, agindo como se dela fosse titular, naturalmente respeitando as condições de exploração contratualmente estabelecidas pelas partes. 
Por fim, convém concluir para o desacerto incorrido pelo legislador, ao conceber o artigo 139, da Lei 9.279/96, mormente quando faz alusão ao "direito" de o licenciante exercer controle efetivo sobre o produto ou serviço ao qual será aposta a marca licenciada. Este dispositivo, por certo, vai na contramão do princípio contratual basilar celebrado pelo Código Civil: o princípio da função social do contrato.

Diante de toda a argumentação trazida à colação, no capítulo que se inclinou ao exame crítico do artigo 139, da Lei 9279/96, ministramos a tese de que o licenciante tem o "dever", e não o simples "direito", de fiscalizar o produto representado pelo sinal licenciado, sob pena de o consumidor quedar-se ludibriado e, por conseguinte, lesado, ao adquirir algo que não condiz com as expectativas por ele criadas, comparativamente ao produto ou serviço que antes era contraído diretamente do licenciante (titular da marca). Nesta acepção, temos que o licenciado atua, perante o público, como um verdadeiro representante do licenciante, assumindo a marca deste e se posicionando no mercado tal como se o último fosse. Eis o espírito da função social: impedir que contratos entabulados entre as partes contratantes lesem os direitos de terceiros que da contratação não tenham participado.

Com efeito, quando o diploma consumerista faz referência a fornecedor, almeja agasalhar todos aqueles que integram o ciclo de produção e distribuição, inclusive o fornecedor aparente, materializado naquele que licencia seu nome ou marca no produto final ou serviço prestado pelo licenciado ${ }^{729}$. Insta lembrar que são passíveis de responsabilização civil os fornecedores que se apresentem nas seguintes modalidades, a saber: (i) fornecedor real, compreendendo o fabricante, o produtor e o construtor; (ii) fornecedor presumido, assim entendido o importador do produto industrializado ou in natura; (iii) fornecedor aparente, ou seja, aquele que apõe seu nome ou marca no produto final. $^{730}$

\footnotetext{
729 "Segundo esse entendimento, o licenciante seria também enquadrado no conceito de fornecedor estabelecido pelo Código de Defesa do Consumidor, podendo ser diretamente acionado pelos consumidores, ainda que em decorrência de produtos vendidos ou serviços prestados por um licenciado" (Cf. IDS - Instituto Dannemann Siemsen de Estudos de Propriedade Intelectual. Comentários à lei da propriedade industrial. Ed. revista e atualizada. Rio de Janeiro: Renovar, 2005. p. 280).

${ }^{730}$ Cf. GRINOVER, Ada Pelegrini, et al. Código Brasileiro do Consumidor: Comentado pelos Autores do Anteprojeto. Rio de Janeiro: Forense Universitária, 1998, p. 145.
} 
Convergimos, outrossim, para a nulidade de cláusula entabulada em contrato de licença de uso de marca que desobrigue o licenciante de qualquer responsabilidade ocasionada em decorrência de eventuais danos gerados pelo licenciado, com arrimo no artigo 25, parágrafo $1^{\circ}$, do Código de Defesa do Consumidor.

Ademais, o licenciante, juridicamente também classificado como fornecedor aparente, pode perfeitamente ser demandado judicialmente pelos consumidores, ainda que os produtos ou serviços por estes adquiridos tenham sido produzidos e/ou oferecidos pelo licenciado (fornecedor real). É o que prescreve a doctrine of apparent authority, tese a qual nos filiamos, e que é, exaustivamente, disseminada pelo ordenamento juridico norteamericano.

Impõe-se concluir, outrossim, que a reconhecida teoria da aparência vem sendo, manifesta e recorrentemente, admitida pelo ordenamento jurídico pátrio. Esta doutrina vem sendo incisivamente aplicada pelos tribunais pátrios, os quais têm emitido decisões reiteradas, determinando que o licenciante pode ser demandado judicialmente pelo consumidor, muito embora não tenha com este contratado diretamente, devendo ser responsabilizado, como consequiência de eventuais danos gerados a terceiros, a despeito do fato de tais prejuízos serem fruto de ação ocasionada tão somente pelo licenciado e não pelo licenciante. ${ }^{731}$ Conforme demonstrado ao longo da presente tese, há, ainda, julgados mais austeros, porque se posicionam totalmente pro consumidor. Estas decisões convergem para o entendimento de que o licenciante deve indenizar o consumidor pelos prejuízos causados, concedendo ao licenciante o direito expresso de ingressar com ação de regresso contra o licenciado ${ }^{732}$. Desta forma: primeiro reponsabiliza-se o licenciante e, após, o licenciado, demonstrando, desta sorte, a colossal reponsabilidade que o licenciante deve, perenemente, manter perante o consumidor, não obstante esteja inoperante no mercado.

\footnotetext{
${ }^{731}$ Cite-se comentário ao artigo 139 da Lei 9.279/96 concernente ao "direito" do titular exercer o controle sobre o uso da marca licenciada, litteris: "Em termos práticos, a obrigação solidária do licenciante de zelar pela qualidade dos produtos ou serviços licenciados pode ser depreendida, de forma indireta, do Código de Defesa do Consumidor (CDC), como decorrência da responsabilidade solidária de qualquer parte integrante da cadeia de fornecimento de produto ou serviço" (IDS - Instituto Dannemann Siemsen de Estudos de Propriedade Intelectual. Comentários à lei da propriedade industrial.....op. cit. p. 279)

${ }^{732}$ Apelação Cível n. ${ }^{\circ}$ 7023610-1. Décima Oitava Câmara de Direito Privado. TJ/RS. Des. Rel. Roque Mesquita. Julg. em 08 de abril de 2008.
} 
Resta demonstrada, assim, a importância que se deve atribuir ao poder/dever de fiscalização exercido pelo licenciante em relação ao uso da marca licenciada. Este dever de fiscalização, a despeito de inoportunamente revogado pelo legislador que participou da elaboração do diploma que hodiernamente regula a propriedade industrial, é decorrência natural do instituto da marca, em seu viés pós-moderno, e que tem como funções capitais: evitar a concorrência deselal e proteger o consumidor ${ }^{733}$.

Parece-nos razoável, pois, em benefício da função social do contrato e do princípio da supremacia da ordem pública, o restabelecimento parcial do comando inserto no art. 90, caput, do revogado Código de Propriedade Industrial ${ }^{734}$, de sorte que os interesses dos contratantes sejam projetados em plena harmonia com os interesses sociais ${ }^{735}$. Faz-se corolário lógico de justiça reaproveitamento de preceito, repise-se extinto, para que se imponha ao licenciante a obrigação de controlar os produtos ou serviços coligados à marca licenciada, caso em que, não o exercendo, o licenciante será responsabilizado por qualquer consumidor que tenha se prejudicado como resultado da qualidade deficiente dos produtos oferecidos ou serviços prestados ${ }^{736}$.

Ante o exposto neste capítulo conclusivo, não nos parece haver proposição técnica mais adequada do que a substituição do termo "direito" consignado no caput do artigo 139 da Lei 9279/96, pela expessão "tendo o dever", bem como a inserção, ao final do caput do aludido artigo de lei, do complemento "em benefício da proteção dos interesses dos consumidores, bem como em razão da função social do contrato".

\footnotetext{
${ }^{733}$ SILVEIRA, Newton. Sinais distintivos da empresa...op. cit. p. 5.

734 "Na redação da lei anterior, tinha-se um claro dispositivo de proteção ao consumidor, aliás, assistemático no campo da propriedade industrial" (Cf. BARBOSA, Denis Borges. Proteção das Marcas: Uma Perspecitva Semiológica. Rio de Janeiro: Ed. Lúmen Juris. 2008. p. 403)

${ }^{735}$ Neste sentido, imperioso trazer à lume magistério de Mário de Camargo Sobrinho, que preleciona: “(...) Os interesses individuais das partes do contrato devem ser exercidos em consonância com os interesses sociais, não podendo apresentar conflitos, pois nessa hipótese prevalecem os interesses sociais (...)" (SOBRINHO, Mário de Camargo. Dos Contratos em Geral in MACHADO, Antônio Cláudio da Costa (org.); CHINELLATO, Silmara Juny (coord.). Código Civil Interpretado: artigo por artigo, parágrafo por parágrafo. $3^{\text {a }}$ ed. São Paulo: Manole, 2010. pp. 335/336).

736 Sobre o tema, manifestou-se Gabriel Leonardos, ao comentar o art. 90 do revogado Código de Propriedade Industrial, ipsis litteris: “(...) Se o licenciante não exerce tal controle de forma efetiva, está ele inadimplindo obrigação decorrente da lei (art. 90, caput, do CPI/71), fato que pode ensejar sua responsabilização pelo licenciado que tenha sido prejudicado pela qualidade deficiente dos mesmos" (LEONARDOS, Gabriel Francisco. Tributação da Transferência de Tecnologia. op. cit. p. 91).
} 
Parece-nos também tecnicamente adequado, à luz do cotejo realizado entre o contrato de edição e o contrato de licença de uso de marca (exclusivo), que se proceda à emenda ao Parágrafo Único, do indigitado artigo 139, de maneira que o licenciado, a título exclusivo e sem reserva de direito concedida ao titular da marca, tenha legitimidade ativa para ingressar em juízo contra terceiros usurpadores do sinal, sem a prévia e expressa autorização do licenciante (titular da marca).

De tal modo, seria de bom termo, se o referido dispositivo legal passasse a ter a seguinte nova redação:

\begin{abstract}
Art. 139. O titular de registro ou o depositante de pedido de registro poderá celebrar contrato de licença para uso da marca, tendo o dever de exercer controle efetivo sobre as especificações, natureza e qualidade dos respectivos produtos ou serviços, em benefício da proteção dos interesses dos consumidores, bem como em razão da função social do contrato.

Parágrafo único. À exceção do licenciado exclusivo, que tem plenos poderes para agir perante terceiros em defesa da marca licenciada, sem a necessária autorização prévia do licenciante, o licenciado poderá ser investido pelo titular de todos os poderes para agir em defesa da marca, sem prejuízo dos seus próprios direitos.
\end{abstract}

Seria, tão-somente, o reconhecimento de um princípio fulcral de direito contratual, recepcionado pela entrada em vigor do Código Civil de 2002, com amplo respaldo na Carta Magna Brasileira e na Lei Federal n. ${ }^{\circ}$ 8.078/90 (Código de Defesa do Consumidor), e que encontra guarida, tanto do ponto de vista doutrinário como jurisprudencial, em ambiência jurídica nacional. 


\section{REFERÊNCIAS BIBLIOGRÁFICAS}

ABRÃO, Eliane Yachoub (org.). Propriedade Imaterial: direitos autorais, propriedade industrial e bens de personalidade. São Paulo: Ed. Senac São Paulo. 2006.

. Direitos de Autor e Direitos Conexos. São Paulo: Editora do Brasil, 2002.

ABRÃO, Nelson. Da Franquia Comercial - “Franchising”. São Paulo. Ed. Revista dos Tribunais, 1984.

ADIERS, Cláudia Marins. As Importações Paralelas à Luz do Princípio da Exaustão do Direito de Marca e seus Reflexos nos Direito Contratual e Concorrencial. in Revista da AJURIS. Porto Alegre: Ano XXIX, n. 88. Dez 2002.

AMARAL, Francisco. Direito Civil: introdução. $7^{\mathrm{a}}$ ed. Rio de Janeiro: Ed. Renovar, 2008.

AMARAL, Luiz Henrique do. A Questão das Importações Paralelas: Reflexos nos Direitos Autorais. XVIII Seminário Nacional da Propriedade Intelectual - A Nova Lei de Direitos Autorais e a Extensão da Proteção da Propriedade Intelectual. Anais. 1998. São Paulo. ABPI - Associação Brasileira de Propriedade Intelectual. 1998.

ANDRADE, Jorge Pereira. Contratos de Franquia e Leasing. $3^{\text {a }}$ ed. ver. atual. São Paulo: Ed. Atlas, 1998.

ANDRIGHI, Fátima Nancy. A arbitragem: solução alternativa de conflitos. Revista da Escola Superior da Magistratura do Distrito Federal, n. 2, p. 149-173, maio/ago.

ARRUDA ALVIM NETTO, José Manoel de. Competência Internacional, Revista de Processo, São Paulo, v. 2, n.7/8, jul/dez. 1977. 
ASCARELLI, Tullio. Teoria della Concorrenza e dei Beni Immateriali. Milão: Giuffrè, 1956.

ASSAFIM, João Marcelo de Lima. A Transferência de Tecnologia no Brasil: Aspectos contratuais e concorrenciais de propriedade intelectual. Rio de Janeiro: Lumen Juris, 2005.

AUTERI, Paolo; FLORIDIA, Giorgio; MANGINI, Vito; OLIVIERI, Gustavo; RICOLFI, Marco; SPADA, P. Diritto Industriale - Proprietà Intellectuale e Concorrenza. $3^{\mathrm{a}}$ ed. G. Giappichelli Editore: Torino, 2009.

AZEVEDO, Álvaro Villaça. Teoria geral dos contratos típicos e atípicos. São Paulo: Atlas, 2002.

. O Novo Código Civil Brasileiro: tramitação; função social do contrato; boa-fé objetiva; teoria da imprevisão e, em especial, onerosidade excessiva (laesio enormis). in DELGADO, Mário Luiz e ALVES, Jones Figueiredo (Coord.). Questões Controvertidas no Novo Código Civil. Vol.2. Ed. Método. São Paulo 2004.

AZEVEDO, Antônio Junqueira de. Novos Estudos e Pareceres de Direito Privado. São Paulo: Saraiva, 2009.

BALDUCCI, Daniele. L'Affitto D'Azienda. 3ª ed. Milano: Edizioni Fag, 2007.

BARBOSA, Cláudio Roberto. Propriedade Intelectual: introdução à propriedade intelectual como informação. Rio de Janeiro: Elsevier, 2009.

BARBOSA, Denis Borges. Tributação da Propriedade Industrial e do Comércio de Tecnologia. Rio de Janeiro: Edição do INPI e da Ed. Revista dos Tribunais. 1983. Juris. 2008.

Proteção das Marcas: Uma Perspecitva Semiológica. Rio de Janeiro: Ed. Lúmen Como conciliar os ditames constitucionais da livre concorrência com o sistema de patentes? Disponível em <www.nbb.com.br>. Acesso em 10 out. 2008.

. Ensaios sobre o Direito Imaterial - Estudos Dedicados a Newton Silveira. Rio de Janeiro: Ed. Lúmen Júris. 2009.

BARRETO FILHO, Oscar. Teoria do Estabelecimento Comercial. $2^{\mathrm{a}}$ ed. São Paulo:Saraiva, 1988. 
BASSO, Maristela. A Importação Paralela e o Princípio da Exaustão. Especial Referência às Marcas. in GRAU-KUNTZ, Karin; BARBOSA, Denis Borges (org.) Ensaios sobre o Direito Imaterial - Estudos Dedicados a Newton Silveira. Rio de Janeiro: Ed. Lúmen Juris. 2009.

BASTOS, Aurélio Wander. Dicionário de Propriedade Industrial e Assuntos Conexos. Rio de Janeiro. Ed. Lúmen Júris. 1997.

BATTERSBY, Gregory J. e GRIMES, Charles W.. License Agreements: Forms and Checklists. Nova Iorque (EUA): Aspen Publishers, 2004.

BERTOLDI, Marcelo M. e RIBEIRO, Márcia Carla Pereira. Curso Avançado de Direito Comercial. $4^{\text {a }}$ ed. atualizada. São Paulo: Revista dos Tribunais. 2008.

BETTI, Emilio. Teoria Generale del Negozio Giuridico. $2^{\mathrm{a}}$ ed. Nápoles: Edizioni Scientifiche Italiane. 1994.

BILANDIC, Michael Anthony. Docket No. 79547--Agenda 11--January 1996. REGINALD O'BANNER, Appellee, v. McDONALD'S CORPORATION et al. (McDonald's Corporation, Appellant - Opinion filed May 31, 1996). Disponível em $<$ http://bulk.resource.org/courts.gov/states/Ill/79547.txt> Acesso em 05/09/09.

BITTAR, Carlos Alberto (coord.). Novos Contratos Empresariais. São Paulo: Ed. Revista dos Tribunais. 1990.

.Curso de Direito Civil. Rio de Janeiro: Forense Universitária, 1994. vol. 2.

Os Direitos de Personalidade. $3^{\text {a }}$ ed. São Paulo: Forense Universitária. 1999.

BOBBIO, Norberto. O Positivismo Jurídico: Lições de Filosofia do Direito. tradução e notas Márcio Pugliesi, Edson Bini, Carlos E. Rodrigues. São Paulo: Ed. Ícone. 1995.

BOITEUX, Fernando Netto. Contratos Mercantis. São Paulo: Ed. Dialética. 2001.

BORJA. Célio de Oliveira. Parecer - Protocolo de Madri. Revista da ABPI. Edição n. 59. jul/ago de 2002. Disponível em $<$ http://www.abpi.org.br/materiais/textospublicos/ParecerProtocolodeMadri.pdf $>$ Acesso em 10 jun. 2010. 
BRAMBILA, Silvio. A Antijuridicidade das Cláusulas Contratuais Abusivas e as Sanções do Ordenamento Jurídico. in Revista de Direito Empresarial. Curitiba. N. ${ }^{o}$ 3. jan./jun. 2005 .

BULGARELLI. Waldírio. Diretrizes Gerais dos Contratos Empresariais. Novos Contratos Empresariais. Carlos Alberto Bittar (coord.). São Paulo: Ed. Revista dos Tribunais. 1990.

.Tratado de Direito Empresarial. $3^{\text {a }}$ ed. São Paulo: Ed. Atlas S.A. 1997.

. Contratos Mercantis. 14 a ed. São Paulo. Atlas. 2001.

BURST, Jean-Jacques. Breveté et Licencie. Paris: Librairies Techniques. 1970.

CAMPINHO, Sérgio. O Direito de Empresa à Luz do Novo Código Civil. $10^{\mathrm{a}}$ ed. rev. e atual. de acordo com a Lei Complementar n. ${ }^{\circ}$ 128/2008. Rio de Janeiro: Ed. Renovar. 2009.

CARMONA. Carlos Alberto. Arbitragem e Processo - um comentário à Lei 9.307/96, São Paulo, Malheiros, 1998.

CARRAU, Juan Manuel Gutierrez. Manual teórico-práctico de marcas. Motevidéo: Fundación de Cultura Universitária, 1997.

CARVAlHO, Patrícia Luciane de (coord.). Propriedade Intelectual - Estudos em homenagem à professora Maristela Basso. $1^{\mathrm{a}}$ ed. Curitiba: Juruá Editora, 2008. vol. 2.

CASELLA, Paulo Borba. Registro Internacional de Marcas, o Brasil e o Protocolo de Madri. in CARVALHO, Patrícia Luciane (coord.). Propriedade Intelectual - Estudos em homenagem à professora Maristela Basso. $2^{\mathrm{a}}$ ed. Curitiba: Juruá Editora. 2008. v. 2.

CERQUEIRA, João da Gama, Tratado da Propriedade Industrial. Rio de Janeiro: Ed. Forense, 1946. vol. I e II.

. Tratado da Propriedade Industrial. $3^{\mathrm{a}}$ ed. Atualizada por: Newton Silveira e Denis Borges Barbosa. Rio de Janeiro: Ed. Lumen Júris. 2010. Vol.I. Parte I.

Tratado da Propriedade Industrial. $3^{\mathrm{a}}$ ed. Atualizada por: Newton Silveira e Denis Borges Barbosa. Rio de Janeiro: Ed. Lumen Júris. 2010. Vol. II. Tomo I.. Parte II. 
Tratado da Propriedade Industrial. $3^{\mathrm{a}}$ ed. Atualizada por: Newton Silveira e Denis Borges Barbosa. Rio de Janeiro: Ed. Lumen Júris. 2010. Vol.II. Tomo II. Parte III.

CHAVES. Antônio. Lições de Direito Civil - Direito das Obrigações. São Paulo: Ed. Revista dos Tribunais. 1977.

CHRISTIE, Andrew; GARE. Stephen. Blackstone's Statutes on Intellectual Property. 10 ed. Nova Iorque: Oxford University Press. 2010.

COMPARATO, Fábio Konder. Ensaios e Pareceres de Direito Empresarial. Rio de Janeiro: Ed. Forense, 1978.

O Poder de Controle na S/A. Rio de Janeiro: Ed. Forense, 1983.

COUTO, Bruno Ornub. Efeitos da Averbação de Contratos no INPI. in "XX Seminário da Propriedade Intelectual. Proteção da Tecnologia e das Criações Intelectuais no II Milênio. Anais 2000". São Paulo. Public. ABPI - Associação Brasileira da Propriedade Intelectual. 2000.

COUTO E SILVA, Clóvis V. do. A obrigação como processo. São Paulo. Ed. José Bushatsky, 1976.

CRESCITELLI, Edson, "O Licenciamento de Marcas. Estudo de Caso: Mattel do BrasilMarcaBarbie”. Disponívelem<www.ead.fea.usp.br/Semead/10semead/sistema/result ado/trabalhosPDF/48.pdf>. Sítio acessado em 30/10/2008.

CRETELLA NETO, José. Contrato Internacional de Franchising. Rio de Janeiro: Ed. Forense. 2000.

DAVISON, Mark J.; MONOTTI, Ann L. e WISEMAN, Leanne. Australian Intellectual Property Law. Nova Iorque: Cambridge University Press, 2008.

DE MARTINO, Douglas L., "Pennsylvania Superior Court Expands Vicarious Liability To American Companies For The Actions Of A Wholly-Owned Foreign Subsidiary: The Doctrine Of Apparent Authority". Disponivel em $<$ http://www.marshalldennehey.com/CM/DefenseDigest/DefenseDigest619.asp> Sítio acessado em 04/09/2009. 
DE MATTIA, Fábio Maria. O Autor e o Editor na Obra Gráfica - Direitos e Deveres. São Paulo: Ed. Saraiva. 1975.

DI BIASI, Gabriel. A Propriedade Industrial: Os Sistemas de Marcas, Patentes, Desenhos Industriais e Transferência de Tecnologia. $3^{\mathrm{a}}$ ed. rev. e atual. Rio de Janeiro: Ed. Forense. 2010.

DIESENDRUCK, Elcan. Com Licença. São Paulo: Nobel, 2000.

DINIZ, Maria Helena. Curso de Direito Civil Brasileiro: Teoria das Obrigações Contratuais e Extracontratuais. 6. ed. São Paulo: Saraiva, 1995. v. 3. . Dicionário Jurídico. São Paulo. Saraiva. 1998.

—. Tratado Teórico e Prático dos Contratos. $4^{\mathrm{a}}$ ed. São Paulo, Saraiva, 2002. vol. 4. .Curso de Direito Civil Brasileiro, Teoria das Obrigações Contratuais e Extracontratuais, 20ª edição, São Paulo: Ed. Saraiva. 2004.

- Curso de Direito Civil Brasileiro. Teoria das Obrigações Contratuais e Extracontratuais. 23a ed. São Paulo: Ed. Saraiva. 2007. v. 3. . Código Civil Anotado. 13ª ed. São Paulo. Ed. Saraiva. 2008.

DOMINGUES, Douglas Gabriel. Marcas e Expressões de Propaganda. São Paulo: Ed. Forense, 1984.

DOWER, Nélson Godoy Bassil. Curso Moderno de Direito Civil, Contratos e Responsabilidade Civil, 3a edição, São Paulo: Ed. Nelpa. 2007.

EICHIN-AMARAL. Pedro. Arbitragem Internacional em Propriedade Intelectual. in Revista Brasileira de Arbitragem n. ${ }^{o}$ 13. São Paulo. Editora Thonson/IOB. Jan-Mar. 2007. pp. 7-23.

ESPÍNOLA, Eduardo; e ESPÍNOLA FILHO, Eduardo. A Lei da Introdução ao Código Civil Brasileiro. 2. ed. atual. por Sílvia Pacheco. V. 1. Rio de Janeiro: Renovar, 1999.

FAZZIO JÚNIOR, Waldo. Manual de Direito Comercial. São Paulo: Ed. Atlas. 2007. 
FERNANDES, Wanderlei (coord.). Fundamentos e Princípios dos Contratos Empresariais. $1^{\text {a }}$ ed. Série GV Law. São Paulo: Saraiva. 2007. pp.75-155.

FERNÁNDEZ-NOVOA, Carlos. Fundamento del derechtito de marcas. Madrid. Editorial Montecorvo, 1984.

FERREIRA, Waldemar. Tratado de Direito Comercial. São Paulo: Ed. Saraiva, 1962. vol. 6.

FERREIRA FILHO, Manoel Gonçalves. Curso de Direito Constitucional. $25^{\mathrm{a}}$ ed. rev. São Paulo: Saraiva. 1999.

FIUZA, César. Direito Civil Completo. 11ª ed. Belo Horizonte: Ed. Del Rey, 2008.

FORGIONI. Paula Andréa. Interpretação dos Negócios Empresariais. in FERNANDES, Wanderlei (coord.). Fundamentos e Princípios dos Contratos Empresariais. $1^{\mathrm{a}}$ ed. Série GV Law. São Paulo: Saraiva. 2007. pp.75-155.

Importações Paralelas no Brasil: a Propriedade Industrial nos Quadrantes dos Princípios Constitucionais. in GRAU-KUNTZ, Karin; BARBOSA, Denis Borges (org.) Ensaios sobre o Direito Imaterial - Estudos Dedicados a Newton Silveira. Rio de Janeiro: Ed. Lúmen Juris. 2009.

FRANCESCHELLI, Remo. Sui Marchi Di Impresa. Milano: Dott A. Giuffrà Editore. 1988.

FRANCO, Vera Helena de Mello. Os Contratos Empresariais e seu tratamento após o advento do Código Civil de 2002. in Revista de Direito Mercantil, Industrial, Ecônomico e Financeiro. Vol. 15'/152. São Paulo: Malheiros Editores. Jan/Dez. 2009. pp. 22-46.

GARCIA, Balmes Vega. Direito e Tecnologia: Regime Jurídico da Ciência, Tecnologia e Inovação. São Paulo: LTr, 2008.

GNOCCHI, Alexandre, Licenças e Roialtes no Brasil, São Paulo: Ed. Revista dos Tribunais, 1960.

GODOY, Cláudio Luiz Bueno. Função Social do Contrato: Os Novos Princípios Contratuais. $2^{\mathrm{a}}$ ed. rev atual. São Paulo: Saraiva. 2007. (coleção prof. Agostinho Alvim. Coord. Renan Lotufo). 
GOMES, Orlando. Obrigações. 13 ${ }^{\mathrm{a}}$ ed. Rio de janeiro. Ed. Forense. 2000. Contratos. 22 $2^{\mathrm{a}}$ ed. Rio de Janeiro. Ed. Forense. 2000.

GONÇALVES, Carlos Roberto. Direito Civil Brasileiro - Contratos e Atos Unilaterais. São Paulo: Ed. Saraiva. 2004, vol. 3.

Direito Civil Brasileiro: contratos e atos unilaterais. $3^{\text {a }}$ ed. São Paulo: Ed. Saraiva, 2007. Vol. 3.

GONÇALVES, Luís M. Couto. Manual de Direito Industrial: Patentes, Marcas, Concorrência Desleal. $2^{a}$ ed. rev. e aumentada. Coimbra: Almedina. 2008.

GONÇALVES NETO. Alfredo de Assis. Manual de Direito Comercial. $2^{\mathrm{a}}$ ed. Curitiba: Juruá. 2000.

GRAU, Eros Roberto. Função Social da Propriedade. Enciclopédia do Direito. Vol. 39. São Paulo: Saraiva, 1979. . O Estado, a empresa e o contrato. São Paulo: Malheiros, 2005.

GRAU-KUNTZ, Karin e SILVEIRA, Newton. A Exaustão do Direito de Marca na União Europeia e o Mercosul. in Revista de Direito Mercantil, Industrial, Econômico e Financeiro. São Paulo: Ed. Malheiros. Ano XXXVI (nova série), n. 106. abril-junho. 1997.

GRINOVER, Ada Pelegrini, et al. Código Brasileiro do Consumidor: comentado pelos autores do anteprojeto. Rio de Janeiro: Forense Universitária, 1998.

HAIDAR, Rodrigo. Estrutura do INPI é obstáculo para adesão ao Protocolo de Madri. Artigo Jurídico publicado na revista Update, da Câmara Americana de Comércio. Disponível em <http://www.conjur.com.br/2005-jun05/estrutura_inpi_obstaculo_adesao_brasil>. Acesso em 11 jun. 2010.

HALLET, Peter. Licensing Trade Marks: What you need to know. Disponível em $<$ http://www.managingip.com/Article/659949/Licensing-trade-marks-what-you-need-toknow.html> Acesso em 22/12/2009.

HANUAGGE, Vinicius Elias. Nótulas sobre a unificação do direito privado brasileiro. Revista de Direito Empresarial. Curitiba. N. 7. 286 p. jan/jun 2007. 
HEATH, Christopher. ROHL, Wilhelm (ed.), History of Law in Japan. Leinden. Ed. Koninklijke Brill NV, 2005.

HIGUCHI, Hiromi; HIGUCHI, Fábio Hiroshi; e HIGUCHI, Celso Hiroyuki. Imposto de Renda das Empresas - Interpretação e Prática. rev. e atual. até. 10.01.2009. São Paulo: IR Publicações, 2009.

HIRONAKA, Giselda Maria Fernandes Novaes. A função social do contrato. Direito Civil: estudos. Belo Horizonte: Ed. Del Rey. 2000.

Novo Código Civil brasileiro - o que muda na vida do cidadão. Seminário realizado na Câmara dos Deputados em 04 jun. 02. Disponível em <www2.camara.gov.br/conheça/ouvidoria/seminários/1partecodigocivil.html>. Acesso em 30 nov. 2008.

Contrato: estrutura milenar de fundação do direito privado - renovando a crise e renovando princípios, no início do vigésimo primeiro século, ao tempo da transição legislativa brasileira. Disponível em <http://www.flaviotartuce.adv.br/secoes/artigosc.asp> Acesso em 20 set. 2010.

IDS, Instituto Dannemann Siemsen de Estudos de Propriedade Intelectual. Comentários à lei da propriedade industrial. Ed. revista e atualizada. Rio de Janeiro: Renovar, 2005.

JABUR, Wilson Pinheiro; SANTOS, Manoel J. Pereira dos (coord). Propriedade Intelectual - Contratos de Propriedade Industrial e Novas Tecnologias. São Paulo: Ed. Saraiva, 2007.

JENNINGS, John. University Trademark Licensing: Creating Value Through a "WinWin” Agreement. WIPO. Disponível em: $<$ http://www.wipo.int/sme/en/documents/uni_trademark_licensing.html $>$. Acesso em: 30/09/09.

KAUFMAN, Roy S., Art Law Handbook. Nova Iorque: Aspen Publishers, 2000.

KELSEN, Hans. Teoria Pura do Direito. tradução João Baptista Machado. $6^{\text {a }}$ ed. São Paulo: Ed. Martins fontes. 1998.

KHOURI, Paulo R. Roque. A revisão judicial dos contratos no Novo Código Civil, Código do Consumidor e Lei 8.663/1993. São Paulo: Atlas. 2006. 
KUMPEL, Vitor Frederico. Direito Civil 3 - Direito dos Contratos. São Paulo: Ed. Saraiva, 2005.

LADAS, Stephen. Patents, trademarks and related rights - National and Internation Protection. Cambridge: Harvard University Press, 1975. vol II.

LANDES, William M.; POSNER, Richard A. The economic structure of Intellectual Property Law. London. The Beolknap Press of Harvard University Press. 2003.

LẼ̃ES, Luiz Gastão Paes de Barros. Pareceres. São Paulo: Ed. Singular. 2004. vol. 1.

LEDESMA, Julio C. Funcion Social de Las Marcas de Fabrica y de Comercio. Buenos Aires: Ed. Valério Abeledo. 1954.

LEONARDOS, Gabriel Francisco. Tributação da Transferência de Tecnologia. Rio de Janeiro: Forense, 2001.

LEONARDOS, Luiz. O Contrato de Licença para Exploração de Privilégio de Invenção e para o Uso de Marca - Tentativa de Análise Jurídica. In: ROSA, Rosa Cioni (coord.). Anuário da Propriedade Industrial. São Paulo: 1978, Ano II, Número 2.

LIPPERT, Márcia Mallmann. A Empresa no Código Civil - Elemento de Unificação do Direito Privado. São Paulo. Ed. Revista dos Tribunais. 2003.

LOBO, Jorge. Contrato de “Franchising”. Rio de Janeiro: Ed. Forense, 2000.

LOBO, Thomaz Thedim. Introdução à nova Lei de Propriedade Industrial, São Paulo: Ed. Atlas, 1997.

LOPES, Miguel Maria de Serpa. Comentário Teórico Prático da Lei de Introdução ao Código Civil. 2 a ed. Rio de Janeiro: Ed. Forense, 1959, vol. 2. . Curso de Direito Civil. $9^{\mathrm{a}}$ ed. Rio de Janeiro: Ed. Freitas Bastos. 2000. vol. 4. 
LOPES DE SÁ, Antônio. Os valores intangíveis da riqueza patrimonial e a contabilidade do intelectual. Disponível em: <http://www.lopesdesa.com.br/intangiveis.html>. Acesso em: 10/10/2008.

LOPEZ, Teresa Ancona. Comentários ao Código Civil. São Paulo: Saraiva, 2003, vol. 7.

LOUREIRO, Luiz Guilherme. A Lei de Propriedade Industrial Comentada (Lei n. 9.279 de 14 de mai de 1996). São Paulo. Ed. Lejus. 1999.

. Contratos no Novo Código Civil: teoria geral e contratos em espécie. $2^{\mathrm{a}}$ ed. rev. e atual. São Paulo: Ed. Método, 2004.

MACHADO, Antônio Cláudio da Costa (org.); CHINELlATO, Silmara Juny (coord.). Código Civil Interpretado: artigo por artigo, parágrafo por parágrafo. $3^{\mathrm{a}}$ ed. São Paulo: Manole, 2010.

MAGALHÃES, José Carlos de \& BAPTISTA, Luiz Olavo. Arbitragem comercial. Rio de Janeiro: Freitas Bastos, 1986.

MARIANI. Irineu. Contratos Empresariais: atualizados pelo Código Civil de 2002 e leis posteriores. Porto Alegre: Ed. Livraria do Advogado, 2007.

MARKY, Thomas. Curso elementar de direito romano. 8. ed. São Paulo: Ed. Saraiva. 1995.

MARTINS, Fran. Contratos e Obrigações Comerciais. $9^{\text {a }}$ ed. Rio de Janeiro. Ed. Forense. 1998.

Curso de Direito Comercial: empresa comercial, empresários individuais, microempresas, sociedades empresárias, fundo de comércio. $33^{\mathrm{a}}$ ed. rev. e atual. por Carlos Henriue Abrão. Rio de Janeiro: Forense. 2010.

MARTINS-COSTA. Judith Hofmeister. A boa-fé no direito privado: sistema e tópica no processo obrigacional. São Paulo: Revista dos Tribunais, 1999.

.O Direito Privado como um "sistema em construção": as cláusulas gerais no Projeto do Código Civil brasileiro. Jus Navegandi, Teresina, ano 4, n. 41, maio 2000. Disponível em: <http://jus2.uol.com.br/doutrina/texto.asp?id=513>. Acesso em 04/11/2008. 
MENDONÇA, José Xavier Carvalho de, Tratado de Direito Comercial Brasileiro. $2^{\mathrm{a}}$ ed. vol. V. Livro III. Rio de Janeiro. Ed. Freitas Bastos. 1934.

. Tratado de Direito Comercial Brasileiro. Rio de Janeiro: Freitas Bastos. $6^{\mathrm{a}}$ ed., 1957. v. 5.

MIRANDA, Francisco Cavalcanti Pontes de. Tratado de Direito Privado. Rio de Janeiro: Ed. Borsoi. 1954. vol. 22.

Tratado de Direito Privado. Rio de Janeiro: Ed. Borsoi. 1956. vol. 16.

.Tratado de Direito Privado. Rio de Janeiro: Ed. Borsoi. 1958. vol. 47.

.Tratado de Direito Privado. atual. por Vilson Rodrigues Alves. Campinas: Bookseller. 2003. tomo XXV.

MIRANDA JÚNIOR, Darcy Arruda. Curso de Direito Comercial. 6 ${ }^{\mathrm{a}}$ ed. rev., atual e aum. São Paulo: Saraiva. 1987. vol. 1.

MONTANÉS, Maria Isabel. Protocolo de Madrid - Vantagens e Desvantagens para o Brasil. Revista Jurídica Consulex $\mathrm{n}^{\circ} 297$. Disponível em $<$ http://profbadaro.blogspot.com/2010/05/protocolo-de-madri-vantagens-e.html> Acesso em 09 jun. 2010.

MONTEIRO. Washington de Barros. Curso de Direito Civil. $8^{\text {a }}$ ed. São Paulo: Ed. Saraiva, 1972. $1979.5^{\circ}$ vol.

Curso de Direito Civil. Direito das Obrigações. $14^{\text {a }}$ ed. São Paulo. Ed. Saraiva. Curso de Direito Civil: Direito das Obrigações - 2. ${ }^{a}$ parte. $27^{\mathrm{a}}$ ed. São Paulo, Saraiva. 1994. v. 5.

Curso de Direito Civil: Direito das Obrigações: $2^{a}$ Parte - Dos Contratos em Geral, das Várias Espécies de Contrato, dos Atos Unilaterais, da Responsabilidade Civil. $35^{\text {a }}$ ed. ver. e atual. Carlos Alberto Dabus Maluf e Regina Beatriz Tavares da Silva. São Paulo: Ed. Saraiva, 2007. v. 5.

MORENO, P.C. Breuer. Tratado de Marcas de Fábrica y Comercio. Buenos Aires: Jesús Menéndez, 1937.

MORO, Maitê Cecília Fabbri. Direito de Marcas: abordagem das marcas notórias da Lei 9.279/1996 e nos acordos internacionais. São Paulo: Ed. Revista dos Tribunais, 2003. 
NADER, Paulo. Curso de Direito Civil-Obrigações. São Paulo: Forense, 2005. vol. 2.

Curso de Direito Civil. $2^{\mathrm{a}}$ ed. São Paulo: Ed. Forense. 2005. vol. 3.

NEGRÃO, Ricardo. Manual de Direito Comercial e de Empresa. $3^{\mathrm{a}}$ ed. São Paulo: Saraiva, 2003, v. 1.

Direito Empresarial - Estudo Unificado. São Paulo: Ed. Saraiva. 2008.

NEGRÃO, Theotônio; GOUVÊA, José Roberto Ferreira. Código de Processo Civil e Legislação Processual em Vigor. 39ª ed. atual. São Paulo: Ed. Saraiva. 2007.

NERY JUNIOR, Nelson. Código Civil Comentado. 6 ${ }^{\mathrm{a}}$ ed. São Paulo. Ed. Revista dos Tribunais, 2008.

NETO, Abílio; CORREIA, Miguel J.A. Pupo. Propriedade Industrial - Legislação Anotada. Lisboa: Ed, Petrony. 1982.

NETO, João Hora. O Princípio da Função Social do Contrato no Novo Código Civil. Disponível em <http://jus2.uol.com.br/doutrina/texto.asp?id=8262>. Acesso em 28/11/2008.

NEVES, Silvério das; VICECONTI, Paulo E. V.; e SILVA JR., Francisco Aguiar da. Curso prático de imposto de renda pessoas jurídica e tributos conexos (CSLL, PIS e COFINS). 14 a ed. rev. e ampl. São Paulo: Frase Editora, 2009.

OIKAWA, Alysson Hautsch. A importação paralela e a licença de marca. in Jornal Valor Econômico, publicado em 19/01/2007, Legislação \& Tributos, p. E2.

OLIVEIRA, James Eduardo. Código Civil anotado e comentado: doutrina $e$ jurisprudência. Rio de Janeiro: Ed. Forense, 2009.

PACHECO, José da Silva. Tratado de Direito Empresarial: Empresário: pessoa e patrimônio. São Paulo: Ed. Saraiva. 1979. vols. 1 e 2.

PAES, Paulo Roberto Tavares. Propriedade Industrial. $2^{\mathrm{a}}$ ed., revista e ampliada. São Paulo: Ed. Saraiva. 1987. 
.Nova Lei da Propriedade Industrial. Lei 9.279, de 14.05.1996., São Paulo: Ed. Revista dos Tribunais, 1996.

PALMA, João Augusto da. Novo Código Civil e Comercial. São Paulo. Ed. Ltr. São Paulo. 2005.

PEREIRA, Cáio Mário da Silva. Instituições de Direito Civil. $8^{\mathrm{a}}$ ed. Rio de Janeiro: Forense, 1990. Instituições de Direito Civil. 19ª ed. Rio de janeiro. Ed. Forense. 1998. v.1. Instituições de direito civil. $11^{\mathrm{a}}$ ed. Rio de Janeiro: Forense, 2003, v. III Instituições de Direito Civil. 12a ed. Rio de Janeiro: Forense, 2006. vol. III. Instituições de Direito Civil - Contratos. 13a ed. Rio de Janeiro: Ed. Forense. 2009.

PEREIRA JR., Antônio Jorge; JABUR, Gilberto Haddad (coord.). Direito dos Contratos. São Paulo: Ed. Quartier Latin, 2006.

PFAFF, Dieter. Conflict of Law Aspects of License Contracts in Germany and Socialist Countries. In International Reviews of Industrial Property and Copyright Law, vol. 8, n.1.

PINTO, Carlos Alberto da Mota. Teoria Geral do Direito Civil. $4^{\mathrm{a}}$ ed. atual. por Antônio Pinto Monteiro e Paulo Mota Pinto. Coimbra. Ed. Coimbra. 2005.

PIZZOL, Patrícia Miranda. Código de Processo Civil Interpretado. Antonio Carlos Marcato (coord). São Paulo: Ed. Atlas, 2004.

PLASSERAUD, Yves. DEHAUT, Martine e PLASSERAUD, Claude. Marques. Creation, valorisation e protection. Paris: Edition Francis Lefebvre. 1994.

POUILLET, Eugene. Traite des marques de fabrique et de la concurrence deloyale en Tous. $6^{\mathrm{a}}$ ed. Paris: Marchal \& Billard, 1912.

PROGOFF, Susan. Understanding the Intellectual Property License. Nova Iorque (EUA): Practising Law Institute, 2004.

REALE, Miguel. Lições Preliminares de Direito. 24ª ed. São Paulo: Ed. Saraiva. 1998. 
Visão Geral do Projeto de Código Civil. Revista Literária de Direito. 23/8-13. Ano 4. São Paulo, maio-junho/1998.

. O Projeto do Novo Código Civil. São Paulo. Saraiva. 1999.

REQUIÃO, Rubens. Curso de Direito Comercial. 23a atual. São Paulo: Ed. Saraiva, 1998. vol. 1 .

Curso de Direito Comercial. 25ª ed. atual. São Paulo: Saraiva, 2003. vol. 1.

RIES AL e TROUT, Jack. Posicionamento. A Batalha por sua Mente. São Paulo: Prenice Hall, 2002.

RIOTTO, Charlles. O licenciamento no mundo: uma visão geral. Artigo publicado em 04 de abril de 2005.2 Disponível em $<$ http://www.abral.org.br/default.asp?tp=1\&pag=noticia/licenciamento.htm $>$. Acesso em 20 out. 2008.

RIZZARDO, Arnaldo. Contratos. 3ª ed. Rio de Janeiro: Ed. Forense, 2004.

. Contratos. $6^{\mathrm{a}}$ ed. Rio de Janeiro: Ed. Forense, 2006.

RODRIGUES, Frederico Viana. Direito de Empresa no Novo Código Civil. Rio de Janeiro. Ed. Forense. 2004.

RODRIGUES, Sílvio. Direito civil - Direito das Coisas. São Paulo. Editora Saraiva, São Paulo. 1997.

. Direito Civil: dos contratos e das declarações unilaterais de vontade.. $27^{\mathrm{a}}$ ed. São Paulo: Saraiva. 2000. vol. 3.

Direito civil - Direito das Coisas. $28^{a}$ ed. São Paulo. Saraiva. 2003. vol. 5.

ROPPO, Enzo. O Contrato. Tradução de Ana Coimbra e M. Januário C. Gomes. Coimbra: Almedina. 1998.

ROPPO, Vincenzo. Il contratto in Trattato de Dirito Privato. Rev. Giovanni Iudica e Paolo Zatti. Milão: Giufré. 2001.

ROUBIER, Paul. Le Droit de la Propriété Industriellle. Paris : Recueil Sirey, 1952. Vol.II. 
Sirey. 1954.

Le Droit de La Propriété Industrielle. $5^{\mathrm{a}}$ ed. vol.III-IV. Paris. Ed. Du Recueil . "Licences et Exclusivités” in Annales de Droit Comercial Français, Etranger et International. Paris: Tomo 45. 1954.

SALLES, Marcos Paulo de Almeida. O Signo que Marca. Revista do Advogado. Ano XXVIII. N. ${ }^{\circ}$ 96. Março de 2008.

SANCHES, Neuza. Show Biz: A Marca da Loira. Revista Veja, São Paulo, pp. 126/127, 29 abr. 1998. <http://www.veja.com.br/acervodigital/home.aspx>. Acesso em 04 de março de 2009.

SARDINHA, Gustavo Augusto Hanum. Marca Comercial: Quanto Vale a Sua? Avaliação estratégica de marcas, aspectos legais e contábeis e casos práticos. Curitiba: Ed. Juruá, 2009.

SENA. Giuseppe. I Diritti Sulle Invenzioni e Sui Modelli Industriali. Milão. Dott. A. Giuffrè Editore. 1976.

SHERMAN, Andrew J. Franchising \& Licensing: Two powerful ways to grow your business in any economy”. 3a ed. Nova Iorquer (EUA): Amacom. 2004.

SILVA, De Plácido. Vocabulário Jurídico. 14ª ed. Rio de Janeiro: Forense, 1998.

SILVA, Regina Beatriz Tavares da. Vocabulário Jurídico. 15a ed. Atual. Nagib Slaibi Filho e Geraldo Magela Alves. Rio de Janeiro: Forense, 1999.

_ (coord.).Código Civil Comentado. 6 $6^{\mathrm{a}}$ ed. São Paulo: Ed. Saraiva, 2008.

SILVEIRA, Newton. A Propriedade Intelectual e as Novas Leis Autorais. $2^{\mathrm{a}}$ ed. São Paulo: Revista dos Tribunais. 1982. 1984.

. Licença de Uso de Marca e Outros Sinais Distintivos. São Paulo. Ed. Saraiva.

A propriedade intelectual e a nova lei de propriedade industrial (Lei 9279 de 14/05/1996). São Paulo: Ed. Saraiva. 1996.

. A Propriedade Intelectual no Novo Código Civil Brasileiro. in "Revista de Direito Empresarial". Curitiba. N.2. jul/dez. 2004. p. 195-117. 
SILVEIRA, Wilson (org.). Estudos e Pareceres de Propriedade Intelectual. Rio de Janeiro: Ed. Lúmen Júris. 2008.

. Sinais Distintivos da Empresa. in "Revista da ABPI- Associação Brasileira da Propriedade Intelectual. São Paulo: ABPI. n. ${ }^{\circ}$ 98. jan/fev 2009.

A propriedade intelectual no novo código civil brasileiro. Disponivel em <http://www.silveiraadvogados.com.br/show_artigo.php?id=52>. Acesso em $10 \mathrm{fev} .2010$.

Marcas: signo do empresário a título originário e a título derivado. Disponível em <http://www.silveiraadvogados.com.br/show_artigo.php?id=66>. Acesso em $20 \mathrm{de}$ maio de 2010.

SILVEIRA, Wilson. Parecer. Revista ABPI. Edição n. 75. São Paulo. Março/Abril 2005. Disponível em <http://www.abpi.org.br/resolucoes/resolucao23.htm> Acesso em 10 jun. 2010.

SIMÃo, José Fernando. Direito Civil: Contratos. $2^{\mathrm{a}}$ ed. São Paulo: Ed. Atlas, 2007 (série leituras jurídicas); v. 5.

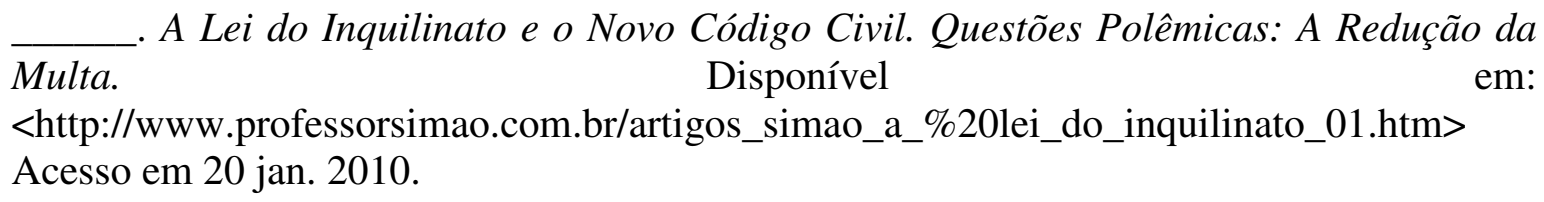

SIMÃO FILHO, Adalberto. Franchising - Aspectos Jurídicos e Contratuais. $3^{\mathrm{a}}$ ed. São Paulo: Ed, Atlas S/A. 1998.

SOARES, José Carlos Tinoco. Lei de Patentes, Marcas e Direitos Conexos. Lei 9.279 de 1996. São Paulo. Ed. Revista dos Tribunais. 1997.

STRENGER, Irineu. Marcas e Patentes. 2a ed. São Paulo: Ed. LTr. 2004.

TARTUCE, Flávio. Direito Civil, v.3: Teoria Geral dos Contratos e Contratos em Espécie. $2^{\mathrm{a}}$ ed. São Paulo. Ed. Método. 2007.

THEODORO JUNIOR, Humberto. O Contrato Imobiliário e a Legislação Tutelar do Consumo. São Paulo: Ed. Forense. 2003.

. Do contrato de agência e distribuição no Novo Código Civil. Artigo public. em 29/09/2005. Disponível em: 
$<$ http://www.mundojuridico.adv.br/sis_artigos/artigos.asp?codigo=645>. Acesso em $12 / 11 / 2008$.

TOMAZETTE, Marlon. A Proteção ao Nome Empresarial. Jus Navegandi, Teresina, ano 10, n. 1062, 29 maio 2006.2 Disponível em: $<$ http://jus2.uol.com.br/doutrina/texto.asp?id=8456>.

VALERI, Giuseppe. Manuale di Diritto Commerciale. Firenze: Casa Editrice Dottore Carlo Cya, 1950, v. II.

VARELLA, Marcelo Dias (org. e co-autor). Propriedade Intelectual e Desenvolvimento. São Paulo: Lex editora, 2005.

VENOSA, Sílvio de Salvo. Direito Civil: Contratos em espécie e responsabilidade civil. São Paulo. Atlas. 2001. vol.3.

. Direito Civil: teoria geral das obrigações e teoria geral dos contratos. $6^{\mathrm{a}}$ ed. São Paulo: Atlas, 2006. vol .2.

Direito Civil, Teoria Geral das Obrigações e Teoria Geral dos Contratos, $7^{\mathrm{a}}$ ed., São Paulo: Ed. Atlas. 2007. vol. 2. vol.3. Direito Civil: Contratos em Espécie. $7^{\mathrm{a}}$ ed. São Paulo: Ed. Atlas S.A. 2007.

VERÇOSA, Haroldo Malheiros Duclerc. Curso de Direito Comercial. $2^{\mathrm{a}}$ ed. São Paulo: Ed. Malheiros. 2008. vol. 1.

O Código Civil de 2002 e a Crise do Contrato - Seus Efeitos nos Contratos Mercantis (Aspectos Relevantes). Tese para Concurso de Livre-Docência para o Departamento de Direito Comercial da Faculdade de Direito da Universidade de São Paulo. São Paulo. 2009.

VIVANTE, Cesare. Instituições de Direito Comercial. 2a ed. São Paulo: Ed. Minelli. 2007.

VIEGAS, Juliana Laura Bruna. Efeitos da Averbação de Contratos no INPI. in "XX Seminário da Propriedade Intelectual. Proteção da Tecnologia e das Criações Intelectuais no II Milênio. Anais 2000". São Paulo. Public. ABPI - Associação Brasileira da Propriedade Intelectual. 2000. 
VIEGAS, Juliana Laura Bruna; NUNES, Luiz Antonio Ricco e DANNEMANN, Pert E. (org.). XIX Seminário Nacional de Propriedade Intelectual - A Propriedade Intelectual no Século XXI. São Paulo: ABPI - Associação Brasileira de Propriedade Intelectual. 1999.

WALD, Arnoldo. Obrigações e Contratos. $14^{\mathrm{a}}$ ed. rev. atual. colaboração do prof. Semy Glanz. São Paulo: Ed. Revista dos Tribunais. 2000.

Direito Civil - Contratos em Espécie. $18^{\mathrm{a}}$ ed. ed. rev. atual. colaboração do prof. Semy Glanz. São Paulo: Ed. Saraiva. 2009.

WILKOF, Neil e BURKITT, Daniel. Trademark Licensing. $2^{\mathrm{a}}$ ed. Londres. Ed. Thomson, Sweet \& Maxwell, 2005. 


\title{
- XI -
}

\begin{abstract}
Anexo
As informações constantes da minuta que adiante se apresenta, concernentes aos nomes e qualificação das partes e seus representantes; e nome e qualificação da marca, são integralmente fictícias, sendo que, qualquer semelhança com a vida real, certamente, terá sido mera coincidência.
\end{abstract}

\section{CONTRATO}

DE

\section{LICENÇA DE USO DE MARCA REMUNERADO}

entre

MiNISTER LTDA.

COMO LICENCIANTE

e

INTELLECTUAL LTDA.

COMO LICENCIADA 


\section{ÍNDICE}

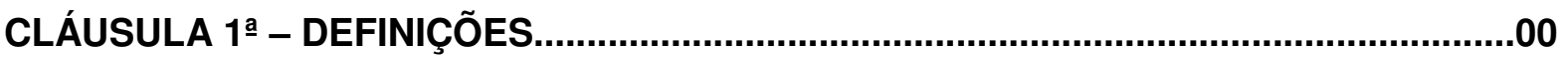

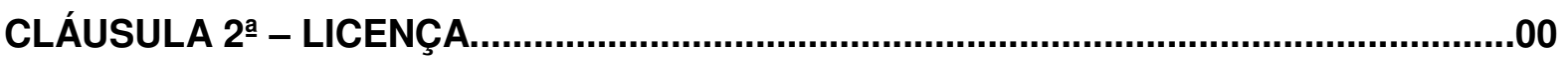

CLÁUSULA 3 3 $^{\text {- SUB }}$

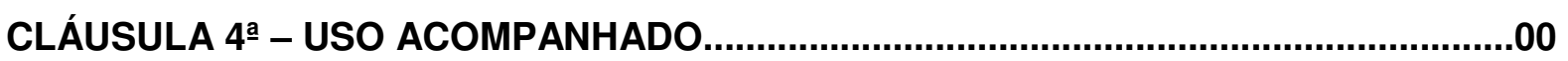

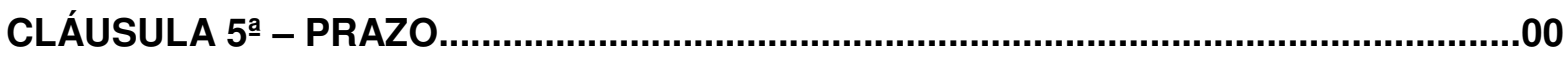

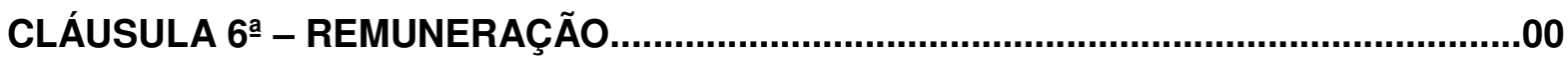

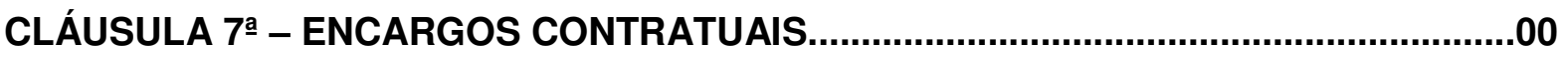

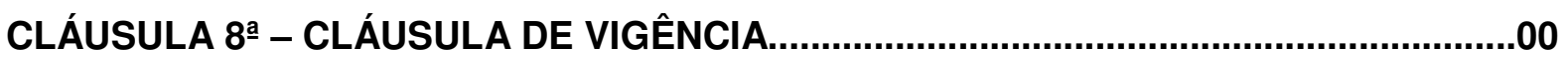

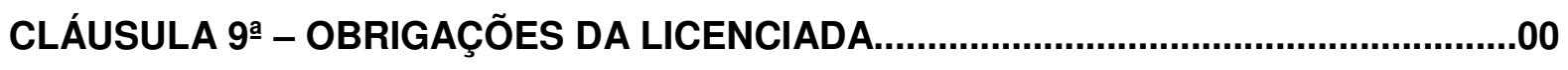

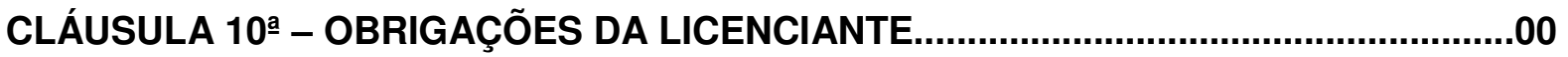

CLÁUSULA 11 a - CONTROLE DE QUALIDADE...........................................................00

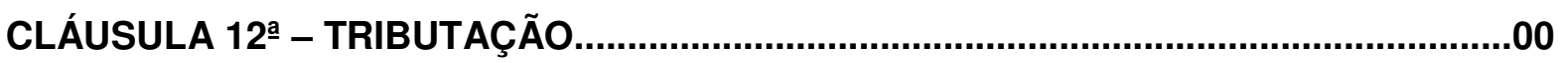

CLÁUSULA 13a - DIREITO DE PREFERÊNCIA.......................................................00

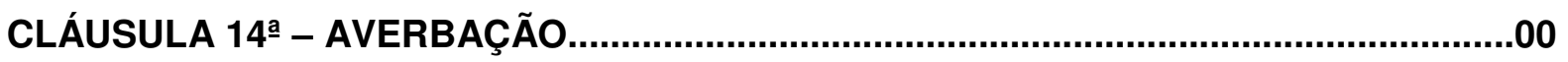

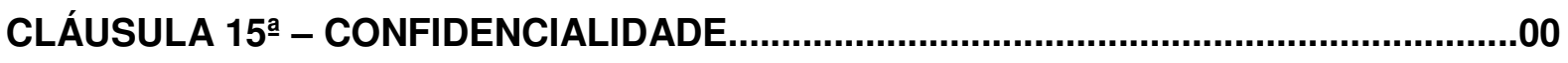

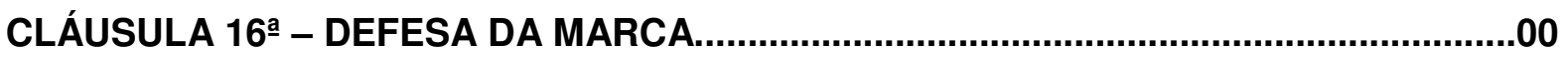

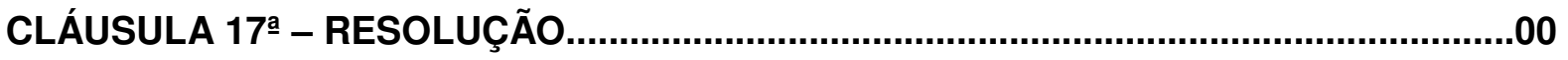

CLÁUSULA 18

CLÁUSULA 19a - LEI APLICÁVEL...........................................................................

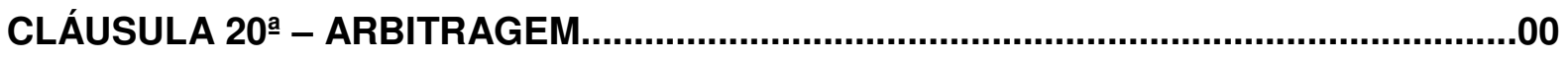

CLÁUSULA 21 a - COMUNICAÇÕES......................................................................

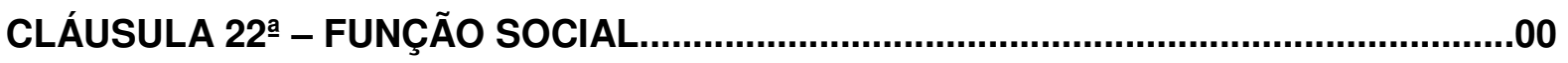

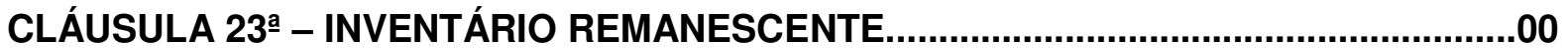

CLÁUSULA 24a - DISPOSIÇÕES FINAIS.................................................................... 00

ANEXO: CERTIFICADO DE REGISTRO EXPEDIDO PELO INPI.................................... 00 
Pelo presente instrumento particular,

de um lado,

Minister LtdA., pessoa jurídica de direito privado, com sede na Rua Vale do Figueira, n. 100, Bairro Jandira, CEP 11111-111, na Cidade de São Paulo, Estado de São Paulo, com atos constitutivos registrado na Junta Comercial do Estado de São Paulo sob NIRE 22.222.222.222, inscrita no Cadastro Nacional de Pessoa Jurídica, do Ministério da Fazenda, sob o n. 33.333.333/3333-33, doravante denominada LICENCIANTE, neste ato representada por seu sócio e representante legal, na forma do contrato social anexo;

e de outro lado,

INTELLectuAl LtDA., pessoa jurídica de direito privado, com sede na Rua Ribeiro de Alcântara, n. 100, Bairro Moema, CEP 2222-222, na Cidade de Belo Horizonte, Estado de Minas Gerais, com atos constitutivos registrado na Junta Comercial do Estado de São Paulo sob NIRE 33.333.333.333, inscrita no Cadastro Nacional de Pessoa Jurídica, do Ministério da Fazenda, sob 0 n. 44.444.444/4444-44, doravante denominada LICENCIADA, neste ato representada por seu sócio e representante legal, na forma do contrato social anexo

\section{CONSIDERANDO QUE:}

(i) a LICENCIANTE é uma sociedade empresária nacional de material esportivo, consolidada no mercado, há 30 anos, tendo como atividades principais: fabricação, distribuição e comercialização de calçados e camisetas esportivas por todo o território nacional;

(ii) a LICENCIANTE detém a titularidade da marca "EKIN", na Classe 25 material esportivo, conforme registros anexos, expedidos pelo Instituto Nacional de Propriedade Industrial (INPI), em 1984;

(iii) a LICENCIADA é uma sociedade empresária nacional, constituída no Brasil, no ano de 2008, tendo como objeto social: a fabricação, distribuição 
e comercialização de calçados e camisetas esportivas por todo o território nacional;

(iv) a LICENCIANTE almeja licenciar para a LICENCIADA, e esta deseja licenciar da LICENCIANTE, a marca "EKIN", de titularidade da LICENCIANTE, conforme certificado anexo, para aposição do sinal licenciado nos produtos (tênis e camisetas esportivas) que a LICENCIADA, doravante, passará a produzir, distribuir e comercializar, em todo o território nacional e, eventualmente, estrangeiro;

Resolvem, de comum acordo, firmar o presente CONTRATO DE LICENÇA DE USO DE MARCA REMUNERADO, em conformidade com as cláusulas e condições seguintes:

\section{CLÁUSULA 1ª - DEFINIÇÕES}

Consoante o presente instrumento, os seguintes termos e interpretações devem ter a definição designada nesta cláusula, a não ser que o contexto do contrato apresente significado diverso:

(a) Averbação: registro do presente contrato no INPI.

(b) Certificado: documento formal emitido pelo Instituto Nacional de Propriedade Industrial (INPI), declarando a titularidade da marca, cujo licenciamento se apresenta como objeto do presente contrato.

(c) Cessionário: é o beneficiário da cessão definitiva da marca de titularidade da LICENCIANTE; aquele que receberá, a título oneroso ou gratuito, a propriedade definitiva da marca da LICENCIANTE.

(d) Classe: classificação utilizada pelo INPI objetivando a agregação de produtos e serviços, utilizando denominações genéricas que delimitem, adequadamente, o âmbito de proteção e, ao mesmo tempo, permitam a análise de colidências por afinidade de produtos/serviços, dentro da mesma classe ou entre classes diferentes. 
(e) Contrato: presente documento, instrumento ao qual se faz alusão no preâmbulo, que estabelece, expressa e formalmente, as cláusulas e condições para o licenciamento do uso da marca de entre Licenciante e Licenciada.

(f) Dia Útil: dia em que os bancos estão regularmente abertos para a realização de atividades bancárias em geral, com exceção de sábados, domingos e feriados públicos.

(g) INPI: Instituto Nacional de Propriedade Industrial. Autarquia federal vinculada ao Ministério do Desenvolvimento, Indústria e Comércio Exterior, responsável por registros de marcas, concessão de patentes, averbação de contratos de transferência de tecnologia e de franquia empresarial, de acordo com a Lei da Propriedade Industrial (Lei ก. $.9 .279 / 96)$.

(h) Licenciada: pessoa jurídica que se utilizará da marca licenciada, consoante os termos e condições previstos em contrato.

(i) Licenciante: pessoa jurídica titular da marca registrada no INPI, objeto do licenciamento a seguir delineado.

(j) Marca: marca mista "EKIN", registrada pela LICENCIANTE, no Instituto Nacional de Propriedade Industrial (INPI), conforme certificado de registro anexo.

(k) Parte ou Partes: Licenciante, Licenciada ou ambas.

(I) Prazo: período cujo termo inicial é a data da subscrição do presente instrumento e termo final é a data prevista na Cláusula $5^{\underline{a}}$ do contrato.

(m) Quebra de Contrato: descumprimento, por uma parte, das obrigações estabelecidas neste contrato.

(n) Registro: significa a aceitação formal, pelo Instituto Nacional de Propriedade Industrial, da marca de titularidade da LICENCIANTE, em acordância com as exigências do INPI e determinações legais da Lei n. ${ }^{\circ}$ 9.279/96 e atos normativos pertinentes.

(o) RPI: Revista de Propriedade Industrial, publicada semanalmente, pela qual o INPI divulga os processos analisados, códigos (despachos), exigências, oposições, pedidos 
de nulidades, pedidos de caducidade, concessão de registro, indeferimentos de processos, entre outros.

(p) Terceiros:pessoa física ou jurídica que não seja a LICENCIANTE ou a LICENCIADA.

(q) Tributos: toda prestação pecuniária compulsória, em moeda ou cujo valor nela se possa exprimir, que não constitua sanção de ato ilícito, instituída em lei e cobrada mediante atividade administrativa plenamente vinculada, conforme determinação do artigo $3^{\circ}$, da Lei $5176 / 66$.

\section{CLÁUSULA 2ª - LICENÇA}

Pelo presente instrumento, e em consonância com as cláusulas e condições neste contrato estabalecidas, a LICENCIANTE concede à LICENCIADA o direito de utilização da marca mista "EKIN", registrada no INPI pelo processo n. 8888888888 , Classe NCL (8)

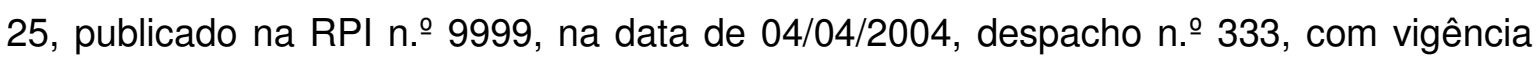
até 04/04/2014.

Parágrafo Primeiro - A marca somente poderá ser utilizada pela LICENCIADA para aposição nos produtos para os quais se encontra registrada no INPI. Considerando-se que a marca encontra-se registrada apenas na Classe $\mathrm{NCL}$ (8) 25 , a sua utilização operar-se-á somente nos produtos seguintes: calçados e camisetas esportivos, os quais serão fabricados, distribuídos e comercializados, pela LICENCIADA, em todo o território nacional.

Parágrafo Segundo - A LICENCIADA terá o direito exclusivo de: (a) usar a marca licenciada nos produtos por ela fabricados, vendidos, comercializados e divulgados; (b) utilizar a marca licenciada em publicidade, anúncios, promoções e atividades públicas; (c) reproduzir, distribuir e disseminar a marca, de acordo com as cláusulas ora estipuladas.

Parágrafo Terceiro - O licenciamento da marca operar-se-á por todo o Brasil, território este em que a marca encontra-se protegida pelo INPI. 
Parágrafo Quarto - A presente licença é concedida a título exclusivo, tendo a LICENCIANTE o dever de: (a) se abster de utilizar a marca durante a vigência do contrato; e (b) se abster de licenciar a marca a terceiros durante o prazo de vigência deste contrato.

Parágrafo Quinto - Sendo a propriedade da marca de titularidade da LICENCIANTE, a LICENCIADA não deverá, sob qualquer hipótese, indicar a terceiros que ela, LICENCIADA, tem a propriedade da marca, admitindo, portanto, que o seu uso, nos termos deste contrato, não criará direito de propriedade, ou qualquer outro título, em seu benefício.

\section{CLÁUSULA 3a - SUBLICENÇA}

A LICENCIADA não poderá sublicenciar a marca a terceiros, sem a prévia, necessária e expressa anuência da LICENCIANTE.

Parágrafo Único - No evento de a LICENCIANTE autorizar o sublicenciamento da marca a terceiros, será necessária a realização de aditamento ao presente instrumento, devendo a SUBLICENCIADA atender a todas as cláusulas e condições consginadas neste contrato.

\section{CLÁUSULA 4⿳a - USO ACOMPANHADO}

Faculta à LICENCIADA, se julgar conveniente, utilizar-se da marca licenciada conjuntamente à marca de sua titularidade, nos termos da Cláusula $2^{\mathrm{a}}$ deste contrato e do artigo 132, inciso I, da Lei 9.279/96.

\section{CLÁUSULA 5a - PRAZO}

O prazo de vigência do presente licenciamento será de 24 (vinte e quatro meses), contado a partir da data da publicação, na RPI, da emissão do certificado de averbação do contrato pelo INPI. 


\section{CLÁUSULA 6a - REMUNERAÇÃO}

A LICENCIADA pagará, a título de royalties, como contraprestação pela utilização da marca, o valor fixo mensal de $\mathrm{R} \$ 20.000,00$ (vinte mil reais), bem como o valor variável de $5 \%$ (cinco por cento) sobre a receita mensal líquida auferida pela comercialização dos produtos designados pela marca licenciada.

Parágrafo Primeiro - A remuneração será reajustada anualmente, de acordo com a variação do IGPM (FGV). No evento de o índice oficial de variação IGP-M(FGV) vier a ser extinto, os reajustes supra mencionados deverão ser abalizados em outro índice oficial que for criado ou autorizado pelo governo, de acordo com o consentimento das partes.

Parágrafo Segundo - Os valores remuneratórios deverão ser pagos, a partir do início do prazo do licenciamento, em todo o $5^{\circ}$ (quinto) dia útil de cada mês, mediante depósito na conta corrente informada pela e de titularidade da LICENCIANTE, valendo o comprovante de depósito como quitação do pagamento.

Parágrafo Terceiro - Fica desde já acordado entre as partes que toda e qualquer importância devida e paga, agora e no futuro, pela LICENCIADA à LICENCIANTE, sofrerá as deduções e retenções previstas em lei.

Parágrafo Quarto - O atraso no pagamento da remuneração devida obrigará a LICENCIADA ao pagamento de multa de 10\% (dez por cento) sobre o valor do débito, acrescido de juro de 1\% (um por cento) ao mês, tudo corrigido monetariamente com base na variação do índice contratualmente estabelecido.

\section{CLÁUSULA 7ª - ENCARGOS CONTRATUAIS}

A LICENCIANTE tem o dever de manter o registro da marca no INPI por todo o tempo de vigência do contrato, devendo, inclusive, pagar todos os encargos e emolumentos de manutenção de registro, exigidos pelo INPI. 
Parágrafo Primeiro - A LICENCIANTE tem o dever de averbar o presente contrato no INPI, devendo arcar com todas as custas e emolumentos necessários para 0 aperfeiçoamento do registro neste órgão.

Parágrafo Segundo - No evento de a LICENCIADA decidir pelo registro do contrato em qualquer outro órgao, que não o INPI, as despesas deste ato decorrentes deverão correr às expensas e responsabilidade da LICENCIADA.

Parágrafo Terceiro - A LICENCIANTE deverá encaminhar à LICENCIADA os comprovantes de pagamento e certificados correspondentes, em conformidade com 0 disposto no caput e parágrafo primeiro desta Cláusula.

Parágrafo Quarto - Na eventualidade de existirem débitos incidentes sobre a marca, anteriores à data do presente licenciamento, a LICENCIANTE obriga-se, desde já, a quitá-los, sob pena de o contrato ser resolvido.

\section{CLÁUSULA 8a - CLÁUSULA DE VIGÊNCIA}

No evento de a LICENCIANTE decidir pela cessão, a qualquer título, da marca a terceiro(s), o presente contrato permancerá vigente até o termo final, previsto na Cláusula 5ā, obrigando-se a eventual CESSIONÁRIA a satisfazer, pontualmente, todas as cláusulas e condições consignadas neste contrato, até o término do prazo avençado entre LICENCIANTE e LICENCIADA.

\section{CLÁUSULA 9ạ - OBRIGAÇÕES DA LICENCIADA}

\section{A LICENCIADA obriga-se a:}

(i) servir-se da marca licenciada para os usos convencionados na Cláusula 2ª , conforme a natureza dela e classe em que se encontra registrada, bem como tratá-la com o mesmo cuidado como se sua fosse; 
(ii) usar a marca, para fins lícitos, em estrita confomidade com a legislação marcária vigente (Lei n.ำ 9.279/96);

(iii) utilizar, efetivamente, a marca licenciada em suas atividades, de sorte a evitar a caducidade, sob pena de resolução do contrato por inadimplência contratual;

(iv) apresentar, semestralmente, à LICENCIANTE, relatório discriminando o "uso efetivo" da marca licenciada, sem prejuízo de a LICENCIANTE exercer seu poder de inspeção e controle de qualidade, nos termos da Cláusula $11^{\text {a }}$ abaixo;

(v) pagar, pontual e integralmente, os valores estipulados, a título de royalties, na Cláusula 6ª do presente instrumento;

(vi) levar ao conhecimento da LICENCIANTE as turbações de terceiros, que se pretendam fundadas em direito;

(vii) findo o licenciamento, restituir (deixar de se utilizar) a marca, no estado em que a recebeu, salvas as depreciações econômicas naturais ao uso regular, extrínsecas à vontade e aos atos encetados pela LICENCIADA quando de sua utilização;

(viii) permitir o acesso da LICENCIANTE a todas suas instalações, com o escopo de que esta realize inspeção e controle de qualidade dos produtos representados pela marca licenciada, nos termos da Cláusula $11^{\underline{a}}$ do contrato;

(ix) admitir a realização, pela LICENCIANTE, de auditorias periódicas concernentes aos seus livros contábeis e demonstrações financeiras, com o escopo de se verificar a veracidade dos valores pagos a títulos de royalties variáveis, decorrentes da comercialização dos produtos representados pela marca licenciada;

(x) durante o período do contrato ou após seu término, não requerer o registro, não auxiliar ou estimular terceiros a requererem o registro da marca licenciada e/ou suas variações, singularmente ou de forma combinada com outros sinais, 
em qualquer região do Brasil, no INPI ou qualquer outra agência governamental, ou ainda em qualquer outro país estrangeiro ou organização governamental, exceto se previamente autorizado pela LICENCIANTE.

\section{CLÁUSULA 10ª - OBRIGAÇÕES DA LICENCIANTE}

A LICENCIANTE obriga-se a:

(i) disponibilizar à LICENCIADA a marca, em estado de servir ao uso a que se destina, e a mantê-la nesse estado, pelo tempo do contrato;

(ii) garantir à LICENCIADA, durante o tempo do contrato, o uso pacífico do bem intangível disponibilizado;

(iii) proteger a LICENCIADA contra terceiros que prejudiquem ou intentem molestar o uso manso e pacífico da marca disposnibilizada, devendo, por igual, responder pelos seus vícios ou defeitos anteriores à subscrição deste contrato;

(iv) adimplir, pontualmente, perante o INPI, as taxas e emolumentos necessários para a manutenção do registro da marca;

(v) ingressar com o registro no INPI, no prazo de 5 (cinco) dias úteis da data da subscrição deste contrato, devendo, por igual, cumprir com todas as exigências emanadas do INPI e adimplir, pontualmente, as taxas e emolumentos necessários para a manutenção do registro do contrato;

(vi) três vez ao ano, realizar inspeção e controle de qualidade dos produtos representados pela marca licenciada, fabricados e comercializados pela LICENCIADA, nos termos da Cláusula $11^{\text {a }}$ do contrato, de sorte a preservar os interesses do fiéis consumidores dos produtos representados pela marca licenciada, fabricados e comercializados pela LICENCIANTE, previamente à subscrição do presente contrato. 


\section{CLÁUSULA 11a - CONTROLE DE QUALIDADE}

A LICENCIANTE realizará fiscalização e controle efetivo sobre as especificações, natureza e qualidade dos produtos, mercadorias ou serviços da LICENCIADA, vinculados à marca licenciada, por meio do estabelecimento de diretrizes a serem observadas pela LICENCIADA.

Parágrafo Primeiro - As diretrizes mencionadas nesta Cláusula, para a manutenção da natureza e qualidade dos produtos e serviços a serem oferecidos pela LICENCIADA, deverão se coadunar com os padrões de qualidade que eram praticados pela LICENCIANTE em momento anterior à subscrição do presente instrumento.

Parágrafo Segundo - Os produtos e serviços oferecidos pela LICENCIADA deverão estar em estrita consonância com as normas nacionais vigentes regulamentadoras do controle de qualidade das atividades praticadas pela LICENCIADA.

Parágrafo Terceiro - A LICENCIANTE poderá fiscalizar as premissas e instalações da LICENCIADA, bem como analisar o sistema de produção e inspecionar os produtos e serviços oferecidos pela LICENCIADA no mercado, assinalados com a marca licenciada, contanto que:

(a) a aludida fiscalização seja realizada por pessoa diretamente ligada à LICENCIANTE ou por esta, expressamente, autorizada, por meio de autorização formal firmada por sócio com poderes de representação previstos em contrato social;

(b) a LICENCIADA seja comunicada, nos termos da Cláusula $21^{\underline{a}}$, com antecedência mínima de 72 (setenta e duas) horas;

(c) a inspeção seja efetivada em horário comercial e sem qualquer prejuízo das atividades da LICENCIADA;

(d) a fiscalização seja operada sob a responsabilidade e às custas da LICENCIANTE. 
Parágrafo Quarto - A fiscalização por parte da LICENCIANTE não desobriga a LICENCIADA de sua responsabilidade quanto à perfeita execução das obrigações previstas em contrato.

Parágrafo Quinto - Os dados e informações técnicas, de qualquer natureza, aos quais, ao longo da fiscalização, a LICENCIANTE tiver acesso, deverão ser mantidos sob absoluto sigilo e confidencialidade, nos termos da Cláusula $15^{a}$ do contrato.

Parágrafo Sexto - A inspeção restringe-se ao exame da qualidade dos produtos, sendo vedado à LICENCIANTE, salvo expressa anuência concedida pela representante legal da LICENCIADA, o acesso aos elementos protegidos por segredo industrial, bem como às listas de clientes, contabilidade interna e outros dados e informações que representem segredo de negócio da LICENCIADA.

Parágrafo Sétimo - A verificação de falhas e/ou defeitos nos produtos oferecidos ao mercado pela LICENCIADA, ensejará a advertência desta pela LICENCIANTE. Se os vícios de qualidade não forem sanados no prazo de 10 (dez) dias úteis, da data do recebimento da comunicação de advertência, será aplicada à LICENCIADA a multa prevista na Cláusula $18^{a}$ deste instrumento.

Parágrafo Oitavo - Em caso de reincidência, no que tange à verificação de vícios de qualidade nos produtos e serviços oferecidos pela LICENCIADA, assinalados com a marca de titularidade da LICENCIANTE, a esta facultará a rescisão contratual, sem prejuízo da propositura das medidas administrativas e judiciais cabíveis para a resolução do contrato, cumulada com o pedido de perdas, danos e lucros cessantes.

\section{CLÁUSULA 12 - TRIBUTAÇÃO}

De conformidade com sua competência legal, cada Parte suportará os tributos incidentes sobre o objeto previsto na Cláusula $2^{a}$ supra, de natureza federal, estadual e municipal, 
bem como se responsabilizará pelas infrações fiscais decorrentes da execução do Contrato.

\section{CLÁUSULA 13a - DIREITO DE PREFERÊNCIA}

Na hipótese de a LICENCIANTE desejar ceder a marca, deverá, primeiro, oferecê-la à LICENCIADA, nos termos da lei, conferindo-lhe o prazo de 30 (trinta) dias para que esta manifeste seu eventual interesse na aquisição.

Parágrafo Primeiro - A LICENCIANTE deverá dar prévio e inequívoco conhecimento à LICENCIADA da intenção de cessão e eventual proposta de aquisição recebida, para que esta se pronuncie quanto ao desejo de adquirir a marca, desde que o faça nas mesmas condições oferecidas por terceiro(s).

Parágrafo Segundo - A igualdade de condições para a aquisição da marca corresponde ao valor oferecido, forma de pagamento, e outras condições e vantangens originariamente oferecidas pela LICENCIANTE a terceiros.

Parágrafo Terceiro - A LICENCIADA não poderá se valer do exercício de seu direito de preferência se, notificada pela LICENCIANTE, recusar a proposta, oferecer preço ou condição diversa do pedido, ou ficar silente. Neste caso, a LICENCIANTE poderá ceder, livremente, a marca a terceiros, sob as mesmas bases e condições oferecidas à LICENCIADA.

Parágrafo Quarto - Havendo regular notificação, judicial ou extrajudicial, de sorte que torne manifesto o conhecimento da proposta pela LICENCIANTE, e conseqüente aceitação por parte da LICENCIADA, as partes estarão obrigadas a cumprir as disposições contidas na proposta de cessão da marca.

Parágrafo Quinto - A cessão da marca, sem que a LICENCIADA tenha tido a oportunidadade de exercer seu direito de preferência, obrigará a LICENCIANTE a ressarcir as perdas e danos suportados pela LICENCIADA, ainda que o contrato não tenha sido averbado no INPI. 
Parágrafo Sexto - Consoante o disposto na Cláusula $8^{\mathrm{a}}$ do presente instrumento, no evento de a LICENCIADA não exercer seu direito de preferência, e se a marca vier a ser cedida a terceiros, o presente contrato deverá ser integralmente observado e cumprido em todas as suas cláusulas e condições.

Parágrafo Sétimo - Enquanto o presente contrato não estiver averbado no INPI, fica a LICENCIANTE obrigada, na hipótese de cessão da marca, a, contratualmente e como condição prévia e essencial para a possível alienação, fazer com que os terceiros adquirentes se comprometam a respeitar integralmente as cláusulas e condições consignadas neste instrumento, estabelecendo, ademais, que, em caso de transgressão, tanto estes terceiros, como a LICENCIANTE, serão responsabilizados pelas perdas e danos, lucros cessantes ou emergentes e despesas ligadas à execução do presente contrato, despendidas pela LICENCIADA.

\section{CLÁUSULA 14a- AVERBAÇÃo}

O contrato de licença deverá ser averbado, pela LICENCIANTE, no INPI para que produza efeitos em relação a terceiros, em consonância com o artigo 140 da Lei n.. 9.279/96.

\section{CLÁUSULA 15a - CONFIDENCIALIDADE}

As informações e os documentos das Partes, especialmente aqueles, mas não se limitando a, de natureza societária, econômica-financeira, judicial, tecnológica, administrativa, operacional, comercial, estratégica, dentre outros transmitidos de uma Parte à outra, seja por que meio for, por força do contrato, constituem informações privilegiadas ou confidenciais e, como tal, têm caráter de estrito sigilo, podendo ser utilizadas pelas Partes exclusivamente para execução deste contrato.

Parágrafo Primeiro - A Partes estão impedidas de se utilizar de informações privilegiadas e/ou confidenciais de qualquer natureza, para fins diversos daqueles 
diretamente ligados à execução deste Contrato, bem como encaminhá-los a terceiros não envolvidos na relação jurídica ora estabelecida.

Parágrafo Segundo - Estão sujeitos às obrigações de manutenção de sigilo das informações chanceladas como confidenciais: todas as pessoas vinculadas, diretamente ou indiretamente, às Partes, sejam sócios, dirigentes, administradores, prepostos, empregados, contratados ou quaisquer outras, as quais, em decorrência deste Contrato, tenham acesso aos dados, informações e documentos aludidos nesta Cláusula.

Parágrafo Terceiro - A obrigação de manter confidencialidade não mais será aplicada para aquelas informações para as quais haja evidência de que: (a) sejam publicamente conhecidas à época da divulgação por uma das Partes; (b) se tornem publicamente conhecidas a partir do início da vigência do presente contrato; (c) tenham sido aprovadas por escrito por ambas as partes; (d) tenham sido solicitadas ou ordenadas por lei para serem divulgadas, sendo que a parte que as divulgará notifique a outra parte, para que esta tome as medidas legais cabíveis.

Parágrafo Quarto - Cada uma das Partes fica obrigada, mediante notificação a ser enviada a qualquer tempo, a devolver à outra Parte as informações escritas, ou gravadas de qualquer outra forma (incluido cópias, se houver) obtidas da Parte remetente.

\section{CLÁUSULA 16a - DEFESA DA MARCA}

Pelo presente contrato, a LICENCIADA é investida pela LICENCIANTE, titular da marca, de todos os poderes para agir em defesa da marca, sem prejuízo dos seus próprios direitos, em consonância com o parágrafo único, do artigo 139, da Lei n.ำ 9.279/96.

\section{CLÁUSULA 17ª - RESOLUÇÃO}

O presente contrato será, automaticamente, resolvido, mediante a inadimplência, por qualquer uma das Partes, de qualquer uma de suas cláusulas, devendo a marca ser imediatamente restituída à LICENCIANTE, sem prejuizo da incidência da multa prevista 
na Cláusula 18ª , bem como sem prejuízo de a parte inocente promover contra a parte infratora as medidas judiciais cabíveis, visando à indenização pelos danos suportados em decorrência da quebra contratual.

Parágrafo Primeiro - No evento de qualquer das partes relevar mora ou transgressão a algum dispositivo contratual, deixando de incidir a multa cabível; abonar violação incorrida pela parte infratora; ou, ainda, perpetrar algum ato em benefício da parte infratora, tais procedimentos não se constituirão em novação contratual, porquanto deverão ser considerados como meras liberalidades da parte prejudicada, em virtude das quais nenhuma obrigação existirá.

Parágrafo Segundo - A demonstração da violação incorrida pela parte infratora, bem como a incidência da multa correspondente, prevista na Cláusula 18ª , deverão, obrigatoriamente, ser precedidas de comunicação escrita.

Parágrafo Terceiro - No evento de qualquer das partes tiver de promover as medidas judiciais ou arbitrais cabíveis, tendo, para o alcance deste objetivo, de recorrer à via judicial ou arbitral para resolver o presente contrato, ficará a parte infratora sujeita, além da multa consignada na Cláusula 18a , a responder por perdas e danos, custas processuais ou arbitrais, honorários periciais e advocatícios, estes fixados em $20 \%$ (vinte por cento) do valor da indenização.

\section{CLÁUSULA 18 - CLÁUSULA PENAL}

Ressalvaldo o parágrafo quarto, da Cláusula $6^{\underline{a}}$, o descumprimento, por qualquer das Partes, diretamente ou por terceiros a ela vinculados na obrigação à sua observância, de qualquer cláusula deste contrato, obrigará o infrator a pagar à parte inocente multa equivalente ao valor de 3 (três) vezes o valor dos royaties mensais pré-fixados, vigentes à época da ocorrência do evento, consoante artigo 408 e seguintes do Código Civil Brasileiro.

Parágrafo Primeiro - A multa aludida na presente cláusula, de caráter penal, não prejudicará o direito de a parte inocente pleitear, judicialmente, indenização suplementar, na qual serão compreendidos os danos materiais e morais, bem como os lucros 
cessantes, sendo que, neste caso, a multa neste instrumento estabelecida corresponderá ao mínimo da indenização, com supedâneo no Parágrafo Único, do artigo 416, do Código Civil Brasileiro.

Parágrafo Segundo - A aplicação da multa conferirá à parte inocente o direito de considerar o presente contrato rescindido de pleno direito, independentemente do envio de notificação judicial, extrajudicial ou qualquer outro tipo de comunicado à parte infratora, devendo esta pagar, acrescido ao valor devido, 20\% (vinte por cento) sobre este, a título de reembolso pelo custeio concernente à contratação de advogados para o ingresso das medidas judiciais cabíveis, honorários estes inicialmente suportados pela parte inocente.

\section{CLÁUSULA 19a - LEI APLICÁVEL}

A regência do licenciamento, objeto deste contrato, se dará pelas cláusulas e condições dispostas no presente instrumento, pela Lei Federal n. 9.279/96 (Lei da Propriedade Industrial), pelos atos normativos expedidos pelo INPI e, subsidiariamente, no que for aplicável, pelos artigos 565 a 578 do Código Civil vigente (Locação de Coisas), bem como, concomitantemente, pelos dispositivos e princípios gerais consignados no Diploma Civil, que se coadunem com a natureza da relação jurídica que ora se estabelece.

\section{CLÁUSULA 20a- ARBITRAGEM}

Qualquer controvérsia decorrente da interpretação ou da execução do presente Contrato será, definitivamente, resolvida por arbitragem, de conformidade com as regras e regulamento de arbitragem do Centro de Arbitragem da Câmara Americana de Comércio São Paulo.

Parágrafo Primeiro - O número de árbitros será de um. 
Parágrafo Segundo - A arbitragem terá sede na Capital do Estado de São Paulo e obedecerá, obrigatoriamente, as regras de arbitragem do Centro de Arbitragem da Câmara Americana de Comércio São Paulo.

Parágrafo Terceiro - O idioma oficial da arbitragem será o português.

Parágrafo Quarto - A arbitragem deverá aplicar a legislação prevista na Cláusula 19a para dirimir os conflitos e controvérsias entre as Partes, que sejam decorrentes da interpretação e/ou execução do presente Contrato.

\section{CLÁUSULA 21a - COMUNICAÇÕES}

As comunicações trocadas entre as Partes somente terão eficácia, produzindo efeitos para todos os fins de direito, se forem realizadas por escrito, via carta registrada ou correspondência entregue mediante recibo.

Parágrafo Primeiro - Fica, desde já, expressamente acordado que qualquer alteração nos endereços e/ou demais informações constantes do preâmbulo do presente contrato deverá ser, prontamente, comunicada pela parte responsável à outra, por escrito, nos termos do caput desta cláusula.

Parágrafo Segundo - O descumprimento dos procedimentos consignados na presente cláusula, tornará nula a comunicação enviada pela parte que inobsevar os regramentos ora estipulados, a qual não gerará efeitos para os fins admitidos em Direito.

Parágrafo Terceiro - A aposição da assinatura no recibo da comunicação, por parte de qualquer pessoa que esteja direta ou indiretamente vinculada à parte receptora, tornará a comunicação plenamente válida.

\section{CLÁUSULA 22ª - FUNÇÃO SOCIAL}

Sob pena de resolução imediata do presente instrumento por inadimplência contratual; visando o preenchimento da função social do contrato, em observância ao disposto no 
artigo 421 do Código Civil Brasileiro; e objetivando a preservação dos direitos de terceiros, bem como a salvaguarda dos direito difusos e coletivos, a LICENCIADA tem o dever de:

(i) cumprir todos os deveres previstos na legislação trabalhista vigente, sendo responsável pelas consequências resultantes da inobservância das leis trabalhistas. O cumprimento deste dever deve ser observado em relação aos seus empregados, subcontratados e colaboradores que, eventualmente, venha a contratar durante vigência do presente contrato;

(ii) observar legislação concernente à segurança e medicina do trabalho, obedecendo, para tanto, todas as normas e regulamentos erigidos das legislações locais e federal, sendo, por conseguinte, integralmente responsável pelo seu descumprimento. O cumprimento desta obrigação deve ser observado em relação aos seus empregados, subcontratados e colaboradores que, eventualmente, venha a contratar durante vigência do presente contrato;

(iii) obedecer o comando do artigo $7^{\circ}$, inciso XXXIII, da Constituição Federal do Brasil, respeitando a proibição de trabalho noturno, perigoso ou insalubre a menores de dezoito e de qualquer trabalho a menores de dezesseis anos, salvo na condição de aprendiz, a partir de quatorze anos;

(iv) defender o meio ambiente, obedecendo as normas ambientais emanadas da Constituição Federal do Brasil e da legislação infraconstitucional vigente, obrigando-se, para tanto, mas não de limitando a: (a) desenvolver técnicas de atuação que não lesem o patrimônio ambiental; (b) adquirir todas as autorizações ambientais, dentro da estrita legalidade; (c) se furtar ao lançamento de qualquer tipo de poluente condenado pela legislação vigente na atmosfera, rios, lagos, lençóis freáticos etc; (d) respeitar todas as normas e exigências da Secretaria de Estado do Meio Ambiente, da Companhia de Tecnologia de Saneamento Ambiental (CETESB), do Instituto Brasileiro do Meio Ambiente e dos Recursos Naturais Renováveis (IBAMA), do Conselho Nacional do Meio Ambiente (CONAMA), do Conselho de Defesa do Patrimônio Histórico, Artístico, Arqueológico e Turístico do Estado de São Paulo (CONDEPHAAT) e de outros Órgãos Governamentais afins; (e) informar a 
LICENCIANTE sempre que a preparação, execução ou término do objeto contratado possa, potencialmente, envolver possível ofensa ao meio ambiente, inclusive delineando os métodos escolhidos e motivando os riscos a serem incorridos, responsabilizando-se, desta sorte, pelos danos gerados ao meio ambiente advindos da execução do presente contrato.

(v) observar os ditames constitucionais e infraconstitucionais atinentes ao exercício da livre concorrência, furtando-se: (a) ao abuso de poder econômico que vise à dominação dos mercados; (b) à eliminação da concorrência; e (c) aumento arbitrário dos lucros, tudo com amplo respaldo na Constituição Federal do Brasil e na Lei Federal n. 8.884/94.

Parágrafo Único - As obrigações da LICENCIADA estabelecidas neste dispositivo deverão ser por ela disseminadas entre seus fornecedores, empregados, colaboradores, prestadores de serviços, clientes e todos aqueles com os quais a LICENCIADA venha a manter qualquer tipo de relação.

\section{CLÁUSULA 23a - INVENTÁRIO REMANESCENTE}

Findo o prazo de licenciamento, os produtos licenciados remanescentes deverão:

(a) primeiramente, ser oferecidos à LICENCIANTE, com desconto de $40 \%$ (quarenta por cento) sobre o valor médio de mercado praticado pela LICENCIADA durante a vigência do contrato;

(b) no evento de a LICENCIANTE não exercer seu direito de preferência quanto à aquisição do inventário remanescente, nos termos da alínea (a) supra, poderá a LICENCIADA, no prazo máximo de 2 (dois) meses, vender os produtos no mercado, com desconto não superior a 30\% (trinta por cento) do preço médio de mercado praticado ao longo da vigência do presente contrato. 


\section{CLÁUSULA 24a - DISPOSIÇÕES FINAIS}

Parágrafo Primeiro - Este contrato não gera qualquer vínculo empregatício entre as partes, nem ao pessoal contratado.

Parágrafo Segundo - A emenda a qualquer cláusula, termo, obrigação ou condição estabelecida no contrato, somente poderá ser efetuada mediante o competente instrumento particular de aditamento a ser celebrado, por escrito, entre as Partes, instrumento este que deverá ser subscrito pelos representantes legais das Partes, nos termos de seus respectivos atos constitutivos.

Parágrafo Terceiro - As partes consentem, em caráter irrevogável e irretratável, que a LICENCIADA, ou suas sucessoras a qualquer título, terão legitimidade e preferência para o exercício do direito à renovação do presente instrumento, caso a LICENCIANTE assim deseje o fazer.

Parágrafo Quarto - O presente Contrato de Licença de Uso de Marca é celebrado em caráter irrevogável e irretratável, obrigando as Partes por si e/ou por seus herdeiros e sucessores a qualquer título.

Parágrafo Quinto - A tolerância por uma das partes em relação à infração a qualquer obrigação incorrida pela parte contrária, será considerada mera liberalidade, não implicando novação de seus termos, nem renúncia do direito de qualquer uma das partes de exigir que a outra Parte cumpra, pontual e integralmente, as suas obrigações, tais como estipuladas no presente instrumento.

Parágrafo Sexto - Eventual nulidade, decretada por meio de decisão judicial definitiva, de qualquer uma das cláusulas e/ou condições estabelecidas no presente instrumento, não se estenderá às demais, as quais remanescerão eficazes e vigentes.

Parágrafo Sétimo - Nenhuma da Partes poderá ceder ou transferir a terceiros o presente contrato, bem como quaisquer obrigações e direitos nele consignados, sem a prévia comunicação e correspondente aprovação, por escrito, da parte adversa, autorizando expressamente referida cessão ou transferência. 
Parágrafo Oitavo - O presente instrumento faz menção a todos e quaisquer compromissos e obrigações concernentes ao licenciamento, objeto deste contrato, substituindo todas e quaisquer tratativas anteriores, celebradas oral ou escrituralmente, previa e eventualmente entabuladas entre as Partes.

E, por estarem as Partes contratantes de pleno acordo, obrigam-se, por si, por seus sucessores e herdeiros, a cumprir fielmente o presente contrato, o qual vai assinado por ambas as Partes e mais 02 (duas) testemunhas, em 02 (duas) vias de igual teor.

São Paulo, 10 de junho de 2011.

\begin{tabular}{|c|c|}
\hline & \\
\cline { 2 - 2 } & \\
\hline MiNISTER LTDA. & INTELLECTUAL LTDA. \\
\hline Licenciante & Licenciada \\
\hline Sr. Julio Inichaigyt & Sr. Daniel Sacirjhu \\
\hline Diretor Presidente & Diretor Presidente \\
\hline
\end{tabular}

Testemunhas :

1.

Nome:

CPF:

RG:
2.

Nome:

CPF:

$R G$ : 


\section{ANEXO AO CONTRATO DE LICENÇA DE USO DE MARCA $\underline{\text { REMUNERADO }}$}

\section{CERTIFICADO DE REGISTRO EXPEDIDO PELO INPI}

\begin{tabular}{|c|c|c|c|c|c|}
\hline $\begin{array}{c}\text { Nome da } \\
\text { Marca }\end{array}$ & $\begin{array}{c}\text { N.․ de } \\
\text { Registro }\end{array}$ & Natureza & Classe & Vigência & Anotação* \\
\hline EKIN & 8888888888 & Mista & NCL (8) 25 & $04 / 04 / 2004$ & \\
\hline
\end{tabular}

* anotar a existência de eventuais pendências administrativas e/ou judiciais que recaiam sobre a marca licenciada; a existência de registros da marca que estejam vigorando em outros países, bem como outras informações que as partes entendam necessárias fazer constar em contrato, em estrita conformidade com o princípio da probidade e boa-fé objetiva, ambos consagrados pelo artigo 422, do Código Civil Brasileiro. 